\title{
Bestuur aan banden : lokaal jeugdbeleid in de greep van nationaal beleid
}

Citation for published version (APA):

Gilsing, R. J. H. (2005). Bestuur aan banden : lokaal jeugdbeleid in de greep van nationaal beleid. [Doctoral Thesis, Maastricht University]. Sociaal en Cultureel Planbureau.

https://doi.org/10.26481/dis.20051028rg

Document status and date:

Published: 01/01/2005

DOI:

10.26481/dis.20051028rg

Document Version:

Publisher's PDF, also known as Version of record

\section{Please check the document version of this publication:}

- A submitted manuscript is the version of the article upon submission and before peer-review. There can be important differences between the submitted version and the official published version of record.

People interested in the research are advised to contact the author for the final version of the publication, or visit the DOI to the publisher's website.

- The final author version and the galley proof are versions of the publication after peer review.

- The final published version features the final layout of the paper including the volume, issue and page numbers.

Link to publication

\footnotetext{
General rights rights.

- You may freely distribute the URL identifying the publication in the public portal. please follow below link for the End User Agreement:

www.umlib.nl/taverne-license

Take down policy

If you believe that this document breaches copyright please contact us at:

repository@maastrichtuniversity.nl

providing details and we will investigate your claim.
}

Copyright and moral rights for the publications made accessible in the public portal are retained by the authors and/or other copyright owners and it is a condition of accessing publications that users recognise and abide by the legal requirements associated with these

- Users may download and print one copy of any publication from the public portal for the purpose of private study or research.

- You may not further distribute the material or use it for any profit-making activity or commercial gain

If the publication is distributed under the terms of Article $25 \mathrm{fa}$ of the Dutch Copyright Act, indicated by the "Taverne" license above, 
Bestuur aan banden 
(6) Sociaal en Cultureel Planbureau, Den Haag 2005

SCP-publicatie $2005 / \mathrm{ro}$

Zet en binnenwerk: Mantext ${ }_{\text {, Moerkapelle }}$

Omslagontwerp: Bureau Stijlzorg, Utrecht

Omslagilitustraties: (0) Bridgeman Art Library, Effeti del buon governo in citta (Effecten van goed bestuur in de stad), (c) Photo Scala, Florence, Effeti del cattivo governo in citta (Effecten van slecht bestuur in de stad); fresco's van Ambrogio Lorenzetri (ca. 129o-1348), Palazzo Pubblico, Siena, Italië.

15BN 90-377-0226-0

NUR 74.0

Dit rapport is gedrulkt op chloarurij papiet.

Saciaal en Cultureel Planbureau

Parnassusplein 5

25 II VX Den Haag

Tel. $(070) 3407000$

Fax $(070) 3407044$

Website: www.scp.nl

E-mail: info@scp.nl 


\section{Bestuur aan banden}

Lokaal jeugdbeleid in de greep van nationaal beleid

\section{PROEFSCHRIFT}

ter verkrijging wan de graad vam doctor

aan de Universiteit Maastricht,

op gezag van de Rector Magnificus,

prof. mr. G.P.M.F. Mols

volgens het besluit van het College van Decanen,

in het openbaar te verdedigen

op vrijdag 28 oktober 2005 om I4.00 uur

door

Robertus Johannes Henricus Gilsing 
Promotor:

Copromotor:
Prof.dr. A.F.A. Korsten

Dr. V.C. Veldheer (Sociaal en Cultureel Planbureau en Hogeschool INHOLLAND)

Beoordelingscommissie: Prof.mr. F.A.M. Stroink (woorzitter)

Prof.dr. VJ.J.M. Bekkers (Erasmus Universiteit Rotterdam)

Prof.dr. W. Derksen (Erasmus Universiteit Rotterdam)

Prof.dr. B.J.S. Hoetjes

Prof.dr. J.G.A. van Mierlo 
Voor ons An 



\section{Voorwoord}

Het Sociaal en Cultureel Planbureau heeft een traditie op het gebied van onderzoek naar lokaal sociaal beleid. De bevindingen over dat beleid geven doorgaans weinig aanleiding tot grote vreugde. Er is vaak gewezen op het rijksbeleid, dat een weinig positieve invloed zou hebben op het lokale beleid. In dit proefschrift heb ik getracht duidelijk te maken op welke wijze rijksbeleid het beleid van lokale overheden beïnvloedt. Hopelijk draagt het bij aan de discussie over interbestuurlijke verhoudingen, die ook in het kader van het regeringsprogramma Andere overheid wordt gevoerd, en aan het sturingsvraagstuk in het jeugdbeleid, zoals dat binnen de Operatie Jong speelt.

Het idee voor dit proefschrift is voor het eerst geopperd door mijn promotor Arno Korsten, in zijn hoedanigheid als voorzitter van de begeleidingscommissie van het onderzoek naar lokaal jeugdbeleid. Mijn aanvankelijke aarzelingen bij dat idee maakten al snel plaats voor erkentelijkheid jegens hem. Zijn resultaatgerichte manier van begeleiden is de afronding van dit proefschrift ten goede gekomen.

Veel dank ben ik verschuldigd aan mijn copromotor en voormalig afdelingshoofd Vic Veldheer. Op onze oude afdeling Besturur en beleid is het voorliggende onderzoek in de steigers gezet. De ruimte en het vertrouwen dat ik daarbij kreeg, de inhoudelijke samenwerking en de meer dan prettige omgang hebben veel bijgedragen aan mijn werkwreugde bij het SCP.

Dit proefschrift had niet geschreven kunnen worden zonder de ruimte en de steun die mijn werkgever, het Sociaal en Cultureel Planbureau, mij heeft geboden. Daarvoor dank ik de directie, Paul Schnabel en Theo Roes, en in het bijzonder het hoofd van de onderzoeksgroep Enancipatie, jeugd en gezin: Saskia Keuzenkamp.

Een aantal (ex) SCP-collega's heeft bijgedragen aan dit onderzoek. Vooral Herma Koops en Elke Zeijl hebben in een eerdere fase een zeer waardevolle bijdrage geleverd, waarvoor veel dank. Mijn oude kamer- en afdellingsgenoot Monique Turkenburg ben ik dankbaar voor de vele uren die we over onderzoek naar lokaal sociaal beleid hebben gesproken.

Een aantal mensen heeft in verschillende fasen van het onderzoek nuttig commentaar geleverd. Van hen noem ik met name Hans Migchielsen en Guust Linders, die de ondankbare taak op zich namen het hoofdstuk over nationaal beleid na te zien op feitelijke onjuistheden. Mochten die er toch nog in staan, dan ligt dat niet aan hen. $B i j$ het veldwerk voor het onderzoek naar het lokale beleid waren verschillende personen betrokken: Adrie Claassen en wijlen Theo Dijkman van het Instituut voor Toegepaste Sociale Wetenschappen (ITs) in Nijmegen; Annemiek Vreeswijk en Yvonne Weijers-Martens van het Instituut voor Sociologisch-Economisch Onderzoek (ISEO) 
van de Erasmus Universiteit Rotterdam; en Anja Klimmer van de Stichting Alexander in Amsterdam. Dank daarvoor. De leden van de begeleidingscommissie van het onderzoek naar lokaal jeugdbeleid ben ik erkentelijk woor hun opmerkingen en suggesties. Naast Arno Korsten maakten de volgende personen deel uit van die commissie: Gerda Bosdriesz, Jan van der Burg, Monique van Diest, Hans Migchielsen, Marja Valkesteijn en Yvonne van Westering.

Ik draag dit proefschrift op aan mijn zus Anke. Het vertrouwen, de moed en de kracht waarmee zij de ziekte die haar trof draagt, zal voor mij altijd een voorbeeld zijn. Mijn ouders dank ik voor de kansen die zij mij in het leven hebben geboden en voor de aandrang die zij uitoefenden om daar ook daadwerkelijk gebruik van te maken.

Arno Korsten heeft me herhaaldelijk gevraagd: steunt het thuisfront je ambitie om een proefschrift te schrijven? IK kon hem steeds bevestigend antwoorden. Daarvoor, en voor haar vlijmscherpe pen, ben ik Agnes zeer dankbaar. En Hanna en Teun steunden wellicht niet bewust, maar hun vanzelfsprekende aanwezigheid was en is onmisbaar.

Rob Gilsing september 2005 


\section{Inhoud}

Lijst met afkortingen

\section{DEEL I INLEIDNNG EN ONDERZOERSOPZET}

1. Inleiding 19

I.I Jeugd en overheidsbeleid $\quad$ I9

I.2 Bestuurlijke rolverdeling in het jeugdbeleid 2 Ir

I.3 Autonome gemeenten en bestuurlijke vervlechting 23

I.3.I Het normatieve debat $\quad 25$

$\begin{array}{lr}\text { r.3.2 Het empirische debat } & 27\end{array}$

$\begin{array}{ll}\text { I.3.3 Conclusie } & 28\end{array}$

I.4 Doel- en vraagstelling 29

r.5 Effectief lokaal jeugdbeleid: onderzoeksvragen en operationalisering $\quad 30$

I.5.I Specifiek jeugdbeleid 30

r.5.2 Effectiviteit en voorwaarden voor effectiviteit $\quad 30$

r.5.3 Tot slot $\quad 35$

1.6 De nationale overheid en lokaal jeugdbeleid: onderzoeksvragen en $\begin{array}{ll}\text { operationalisering } & 35\end{array}$

r.6.I Onderzoeksvragen 35

1.6.2 Naar een beoordelingskader voor nationaal beleid $\quad 36$

$\begin{array}{ll}\text { r.7 Indeling van het boek } & 44\end{array}$

$\begin{array}{ll}\text { Noten } & 47\end{array}$

2 Opzet vant het onderzok 50

$2.1 \quad$ Inleiding 50

2.2 Onderzoek naar lokaal jeugdbeleid 50

2.2.I Het onderzoek naar lokaal jeugdbeleid: de inhoud en het proces 56

2.2.2 Het onderzoek naar lokaal jeugdbeleid: de beleidsuitkomsten 58

2.2.3 Overzicht onderzoeksopzet lokaal jeugdbeleid 63

$\begin{array}{ll}2.3 & \text { Onderzoek naar mational beleid }\end{array}$

DEEL. II LOKAAL JEUGDBELED

3 De ontwikkeling van specifiek jeagdbeleid in gemeenten 67

$\begin{array}{ll}3 . x & \text { Inleiding }\end{array}$

3.2 Het meetinstrument: de staat wan her jeugdbeleid 69

$\begin{array}{ll}3 \cdot 3 & \text { Beleidsformulering } \\ 32\end{array}$

3.4 Integrale beleidswoering 76

3.4.I Breedte wan beleid 76 
3.4.2 Politicke sturing

3.4.3 Ambtelijke coördinatie

3.4.4 Gemeente als regisseur

3.5 Meting van beleidseffecten $\quad 82$

3.6 Staatwan het lokale jeugdbeleid 83

3.7 Samenvatting en conclusies 84

$\begin{array}{ll}\text { Noten } & 87\end{array}$

4. De inhoud wan het lokale jeugdbeteid 89

4. $x$ Inleiding 89

4.2 Accenten in het jeugdbeleid 90

4.2.I Algemeen preventief, gericht preventief en curatiefjengdbeleid go

4.2.2 Thema's in het jeugdbeleid $\quad 9 \mathrm{I}$

4.2.3 Prioriteiten in het jeugdbeleid 94

4.2.4 Aandacht voor leeftijdsgroepen 97

4.3 Specifieke inhoudelijke thema's 98

4.3.1 Jeugd en veiligheid $\quad 98$

4.3.2 Afstenming jeugdzorg en lokaal jeugdbeleid 103

4.3.3 Afstemming jeugd-en onderwijsbeleid $\quad 107$

4.3.4 Sluitende aanpak o- tot 6-jarigen

4.4 Samenvatting en conclusies $\quad$ II7

Noten $\quad 120$

$5 \quad$ Het betrekkan wan de jeugd biy lokad jeugdbeleda

5.I Inleiding

5.2 Aandacht woor jeugdparticipatie

5.3 Leeftijdsgroepen en thema's $\quad$ I26

5.4 Instrumenten ter bevordering van jeugdparticipatie $\quad \times 27$

5.5. Zicht op de jeugd en informatie aan de jeugd $\quad$ 130

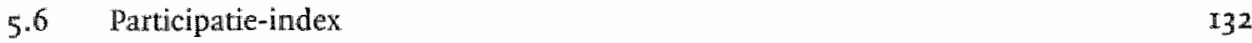

5.7 Samenwatting en conclusies $\quad$ I33

Noot: 135

6 De gentente als sturende antor in het lokale jeugdheteid 136

$6.1 \quad$ Inleiding $13^{6}$

6.2 Beleidsmetwerken rond lokaal jeugdbeleid

6.2.I. Aantallen netwerken $\quad{ }_{13} 8$

6.2.2 Werkvelden van netwerken $\quad$ r.39

6.2.3 Positie netwerken in beleidsproces. $\quad \mathrm{L}_{42}$

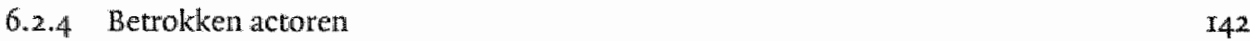

6.2.5 Classificatie van netwerkworming $\quad$ I47

6.2.6 Conclusie $\quad$ I48

6.3 Beleidsworming: de beleidswisie als sturingsinstrument $\quad 148$ 
6.3.I Aanwezigheid visie 148

6.3.2 Richtinggevendheid visie en consensus over visie

6.3.3 Betrokkenheid bij ontwikkeling visie

6.3.4 Conclusie 153

6.4 Beleidsuitwoering $\quad 154$

6.4.I Aansturing van de beleidsuitvoering $\quad 154$

6.4.2 Beleidsafwijkingen in de uitwoering $\quad$ x55

6.4 .3 Conclusie $\quad 162$

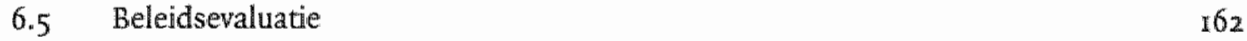

6.5.1 Evaluatie volgens ambtenaren $\quad 163$

6.5.2 Evaluatie volgens instellingen $\quad 164$

6.5 .3 Conclusie $\quad 165$

$\begin{array}{ll}6.6 & \text { Samenvatting en conclusies } \\ 165\end{array}$

$\begin{array}{ll}\text { Noten } & \mathbf{I} 68\end{array}$

7 Internezzo: typologie van het lokale jeughtyeleid $\quad 169$

$7+\pi$ Inleiding $\quad$ I69

7.2 Constructie van de beleidstypologie $\quad 169$

7 7.3 De beleidstypologie $\quad 172$

8 Beleidsactoren over de wikomsten van het lokale jeugdbeleid 175

8.r Inleiding 175

8.2 Oordelen over de mate van doelbereiking $\quad 176$

8.2.I Naar type instelling $\quad 176$

8.2.2 Naar type jeugdbeleid $\quad$ I77

$\begin{array}{ll}8.2 .3 & \text { Oordelen van ambtenaren } \\ 8.2 .48\end{array}$

8.2.4 Conclusies $\quad 179$

8.3 Oordelen over (de resultaten van) het jeugdbeleid 180

8.3.I Totaalbeeld $\quad 180$

8.3.2 Naar type instelling $\quad 180$

8.3.3 Naar betrokkenheid bij het jeugdbeleid $\quad 182$

8.3.4 Naar type jeugdbeleid $\quad 183$

8.3.5 Oordelen van ambtenaren $\quad 184$

8.3.6 Conclusies $\quad 185$

8.4 Samenvatting en conclusies $\quad 186$

$\begin{array}{ll}\text { Noten } & 188\end{array}$

$9 \quad$ Resultaten van lokal jeugdbeleid $\quad 189$

9.I Inleiding 189

9.2 Overzicht wan de resultaten 190

9.3 Resultaten en beleidskenmerken $\quad 192$

9.4 Samenvatting en conclusies $\quad 193$

$\begin{array}{ll}\text { Noten } & 194\end{array}$ 
20 Jongeren over het jeugdoeldid van hun genterite 195

IO.I Inleiding I95

10.2 De werkwijze van de Jongeren Inspectie Teams I95

10.3 Jongeren over hun gemeente: resultaten $\quad 197$

$\begin{array}{ll}10.4 & \text { Samenvatting en conclusies } \\ & 207\end{array}$

Noten 210

11. De effectivitet van lokad jeugabeleid: condusies 211

II.I Inleïding $2 \mathrm{II}$

Ir.2 De ontwikkeling van een lokaal jeugdbeleid 2 II

II.3 Resultaten van het lokale jeugdbeleid $2 \mathrm{I}_{3}$

II.3.I Onderzoeksuraag 2: output en outcome $2 \mathrm{r}_{3}$

II.3.2 Onderzoeksvraag 3: waardering jongeren $\quad 213$

II.3.3 Onderzoekswraag 4: intersubjectieve beoordeling beleid'sactoren $\quad 2 \mathrm{I4}$

II.4 Woorwaarden voor een effectief jeugdbeleid 214

II.4. I Onderzoekswraag 5: maatwerk $2 \mathrm{I} 4$

M.4.2 Onderzoekswraag 6: integrale beleidsvoering 216

II.4.3 Onderzoekswraag 7: slagvaardig beleid 218

II.4.4 Onderzoekswraag 8: toegankelijkheid lokaal bestuur 219

Ix.5 Conciusie: de effectiviteit van lokaal jeugdbeleid $\quad 2.20$ Noot $\quad 221$

DEEL III DE INULOED VAN NATIONAAL BELEID OP LOKAAL JEUGDBELEID

12 Het nationale jeugdbeléd 225

I2.I Inleiding 225

I2.2 Werkwijze bij de analyse van het nationale jeugdbeleid 227

12.3 Het nationale jeugdbeleid $\quad 229$

I2.3.I Gemeentelijke regie in het jeugdbeleid $\quad 229$

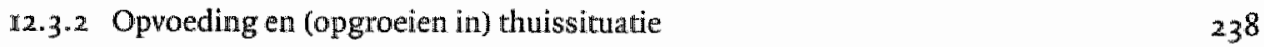

$\begin{array}{lr}\mathrm{r} 2.3 .3 \text { Onderwijs en scholing } & 248\end{array}$

$\begin{array}{ll}\mathbf{1 2 . 3 . 4} \text { Gezondheid } & \mathbf{2 6 8}\end{array}$

12.3.5 Vrije tijd $27 \mathrm{I}$

r2.3.6 Kinderopvang $\quad 277$

12.3.7 Veiligheid en openbare orde $\quad 286$

12.3 .8 Arbeid en inkomen $\quad 302$

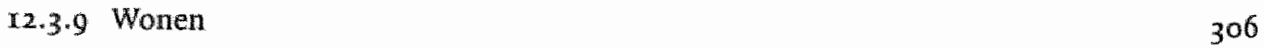

$\begin{array}{ll}12.4 \text { Conclusies } & 306\end{array}$

$\begin{array}{ll}\text { Noten } & 3 \text { II } \\ & 3\end{array}$

13 Slotbeschouwing: lokad en national beleid geconfronteed $\quad 316$

I3.I Inleiding 316

13.2 Beknopte samenvatting van de bevindingen
316 
I3.3 Doorwerking nationaal beleid in lokaal jeugdbeleid

I3.4 De bestuurlijke rolverdeling in het jeugdbeleid

13.5 Epiloog: naar een effectief jeugdbeleid

Noten

Sumthany 



\section{Gebruikte afkortingen}

$\begin{array}{ll}\text { ABW } & \text { Algemene bijstandswet } \\ \text { AMK } & \text { Advies- en Meldpunt Kindermishandeling } \\ \text { AMvB } & \text { algemene maatregel van bestuur } \\ \text { AWBZ } & \text { Algemene wet bijzondere ziektekosten } \\ \text { BANS } & \text { Bestuursakkoord Nieuwe Stijl } \\ \text { B\&W } & \text { Burgemeester en wethouders } \\ \text { BJZ } & \text { Bureau Jeugdzorg } \\ \text { BNP } & \text { Beleidsplan Nederlandse Politie } \\ \text { bSO } & \text { buitenschoolse opvang } \\ \text { BZK } & \text { Binnenlandse Zaken en Koninkrijksrelaties } \\ \text { CBS } & \text { Centraal Bureau voor de Statistiek } \\ \text { CMP } & \text { Centraal Meldpunt Jeugdhulpverlening } \\ \text { CPB } & \text { Centraal Planbureau } \\ \text { CRIEM } & \text { Criminaliteit in relatie tot de integratie van etnische minderheden } \\ \text { CtC } & \text { Communities that Care } \\ \text { GGD } & \text { Gemeentelijke, gewestelijke of gemeenschappelijke gezondheidsdienst } \\ \text { GOA } & \text { gemeentelijk onderwijsachterstandenbeleid } \\ \text { GSB } & \text { grotestedenbeleid } \\ \text { ho } & \text { hoger onderwijs } \\ \text { ICT } & \text { informatie- en communicatietechnologie } \\ \text { IPO } & \text { Interprovinciaal Overleg } \\ \text { ITB } & \text { individuele trajectbegeleiding } \\ \text { IVP } & \text { Integraal Veiligheidsprogramma } \\ \text { JGZ } & \text { Jeugdgezondheidszorg } \\ \text { IIB } & \text { Jeugd in Beweging } \\ \text { IIP } & \text { Jongeren Informatie Punt } \\ \text { IIT } & \text { Jongeren Inspectie Team } \\ \text { IJT } & \text { Jeugd-en Jongerenteam } \\ \text { JOP } & \text { Jongeren Ontmoetingsplaats } \\ \text { JUP } & \text { Jeugd Utrecht Peiling } \\ \text { IWG } & \text { Jeugdwerkgarantiewet } \\ \text { KOA } & \text { Kinderopvangregeling Alleenstaande Ouders } \\ \text { LBK } & \text { landelijk beleidskader } \\ \text { LVT } & \text { Landelijke Vereniging voor Thuiszorg } \\ \text { mbo } & \text { middelbaar beroepsonderwijs } \\ \text { NIZW } & \text { Nederlands Instituut voor Zorg en Welzijn } \\ \text { O\&O } & \text { opvoedingsondersteuning en ontwikkelingsstimulering } \\ \text { OALT } & \text { Onderwijs in Allochtone Levende Talen } \\ \text { OBD } & \text { Onderwijsbegeleidingsdienst } \\ \text { OCW } & \text { Onderwijs, Cultuur en Wetenschap } \\ & \end{array}$




\begin{tabular}{ll} 
OLPJ & Ontwikkeling lokaal preventiefjeugdbeleid \\
OM & Openbaar Ministerie \\
OOGO & Op Overeenstemming Gericht Overleg \\
po & primair onderwijs \\
RFV & Raad voor de financiële verhoudingen \\
RMC & Regionaal Meld- en Coördinatiepunt voortijdige schoolverlaters \\
ROC & Regionaal Opleidingencentrum \\
SCP & Sociaal en Cultureel Planbureau \\
SER & Sociaal-Economische Raad \\
SGBO & Onderzoeks- en Adviesbureau van de vNG (afkorting van: sociaal- \\
& geografisch en bestuurskundig onderzoek) \\
SRJV & Stichting Registratie Jeugd Voorzieningen \\
SST & Stedelijk Straathoekteam \\
SZW & Sociale Zaken en Werkgelegenheid \\
vmbo & Voorbereidend middelbaar beroepsonderwijs \\
vNG & Vereniging van Nederlandse Gemeenten \\
vo & voortgezet onderwijs \\
vSO & voortgezet speciaal onderwijs \\
vSV & voortijdig schoolverlaten \\
vve & voor- en vroegschoolse educatie \\
VWS & Volksgezondheid, Welzijn en Sport \\
WCPV & Wet Collectieve Preventie Volksgezondheid \\
WGR & Wet gemeenschappelijke regelingen \\
WiW & Wet inschakeling werkzoekenden \\
WMO & Wet maatschappelijke ondersteuning \\
WSNS & Weer Samen Naar School \\
WvC & Welzijn, Volksgezondheid en Cultuur \\
wW & Werkloosheidswet \\
& \\
\hline
\end{tabular}


Deel I

Inleiding en onderzoeksopzet 
Het gaat goed met de overgrote meerderheid van de Nederlandse jeugd, zo blijkt uit diverse recent verschenen publicaties (Zeijl et al. 2003; CBS 2003a; Ter Bogt et al. 2003; Zeijl et al. 2005). De meeste jeugdigen vinden dat zij opgroeien in welvarende gezinnen, woelen zich fysiek goed, melden weinig emotionele problemen en hebben goede contacten met ouders, vrienden en wriendinnen. Kortom: een groot deel van de jeugd is gelukkig en tevreden met het leven dat ze leidt. Dat neemt niet weg dat er een groep jeugdigen is die te maken heeft met problemen, dan wel in de ogen van de maatschappij problemen veroorzaakt. In het maatschappelijke debat is er veel aandacht voor de jeugd. Er is aandacht voor het opgroeien van kinderen in probleemgezinnen, zoals onder meer blijkt uit de maatschappelijke ophef rond de moord op de 3-jarige peuter Savanna en de rol van de jeugdzorg in het gezin. In 2002 vestigde een brandstichting in Roermond eveneens de aandacht op de rol van de jeugdzorg en van gezinsvoogden en andere opvoedingsondersteuners. Daarnaast is er aandlacht voor jongeren die problemen veroorzaken: allochtone jongeren die de leefbaarheid in de Amsterdamse Diamantbuurt aantasten, autochtone jongeren in onder meer Uden en Venraij die openlijk het conflict zoeken met de moslimgemeenschap in Nederland en jongeren die vanaf viaducten voorwerpen op de snelweg gooien.

De jeugd vormt dus een belangrijk thema in het maatschappelijke debat. Gezien het aandeel in de bevolking is dat ook niet zo vreemd. Circa eenderde van de Nederlandse bevolking is jonger dan 25 jaar. Bovendien maakt deze bevolkingscategorie een ontwikkelingsproces naar volwassenheid door waarin zich cruciale overgangen voordoen - zoals van gezinssituatie naar school en van school naar werk. En '(...) als het bij die ene schakel mis gaat, dan gaat het vermoedelijk ook mis in latere schakels (...)' (Schuyt 1995: 38-39). Het grote aantal schakels - Schuyt noemt er tien - maakt jeugdigen in potentie kwetsbaar en leidt ertoe dat zij een doelgroep voor het overheidsbeleid vormen (zie ook SCP 1998: IrI-Ir3). De groep jeugdigen die daadwerkelijk met problemen te maken heeft, is weliswaar relatief klein, maar de overheid streeft ernaar om problemen zoveel mogelijk te voorkomen.

Het is dan ook niet vreemd dat de jeugd sinds lange tijd object is van overheidsbeleid. Veel beleidssectoren raken in meer of mindere mate de leefsituatie van de jeugd. Dat geldt zeker woor het onderwijsbeleid, waarvan de meeste inspanningen direct gericht zijn op de jeugd. Maar ook het welzijnsbeleid, het arbeidsmark tbeleid, het veiligheidsbeleid en het zorgbeleid zijn voor een niet onaanzienlijk deel gericht op de jeugd. Naast dit algemene sectorale beleid is er specifiek beleid, ook wel categoraal jeugdbeleid genoemd, dat exclusief is gericht op de jeugd. Doorgaans wordt met dit 
beleid getracht de samenhang te bevorderen tussen het voor jeugdigen relevante beleid vanuit de verschillende sectoren. Indien sectorale regelingen onvoldoende zijn toegesneden op een bepaalde soort jeugdproblematiek, dan vormt categoraal beleid eventueel een aanvulling op het sectorale beleid. Het bestaan van sectoraal en specifiek jeugdbeleid maakt het jeugdbeleid tot een breed, veelomvattend beleidsterrein. Dit komt doordat in het specifieke beleid de verschillende sectoren samenkomen en er getracht wordt om daar samenhang in aan te brengen. De daaruit voortvloeiende spanning tussen enerzijds sectoraal en anderzijds specifiek, categoriaal beleid is inherent aan het jeugdbeleid.

Het specifieke jeugdbeleid heeft een kortere historie dan het sectorale jeugdbeleid. Kort na de Eerste Wereldoorlog was er voor het eerst sprake van een specifiek jeugdbeleid. ${ }^{x}$ Dit kwam voort uit de ongerustheid over het baldadige gedrag van jeugdigen. Een dergelijke ongerustheid lag daama vaker ten grondslag aan de roep om specifiek jeugdbeleid. Soms hebben echter ook positieve gedachten over de jeugd een rol gespeeld, zoals in de jaren zestig en zeventig. Men erkende toen dat jeugdigen een eigen identiteit hebben, en begon de jeugd vaker te zien als vernieuwingsbeweging. Tot in de jaren zeventig lag het accent in het specifieke jeugdbeleid op de vrijetijdsbesteding. Het doel was daarbij aanvankelijk vooral om de jeugd zedelijk en cultureel te verheffen. Later kreeg men meer oog voor de wensen van jongeren zelf. Vanaf de jaren zeventig kwam bovendien de nadruk veel meer te liggen op de aanpak van (achterstands) problemen onder jongeren. Daardoor werden met het specifieke jeugdbeleid voortaan ook sectoren als huisvesting, arbeidsbemiddeling, inkomensverwerving en justitie bestreken. Deze beleidskeuze impliceerde dus een ontwikkeling van een smal naar een breed specifiek jeugdbeleid, waarin de noodzaak van intersectorale afstemming groter werd en daarmee ook de spanning tussen sectoraal en categoriaal beleid.

In de jaren tachtig koos de rijksoverheid in eerste instantie voor een ambitieus en breed geformuleerd jeugdbeleid, waarvan het doel zou moeten zijn het scheppen van voorwaarden voor een optimale ontplooiing van de jeugd. In het midden van de jaren tachtig werden de ambities wat bescheidener. Het jeugdbeleid zou moeten bijdragen aan de groei van de jeugd naar zelfstandigheid. De primaire verantwoordelijkheid voor dit proces lag echter niet bij de overheid, maar bij gezin, school en verenigingsleven. De overheid zou voorwaarden moeten scheppen en aanvullend beleid moeten voeren in het geval van probleemcumulatie en daar waar de traditionele socialisatiekaders tekortschoten. Men kan stellen dat in de jaren zeventig en tachtig de aandacht werd verlegd van de jeugd in haar geheel naar risicogroepen en van een algemeen naar een probleemgericht specifiek jeugdbeleid.

In de jaren negentig werd op nationaal niveau een andere richting gekozen in het specifieke jeugdbeleid. De belangrijkste doelen werden het bevorderen van kansen en het voorkomen van uitval (Wrc 1993; wvC en Justitie r994). Deze twee hoofddoelen 
werden vertaald in een aantal meer concrete beleidsdoelstellingen (wvc r993: 38): de participatie van jeugdigen zou bevorderd moeten worden, voorzjeningen en beleid zouden zo ingericht moeten zijn dat alle jeugdigen deelnemen aan onderwijs en/of arbeidsproces, jeugdproblematiek zou systematisch en gericht voorkomen moeten worden, en jeugdigen die uitvallen of dreigen dat te doen zouden opgevangen en teruggeleid moeten worden. Een van de achterliggende gedachten was om de effectiviteit en de efficiëntie in de jeugdhulpverlening te versterken, door het toenemende beroep op de jeugdzorg in te dammen (WvC en Justitie 1994). Het preventieve beleid zou langs verschillende lijnen gestalte moeten krijgen - veiligheid, onderwijs, gezondheids- en jeugdzorg, jeugdwelzijnswerk en arbeidsbemiddeling - en daarbij zou gestreefd moeten worden naar een integrale, sluitende benadering.

Ook in het huidige overheidsbeleid neemt de jeugd een belangrijke plaats in. $\mathrm{Op}$ Prinsjesdag 2002 onderstreepte de regering in de Troonrede nog maar eens hoe belangrijk het is om de lijn voort te zetten die sinds het midden van de jaren negentig bepalend is voor het jeugdbeleid. Er wordt groot belang gehecht aan een geïntegreerd jeugdbeleid dat inzet op preventie, met indien nodig ook corrigerende en repressieve maatregelen. De algemene doelstelling van het jeugdbeleid is, zo blijkt uit de begroting van het coördinerende ministerie van Volkshuisvesting, Welzijn en Sport (vws), de versterking van de positie van jongeren in de samenleving, de vergroting van hun kansen en het tegengaan van uitval. Om die doelstelling te bereiken, wordt veel nadruk gelegd op het belang van effectieve bestuurlijke samenwerking tussen bij het jeugdbeleid betrokken partijen: 'we spannen ons in voor een samenhangende, sluitende en vraaggeoriënteerde infrastructuur voor jeugdigen (jeugdketen)' (TK 2002/2003a).

\subsection{Bestuurtijke rolverdeling in het jeugdbeleid}

Lange tijd speelde de centrale overheid een dominante rol in voor het jeugdbeleid relevante sectoren. In het welzijnsbeleid (jeugdwerk, peuterspeelzalen, speeltuinen, kinderopvang) was het rijk tot $x_{97} 6$ de belangrijkste subsidiegever, en leverden provincies en gemeenten eventueel bijdragen. Vanaf 1976 werd begonnen met de decentralisatie van het welzijnsbeleid, aanvankelijk via rijksbijdrageregelingen, en vanaf 1987 via de Welzijnswet. ${ }^{2}$ De beleidsvrijheid voor gemeenten werd daarbij steeds groter. Het beleid op het gebied van de jeugdzorg werd tot $r 989$ door het rijk of via de AWBZ gefinancierd. Met de Wet op de jeugdhulpverlening vond in 1989 een overdracht van bevoegdheden plaats aan provincies en de drie grootstedelijke regio's Amsterdam, Rotterdam en Haaglanden. Ook op het gebied van onderwijsbeleid hebben gemeenten vanaf het midden van de jaren negentig meer taken en bevoegdheden gekregen (Bronneman-Helmers r999: 46-47), vooral op het gebied van onderwijshuisvesting, onderwijsachterstandenbeleid, het beleid rond de allochtone levende talen en de schoolbegeleiding. 
De inhoudelijke koerswijziging in het begin van de jaren negentig, zoals in paragraaf $\mathrm{I} . \mathrm{x}$ is beschreven, ging gepaard met de formele bevestiging van de langzaam gegroeide bestuurlijke rolverdeling, waarin gemeenten een steeds belangrijker plaats in gingen nemen. In het regeringsstandpunt Regie in de jeugdzorg werd een expliciete bestuurlijke rolwerdeling voorgestaan. Gemeenten zouden de regie moeten gaan voeren over een gericht preventief jeugdbeleid, om het toenemende beroep op de jeugdzorg in te dammen. "Een dergelijk beleid zal tot doel moeten hebben de samenwerking tussen relevante sectoren als het onderwijs, de eerstelijnsgezondheidszorg en de collectieve preventie (...), de arbeidsvoorziening, justitie, politie en de sociale diensten te versterken om zodoende een vroegtijdige uitval van jeugdigen te voorkomen.' (wvc en Justitie 1994: 7) Provincies en de drie grootstedelijke overheden kregen als taak een samenhangende jeugdzorg vorm te geven. Daarbij diende in ieder geval de samenwerking tussen de jeugdbescherming, de geestelijke gezondheidszorg voor jeugdigen en de geïndiceerde jeugdhulpverlening te verbeteren. De centrale overheild zou zich beperken tot kerntaken, en in nauw overleg met andere overheden een richtinggevend kader aangeven. Faciliteren, innoveren en monitoren horen tot die kerntaken (vws I995). Daarnaast is de centrale overheid, c.q. de minister van Welzijn, Volksgezondheid en Cultuur (wvc), verantwoordelijk voor het bevorderen van de noodzakelijke samenhang in het beleid (wvC 1993: 4I).

Deze bestuurlijke rolverdeling is onder meer in twee zogenaamde Bestuursakkoorden Nieuwe Stijl werder uitgewerkt (BANS I999a; BANS 2001). In deze overeenkomsten tussen diverse departementen, het Interprovinciaal Overleg (IPO) en de Vereniging van Nederlandse Gemeenten ( $\mathrm{VNG}$ ) is getracht tot een gezamenlijke visie op het jeugdbeleid te komen. Ook in deze BANS-akkoorden komt de prominente positie van gemeenten in het jeugdbeleid tot uiting. Het zijn gemeenten die de taak hebben om te komen tot een sluitende-omvattende en samenhangende-aanpak in het jeugdbeleid. De provincies blijven verantwoordelijk voor de jeugdzorg, die hoofdzakelijk curatief is georiënteerd, en worden verondersteld gemeenten te ondersteunen. Dit laatste geldt ook voor het rijk. Naast een ondersteunende functie door het stimuleren van kwaliteit en vernieuwing en door onderzoek en monitoring, is het rijk verantwoordelijk voor de wettelijke kaders en gedeeltelijk voor de financiering van voorzieningen voor jeugdigen.

Aan gemeenten wordt in het jeugdbeleid dus een regierol toebedacht. In de beleidsnota Perspectief voor jeugdigen, kansen voor gemeenten (Vws x995) wordt nader ingegaan op de gemeentelijke regie in het jeugdbeleid. De belangrijkste elementen daarin zijn een eenduidige visie met daaraan gekoppelde concrete doelen, het daartoe beschikbaar krijgen van in formatie over de jeugd en het relevante voorzieningenaanbod ('zicht op jeugd') , en de aansturing van yoorzieningen zodat de samenhang in het aanbod wordt versterkt. Uitgangspunt in de gemeentelijke regie is de gelijkwaardigheid van de drie betrokken partijen: gemeente, voorzieningen en jeugdigen en hun opvoeders. Belangrijke instrumenten in de gemeentelijke regie zijn netwerkvorming en netwerksturing (Hupe en Klijn $1997: 34-35) .^{3}$ 
De voorgestane bestuurlijke rolverdeling heeft bijgedragen aan een complexe bestuurlijke context (Gilsing et al. 2000: 106). Gemeenten hebben te maken met weten regelgeving en beleidskaders van diverse departementen, die vaak verschillend omgaan met de decentralisatie van taken en bevoegdheden. De mate van beleidsvrijheid wan gemeenten verschilt per sector, en is afhankelijk van de aard van de opgedragen taken, de instrumenten, de financieringswijze, de instructienormen en de verantwoordingsprocedures. De beleidscultuur verschilt per departement (Bressers en Ringeling 1989; Veenswijk en Kickert r993; Kickert r993a; Veenswijk 1996; Koot en Dobbinga 2004). Dit uit zich in verschillende ambitieniveaus en wijzen waarop taken aan gemeenten worden opgelegd, respectievelijk waarop gemeenten om medewerking worden gevraagd. Niettemin wordt van gemeenten verwacht dat zij tot een integraal jeugdbeleid komen.

Er wordt dus verwacht dat de in paragraaf I.I gesignaleerde spanning tussen sectoraal en specifiek jeugdbeleid vooral door gemeenten wordt opgelost, of in ieder geval hanteerbaar wordt gemaakt. Hupe en Klijn (1997: 25) waarschuwen in dit verband voor de zogenoemde decentralisatieval: 'de veronderstelling dat sturingstekorten automatisch worden vermeden door sturingsambities op rijksniveau op de gemeente te projecteren. Ook de gemeente is niet a priori de rationele publieke actor die dwingend ervoor kan zorgen dat aan de voorwaarden voor effectieve directe sturing wordt voldaan.' (zie ook Pierre en Peters 2000: 88). Op deze spanning zullen we verder ingaan in paragraaf $\mathrm{x} .3$.

\subsection{Autonome gemeenten en bestuurlije vervlechting}

De geschetste bestuurlijke rolverdeling is niet uniek voor het jeugdbeleid. In een meer algemene schets van de historische ontwikkeling van de relatie tussen centrale overheid en lokale overheden in Nederiand neemt Veldheer (1994: 236-237) een ontwikkeling waar van een situatie waarin lokale overheden relatief autonoom opereerden (van het midden tot het einde van de negentiende eeuw) naar een situatie waarin de interactie tussen overheden het meest kenmerkend is voor de relatie. Daarbij is sprake van beleidswervlechting (vgl. Bleker en Van den Breemen 1983: 15; Roes et al. 1987; Pröpper 1996), ook wel aangeduid als co-governance (Goldsmith 2002: 108). ${ }^{4} \mathrm{De}$ overheden zijn wederzijds afhankelijk en in de praktijk zijn daardoor complexe en ondoorzichtige bestuurlijke verhoudingen ontstaan. Toonen (2000: 203) typeert het Nederlandse politiek-bestuurlijke systeem als hybride: 'a strange marriage between unity and plurality', weerspiegeld in het begrip 'gedecentraliseerde eenheidsstaat'. Op het terrein van het welzijnsbeleid spreken Van Kesteren en Korsten (r993:465) van functionele complementariteit: de verantwoordelijkheid voor diverse typen voorzieningen is in de Welzijnswet bij verschillende overheidslagen gelegd.

De complementaire bestuurlijke rolverdeling tussen de overheden is niet onproblematisch, want deze leidt tot een onduidelijke afbakening van taken en verantwoor- 
delijkheden (vgl. Hesse en Sharpe I9gr: 615). Enerzijds wordt geleund op de gedachte dat de decentrale uitvoering van taken en bevoegdheden tot effectiever beleid leidt dan in het geval van centraal beleid. Anderzijds wordt de lokale beleidsruimte ingeperkt door de (sectorale) ambities van de centrale overheid, die tot uiting komen in wet- en regelgeving en in andere beleidsinstrumenten die de lokale beleidsruimte inperken. Het aan lokaal bestuur inherente conflict (ineradicable ambiguity, Page I9gI) tussen de zeggenschap van de lokale gemeenschap en de ondergeschiktheid aan de nationale overheid die de structuur en bevoegdheden van het lokaal bestuur bepaalt (vgl. Baldersheim en Ståh.lberg 2002), is in de Nederlandse situatie versterkt aanwezig.

Het bijzondere aan de Nederlandse interbestuurlijke verhoudingen is bovendien dat lokale overheden sterk financieel af hankelijk zijn van de nationale overheid (Goldsmith 2002: 108; Hoogerwerf I980). Vergeleken met andere staten met soortgelijke interbestuurlijke verhoudingen is Nederland het enige land waarin lokale overheden financieel grotendeels afhankelijk zijn van de nationale overheid en over een beperkt eigen belastinggebied beschikken (vgl. Hesse en Sharpe I99r; Goldsmith 2005). De financiële afhankelijkheid verschilt echter per sector van het overheidsbeleid (Osterkamp en Eller 2003).

Deze duale opvatting wordt ook weerspiegeld in het debat over de positie van de gemeente in de Nederlandse staatsinrichting. Het debat ontspint zich tussen aanhangers van het model van de eenheidsstaat en die van het organische model. In het model van de eenheidsstaat wordt de verhouding tussen nationale en lokalle overheden vooral beschreven in termen van hiërarchische structuren (Van Poelje rg63: I2r; Hennekens 2000). Er is sprake van centrale sturing van lokale waarden (Derksen 1985). Gemeenten zijn uityoerders van centraal beleid en kunnen worden gezien als instrumenten van de centrale overheid. Decentralisatie is in deze visie het overhevelen van bevoegdheden, en niet een weerspiegeling van veranderende machtsverhoudingen. In het organische model beschikken de verschillende delen van de staat echter elk over een zekere zelfstandigheid, zijn zij soms afhankelijk van andere delen, en kan hun zelfstandigheid worden beperkt als het belang van de staat, of een deel daarvan, in het geding is (Willemse 200r: 10-In). Gemeenten beschikken over een eigen huishouding: zij nemen op bepaalde terreinen zelf initiatieven, doen dit in samenhang met andere terreinen, en verschillen daarin onderling en in de tijd van elkaar (Willemse 200I: 12). Kortom: gemeenten hebben in deze visie een belangrijke mate van autonomie en er is sprake van wederzijdse afhankelijkheid tussen de overheidslagen. ${ }^{5}$

Het debat over de twee modellen wordt op normatief en empirisch niveau gevoerd. Het normatieve debat spitst zich toe op de vraag hoe de verhouding tussen centrale overheid en lokale overheden eruit zou moeten zien, gegeven de fundamenten van het huis van Thorbecke (vgl. Elzinga en Hagelstein 1998; Willemse 20or; Fleurke 2004). Is er in de Nederlandse staatkundige verhoudingen ruimte voor gemeenten met een relatief zelfstandige huishouding (Toonen 1998: 46) en zijn zij te zien als partners van de centrale overheid? Of is er meer te zeggen voor gemeenten als agenten 
van de centrale overheid, primair belast met de uitvoering van centraal beleid (vgl. Toonen $198 \mathrm{I}$ )? In het empirische debat staat de vraag centraal hoe de relatie er daadwerkelijk uitziet. Hebben gemeenten een autonome, eigen huishouding, of voeren zij vooral taken uit op gezag van de centrale overheid? In paragraaf I.3.I en I.3.2 gaan we beknopt in op beide debatten, waarbij geenszins ook maar de schijn van volledigheid wordt nagestreefd. ${ }^{6}$

\subsubsection{Het normatieve debat}

Argumenten voor een organisch staatsmodel

De overwegingen voor een relatief zelfstandig, democratisch gemeentebestuur zijn in grote lijnen terug te brengen tot drie hoofdargumenten: doelmatigheid, machtsevenwicht en participatie (Denters 1989: 324-326).

Het doelmatigheidsargument komt er op neer dat zelfstandige, democratische gemeenten beter in staat zijn de lokale overheidswoorzieningen te leveren die de burgers wensen. Het gaat in feite om twee argumenten: technische en allocatieve doelmatigheid.

Het argument van technische doelmatigheid stelt dat gemeenten bepaalde lokale voorzieningen tegen lagere kosten kunnen treffen dan de centrale overheid. Hiermee hangt het idee samen dat gemeenten bij een gecentraliseerde besluitvorming over voorzieningen minder zorgvuldig een afweging tussen kosten en baten zullen maken omdat de voorzieningen voor hen bijna gratis zijn. Voor de centrale overheid is het veel moeilijker voor elke gemeente afzonderlijk deze afweging te maken. Dit argument wordt in het vervolg van dit onderzoek aangeduid als de efficiëntie van beleid.

Allocatieve doelmatigheid houdt in dit kader in dat democratische gemeenten beter dan de centrale overheid kunnen inspelen op de lokale behoeften aan (overheids)voorzieningen. Gekozen vertegenwoordigers, en indirect de inwoners van een gemeente, kunnen zelf zorgvuldig de kosten en baten van alternatieve voorzieningen afwegen. Op deze manier is het bovendien beter mogelijk rekening te houden met specifiek lokale omstandigheden, omdat lokale vertegenwoordigers hiervan beter op de hoogte zijn. Dit argument duiden we in het vervolg aan als de effectiviteit van beleid.

Het tot stand brengen van machtsevenwicht (checks and balances), het tweede hoofdargument, komt voort uit het klassieke idee van de machtenscheiding. Naast horizontale machtenscheiding tussen wetgevende, uitvoerende en rechterlijke macht, kan ook verticale machtenscheiding voorkomen dat staatsmacht in te sterke mate op een beperkt aantal plaatsen geconcentreerd raakt. Spreiding van staatsmacht over verschillende bestuurslagen leidt ertoe dat burgers nilet afhankelijk zijn van één bestuurslaag.

Het bevorderen van politieke participatie is het derde hoofdargument. Door de politiek op kortere afstand van de burger te brengen, nemen de mogelijkheden voor politieke participatie toe. Politieke participatie wordt om verschillende redenen positief gewaardeerd. In de eerste plaats wordt er een educatieve functie aan toegedicht. Door 
de kleinschaligheid van de gemeentepolitiek wordt in deze zin vaak gesproken van de gemeente als leerschool van de democratie (zie bijvoorbeeld Van Poelje r95I: I27-130; Almond en Verba 1963: I64; Veldheer 1994: 28; Castenmiller 1994: 2). In de tweede plaats zou politieke participatie een meer instrumentele rol vervullen: het stelt burgers in staat hun belangen te behartigen bij de overheid. Gemeenten zijn woor burgers en maatschappelijke organisaties toegankelijker dan de nationale overheid (vgl. Lelieveldt 1999). Deze rol is ook belangrijk in het licht van de eerder genoemde doelmatigheids- en machtsevenwichtargumenten. De gemeente is slechts in staat om op lokale behoeften toegespitste voorzieningen te treffen en als belangenbehartiger voor haar burgers bij hogere overheden op te treden, indien zij op de hoogte is van de wensen en eisen van haar burgers. Hoe meer burgers participeren, hoe beter gemeenten worden geïnformeerd over die wensen en eisen.

In de discussies over decentralisatie die vanaf de jaren tachtig van de vorige eeuw in het Nederlandse openbaar bestuur zijn gevoerd, spelen vooral het doelmatigheids- en participatieargument een rol (Fleurke et al. 1997: 9).7 Ook het machtsevenwichtargument wordt echter soms genoemd (zie bijwoorbeeld TK 1992/1993: Ir). Bij het doelmatigheidsargument wordt zowel aan efficiëntie als aan effectiviteit gerefereerd. Bij het participatieargument is vooral de instrumentele rol van participatie - de belangenbehartiging van burgers bij de overheid - van belang. Zo werden in de in 1980 verschenen Decentralisatienota van de regering als voordelen van decentralisatie genoemd: de mogelijkheid tot maatwerk, betere toegankelijkheid voor de burger, efficiëntie, betere beheersbaarheid en effectiviteit, vrijheid en variatie, en meer democratische invloed van burgers op concrete voorzieningen (TK $1980 / \mathrm{Ig} 8 \mathrm{I}$ ). In het advies van de commissie-Franssen uit 1993 werden in grote lijnen dezelfde overwegingen genoemd (TK 1992/1993: 42-43). Zij worden als volgt samengevat (TK r992/I993: 95): 'Decentralisatie wordt vaak aangeprezen als het middel bij uitstek om de publieke besluitvorming van haar bureaucratische ballast en haar onsamenhangende karakter te ontdoen. De lokale (en onder voorwaarden regionale en provinciale) democratie zouden borg staan voor politieke betrokkenheid en een grotere doelmatigheid.' Er wordt gestreefd naar meer maatwerk en diversiteit op een zo laag mogelijk bestuurlijk niveau vanuit de veronderstelling dat het op decentraal niveau eenvoudiger is voor samenhang in beleid te zorgen.

\section{Argumenten voor de eenheidsstaat}

Voorstanders van de eenheidsstaat, waarbij decentrale overheden als uitvoerende agenten van de centrale overheden fungeren, wijzen op het belang van uniformiteit, rechtsgelijkheid en de te behalen schaalvoordelen (vgl. Lane 1993: 203). Centrale overheidssturing wordt gezien als noodzakelijke voorwaarde voor uniformiteit (Toonen r987: 156). Veel maatschappelijke problemen die op de beleidsagenda van de overheid komen, overstijgen het lokale niveau. Zij zijn gebaat bij een nationale aanpak, die effectiever en efficiënter kan zijn dan een decentrale aanpak. Een eenheidsstaat zou een betere garantie vormen woor een evenwichtige spreiding en een 
voldoende kwaliteit van voorzieningen (vgl. TK 1980/1981; rK 1992/r993; Van Kesteren en Korsten 1993: 443). Van Poelje heeft in 1946 zelfs betoogd dat het toen reeds in gang zijnde en omwille van de uniformiteit noodzakelijke proces van centralisatie doet vrezen voor het bestaan van gemeenten (Willemse 20or: 37). Andere auteurs benadrukken de functie van gemeenten als werktuig van het rijk, zoals Brasz ( $\mathrm{g} 960$ ). Hij beschrijft de ontwikkeling naar een in belang toenemend functioneel bestuur en de ontwikkeling van maatschappelijke schaalvergroting. Beide ontwikkelingen doen de betekenis van de gemeente als autonome bestuurslaag afnemen. Bovendien is door de opkomst van de massamedia een gelijkvormig voorzieningenniveau bij de gemeenten wenselijk geworden. Gemeenten dienen dan ook vooral uitvoering te geven aan landelijke eisen ten aanzien van dit voorzieningenniveat. Een eigen, zelfstandige huishouding van gemeenten wordt daardoor overbodig. In het algemeen geldt dat in het model van de eenheidsstaat functionele decentralisatie te prefereren is boven territoriale decentralisatie.

\subsubsection{Het empirische debat}

Ook empirisch heeft de vraag of gemeenten in de Nederlandse bestuurlijke verhoudingen een relatief zelfstandige positie innemen, dan wel in hoofdzaak een werktuig van het rijk zijn, tot stevige debatten geleid. Deze debatten weerspiegelen voor een deel de in de tijd veranderende verhouding tussen overheden. Die verhouding is immers niet statisch (vgl. Sharpe r988; Goldsmith en Newton 1983 ; Willemse 200r; Veldheer 1994; Denters en Veldheer 1998).

Aanwijzingen voor het bestaan van een organische staat

Recent heeft Willemse (200r) geconstateerd dat de uitgangspunten van de organische staatstheorie nog recht overeind staan in de Nederlandse bestuurlijke praktijk. Hij verrichtte in vier gemeenten onderzoek naar de veronderstelde beperking van de zelfstandige positie van gemeenten en vond geen aanwijzingen voor een dergelijke beperking. Eerder moesten Hesse en Sharpe (199r) de hypothese van een sterk centralisme in Nederland verwerpen, die zij formuleerden op basis van het gegeven dat Nederlandse gemeenten sterk financieel afhankelijk zijn van de nationale overheid.

In het debat wordt vaak aangevoerd dat de feitelijke verhouding tussen gemeenten en de nationale overheid niet noodzakelijk gelijk is aan de formele (juridische) verhouding (Bleker en Van den Breemen r983: 97; Derksen 1985; Toonen en Hendriks 1998 ). Gemeenten beschikken over een aantal specifieke machtsbronnen, zoals lokale kennis, informatie, steun en legitimiteit, die maken dat er een wederzijdse afhankelijkheid tussen rijk en gemeenten bestaat. Bovendien kunnen gemeenten door gebruik te maken van de verkokering bij het rijk hun beleidsruimte groter maken dan deze in formele zin is (Derksen 1985 ; Roes et al. 1987:5). Of, zoals Toonen en Hendriks (1998: 127) stellen: 'De in hoofdlijnen hiërarchische staatsrechtelijke structuur blijkt de invloed van gemeenten op veel beleidsterreinen niet in de weg te staan.' 
Aanwijzingen voor het bestaan van een eenheidsstaat

veelvuldig is de afgelopen decennia gewezen op de centralisatie van het Nederlandse openbaar bestuur (zie het overzicht in Willemse 2001). De autonomie van gemeenten is afgenomen, het belang van regio's en van functioneel bestuur is toegenomen. Bekke (Ig9r: 123) formuleert het zeer stellig: 'In the last four decades in particular a growing central government has brought about a situation in which local authorities function to a great extent as offices for central government in the local community. Departments and ministries in The Hague take most of the main policy decisions, giving instructions and financial resources to their local outstations. Only a small part of the real political policy-making is reserved to the city-councils.' Groenendijk (1998) concludeert dat de lokale responsiviteit beperkt is en dat de decentralisatie wordt gefrustreerd door de gevoelde noodzaak tot gelijkheid tussen gemeenten (vgl. Langbroek $1988: 338$ ).

De positie van het lokale bestuur is onder meer verzwakt door functionele decentralisatie. Het takenpakket en de beleidsmarges van functionele organen interfereren niet zelden met het takenpakket van gemeenten. Bovendien zijn gemeenten afhankelijk geworden van deze functionele organen en beschikken zij over onvoldoende instrumenten om de medewerking van functionele organen aan lokaal beleid af te dwingen (Hagelstein 1993; RBB 1995: 21). Het voeren van integraal beleid door gemeenten wordt belemmerd door de functionele verbrokkeling van het werkterrein (vgl. Willemse 200I: 6g).

Er wordt bovendien gewezen op het gebrek aan eigen middelen bij gemeenten. Het eigen belastinggebied is beperkt, en van de rijksmiddelen wordt het grootste deel uitgekeerd als specifieke uitkering. Voor Willemse is dit aanleiding zijn hypothese van het onmogelijke initiatief van gemeenten te formuleren (die hij uiteindelijk verwerpt; zie hierboven): gemeenten zouden bepaalde initiatieven niet kunnen nemen va nwege een gebrek aan eigen middelen. Volgens Brasz (I960) vloeit het geringe eigen belastinggebied op logische wijze voort uit het gelijkheidsbeginsel (de egalisatie van de plaatselijke voorzieningencapaciteiten). Een groot belastinggebied zou de kans op ongewenste verschillen tussen gemeenten te groot maken.

\subsubsection{Conclusie}

Over de vragen welke positie de gemeente in het staatsbestel in zou moeten nemen en welke zij daadwerkelijk inneemt, bestaat geen consensus. Het is echter duidelijk dat in het politieke discours aan de idee van de organische staat de laatste twee decennia veel lippendienst wordt bewezen, getuige de voornemens ten aanzien van (territoriale) decentralisatie. Uniformiteit en gelijkvormigheid in voorzieningen lijken aan belang in te boeten.

In het empirische debat wordt er vanuit een juridische of formele benadering vaak op gewezen dat de centralisatietendensen kenmerkend zijn voor de bestuurlijke verhoudingen. Vanuit bestuurskundig oogpunt wordt vooral gewezen op de vervlechting van bestuurslagen. Toonen en Hendriks (1998: 133) signaleren 'een ontwikkeling naar een bestuurlijk stelsel waarin differentiatie en interdependentie de wezenskenmerken zijn', waarbij territorialle en functionele scheidslijnen door elkaar heen lopen. 
Voor de bestuurlijke rolverdeling in het jeugdbeleid is de vraag naar de feitelijke rolverdeling relevant. Wat zijn nu precies de opvattingen over deze rolverdeling en hoe ziet de verhouding tussen nationaal en lokaal jeugdbeleid er daadwerkelijk uit? Hebben gemeenten een relatief zelfstandige positie op het terrein van jeugdbeleid? Zijn zij in staat een adequaat jeugdbeleid te ontwikkelen? En wat is dan de toegevoegde waarde van het centrale beleid? Of is de gemeente toch wooral uitvoerder van centraal beleid? Het doel van dit onderzoek is een antwoord te geven op deze vragen.

Bovenstaande vragen naar de mogeiljkheden die gemeenten hebben om binnen de gegeven bestuurlijke rolverdeling in het jeugdbeleid een eigen, effectief jeugdbeleid te voeren, vormen het uitgangspunt van dit onderzoek. Daarom worden twee centrale vragen gesteld. De eerste vraag gaat over de verwachtingen ten aanzien van decentralisatie. Kunnen gemeenten in hun jeugdbeleid de normatieve verwachtingen met betrekking tot een zelfstandige, democratisch gelegitimeerde positie waarmaken? De vraag is als volgt geformuleerd:

Centrale vraag 1: In hoeverre blijken gemeenten in staat om een effectief jeugdbeleid tot stand te brengen?

Bij het formuleren van deze eerste centrale vraag is participatie als intrinsiek motief voor decentralisatie benaderd vanuit een instrumenteel perspectief (zie Elsinga 1985 : 22-30; Castenmiller 1988:23-26). Met andere woorden: participatie is van belang omdat het bijdraagt aan het toespitsen van het beleid op de wensen en behoeften van burgers, c.q. jeugdigen, en daarmee aan een effectief beleid. Daarom wordt participatie opgevat als een factor die bij kan dragen aan een effectief beleid. ${ }^{8}$ Bovendien wordt efficiëntie opgevat als een afgeleide van effectiviteit: als beleid niet effectief is - de gewenste doelen worden niet gehaald - kan het per definitie niet efficiënt zijn. De verhouding tussen beleidskosten en -baten is daarom geen object van onderzoek in deze studie.

Deze centrale vraag wordt in paragraaf $\mathrm{x} .5$ uitgewerkt in onderzoekswragen.

De tweede centrale vraag gaat over de wijze waarop de centrale overheid zich in het jeugdbeleid positioneert ten opzichte van lokale overheden, en over de gevolgen daarvan voor het lokale jeugdbeleid:

Centrale vraag 2: Op welke wijze tracht de centrale overheid het lokale jeugdbeleid te beinuloeden en wat betekent dat voor de mogelijkheden die gemeenten hebben om een effectiefjeugdbeleid tot stand te brengen?

In paragraaf I.6 wordt deze tweede centrale vraag uitgewerkt in onderzoeksvragen. 
Omdat in dit onderzoek een sterke nadruk ligt op de effectiviteit van beleid, hanteren we hier een instrumentele beleidsopvatting (vgl. Gilsing et al. 1999: 24-25). In beleidswetenschappelijk onderzoek is vaak de vraag aan de orde of de nadruk wordt gelegd op de meest krachtige verklarende variabelen, dan wel op de voor beleidsactoren meest manipuleerbare predictoren (Bressers I988: 270; Lane rg93: 22I-222). Het laatste, instrumentele perspectief impliceert dat er niet naar een maximale verklaring wordt gezocht. Vaststaande omgevingsfactoren kunnen een sterk werklarende kracht hebben, maar worden desondanks slechts als achtergrondvariabelen meegenomen. Simonis en Lehning (1987: 12-18) spreken in dit verband van het actorenperspectief; dit wordt ook wel de beleidsanalytische of subjectivistische benadering genoemd. ${ }^{9}$

In deze instrumentele visie wordt beleid opgevat als een rationele ordening van doeleinden en middelen (vgl. Van de Graaf en Hoppe r989: 43-46). Er wordt uitgegaan van de opvatting dat de beleidsuitkomsten primair afhankelijk zijn van het geformuleerde beleid, en van de wijze waarop de beleidsvorming, beleidsuitvoering en beleidsevaluatie zijn vormgegeven.

\subsection{Effectief lokaal jeugdbeleid: anderzoeksuragen en operationalisering}

\subsubsection{Specifiek jeugdbeleid}

In deze paragraaf zal nader worden ingegaan op vragen die betrekking hebben op de eerste centrale onderzoeksvraag: zijn gemeenten in staat een effectief jeugdbeleid te voeren. De eerste vraag daarbij is of gemeenten een specifiek, gericht jeugdbeleid hebben ontwikkeld. Het voeren wan dergelijk beleid is vanzelfsprekend een noodzakelijke voorwaarde om te kunnen oordelen over de effectiviteit ervan.

Onderzoeksuraag 1) In hoeverre hebben gemeenten een specifiek jeugdbeleid ontwikkeld?

In het eerdere onderzoek van het Sociaal en Cultureel Planbureau (SCP) naar lokaal jeugdbeleid (Gilsing 1999) is een maat geconstrueerd om de ontwikkeling van het jeugdbeleid te kunnen meten. In deze maat 'staat van het jeugdbeleid' zijn een aantal aspecten van het jeugdbeleid betrokken. Er wordt gekeken naar de formulering van een specifiek, categoraal jeugdbeleid, naar de mate van integraliteit van dat beleid, en naar de aandacht voor het in kaart brengen van beleidseffecten. De staat van het jeugdbeleid wordt ook in dit onderzoek onderzocht, en daardoor wordt het mogelijk om de veranderingen sinds 1998 in kaart te brengen.

\subsubsection{Effectiviteit en voorwarden voor effectiviteit}

Effectiviteit is een complex onderzoeksthema. In enge zin duidt het op doelbereiking, ofwel de mate waarin vooraf gestelde beleidsdoelen zijn gerealiseerd. Zeker in het geval van sociaal beleid speelt de meetbaarheid van gewenste doelen of resultaten vaak een rol. Doelen of resultaten worden immers vaak geformuleerd als veranderingen in bepaalde aspecten van de leefsituatie van burgers. Om te bepalen of het doel is bereikt, is dan al snel afzonderlijk vergaarde informatie noodzakelijk. Tevens zijn de 
doelen van sociaal beleid vaak niet of slechts vaag omschreven. In brede zin gaat het bij effectiviteit om de bijdrage van het beleid aan die doelbereiking - de doeltreffendheid. Was het doel ook bereikt indien er geen beleid was geweest, of was juist het gevoerde beleid verantwoordelijk woor de bereikte doelen?

Vanwege de complexiteit van het effectiviteitsbegrip wordt effectiviteit in dit onderzoek langs twee wegen benaderd. In de eerste plaats kijken we naar de uitkomsten van het jeugdbeleid. Daarnaast zullen we ingaan op een aantal voorwaarden voor effectief beleid.

\section{Effectiviteit}

In de eerste plaats komt dus de vraag naar de uitkomsten van het lokale jeugdbeleid. De term beleidsuitkomsten wordt gebruikt als een verzamelbegrip voor verschillende manieren waarop tegen de resultanten van beleid kan worden aangekeken. Er worden drie typen beleidsuitkomsten onderscheiden: (maatschappelijke) effecten van beleid, waardering van beleid door (groepen) burgers, en beoordeling van het beleid door betrokken actoren. Deze worden hieronder nader toegelicht en voorzien van een onderzoeksvraag.

Onderzoeksuraag 2) Hoe hebben de scores op voor het jeugdbeleid relevante output- en outcome-indicatoren zich ontwikkeld in de periode van 1998 tot en met 2001?

Output-indicatoren hebben betrekking op de prestaties van betrokken beleidsactoren, terwijl outcome-indicatoren bepaalde aspecten van het uiteindelijk te beïnvloeden object weerspiegelen; bij sociaal beleid zijn dit meestal aspecten van de leefsituatie van individuen of groepen. Door indicatoren op verschillende tijdstippen te meten is het mogelijk ontwikkelingen in de tijd aan te geven. In de onderzoeksvraag wordt I998 als het eerste tijdpunt gedefimieerd. Deze keuze vloeit voort uit het feit dat het scP-onderzoek naar lokaal jeugdbeleid in dat jaar is gestart en er vanaf dat jaar dus gegevens over het gevoerde beleid beschikbaar zijn.

Onderzoeksuradg 3) Hoe beoordelen jeugdigen het jeugdbeleid van de gemeente waarin zij woonathtig zijn?

Het gaat om de waardering van beleidsprogramma's en/of beleidsmaatregelen, of het ontbreken daarvan, door groepen waarop het beleid is gericht. Die waardering is gebaseerd op een (individuele) evaluatie van de outcomes en outputs van het politieke systeem. Vedung (1997) spreekt in dit verband van het cliëntgerichte evaluatiemodel. 
Onderzoeksvraag 4) Hoe beoordelen bij het jeugdbeleid betrokken actoren de resultaten van het jeugdbeleid van de gemeente waar zij een rol in spelen?

Het gaat hier om de intersubjectieve beoordeling wan beleidsresultaten door bij beleidsworming, -uitwoering en -evaluatie betrokken actoren. De betrokken actoren schatten de beleidseffecten in in termen van outcome en output.

\section{Voorwaarden voor effectiviteit}

In de tweede plaats wordt gekeken naar zogenoemde noodzakelijke en faciliterende voorwaarden voor effectief beleid. Als beleid niet aan deze voorwaarden voldoet dan is de kans op beleidseffectiviteit gering of neemt deze kans af. Voldoet het beleid wel aan deze voorwaarden, dan impliceert dat nog niet dat beleild effectief is, maar is de kans erop well hoger. Fleurke et al. (rog7) onderscheiden drie noodzakelijke en faciliterende voorwaarden voor effectiviteit: maatwerk, integrale beleidsvoering en slagvaardigheid. Wij voegen daar participatie aan toe als faciliterende voorwalarde voor effectief beleid. Door participatie van burgers is het bestuur beter in staat het beleid verder toe te spitsen op de lokale situatie.

De beleidstheorie bij decentralisatie van Fleurke et al. (1997) is leidend in het formuleren van onderzoekswragen naar de voorwaarden voor effectiviteit.

Maatwerk is in algemene zin omschreven als het afstemmen van het beleid op de eigen aard van het voorliggende geval of probleem (Fleurke et al. 1997: 20). In dit onderzoek verstaan we onder maatwerk 'de toespitsing van het beleid op de lokale situatie, problemen en behoeften'. In de beleidstheorie wordt op twee manieren een verband gelegd tussen decentralisatie en de mogelijkheid om tot maatwerk te komen. In de eerste plaats is het in een gedecentraliseerde situatie mogelijk een pluriform aanbod tot stand te brengen, terwijl in een gecentraliseerde situatie in het algemeen een uniform aanbod wordt gerealiseerd. Het pluriforme aanbod zal eerder aansluiten op de verschillen tussen de verschillende territoriale eenheden. In de tweede plats heeft het relatief grote aantal uitvoeringsorganisaties dat bij gedecentraliseerd beleid is betrokken een grotere informatiecapaciteit dan éen centrale uitvoeringsorganisatie (vgl. Fortuin i998). Daardoor is het eenvoudiger om maatwerk te bewerkstelligen.

Onderzoeksuraag 5) In welke mate is er in het lokale jeugdbeleid sprake uan maatwerk, dat wil zeggen: op de lokale situatie toegespitst beleid?

Een noodzakelijke voorwaarde om te kunnen spreken wan maatwerk is dat het beleid tussen gemeenten verschilt. De lokale omstandigheden en de leefsituatie van de jeugd verschillen immers per gemeente (zie Gilsing 1999: 27-36). Het is daarom van belang de inhoud van het lokale jeugdbeleid nader te beschouwen: ligt de nadruk op algemeen jeugdbeleid, op (gericht) preventief beleid, of op curatief en repressief beleid? Wat zijn de prioriteiten in het jeugdbeleid? Welke leeftijdsgroepen krijgen 
de aandacht? De wraag naar maatwerk komt ook aan de orde bij onderzoek naar het proces van beleidsvorming. Verondersteld wordt dat het betrekken van andere actoren in het proces van beleidsvorming bijdraagt aan de vorming van beleid dat op de lokale situatie is toegesneden, omdat het leidt tot de vergaring van meer lokaalspecifieke beleidsrelevante informatie. Tot slot is aan betrokken beleidsactoren de vraag voorgelegd in hoeverre er sprake is van maatwerk in het lokale jeugdbeleid.

Integrale beleidsvoering wordt omschreven als "de onderlinge afstemming van beleid in verschillende sectoren ten behoeve van de aanpak van een multidimensionaal maatschappelijk vraagstuk' (Fleurke et al. I997: 30). Maatschappelijke problemen vragen vaak om beleid waarbij meerdere beleidssectoren betrokken zijn. Afstemming en coördinatie zijn dan vereist om tot effectief beleid te komen en zijn eenvoudiger te realiseren als de taken en bevoegdheden bij één bestuurslaag of bestuursorgaan zijn geconcentreerd. Er wordt een centrale sturende actor verondersteld. Integrale beleidsvoering is een belangrijke voorwaarde voor effectief beleid. Bij het jeugdbeleid heeft de integrale beleidsvoering een bijzondere waarde omdat de aard van het beleidsobject veronderstelt dat er verschillende beleidssectoren bij betrokken zijn (Schuyt 1995).

\section{Onderzoeksuraag 6) In hoeverre is het lokale jeugdbeleid te typeren als integraal?}

In dit onderzoek is op twee manieren naar integrale beleidswoering gekeken. In de eerste plaats komt de inhoudelijke breedte van het jeugdbeleid aan de orde. Is het zo dat gemeenten een sectoroverstijgend jeugdbeleid ontwikkelen? De inhoudelijke breedte van het jeugdbeleid is in dit onderzoek geoperationaliseerd door het aantal thema's dat deel uitmaakt van het jeugdbeleid te bepalen. Deze acht thema's zijn aspecten van de leefsituatie van jeugdigen.

In de tweede plaats gaan we in op de organisatie van de integrale beleidsvoering. Integraal beleid vergt adequate interne afstemming en coördinatie en een adequate sturing van instellingen die bij het beleid zijn betrokken (Van der Wouden 1994: 265). De interne afstemming en coördinatie brengen we in beeld door te kijken naar de mate van samenwerking tussen wethouders en tussen ambtenaren, en naar de aanwezigheid van coördinatiemechanismen. De (externe) sturende rol die de gemeente in het jeugdbeleid op zich neemt, komt op verschillende manieren aan de orde. Zijn er netwerken rond het jeugdbeleid gevormd en zo ja, op welke wijze? Welke sturingsinstrumenten hanteren de gemeenten? Bij de sturingsinstrumenten kijken we naar de aanwezigheid van een richtinggevende visie en naar de mate van politieke sturing.

Slagvaardigheid duidt op het tijdig en adequaat reageren op maatschappelijke veranderingen of op veranderingen in de omstandigheden waarin doelstellingen moeten worden gerealiseerd (Fleurke et al. 1997: 45). Maatschappelijke veranderingen kunnen nieuwe of bijgestelde beleidsdoelen vereisen, terwijl veranderingen in de beleidsomgeving de veronderstellingen bij het beleid kunnen ondergraven. 
Door decentralisatie worden taken en bevoegdheden geconcentreerd, en dit heeft in beginsel een positief effect op het vermogen slagvaardig te handelen. Ook de omvang van het beschikbare beleidsinstrumentarium heeft een positief effect op slagvaardigheid. Daarentegen belemmert het preventieve toezicht door hogere overheden het vermogen slagvaardig op te treden.

\section{Onderzocksuraag 7) In hoeverre is het lokale jeugdbeleid te typerem als slaguaardig?}

In dit onderzoek definiëren we slagvaardigheid als het vermogen van beleidsactoren om adequaat in te spelen op onverwachte veranderingen in de beleidsomgeving, zowel in het proces van beleidsformulering als in het proces van beleidsuitvoering. De slagvaardigheid van actoren die betrokken zijn bij het jeugdbeleid wordt onder meer bepaald door de wijze waarop zij onderling samenwerken. De vraag is of de samenwerkingsrelaties zijn georganiseerd op een wijze die slagvaardig optreden mogelijk maakt; dit kan onder andere door netwerkvorming. De potentie om slagvaardig op te kunnen treden is ook afhankelijk van de mate van beleidsvrijheid die uitvoerende actoren genieten. Is hun handelingsvrijheid nihil, of hebben zij ruime bevoegdheden om op ontwikkelingen in te spelen? Tot slot kan tussentijdse evaluatie van beleid ertoe bijdragen dat beieidsdoelen tijdig worden bijgesteld als de omstandigheden dat vereisen.

Voor de participatie van burgers noemen Fleurke et al. (r997) twee indicatoren: de betrokkenheid van politieke organen en de toegankelijkheid van het openbaar bestuur. Omdat de betrokkenheid van politieke organen niet direct van invloed is op het vermogen tot een effectief beleid te komen en we een instrumenteel perspectief op participatie hanteren, wordt deze indicator voor participatie in dit onderzoek verder niet behandeld. ${ }^{10}$ De mate waarin er mogelijkheden zijn voor directe invloedsuitoefening door individuele en georganiseerde burgers en maatschappelijke instellingen, bepaalt de toegankelijkheid van het openbare bestuur (Fleurke et al. 1997: 65). Dankzij een kleinere afstand tot de lokale samenleving is het bestuur makkelijker aanspreekbaar en is de invloed van de lokale samenleving op de besluitvorming in potentie groter. Daardoor kan het beleid responsiever zijn dan zonder deze invloed.

Onderzoeksuraag 8) In hoeverre is het lokale bestuut toegankelijk voor maatschappelijke actoren, in het bijzonder jeugdigen, als het gaat om lokaal jeugdbeleid?

Jeugd is de primaire doelgroep van het lokale jeugdbeleid; soms is het beleid ook op opvoeders gericht. Om maatwerk te realiseren is het van belang dat de jeugd gehoord wordt bij de vorming en uitvoering van het jeugdbeleid. Overigens wordt participatie van jeugdigen in het jeugdbeleid ook om andere redenen van belang geacht (De Winter 1995; Gilsing 200r; Zeijl 2003). In het nationale jeugdbeleid wordt gesteld dat het belangrijk is beleid samen met de jeugd te maken, en niet over hun hoofden heen (BANS 1999a, 200I). In dit onderzoek kijken we naar de inspanningen van gemeenten 
om de jeugd bij het beleid te betrekken en vragen we jongeren hoe zij hun betrokkenheid bij het beleid beoordelen. De participatie van andere maatschappelijke actoren, zoals instellingen en maatschappelijke organisaties, komt aan de orde bij de sturende rol van gemeenten en in het bijzonder bij de vorming van beleidsnetwerken en de processen van beleidsvorming en -uitvoering.

\subsubsection{Tot slot}

De onderzoeksvragen over de voorwaarden voor een effectief beleid zijn exclusief gericht op het gevoerde jeugdbeleid, en niet op de beleidsuitkomsten. In het onderzoek zijn twee elementen in het jeugdbeleid onderscheiden: de beleidsinhoud en het beleidsproces. Bij het beleidsproces wordt een nader onderscheid gemaakt tussen beleidsvorming, beleidsuitvoering en beleidsevaluatie. Het beleid zal vooral worden beoordeeld op haar bijdrage aan de effectiviteit.

De wijze waarop de eerste centrale vraag wordt beantwoord, is schematisch samengevat in tabel r.I. Daarin zijn drie aspecten van het lokale beleid onderscheiden, met daaraan gekoppeld de wijze waarop daar in dit onderzoek naar wordt gekeken.

Tabel 1.1

Effectiviteit wan lokaal jeugdbeleid: schematische weergave van de onderzoekswragen

\begin{tabular}{|c|c|}
\hline \multirow{4}{*}{$\begin{array}{l}\text { ontwikkeling specifiek jeugdbeleid } \\
\text { effectiviteit van lokaal jeugdbeleid }\end{array}$} & - statat van het jeugdbeleid \\
\hline & -ontwikkeling scores output-en outcome-indicatoren \\
\hline & oordeel jeugdigen over lokaal jeugdbeleid \\
\hline & - intersubjectieve beoordeling beleidsactoren \\
\hline \multirow[t]{4}{*}{ yoorwaarden yoor effectief lokaal jetugdbeleid } & -maatwerk \\
\hline & - Integrale beleidswoering \\
\hline & -slagvaardigheid \\
\hline & - toegankelijkheid maatschappelijke actoren, m.n. je \\
\hline
\end{tabular}

1.6 De rationale overheid en lokad jeugdbeleid: anderzoeksuragen en operationalisering

\subsubsection{Onderzoeksuragen}

In paragraaf $\mathrm{I} .2$ is ingegaan op de bestuurlijke rolverdeling in het jeugdbeleid. De nationale overheid is onder meer verantwoordelijk voor een richtinggevend kader voor zowel het preventieve jeugdbeleid als de curatieve jeugdzorg (wvc en Justitie 1994: 7). Daarnaast heeft de nationale overheid de taak om de overige in het jeugdbeleid betrokken actoren te ondersteunen door hen te faciliteren, door innovaties te stimuleren en door te monitoren. De vraag is of de wijze waarop het rijk vorm heeft gegeven aan deze rol, gemeenten heeft belemmerd of gestimuleerd in het ontwikkelen van een effectief jeugdbeleid, dat wil zeggen: van een beleid dat op de lokale 
situatie is toegesneden en dat integraal en slagvaardig is. De tweede centrale onderzoeksvraag luidde dan ook:

Op welke wijze tracht de nationale overheid het lokale jeugdbeleid te beinuloeden en wat betekent dat voor de mogelijkheden die gemeenten hebben om een effectiefjeugdbeleid tot stand te brengen?

Het eerste deel van de vraag beantwoorden we door het beleid van de nationale overheid te onderzoeken op zijn relevantie voor het lokale jeugdbeleid. We willen achterhalen door middel van welk soort beleid de nationale overheid trachtte het lokale jeugdbeleid te beïnvloeden. Omdat het in het onderzoek naar het lokale jeugdbeleid gaat om de periode van 1998 tot en met 200r, kijken we voor het onderzoek naar het nationale beleid naar dezelfde periode. We stellen de volgende onderzoeksvragen:

Onderzoeksuraag g) Wat waren van 1998 tot en met 2001 de doelen in het nationale beleid ten aanzien van jeugd en in hoeverre werd aan gemeenten en lokale actoren een rol toegekend in het realiseren van die doelen?

Onderzoeksuraag 10) Welke instrumenten zette de nationale overheid in de periode van 1998 tot en met 2001 in om gemeenten en andere lokale actoren te ondersteunen bij of te faciliteren in het realiseren van die doelen?

Om het tweede deel van de centrale vraag naar het nationale beleid te beantwoorden is naast deze beschrijvende vragen een meer evaluatieve onderzoeksvraag nodig naar de mate waarin het nationale jeugdbeleid gemeenten heeft belemmerd of gestimuleerd in de ontwikkeling van lokaal jeugdbeleid:

Onderzoeksuraag 11) In hoeverre kan het nationale jeugdbeleid van 1998 tot en met 2001, in termen van doelen en instrumenten, gezien worden als een belemmering dan wel een stimulans voor het ontwikkelen van een op de lokale situatie toegesneden integraal, slagvaardig en effectief lokaal jeugdbeleid?

\subsubsection{Naar een beoordelingskader voor nationaal beleid}

Om onderzoeksvraag Ir te beantwoorden moeten we een beoordelingskader voor het nationale beleid ontwikkelen. We willen immers weten in hoeverre het nationale beleid de kansen op een effectief lokaal jeugdbeleid beïnvloedt. Daartoe staan we eerst stil bij het object van beïnvloeding: het lokale jeugdbeleid.

De arena van het lokale jeugdbeleid ${ }^{\mathrm{II}}$

Het lokale jeugdbeleid wordt gekenmerkt door de betrokkenheid van veel verschillende actoren. Onderwijsinstellingen, politie, kinderopvang, peuterspeelzaalwerk, Bureaus Jeugdzorg en jeugdgezondheidszorg zijn, om maar een aantal mogelijke actoren te noemen, in de meeste gemeenten betrokken bij het jeugdbeleid. De lokale 
beleidsarena rond het jeugdbeleid - het samenstel van de betrokken actoren - is dus breed samengesteld. Dat heeft gevolgen voor de rol van de gemeente. In de voorgestane bestuurlijke rolverdeling wordt verondersteld dat de gemeente een sturende rol heeft in de lokale beleidsarena. In dit onderzoek definiëren we sturing als het gericht invloed trachten uit te oefenen op maatschappelijke veranderingsprocessen (Kickert I993b: 29). Het type sturing - Hupe en Klijn (1997) spreken van sturingsparadigmata - en de daarop gebaseerde selectie van sturingsinstrumenten wordt mede bepaald door de kenmerken van de beleidsarena. De effectiviteit van de instrumenten is immers deels afhankelijk van de context waarin zij worden ingezet (Hupe rggo: 232). Ben aantal kenmerken van de beleidsarena is van invloed op de geschiktheid van sturingsparadigmata (Hupe en Klijn I997): de variëteit aan actoren, de verscheidenheid aan bestuurlijke regimes waarmee deze actoren te maken hebben, de machtsongelijkheid tussen de actoren, en de mate waarin de ambities van de actoren gericht zijn op de realisatie van collectieve doeleinden.

De lokale beleidsarena rond het jeugdbeleid kenmerkt zich door een grote variëteit aan actoren: van grote instellingen voor voortgezet onderwijs via de politie tot aan organisaties voor peuterspeelzaalwerk. Deze vele typen actoren bevinden zich in zeer uiteenlopende bestuurlijke regimes: vergelijk de positie van onderwijsinstellingen, die vooral met wet- en regelgeving van de nationale overheid te maken hebben met die van sterk door de lokale overheid aangestuurde welzijnsinstellingen. Er is bovendien sprake van een grote machtsongelijkheid tussen actoren. De hulpbronnen waarover consultatiebureaus kunnen beschikken zijn wezenlijk anders dan die van het jongerenwerk. Ten slotte kunnen we vaststellen dat de actoren die bij het jeugdbeleid zijn betrokken verschillen in de mate waarin zij gericht zijn op collectieve doeleinden. Sommige actoren behoren tot de overheid (bijvoorbeeld Bureau Jeugdzorg), andere zijn particuliere organisaties (zoals de kinderopvang).

Gezien de kenmerken van de lokale beleidsarena rond het jeugdbeleid achten Hupe en Klijn (1997) het politiek-maatschappelijke sturingsparadigma het meest geschikt voor het lokale jeugdbeleid. In dit sturingstype wordt rekening gehouden met de autonome positie die de actoren innemen in de beleidsarena en met de sterke wederzijdse afhankelijkheden. Dit type sturing is meer dan hiërarchische sturing en marktsturing toegesneden op een arena met een relatief hoge bestuurlijke complexiteit waarin bovendien ruimte is voor relatief hoge sturingsambities. De rol van de overheid, c.q. de gemeente, wordt door Hupe en Klijn (1997) omschreven met de metafoor 'regisseur'. Zij nodigt uit tot deelname, formuleert gemeenschappelijke doelen, stemt verkokerde uitwoeringsbeslissingen op elkaar af en tracht tot overeenstemming over te leveren beleidsprestaties te komen (Gilsing et al. 2000: rr). Deze positie van de gemeente in het lokale jeugdbeleid sluit aan bij de ontwikkelling van government naar governance, ook wel aangeduid als een overgang van verticaal naar horizontaal bestuur; een vergelijkbare ontwikkeling wordt ook op andere beleidsterreinen waargenomen (Rhodes 1997; Pierre en Peters 2000; Denters en Rose 2004; 
Van Heffen et al. 2000; Michels 2002; John 2001; Bovaird et al. 2002; Algemene Rekenkamer 2003). ${ }^{12}$ De ontwikkeling en uitwoering van beleid gebeurt gezamenlijk door overheid en andere actoren. In de uitvoering is er een grotere vrijheid en verantwoordelijkheid voor de uitvoerende actoren. De sturende rol van de overheid is meer dan voorheen gebaseerd op de erkenning van de autonomie van andere actoren.

Nationaal beleid en de beleidsarena rond het lokale jeugdbeleid

Het nationale jeugdbeleid dat we in dit deel van het onderzoek bestuderen, is gericht op de beïnvloeding van de beleidsarena rond het lokale jeugdbeleid. Deels is dat beleid gericht op beïnvloeding van het gedrag van de gemeente als sturende actor (of regisseur) in het lokale jeugdbeleid. Voor een ander deel is het nationale beleid gericht op beïnvloeding van het gedrag van actoren die bij het jeugdbeleid zijn betrokken. In figuur I.r zijn deze twee lijnen schematisch weergegeven. Bij figuur I.I past de kanttekening dat de relaties tussen de nationale overheid en de non- en paragouvernementele lokale en regionale actoren niet altijd direct hoeven te zijn. In sommige gevallen nemen koepels op nationaal of regionaal niveau of andere (semi-) overheidsorganen een intermediaire positie binnen deze relatie in. De nationale overheid is bijvoorbeeld verantwoordelijk voor het bestuurlijke regime van deze actoren - denk aan de consultatiebureaus in relatie tot de jeugdgezondheidszorg - of heeft een bepaalde sturingsrelatie met deze actoren, zoals justitie en politie. Het gaat in het jeugdbeleid dus niet alleen om de relaties tussen overheden, maar ook om de relaties tussen zowel de nationale als de gemeentelijke overheid en lokaal en regionaal opererende para- en non-gouvernementele actoren.

Figuur 1.1

De relatie tussen nationaal beleid en de lokale beleidsarena

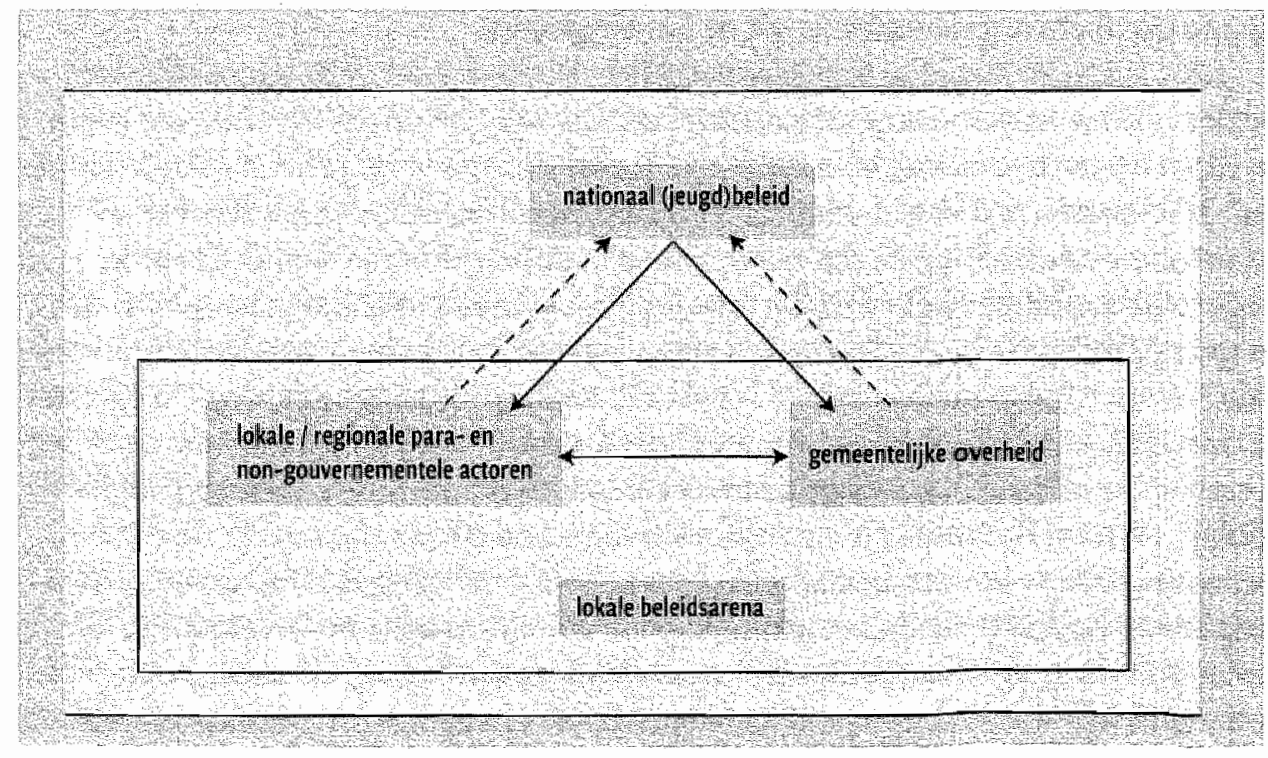


De geschetste verhoudingen tussen de actoren die bij het jeugdbeleid zijn betrokken hebben implicaties voor de sturing van het lokale jeugdbeleid door de nationale overheid (vgl. Kalders et al. 2004). De gemeente krijgt te maken met een discrepantie tussen de andersoortige, horizontale sturing die van haar wordt verwacht en de formele bevoegdheden die tot haar beschikking staan (ROB 2000). De gemeente wordt geacht actoren te sturen met instrumenten die niet in wet- of regelgeving zijn verankerd en dient daarom (deels) gebruik te maken van zogenoemde sturingsinstrumenten van de tweede generatie (De Bruijn en Ten Heuvelhof r991). Bij de toepassing van dergelijke instrumenten bestaat meer ruimte voor wederzijdse beïnvloeding en is er veel aandacht voor het committeren van actoren aan gemeenschappelijke doelen. Dergelijke vormen van sturing veronderstellen een aanzienlijke handelingsruimte voor de gemeente (ROB rggga: 45 ) en vragen daarom om vergroting van de gemeentelijke beleidsvrijheid - de relatieve zelfstandigheid zoals die in paragraaf $\mathrm{r} .3$ aan de orde kwam (Denters et al. 1999a; ROB iggga: 36). Daartoe is ontschotting en ontkokering van nationaal beleid noodzakelijk. Bovendien zou de financiële ruimte voor gemeenten vergroot moeten worden, onder meer door bundeling van financiële middelen en vergroting van de bestedingsvrijheid. Ook stelt de ROB (1999a: 46) dat landelijke beleidskaders die richting moeten geven aan het beleid van lokale overheden globaal van karakter dienen te zijn en vooral doelstellingen moeten formuleren die betrekking hebben op de effecten van het beleid (vgl. Schnabel 2002; Roes et al. 2002; RMO 2002; Kalders et al. 2004). Volgens Pröpper et al. (2004) dient er sprake te zijn van een balans tussen centrale aansturing en lokale autonomie.

Samengevat: het beleid van de nationale overheid dient, in zoverre het gericht is op de indirecte dan wel directe sturing van het lokale jeugdbeleid, recht te doen aan de positie van de gemeente als sturende actor in een complexe lokale beleidsarena. Dit impliceert dat de nationale overheid op hoofdlijnen richting geeft aan het lokale jeugdbeleid en dat er wordt gestreefd naar een maximale beleidswrijheid voor de gemeente en andere actoren uit de lokale beleidsarena om het lokàle jeugdbeleid langs die hoofdlijnen te ontwikkelen.

Daarmee is het uitgangspunt voor het formuleren van een beoordelingskader voor nationale beleidsdoelen en -instrumenten gegeven. We zullen nu nader op dit beoordelingskader ingaan en daarbij het kader voor doelen, respectievelijk instrumenten bespreken.

Doeler van nationaal beleid (onderzoeksuraag g)

Nationaal beleid kan gericht zijn op de keuze van beleidsdoelen door lokale actoren. Dergelijk beleid richt zich op de output (te leveren beleidsprestaties) of op de outcome (maatschappelijke effecten) die in het lokale jeugdbeleid worden nagestreefd.

Dit beleid heeft gevolgen voor het vermogen van gemeenten om tot maatwerk te komen. Maatwerk heeft immers vooral te maken met de richting van het beleid: de maatschappelijke effecten die beoogd worden en de beleidsresultaten die verlangd 
worden. In de tweede plaats is het nationale beleid gericht op beïnvloeding van lokale beleidsprocessen. Dergelijk beleid beïnvloedt de mogelijkheden van gemeenten om tot een integraal, slagvaardig beleid te komen. Met andere woorden: het is van belang voor de gemeente als sturende actor in de beleidsnetwerken rond jeugdbeleid.

In algemene zin is de veronderstelling dat nationaal beleid waarvan de doelen op outcome-niveau zijn geformuleerd de meeste vrijheid laat aan gemeenten (vgl.

Koppenjan et al. 200I: 460). Deze doelen hebben eventueel wel effect op het vermogen om maatwerk te leveren. Voor doelen op output-niveau geldt dat zij al in wat sterkere mate interfereren met de lokale beleidsvrijheid; ook hier geldt dat vooral voor het aspect van maatwerk. Doelen in het nationale beleid op throughput-niveau perken de lokale beleidsruimte echter het sterkst in. Deze hebben gevolgen voor met name het vermogen tot een integrale en slagvaardige beleidswoering te komen, omdat zij beogen het lokale beleidsproces te beïnvloeden.

\section{Nationale beleidsinstrumenten (onderzoeksuraag 10)}

Een voor dit onderzoek belangrijk kenmerk van beleidsinstrumenten is de mate waarin zij beperkend dan wel verruimend werken (Van der Doelen rg89: 56). De verruiming of beperking heeft betrekking op de vraag of het aantal beschikbare gedragsalternatieven van de doelgroep van het beleid wordt verruimd of beperkt. Bij verruimende instrumenten wordt de keuzevrijheid vergroot, terwijl die bij beperkende instrumenten juist wordt ingeperkt. We onderscheiden een aantal kenmerken van beleidsinstrumenten die van invloed zijn op het gemeentelijke vermogen tot maatwerk, integraliteit en slagvaardigheid. Achtereenvolgens gaan we in op types beleidsinstrumenten, op de al dan niet selectieve toepassing ervan, op de mate van uitvoeringsregulering en op het object van de instrumenten. Tot slot bespreken we een afzonderlijke categorie instrumenten die niet primair gericht zijn op gedragsbeïnvloeding.

\section{Types beleidsinstrumenten}

Voor de typering van beleidsinstrumenten sluiten we in grote lijnen aan bij de taxonomie van beleidsinstrumenten van Van der Doelen ( 1989 ; vgl. Van der Doelen en Klok 1998; Bemelmans-Videc et al. 1998; Hood r983; Van den Heuvel 1998; De Bruijn en Hufen 1998). Van der Doelen onderscheidt vijf typen overheidsingrijpen: algehele staatsonthouding, informatieoverdracht, financiële prikkels, voorschriften en overheidsvoorzieningen. In het eerste geval, ook wel aangeduid met laissez-faire, heeft de overheid wel bepaalde doelen, maar kiest zij er bewust voor niet in te grijpen. De realisatie van doelstellingen wordt aan andere maatschappelijke actoren overgelaten. De laatste vorm van overheidsingrijpen, de overheidsvoorziening, behelst het door de overheid zelf produceren van een bepaalde voorziening - denk aan de belastingdienst. De overige drie vormen van overheidsingrijpen zijn erop gericht het gedrag van de beleidsdoelgroep te beïnvloeden. ${ }^{\mathrm{I}}$ Omdat we het in dit onderzoek hebben over de beïnvloeding van het gedrag van lokale actoren door de nationale overheid, 
ofwel instrumenten die de nationale overheid inzet voor het lokale jeugdbeleid, beperken we ons tot de volgende drie vormen van overheidsingrijpen:

I Het communicatieve sturingsmodel is gebaseerd op informatieoverdracht. Het gaat onder meer om voorlichting, propaganda en onderwijs. Door informatie aan te reiken wordt getracht de kennis of waardering van bepaalde gedragsmogelijkheden bij de te sturen actoren te veranderen, waardoor de keuze uiteindelijk anders uit kan vallen.

2 Bij het economische sturingsmodel worden de consequenties van bepaalde keuzemogelijkheden ten nadele of ten voordele beïnvloed. De kosten en baten ervan worden veranderd, vaak door financiële prikkels.

3 Het juridische sturingsmodel richt zich op voorschriften. Door waarden en normen vast te leggen in regels of voorschriften worden bepaalde aanspraken en verplichtingen gecreëerd die de keuze voor een bepaalde gedragsmogelijkheid dwingend beïnvloeden.

Belangrijk voor de invloed van de typen beleidsinstrumenten op het lokale jeugdbeleid is het dwingende karakter van het juridische sturingsmodel. In beginsel, maar ook afhankelijk van de context, hebben voorschriften daardoor een belemmerende invloed op het vermogen tot maatwerk en integraal en slagvaardig beleid. Ze dwingen de lokale actoren keuzen te maken en beperken daarmee de lokale beleidsvrijheid. Dat geldt voor de overige twee sturingsmodellen niet. Het economische sturingsmodel heeft in het geval er sprake is van (positieve) financiële prikkels een positieve invloed op het vermogen tot maatwerk te komen, en werkt dus verruimend. Het vergroot immers de keuzemogelijkheden van lokale actoren door hen ruimere financiële mogelijkheden toe te kennen. In het geval van sancties (negatieve prikkels) beperkt dit sturingsmodel juist het vermogen tot maatwerk. Op het vermogen tot een integrale en slagvaardige beleidswoering heeft het economische sturingsmodel geen (directe) invloed, zo nemen we in dit onderzoek aan. Het communicatieve sturingsmodel tot slot kan afhankelijk van het onderwerp van informatie op alledrie de aspecten van het lokale jeugdbeleid een positieve invloed hebben. Betreft het informatie over de lokale situatie en de effectiviteit van bepaalde beleidsmaatregelen in die situatie, dan voedt het de keuze van beleidsdoelen en daarmee het vermogen tot maatwerk. Gaat het om informatie die gericht is op verbetering van het beleidsproces, dan heeft het in principe een positieve invloed op het vermogen tot integrale en/of slagvaardige beleidsvoering.

\section{Toepassing: generiek versus specifiek}

De verruimende of beperkende werking van de sturingsmodellen wordt, naast de mate van vrijwilligheid en de aard van de prikkel, echter ook door andere factoren beïnvloed. Een eerste factor is de toepassing van het instrument. Is er sprake van een standaardtoepassing van het instrument of wordt het instrument toegesneden op het object van sturing, c.q. de lokale beleidsarena? We spreken in dit verband van generieke versus specifieke beleidsinstrumenten. We veronderstellen dat een specifieke toepassing van het instrument een positieve invloed heeft op het vermogen tot maatwerk en tot 
integrale en slagvaardige beleidsvoering, afhankelijk van het aspect van het jeugdbeleid waarop het is gericht. Een op de situatie toegesneden, specifiek instrument verruimt vanzelfsprekend de handelingsruimte van lokale actoren in grotere mate dan een generiek instrument. Tot de specifieke instrumenten rekenen we ook de instrumenten waarin er ruimte voor een lokale inbreng bestaat, zoals in het geval waar lokale actoren worden verzocht projectplannen in te dienen om voor een financiële bijdrage in aanmerking te komen.

\section{Mate van uitvoeringsregulering}

Een volgende factor is de mate waarin de uitvoering van het instrument aan regels is gebonden. De uitvoeringsbepalingen kunnen door een sterke mate van gedetailleerdheid een belemmering vormen voor de integrale en slagvaardige beleidsvoering, terwijl het ontbreken van dergelijke bepalingen deze zaken juist kunnen bevorderen. We duiden deze factor aan als de mate van uitvoeringsregulering. De ROB (1999:46) formuleerde dit punt als volgt:

'De Raad is van mening dat de te stellen eisen (aan de verantwoording van de besteding en aan rapportages omtrent gevoerd beleid) de gegeven bestedingsvrijheid niet mogen beperken. Voorkomen moet worden dat het gemeentelijk beleid en de uitwoering daarvan worden bepaald door gedetailleerde verantwoordingseisen.'

\section{Object van de instrumenten}

Verder is het met het oog op de eerder in deze paragraaf beschreven gemeentelijke regierol in het jeugdbeleid van belang om een onderscheid te maken tussen wat we hier zullen aanduiden als directe en indirecte beleidsinstrumenten. Directe beleidsinstrumenten hebben tot doel direct het gedrag van gemeenten te beïnvloeden. Indirecte beleidsinstrumenten zijn niet direct gericht op de gemeentelijke overheid, maar op andere lokaal opererende actoren. Daarbij veronderstellen we dat indirecte beleidsinstrumenten de integrale beleidsvoering, waarvoor de gemeente verantwoordelijk is, niet ten goede komen.

Niet primair op gedragsbeinvloeding gerichte instrumenten

Buiten de categorie beleidsinstrumenten vallen de zogenoemde bestuursinstrumenten en vormen van constituerende sturing (Van der Doelen en Klok 1998: 212). Deze kaderen de beleidsinstrumenten, die direct gericht zijn op gedragsbeïnvloeding van de te sturen actoren, vaak in. Bestuursinstrumenten zijn instrumenten als normering, toezicht en financiering die het bestuurlijke regime van een actor bepalen. De algemene grondslag van beleidsinstrumenten bestaat vaak uit vormen van constituerende sturing. Het meest duidelijke voorbeeld hiervan zijn de algemene wetten die de juridische grondslag vormen om subsidies als beleidsinstrument in te zetten. Maar ook kennis die door onderzoek is verkregen is een vorm van constituerende sturing die noodzakelijk kan zijn voor het communicatieve sturingsmodel. Het belangrijkste 
kenmerk van bestuursinstrumenten en vormen van constituerende sturing is dat. zij niet direct gericht zijn op gedragsbeïnvloeding. Ook deze instrumenten kunnen worden ingezet door de nationale overheid, bijvoorbeeld ter ondersteuning van de inzet van beleidsinstrumenten.

\section{Verruimende of beperkende werking van beleidsinstrumenten}

We hebben nu vier kenmerken van beleidsinstrumenten genoemd, en een afzonderlijke categorie bestuursinstrumenten aangewezen. In de analyse zullen we trachten de beleidsinstrumenten op de vier kenmerken te beoordelen naar de mate waarin ze de handelingsalternatieven van het lokale jeugdbeleid beperken dan wel verruimen. Daarbij dient te worden opgemerkt dat de beoordeling van instrumenten contextgebonden is. Afhankelijk van de uitgangssituatie kan een instrument de ene keer verruimend zijn, omdat het de handelingsmogelijkheden ten opzichte van die uitgangssituatie vergroot, terwijl het in een andere situatie juist beperkend is. In een situatie waarin de te sturen actor een grote mate van beleidswrijheid geniet zal een instrument eerder als beperkend worden getypeerd dan in een situatie waarin de beleidsvrijheid relatief gering is.

In tabel $\mathrm{r} .2$ is de invloed van de verschillende kenmerken van de beleidsinstrumenten op de onderscheiden aspecten van het jeugdbeleid, zoals hierboven uiteengezet, schematisch weergegeven.

Bestuursinstrumenten en constituerende instrumenten zijn niet in de tabel opgenomen, omdat zij niet kunnen worden beoordeeld op hun beperkende dan wel verruimende invloed.

\section{Tabel o. 2}

Invloed van beleidsinstrumenten op aspecten van het lokaal jeugdbeleid ${ }^{\mathrm{a}}$

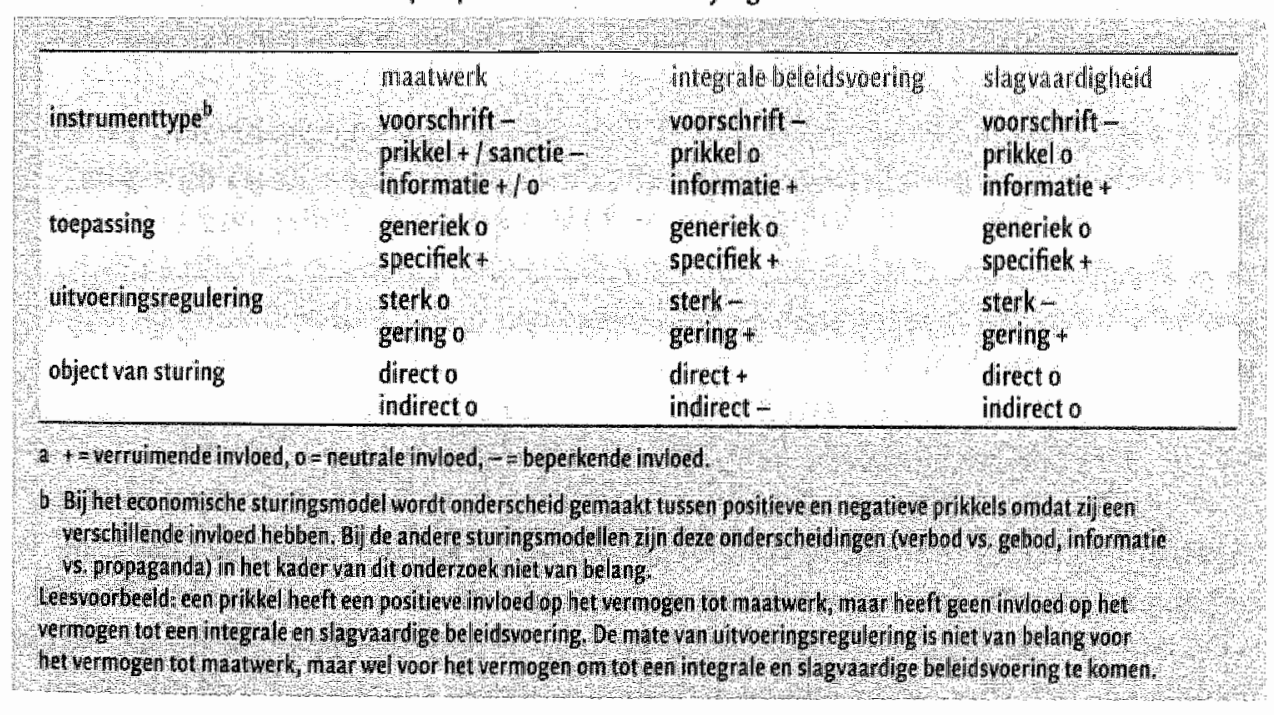


Het beoordelingskader fungeert in dit onderzoek als hulpmiddel om de werking van nationale instrumenten 'op de hand' te wegen. Het is niet mogelijk om verruimende en beperkende werkingen van een instrument rekenkundig bij elkaar op te tellen of van elkaar af te trekken. We zullen steeds beargumenteren waarom een instrument gegeven zijn kenmerken een bepaalde invloed heeft; daarbij zal bovenstaand schema als hulpmiddel dienen. Het is bijwoorbeeld duidelijk dat een forse financiële prikkel een sterkere verruimende invloed heeft op het vermogen tot maatwerk dan de specifieke toepassing van een instrument, of het verstrekken van informatie.

\section{Nationaal beleid in samenhang}

Tot slot is het geheel van nationaal beleid van belang. Het is bekend dat het nationale beleid vaak verkokerd is. Het wordt ontwikkeld door verschillende departementen en zelfs door verschillende directies binnen departementen, en de beleidscoördinatie is daarbij vaak niet optimaal. Men kan zich afvragen of de verkokering door het nationale beleid niet geëxporteerd wordt naar gemeenten, waardoor deze met een nadelige invloed op het vermogen tot een integrale, slagvaardige beleidswoering worden geconfronteerd. ${ }^{14}$ Zou bijvoorbeeld de gevonden slagvaardigheid van lokale overheden gerelateerd kunnen worden aan de mate van complexiteit in het nationale centrale beleid, zoals een van de hypothesen luidt die Willemse (200I) op basis van de literatuur formuleert? Kan er worden gesproken van coördinatie van het nationale jeugdbeleid, in de zin dat er sprake is van een samenhangend beleid van de verschillende betrokken departementen?

Ook is het van belang of instrumenten zijn gericht op het jeugdbeleid van alle gemeenten of op het beleid van een deel daarvan. In dit verband maakt Van der Doelen (I989: 55-56) een onderscheid tussen algemene en individuele vormen van de sturingsmodellen. Wordt er getracht het gedrag van veel of weinig actoren te beïnvloeden? Ook de mate van vrijwilligheid, zoals dat bij de typering van beleidsinstrumenten aan de orde is geweest, speelt hierbij een rol. Omdat de reikwijdte van een instrument niet uitmaakt voor de beperkende dan wel verruimende invloed - het heeft immers geen gevolgen voor individuele gemeenten - makkt dit aspect geen deel uit van het beoordelingskader. Wel zal regelmatig worden verwezen naar de reikwijdte van een instrument, omdat instrumenten die in een beperkt aantal gemeenten worden ingezet, in de uiteindelijke beoordeling van het nationale jeugdbeleid geen grote rol spelen.

\subsection{Indeling van het boek}

Hoofdstuk 2 van deze studie bevat de verantwoording van de onderzoeksopzet: de gehanteerde methoden en het verloop van het veldwerk. In de hoofdstukken daarna - het tweede deel van deze studie - gaan we in op de onderzoeksvragen die het lokale jeugdbeleid betreffen. Eerst komen in de hoofdstukken 3 tot en met 6 de inhoud en het proces rond het lokale jeugdbeleid aan de orde. We besteden achtereenvolgens 
aandacht aan de mate waarin het jeugdbeleid is ontwikkeld (hoofdstuk 3 ), aan de inhoud van het jeugdbeleid (hoofdstuk 4), aan het betrekken van jeugdigen bij het jeugdbeleid (hoofdstuk 5 ) en aan de gemeentelijke sturing (hoofdstuk 6). In een 'tussenhoofdstuk' 7 leiden we uit de hoofdstukken 3 tot en met 6 een typologie van het jeugdbeleid af, die in de hoofdstukken over beleidsuitkomsten (hoofdstuk 8 tot en met xo) zal worden gebruikt om kenmerken wan het jeugdbeleid te relateren aan de mate waarin er resultaten in het jeugdbeleid worden geboekt. In hoofdstuk 8 gaan we in op de mening die bij het jeugdbeleid betrokken actoren over dat beleid koesteren. Hoofdstuk 9 bevat een presentatie van de resultaten van het onderzoek naar output- en outcome-indicatoren, en in hoofdstuk ro komt de jeugd aan het woord. Het tweede deel besluit met hoofdstuk II, waarin de onderzoeksvragen I tot en met 8 worden beantwoord.

In het derde deel wordt in een uitvoerig twaalfde hoofdstuk het nationale beleid dat voor het lokale jeugdbeleid van belang is, beschreven en getypeerd; dit gebeurt aan de hand van de onderzoeksvragen 9 tot en met rr die betrekking hebben op de doelen en instrumenten van het nationale beleid. In het slothoofdstuk 13 gaan we in op de gevolgen die het nationale beleid heeft voor het lokale jeugdbeleid, vooral waar het gaat om de verwachtingen die een zelfstandige positie van de gemeente rechtvaardigen. In hoofdstuk 13 zullen ook aanbevelingen voor het nationale beleid worden geformuleerd.

Tabel 1.3 geeft een overzicht van de plaatsen in deze studie waar de twaalf onderzoeksvragen worden beantwoord. Daaruit blijkt dat de vragen naar maatwerk en naar de toegankelijkheid van de lokale overheid in verschillende hoofdstukken worden behandeld. De vraag naar integrale beleidsvoering wordt hoofdzakelijk in hoofdstuk 6 beantwoord en voor een beperkt deel in hoofdstuk 3 . 
Tabel 1.3

Schematische weergave behandeling onderzoekswragen lokaal jeugdbeleid

onderzoekswiaag

hoofdstuk/paragraaf

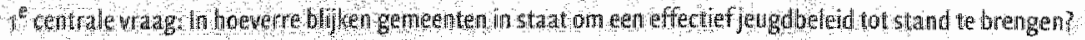

1 In hoeverre hebben gemeenten een specifiek jeugdbeleid ontwikkeld?

2 Hoe hebben de scores op (voor het jeugdbeleid relevante) output en outcome-indicatoren zich ont wilkkeld in de periode van 1998 tat en met 2001 ?

3 Hoe beoordelen jeugdigen het jeugdbeleid van de gemeente waarin zit woonachtig zijn?

4 Hoe beoordelen bij het jeugdbeleid betrokken actoren het jeugdbeleid van de gemeente waar zij een rol in spelen?

5 In welke mate is er in het lokale jeugdbeleid sprake wan maatwerk, dat wil zeggen: op de lokale situatie toegespitst beleid?

6 In hoeverre is het lokale jeugdbeleid te typeren als integraal?

3 ontwikkeling van een specifiek jeugd beleid

9 resultaten van beleid

10 jongeren over het jeugdbeleid van hun gemeente

8 oordelen over withomsten lokaal jeugdbeleid

7 In hoeverre is het lokale jeugdbeleid te typeren als slagvaardig?

8 In hoeverre is het lokale bestuur toegankelijk voor maatschappelijke actoren, in het bijzonder jeugdigen, als het gaat on lokaal jeugdbeleid?

ontwikkeling van een specifiel jeugdbeleid

4.2 accenten in het jeugdbeleid

6.2 beleidsnetwerken rond lokaal je ugdbeleid

8.3 oordelen jeugdbeleid en uitkomsten

3.4 integrale beleidswoering

6.2 beleidsnetwerken rond lokaal jeugdbeleid

6.3 beleidsvorming beleldswisie als sturingsinstrument:

6 gemeente als sturende actor

5 het betrekkenvan jeugd

6.2 beleidsnetwerken rond lokaal jeugdbeleid

10.3 jongeren over hungemeente: resultaten

$2^{2}$ centrale vragg: op welke wijze tracht de centrale overhe het lokale jeugtheleid te beinnloeden en wat betekent dat woor de nogellijkheden die gemeenten hebben on een effectief jeugdbeleid tot stand te brengen?

9 Wat waren van 1998 tot en met 2001 de doelen in het nationale beleid ten aanzien van jeugd en in hoewerre werd aan gemeenten en lokkale actoren een rol toegekend in het realiseren van die doelen?

10 Welke instrumenten zette de nationale overheid in de periode van igg 8 tot en met zoot in on gemeen12 het nationale jeugdbeleid ten en andere lokale actoren te ondersteunen bij of te faciliteren in het:realiseren wan die doelen?

11 In hoeverre kan het nationale jeugdbeleid van 1998 tot en met 2001 , in termen van doelen en instrumenten, gezien worden als cen belemmering dan wel een stimulans voor het ontwikikelen vaneen op de lokale situatie toegesneden integral, slagvaardig en effectief lokal jeugdbeleid?

12. het nationale jeugdbeleid 
Het historische overzicht van het jeugdbeleid is gebaseerd op Ter Bogt en Van Praag (1992: $9,13,189-187)$ en SCP (1985: 19-23, 101-104). Voor een historisch overzicht van het welzijnsbeleid, zie Van der Pennen et al. 1995 . "Bij het streven naar een preventief jeugdbeleid bevinden gemeenten zich in een netwerk van actoren die voor de realisering van dat beleid onmisbaar zijn (...). Het is verstandig om bij de inwulling wan de regiefunctie van gemeenten met die afhankelijkheid rekening te houden. Gemeenten hebben beperkte informatie tot hun beschikking. Voor de realisatie van preventief jeugdbeleid zijn zij in aanzienlijke mate afhankelijk van de know how en inzet van andere organisaties. De gemeente als regisseur is dan ook vooral een netwerkmanager die poogt complexe processen tussen organisaties op het gebied van het jeugdbeleid te stimuleren, organiseren en begeleiden.' (Hupe en Klijn I997: 37) Batley en Stoker ( $(99 \mathrm{I})$ onderscheiden drie ideaaltypische modellen voor de relatie tussen nationale en lokale overheden: relatieve autonomie, agentschap en interactie. Nederland zou tot het laatste behoren, met 'a complex pattern of relationships, in which the emphasis is on mutual influence. The political processes of central and local government are closely inter-related (...) with issues often being resolved by mutual discussion.'

5 Scharpf $(1978: 359)$ formulleert de afhankelijkheid van de nationale overheid ten opzichte van de lokale overheden als wolgt: "While the seemingly dominant party may exercise hierarchical authority or control over monetary resources, it may, at the same time, be fully dependent upon the specialist skills, the clientele contacts and the information available only to subordinate units.'

6 Het vervolg op paragraaf 1.3 is deels gebaseerd op de uitwoerige weergave van het overwegend empirische debat in Willemse (200I: 33-74). Overigens is er ook een tussenpositie in het normatieve debat: een naar taken gedifferentieerd model. Vooral in de public-choice-theorieën wordt decentralisatie vanuit economisch perspectief beoordeeld. In deze benadering bepalen de externe effecten wan beleid of dit het beste aan de nationale overheid dan wel aan lokale overheden kan worden overgelaten. Externe effecten worden gedefinieerd als effecten op de situatie wan actoren die niet tot het domein van de handelende actor behoren (Denters en Veldheer $1998: 67$ ). Voorzieningen en beleid met weinig externe effecten zouden dan am lokale overheden moeten worden overgelaten, omdat dit de kosten en het niveau van dienstverlening ten goede komt. Beleid en voorzieningen met grotere externe effecten vragen om centrale coördjnatie en kwnnen daarom beter op nationaal of eventueel regionaal niveau worden geregeld: 'Certain types of service bave intrinsic qualities, such as divisibility of benefits and spillover effects, which should make them a subnational function in order to optimise costs and levels of delivery. Thus one might expect some services with fewer spillovers, such as leisure and recreation, to be local rather than national.' (Page en Goldsmith 1987: 10; zie ook King 1984; Scharpf et al. 1978; Owens en Panella 199r).

In het empirische debat wordt door werschillende auteurs dan ook gewezen op verschil.len per beleidsterrein. Zo stelt Veldheer (1994) dat gemeenten vooral op het culturele en sociale terrein een taak hebben. Raadschelders (r990: 249) wijst echter juist op het belang van de terreinen ruimtelijke ordening en openbare werken in het takenpakket. Als we naar de gemeentelijke uitgaven kijken, dan blijkt dat beide beleidsterreinen elkaar niet veel ontlopen (Osterkamp en Eller 2003; Kuhry en Veldheer 2004).

7 Zo stellen Fleurke et al. ( $1997: 9$ ) dat het decentralisatiebeleid van het ministerie van Binnenlandse Zaken op twee noties is gestoeld. In de eerste plaats een notie die samen- 
hangt met het participatieargument: versterking van de lokale democratie, toegankelijkheid van het bestuur en verkleining van de afstand tussen bestuur en bestuurden. In de tweede plaats is er de notie die aansluit bij het doelmatigheidsargument: decentralisatie vormt (ten dele) een oplossing voor een aantal problemen in het functioneren van het openbare bestuur, zoals verkokering, onvoldoende uitwoeringsgerichtheid en gebrek aan maatwerk.

8 Dat er ook wen zekere spanning kan bestaan tussen participatie en effectiviteit kan bestaan, tonen Dahl en Tufte (r973) aan. Zij stellen dat in een klein politiek systeem de effectiviteit (system capacity) beperkt is, terwijl de mogelijkheden voor participatie (citizen effectiventess) groter zijn. Voor een nuancering van deze stelling bij Nederlandse gemeenten, zie Denters et al. (1990) en Derksen et al. (1987).

9 Simonis en Lehning (1987: 12-18) stellen het actorenperspectief tegenover het waarnemersperspectief, waarbij beleid als sociaal verschijnsel wordt opgevat. In tegenstelling tot de actorenbenadering ligt bij het waarnemersperspectief de nadruk niet zozeer op de vraag hoe de werkelijkheid gemanipuleerd kan worden, als wel op vragen die voortvloeien wit wetenschappelijke nieuwsgierigheid. Er is meer aandlacht voor het historisch en cultureel bepaalde karakter van beleid; prescriptie speelt in principe geen rol.

to Vanuit de opvatting van democratie als methode van beshitvorming waarmee beleid wordt gevormd en gecontroleerd, is het noodzakelijk dat de gekozen organen in een representatieve democratie betrokken zijn bij de beleidsvorming en -controle (vgl. Van der Kolk 1997). Slechts als zij daadwerkelijk participeren in deze processen, is het voor kiezers van belang hun invloed uit te oefenen op de samenstelling van deze politieke organen, dan wel zich tot deze organen te richten om directe invloed uit te oefenen op de besluitvorming. Als private uitwoeringsorganisaties volledig autonoom opereren, is de lokale politiek voor burgers van geen belang op de desbetreffende beleidsterreinen. Democratische controle, direct door de gemeenteraad en indirect door kiezers, vindt in dat geval niet plaats. De beleidstheorie zegt dat gekozen politieke organen van lagere overheden door de kleinere schaal beter in staat zijn tot 'instructie' en controle van het dagelijkse bestuur (en indirect van de ambtelijke organisatie), en daardoor meer bij dit: bestuur zijn betrokken.

II Er is opzettelijk voor gekozen om het begrip beleidsarena te hanteren in plaats van het gangbare 'netwer.k', om verwarring met beleidsnetwerken als sturingsinstrument ('deliberately sought interactions among individual organizations for purposes of effective policy co-ordination', Hanf $x 978:$ r2) te voorkomen. Actoren kunnen op de een of andere manier relevant zijn voor het jeugdbeleid van een gemeente, zonder dat zij deel uitmaken varn een (opzettelijk gecreëerd) beleidsnetwerk. Van Tatenhove en Leroy (I995) maken een soortgelijk onderscheid tussen 'het beleidsnetwerk als analytisch model' en 'het beleidsnetwerk als sturingsmodel'.

12 Rhodes (I997: 46-53) geeft een goed inzicht in de vele betekenissen die aan governance worden gegeven. Hij komt op basis daarwan tot een stipulatieve definitie met daarin een aantal kenmerken van govemunce:

- interdependentie tussen organisaties, waaronder niet-statelijke actoren;

- voortdurende interacties tussen leden van netwerken wanwege de noodzaak hulpbronnen te delen en over gezamenlijke doelen te onderhandelen;

- spelachtige interacties, gebaseerd op vertrouwen en gereguleerd door overeengekomen spelregels;

- aanzienlijke autonomie van de staat. De staat heeft geen soevereine positie, maar kan netwerken wel indirect (en imperfect) sturen.

Het concept governance heeft een flinke impuls gekregen door het new public managementgedachtegoed (Osborne en Gaebler 1992). 
13. Van der Doelen ( 1989 ) spreekt in dit verband van sturingsmodellen; De Bruijn en Ten Heuvelhof (1991: 5) spreken van instrumentenfamillies.

14 Er zijn ook auteurs (zoals Toonen $198 \mathrm{n}$ ) die beweren dat de versnippering tussen departementen juist extra mogelijkheden en ruimte voor gemeenten biedt. 


\section{$2.1 \quad$ Inleiding}

Dit onderzoek kent twee centrale vragen, met ieder bijbehorende onderzoeksvragen. Op welke wijze een antwoord is gezocht op de onderzoeksvragen, wordt in dit hoofdstuk uiteengezet. In paragraaf 2.2 gaan we in op de gehanteerde methoden voor de beantwoording van de onderzoeksvragen die bij de eerste centrale vraag horen. Deze vragen hebben allen betrekking op het lokale jeugdbeleid. In paragraaf 2.3 gaan we nader in op de methoden die zijn toegepast om tot een antwoord op de aan de tweede centrale vraag verbonden onderzoeksvragen te komen. Deze vragen betreffen het nationale beleid ten aanzien van jeugdigen in relatie tot het lokale jeugdbeleid.

\subsection{Onderzoek naar lokal jeugdbeleid}

De onderzoeksvragen naar het lokale jeugdbeleid vallen grofweg in twee delen uiteen. Het eerste deel betreft de inhoud en het proces van het lokale jeugdbeleid. Tot dit deel behoren de vragen over de ontwikkeling van een lokaal jeugdbeleid, de mate waarin dat voldoet aan een aantal voorwaarden voor effectief beleid (maatwerk, integraliteit en slagvaardigheid) en de mate waarin ruimte wordt geboden aan participatie. Her tweede deel van de vragen naar lokaal jeugdbeleid bestaat uit vragen naar de beleidsuitkomsten van het lokale jeugdbeleid. In deze paragraaf gaan we in op de wijze waarop de onderzoeksvragen bij beide delen zijn beantwoord.

Allereerst dient echter uiteengezet te worden dat in het onderzoek naar lokaal jeugdbeleid twee sporen zijn gevolgd. Om een representatief beeld te geven van het lokale jeugdbeleid in Nederlandse gemeenten is in de eerste plaats een meer kwantitatief spoor gevolgd. Dit spoor is uitgezet in het onderzoeksprogramma Lokaal sociaal beleid (Gilsing et al. 1999) van het Sociaal en Cultureel Planbureau (SCP), waar het onderzoek naar lokaal jeugdbeleid deel van uitmaakt. In dit kwantitatieve onderzoek naar lokaal jeugd beleid wordt gewerkt met een gestratificeerde, representatieve steekproef van 72 gemeenten. Het tweede spoor is kwalitatief van aard. Dit deel had de functie om de vraagstellingen in het kwantitatieve deel te voeden. Daarnaast werd ermee beoogd de kwantitatieve resultaten te illustreren.

Kwantitatief beleidsonderzoek

Uitgangspunt in de steekproef is dat recht wordt gedaan aan de verscheidenheid in omvang en intensiteit van de sociale problematiek tussen gemeenten, omdat verwacht mag worden dat de omvang en aard van de problematiek van invloed is op het gevoerde beleid. De steekproef is daarom gestratificeerd naar de stedelijkheid en sociaal-economische status van gemeenten. 
Om de sociaal-economische status van gemeenten of delen daarvan (postcodegebieden) uit te kunnen drukken, heeft het SCP een achterstandsindex geconstrueerd. Deze index geeft een indruk wan de sociaal-economische positie van inwoners van een gemeente of postcodegebied en bestaat uit drie indicatoren: het aandeel personen met een inkomen beneden modaal, het aandeel personen met een lage opleiding en het percentage werklozen.

De gegevens zijn afkomstig uit de WoonMilieu Database 1995 en uit het GeoMarktProfiel-bestand 1994 (zie Bijlage A voor een overzicht van de gebruikte databestanden). Meer precies gaat het on de volgende indicatoren:

- aandeel personen met een inkomen beneden modaal : geschat aantal huishoudens dat een minimuminkomen of een inkomen tussen minimum en modaal heeft als percentage van het totale aantal huishoudens;

- aandeel personen met een lage opleiding: aantal personen met een opleiding op maximaal lbo-niveau verdeeld in negen klassen, lopend van extreem weinig via gemiddeld tot extreem veel;

- percentage werklozen: geschat percentage mensen zonder een betaalde baan.

Met een factoranalyse zijn deze drie indicatoren tot één index samengevoegd. Er is rekening gehouden met het aantal huishoudens per postcodegebied: hoe meer huishoudens, des te zwaarder de bijdrage van dat postcodegebied aan de score. Gebieden met minder dan 25 huishoudens en/of minder dan roo personen zijn niet in de analyse opgenomen; het grootste deel van de gebieden met overwegend andere dan woonfuncties (bedrijfsterreinen) verdwijnt op deze wijze. De scores voor zowel de gemeenten als voor de postcodegebieden zijn opnieuw geschaald zodat in beide gevallen de gemiddelde score (voor heel Nederland) ' 0 ' is. Een lagere score staat dan voor een relatief hoge en een hogere score voor een relatief lage sociaal-economische status. De index loopt voor alle gemeenten van $-1,5 \mathrm{r}$ tot 2,33 .

Na rangschikking volgens de achterstandsindex zijn de gemeenten gescheiden in gemeenten met een score boven het gemiddelde en in gemeenten met een score onder het gemiddelde. De gemeenten die 'o' scoren zijn netjes opgedeeld over de beide categorieën. De twee groepen van gemeenten zijn vervolgens opgedeeld naar stedelijkheid. Als indicator voor stedelijkheid wordt een door het Central Bureau voor de Statistiek (CBS) ontwikkelde maatstaf gebruikt (Den Dulk et al. 1992). In deze maatstaf vormt de concentratie van menselijke activiteiten, zoals wonen, werken en voorzieningengebruik, het kenmerk van stedelijkheid. De concentratie van menselijke activiteiten wordt door het cBs geoperationaliseerd door voor ieder adres de omgevingsadressendichtheid te bepalen. De omgevingsadressendichtheid van een gemeente is gedefinieerd als het gemiddelde van de omgevingsadressendichtheden van alle afzonderlijke adressen binnen de gemeente. De aldus ontwikkelde stedelijkheidsmaat is door het CBS gevalideerd door de samenhang te bekijken tussen de omgevingsadressendichtheid en andere indicatoren voor stedelijkheid enerzijds en variabelen waarvan aangenomen wordt dat zij met stedelijkheid samenhangen anderzijds. Het blijkt dat de omgevingsadressendichtheid vrijwel zonder 
uitzondering beter correleert dan de andere indicatoren voor stedelijkheid, te weten de 'oude' urbanisatiegraad van het CBS, het inwoneraantal en de bevolkingsdichtheid. Het $C B$ s onderscheidt gemeenten in vijf stedelijkheidsklassen:

- zeer sterk stedelijk: een omgevingsadressendichtheid van 2500 adressen of meer per $\mathrm{km}^{2}$;

- sterk stedelijk: een omgevingsadressendichtheid van 1500 tot 2500 adressen per $\mathrm{km}^{2}$;

- matig stedelijk: een omgevingsadressendichtheid van 1000 tot 1500 adressen per $\mathrm{km}^{2}$;

- weinig stedelijk: een omgevingsadressendichtheid van 500 tot 1.00o adressen per $\mathrm{km}^{2}$;

- niet stedelijk: een omgevingsadressendichtheid van minder dan 500 adressen per $\mathrm{km}^{2}$.

Zo ontstaan er tien groepen van gemeenten: vijf groepen met een relatief hoge en vijf met een relatief lage sociaal-economische status. Besloten is uit elke groep at random een gelijk aantal gemeenten te trekken. Op deze wijze zijn acht gemeenten uit elke groep getrokken; aangezien één groep slechts twee gemeenten bevat, kwam de totale steekproef op 74 gemeenten. Met dit aantal gemeenten was in 1999 ruim $13 \%$ van het toenmalige aantal gemeenten in de steekproef vertegenwoordigd.

Door deze wijze van steekproeftrekking zijn de (zeer) sterk stedelijke gemeenten oververtegenwoordigd in de steekproef. Deze keuze is bewust gemaakt vanwege de naar verwachting hogere intensiteit van de sociale problematiek in in ieder geval delen van deze gemeenten. De gemeenten zijn in voldoende mate gespreid over de provincies.

Het kwantitatieve beleidsonderzoek is op twee momenten verricht. Op het eerste moment, in 1999 , is gebruikgemaakt van de steekproef zoals hierboven omschreven. Daarna is opnieuw in 2002 onderzoek gedaan. In de periode tussen het moment van steekproeftrekking en het herhaalde onderzoek in 2002 hebben verschillende gemeenten te maken gehad met processen van gemeentelijke herindeling. Op twee na zijn alle gemeenten uit de oorspronkelijke steekproef gehandhaafd. Twee gemeenten (Gendt en Egmond) die in die periode zijn opgegaan in grotere gemeenten, waarbij zij zelf niet de grootste samenstellende gemeente waren, zijn uit de steekproef verwijderd.

De steekproefgemeenten en de eventuele herindelingsprocessen waarbij zij in de periode van r 998 tot en met 200 I betrokken zijn geweest, staan opgesomd in Bijlage B.

\section{Kwalitatief beleidsonderzoek}

Naast het meer kwantitatieve onderzoek in alle steekproefgemeenten is in het onderzoek naar lokaal jeugdbeleid ook nadrukkelijk voor een kwalitatief spoor gekozen. In het eerste SCP-onderzoek naar lokaal jeugdbeleid (Gilsing 1999) is het beleid van de steekproefgemeenten ingedeeld op basis van een typologie die bestond uit drie beleidstypen. In de eerste plaats waren er gemeenten met een interactief beleidstype: 
een relatief ver ontwikkeld jeugdbeleid, met een relatief hoog niveau wan voorzieningen voor de jeugd en een beleid dat relatief sterk gericht was op het betrekken van de jeugd. In de tweede plaats werd het actieve beleidstype onderscheiden: een redelijk ver ontwikkeld jeugdbeleid, een wat meer dan gemiddeld voorzieningenniveau, en een beleid dat beperkt gericht is op het betrekken van jeugd. In het derde beleidstype - passief beleid - is het beleid zeer beperkt ontwikkeld, is het voorzieningenniveau relatief laag en wordt de jeugd zeer beperkt bij het beleid betrokken. Voor ieder beleidstype zijn drie gemeenten geselecteerd, waarbij ook rekening is gehouden met achtergrondkenmerken van gemeenten, zoals stedelijkheid, omvang en sociaal-economische status. In deze negen gemeenten is in de periode tussen de twee kwantitatieve onderzoeken van 1999 en 2002 meer diepgaand onderzoek verricht naar het lokale jeugdbeleid. In tabel 2.ris een overzicht opgenomen van de negen gemeenten (zie ook box 2.I).

\section{Tabel 2.1}

Overzicht onderzoeksgemeenten kwalitatief anderzoek

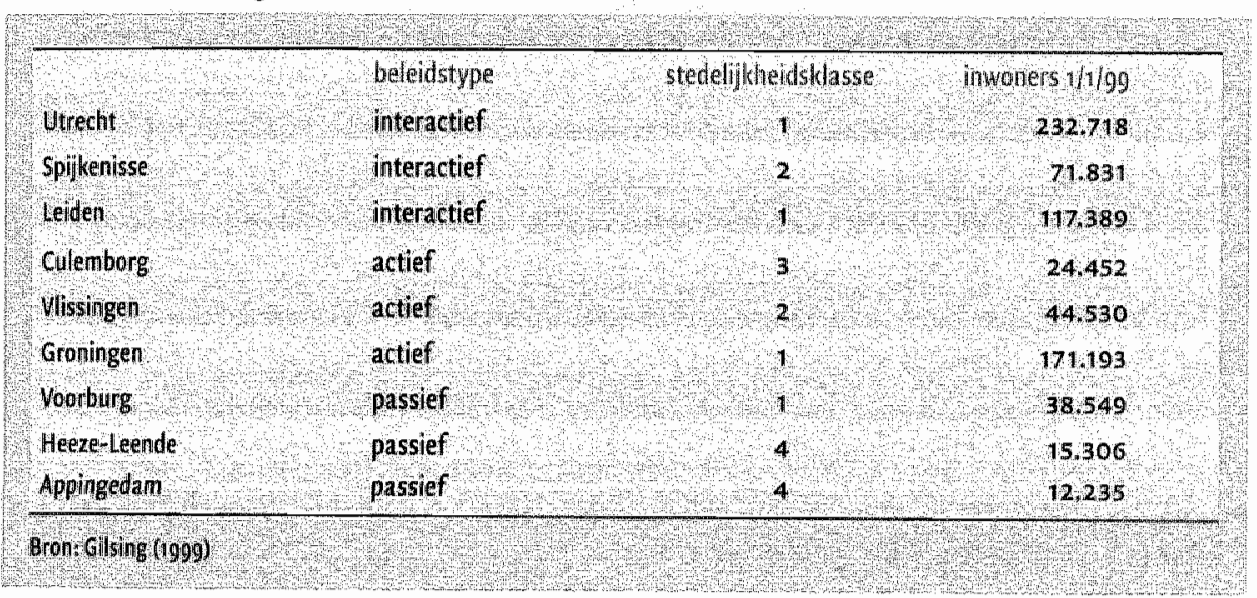

In de loop van 2000 is in deze gemeenten het grootste deel van het kwalitatieve deel van het onderzoek verricht. Daarnaast is in 2002 de methode van Jongereninspectieteams ingezet in deze gemeenten - waarover meer in paragraaf 2.2 .4 . 


\section{Box 2.1 Typering onderzoeksgemeenten kwalitatief onderzoek}

\section{Appingedam}

De gemeente Appingedam behoort tot de weinig stedelijke gemeenten. Ze had in 1999 ruim 12.000 inwoners, van wie bijna $30 \% 0-25$-jarigen. Van het totale aantal inwoners is $4,6 \%$ van niet-westerse allochtone afkomst. $27 \%$ van de basisschoolleerlingen behoort tot de gewichtenleerlingen. Het gaat om ongeveer evenveel 1,9 -leerlingen alls 1,25 -leerlingen. Al deze kinderen hebben ouders die een laag beroep5- en opleidingsniveau hebben. Appingedam kent relatiefveel huishoudens met een laag inkomen en ook relatilef veel eenpersoonshuishoudens met kinderen met een laag inkomen. De gemeente is in het onderzoek van 1998 getypeerd als een gemeente met een passief jeugdbeleid: een relatief laag voorzieningenniveau, een weinig ontwikkeld jeugdbeleid en weinig aandacht voor het betrekken van de jeugd bij het lokale jeugdbeleid.

\section{Culemborg}

Culemborg telde in 1999 rond 25.000 inwoners en behoort tot de klasse 'matig stedehijk'. Ruim een derde van de bevolking is jonger dan 25 jaar. Bijna $20 \%$ van de bevolking is van allochtone afkomst, waarvan $11 \%$ van niet-westerse afkomst. Vooral Marokkanen vormen een relatief groot deel van de bevolking. Het aandeel 1,25-leerlingen in het basisonderwijs is met $8 \%$ rellatieflaag, terwijl het aandeel van 1,9 -leerlingen met $19 \%$ relatief hoog is. Het percentage huishoudens met kinderen en een laag inkomen is ongeveer gelijk aan het landelijke percentage. De gemeente Culemborg had in 1998 een relatief ver ontwikkeld jeugdbeleid en werd gerekend tot de "actieve' gemeenten. De doelstellingen van het beleid waren weliswaar algemeen geformuleerd, maar er was sprake van een relatief sterke integrale beleidswoering. Aan de participatie van jeugd werd iets meer dan gemiddeld aandacht besteed. Het voorzieningenniveau bleef achter en lag onder het landelijke gemiddelde.

\section{Groningen}

Groningen is een zeer sterk stedelijke gemeente, waar in 1999 zo" $n$ 175.000 mensen woonden. Het percentage 0 - tot 25 -jarigen is bijna 37 . Dit is relatief hoog, zeker gezien de stedelijkheidsklasse. Er wonen relatief veel Antillianen en Surinamers in Groningen. Het aandeel allochtonen in de bevolking is voor een grote stad echter klein, wat zich vertaalt in een relatief laag percentage 1,9 -leerlingen in het basisonderwijs. In totaal behoort $28 \%$ van de leerlingen in het basisonderwijs tot de gewichtenleerlingen. De gemeente kent, rekening houdend met de stedelijkheid, een hoog a andeel huishoudens met lage inkomens. Het gemeentelijke jeugdbeleid was in 1999 behoorlijk ontwikkeld, maar jong. In de nota van 1999 zijn veel beleidsvoornemens opgenomen, waarvan een deel pas in latere jaren uitgevoerd zal worden. Het beleid is deels uitgewerkt in kwantitatieve en deels in kwalitatieve doelstellingen. De mate van integraliteit was hoog en er was veel aandacht voor regievoering. 


\section{Vervolg Box 2.1 Typering onderzoeksgemeenten kwalitatief onderzoek}

Op het gebied wan het betrekken van jeugd scoorde de gemeente iets boven het gemiddelde. Het woorzieningenniveau was hoog, wat samenhangt met de centrumfunctie van de stad. Groningen was in 1999 te typeren als actieve gemeente.

\section{Heeze-Leende}

Heeze-Leende is een weinig stedelijke gemeente en telde in 199915.306 inwoners. $30 \%$ van de bevolking van Heeze-Leende is jonger dan 25 jaar. De gemeente heeft weinig gewichtenleerlingen en een laag aantal huishoudens met een laag inkomen. Er wonen nauwelijks niet-westerse allochtonen in de gemeente. Het jeugdbelleid van de gemeente is in het vorige onderzoek getypeerd als passief: een laag voorzieningenniveau en een weinig ontwilkkeld jeugdbeleid waarbij weinig wordt gedaan aan het betrekken van de jeugd.

\section{Leiden}

De gemeente Leiden had in 1998 van de negen onderzoeksgemeenten die in het kwalitatieve onderzoek betrokken zijn het meest ontwikkelde jeugdbeleild. Het beleid strekte zich uit over een groot aantal voor jeugd relevante beleidssectoren, er was relatief weel aandacht voor effectmeting en er vond relatief veel interne en externe afstemming van het beleid plaats. De jeugd werd er meer dan gemiddeld bij het beleid betrokken en het voorzieningenaanbod voor jeugdigen was hoog. Leiden behoort tot de zeer sterk stedelijke gemeenten. In 1999 woonden er $117.3^{89}$ mensen. Eenderde daarvan was jonger dan 25 jaar. Ongeveer $12 \%$ van de Leidse bevolking is van niet-westerse allochtone afkomst. Er zijn, gelet op stedelijkheidsklasse, relatief weinig gewichtenleerlingen in Leiden. Ook zijn er, rekening houdend met de stedelijkheidsklasse, minder dan gemiddeld huishoudens met een laag inkomen.

\section{Spijkenisse}

Spijkenisse behoorde in 1998 tot de gemeenten met een interactief beleidstype. Het beleid was er relatief ver ontwikkeld ( uitgewerkt in kwalitatieve doelstellingen en daaraan gekoppelde beleidsmaatregelen), er werd veel gedaan om de jeugd bij het beleid te betrekken, en het voorzieningenniveau was er boven gemiddeld. In 1999 woonden er ruim 70.000 mensen. Ruim een derde daarvan bestond uit mensen jonger dain 25 jaar. $11 \%$ van de bevolking is van een niet-westerse allochtone afkomst. Het grootste deel hiervan bestaat uit Surinamers en Antillianen.

Spijkenisse behoort tot de sterk stedelijke gemeenten. In vergelijking met andere sterk stedelijke gemeenten heeft Spijkenisse veel gewichtenleerlingen, zowel 1,25-leerlingen als 1,9 -leerlingen. Het percentage huishoudens met een laag inkomen is gemiddeld. 


\section{Vervolg Box 2,1 Typering onderzoeksgemeenten kwalitatief onderzoek}

\section{Utrecht}

De gemeente Utrecht had in 1999 232.718 inwoners, van wie ruim een derde jonger was dan 25 jaar Utrecht behoort tot de zeer sterk stedelijke gemeenten. Er zijn relatief erg veelgewichtenleerlingen, vooral 1,9-leerlingen, dus leerlingen waarvan de ouders én een laag beroeps - en opleidingsniveau hebben én behoren tot én van de erkende minderheidsgroeperingen. Ongeveer $19 \%$ wan de bevolking van de gemeente Utrecht is van niet-westerse allochtone afkomst. Het percentage huishoudens met een laag inkomen is ongeveer gemiddeld vergeleken met andere gemeenten in deze stedelijkheidsklasse. Utrecht is in het vorige onderzoek naar lokaal jeugdbeleid geplaatst bij de gemeenten met een interactief beleidstype. Dat wil zeggen dat in deze gemeente het voorzieningenniveau hoog is, het jeugdbeleid er ver is ontwikkeld en de jeugd in sterke mate wordt betrokken bij het jeugdbeleid.

\section{Vlissingen}

Vlissingen is een sterk stedelijke gemeente. Naar aanleiding van het vorige onderzoek is het jeugdbeleid getypeerd als actieff een redelijk voorzieningenniveau, vooral wat betreft algemeen preventieve voorzieningen, en een meer dan gemiddeld ontwikkeld jeugdbeleid, waarbij jeugdigen echter maar in beperkte mate betrokken worden. De gemeente Vissingen had in 1999 bijna 45.000 inwoners, van wie ongeveer $30 \%$ kinderen en jongeren tot 25 Jaar. Ruim $20 \%$ van de Vissingers is van niet-westerse allochtone aflomst Er zijn relatief veel 1,25- en 1,9 gewichtenleerlingen. Het percentage huishoudens noet een laag inkomen is wat hoger dan gemiddeld in deze stedelijkheidsklasse.

\section{Voorburg}

De gemeente Voorburg is een zeer sterk stedelike gemeente. Ze had in 1999 een kleine 40.000 inwoners Van de gemeentebevolking is $23 \%$ van niet-westerse afkomst. Het gaat vooral om Surinamers. Er zijn relatief weinig gewichtenleerlingen, Ook zijn er relatief weinig huishoudens met een laag inkomen. Het jeugdbeleid was in 1998 te typeren als passief beleid. Er was een lager dan gemiddeld voorzieningenniveau, een weinig ontwikkeld jeugdbeleid en er werd weinig gedaan aan het betrekken van de jeugd. Per 01-01-02 is de gemeente Voorburg officieel gefuseerd met de gemeente Leidschendam tot de gemeente Leidschendam-Voorburg. In dit onderzoek gaat het echter nog alleen on de gemeente Voorburg

\subsubsection{Het onderzoek naar lokaal jeugdbeleid: de inhoud en het proces}

In I998 zijn in de (toen nog) 74 onderzoeksgemeenten de ambtelijke sleutelinformanten jeugdbeleid benaderd met een gestructureerde vragenlijst, die voor een belangrijk deel de beleidsinhoud en in mindere mate het beleidsproces betrof. De 
vragenlijst werd mondeling afgenomen. In dat jaar zijn $7 \mathrm{r}$ interviews gehouden, wat neerkomt op een responspercentage van 96 . In 2002 zijn de ambtelijke sleutelinformanten opnieuw benaderd, ditmaal met een schriftelijke vragenlijst. Deze lijst bevatte voor een deel dezelfde vragen als in 1998 , maar was meer dan in 1998 gericht op het beleidsproces en dan met name op de sturende rol van gemeenten. In 2002 zijn uiteindelijk 60 van de 72 vragenlijsten geretourneerd $(83 \%)$. De vragenlijsten zijn opgenomen in Bijlage $\mathrm{C}$.

Daarnaast zijn zowel in 1998 als in 2002 de voor het jeugdbeleid relevante beleidsdocumenten geanalyseerd op een aantal punten. Op deze punten werden de gemeenten gescoord. Van r 998 zijn in totaal van 67 gemeenten de resultaten van deze documentanalyse bekend. In 2002 is hetzelfde gedaan, maar dan alleen voor de 36 gemeenten die sinds 1998 nieuwe, voor het jeugdbeleid relevante kader- of strategische nota's hebben opgesteld. Als gemeenten geen nieuwe nota hadden uitgebracht in de periode van 1998 tot 2002, werden de resultaten van 1998 ook voor het jaar 2002 gebruikt. De punten waarop de nota's zijn gescoord, zijn te vinden in Bijlage A.

In de loop van 2000 is in negen gemeenten het kwalitatieve deel van het onderzoek verricht. Er is gesproken met de voor het jeugdbeleid verantwoordelijke wethouders en - afzonderlijk - met de ambtelijke sleutelinformanten. In total zijn er dus achttien interviews gehouden. Het doel daarvan was om een meer diepgaand inzicht te verkrijgen in de prioriteiten in het jeugdbeleid, en in de wijze waarop de gemeenten het samenwerkingsproces met andere actoren trachtten te sturen. De inzichten die uit deze interviews zijn verkregen zijn dan ook gebruikt bij het opstellen van de vragenlijsten voor het onderzoek in 2002.

De interviews waren semi-gestructureerd van opzet. Alle interviews zijn uitgewerkt in verslagen.

Daarnaast is in elk van deze gemeenten gesproken met vertegenwoordigers van uitvoerende instellingen. In elke gemeente is getracht een interview te houden met een vertegenwoordiger van een Bureau Jeugdzorg, een vertegenwoordiger van een bij het 0 - tot 6-jarigenbeleid betrokken instelling, een vertegenwoordiger van het basisonderwijs en een vertegenwoordiger van een welzijnsinstelling betrokken bij het jeugd- en jongerenwerk. De keuze van de instellingen werd voor een belangrijk deel bepaald door de speerpunten van het Bestuursakkoord Nieuwe Stijl (BANS I999a). Ook in deze semi-gestructureerde interviews werd met item-lijsten gewerkt, die per type instelling verschilden. In de interviews met de instellingen stonden steeds de inhoud en een aantal procesmatige aspecten van het lokale jeugdbeleid centraal, vanzelfsprekend benaderd vanuit het perspectief van de betreffende instelling. Uiteindelijk zijn 35 van de 36 interviews gehouden die in deze negen gemeenten waren gepland. 
Bovendien zijn de voor het jeugdbeleid relevante en beschikbare beleidsdocumenten in deze gemeenten op meer diepgaande wijze geanalyseerd dan bij de documentanalyse in het kwantitatieve onderzoeksdeel het geval was. Deze documentanalyse is gebruikt om de interviewresultaten in een kader te plaatsen en te verdiepen (Netten 2000).

In dit onderzoek wordt het kwalitatieve onderzoeksmateriaal gebruikt om de meer kwantitatieve beschrijvingen van de ontwikkelingen in het jeugdbeleid (de hoofdstukken $3 \mathrm{t} / \mathrm{m}$ 6) te ondersteunen en illustreren. Daarbij past nogmaals de opmerking dat het kwalitatieve materiaal dateert uit 2000 en daarmee minder actueel is dan de kwantitatieve onderzoeksgegevens. Daardoor is het materiaal ter illustratie echter niet minder bruikbaar.

\subsubsection{Onderzoek naar lokaal jeugdbeleid: de beleidsuitkomsten}

\section{Beleidseffecten}

Ten behoeve van het onderzoek naar de effecten van beleid is in 2002 getracht om voor de 72 onderzoeksgemeenten cijfers voor zowel 1998 als 20or op een aantal voor het jeugdbeleid relevante output- en outcome-indicatoren te verzamelen. Voor een deel konden deze gegevens worden betrokken uit centrale registraties, maar voor het grootste deel van de indicatoren waren gemeenten en lokale instellingen de leverancier. Omdat voorzien was dat het verzamelen van gegevens bij gemeenten moeizaam zou kunnen verlopen, vanwege beperkte beschikbaarheid en het gebruik van uiteenlopende definities, is voor dit deel van het onderzoek in vijf gemeenten een pilotstudy uitgevoerd. Deze pilotstudy leidde ertoe dat een van de indicatoren van de lijst verwijderd moest worden. Bovendien bleek dat het voor geen van de indicatoren mogelijk was een uitsplitsing te maken naar bepaalde subgroepen van de populatie jeugdigen, behalve op basis van leeftijd. Voor het overige leverde de pilotstudy geen noemenswaardige problemen op, zodat werd besloten opdracht te geven voor de uitvoering van het onderzoek in de overige 67 gemeenten.

Het verzamelen van de gegevens bleek echter zeer moeizaam te verlopen. In tabel 2.2 is een overzicht opgenomen van de item-respons. De meeste gemeenten leverden ofwel geen gegevens, ofwel gegevens voor een deel van de indicatoren, ofwel niet de gegevens voor beide gevraagde jaren 1998 en 2001. Voor indicatoren waarvoor de cijfers bij gemeenten moesten worden verzameld zijn in het beste geval, en dit geldt een beperkt aantal indicatoren, van maximaal 25 gemeenten de cijfers voor 1998 en 200 beschikbaar. Het betreft de cijfers over het bereik en de capaciteit van kinderdagverblijven en over het aantal openbare speelvoorzieningen en ontmoetingsplekken. Voor de overige indicatoren geldt dat van minder dan twintig gemeenten de cijfers bekend zijn. Het laagst scoort de indicator voortijdig schoolverlaten, waar niet meer dan een luttel aantal gemeenten en/of Regionale Meld- en Coördinatiepunten voortijdige schoolverlaters (RMC's) in staat bleek überhaupt cijfers voor de eigen gemeente boven tafel te krijgen. 
Thete: 2

Output- en outcome-indicatoren: item-respons, naar jaartal (aantal gemeenten, maximum $=72$ )

\begin{tabular}{|c|c|c|c|c|c|}
\hline . & 1998 & 2000 & 2001 & 1998 enzons & bram \\
\hline berek kinderdagverblijven & 25 & 7 & 31 & 23 & gemieente \\
\hline bereilk peuterspeelzalen & 18 & 8 & 30 & 16 & gemeente \\
\hline $\begin{array}{l}\text { omwang wachtijijsten } \\
\text { kinderdagverblijven }\end{array}$ & 15 & 3 & 21 & 13 & gemeente \\
\hline $\begin{array}{l}\text { capaciteit kinderdag- } \\
\text { werblijven }\end{array}$ & 28 & 8 & 31 & 25 & gemeente \\
\hline $\begin{array}{l}\text { omvang wachtlijsten } \\
\text { peuterspeelzalen }\end{array}$ & $\because$ & 3 & 26 & 13 & gemeente \\
\hline $\begin{array}{l}\text { bereik projecten voor- en } \\
\text { wroegschoolse educatie }\end{array}$ & 21 & 5 & 31 & 19 & gemeente \\
\hline $\begin{array}{l}\text { omvang wachtijsten specialal } \\
\text { basisonderwils }\end{array}$ & 11 & 0 & 17 & 11 & gemeente \\
\hline bereik brede scholen & 16 & 3 & 21 & 15 & gemeente \\
\hline $\begin{array}{l}\text { andeel voortijdige school- } \\
\text { verltaters, teruggeleid }\end{array}$ & 0 & 0 & 1 & 0 & gemeente/RMC \\
\hline $\begin{array}{l}\text { aandeell woontijdige school- } \\
\text { verlaters groep } 17-22 \text {-jarigen }\end{array}$ & 1 & 0 & 3 & 1 & gemeente/RMC \\
\hline $\begin{array}{l}\text { percentage leerlingen in } \\
\text { speciaal basisonderwijs }\end{array}$ & 20 & 6 & 29 & 17 & gemeente \\
\hline $\begin{array}{l}\text { gemiddelde Cito-scores } \\
\text { basisonderwils }\end{array}$ & $67(1999)$ & 0 & 71 & 67 & Cito \\
\hline aandeel met uitkering & 12 & 71 & $\pi$ & 72 & CBS \\
\hline antal Halt-afdoeningen & 0 & 0 & 58 & 0 & Halt Nederland \\
\hline $\begin{array}{l}\text { aandeel minderjaris } \\
\text { gehoorde verdachten }\end{array}$ & 72 & 0 & 72 & 72 & CBS \\
\hline aandeel lid sportvereniging & 15 & 6 & 15 & 8 & gemeente \\
\hline aandeel lid bibliotheek & 62 & 7 & 64 & 53 & $\begin{array}{l}\text { Vereniging van } \\
\text { Openbare } \\
\text { Bibliotheken }\end{array}$ \\
\hline $\begin{array}{l}\text { gantal openbare speelvoor- } \\
\text { zieningen }\end{array}$ & 24 & 2 & 35 & 21 & gemeente. \\
\hline aantal ontmoetingsplekken & 24 & 1 & 38 & 24 & gemeente \\
\hline bereik consultatiebureaus. & 36 & o & 46 & 36 & $\begin{array}{l}\text { thuiszorg: } \\
\text { organisaties }\end{array}$ \\
\hline
\end{tabular}

Dons SCP (MB geggetillen 2002$)$

De indicatoren waarvan de gegevens afkomstig zijn uit centrale bronnen gaven minder problemen. Niettemin betreffen de cijfers over het aantal Halt-afdoeningen alleen het jaar 2001 , terwijl de cijfers over het bereik van de consultatiebureaus slechts voor de helft van de gemeenten voor beide jaren beschikbaar zijn. Ook de cijfers over de jeugdzorg leverden problemen op. Voor 1998 zijn bij de Stichting Registratie Jeugdvoorzieningen (SRJV) van ongeveer $80 \%$ van de instellingen de cijfers bekend, en voor 2000 van $60 \%$. Dat heeft tot gevolg dat de cijfers op gemeentelijk niveau op (bijna) alle fronten een daling laten zien in instroom en gebruik. Een der- 
gelijke trend staat haaks op de trendrapporten van de SRJV, die op veel punten een toename laten zien. Dit is mogelijk doordat de totale cijfers per jaar worden bijgeschat tot 100\% van de instellingen. Deze bijschatting is op gemeentelijk niveau niet mogelijk. Omdat tevens onduidelijk is hoe de respons van instellingen in beide jaren de cijfers van afzonderlijke gemeenten beïnvloedt, moet geconcludeerd worden dat de sRjV-cijfers voor het doel van dit onderzoek onbruikbaar zijn.

Een andere beperking van dit deel van het onderzoek is dat gemeenten in relatief veel gevallen aangaven dat de door hen geleverde cijfers niet helemaal voldeden aan de aan de indicatoren gekoppelde omschrijvingen. Met andere woorden, de gehanteerde definities lopen uiteen.

Als we de 'duur van de wachtlijst'-indicatoren en de 'voortijdig schoolverlaten'-indicatoren buiten beschouwing laten, dan blijven er twaalf indicatoren over waarvoor gemeenten gevraagd zijn cijfers te leveren. Van de 72 gemeenten hebben er 32 voor geen enkele indicator cijfers voor 1998 en zoor geleverd. Negentien gemeenten leverden cijfers over beide jaren voor één tot vijf indicatoren, twintig voor zes tot tien, en slechts vier voor elf of twaalf indicatoren.

De vraag is of er sprake is van een selectieve respons door gemeenten. Het zou kunnen zijn dat de gemeenten met een relatief omvangrijk ambtelijk apparaat, of gemeenten met veel aandacht voor het jeugdbeleid, vaker over cijfers beschikken dan andere gemeenten. Het gemiddelde aantal indicatoren waarop voor beide jaren cijfers zijn geleverd, ligt voor alle gemeenten iets boven de drie. De meest stedelijke gemeenten leveren gemiddeld weliswaar meer gegevens dan de minst stedelijke gemeenten $(3,9$ vs. 2,5$)$, maar het verschil is niet significant.

De lage respons, gevoegd bij de variëteit in gehanteerde definities, heeft ons doen besluiten in dit onderzoek alleen over de gegevens uit centrale bronnen te rapporteren. Daarmee verliest het onderzoek naar de resultaten van het beleid aan kracht. Er blijft immers een beperkt aantal indicatoren over, zodat er nauwelijks sprake kan zijn van een brede beoordeling van het jeugdbeleid. Bovendien was de verwachting dat resultaten beter geïnterpreteerd zouden kunnen worden als deze in een breder kader van resultaten zouden kunnen worden geplaatst. Ook dat is nu niet mogelijk.

Intersubjectieve beoordeling beleidsactoren

In 2002 zijn in de 72 gemeenten steeds tien instellingen benaderd waarvan verondersteld mag worden dat zij betrokken zijn bij het jeugdbeleid. In de schriftelijke, gesloten vragenlijst waren vragen opgenomen over het beleidsproces - de wijze waarop de instelling bij het lokale jeugdbeleid betrokken is - en vragen naar een oordeel over verschillende aspecten van het jeugdbeleid (zie Bijlage $\mathrm{C}$ ). Deze vragen zijn voor een deel ook opgenomen in de vragenlijst voor de ambtelijke sleutelinformanten jeugdbeleid (zie \$2.2.I), zodat ook van de ambtenaren hun oordeel over het beleid bekend is. 
De (in principe) in alle gemeenten benaderde instellingen zïjn weergegeven in tabel 2.3. Voor een deel zijn de adressen en de namen van contactpersonen bij de instellingen aangeleverd door de ambtelijke sleutelinformanten aan het eind van hun vragenlijst. Als dit niet het geval was, hebben de onderzoekers de adressen van instellingen zelf opgezocht en zijn de lijsten niet op naam gesteld verzonden. Omdat in sommige gemeenten bepaalde typen instellingen niet werkzaam bleken te zijn - dit geldt met name voor het voortgezet onderwijs - of omdat van sommige instellingen adressen niet achterhaald konden worden, zijn uiteindelijk 682 vragenlijsten verstuurd. In totaal hebben $37 x$ instellingen gereageerd, wat neerkomt op een respons van $55 \%$. Daarbij dient opgemerkt te worden dat sommige instellingen, vooral Bureaus Jeugdzorg, RMC's en GGD's meerdere vragenlijsten hebben ontvangen, omdat zij bij het jeugdbeleid van verschillende gemeenten in een regio betrokken zijn. De respons onder deze dubbel aangeschreven instellingen wijkt met $56 \%$ echter niet af van de respons onder alle instellingen. Ook onder de instellingen die niet waren 'aangereikt' door de gemeenteambtenaren week de respons met $57 \%$ niet noemenswaardig af van de totale respons.

\section{Tabel 2.3}

Actoren betrokken bij beoordeling jeugdbeleid

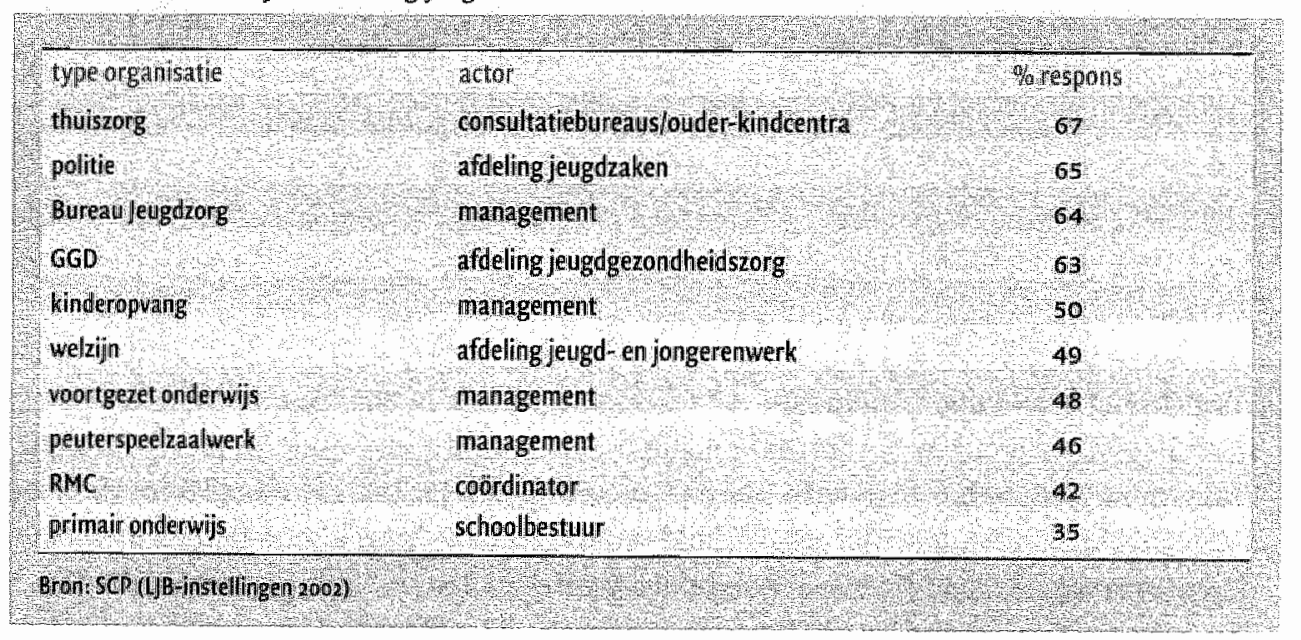

De respons verschilt wel naar type instelling (zie tabel 2.3). Organisaties voor thuiszorg, de politie, Bureaus Jeugdzorg en GGD's hebben in veel sterkere mate meegewerkt aan het onderzoek dan RMC's en schoolbesturen in het primaire onderwijs. Gedurende de uitvoering van het veldwerk bleek verscheidene malen dat R.MC-functionarissen het lastig vonden om het jeugdbeleid van de gemeente waar zij als ambtenaar werkzaam zijn, of het jeugdbeleid van regiogemeenten, te beoordelen. Een verklaring voor de relatief lage respons van de schoolbesturen in het primaire onderwijs is niet direct voorhanden. Mogelijk speelt de relatief geringe betrokkenheid van deze besturen bij het lokale jeugdbeleid een rol. 
De respons verschilt sterk per gemeente (zie tabel 2.4) en bedroeg gemiddeld 5,2. Er zijn geen gemeenten waar geen enkele instelling heeft gereageerd. Tegelijkertijd zijn er ook geen gemeenten waar alle tien de instellingen hebben gereageerd. In een deel van de analyses in de hoofdstukken 6 en 8 worden de instellingsgegevens per gemeente samengevoegd, om zo uitspraken op het niveau van de gemeente te kunnen doen. Deze aggregatie van gegevens vond alleen plaats als er minimaal drie instellingen hadden gereageerd, die uit een bepaalde gemeente komen of daarbij betrokken zijn. Op die manier wordt voorkomen dat uitspraken over het jeugdbeleid van een gemeente in te sterke mate door één instelling worden bepaald. Deze werkwijze sluit ${ }_{12} \%$ van de gemeenten uit van de analyses op geaggregeerd niveau.

Tiabel 2.4

Respons instellingen, per gemeente $(n=72)$

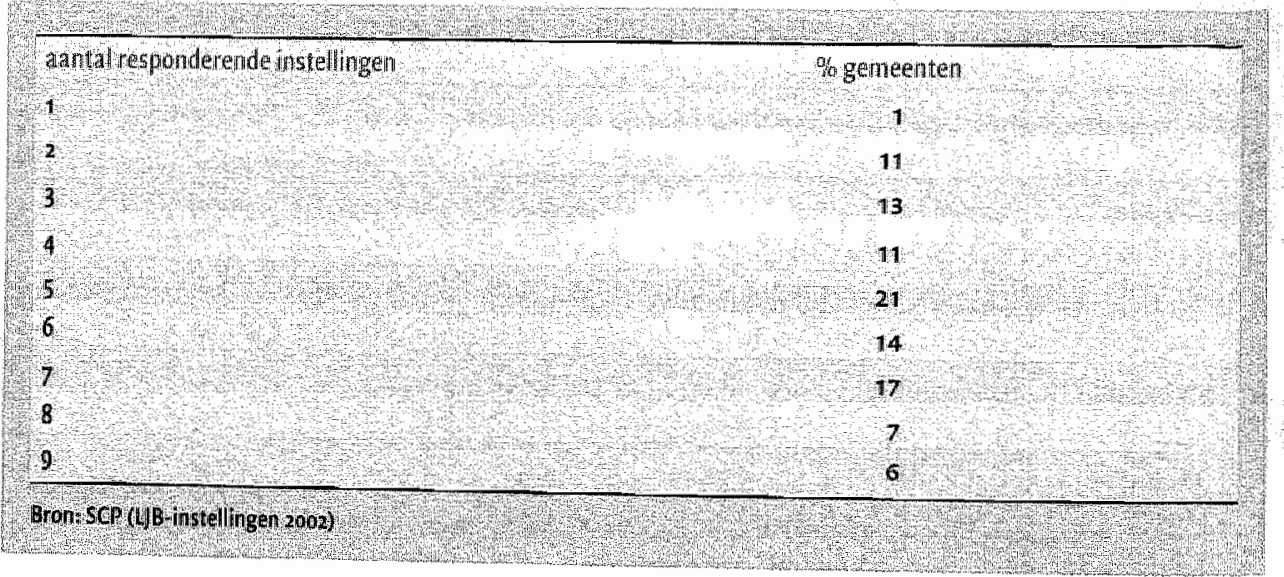

Waardering beleid door doelgroep

In de negen gemeenten die betrokken zijn bij het kwalitatieve onderzoeksspoor zijn zogenoemde Jongeren Inspectie Teams (JIT's) ingezet. Deze methode is door de Stichting Alexander speciaal ontwikkeld om jongeren te betrekken bij de beoordeling en vormgeving van het voor hen relevante beleid van instellingen en overheden. Ten behoeve van dit onderzoek liet men jongeren een oordeel vellen over het lokale jeugdbeleid. In iedere gemeente werden tien tot twintig jongeren gerekruteerd om deel te nemen aan een groepsgesprek over het jeugdbeleid. Hierna werden vier tot zes jongeren geselecteerd om een JIT te vormen. De JIT-leden hebben in iedere gemeente in totaal zo'n zestig interviews met andere jongeren gehouden (voor de basisvragenlijst, zie Bijlage $C$ ). De resultaten van deze interviews werden in een afsluitende bijeenkomst door het JIT besproken. De producten van deze methode zijn een databestand met daarin 504 jongeren en hun oordeel over het jeugdbeleid van hun gemeente, en negen door de JIT's opgestelde rapporten over het lokale jeugdbeleid (voor een veldwerkverslag zie Bijlage $D$ ). 


\subsubsection{Overzicht onderzoeksopzet lokaal jeugdbeleid}

Het onderzoek naar lokaal jeugdbeleid is een complex onderzoek door de verschillende deelonderzoeken met steeds eigen methoden. In tabel 2.5 wordt het gehele onderzoek schematisch gepresenteerd.

Tabel 2.5

Overzicht onderzoeksopzet lokaal jeugdbeleid

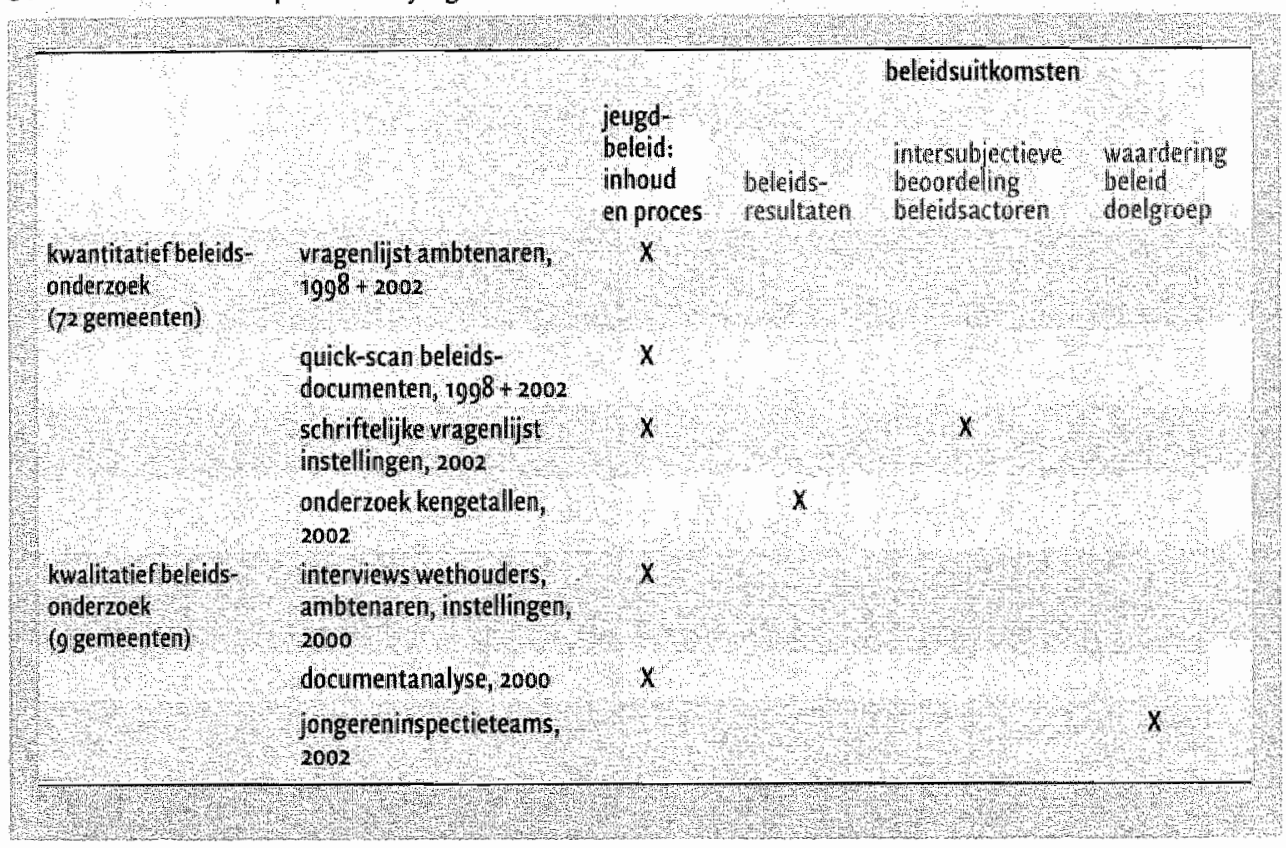

\subsection{Onderzoek naar nationaal jeugdbeleid}

Het onderzoek naar de doelen en instrumenten van het jeugdbeleid van de nationale overheid bestaat uit documentanalyse. Om te beginnen zijn de Rijksbegrotingen van de ministeries van Volksgezondheid, Welzijn en Sport (vws), Binnenlandse Zaken en Koninkrijksrelaties (BZK), Onderwijs, Cultuur en Wetenschap (OCW), Justitie, en Sociale Zaken en Werkgelegenheid (szW) voor de jaren van 1998 tot en met 2002 doorgenomen om vast te stellen of er sprake was van (voorgenomen) beleid gericht op de jeugd. Vervolgens zijn bij deze beleidswoornemens of verwijzingen naar reeds lopend beleid de relevante beleidsstukken verzameld. Dit betreft veelal officiële stukken van de Tweede of Eerste Kamer, publicaties van wetten en regelingen in het Staatsblad, en publicaties van ministeriële regelingen met toelichting in de Staatscourant. Als er voor een bepaald beleid geen primaire bronnen werden aangetroffen, werd er gezocht naar secundaire literatuur: rapporten van externe organisaties over een bepaald beleidsonderwerp. Vooral rapporten waarin verslag werd gedaan van evaluatieonderzoek zijn daarbij geraadpleegd. 
Met behulp van de primaire en secundaire bronnen is getracht een beeld te verkrijgen van de doelstellingen van de nationale overheid en van de instrumenten die werden ingezet om deze doelen te bereiken. De zoektocht naar beleidsdoelen is bemoeilijkt doordat niet altijd even duidelijk is wanneer sprake is van een beleidsdoel of van een meer of minder concreet voornemen. De 'hardere' instrumenten (voorschriften, prikkels) zijn vaak terug te vinden in het Staatsblad of de Staatscourant. Van communicatieve instrumenten is vaak moeilijker te achterhalen hoe zij concreet zijn ingezet. 
Deel il

Lokaal jeugdbeleid 


\subsection{Inleiding}

In de visie op de bestuurlijke rolverdeling in het jeugdbeleid die in 1994 werd uitgebracht, werd van gemeenten verwacht dat zij een specifiek jeugdbeleid zouden ontwikkelen. Zo'n beleid is tevens de sine qua non voor de verwachtingen die ten grondslag lagen aan de decentralisatie. Zonder specifiek jeugdbeleid kan er geen sprake zijn van een integraal, op de lokale situatie afgestemd, slagvaardig en effectief jeugdbeleid waarin ruimte is voor de participatie van burgers. In dit hoofdstuk gaan we daarom in op de mate waarin gemeenten een specifiek jeugdbeleid hebben ontwikkeld. In het eerste onderzoek van het Sociaal en Cultureel Planbureau naar lokaal jeugdbeleid (Gilsing 1999) is hiervoor een meetinstrument ontwikkeld, dat is aangeduid als de 'staat van het jeugdbeleid'. Dit meetinstrument gebruiken we, licht aangepast, ook in dit onderzoek. ${ }^{1}$ Het omvat verschillende aspecten van het lokale jeugdbeleid, die worden samengevat in een gestandaardiseerde score. Hebben gemeenten een specifiek jeugdbeleïd geformuleerd, dat wil zeggen: een zelfstandig categoraal beleid voor de jeugd in de gemeente? En zo ja, in hoeverre is dat beleid nitgewerkt in concrete doelen en maatregelen? Een hiermee samenhangende vraag is hoe het jeugdbeleid in de gemeentelijke organisatie is ingebed. Hoe krijgt de politieke sturing van het jeugdbeleid gestalte en op welke wijze wordt het beleid op ambtelijk niveau gecoördineerd? Ook de gemeentelijke sturing van bij het jeugdbeleid betrokken actoren is daarbij van belang. Tot slot is de vraag aan de orde of en op welke wijze gemeenten de effecten van het door hen gevoerde jeugdbeleid meten.

In dit hoofdstuk zal steeds een vergelijking worden gemaakt tussen de situatie in rg98 en die in 200r, zodat de vraag beantwoord kan worden of gemeenten in die periode nog bezig waren hun jeugdbeleid vorm te geven. Als er sprake is van relatieve stilstand in de beleidsontwikkeling, dan mag, onder de assumptie van een ongewijzigde beleidsomgeving, verondersteld worden dat er ook in de periode na 2001 weinig is veranderd. Als er wel sprake is van dynamiek in de periode 1998-200I, dan mag worden aangenomen dat het lokale jeugdbeleid ook in de periode na $200 \mathrm{r}$ nog verder in ontwikkeling was.

Daarnaast zullen gemeenten op een aantal punten worden vergeleken op basis van de stedelijkheidsklasse waartoe zij behoren. Dit heeft te maken met de 'maatwerkgedachte' uit de decentralisatieredenering. Een veronderstelling bij decentralisatie is immers dat als decentrale overheden over grote beleidsvrijheid beschikken, zij het beleid af zullen stemmen op de lokale situatie en problematiek. Een gemeente met grote groepen jeugd met een verhoogd risico van uitval zal een ander beleid woeren dan een gemeente waarin er geen problemen zijn met de jeugd. In dit onderzoek 
wordt met dergelijke verschillen tussen gemeenten rekening gehouden. Bij de selectie van onderzoeksgemeenten is namelijk rekening gehouden met de stedelijkheid en de sociaal-economische status van gemeenten (zie hoofdstuk 2 ). In het eerste onderzoek naar lokaal jeugdbeleid is uitgebreid aangetoond dat met de stedelijkheid ook de omvang van de groep kwetsbare jeugd toeneemt. Daarnaast blijkt de sociaal-economische status van gemeenten samen te hangen met de omvang van deze groep (Gilsing 1999: 27-36). Stedelijkheid en sociaal-economische status zijn beide relevante indicatoren voor de omvang van de groep kwetsbare jeugd. Deze twee indicatoren hangen onderling beperkt samen.

De verwachting is dat in meer stedelijke gemeenten het jeugdbeleid verder is ontwikkeld, en dat het meer gericht preventief en curatief van aard zal zijn dan in minder stedel ijke gemeenten. Deze verwachting is niet alleen gestoeld op de grotere omvang van de problematiek, maar ook op de grotere omvang van zowel het politieke bestuur als het ambtelijke apparaat. Deze - ook gerelateerd aan het inwoneraantal - grotere omvang van het politieke bestuur en het ambtenarenapparaat heeft te maken met de financiële toerusting van gemeenten door de centrale overheid. Bij de verdeling van middelen uit het Gemeentefonds wordt sinds de invoering van de Financiële-verhoudingswet 1997 onder meer rekening gehouden met de sociale structuur van gemeenten: gemeenten met een zwakke sociale structuur krijgen een relatief hoge uitkering uit het Gemeentefonds. In principe hebben gemeenten met een zwakke sociale structuur daardoor meer bestuurlijke hulpbronnen tot hun beschikking dan sociaal sterkere gemeenten, waardoor zij ook in staat zijn een grotere bestuu rskracht te ontwikkelen. Bovendien wordt met het grotestedenbeleid een aantal steden met specifiek stedelijke problemen extra toegerust om hun sociale problematiek aan te pakken.

In de analyses is steeds een driedeling in stedelijkheidsklassen gehanteerd. De twee meest stedelijke klassen (zeer sterk en sterk stedelijk) zijn samengevoegd, evenals de twee minst stedelijke klassen (weinig en niet stedelijk). Voor een nadere toelichting op de indeling in stedelijkheidsklassen wordt verwezen naar hoofdstuk 2.

In paragraaf 3.2 gaan we eerst in op het gebruikte meetinstrument: de aspecten van het lokale jeugdbeleid die erin zijn opgenomen en de wijze waarop de score is geconstrueerd. In de daarop volgende paragrafen wordt ingegaan op de afzonderlijke aspecten van de maat. Dit zijn achtereenvolgens de beleidsformulering in paragraaf 3.3 , de integrale beleidsvoering in paragraaf 3.4 , en de meting van beleidseffecten in paragraaf 3.5 . In paragraaf 3.6 komen de afzonderlijke lijnen samen in de samenvattende maat 'staat van het jeugdbeleid'. Het hoofdstuk wordt in paragraaf 3.7 afgerond met conclusies. De bevindingen uit het kwantitatieve beleidsonderzoek worden in box 3.I en 3.2 geillustreerd met resultaten van het kwalitatieve onderzoek in negen gemeenten (zie hoofdstuk 2 ). 


\subsection{Het meetinstrument: de staat van het jeugdbeleid}

In de maat 'staat van het jeugdbeleid' is in de eerste plaats de mate van beleidsformulering opgenomen als indicator. Onder de mate wan beleidsformulering verstaan we de uitwerking van het beleid in beleidsdoelen en bijbehorende beleidsinstrumenten. Deze uitwerking is per gemeente op basis van gemeentelijke beleidsnota's en andere voor het jeugdbeleid relevante gemeentelijke documenten vastgesteld. In 1998 is dit gedaan voor alle onderzoeksgemeenten en in 2002 opnieuw voor de gemeenten waarin tussen 1998 en 2002 nieuwe, voor het jeugdbeleid relevante, gemeentelijke nota's zijn vastgesteld. Gemeenten die in die periode geen nieuwe nota's hebben vastgesteld, kregen op deze indicator de score van I 998 .

Het in de nota's neergelegde beleid is ingedeeld in een van de vijf onderstaande categorieën: ${ }^{2}$

I De gemeente heeft geen doelstellingen en bijbehorende beleidsmaatregelen vastgesteld.

2 De gemeente heeft een beperkt aantal doelstellingen en/of beleidsmaatregelen op voor de jeugd relevante beleidsterreinen vastgesteld. Er is geen sprake van specifiek jeugdbeleid.

3 De gemeente voert een specifiek jeugdbeleid; de doelstellingen en/of beleidsmaatregelen zijn in zeer algemene, abstracte termen vastgesteld.

4 De gemeente voert een specifiek jeugdbeleid, waarbij de doelstellingen en/of maatregelen zijn vastgesteld met daarbijbehorende kwalitatieve eindtermen;

5 De gemeente voert een specifiek jeugdbeleid, waarbij de doelstellingen en/of maatregelen zijn vastgesteld met daarbijbehorende kwantitatieve eindtermen.

Een aantal indicatoren voor de samenvattende maat voor beleidsontwikkeling hebben te maken met de mate van integrale beleidswoering.

In de eerste plaats is de breedte van het jeugdbeleid opgenomen als indicator. De leefsituatie van de jeugd omvat immers een veelheid aan onderling samenhangende aspecten en een samenhangend jeugdbeleid zou (een deel van) die verschilJende aspecten moeten omvatten. De breedte van het jeugdbeleid wordt daarom gezien als een indicator voor integrale beleidsvoering. Deze is in beeld gebracht door te kijken naar het aantal voor de jeugd relevante levensterreinen dat door het jeugdbeleid wordt bestreken. De beleidsnota's van de onderzoeksgemeenten zijn gescand op het aantal levensterreinen waarop beleid wordt geformuleerd. Er is gescand op acht levensterreinen. Voor een beschrijving hiervan wordt verwezen naar hoofdstuk 4 , dat een meer inhoudelijke beschrijving bevat. In het perspectief van de huidige paragraaf 3.2 gaat het om de breedte en niet zozeer om de inhoud.

De tweede indicator die betrekking heeft op de mate van integrale beleidswoering is de wijze van onderlinge samenwerking tussen leden wan het college van Burgemeester en Wethouders (B\&W) met portefeuilles die van belang zijn voor het jeugdbeleid. In het onderzoek uit 1999 bleek dat in slechts weinig gemeenten de voor het jeugdbeleid 
relevante beleidsterreinen voor rekening komen van één en dezelfde portefeuillehouder. Voor een integraal beleid is afstemming tussen leden van $\mathrm{B} \& \mathrm{~W}$ daarom van belang. In het onderzoek is aan de gemeentelijke ambtenaren gevraagd hoe vaak de betreffende leden van het college samenwerken op de volgende manieren:

- onderlinge afstemming wanneer er raakvlakken zijn tussen het beleid van verschillende portefeuillehouders;

- het gezamenlijk formuleren van doelstellingen;

- het koppelen van budgetten.

Als indicator voor de samenvattende maat is het aantal manieren genomen waarop wethouders altijd, vaak of soms samenwerken. De scores lopen daarom van o tot en met 3 .

Twee indicatoren hebben betrekking op ambtelijke coördinatie als aspect van integrale beleidsvoering. De eerste is of er wel of niet enige vorm van formele ambtelijke coördinatie in het jeugdbeleid bestaat (scores respectievelijk $x$ en o). De tweede is soortgelijk aan de indicator voor de samenwerking tussen wethouders en betreft eveneens het aantal manieren waarop ambtenaren die op verschillende beleidsterreinen werken altijd, vaak of soms met elkaar samenwerken (scores van o tot en met 3).

De laatste in de maat opgenomen indicator die betrekking heeft op integrale beleidsvoering is de wijze waarop en de mate waarin gemeenten de samenwerking tussen externe actoren trachten te sturen. Gemeenten hebben in het jeugdbeleid doorgaans te maken met een grote variëteit aan externe actoren. Te denken valt onder meer aan welzijnsinstellingen, GGD's, politie, onderwijsinstellingen en Bureaus Jeugdzorg. Voor de uitwoering van het jeugdbeleid en de realisatie van de doelen zijn gemeenten meestal a fhankelijk van in ieder geval een aantal van deze actoren. In zulke gevallen is sturing door de gemeente, ook wel aangeduid als regie, noodzakelijk. Ten behoeve van de maat 'staat van het jeugdbeleid' wordt in dit hoofdstuk een element van de gemeentelijke sturing behandeld: de vraag in hoeverre gemeenten zich tot doel hebben gesteld de sturing van externe actoren op zich te nemen. Aan de ambtenaren die belast zijn met de coördinatie van het jeugdbeleid in hun gemeente is gevraagd of er in de gemeente doelstellingen zijn geformuleerd voor de sturing van externe actoren op de volgende punten:

- het stimuleren van de samenwerking tussen instellingen onderling;

- het op elkaar afstemmen van het aanbod van de diverse instellingen;

- het structureren van de samenwerking tussen gemeente en instellingen.

Het aantal terreinen waarop doelen zijn geformuleerd is genomen als score op de indicator 'externe regie'. De scores lopen daarom van o tot en met 3 .

Tot slot is in de samenvattende maat de meting van beleidseffecten als indicator opgenomen. Het vaststellen van beleidseffecten is een belangrijk onderdeel van de 
beleidscyclus. Het vormt de basis voor de voortzetting, wijziging of beëindiging van beleid of onderdelen daarvan. In hoofdstuk 6 wordt nader ingegaan op de vraag of, en zo ja hoe, gemeenten hun jeugdbeleid evalueren. Om de maat 'staat van het jeugdbeleid' vast te stellen wordt alleen ingegaan op effectmeting door het periodiek vastleggen wan gegevens. In grote lijnen kan dit op twee manieren worden gedaan. ${ }^{3}$ In de eerste plaats kan er een periodieke meting onder jongeren plaatsvinden. Vaak wordt een dergelijke werkwijze als jeugdmonitor aangeduid. In de tweede plaats kan effectmeting plaatsvinden door de periodieke of permanente registratie van administratieve gegevens, zogenoemde kengetallen. De score op de indicator is dichotoom: positief (I) als op ten minste één van beide manieren naar de effecten van het lokale beleid wordt gekeken, en negatief (o) als dit op geen van beide manieren wordt gedaan.

Samenvattend zijn de zeven indicatoren voor de maat 'staat van het jeugdbeleid':

- mate van beleidsformulering;

- breedte van het jeugdbeleid, volgens beleidsdocumenten;

- aantal wijzen van samenwerking tussen wethouders;

- de vraag of er enige vorm van ambtelijke coördinatie plaatswindt;

- aantal wijzen van samenwerking tussen ambtenaren;

- aantal doelen dat geformuleerd is voor de samenwerking met en tussen instellingen;

- effectmeting door een monitor of door de periodieke registratie van kengetallen.

Met behulp van principale-componentenanalyse is van de zeven indicatoren één maat gevormd. ${ }^{4}$ In tabel 3.I zijn de resultaten van deze analyse opgenomen. De eerste component verklaart $36 \%$ van de variantie. Bovendien zijn de ladingen voldoende hoog om te kunnen spreken van één dimensie. ${ }^{5}$ De scores op de maat zijn berekend door de gestandaardiseerde scores per indicator te vermenigvuldigen met de factorlading, en deze producten vervolgens te sommeren. Dit betekent dat hoe hoger de lading van een indicator, des te zwaarder deze meetelt in de berekening van de factorscore 'staat van het jeugdbeleid'. De scores op de samenvattende maat zijn voor 1998 gestandaardiseerd, wat betekent dat de gemiddelde score voor alle onderzoeksgemeenten in dat jaar nul is, terwijl de standaardafwijking één is. Een positieve score duidt op een in 1998 meer dan gemiddeld ontwikkeld jeugdbeleid, een negatieve score op een minder dan gemiddeld ontwikkeld jeugdbeleid. Hoe hoger de score, hoe verder het jeugdbeleid is ontwikkeld. 
Tabel 3.1

Principale-componentenanalyse 'staat van het jeugdbeleid', 1998 ( $(=72$, ladingen per aspect)

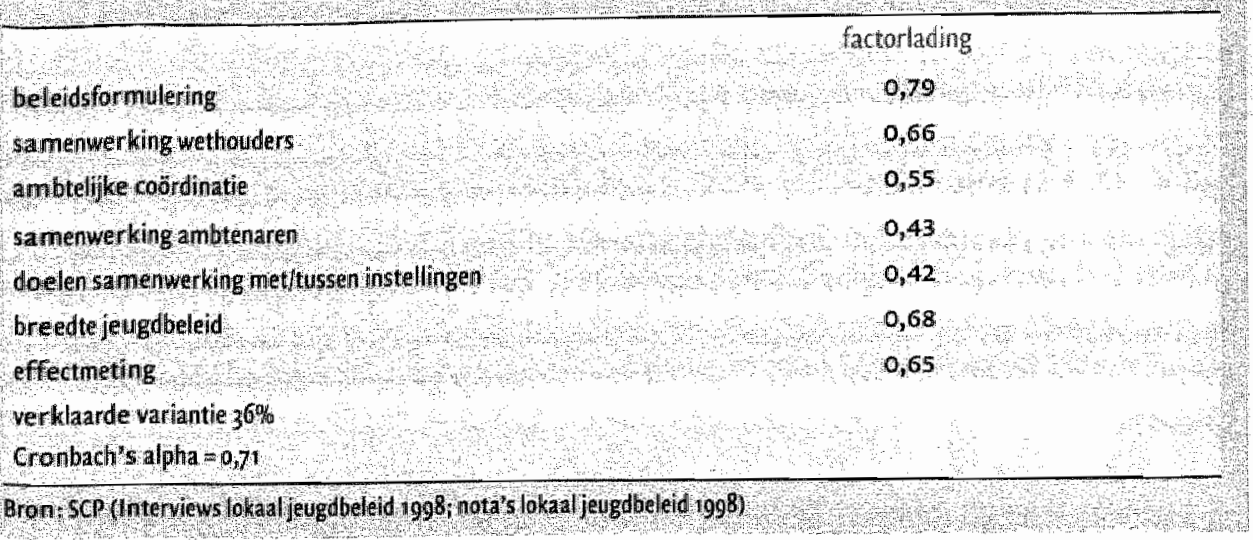

\subsection{Beleidsformulering}

In hoeverre hebben gemeenten hun jeugdbeleid vastgelegd in politiek - lees: door de gemeenteraad - vastgestelde beleidsnota's?

Eind 200 beschikt $90 \%$ van de onderzoeksgemeenten over een (kader)nota jeugdbeleid. In 1998 bedroeg dit percentage 58 . Eén op de tien gemeenten heeft eind 200I geen (kader)nota jeugdbeleid; het grootste deel daarvan heeft het jeugdbeleid echter eerder wel vastgelegd in nota's op deelterreinen of op een andere manier. Er zijn maar twee onderzoeksgemeenten $(3 \%)$ die eind 2001 op geen enkele wijze hun jeugd beleid hebben vastgelegd. Na I 998 heeft de helft van de onderzoeksgemeenten een nota jeugdbeleid ontwikkeld, waarvan twee vijfde al eerder over een eigen nota beschikte. Dit betekent dat ruim $30 \%$ van de onderzoeksgemeenten in die periode voor het eerst een nota jeugdbeleid heeft geschreven en vastgesteld. 


\section{Box 3.1 Jeugdbeleid: ontstaan en uitgangspunten}

Tussen gemeenten bestaan duidelijke verschillen in de aanleidingen en uitgangspunten van het lokale jeugdbeleid. Deze box illustreert dat door het ontstaan van het jeugdbeleid in vijf gemeenten te schetsen.

\section{Onderwijs als vertrekpunt}

Het jeugdbeleid van de gemeente Appingedom is vastgelegd in de nota Gemeentelijk onderwijsachterstandenbeleid en lokaal preventief jeugdbeleid 1998-2002. De aanleiding om deze nota te schrijven was tweeledig. In de eerste plaats is de gemeente planplichtig met betrekking tot het onderwijsachterstandenbeleid. In de tweede plaats werd het verder ontwikkelen van een lokaal (preventief) jeugdbeleid al langer van bellang geacht. Het belleid is tot stand gekkomen in samenspraak met sleutelfiguren binnen het onderwijs, het welzijnswerk en andere organisaties.

Appingedam kiest voor zowel een longitudinale als een integrale aanpak. De longitudinale aampak houdt in dat het beleid zal moeten bestaan uit een doordacht geheel van activiteiten voor jeugdigen van o tot $18 / 23$ jaar. De integrale aanpak betekent dat het voor de jeugd niet alleen gaat om onderwijs, maar om alle facetten van het maatschappelijke leven. Hiermee komt de relatie tussen het onderwijs en het bredere jeugdbeleid in beeld. Scholen en maatschappelijke instellingen zullen gezamenlijk inspanningen moeten verrichten om de doelen wan het onderwijs en het brede jeugdbeleid te kunnen realiseren.

Oak in Groningen vormde het onderwijs min of meer het startpunt voor het jeugdbeleid. In 1996 verscheen een notitie over de inrichting van vensterscholen (brede scholen), een van de pijlers van het jeugdbeleid. Later werd het jeugdbeleid verder uitgebouwd met een startnotitie integraal jeugdbeleid (1998). In 1999 werd de beleidsnota integraal jeugdbeleid vastgesteld. Er zijn met betrekking tot het jeugdbeleid verder nota's verschenen op het gebied van jeugdcriminaliteit, onderwijsachterstanden, voortijdig. schoolverlaten, kinderopvang, vensterscholen en de vroeg- en voorschoolse periode. De missie van het integrale jeugdbeleid is als volgt geformuleerd: "Wij willen meehelpen bij het opbouwen van een samenleving die niemand buitensluit en waarbinnen ieders welzijn van groot bellang is. Hierbij past een integraal jeugdbeleid dat als doel heeft om alle kinderen en jongeren te brengen tot persoonlijke zelfstandigheid, tot een tolerante en democratische opstelling en tot een actieve deelname aan het maatschappelijke, economische en culturele leven. Wij proberen hiervoor alle betrokkenen in de (lokalle) samenlewing te mobiliseren." Eén van de uitgangspunten wan het Groningse jeugdbeleid is dat het beleid resultaatgericht moet zijn. Aan voorgestelde maatregelen zijn daarom zo mogelijk meetbare doelstellingen gekoppeld. 


\section{Vervolg Box 3.1 Jeugdbeleid: ontstaan en uitgangspunten}

\section{Overlastproblematiek als aanleiding}

De eerste aanzet om aan de slag te gaan met het jeugdbeleid in Culemborg was het signalleren van problemen met opgroeiende jongeren. Geconstateerd werd dat op preventief gebied de voorzieningen minimal waren en dat er op curatiefgebied niets was. Sinds 1994 wordt er in Culemborg gewerkt met netwerken jeugdhulpverlening en is er een projectgroep Jeugdhulpverlening. In 1997 verscheen de kadernotitie integraal jeugdbeleid. De missie voor het jeugdbeleid in Culemborg is daarin als volgt geformuleerd: "Het integraal jeugdbeleid daagt eenieder (...) uit om alle krachten en kwaliteiten te mobiliseren, waar ook canwezig binmen de (...) samenleving, om alle kinderen, jeugdigen en jongeren op weg te brengen naar maatschappelijke zelfstandigheid en een positieve deelname oan het maatschappelijk lewen.'

Ook het jeugdbeleid in Heeze-Leende is tot stand gekomen naar aanleiding van overlast die veroorzalkt werd door rondhangende jongeren. Daarnaast waren er 'maatschappelijke tendensen' die een reden vormden om na te denken over het jeugdbeleid. Het jeugdbeleid verkeert nog in een aanlloopfase, er is geen sprake van overkoepelend jeugdbeleid. In de nota worden dan ook een aantal randvoorwaarden genoemd voor een meerjaren jeugdbeleid, zoals het aanstellen van een jongerenopbouwwerker en het instellen van een werkgroep jeugdbeleid. De nota is opgesteld in opdracht van de gemeente door een stuurgroep met vertegenwoordigers uit verschillende (jeugd)instellingen en onderwijs, onder begeleiding wan het Brabants Steunpunt Jeugdwelzijn (BSj).

\section{Start vanuit behoefte aan samenhangende aanpak}

Het integrale jeugdbeleid in de gemeente Leiden is vormgegeven in 1998 en veel verschillende instellingen zijn intensief bij dat proces betrokken. Ook de jeugd van een aantal scholen is betrokken, maar het is ond uidelijk wat hun inbreng is geweest bij de waststelling van het jeugdbeleid. Er is een kadernota jeugdbeleid vastgesteld, waarin men heeft getracht het bestaande beleid verder te ontwikkelen en daar meer samenhang in aan te bremgen. In de kadernota is meer dan voorheen aandacht voor de positie van de gehele groep jongeren. Eerder was het beleid vooral gericht op jeugdigen met problemen of jeugdigen die dreigden in een problematische situatie terecht te komen. Twee uitgangspunten staan in het jeugdbeleild centraal. Ten eerste is het jeugdbeleid er op gericht ciat alle jeugdigen hun talenten en (sociale) vaardigheden in brede zin kunnen ontwikkelen in een gezonde en weilige leefomgeving. Ten tweede streeft de gemeente naar een leefbare en duurzame samenleving, met een eigen plaats voor de jeugd. 
In tabel 3.2 is de mate van beleidsformulering in 1998 en eind $200 \mathrm{r}$ afgezet tegen de stedelijkheid van gemeenten. In algemene zin blijkt uit de tabel dat de mate van beleidsformulering in $200 \mathrm{r}$ is toegenomen ten opzichte van 1998 . Het aandeel onderzoeksgemeenten zonder doelstellingen of met doelstellingen op deelterreinen is fors afgenomen. Het aandeel gemeenten met een specifiek jeugdbeleid, neergelegd in een nota, nam in dezelfde periode sterk toe. Weliswaar heeft een deel van deze gemeenten de doelen in zeer algemeen of vaag gestelde bewoordingen geformuleerd, maar het aandeel gemeenten met uitgewerkte doelen (kwalitatief of kwantitatief) bedraagt eind $200 \mathrm{r}$ meer dan $50 \%$.

Tabel 3.2

Mate van beleidsformulering in 1998 en 2001 , naar stedelijkheidsklasse (percentage gemeenten)

\begin{tabular}{|c|c|c|c|c|c|c|c|c|}
\hline \multirow[b]{2}{*}{ mate van beleids ormulering } & \multicolumn{2}{|c|}{$\begin{array}{c}\text { (zeer) sterk } \\
\text { stedelijk }\end{array}$} & \multicolumn{2}{|c|}{ matig stededijk } & \multicolumn{2}{|c|}{$\begin{array}{c}\text { weing/niet } \\
\text { stedelijk }\end{array}$} & \multicolumn{2}{|c|}{ totaal } \\
\hline & 1998 & 200 & 1908 & 2001 & 1998 & 2001 & 1998 & 2001 \\
\hline geendoelstellingen & 9 & 0 & 7 & 0 & 40 & 16 & 21 & 6 \\
\hline doelstellingen op deelterreinen & 23 & 4 & 27 & 6 & 24 & 12 & 24 & 8 \\
\hline algenene doelstellingen & 5 & 13 & 27 & 28 & 28 & 44 & 19 & 28 \\
\hline kwalitat leve doelstellingen & 27 & 42 & 33 & 56 & 8 & 28 & 21 & 40 \\
\hline kwantitatieve doelstellingen & 36 & 42 & 7 & 11 & 0 & 0 & 15 & 18 \\
\hline (n) & (22) & (24) & $(15)$ & (18) & $(25)$ & (25) & (62) & (67) \\
\hline
\end{tabular}

Brons SCP (notás leugdbeleid 2002 , nota s loka l leugdbeleid 1998 )

Nadere beschouwing van de gegevens leert dat slechts twee onderzoeksgemeenten erop achteruit zijn gegaan. ${ }^{6}$ Meer in het oog springend is evenwel het feit dat eenderde van de zestig gemeenten waarover voor beide jaren gegevens beschikbaar zijn, vooruit is gegaan in de mate van beleidsformulering. Dit zijn vooral gemeenten die van een situatie zonder specifiek jeugdbeleid (geen doelen en maatregelen, of alleen op deelterreinen) naar een situatie van wel een specifiek jeugdbeleid met kwalitatief uitgewerkte doelstellingen zijn gegaan. Ondanks het feit dat bijna twee derde van de gemeenten in 200I nog dezelfde mate van beleidsformulering heeft als in 1998, kan over de hele linie worden gesproken van een significante toename op dit aspect van het jeugdbeleid?

Net als in r 998 is er in 200r een duidelijk verband tussen de stedelijkheïd van de gemeente en de mate van beleidsformulering: het jeugdbeleid is in de meer stedelijke gemeenten uitgebreider geformuleerd, en veel vaker in termen van meetbare doelstellingen, dan in minder stedelijke gemeenten. Niettemin is in alle drie de naar stedelijkheid onderscheiden groepen gemeenten sprake van een duidelijke toename in de mate van beleidsformulering. 
Het jeugdbeleid bestrijkt in principe diverse beleidsterreinen: welzijn, onderwijs, zorg, sociale zaken, ruimtelijke ordening en openbare orde en veiligheid. De eerste vraag die in deze paragraaf aan de orde komt, is hoe breed gemeenten hun jeugdbeleid nu eigenlijk geformuleerd hebben. In gemeenten waar het beleid breed is gedefinieerd, vraagt de diversiteit aan beleidsterreinen om integrale beleidsvoering. Belangrijke elementen daarin zijn politieke sturing en ambtelijke coördinatie. Beleid waarbij meerdere portefeuillehouders en verschillende gemeentelijke afdelingen zijn betrolkken, vraagt immers om coördinatie en afstemming. Tevens komt de vraag aan de orde in hoeverre gemeenten de samenwerking met en tussen relevante instellingen als onderdeel van het jeugdbeleid zien. De breedte van het jeugdbeleid maakt dat gemeenten in ieder geval in de uitvoering afhankelijk zijn van een breed scala aan instellingen.

\subsubsection{Breedte van beleid}

Gezien de veelheid aan onderling samenhangende aspecten in de leefsituatie van de jeugd, kan worden gesteld dat jeugdbeleid dat zich uitstrekt over meer levensterreinen een noodzakelijke maar geen voldoende voorwaarde is om te kunnen spreken van een integraal jeugdbeleid. De breedte van het jeugdbeleid wordt daarom gezien als een indicator voor integrale beleidsvoering.

\section{Box 3.2 Integraal jeugdbeleid}

Regie en integraliteit zijn veel gebezigde begrippen in het lokale jeugdbeleid. Hoe divers deze begrippen kunnen worden gehanteerd en hoe omvattend ze zijn, blijkt uit deze drie voorbeelden.

Een knelpunt in het voeren van regie door de gemeente Culemborg is de budgettaire scheiding tussen onderwijs- en jeugdbeleid. Een meer structurele koppeling van budgetten zou de beleidsintegratie ten goede komen. De respondenten van uitvoerende instellingen zijn in het algemeen positief over de inspanningen die de gemeente doet om de regierol invulling te geven. Dat neemt niet weg dat er ruimte is voorverbetering: er zou bijvoorbeeld meer structuur en meer aandacht voor continuiteit mogen zijn.

Daarnaast vinden de respondenten dat er meer aangesloten moet worden bij het wijkgerichte werken en dat de samenwerking tussen welzijn en onderwijs meer zou moeten worden gestimuleerd.

Vanaf 1995 is het jeugdbeleid in Spijkenisse bijna voortdurend in beweging. In augustus 1995 verscheen een inventarisatienota jeugdbeleid, waarin de jeugdproblematiek in de gemeente wordt geschetst naar aanleiding van signalen dat inwoners van de gemeente 


\section{Vervolg Box 3,2 Integraal jeugdbeleid}

problemen ondervinden van jeugdigen. De jeugdproblematiek is geïnventariseerd door een werkgroep die bestond uit gemeenteambtenaren en die in een latere fase is aangevuld met vertegenwoordigers van organisaties die te maken hebben met overlastproblematiek. De werkgroep constateerde onder meer dat een visie op de activiteiten die het gemeentebestuur voor de jeugd ondernam, ontbrak, en dat samenwerking tussen verschillende instellingen al veel winst op zou kunnen leveren. De notitie van deze werkgroep was aanleiding voor een conferentie over de noodzaak tot een integraal jeugdbeleid te komen. Daarbij waren verschillende instellingen, raadsleden, ambtenaren en ook jongeren betrokken. Besloten werd het jeugdbeleid vorm te geven in een matrixstructuup, waarin sprake is van een stuurgroep, een coördinator en werkgroepen. In 1999 is de structuur rond het jeugdbeleid herzien. Ondanks het aanvankelijke enthousiasme om een daadwerkelijk integraal beleid te realiseren; bleek in de praktijk dat de deelnemers van de werkgroepen hun prioriteit bij andere zaken dan het jeugdbeleid legden. "Het jeugdbeleid is te veel afhankelijk geworden van het enthousiasme van mensen en is ook deels ten prooi gevallen aan willekeur', zo staat er in een nota van 1999 geschreven. Bovendien was er nauwelijks een relatie tussen de stuurgroep en de coördinator, waardoor de noodzakelijke sturing ontbrak. Daarvoor achtte men het noodzakelijk een projectstructuur in te voeren. Het woordeel hiervan is dat per onderwerp vooraf wordt vastgesteld wat de doelstelling is, dat er een begin- en eindpunt (in tijd en werk) wordt vastgesteld, en dat bevoegdheden en verantwoordelijkheden duidelijker zijn dan bij de matrixstructuur.

De gemeente Voorburg ziet integraal jeugdbeleid als beleid waarbij alle gemeentelijke beleidsterreinen en het voltallige college betrokken zijn. De afdeling Onderwijs, Cultuur, Recreatie en Maatschappelijke zorg is in het kader van het facetbeleid verantwoordelijk voor de coördinatie en afstemming van beleid voor jeugdigen binnen alle gemeentelijke beleidsterreinen. De gemeente vindt samenwerking met uitvoerende instellingen heel belangrijk en zal initiatieven nemen tot deze samenwerking. In de regierol van de gemeente gaat het volgens de wethouder om het samenbrengen, in gesprek houden en afstemmen van partijen die met jeugd te maken hebben, bijvoorbeeld via de netwerken. Integratie van het jeugdbeleid in verschillende sectoren lukt redelijk goed, maar dit punt vraagt wel permanente aandacht. Ook aan de (ambtelijke) samenwerking tussen afdelingen moet gewerkt blijven worden. Dat integraliteit een lastig punt is blijkt onder andere uit de opmerking van de ambtenaar dat het moeilijk is andere afdelingen en portefeuillehouders enthousiast te maken voor het jeugdbeleid. Het gemis aan interne samenhang wordt ook opgemerkt door een respondent van een instelling. 
Uit tabel 3.3 blijkt dat er in 200 zeer weinig gemeenten zijn waarin geen enkel levensterrein beleidsmatig wordt geoperationaliseerd, terwijl dit in 1998 nog in een op de vijf onderzoeksgemeenten het geval was. Waar dit in $200 \mathrm{r}$ nog wel aan de orde is, betreft het weinig tot niet-stedelijke gemeenten. Het aantal gemeenten waar beleid is geformuleerd op zeven of acht van de acht levensterreinen, is in dezelfde periode gegroeid van $35 \%$ naar $46 \%$. Deze ontwikkelingen zijn duidelijk waarneembaar in het gemiddelde aantal levensterreinen dat in het jeugdbeleid aandacht krijgt. Dit is voor alle onderzoeksgemeenten toegenomen van 4,5 naar $5,7 .{ }^{8}$ De toename vond plaats in alle stedelijkheidsklassen, waarbij vooral de weinig tot niet-stedelijke gemeenten gemiddeld een relatief grote sprong hebben gemaakt. Gesteld kan worden dat het jeugdbeleid in de onderzoeksperiode aanzienlijk is verbreed.

Tabel 3.3

Aantal in nota's jeugdbeleid geoperationaliseerde levensterreinen, 1998 en 2001, naar stedelijkheid (percentage gemeenten)

\begin{tabular}{|c|c|c|c|c|c|c|c|c|}
\hline \multirow[b]{2}{*}{ aantal levenstereinen } & \multicolumn{2}{|c|}{$\begin{array}{l}\text { (zeer) sterk } \\
\text { sted lijk }\end{array}$} & \multicolumn{2}{|c|}{ matig stedelijk } & \multicolumn{2}{|c|}{$\begin{array}{l}\text { weinig/niet } \\
\text { stedelijkc }\end{array}$} & \multicolumn{2}{|c|}{ total } \\
\hline & 1998 & 2001 & 1998 & 2001 & 1998 & 2001 & 1998 & 2001 \\
\hline 0 & 14 & 0 & 7 & 0 & 32 & 9 & 19 & 3 \\
\hline 13 & 0 & 8 & 20 & 17 & 28 & 18 & 16 & 18 \\
\hline 4-6 & 28 & 30 & 34 & 39 & 28 & 43 & 30 & 37 \\
\hline 78 & 59 & 63 & 40 & 44 & 12 & 31 & 35 & 46: \\
\hline gemiddeld aantal & 6,0 & 6,5 & 5,3 & 5,8 & 2,8 & 4,9 & 4,5 & 5,7 \\
\hline (n) & (22) & (24) & (15) & (18) & (25) & (23) & (62) & (65) \\
\hline
\end{tabular}

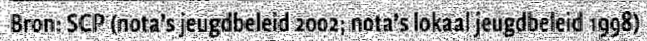

\subsubsection{Politieke sturing}

Eind $200 \mathrm{r}$ blijkt in 10\% van de onderzoeksgemeenten één lid van het college verantwoordelijk voor alle voor de jeugd relevante beleidsterreinen. Het betreft in alle gevallen matig tot niet-stedelijke gemeenten. In twee derde van de gemeenten zijn drie of meer leden van het college bij het jeugdbeleid betrokken. Dat betekent dat integrale beleidsvoering samenwerking tussen de betreffende leden van B\&W vereist.

In het onderzoek uit I999 (Gilsing 1999 ) is tevens geconstateerd dat de politieke sturing van het jeugdbeleid te wensen overlaat, zodat de kans op verkokerd beleid reëel is. Alhoewel er relatief vaak een coördinerend wethouder jeugdbeleid werd aangetroffen, bleek er weinig samenwerking te zijn tussen de verschillende betrokken portefeuillehouders. De conclusie gold zowel (zeer) sterk stedelijke als matig tot niet-stedelijke gemeenten. 
In 200r zijn, zoals we net constateerden, in 90\% van de onderzoeksgemeenten ten minste twee collegeleden betrokken bij het jeugdbeleid. In het overgrote deel van deze gemeenten - bijna driekwart - draagt één van de collegeleden de verantwoordelijkheid voor de politiek-bestuurlijke afstemming van het jeugdbeleid. De overige gemeenten kennen niet zo'n coördinerende portefeuillehouder. Het is opmerkelijk dat dit ook in bijna een kwart van de (zeer) sterk stedelijke onderzoeksgemeenten het geval is.

Net als in 1999 is aan de ambtelijke sleutelinformanten gevraagd of er sprake is van integrale beleidswoering op politiek-bestuurlijk niveau: werken de bij het jeugdbeleid betrokken leden van het college onderling samen? Concreet gaat het om drie vormen van samenwerking: het afstemmen van beleid in het geval van raakvlakken met andere portefeuilles, het gezamenlijk formuleren van doelstellingen en het koppelen van budgetten. In tabel 3.4 zijn de resultaten weergegeven. Voor de drie vormen van samenwerking geldt dat $z$ ij in 2001 niet in meer gemeenten plaatsvinden dan in 1998 . Vooral het formuleren van gezamenlijke doelen en het koppelen van budgetten door portefeuillehouders vindt in $200 \mathrm{r}$ in nog steeds een substantieel deel van de onderzoeksgemeenten niet of nauwelijks plaats.

\section{Tabel 3.4}

Samenwerking tussen de leden van het college van B\&W, 1998 en 2001 (percentage gemeenten waarin deze vorm voorkomt)

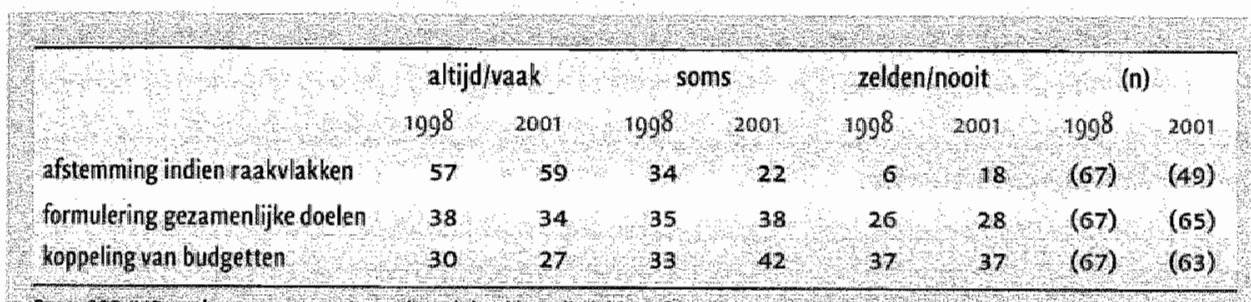

Brom Scr 4 b ambrenaren 2002 Intervervs lokal jeugdbeled 1998

Als de drie vormen van samenwerking in samenhang worden bekeken, dan blijkt dat in $40 \%$ van de onderzoeksgemeenten waar meerdere collegeleden bij het jeugdbeleid betrokken zijn, geen enkele samenwerkingsvorm frequent (altijd of vaak) voorkomt. In bijna een kwart - overwegend (zeer) stedelijke gemeenten - wordt altijd of vaak op alle drie de manieren samengewerkt.

De conclusie is dat de politieke sturing over de hele linie niet of nauwelijks is toe- of afgenomen. Ondanks de toegenomen breedte van het beleid en de aanwezigheid van een coördinerende portefeuillehouder in de meeste gemeenten, wordt er in $200 \mathrm{I}$ nog steeds relatief weinig samengewerkt tussen betrokken portefeuillehouders. Daarmee blijft er, ondanks de veelvuldige pleidooien voor een integrale benadering, een aanzienlijke kans op verkokering in het gemeentelijke jeugdbeleid. 


\subsubsection{Ambtelijke coördinatie}

Een punt dat evenzeer van belang is voor het realiseren van een integrale beleidsvoering is de vraag hoe er op ambtelijk niveau wordt samengewerkt. Het belang van hechte samenwerking en afstemming tussen bij het jeugdbeleid betrokken afdelingen werd in het vorige onderzoek door meer dan $90 \%$ van de ondervraagde ambtenaren onderschreven. Gezien de ontwikkelingen in het jeugdbeleid - meer gemeenten hebben specifiek jeugdbeleid geformuleerd, het jeugdbeleid is inhoudelijk gemiddeld breder geworden - is er geen aanleiding om te veronderstellen dat dat belang is afgenomen.

Aan de ambtelijke sleutelinformanten is in de eerste plaats gevraagd of er ambtelijke capaciteit is vrijgemaakt voor de coördinatie van het jeugdbeleid. In ruim $80 \%$ van de onderzoeksgemeenten blijkt dit het geval te zijn. Dat betekent dat er een behoorlijke stijging is ten opzichte van 1998 , toen in zo'n $60 \%$ van de gemeenten op ambtelijk niveau werd gecoördineerd. In $40 \%$ van de gemeenten is de omvang van de coördinatiefunctie minder dan een halve formatieplaats, terwijl in enkele grote gemeenten meer dan één formatieplaats is vrijgemaakt voor de ambtelijke coördinatie van het jeugdbeleid.

Ambtelijke coördinatie van het jeugdbeleid kan ook plaatsvinden door een ambtelijke stuurgroep, waarin verschillende afdelingen zijn vertegenwoordigd. In 1998 kende een kwart van de onderzoeksgemeenten een dergelijke stuurgroep. In 2001 is het aandeel gemeenten met een stuurgroep licht gegroeid tot ruim eenderde. De ambtelijke stuurgroep staat in een beperkt aantal gevallen ( 4 \%) onder leiding van een lid van het college van B\&w. De stuurgroepen houden zich in bijna alle gevallen bezig met beleidsvoorbereiding en beleidsafstemming. Daarnaast houdt ongeveer de helft van de stuurgroepen zich bezig met taken als actieve informatie-uitwisseling en uitvoeringscoördinatie.

Gezien het bovenstaande zal het geen verbazing wekken dat het aandeel onderzoeksgemeenten waarin ten minste één van beide vormen van ambtelijke coördinatie voorkomt, is gestegen. In 1998 lag dit percentage op 75 ; in 2001 is het (licht) toegenomen tot $83 \%$.

Naast coördinatie is ook ambtelijke samenwerking van belang voor een daadwerkelijke integrale beleidswoering. Hier is op dezelfde wijze naar gevraagd als bij de samenwerking tussen leden van het college. Het valt op dat er in sterkere mate wordt samengewerkt tussen ambtenaren die op verschillende beleidsterreinen werken dan op politiek-bestuurlijk niveau tussen bij het jeugdbeleid betrokken portefeuillehouders. Kennelijk is de benadering van het jeugdbeleid op ambtelijk niveau meer integraal dan op politiek-bestuurlijk niveau. Maar ook op dit vlak zijn er in 2001 nauwelijks veranderingen waar te nemen ten opzichte van 1998 (zie tabel 3.5). Slechts wat betreft de koppeling van budgetten kan worden gezegd dat er in zoor minder gemeenten zijn waar dit zelden of nooit gebeurt dan in 1998. Opmerkelijk is dat de aanwezigheid van een ambtelijke coördinatiefunctie niet samenhangt met de drie vormen van ambtelijke samenwerking. Waar verwacht mocht worden dat een ambtelijke coördinator aanzet tot meer ambtelijke samenwerking, blijkt dit niet het geval te zijn. 
Tabel 3.5

Ambtelijke samenwerking, 1998 en 2001 (percentage gemeenten waarin deze vorm voorkomt)

\begin{tabular}{|c|c|c|c|c|c|c|c|}
\hline & \multicolumn{2}{|c|}{ altuldoraak } & \multicolumn{3}{|c|}{ soms zelden/nooit } & \multicolumn{2}{|c|}{ (n) } \\
\hline & 1998 & 2001 & 1998 & 1998 & 2001 & 1998 & 2001 \\
\hline afstemming indien a a kwlakken & 70 & 66 & 27 & 29 & 5 & (73) & (59) \\
\hline formulering gezamenlijke doelen & 52 & 41 & 34 & 41 & $\$ 7$ & (73) & (58) \\
\hline Koppeling van budgetten & 34 & 35 & 34 & 44 & 21 & (73) & (57) \\
\hline
\end{tabular}

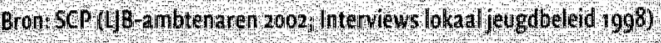

De conclusie over de ambtelijke coördinatie en afstemming is dat het jeugdbeleid nu in ruim $80 \%$ van de onderzoeksgemeenten op ambtelijk niveau gecoördineerd wordt: door een coôrdinator, door een stuurgroep of door beide. Dit betekent een lichte toename ten opzichte van 1998 . Gemeenten zonder ambtelijke coördinatie zijn zonder uitzondering kleine gemeenten. De samenwerking tussen ambtelijke diensten bevindt zich grofweg op hetzelfde niveau als in 1998 , en blijft daarmee, ook gezien het belang dat eraan gehecht wordt door de ambtenaren zelf, voor verbetering vatbaar.

\subsubsection{Gemeente als regisseur}

Aan de ambtelijke sleutelinformanten is gevraagd of er in het jeugdbeleid doelen zijn geformuleerd op het gebied van externe regie, dat wil zeggen: de samenwerking tussen gemeente en instellingen en tussen instellingen onderling. Concreet is gevralagd naar beleid ter bevordering van de samenwerking tussen instellingen, beleid gericht op de afstemming van het aanbod van instellingen en beleid gericht op het structureren van de samenwerking tussen gemeente en instellingen.

\section{Tabel 3.6}

Doelstellingen externe regie, 1998 en 2001 (percentage gemeenten dat doelstelling heeft geformuleerd)

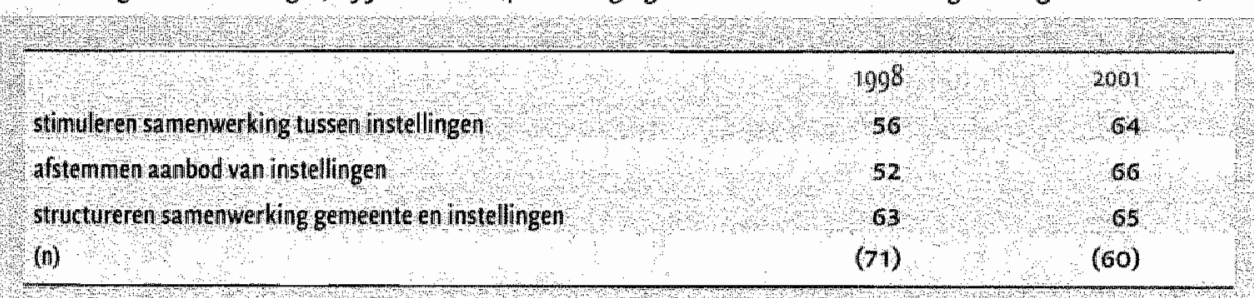

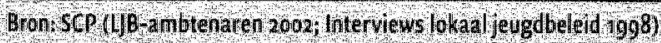

In $200 \mathrm{I}$ is er een lichte toename waarneembaar ten opzichte van I9g8 wan het aandeel onderzoeksgemeenten met doelstellingen op het gebied van de sturing van externe actoren (zie tabel 3.6). De verschillen zijn niet groot, en gelden vooral doelstellingen aangaande de verhoudingen tussen instellingen onderling. Het structureren van de samenwerking tussen gemeente en instellingen is in de periode 1998 en 200 niet waker als doel van het jeugdbeleid neergezet. Gemeenten die op dit terrein beleid hebben geformuleerd, hebben in de meeste gevallen doelstellingen aangaande 
alle drie de regievormen; het gaat om iets meer dan de helft van de onderzoeksgemeenten. Ongeveer een kwart van de gemeenten heeft geen enkel doel in haar beleid opgenomen. ${ }^{9}$ De conclusie moet zijn dat een ruime meerderheid van de onderzoeksgemeenten beleid op het gebied van de sturing van externe actoren heeft geformuleerd.

\section{5}

\section{Meting van beleidseffecten}

Effectmeting kan in grote lijnen op twee manieren worden verricht. In de eerste plaats kan er een periodieke meting onder jongeren plaatsvinden. Vaak wordt een dergelijke werkwijze als jeugdmonitor aangeduid. In de tweede plaats kan effectmeting plaatsvinden door de periodieke of permanente registratie van administratieve gegevens, zogenoemde kengetallen. In tabel 3.7 is weergegeven in welke mate beide methoden van effectmeting voorkomen.

Tabel 3.7

Methode van meting beleidseffecten, 1998 en 2001, naar stedelijkheid (percentage gemeenten dat methode, resp. één van beide methoden hanteert)

\begin{tabular}{|c|c|c|c|c|c|c|c|c|}
\hline & \multicolumn{2}{|c|}{$\begin{array}{l}\text { (zeer) sterk } \\
\text { stedelijk }\end{array}$} & \multicolumn{2}{|c|}{ matig stedelijk } & \multicolumn{2}{|c|}{$\begin{array}{l}\text { weinig/niet } \\
\text { stedelijk }\end{array}$} & \multicolumn{2}{|c|}{ totaal } \\
\hline & 998 & 2001 & 1998 & 2001 & 1998 & 2001 & 1998 & 2001 \\
\hline periodieke meting onder jongeren & 46 & 48 & 7 & 13 & 9 & 5 & 22 & 23 \\
\hline registratie administratieve gegevens & 42 & 61 & 14 & 31 & 22 & 10 & 28 & 35 \\
\hline minimatal éen van beide methoden & 54 & 74 & 14 & 38 & 31 & 10 & 36 & 42 \\
\hline (n) & (26) & (23) & (14) & (16) & (32) & (21) & (72) & $(60)$ \\
\hline
\end{tabular}

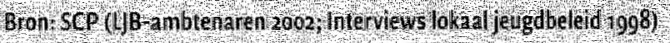

In 20or zegt bijna een kwart van de onderzoeksgemeenten te werken met een jeugdmonitor, nagenoeg hetzelfde aandeel als in 1998 . Net als toen is er een sterke relatie tussen de stedelijkheid van gemeenten en het voorkomen van een jeugdmonitor. Van de (zeer) sterk stedelijke gemeenten heeft in 200 r bijna de helft een jeugdmonitor, van de overige gemeenten nog geen $10 \%$. Overigens zegt nog eens $11 \%$ van de onderzoeksgemeenten een jeugdmonitor in voorbereiding te hebben.

Ruim eenderde van de onderzoeksgemeenten zegt kengetallen te registreren om de effecten van het jeugdbeleid te kunnen meten. Dat percentage ligt wat hoger dan in rg98. Ook op dit punt zijn de (zeer) sterk stedelijke gemeenten actiever dan de overige gemeenten. De stijging bij de meest stedelijke gemeenten is misschien deels te verklaren uit de invoering van de monitor voor het grotestedenbeleid, waarin ook gebruik wordt gemaakt van registraties. Maar ook bij de matig stedelijke gemeenten, die daar niet mee te maken hebben, is een behoorlijke stijging waarneembaar in het percentage gemeenten dat kengetallen registreert. In totaal hanteert $42 \%$ van de onderzoeksgemeenten ten minste één van beide methoden. 
De conclusie is dat er over de gehele linie een beperkte toename is in het aandeel onderzoeksgemeenten waar beleidseffecten worden vastgesteld. Daarbij past de opmerking dat de toename duidelijk is in de (zeer) sterk en matig stedelijke gemeenten, in scherpe tegenstelling tot de ontwikkeling bij de minst stedelijke gemeenten.

\subsection{Staat van het lokale jeugdbeleid}

In paragraaf 3.2 is ingegaan op de wijze waarop de scores voor de maat 'staat van het jeugdbeleid'zijn berekend. Tabel 3.8 geeft een overzicht van de scores 'staat van het jeugdbeleid' voor zowel 1998 als 20or, afgezet tegen de stedelijkheid van de gemeente. Tevens is de ontwikkeling in de score tussen beide jaren opgenomen.

\section{Tabel 3.8}

Scores 'staat van het jeugdbeleid' 1998 en 2001 en verloop in scores, naar stedelijkheidsklasse (percentage gemeenten met score, resp. scoreontwikkeling)

\begin{tabular}{|c|c|c|c|c|c|c|}
\hline \multirow[b]{2}{*}{ scores } & \multicolumn{2}{|c|}{$\begin{array}{l}\text { (zeer) sterk } \\
\text { stedelijk }\end{array}$} & matig stedelijk & $\begin{array}{l}\text { weinig/niet } \\
\text { stedelijk }\end{array}$ & \\
\hline & $199^{8}$ & 2001 & $1998 \quad 2001$ & $1998 \quad 2000$ & 1998 & 2001 \\
\hline$-0,5$ & 19 & 9 & 19 & 33 & 35 & 20 \\
\hline$-0,5>0,5$ & 27 & 22 & 40 & 48 & 33 & 34 \\
\hline$>0,5$ & 53 & 70 & 33 & $11>19$ & 32 & 46 \\
\hline gemiddellde score & 0,52 & 0,87 & 0,07 & $-0,52$ & 0,00 & 0,32 \\
\hline (i) & $(26)$ & (23) & $(15) \bullet(16)$ & $(28) \quad(21)$ & $(69)$ & (60) \\
\hline \multicolumn{7}{|c|}{ Leesvoorbeeld: in 1998 had $\| 9 \%$ van de (zeer) sterk stedelijke gemeenten een score lager dan $-0,5$. } \\
\hline \multicolumn{7}{|l|}{ ontwikkeling in scores } \\
\hline \multicolumn{7}{|l|}{ afname $>0,5$} \\
\hline \multicolumn{7}{|l|}{ af of toename $0,0,5$} \\
\hline \multicolumn{7}{|l|}{ toename $>0,5$} \\
\hline \multicolumn{7}{|l|}{ gemiddelde toe-of afiname } \\
\hline (n) $1+28$ & & & (13) & (21) & $(57)$ & \\
\hline
\end{tabular}

Tabel 3.8 geeft een duidelijk beeld: de onderzoeksgemeenten hebben in 2001 gemiddeld een hogere score op de maat 'staat van het jeugdbeleid' dan in 1998. De gemiddelde toename is 0,32 , wat een significante toename is ten opzichte van r998. De toename is in alle stedelijkheidscategorieën ongeveer gelijk. Dit betekent ook dat de verschillen die er in 1998 tussen de stedelijkheidsklassen bestonden in 2001 ongeveer hetzelfde gebleven zijn. Het jeugdbeleid is in de meest stedelijke gemeenten gemiddeld beduidend verder ontwikkeld dan in de matig stedelijke gemeenten, terwijl de minst stedelijke gemeenten gemiddeld weer fors bij deze middelste groep achter- 
blijwen. Het aandeel gemeenten met een score lager dan $-0,5$ is onder de minst stedelijke gemeenten dan ook aanzienlijk hoger dan onder de andere gemeenten. Onder de meest stedelijke gemeenten komt een dergelijke score nog maar weinig voor.

De gemiddelde stijging is dus in alle stedelijkheidsklassen ongeveer gelijk. $70 \%$ van de meest stedelijke gemeenten heeft in 200 r een score die hoger is dan 0,5 , tegen $53 \%$ in 1998 . Bij de matig stedelijke gemeenten is dit percentage gestegen van 33 naar 50 . Bij de minst stedelijke gemeenten valt vooral de afname op van het aandeel gemeenten met een score in de laagste klasse: van $54 \%$ in 1998 naar $33 \%$ in 2001 .

Als we louter kiijken naar de vraag of gemeenten in hun score tussen 1998 en $200 \mathrm{I}$ gestegen of gedaald zijn, dan blijkt dat eenderde van de gemeenten een aanzienlijke toename laat $z$ ien $(0,5$ of meer). De helft van de gemeenten is min of meer stabiel, terwijl $16 \%$ een substantieel lagere staat van het jeugdbeleid heeft dan in $1998(-0,5$ of minder). ${ }^{10}$

\subsection{Samenvatting en conclusies}

In dit hoofdstuk is ingegaan op de mate waarin het jeugdbeleid in de onderzoeksgemeenten ontwikkeld is. Het blijkt dat op de samenvattende maat 'staat van het jeugdbeleid' tussen 1998 en 200 gemiddeld duidelijk (en significant) progressie is geboekt. Deze progressie doet vermoeden dat de ontwikkeling van het lokale jeugdbeleid in 200 nog niet tot stilstand is gekomen.

Een derde van de gemeenten blijkt een aanzienlijk verder ontwikkeld jeugdbeleid te hebben dan in 1998 . Daartegenover staat dat $16 \%$ van de onderzoeksgemeenten er aanzienlijk op achteruit gaat, wat vooral te maken heeft met de geringere inspanningen op het gebied van effectmeting en op het gebied van integrale beleidsvoering: politieke sturing, ambtelijke coördinatie en externe regie. De gemiddelde stijging in de beleidsontwikkeling doet zich voor in alle stedelijkheidsklassen, waardoor de verschillen tussen minder en meer stedelijke gemeenten gehandhaafd blijven. Het is natuu rlijk de vraag hoe zwaar aan dit punt moet worden getild. Het ligt voor de hand dat kleine plattelandsgemeenten een minder opgetuigd jeugdbeleid hebben dan grote steden. De problematiek is er minder omvangrijk, waardoor beleid meer algemeen van karakter kan zijn, dat wil zeggen, gericht op alle jongeren. Vaak betekent dit het in stand houden of versterken van voorzieningen. In grote steden is het beleid veel probleemgerichter, zoals ook in hoofdstuk 4 aangetoond zal worden. Dergelijk beleid is in het algemeen complexer van aard, omdat het vaak directe interventies betreft. Een andere factor die een rol speelt is natuurlijk de omvang van het politieke bestuur en het a mbtelijke apparaat. Colleges en ambtelijke apparaten zijn kleiner in minder stedelijke gemeenten, waardoor bijwoorbeeld afstemming en overleg eenvoudiger en op meer informele wijze dan in grote steden kunnen worden geregeld. ${ }^{\mathrm{II}}$ De stijging op de samenvattende maat 'staat van het jeugdbeleid' betekent niet dat 
de onderzoeksgemeenten er op alle aspecten van de maat gemiddeld op vooruit zijn gegaan. De meeste winst is geboekt op het gebied van beleidsformulering. Er zijn in zoor nog maar weinig gemeenten die geen zelfstandig, categoraal jeugdbeleid hebben geformuleerd - dat laatste is bij ongeveer één op de zeven gemeenten het geval. Bijna eenderde van de gemeenten heeft gedurende de onderzoeksperiode het jeugdbeleid nauwkeuriger geformuleerd, of heeft het op een meer integrale wijze benaderd. Daardoor heeft in 200 r ruim de helft van de onderzoeksgemeenten een zelfstandig, categoraal jeugdbeleid dat is uitgewerkt in kwalitatieve dan wel in kwantitatieve doelen. De groep onderzoeksgemeenten is echter niet representatief voor alle Nederlandse gemeenten, omdat de streekproef gestratificeerd is: de (zeer) sterk stedelijke gemeenten zijn oververtegenwoordigd, en de overige gemeenten ondervertegenwoordigd. Rekening houdend met de stratificatie, waarbij bovenstaande gegevens worden gewogen naar de stedelijkheid van alle Nederlandse gemeenten, zouden de onderzoeksresultaten betekenen dat ongeveer $20 \%$ van alle gemeenten geen specifiek jeugdbeleid kent - iets meer dan de $14 \%$ onder de onderzoeksgemeenten. Ruim eenderde van de gemeenten heeft een specifiek jeugdbeleid dat weinig is uitgewerkt, en ruim $40 \%$ kent een beleid dat in kwalitatieve en/of kwantitatieve doelstellingen is uitgewerkt.

Een ander aspect waarop de onderzoeksgemeenten het in zoor gemiddeld beduidend beter doen dan in 1998 is de breedte van het beleid. Het gemiddelde aantal velden dat in het jeugdbeleid wordt geoperationaliseerd, is gestegen van 4,5 in 1998 naar 5,7 in 20or. Dat is op een schaal van acht mogelijke aandachtsvelden een duidelijke toename. Deze toename is niet vreemd, omdat ook in het onderzoek van 1999 al bleek dat er een sterk positieve samenhang bestaat tussen de mate van beleidsformulering en het aantal beleidsvelden in het jeugdbeleid. Hoe verder het beleid is uitgewerkt, hoe meer beleidsvelden in het jeugdbeleid aandacht krijgen. Vanuit het oogpunt van integrale beleidsvoering is deze ontwikkeling positief te waarderen. De verschillende thema's in het jeugdbeleid hangen vaak inhoudelijk samen, waardoor het jeugdbeleid gebaat is bij een omvattende, integrale aanpak. Of, om het voorzichtiger te stellen, het jeugdbeleid is in ieder geval gebaat bij het goed doordenken van de mogelijke samenhangen tussen bij het jeugdbeleid betrokken beleidssectoren.

Op de overige, meer procesmatige aspecten die in dit hoofdstuk zijn behandeld, wordt in het algemeen gemiddeld genomen wel enige vooruitgang geboekt, maar deze vooruitgang is gering en van beperkte betekenis. Het blijft zo dat de ambtelijke samenwerking en politieke sturing voor verbetering vatbaar blijven. Een uitzondering moet worden gemaakt voor de meting van de beleidseffecten. Alhoewel het op het eerste gezicht lijkt alsof de aandacht hiervoor nauwelijks is toegenomen, blijkt bij nadere beschouwing dat alleen onder de minst stedelijke onderzoeksgemeenten, die hier relatief toch al weinig aandacht voor hebben, sprake is van een afgenomen aandacht. Bij de overige gemeenten is de aandacht voor effectmeting duidelijk toegenomen. Dat hangt waarschijnlijk samen met de in deze gemeenten in het algemeen verder gevor- 
derde uitwerking van het jeugdbeleid in termen van doelstellingen, waardoor evaluatie meer voor de hand ligt. Zeker in een periode waarin een verdere rationalisatie van beleidsprocessen middels beleidsverantwoording, toegenomen aandacht voor evaluatie, en het monitoren van beleid en de effecten ervan het debat in kringen van beleidsmakers en -volgers domineert, kon deze toegenomen aandacht worden verwacht. Aan de andere kant had dan ook een toename in politieke sturing en ambtelijke coördinatie verwacht kunnen worden, en die is in dit onderzoek niet aangetoond. 
I In 1998 zijn acht aspecten van het jeugdbeleid ondergebracht in de factor "staat van het jeugdbeleid'. Voor het huidige onderzoek is een van deze aspecten uit de factor werwijderd: 'afstemming met de jeugdzorg'. Dit aspect heeft meer betrekking op de inhoud van het jeugdbeleid dan op de ontwikkeling ervan. De afstemming met de jeugdzorg komt dan ook uitgebreid in hoofdstuk 4 aan de orde.

2 Bij afwezigheid van relevante beleidsdocumententen kreeg de betreffende gemeente de score I op deze indicator.

3. Hier wordt een enge definitie van effectmeting gehanteerd: het gaat alleen om de vraag of beleidsdoelen zijn gerealiseerd, niet om de vraag wat daarbij de bijdrage van het gevoerde beleid is.

4 Omdat er nu in tegenstelling tot in 1998 zeven indicatoren in de factor zijn opgenomen (zie noot $x$ ), zijn de factorladingen veranderd ten opzichte van 1998. De scores op de mat 'staat wan het jeugdbeleid' zijn dan ook licht gewijzigd, maar de samenhang tussen de beide factorscores is bijna volledig (Pearson's correlatiecoëfficiënt tussen de factorscores in beide jaren is 0,96 ).

Een andere verandering ten opzichte van 1998 is dat op een andere manier met ontbrekende waarden is omgegaan. Voor gemeenten met maximaal twee ontbrekende waarden op de zeven indicatoren (in I9g8 drie gemeenten, in 2002 20) zijn deze waarden geïmputeerd met behulp van het programma Norm (Schafer 1999). Dit programma zocht op basis wan wel belkende waarden van een case de best passende waarden, waarbij voldoende spreiding gegarandeerd wordt door op willekeurige wijze "error'-termen toe te woegen.

5 Cronbach's alpha voor de schaal van 1998 is $0,7 \mathbb{I}$ en die voor $200 \pi$ is 0,68 .

6 Het betreft een niet-stedelijke gemeente die weliswaar een nota jeugdbeleid heeft, maar daarin alleen in vage termen aangeeft in de toekomst een jeugdbeleid te gaan ontwikkelen. Deze gemeente had in 2oor dus geen doelstellingen en maatregelen op het gebied van jeugdbeleid. De andere gemeente heeft in haar na 1998 verschenen nota de doelstellingen in kwalitatieve in plaats van kwantitatieve zin geformuleerd.

7 Daarbij dient bedacht te worden dat $15 \%$ van de onderzoeksgemeenten in 1998 al de hoogst mogelijke score had, en het voor hen dus niet mogelijk was vooruitgang te boeken.

8 Het gemiddelde aantal aandachtsvelden in 1998 wijkt af van het genniddelde aantal dat is gerapporteerd in 1999 . Dat heeft te maken met het in de luuidige analyse ontbreken van twee gemeenten en drie deelgemeenten/stadsdelen die in 1999 wel in de analyse waren betrokken. De twee gemeenten ontbreken nu vanwege herindeling, terwijl in thet huidige onderzoek ook niet afzonderlijk aandacht is besteed aan deelgemeenten in Rotterdam en stadsdelen in Amsterdam.

9 Deze bevindingen worden ondersteund door de analyse van de na 1998 verschenen nota"s lokaal jeugdbeleid. In 26 van de 36 nota"s wordt veel aandacht besteed aan een actieve regierol van de gemeente. In zeven van deze nota's is er wel aandacht, maar is de voorgestelde regierol hoofdzakelijk als passief te omschrijven, en in de overige drie nota"s is geen aandacht voor gemeentelijke regie.

ro Ook hier past de opmerking dat het voor gemeenten die in 1998 hoog scoorden relatief moeilijker is significante vooruitgang op de factor 'staat van het jeugdbeleid" te boeken.

II Een vraag die vaak wordt gesteld, is of een eventueel aangetroffen verband tussen de mate waarin het beleid van gemeenten is ontwikkeld en de stedelijkheid van gemeenten erop duidt dat meer stedelijke gemeenten inspelen op de grotere sociale problematiek. Is 
het niet vanzeilfsprekend dat deze gemeenten meer beleid hebben ontwikkeld, gezien de omvang van hun besturulijke hulpbronnen? Beide vragen dienen bevestigend te worden beantwoord. Meer stedelijke gemeenten, die doorgaans te maken hebben met een grotere sociale problematiek, hebben vaak meer beleid ontwikkeld, wat mede verklaard wordt door de grotere beschikbaarheid van bestuurlijke hulpbronnen. Die hulpbronnen worden hen echter in vergelijking met minder stedelijke gemeenten ruimschoots toebedeeld, omdat de financieringssystematiek rust op de veronderstelling dat zij deze hulpbronnen, gezien de meer omwangrijke problemen, meer nodig hebben. De verwachting dat meer stedelijke gemeenten meer beleid ontwikkelen, is daarom in overeenstemming met de gedachte die aan de financiële toerusting van gemeenten ten grondslag ligt. 


\section{4 \\ De inhoud van het lokale jeugdbeleid}

\subsection{Inleiding}

Een van de belangrijkste argumenten voor de decentralisatie van bevoegdheden naar zelfstandige, democratisch gelegitimeerde gemeentelijke overheden is dat deze beter dan de centrale overheid in staat zijn het beleid toe te spitsen op de lokale situatie, waardoor de kans op effectief en efficiënt beleid toeneemt. In hoofdstuk 3 hebben we gezien dat in meer stedelijke gemeenten, waar doorgaans de groep kwetsbare jeugd groter is dan in minder stedelijke gemeenten, het jeugdbeleid gemiddeld verder ontwikkeld is dan in deze minder stedelijke gemeenten. Dit zou erop duiden dat de lokale situatie met betrekking tot het beleidsobject, in lijn met de argumenten voor decentralisatie, van betekenis is voor de bij beleidsmakers aanwezige urgentie om beleid te ontwikkelen.

Het antwoord op de vraag of er beleid ontwikkeld is, zegt echter nog nilets over de inhoudelijke inrichting van dat beleid. Is het ook zo dat uit de inhoud van het beleid geconcludeerd kan worden dat er sprake is van maatwerk? Op die vraag gaan we in dit hoofdstuk in. De vraag wordt, weliswaar tentatief, op twee manieren beantwoord. In de eerste plaats gaan we ervan uit dat, willen we kunnen spreken van maatwerk, in de meer stedelijke gemeenten het beleid sterker gericht zal zijn op de kwetsbare jeugd, omdat de omvang van die groep in die gemeenten ook in relatieve zin groter is dan in minder stedelijke gemeenten. In de tweede plaats veronderstellen we dat de lokale situatie met betrekking tot jeugd varieert en dat er dientengevolge inhoudelijke verschillen zijn in de inhoudelijke beleidsprioriteiten tussen gemeenten. In het geval er sprake is van sterke conformiteit in de beleidsprioriteiten, zijn kennelijk andere factoren dan de lokale situatie (mede) bepalend voor de inhoudelijke inrichting van het jeugdbeleid.

Het hoofdstuk bestaat uit twee delen. In het eerste deel $(\$ 4.2)$ wordt gekeken naar het jeugdbeleid in brede zin. Wat zijn de aandachtsvelden en leeftijdsgroepen waar gemeenten zich op richten? Wat is de benadering die gemeenten kiezen? Wat zijn hun beleidsmatige prioriteiten? Het tweede deel van het hoofdstuk ( $\$ 4.3$ ) gaat wat dieper in op een aantal specifieke aandachtsgebieden in het jeugdbeleid. Daarbij is gekozen voor vier thema's die in de periode van 1999 tot en met 2002 nadrukkelijk onder de aandacht van gemeenten zijn gebracht door de Vereniging van Nederlandse Gemeenten (VNG) middels het door de nationale overheid gefinancierde project Lokaal jeugdbeleid. Deze thema's zijn:

- jeugd en veiligheid;

- de afstemming tussen de jeugdzorg en het lokale jeugdbeleid;

- de afstemming tussen lokaal jeugd- en lokaal onderwijsbeleid;

- de sluitende aanpak van het beleid gericht op 0- tot 6-jarigen. 
Bekeken wordt of gemeenten beleid hebben geformuleerd op deze inhoudelijke thema's en zo ja, welke prioriteiten er in dat beleid zijn.

De bevindingen in dit hoofdstuk zijn gebaseerd op de bij de coördinerende ambtenaren afgenomen vragenlijsten. Op een enkel punt zijn de bevindingen ondersteund door de analyse van beleidsdocumenten die voor het jeugdbeleid relevant zijn. De kwantitatieve bevindingen worden op verschillende plaatsen geïlustreerd met bevindingen uit de negen gemeenten van het kwalitatieve onderzoek.

\subsection{Accenter in het jeugdbeleid}

\subsubsection{Algemeen preventief, gericht preventief en curatief jeugdbeleid}

In het algemeen kan in het jeugdbeleid onderscheid gemaakt worden tussen verschillende 'typen' jeugdbeleid, die betrekking hebben op verschillende groepen jeugd. De terminologie omtrent deze typen varieert door de tijd. In aansluiting op het onderzoek van het Sociaal en Cultureel Planbureau ( $\mathrm{SCP}$ ) uit I9g9 (Gilsing 1999) wordt hier een onderscheid gehanteerd tussen algemeen preventief, gericht preventief en curatief jeugdbeleid. ${ }^{\mathrm{I}}$

Algemeen preventief jeugdbeleid richt zich op alle jeugd en in het bijzonder op de deelname van kinderen en jongeren aan algemene voorzieningen - van peuterspeelzaal tot en met onderwijs en vrijetijdsvoorziening - om hen in hun groei naar volwassenheid te ondersteunen. In dit beleid wordt gestreefd naar een wersterking van dit voorzieningenaanbod.

Gericht preventief en curatief jeugdbeleid hebben uitsluitend betrekking op risicogroepen jeugd. Het streven is de problemen van deze jeugdigen vroegtijdig te signaleren en aan te pakken. Gericht preventief beleid heeft tot doel (mogelijke) problemen van risicojeugd zo snel mogelijk aan te pakken en, waar mogelijk, te voorkomen. Het gaat hier onder meer om maatregelen als voor- en vroegschoolse educatie (vve) en opvoedingsondersteuning en ontwikkelingsstimulering (O\&O) voor specifieke groepen jonge kinderen, maar ook om het voorkomen van schooluitval en jeugdwerkloosheid onder tieners en jongvolwassenen.

Curatief beleid beoogt jongeren met meervoudige problemen, die als gevolg daarvan zijn ontspoord of dreigen te ontsporen, aan te pakken en/of te ondersteunen. Daarbij moet onder andere gedacht worden aan de jeugdhulpverlening, maatschappelijke opvang en de verslaafdenzorg.

Aan de ambtelijke sleutelinformanten is gevraagd hoe zij het jeugdbeleid van hun gemeente typeren: als algemeen preventief, als gericht preventief of curatief. Het accent ligt voor de meeste gemeenten op algemeen preventief en gericht preventief jeugdbeleid (zie tabel 4.I). Bijna $60 \%$ van de gemeenten typeert het eigen beleid als algemeen preventief en bijna de helft geeft aan gericht preventief jeugdbeleid te voeren. In de sterk en matig stedelijke gemeenten is er meer aandacht voor gericht 
preventief beleid dan in de minst stedelijke gemeenten. Het curatieve beleid krijgt doorgaans in alle typen gemeenten weinig aandacht. Een kwart van de gemeenten voert een duidelijk curatief jeugdbeleid. Lokale nota's jeugdbeleid ondersteunen deze bevinding. In op één na alle onderzochte nota's jeugdbeleid is er sprake van algemeen preventief jeugdbeleid. In $70 \%$ van de nota's is het beleid tevens te typeren als gericht preventief.

Acht van de 60 onderzochte gemeenten ( $14 \%$ ) besteden veel aandacht aan alle drie de beleidstypen. Dertien gemeenten ( $22 \%$ ) besteden aan geen enkel type veel aandacht. De rest richt zich vooral op één of twee beleidstypen. Daarbij blijkt een verband te bestaan tussen gericht preventief en curatief jeugdbeleid. Het hebben van een gericht preventief jeugdbeleid gaat relatief vaak samen met het hebben van curatief jeugdbeleid, terwijl gemeenten met veel aandacht voor curatief beleid relatief vaak ook gericht preventief beleid voeren. Geen duidelijk verband wordt daa rentegen gevonden tussen algemeen preventief jeugdbeleid en gericht preventief en curatief jeugdbeleid. Daaruit blijkt dat het lokale jeugdbeleid over twee sporen loopt. Er is beleid gericht op alle jeugd en, los daarvan, beleid gericht op risicogroepen (vgl. Roes et al. 2002).

\section{Tabel 4.7}

Typering van het jeugdbeleid volgens ambtenaren jeugdbeleid, $2001 \quad(n=59$; in procenten)

\begin{tabular}{|c|c|c|c|}
\hline & zeer & engstins & naumelifis of thitat \\
\hline algemeen preventief jeugdbeleid & 58 & 39 & 3 \\
\hline gericht preventief jeugdbeleid & 51 & 44 & 5 \\
\hline curatief jeugdbeleid & 25 & 58 & 17 \\
\hline
\end{tabular}

Bron SCP (U] B anb tenaren 2002 )

\subsubsection{Thema's in het jeugdbeleid}

In dit onderzoek worden in het jeugdbeleid acht inhoudelijke thema's onderscheiden, die allen een bepaald aspect van de leefsituatie van jeugdigen betreffen. Door de keuze voor deze levensterreinen van jeugdigen wordt vermeden dat een sectorale indeling wordt gemaakt. De veronderstelling was dat door deze indeling in levensterreinen te gebruiken in plaats van veel gebruikte standaardindelingen, de respondenten werden gedwongen verder na te denken over de thema's die in het jeugdbeleid aan de orde komen. De levensterreinen die zijn gekozen, zijn de volgende:

- opvoeding en thuissituatie;

- (lichamelijke en geestelijke) gezondheid;

- kinderdag-en buitenschoolse opvang;

- onderwijs en scholing;

- vrijetijdsbesteding en (buurt)voorzieningen;

- arbeid en inkomen;

- jongerenhuisvesting en woonruimte;

- openbare orde en veiligheid. 


\section{Box 4.1 Prioriteiten en accenten in het jeugdbeleid}

Het lokale jeugdbeleid kent verschillende prioriteiten en accenten. Hoewel er ook weel overlap is, leiden verschillende prioriteiten tot andere accenten in het jeugdbeleid.

\section{Prioriteit: achterstandbestrijding}

Het jeugdbeleid in Appingedam is gericht op het voorkomen van achterstanden in brede $\mathrm{zin}$. Het gaat vooral om preventie. Appingedam heeft naar verhouding veel inwoners met een lage sociaal-economische status, wat gevolgen heeft voor het beleid op de terreinen onderwijs, welzijn en socilale zaken. Het jeugdbeleid bestaat uit een aanbod van welzijnsinstellingen en het onderwijsachterstandenbeleid. Het gaat nog niet om de "leuke dingen', maar om een gerichte aanpak van de achterstanden, aldus de wethouder. De ambtenaar karakteriseert het jeugdbeleid als 'sober doch humaan'. De speerpunten van het jeugdbeleid zijn gericht op het onderwijs. In grote lijnen gaat het om: meer investeren in de woorschoolse periode, meer aandacht voor ondersteuning in de schoolse periode, en in het voortgezet onderwijs aanvullende aandacht voor versterking van de (onderwijs) positie van allochtone leerlingen en voor de veilige school/veilige stad.

\section{Prioriteit: specifieke groepen}

In de nota jeugdbeleid van de gemeente Culemborg komt naar voren dat de prioriteit ligt bij twee leeftijdsgroepen: de 0-4-jarigen en de 10-15-jarigen. De wethouder legt een sterke prioriteit bij 12-plussers. Bij die groep, in het bijzonder de allochtone jongeren, is de problematiek het grootst, wat zich onder meer uit in voortijdig schoolverlaten. Het beleid voor deze groep zou meer pro-actief moeten zijn. Belangrijke elementen van zo'n beleid zijn het in sterke mate betrekken van ouders bij het onderwijs en het organiseren van vangnetten voor potentiële uitvallers in het voortgezet onderwijs. Een andere prioriteit is het aanpakken van de ervaren overlast veroorzaakt door jongeren. De coärdinerende ambtenaar jeugdbeleid legt een sterke nadruk op de relatie tussen onderwijs en jeugdbeleid. Een andere prioriteit ligt volgens de ambtenaar bij de veelal allochtone achterstandsgroepen. Het is belangrijk voor deze groepen voorwaarden te creëren waardoor hun positie kan verbeteren. In de toekomst zou er meer aandacht moeten komen voor de brede groep jeugd. Op dit moment hebben deze groep en de daarvoor bestemde algemene voorzieningen echter niet de hoogste prioriteit.

\section{Prioriteit: zowel algemeen als gericht preventief}

De Groningse wethouder wil in het jeugdbeleid een evenwichtige mix hebben van wat aangeduid wordt als de breedte- en de dieptestrategie. De breedtestrategie is gericht op het realiseren van goede basisvoorzieningen en heeft in principe betrekking op alle jeugdigen. Hiertoe behoort de invoering van het bredeschoolconcept. De dieptestrategie is gericht op het leveren van op maat gesneden, flexibele ondersteuning aan kinderen en hun ouders bij de aanpak van een gesignaleerd probleem. In de dieptestrategie gaat het 


\section{Vervolg Box 4,1 Prioriteiten en accenten in het jeugdbeleid}

om ander meer opvoedingsondersteuning, het onderwijsachterstandenbeleid ("kansenbeleid') en de sluitende aanpak tussen school en werk. Als concrete prioriteiten noemt hij de uitbreiding van de vensterscholen, een structurele financiering jeugd - en jongerenteams, ruimte voor jongeren, de voorschoolse periode en participatie van jongeren. De ambtenaar noemt ook zaken als uitbreiding van de kinderopvang, tieneropvang en de gezonde en veilige school.

\section{Priorite t uoorzieningem}

Dewethouder van Spijkenisse noemt als eerste en enige prioriteit in het beleid het realiseren van voorzieningen die voor jeugdigen aantrekkelijk zijn. Het gaat daarbij onder meer om jeugdhonken, om culturele voorzieningen en om speeltuinen, In het algemeen krijgt de vrijetijdsbesteding van de jeugd in de beleidsnotitie veel aandacht van de acht beleidsthema's die samen het integrale jeugdbeleid vormen, heeft zeker de helft hier direct mee te maken, zoals jeugd op straat, sportstimulering en jeugd en vrije tijd. Daarnaast is het onderwijsachterstandenbeleid in zijn geheel een prioriteit in het beleid volgens de coördinerende ambtenaars projecten gericht op kinderen uit risicogezinnen, uitbreiding van het bereik van peuterspeelzalen, preventie voortijdig schoolverlaten en opvang van uitvallers.

Uit de enquête onder ambtenaren jeugdbeleid komt naar voren dat de grote meerderheid van de gemeenten ( $88 \%$ ) zich concentreert op onderwijs en kinderopvang. De daarna meest genoemde thema's zijn vrijetijdsbesteding en veiligheid/openbare orde $(70 \%$ ) (zie tabel 4.2 ). Jongerenhuisvesting geniet daarentegen weinig belangstelling. Slechts twee gemeenten houden zich hier intensief mee bezig. Een mogelijke verklaring hiervoor is dat de invloed van gemeenten op de woningvoor raad in het algemeen beperkt is, omdat die in handen is van woningbouwcorporaties en particulieren. Gemeenten kunnen echter wel prestatieafspraken maken met de corporaties, met name op het gebied van doelgroepenbeleid (Puts en Wever 1998). Ook arbeid en inkomen staat niet hoog op het prioriteitenlijstje van gemeenten. Iets meer dan een kwart van de ambtenaren vindt dit een onderwerp van grote betekenis en legt hier een duidelijk accent op. Op dit terrein hebben gemeenten, onder andere via de Wet inschakeling werkzoekenden (Wiw) wel degelijk mogelijkheden om beleid te maken (zie hoofdstuk I2).

De in paragraaf 4.2.I aangetroffen relatie tussen de aandacht voor gericht preventief beleid en stedelijkheid zien we ook hier terugkomen. De meer stedelijke gemeenten hebben vaker dan minder stedelijke gemeenten aandacht voor onderwijs, opvoeding en veiligheid, thema's die zich in het algemeen kenmerken door een meer gericht preventieve benadering. 
Tabel 4.2

Aandacht voor levensterreinen in jeugdbeleid volgens ambtenaren jeugdbeleid, 2001 (in procenten)

\begin{tabular}{|c|c|c|c|c|}
\hline lewensterrein & $\begin{array}{l}\text { Theel) weet } \\
\text { aandacht }\end{array}$ & $\begin{array}{l}\text { niet weel, } \\
\text { niet weing } \\
\text { aandacht }\end{array}$ & $\begin{array}{l}\text { (heel) weinig } \\
\text { aandacht }\end{array}$ & (n) \\
\hline Kinderdag - en burterischoolse opvang & 88 & 12 & 0 & (59) \\
\hline onderwijs/seholing & 88 & 10 & 2 & (59) \\
\hline vrijetijdsbested ingl (buuurt)voorzieningen & 70 & 27 & 3 & $(60)$ \\
\hline openbare orde/veiligheid & 69 & 24 & 7 & (59) \\
\hline opvoeding/thuissituatie & 53 & 31 & 16 & (58) \\
\hline gezondheid (fichamelijk/geestelijk) & 41 & 46 & 13 & (56) \\
\hline arbeidinkomen & 27 & 36 & 38 & (56) \\
\hline jongerenhuisvesting/wwoonruimte: & 4 & 36 & 61 & (56) \\
\hline
\end{tabular}

Zijn de genoemde thema's ook terug te vinden in de jeugdnota's van de onderzochte gemeenten? Het beeld dat uit de nota's naar voren komt, correspondeert in grote lijnen met het beeld dat de ambtenaren zelf schetsen (zie tabel 4.3). Vrijetijdsbesteding, onderwijs en veiligheid zijn belangrijke kernthema's. Opvoeding, zo blijkt uit de nota's, hoort daar ook bij. Jongerenhuisvesting en arbeid/inkomen spelen daarentegen een ondergeschikte rol.

\section{Tabel 4.3}

Aandacht voor levensterreinen in jeugdbeleid volgens nota's jeugdbeleid, 2001 (in procenten)

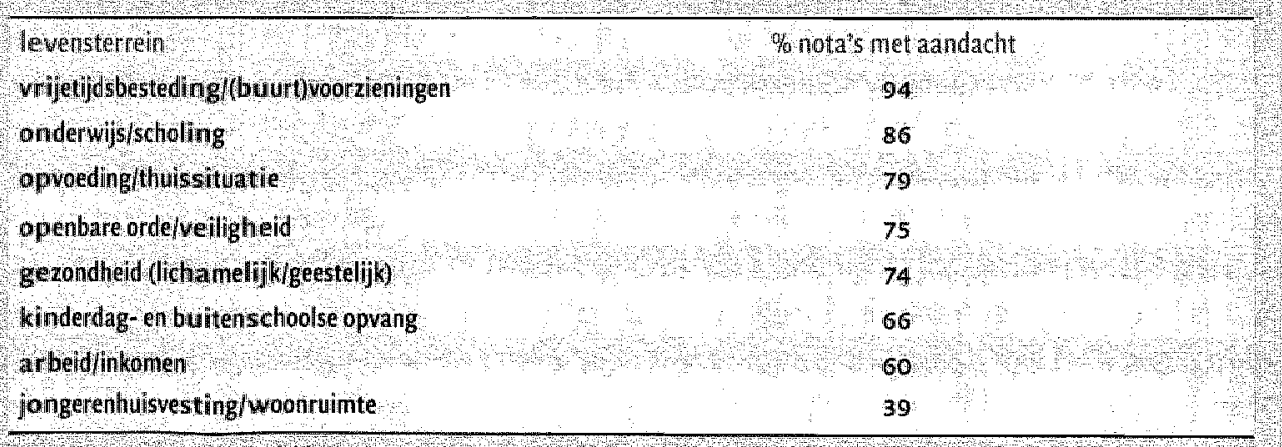

BremscP (notas ievgd beleid 2002$)$

\subsubsection{Prioriteiten in het jeugdbeleid}

Om meer zicht te krijgen op de in houdelijke prioriteiten in het lokale jeugdbeleid is aan de ambtenaren jeugdbeleid een lijst met beleidsmaatregelen en doelstellingen voorgelegd. Deze zijn in tabel 4.4 met behulp van de in paragraaf 4.2.I gemaakte indeling onderverdeeld in algemeen preventieve, gericht preventieve, gericht preven- 
tieve/curatieve en curatieve maatregelen en doelstellingen, afhankelijk van de doelgroep en/of voorzieningen waar de maatregel primair betrekking op heeft.

Op het gebied van het algemeen preventieve beleid, gericht op alle jeugd, genieten maatregelen met betrekking tot opvang en vrijetijdsbesteding de meeste aandacht. $85 \%$ van de onderzochte gemeenten vindt de uitbreiding van de kinderdagopvang en de buitenschoolse opvang belangrijk. Daarnaast spelen het verbeteren wan speelgelegenheden voor kinderen $(66 \%)$, het stimuleren van sportdeelname $(52 \%)$ en de ontwikkeling van brede scholen $(50 \%)$ een centrale rol in het lokale jeugdbeleid.

Opvallend weinig aandacht gaat echter uit naar de verlengde schooldag: voor slechts $16 \%$ van de gemeenten vormt dit een belangrijk accent in het jeugdbeleid. Deze geringe belangstelling kan niet los gezien worden van de opkomst van de brede school. De experimenten met de 'verlengde schooldag', die begin jaren negentig zijn opgezet door het Nederlands Instituut voor Zorg en Welzijn (NIZW) en gefinancierd door het ministerie van Volksgezondheid, Welzijn en Sport (vws) en die beoogden leerlingen na schooltijd een 'leerzame' vrijetijdsbesteding aan te bieden, zijn woor de basisschool afgesloten in 1996 en voor het voortgezet onderwijs in 20or. Bij deze experimenten is het veelal gebleven. Halverwege de jaren negentig ontstaan echter wel 'brede scholen'. ${ }^{2}$ De brede school omvat meer dan de verlengde schooldag. Bij de brede school gaat het niet alleen om samenwerking met vrijetijdsorganisaties, maar ook met kinderopvang (buitenschoolse opvang), peuterspeelzaal (vve), politie, jeugdhulpverlening en/of schoolmaatschappelijk werk. De ontwikkeling van brede scholen blijkt krachtig doorgezet te zijn. In 2002, zo laten cijfers van de bredeschoolmonitor zien, werken 268 gemeenten aan de totstandkoming van brede scholen en zijn bijna 450 brede scholen operationeel (Oberon 2002). In paragraaf 4.3.3 komen we terug op de ontwikkeling van brede scholen.

Bij voorzieningen en activiteiten die zich richten op risicogroepen valt op dat veel zich concentreert rond het onderwijs. De topvijf van prioriteiten heeft volledig betrekking op voorschoolse en schoolse voorzieningen. Het gaat hier om de aanpak van onderwijsachterstanden ( $73 \%$ ), het initiëren van voor- en vroegschoolse educatie $(71 \%)$, het bevorderen van de aansluiting tussen peuterspeelzaal en basisschool $(67 \%)$, het bestrijden van schoolverzuim $(67 \%)$ en het professionaliseren van het peuterspeelzaalwerk ( $66 \%$ ). Daarnaast is er de nodige aandacht voor (jonge) kinderen. Een aanzienlijk aantal gemeenten streeft naar een sluitende aanpak voor 0 -6-jarigen ( $61 \%$ ), vroegtijdige signalering van problemen bij kinderen $(57 \%)$ en het initiëren van opvoedingsondersteuning $(45 \%)$. Bij de tieners ligt een duidelijk accent op curatieve maatregelen, in het bijzonder op gerichte interventies bij de probleemjeugd $(52 \%)$, en op het afstemmen met de jeugdzorg $(48 \%)$.

Opvallend weinig belangstelling is er voor gezondheidswoorlichting, het begeleiden van starters op de arbeidsmarkt en de aanpak van jeugdwerkloosheid. ${ }^{3}$ Slechts II\% van de gemeenten doet aan gezondheidsvoorlichting, maar $17 \%$ houdt zich intensief mee bezig de bestrijding van de jeugdwerkloosheid en $19 \%$ legt prioriteit bij de begeleiding van starters op de arbeidsmarkt. 
Tabel 4.4

Speerpunten in het Hokale jeugdbeleid, $2001(n=48-60$; in procenten)

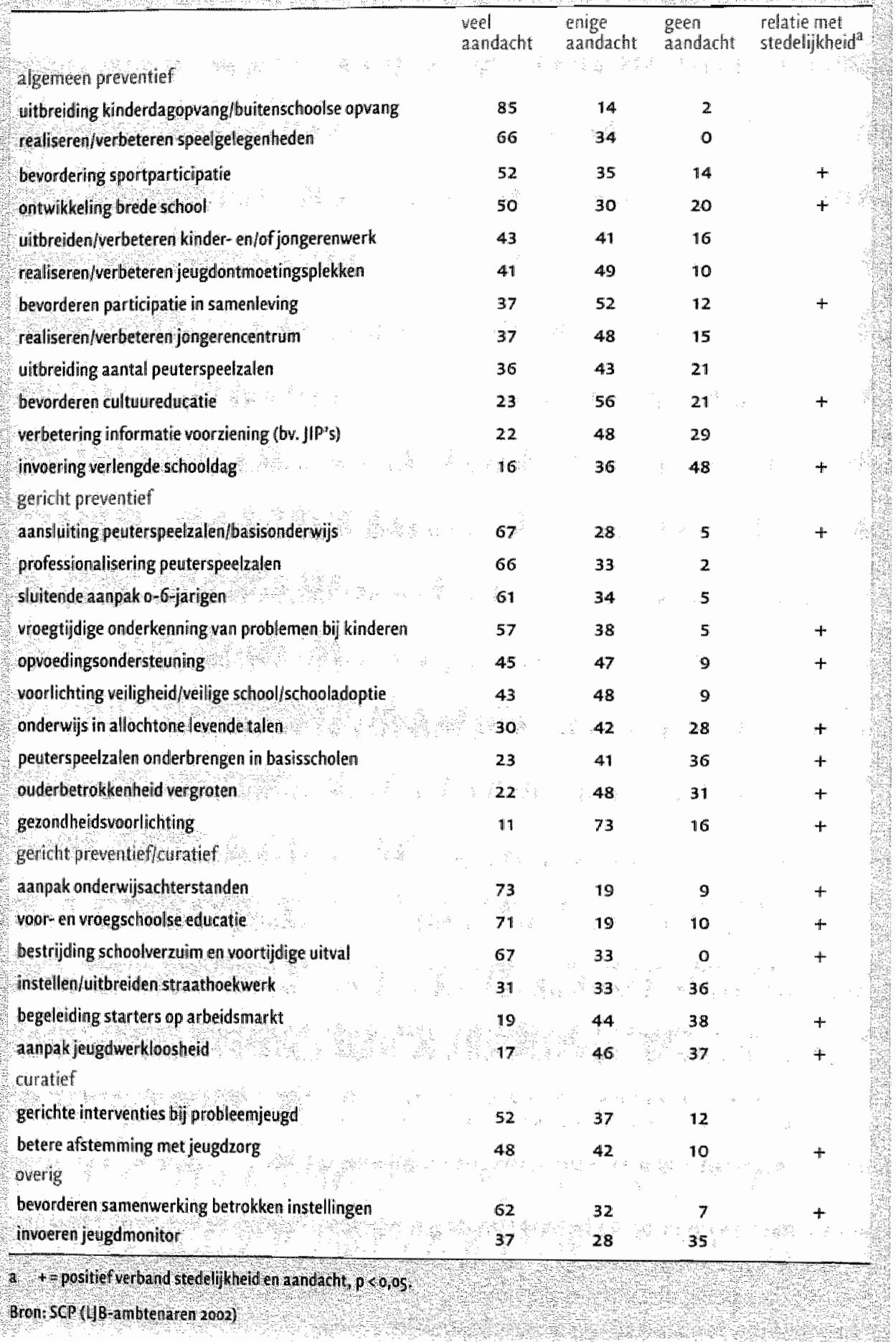


Tabel 4.4 maakt duidelijk dat een groot aantal speerpunten verband houdt met de stedelijkheid van gemeenten. Met name voor voorzieningen en activiteiten die bestemd zijn voor risicojeugd - gericht preventief en curatief beleid - valt op dat sterk stedelijke gemeenten hier doorgaans meer aandacht aan besteden dan minder stedelijke gemeenten. Dit is in overeenstemming met eerdere bevindingen uit dit hoofdstuk. Van de achttien genoemde (gericht preventieve en curatieve) regelingen hangen er dertien samen met stedelijkheid. Uitzonderingen op deze algemene regel zijn de professionalisering van het peuterspeelzaalwerk en de sluitende aanpak voor o-6-jarigen - maatregelen die in het landelijke jeugdbeleid veel aandacht genieten en sterke (financiële) impulsen krijgen (zie hoofdstuk $\mathrm{I}_{2}$ ) - alsook de voorlichting over veiligheid, de uitbreiding van het straathoekwerk en gerichte interventies bij probleemjeugd. Voor deze maatregelen vinden we geen werschillen tussen meer en minder stedelijke gebieden. Voor voorzieningen en activiteiten die voor de gehele jeugd bestemd zijn, worden minder verschillen gevonden tussen meer en minder stedelijke gebieden. Van de twaalf maatregelen die in dit kader zijn opgesomd houden zeven geen verband met stedelijkheid en vijf wel. Het gaat in het laatste geval om een keur aan regelingen, waaronder de ontwikkeling van de brede school, de bevordering van sportparticipatie en deelname aan de samenleving, cultuureducatie en invoering van de verlengde schooldag. Deze activiteiten worden vaker ondernomen in meer stedelijke gemeenten.

\subsubsection{Aandacht voor leeftijdsgroepen}

Volgens de nationale overheid dient het jeugdbeleid gericht te zijn op de bevolking van o tot 25 jaar. Het is de vraag of in het lokale jeugdbeleid deze gehele bevolkingsgroep even belangrijk wordt geacht. Daarom is gekeken naar de beleidsmatige aandacht voor verschillende leeftijdsgroepen. De gehanteerde indeling is gerelateerd aan de doorsnee onderwijscarriere: in de leeftijd van o tot 4 jaar doorloopt het kind de voorschoolse periode, van 4 tot $\mathrm{I} 2$ de basisschoolperiode, van 12 tot 18 ruwweg de middelbareschoolperiode en 18 jaar en ouder betreft de tijd na de middelbare school en van vervolgonderwijs of arbeidsmarktparticipatie.

Het blijkt dat gemeenten zich vooral op de groep tot 18 jaar richten, waarbij de jongste leeftijdsgroep er het meest uitspringt (zie tabel 4.5). In minder dan eenderde van de onderzoeksgemeenten is er veel aandacht voor de groep van 18 jaar en ouder. Voor de tieners (12 tot 18 jaar) blijkt de aandacht samen te hangen met de stedelijkheid van de gemeente: hoe stedelijker, hoe groter de kans op ruime aandacht voor deze groep. Ook deze bevinding past in het beeld dat de meer stedelijke gemeenten doorgaans een sterker probleemgericht jeugdbeleid hebben. 
Tabel $4: 5$

Aandacht voor leeftijdsgroepen in jeugdbeleid, 2001 ( $n=60$; in procenten)

\begin{tabular}{|c|c|c|c|}
\hline & (teel) veel aundacht & $\begin{array}{l}\text { qiec veel, hiet weing } \\
\text { aafidacht }\end{array}$ & (heel) weing aandacht \\
\hline $0-3$ jaar & 85 & 14 & 2 \\
\hline 4-11 jaar & 75 & 22 & 3 \\
\hline $12.17 \mathrm{jar}$ & 70 & 25 & 5 \\
\hline $218 \mathrm{jaar}$ & 28 & 35 & 35 \\
\hline
\end{tabular}

Bron SCP (4B - ambitenaren 20o2)

Volgens de bestudeerde nota's jeugdbeleid gaat de meeste aandacht in het lokale jeugdbeleid uit naar o- tot 4-jarigen. Meer dan $80 \%$ van de onderzochte gemeenten richt zich op deze groep. Daarnaast ligt er een belangrijk accent op oudere kinderen en tieners onder 18 jaar. Dit kan niet losgezien worden van de centrale thema's in het lokale jeugd beleid, te weten scholing, vrijetijdsbesteding, opvoeding en veiligheid.

De belangstelling voor de jeugd van 18 jaar en ouder is duidelijk geringer. Zoals aangegeven, bestaat er in het lokale jeugdbeleid doorgaans weinig belangstelling voor de beleidsterreinen die zich richten op deze leeftijdsgroep, waaronder jongerenhuisvesting en arbeid en inkomen.

Is er een verband tussen beleid dat zich richt op kinderen en beleid voor jongeren? Hebben gemeenten die veel aandacht geven aan kinderen eveneens de nodige belangstelling voor tieners? De analyses wijzen uit dat er sprake is van een doorgaande beleidslijn als het gaat om kinderen onder de 12 jaar. Gemeenten die veel aandacht hebben voor jonge kinderen (tot 4 jaar) concentreren zich ook vaak op oudere kinderen (tot 12 jaar). Kijken we naar de tieners van 12 jaar en ouder, dan vinden we iets soortgelijks. Gemeenten die zich richten op 12-17-jarigen ondernemen relatief vaak ook diverse acties die betrekking hebben op jongeren van 18 jaar en ouder en andersom.

Geen verband wordt daarentegen gevonden tussen het beleid voor 12 -minners en 12-plussers. Deze beleidstypen staan los van elkaar. Er is niet altijd sprake van een doorlopende beleidslijn tussen kinder- en tienerbeleid, ondanks het feit dat zich in deze periode een belangrijk schakelmoment voordoet: de overgang van het basisonderwijs naar het voorgezet onderwijs (Schuyt r995; BANS 2001).

\subsection{Specifieke inhoudelijke thema's}

\subsubsection{Jeugd en veiligheid}

In het regeerakkoord van het tweede kabinet-Kok is voor gemeenten een belangrijke taak op het gebied van jeugd en veiligheid vastgelegd. Het beleid hieromtrent zou nauw moeten aansluiten bij het lokale jeugdbeleid en zich onder andere moeten concentreren op problemen en probleemgedrag van jongeren. Het jeugd-en veiligheidsbeleid dient echter niet alleen curatief van aard te zijn, maar ook preventief. Eén van 
de centrale speerpunten van dit beleid is dat gestreefd wordt naar een integrale sluitende aanpak ter voorkoming van overlast door de jeugd en van jeugdcriminaliteit. Hierbij zijn vele actoren betrokken, waaronder het onderwijs, het welzijnswerk, politie en justitie, de jeugdzorg, de stadswacht, gezinswoogdij-instellingen, maatschappelijk werk en de kinderbescherming. Regie en afstemming door de lokale overheid zijn dan ook noodzakelijk (zie verder hoofdstuk 12 voor het nationale beleid op het. gebied van jeugd en veiligheid).

Aan de ambtelijke sleutelinformanten is gevraagd of de gemeente een specifiek weiligheidsbeleid gericht op de jeugd heeft, en zo ja, hoe dat er uitziet. Bijna eenderde van de onderzochte gemeenten heeft geen specifiek jeugd- en veiligheidsbeleid. De rest voert wel beleid op dit terrein.

\section{Box 4.2 Jeugd en veiligheid}

Op het gebied van jeugd en veiligheid zijn er duidelijke verschillen tussen de meer en de minder stedelijke gemeenten. Onderstaande portretjes illustreren dat.

\section{Weinig stedelijk}

De gemeente Heeze-Leende heeft geen specifiek jeugd-en veiligheidsbeleid. Op aandrang van de politie is er eind 1999 een jongerenopbouwwerker aangesteld die (probleem)jongeren moet leren kennen en op basis daarvan tot aanbevelingen aan politie en gemeente moet komen. $\mathrm{Er}$ is veel overleg tussen deze functionaris en de politie. Het gaat daarbij vooral om de bestrijding van de overlast. De gemeente wordt 'geplaagd' door een kleine groep jongeren die problemen veroorzaken. De jongerenwerker is er vooralsnog niet in geslaagd contact te leggen met deze groep. Voor het jeugdbeleid van de gemeente zijn deze gebeurtenissen een belangrijk signaal: er doen zich ontwikkelingen voor waarop de gemeente (nu) nog onvoldoende is voorbereid. Zo is er een steeds grotere groep jongeren die onvoldoende wordt aangesproken door het verenigingsleven. De wethouder geeft aan dat hij weinig invloed heeft op de groep 12-16-jarigen vanwege het ontbreken van het voortgezet onderwijs in de gemeente.

\section{Matig stedelijk}

Vanaf 1999 kan er in Culemborg gesproken worden van een jeugd- en veiligheidsbeleid. Dit belleid is gericht op het creëren van voorzieningen voor een aantal groepen 'hangjongeren'. Om deze te realiseren, is een werkgroep onder voorzitterschap van de wethouder jeugdbeleid ingesteld. Daarin is ook een aantal uitvoerende instellingen betrokken, waaronder de politie. Op wijkniveau is er ook aandacht voor overlastproblematiek: er zijn projectgroepen waarin de belanghebbenden, waaronder de jeugd, oplossingen trachten te vinden. Door verschillende actoren wordt naar voren gebracht dat het betrekken van overlast veroorzakende jongeren bij het zoeken naar een oplossing, een positieve werking heeft op de effectiviteit. Er is een afzonderlijk overleg over vandalisme en criminaliteit door Marokkaanse jongeren. In dit overleg zitten de burgemeester, de politie en vertegenwoordigers van de Marokkaanse gemeenschap. 


\section{Vervolg Box 4.2 Jeugd en veiligheid}

\section{Sterk stedelijk}

De gemeente Spijkenisse heeft samen met andere gemeenten in de regio subsidie ontvangen van het ministerie van Binnenlandse Zaken en Koninkrijksrelaties (BzK) in het kader van 'jeugd en veiligheid'. Hiermee zijn tal van projecten gesubsidieerd: onderzoek naar het gebruik van genotmiddelen, een opvoedbureau, een Home-startproject, coaching van het jongerenwerk, buurtnetwerken, een Jongeren Informatie Punt (Jip) en nog veel meer. In het algemeen ligt het accent in deze projecten op preventie. Deze preventieprojecten worden nadrukkelijk tot het integrale jeugdbeleid gerekend. Meestal is in ieder geval het jongerenwerk hierbij betrokken. Repressief beleid behoort tot de bevoegdheid van de burgemeester en valt buiten het jeugdbeleid. Het jeugd- en veiligheidsbeleid van de gemeente kenmerkt zich door een structurele aanpak en het maakt deel uit van het integrale veiligheidsbeleid van de gemeente.

\section{Zeer sterk stedelijk}

Het onderwerp veiligheid staat zeer centraal in de gemeente Utrecht, zowel in het gemeentebeleid als in het beleid van de uitvoerende instanties. Dit blijkt onder andere uit de verschillende nota's die de laatste jaren over dit onderwerp zijn verschenen. De coördinerende ambtenaar jeugd en veiligheid geeft aan dat de gemeente een regierol heeft op het gebied van veiligheid. Alle partners dile met veiligheid te maken hebben zijn om tafel gebracht en hebben gezamenlijk een beleidsplan opgesteld. Een belangrijk speerpunt in het programma 'jeugd en veiligheid' is het vroegtijdig, snel en consequent reageren op strafbare feiten. Daarbij word t veelal wijkgericht gewerkt. In elke wijk is er een wijkbureau en elke wijk maakt een eigen veiligheidsprogramma. Veel gebeurt in het kader van preventie. Er is bijvoorbeeld aandacht voor de verdere ontwikkeling van woorzieningen in de wijk, zodat minder jongeren instromen in het justitiële circuit. Ook moeten deze voorzieningen perspectieven bieden aan jongeren die al met politie en/of justitie in contact zijn geweest. In het kader van preventie is er ook aandacht voor voorzieningen voor opvoedingsondersteuning en voor- en naschoolse opvang. De aanpak van Marokkaanse probleemjongeren heeft daarbij prioriteit.

In Gromingen loopt een aantal projecten die overlap vertonen met andere thema's binnen het jeugdbeleid, waaronder scholing. Zo is er bijwoorbeeld het project Voortijdig Schoolverlaten/ bestrijding spijbelen. Daarnaast is er het Clip-programma, dat als doel heeft de veiligheid en de veiligheidsbeleving in en rondom de scholen van het voortgezet onderwijs te verbeteren. Door een samenhangend pakket van maatregelen en regels wordt door scholen samen met jeugdhulpverleningsinstellingen, onderwijsbegeleidingsdienst, GGD, Halt, politie en anderen gewerkt aan een pedagogisch klimaat waarin zowel leerlingen als leerkrachten zich veilig voelen. Er zijn ook projecten specifiek gericht op allochtone jongeren, bijvoorbeeld voor Antillianen en Arubanen. 


\section{Vervolg Box $4 \times 2$ Jeugd en veiligheid}

Sinds 1 april 1999 zijn er in Groningen vier Jeugd-en Jongerenteams (jir's) op wijk-niveau actief. Deze teams zoeken contact met jongeren die overlast veroorzaken. Samen zoeken zij vervolgens naar oplossingen. De Jj's proberen aansluiting te zoeken bij de vraag van de jongeren en bouwen een vertrouwensrelatie met hen op. Daamaast is er een Stedelijk Straathoekteam (SST) opgezet dat zich richt op stedelijke problematiek, waaronder drugshandel. Het jeugd-en veiligheidsbeleid maakt deel uit van het integrale veiligheidsbeleid van de gemeente.

In aanvulling op de informatie van de ambtelijke sleutelinformanten is onderzocht in hoeverre het thema 'jeugd en veiligheid' is opgenomen in lokalle beleidsdocumenten. Van de jeugdnota's die na 1998 zijn verschenen $(n=36)$ is in tien nota's $(28 \%)$ niets opgenomen over dit thema. Van de 26 gemeenten die wel aandacht besteden aan het jeugd- en veiligheidsbeleid, besteedt ruim $75 \%$ tamelijk veel aandacht aan dit onderwerp. Het beeld dat uit deze bevindingen ontstaat, is dat een meerderheid van de onderzochte gemeenten actief bezig is met een veiligheidsbeleid gericht op jeugd, maar dat er ook een aanzienlijke minderheid is die op dit moment weinig tot geen beleid voert.. Dit betreft overwegend minder stedelijke gemeenten.

In het kader van het VNG-project Lokaal jeugdbeleid is tussen het kabinet, het Interprovinciaal Overleg ( $\mathrm{YPO}$ ) en de VNG afgesproken dat gemeenten gestimuleerd worden actieplannen 'Jeugd en veiligheid' op te stellen, waarin de beleidslijn voor dit thema uitgewerkt wordt. Ook zou gestimuleerd moeten worden dat er zorgprogramma's worden ontwikkeld voor jongeren die met justitie in aanraking zijn gekomen (vNG I999: 27). Het blijkt dat bijna de helft een actieplan Jeugd en veiligheid of een soortgelijk programma heeft (zie tabel 4.6). Daarnaast werkt $40 \%$ van de gemeenten aan preventie via veilligeschoolprogramma's (zie hoofdstuk 12 ) en heeft ongeveer een kwart van de gemeenten zorgprogramma's voor jongeren die met justitie in aanraking komen. In beide gevallen zijn de meer stedelijke gemeenten oververtegenwoordigd.

\section{Tabel 4.6}

Aantal gemeenten met een jeugd en veiligheidsbeleid, $2001(n=60$; in procenten)

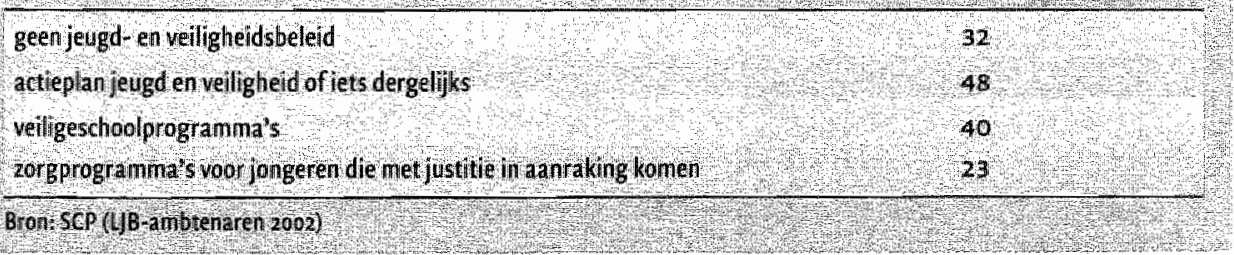

In de enquête onder ambtelijke sleutelfiguren is een aantal mogelijke speerpunten voorgellegd die verbonden zijn met het jeugd- en veiligheidsbeleid. Gevraagd is in 
hoeverre deze speerpunten van belang zijn in het jeugd- en veiligheidsbeleid in hun gemeente (tabel 4.7). De grote meerderheid van de gemeenten met een jeugd- en veiligheidsbeleid hecht sterk aan het tegengaan van de overlastproblematiek. Voor $86 \%$ van de gemeenten is dit van groot belang; geen enkele gemeente hecht hier geen belang aan. Daarnaast zijn het tegengaan van geweld op straat en het aanpakken van de 'harde kern' belangrijke thema's binnen het veiligheidsbeleid gericht op jeugd. Het verbeteren van de positie van allochtone en autochtone probleemjeugd speelt daarbij eveneens een rol. Het sterke accent op overlastbestrijding en het aanpakken van 'de harde kern' verklaart mogelijk ook waarom gemeenten die een jeugd-en veiligheidsbeleid hebben, zich concentreren op I2- tot I8-jarigen en op 18-plussers en relatief weinig aandacht hebben voor kinderen.

Minder prioriteit wordt gegeven aan maatregelen die verband houden met de verkeersveiligheid. Door het relatief geringe belang dat aan deze maatregelen wordt gehecht, ontstaat de indruk dat het jeugd- en veiligheidsbeleid in de onderzochte gemeenten voor een belangrijk deel doelgroepenbeleid is, dat beoogt overlast en jeugdcriminaliteit onder risicogroepen te voorkomen. Maatregelen die meer omvatten dan overlastbestrijding spelen een ondergeschikte rol. In het algemeen lijken gemeenten meer oog te hebben voor een curatieve dan wel repressieve benadering van het jeugd- en veiligheidsvraagstuk, dan voor een preventieve aanpak.

\section{Tubel 4.7}

Speerpunten van het jeugd- en veiligheidsbeleid in gemeenten, 2001 (in procenten)

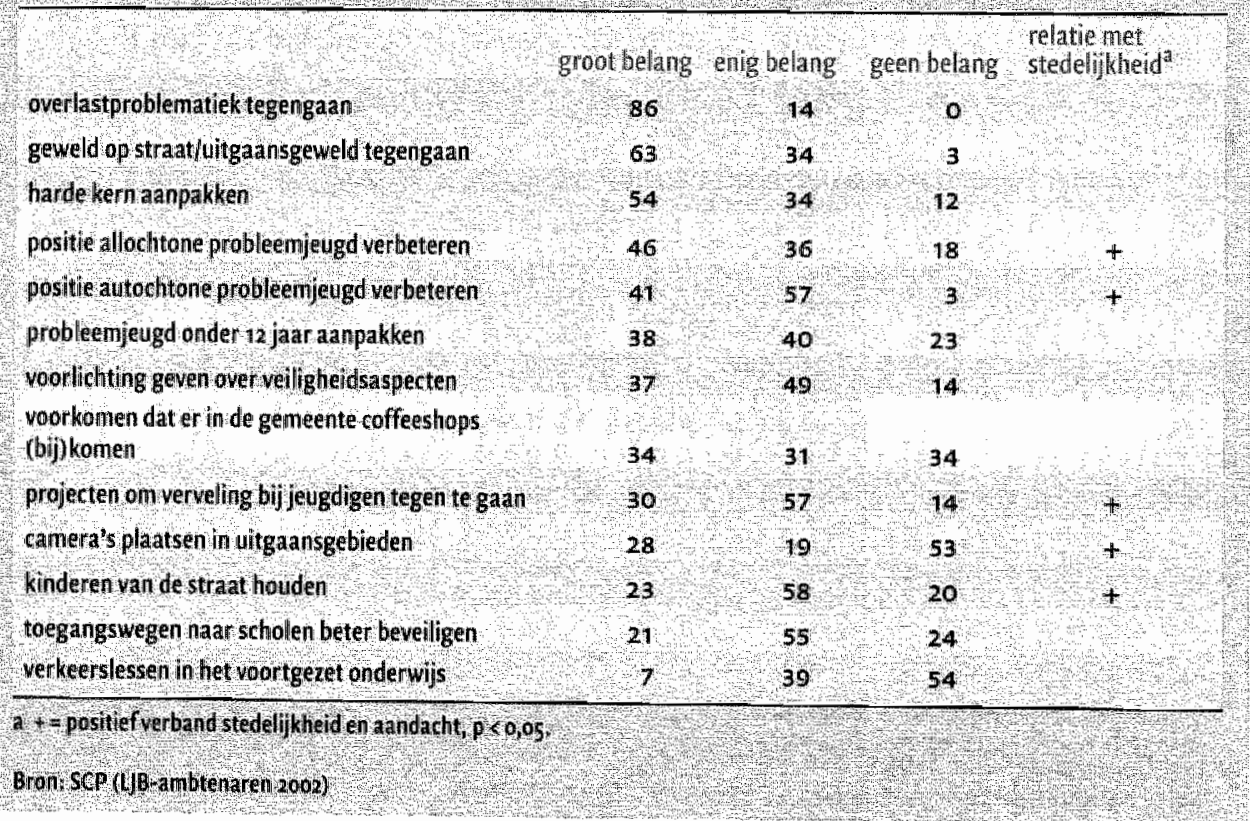

Tot slot laat tabel 4.7 zien dat voor een minderheid van de genoemde speerpunten een relatie met stedelijkheid wordt gevonden. Slechts vijf van de dertien doelstellingen of 
maatregelen komen vaker voor in meer stedelijke gemeenten. Hierbij past de kanttekening dat de gemeenten zonder jeugd- en veiligheidsbeleid, die overwegend matig tot niet-stedelijk zijn, niet in deze analyse zijn betrokken.

\subsubsection{Afstemming jeugdzorg en lokaal jeugdbeleid}

De afstemming tussen jeugdzorg en lokaal jeugdbeleid verloopt doorgaans niet zonder problemen (Gilsing 1999: 68). Dit hangt onder meer samen met de huidige verdeling van bestuurlijke verantwoordelijkheden, waarbij provincies (en de drie grote steden) verantwoordelijk zijn voor het beleid voor de Bureaus Jeugdzorg en de jeugdhulpverlening, terwijl gemeenten verantwoordelijk zijn voor algemene zorgvoorzieningen, zoals consultatiebureaus, (school)maatschappelijk werk en jeugdwerk. In het kader van het vroegtijdig signaleren van en ingrijpen bij problemen van de jeugd is het echter van belang dat zorgvoorzieningen hun activiteiten op elkaar afstemmen zodat bijtijds kan worden doorverwezen. Een goede afstemming tussen het provinciale beleid inzake jeugdzorg en het gemeentelijke jeugdbeleid is wenselijk. De afstemming tussen jeugdzorg en het gemeentelijke beleid is dan ook een element in de Wet op de jeugdzorg, die ten tijde van het onderzoek werd ontwikkeld en die per $r$ januari 2005 in werking is getreden.

\section{Tabel 4.8}

Mate van afstemming tussen provinciaal/grootstedelijk belieid over jeugdzorg en lokaal jeugdbeleid naar stedelijkheidsklasse, 2001 (in procenten)

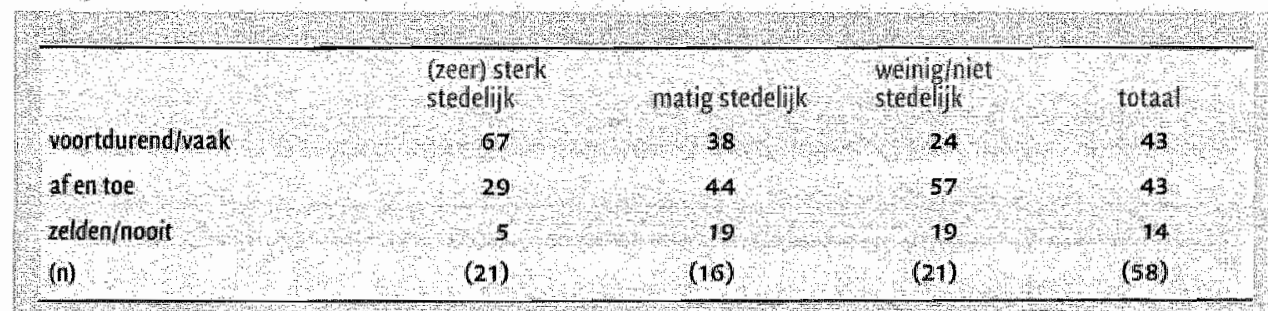

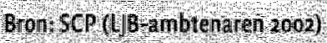

Een ruime meerderheid van de gemeenten $(86 \%)$ geeft aan te streven naar afstemming tussen het provinciaal/grootstedelijk beleid en het lokale jeugdbeleid, zo blijkt. uit de enquête onder ambtelijke sleutelfiguren. In $43 \%$ van de gemeenten vindt op dit moment vaak afstemming plaats; in eenzelfde percentage gebeurt dit af en toe (tabel 4.8). Dit beeld correspondeert met de indruk die ontstat uit de nota's jeugdbeleid die na 1998 in 36 onderzoeksgemeenten zijn verschenen. Bijna $70 \%$ van de nota's gaat in op het belang van afstemming, maar in nog niet de helft daarvan wordt concrete aandacht aan dit thema besteed. Op basis van deze gegevens ontstaat de indruk dat het onderwerp 'afstemming met de jeugdzorg' nog in ontwikkeling is. Veel gemeenten hechten belang aan dit onderwerp, maar een minderheid was er ten tijde van het onderzoek intensief mee bezig en heeft concrete plannen uitgewerkt in lokale nota's jeugdbeleid. 


\section{Box 4-3 Afstemming lokaal jeugdbeleid en jeugdzorg}

De afstemming tussen het lokale jeugdbeleid en de jeugdzorg is in niet alle gemeenten even ver ontwikkeld. Van belang daarbij is onder meer de mate waarin de ontwikkeling van de Bureaus Jeugdzorg ( $\mathrm{B} \| \mathrm{Z}$ ) is gevorderd. Daarmaast verschilt de rol van de Bureaus Jeugdzorg in het lokale jeugdbeleid per gemeente. Ook hier is er sprake van verschillen tussen de meer en minder stedelijke gemeenten.

\section{(Zeer) sterk stedelijke gemeenten}

De provincie Groningen heeft de regieroll in de jeugdzorg en is daarmee onder andere verantwoordelijk voor de ambulante jeugdhulpverlening. De gemeente Groningen neemt deel aan de Regiegroep Jeugdzorg. Op basis van een regiovisie formuleert de Regiegroep prioriteiten voor de afstemming tussen vraag en aanbod en stelt zij jaarlijkse actieprogramma's op. Ondanks het gevarieerde hulpaanbod constateert de gemeente dat jongeren met meerwoudige problematiek niet uit zichzelf naar de reguliere hulpverlening toestappen. Zij heeft de verantwoordelijkheid voor deze groep op zich genomen. De gemeentelijk georganiseerde jeugdhulpverlening (Giska) en het Stedelijk Straathoekteam (S5T) zoeken jongeren vooral op straat op of via signalen, vooral van politie en het onderwijs. Er wordt door verschillende instellingen samengewerkt en op lokaal niveau functioneert in dat verband het stedelijk Centraal Meldpunt Jeugdhulpverlening (CMP), een preventief netwerk dat gegevens verzameit en registreert van risicojongeren en (dreigende) probleemsituaties.

Aansluiting op het lokale jeugdbeleid van de gemeente Leiden wordt door het BJz lastig geacht. Noch de provincie, noch de gemeente stelt budget beschikbaar om deze aansluiting te realiseren. Er was eigenlijk alleen een provinciale startsubsidie. In de eerste jaren was het belangrijk om als ojz op veel plekken aanwezig te zijn, om bekend te raken bij instellingen. Nu is het een kwestie van 'de boter overal wat dunner smeren". Het BJz neemt deel aan veel overleggen. Die zijn geconcentreerd rond het onderwijs en rond het vroegtijdig signaleren van problemen bij jeugdigen. De deelname aan al deze overleggen is voor bjz zeer belastend, wat versterkt wordt door het gegeven dat bij het Byz $50 \%$ meer aanmeldingen zijn binnengekomen dan gepland. Door een gebrek aan gekwalificeerd personeel is het daardoor moeilijk voldoende tijd vrij te maken voor deelname aan alle overleggen.

Binnen de gemeente Spijkenisse is er een ambtenaar die zich specifiek bezighoudt met de jeugdhulpverlening. Zij verzorgt onder andere de contacten met de regionale partners in de jeugdzorg - waar ook de leerplichtambtenaar vaak bij betrokken is - en neemt deel aan het bestuurlijk stadsregionaal overleg. Belangrijk uitgangspunt voor het regionale $B J z$ is het versterken van de preventieve activiteiten, om zo de curatieve zorg te ontlasten. Erwordt meer samenwerking gezocht met hulpverleners, preventieve 


\section{Vervolg Box 4-3 Afstemming lokaal jeugdbeleid en jeugdzorg}

voorzieningen, opvoedingsondersteuning, onderwijs, arbeidswoorzieningen en intensieve gezinsbegeleiding. Dit komt onder meer tot uiting in de betrokkenheid van de jeugdzorg bij het schoolmaatschappelijk werk op een aantal scholen un het voortgezet onderwijs. Ook het aanpakken van voortijdig schoolverlaten is een gezamenlijke verantwoordelijkheid van jeugdzorg en onderwijsinstellingen. De respondent van het $\mathrm{Bjz}$ vindt dat er een goede samenwerking is tussen de jeugdzarg en Spijkenisse in vergelijking met sommige andere gemeenten. $\mathrm{Zij}$ geeft aan dat vooral met de zorgambtenaar veel contact is; de contacten met de ambtenaar jeugdbeleid zijn minder frequent. Maar ze heeft de indruk dat beide ambtenaren onderling veel overleggen.

Matig en weinig stedelijke gemeenten

In Appingedam is men tevreden over de samenwerking met Bjz in Delfzijl. Er is volgens de respondent van de jeugdhulpverlening geen onrust geweest over de terugtrekkende beweging van de jeugdhulpverlening in verband met de komst van het $B J \mathrm{z}$, want er waren eigenlijk geen goede lokale voorzieningen. Met de komst van het $\mathrm{B}\rfloor z$ verbeterde de situatie voor de gemeente. De problemen ontstonden pas later, toen duidelijk werd dat de ambulante hulp geïndiceerde zorg betrof, waarover de gemeente geen zeggenschap heeft. De afstemming van het jeugdbeleid op de jeugdzorg komt in de nota en de interviews verder niet aan bod, met uitzondering vam de jeugdhulpverlening. Deze maakt deel uit van de buurtnetwerken en heeft structureel contact met de leerplichtambtenaar, het algemeen maatschappelijk werk, het sociaal en cultureel werk, het onderwijs, politie en Openbaar Ministerie en de Wiw-organisatie. Het belang van het onderwijs neemt de laatste jaren snel toe. Regelmatig contact wordt erg op prijs gesteld en er is een groeiend bewustzijn bij de jeugdhulpverlening dat men zelf niet in staat is alle problemen het hoofd te bieden.

De afstemming tussen het lokale jeugdbeleid en de jeugdzorg vindt in Culemborg primair plaats in een regionaal platform jeugdbeleï. . Dit platform bestaat uit bestuurders van regiogemeenten en vertegenwoordigers van instellingen op het gebied van jeugdzorg. Het platform wordt ondersteund door een ambtelijke voorbereidingsgroep. Op het moment van interviewen is de ontwikkeling van het $\mathrm{Bjz}$ nog in volle gang en moet afstemming op het lokale preventieve beleid nog gestalte krijgen. Er is voor Culemborg weinig aanleiding om bij de komst van het BJz te spreken van een 'terugtrekken van de jeugdhulpverlening uit het lokale voorzieningenpakket', vindt de respondent van Byz, want voor jongeren onder de 12 jaar was er niets, en voor de 12-plusser maar heel weinig. Bovendien was het aanbod van hulpverlening geografisch sterk gespreild. 


\section{Vervolg Box 4.3 Afstemming lokaal jeugdbeleid en jeugdzorg}

Aan afstemming met de jeugdzorg wordt in de nota jeugdbeleid van de gemeente HeazeLeende geen aandacht besteed. De wethouder geeft aan dat de gemeente zeer beperkt diensten afneemt van de jeugdzorg. De gemeente zou volgens hem eerst de eigen positie in het jeugdbeleid duidelijker moeten maken, voordat zaken worden gedaan met het $B J Z$ in Eindhoven. Het BJZ staat volgens de respondenten van instellingen nog in de kinderschoenen. Men heeft inmiddels voor allerlei zaken protocollen, maar die zijn nog niet beproefd. De wachttijden zijn erg lang; ouders die professionele hulp zoeken moeten maanden wachten op een intakegesprek en daarna moeten ze weer wachten op het behandelplan.

In het kader van de afstemming tussen jeugdzorg en lokaal jeugdbeleid kunnen verschillende acties ondernomen worden. Op beleidsniveau kunnen visies worden opgesteld, waarin de verhouding tussen de jeugdzorg en het lokale jeugdbeleid wordt geregeld. Op voorzieningenniveau kunnen netwerken opgericht worden en/of kunnen ondersteunende activiteiten worden georganiseerd. Onderzocht is in hoeverre dergelijke activiteiten plaatsvinden in gemeenten. Ruim $40 \%$ van de onderzochte gemeenten heeft te maken met een regiovisie of een beleidskader jeugdzorg (geformuleerd in samenspraak met het Bureau Jeugdzorg), waarin de verhouding tussen de jeugdzorg en het lokale jeugdbeleid wordt geregeld. Eenderde van de gemeenten heeft wel te maken met een regiovisie, maar daarin is niets geregeld over de relatie met het lokale jeugdbeleid. De overige gemeenten zijn niet betrokken bij een regiovisie jeugdzorg of geven aan dat deze in voorbereiding is.

Als we kijken naar het voorzieningenniveau dan blijkt dat ongeveer driekwart van de gemeenten (buurt)netwerken jeugdhulpverlening heeft die gericht zijn op signalering en vroegtijdige onderkenning van problemen bij jeugdigen. Deze netwerken jeugdhulpverlening kunnen doorverwijzen naar de jeugdzorg. De jeugdzorg maakt bovendien vaak deel uit van deze netwerken (zie hoofdstuk 6). In een kwart van deze gemeenten opereert een dergelijk netwerk in alle buurten en in de overige $75 \%$ in één of meerdere buurten.

In verschillende gemeenten geeft het Bureau Jeugdzorg bowendien ondersteuning aan voor de jeugd relevante eerstelijnswoorzieningen, zoals het consultatiebureau of maatschappelijk werk. Deze ondersteuning kan bestaan uit afstemming, consultatie en deskundigheidsbevordering. Soms vinden er meerdere soorten ondersteuning plats. Tabel 4.g laat zien dat "afstemming" de ondersteuningsvorm is die het meeste plaatsvindt. Consultatie komt ook regelmatig voor, met name bij voorzieningen die te maken hebben met school (voortgezet onderwijs, primair onderwijs en schoolmaatschappelijk werk). De zorgstructuren voortgezet onderwijs, waarin de onderwijsinstelling samenwerkt met andere partijen zoals het (school)maatschappelijk 
werk om leerlingen met problemen adequate zorg te bieden, krijgen de meeste ondersteuning en de meest verschillende soorten ondersteuning door Bureau Jeugdzorg (zie ook hoofdstuk 6). Vergeleken met andere eerstelijnsvoorzieningen vindt hier ook veel deskundigheidsbevordering plaats.

Tabel 4.9

Vorm van ondersteuning door Bureau Jeugdzorg an eerstelijnswoorzieningen, $2001(n=60 \text {; in procenten })^{2}$

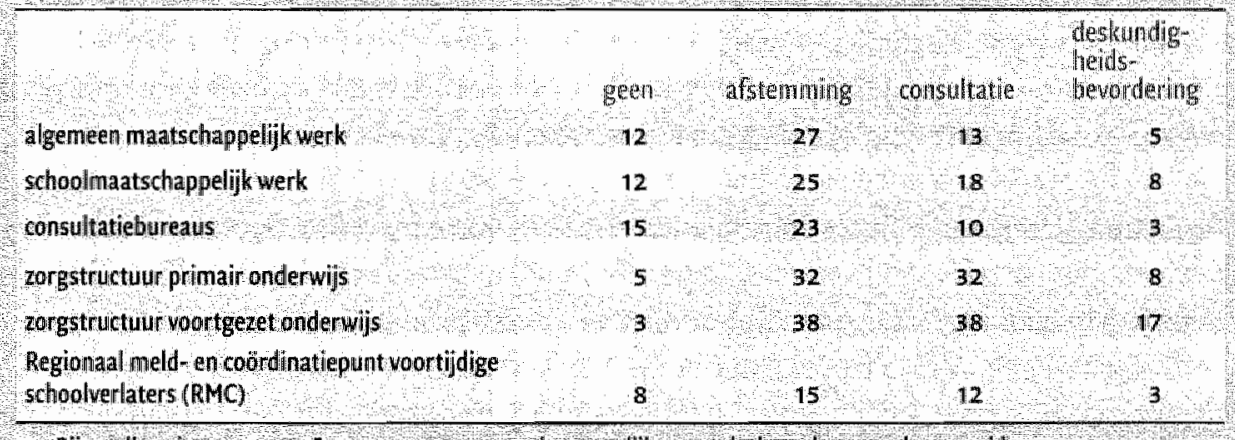

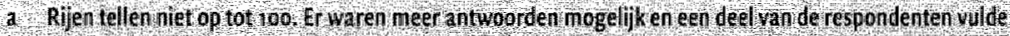
in weet niel:

Bron SCP (1) B ambtenaren zoa2)

Resumerend kan gesteld worden dat als het gaat om het voorzieningenniveau er het nodige in beweging is. Een duidelijke meerderheid van de bestudeerde gemeenten heeft een buurtnetwerk jeugdhulpverlening en diverse Bureaus Jeugdzorg bieden ondersteuningsactiviteiten aan verschillende voorzieningen. Kijken we echter naar het beleidsniveau en dan in het bijzonder naar de mate waarin visies zijn opgesteld waarin de verhouding tussen de jeugdzorg en het lokale jeugdbeleid wordt geregeld, dan moeten we concluderen dat hier nog het nodige te doen is. Ook al zegt $86 \%$ van de geïnterviewde ambtenaren jeugdbeleid dat zij het beleid over jeugdzorg en het jeugdbeleid soms of vaak afstemmen, in slechts $40 \%$ van de onderzochte gemeenten heeft dat tot nu toe geresulteerd in een visie waarin deze samenwerking wordt geregeld.

\subsubsection{Afstemming jeugd-en onderwijsbeleid}

De invoering van het gemeentelijk onderwijsachterstandenbeleid (GOA) eind jaren negentig, waarin werd bepaald dat de aanpak van achterstandsleerlingen voortaan voor een belangrijk deel voor rekening kwam van gemeenten (zie Turkenburg 1999 en 2003), is voor een aantal gemeenten aanleiding geweest een lokaal jeugdbeleid te formuleren. De school is een belangrijke spil in het lokale jeugdbeleid. Allereerst omdat het onderwijs van centraal belang is voor het behalen van een startkwalificatie voor de arbeidsmarkt. De zorg om en voor voortijdige schoolverlaters - schoolverlaters zonder deze kwalificatie - is dan ook groot. Bovendien is de afgelopen jaren veel ingezet op programma's voor jonge kinderen wan allochtone herkomst en uit lagere sociale milieus. Geprobeerd wordt de taal- en rekenachterstanden die deze 
kinderen aan het begin van de basisschool vaak hebben, terug te dringen door op de peuterspeelzaal en in de eerste jaren van het basisonderwijs specifieke programma's aan te bieden (Herweijer 2003).

Daarnaast wordt de school vaak gezien als belangrijke vindplaats van sociaal-emotionele problemen - de plaats waar dergelijke problemen worden gesignaleerd, geregistreerd en doorverwezen. In die zin is het onderwijs een belangrijke schakel in de totale voorzieningenstructuur voor jeugdigen. Om deze functie (beter) uit te kunnen oefenen zijn in de loop van de jaren negentig verschillende samenwerkingsverbanden ontstaan tussen scholen en woor- en buitenschoolse voorzieningen, waaronder peuterspeelzalen, vrijetijdsverenigingen, maatschappelijk werk, opvangvoorzieningen, politie, enzovoort. Er wordt in dit kader gesproken van 'brede scholen'.

Om het onderwijs deze functies te laten vervullen, wordt afstemming tussen schoolse en niet-schoolse voorzieningen nodig geacht en daarmee tussen het jeugdbeleid en het onderwijsbeleid. Om na te gaan in hoeverre er sprake is van afstemming en hoe deze wordt vormgegeven, is in deze paragraaf gekeken naar twee thema's: de samenwerking tussen het basisonderwijs en andere instellingen ('brede scholen') en het beleid omtrent woortijdig schoolverlaten. Aan de acties die op gemeentelijk niveau zijn ondernomen in het kader van het bestrijden van taal-en rekenachterstanden bij jonge kinderen wordt in paragraaf 4.3 .4 aandacht besteed.

\section{Box 4.4 Afstemming jeugd - en onderwijsbeleid}

In sommige gemeenten is er sprake van vergaande afstemming tussen het jeugdbeleid en het onderwijsbeleid, in andere gemeenten in veel mindere mate. Onderstaande schetsen illustreren beide situaties.

\section{Sterke afstemming jeugdbeleid en onderwijsbeleid}

Het gemeentelik onderwijsachterstandenbeleid (GOA) vorm het kader waarin het jeugdbeleid van de gemeente Appingedam gestalte krijgt. Uitgangspunt in het GOAbeleid is dat de school een instituut is dat zich in de eerste plaats moet richtem op het primaire proces van het onderwijs, de interactie tussen leerkracht en leerlingen. De wethouder geeft aan dat het onderwijs-en het jeugdbeleid een geheel vormen. In het op Overeenstemming Gericht Overleg $(0 a g 0)$ zitten bijwoorbeeld zowel scholen en andere onderwijsinstellingen als welzijnsinstelingen. Tussen de instellingen voor welzijn en het basisonderwijs zijn contacten en er lopen verschillende projecten, Er wordt nagegaan ofer behoefte is aan nauwere samenwerking in het kader van naschoolse opvang. Tussen welzijn en het voortgezet onderwijs is geen contact. Het onderwijs maakt deel uit van de buurtnetwerken. In het netwerk wordt op basis van een verkenning van de problematiek onderling afgesproken op wiens weg een bepaald probleem ligt. 


\section{Vervolg Box 4.4 Afstemming jeugd-en onderwijsbeleid}

Het onderwijsbeleid en het jeugdbeleid van Culemborg liggen sterk in elkaars verlengde en komen overeen in hun inhoudelijke accenten. Ook het veiligheidsbeleid sluit hierbij aan. In het onderwijsachterstandenbeleid is een aantal beleidsmaatregelen opgenomen die oorspronkelijk tot het jeugdbeleid behoorden. Belangrijke elementen van het GOA zijn de PeuterPlus-projecten, de invoering van een verlengde schooldag op drie achterstandsscholen, Onderwijs in Allochtone Levende Talen (OALT) in de worm van taalondersteuning, en trajecten voor leerlingen die dreigen uit te vallen respectievelijk voortijdig het onderwijs hebben verlaten. Ook organisatorisch is er een sterke relatie tussen jeugdbeleid en onderwijsbeleid. Zo heeft de wethouder onderwijs zitting in de regiekamer jeugdbeleid en is de coördinerende ambtenaar jeugdbeleid ook verantwoordelijk voor het onderwijsachterstandenbeleid. Het onderwijs participeert in de meeste netwerken rond het jeugdbeleid.

De aandacht van de wethoudervan Leiden gaat in sterke mate uit naar de jeugd die extra aandacht behoeft. Dat komt tot witing in ruime beleidsmatige aandacht voor onderwijs en vooral voor het onderwijsachterstandenbeleid. Het onderwijsachterstandenbelleid maakt deel uit van het integrale jeugdbeleid. Belangrijke aandachtspunten in dit thema zijn de bijzondere aandacht voor kinderen met een taal- of ontwikkelingsachterstand, het voorkomen en bestrijden van schooluitwal en het betrekken van ouders bij de ontwikkeling van hun kinderen en waar nodig het ondersteunen van de ouders. in het onderwijsachterstandenbeleid heeft de afdeling onderwiis van de Onderwijsbegeleidingsdienst (OBD) een prominente rol. Deze afdeling fungeert als makelaar: zijj sluit samenwerkingsovereenkomsten met uitwoerende instellingen. Een belangrijk element in het onderwijsbeleid is de totstandbrenging van brede scholen.

\section{Beperkte afstemming jeugdbeleid en onderwijsbeleid}

De gemeente Spijkenisse kent eigen onderwijsbeleidsplannen. Hierin komen het gemeentelijk onderwijsachterstandenbeleid - de gemeente is planplichtig - en het beleid aangaande de schoolbegeleiding aan de orde. Er is een coördinerende ambtenaar jeugdbeleid, die werkzaam is op de afdeling onderwijs en welzijn. Deze ambtenaar regelt de betrokkenheid van de verschillende gemeentelijke afdelingen op projectmatige wijze. De bestuurlijke aansturing van de ambtenaar berust bij de wethouder die daarnaast onder meer welzijn, onderwijs, en kunst en cultuur in zijn portefeuille heeft. De wethouder en de ambtenaar geven beiden aan dat er maar beperkte afstemming is tussen het jeugdbeleid en het onderwijsbeleid. Samenwerking is er wel, maar deze is beperkt tot het uitvoerende niveau. Op strategisch niveau is er weliswaar een functioneel overleg jeugd binnen de afdeling onderwijs en welzijn, maar dit speelt geen grote roll in het jeugdbelleid. 


\section{Vervolg Box $4 \times 4$ Afstemming Jeugd-en onderwijsbeleid}

Heeze-Leende kent geen nota die handelt over het onderwijsbeleid en het is niet duidelijk wat de visie van de gemeente op het onderwijsbeleid is en hoe uitvoering wordt gegeven aan het belleil, zo staat er in de nota jeugdbeleid geschreven. Wel wordt de wenselikheid van zo'n nota benadrukt. In de praktijk is er nog weinig afstemming met het onderwijsbeleid en het ond erwijs functioneert betrekkelijk autonoam. Aangezien er geen voortgezet onderwijs in de gemeente is, gaat het onderwijsbeleid vooral om de groep o-12-jarigen.

\section{Brede scholen}

Uit tabel 4. Io blijkt dat eenderde van de onderzochte gemeenten één of meer brede scholen heeft. Daarvan zijn er ongeveer evenveel gericht op achterstandsleerlingen als op alle soorten leerlingen. Dit aantal lijkt aan de lage kant, zeker als we deze cijfers vergelijken met de uitkomsten van de bredeschoolmonitor van Oberon (2002), waarin is vastgesteld dat in 2002268 van de 489 gemeenten die Nederland in dat jaar telde, één of meerdere brede scholen hadden. Uit dit onderzoek blijkt wel dat bijna de helft van de onderzochte gemeenten bezig is met de oprichting van een brede school. Het grootste deel daarvan concentreert zich op alle leerlingen. Bovendien heeft ruim $40 \%$ van de 47 gemeenten met (plannen voor) een brede school een platform of netwerk dat specifiek gericht is op de brede school. We kunnen dus concluderen dat voor de hier onderzochte gemeenten geldt dat brede scholen nog in een minderheid daarvan voorkomen, maar wel in opkomst zijn. Minder dan voorheen gaat het bij de ontwikkeling van brede scholen om scholen met veel achterstandsleerlingen.

\section{Tabel 4.10}

Aantal brede scholen en de doelgroep waarop zij zich richten, $2001 \quad(n=60$; in procenten)

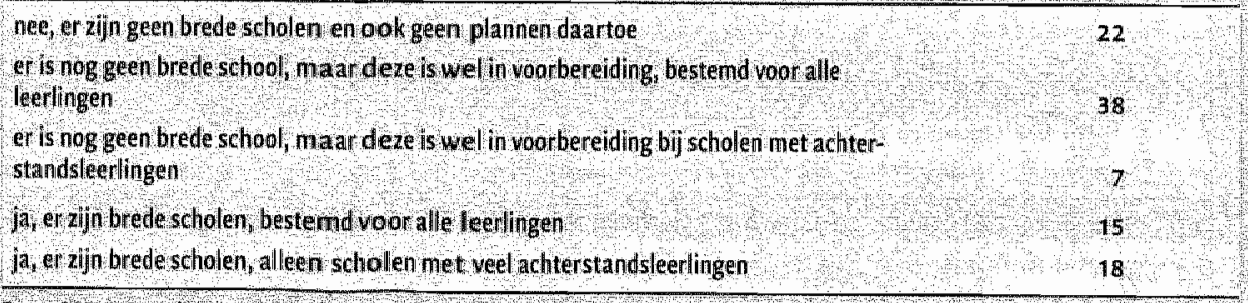




\section{Box 4.5 Brede scholen}

Dat achterstandsbestrijding één van de belangrijkste motieven is en was om een brede school op te zetten, wordt duidelijk als we kijken naar de gemeenten Leiden, Groningen en Utrecht. Daaruit komt eveneens naar voren dat opvang een steeds belangrijkere rol begint te spelen.

Een belangrijk element in het Leidse onderwijsbeleid is de totstandbrenging van brede scholen. Dit beleid bestaat uit drie sporen. In het eerste spoor worden in achterstandswijken brede scholen gecreëerd, waarin de aanpak van achterstanden een belangrijke plaats heeft. In het tweede spoor gaat het om nieuw te stichten scholen in nieuwbouwwijken. Hier is de brede school niet specifiek gericht op achterstand, maar is het wooral een brede voorziening. Het derde spoor van het bredescholenbeleid is de verlengde schooldag, waarbij op basisscholen naschoolse activiteiten worden aangeboden. Vanuit het onderwijs wordt aangegeven dat de gemeente weliswaar verantwoordelijk is voor het beleid, maar dat de wijze waarop dit gebeurt sterk wordt medebepaald doar het onderwijs zelf. De rol van de gemeente wordt zowel sturend als aanmoedigend genoemd.

Het onderwijsbeleid van de gemeente Graningen gaat ondanks de eigen financiering op in het jeugdbeleid, zo stelt de wethouder, die zowel integraal jeugdbeleid als onderwijs in zijn portefeuille heeft. De nota's onderwijsbeleid en jeugdbeleid lopen moeiteloos in elkaar over. Je kunt geen jeugdbeleid voeren zonder het onderwijs daarbij te betrekken. Het onderwijs is de enige plek waar je alle jeugdigen kunt bereiken, daar moet je gebruik van maken.'

De relatie tussen thet jeugdbeleid en het onderwijsbeleid krijgt vooral gestalte in de brede school (Vensterschool). Deze is in de stad Groningen gericht op onderwijs en opvoeding van kinderen van o tot 15 jaar en op hun ouders en behelst een intensieve samenwerking tussen onderwijs, welzijnsinstellingen, gezondheidszorg en instellingen gericht op kunst, cultuur en vrije tijd. Het gaat om een wijkgebonden woorziening. De brede school moet gezien worden als een algemene voorziening en wordt niet alleen gerealiseerd in bepalde achterstandsgebieden. Wel is de invulling van de brede school per wijk heel verschillend. In achterstand swijken zijn de voorzieningen gratis of bijna gratis, terwijl in bijvoorbeeld een wijk met overwegend tweeverdieners het aandeel van ouderbijdragen in de financiering veel groter is. De brede school herbergt, naast het reguliere basisonderwijs, in ieder geval peuterspeelzalen en kinder- en buitenschoolse opvang. Het is de bedoeling in 2005 met de brede scholen $75 \%$ van de basisschoolleerlingen en $50 \%$ van de 12 - tot 15 -jarigen te bereiken. In 2001 waren er megen Vensterscholen in Groningen. 


\section{Vervolg Box 4.5 Brede scholen}

Utrecht kent de zogenoemde Forumscholen. Deze zijn gericht op alle jeugdigen. De drie uitgangspunten van de Forumschool zijn: veiligheid, kwaliteit en openheid. Het streven is om in 2007 in elk wan de regen Utrechtse wijken een Forumlocatie te hebben. De vertegenwoordigers van uitwoerende instellingen vinden dat het Forumproject een voorbeeld is van een duidelijke toenadering tussen welzijn en onderwijs. Tegelijkertijd geven ze aan dat de geldstromen voor onderwijs en jeugdbeleid (bv welzijn) nog gescheiden verlopen. Het feit dat de gemeente niet één gesprekspartner is, maar meerdere, vinden instellingen wel eens lastig. De wethouder geeft aan dat Forumscholen goed zouden zijn voor elke wijk en niet alleen voor de achterstandswijken. In verschillende wijken kun je wel een andere invalshoek tegenkomen op de invulling van de Forumschool.

Welke doelstellingen zijn volgens gemeenten van belang (geweest) bij de totstandkoming van deze scholen? Voor $80 \%$ van de gemeenten staat het vergroten van de sociale competentie van kinderen centraal bij de oprichting van een brede school (tabel 4.Ir). Geen enkele gemeente vindt dit argument van geen belang. Daarnaast wordt veel waarde gehecht aan achterstandsbestrijding $(77 \%)$, vergroting van de participatie van kinderen in de samenleving $(70 \%)$, gevolgd door het zo snel mogelijk kunnen bieden van de nodige zorg aan kinderen $(65 \%)$. Deze doelstellingen hebben primair te maken met het bevorderen van de ontwikkeling van kinderen, in het bijzonder de ontwikkeling van achterstandsleerlingen. De overige doelstellingen, die deels te maken hebben met overwegingen van opvang en dagindeling, spelen in beduidend minder gemeenten een rol.

Tabel 4.11

Doelstellingen bij de totstandkoming wan brede schollen, 2001 (in procenten)

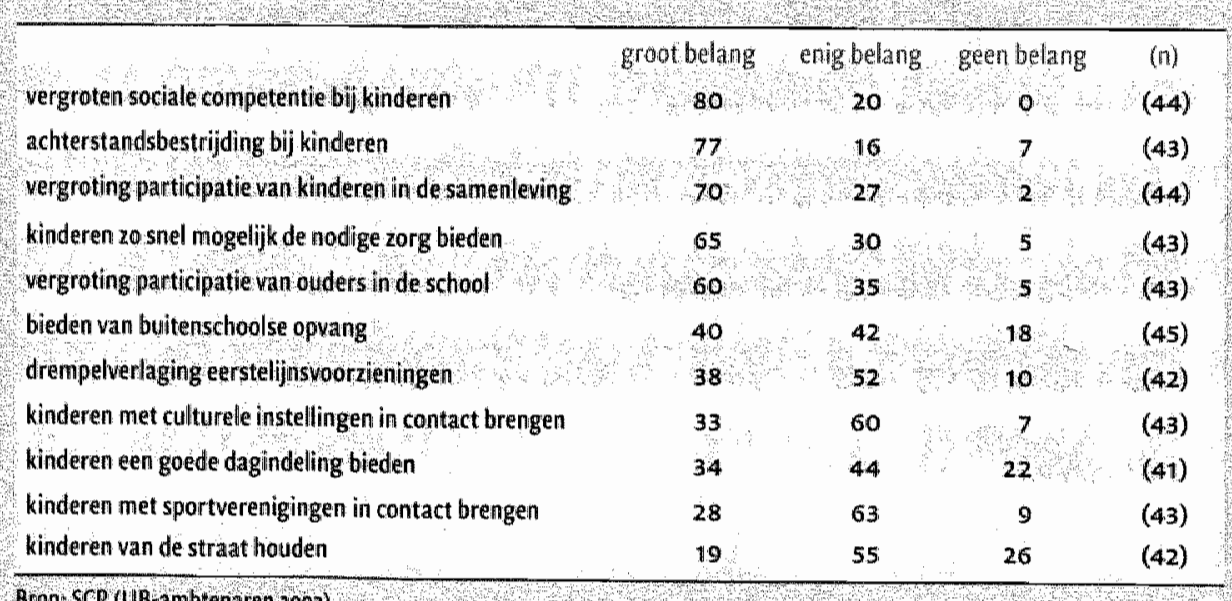

Bron SCP (LB ambtenaren 20oa) 
Voortijdig schoolverlaten (usv)

De aanpak van het voortijdig schoolverlaten is een van de speerpunten in het nationale jeugdbeleid, zoals in hoofdstuk 12 zal blijken. Het is ook het door gemeenten op een na meest genoemde speerpunt in het jeugdbeleid (zie tabel 4.4).

Aan de ambtelijke sleutelinformanten is gevraagd of de gemeente beleid geformuleerd heeft om het woortijdig schoolverlaten tegen te gaan. Meer dan een kwart van de gemeenten heeft geen eigen beleid en geeft aan dat het beleid omtrent voortijdig schoolverlaten helemaal is ondergebracht bij het Regionaal Meld- en Coördinatiepunt voortijdige schoolverlaters ( $R M C$ ). Dit is een regionaal samenwerkingsverband tussen overheden, scholen en instellingen werkzaam op het terrein van arbeidsvoorziening, onderwijs, justitie, jeugdhulpverlening en welzijn. Het doel van deze samenwerking is jongeren te behoeden voor het voortijdig stoppen met school en hen te stimuleren een startkwalificatie te behalen. Scholen zijn verplicht voortijdige schoolverlaters tot 23 jaar bij het RMC aan te melden. Bijna driekwart van de gemeenten heeft wel een eigen vsv-beleid; de overgrote meerderheid voert dit beleid in samenwerking met het RMC en een kleine minderheid heeft een geheel zelfstandig beleid, los van het RMC.

Gemeenten hebben in het kader van vsv verschillende taken. Preventieve taken zijn onder andere leerplichthandhaving, het verzorgen van een goede registratie en samenwerking met scholen. Ook is intergemeentelijke samenwerking van belang ter versterking van een sluitende aanpak van (potentiële) voortijdige schoolverlaters (VNG 1999: 35). In tabel 4.12 wordt weergegeven hoeveel belang gemeenten hechten aan deze en aanverwante doelstellingen en maatregelen.

\section{Tabel 4.12}

Speerpunten in het vsv-beleid, 2001 (in procenten)

\begin{tabular}{|c|c|c|c|c|}
\hline & Groot belang: & enig belang: & geen belang: & (ii) \\
\hline versterking leerplichthandhaving & 86 & 14 & 0 & (43) \\
\hline versterking zorgsystemen voortgezet onderwijs & 66 & 32 & 2 & (41) \\
\hline versterking RMC-functie & 62 & 33 & 5 & (42) \\
\hline $\begin{array}{l}\text { bevorderen doorllopende leerwegen umbo en ROCs op } \\
\text { beroepswoorbereidende trajecten }\end{array}$ & 59 & 33 & 8 & (39) \\
\hline $\begin{array}{l}\text { negeling meldingsplicht niet-leerplichitige voortijdige } \\
\text { schoolverlaters }\end{array}$ & 57 & 33 & & (42) \\
\hline instellen individuele trajectbegeleiding & 53 & 25 & 23 & (40) \\
\hline mauwere samenwerking met justitie & 32 & 54 & 15 & (41) \\
\hline $\begin{array}{l}\text { nauwere samenwerking met Centrum voor werk en inko- } \\
\text { men/Regionaal bureau voor de arbeidsvoorziening }\end{array}$ & 35 & 43 & 22 & (37) \\
\hline $\begin{array}{l}\text { aanscherping instroombeleid yoortgezet onderwi)s } \\
\text { (selectie) }\end{array}$ & 18 & 42 & 39 & $(38)$ \\
\hline
\end{tabular}

Bron SCP $(16 \mathrm{~B}, \mathrm{mbtenaren} 2002)$ 
De meeste gemeenten hechten veel belang aan de versterking van de leerplichthandhaving in het kader van het vsv-beleid. Er is niet één gemeente die dit niet belangrijk vindt. Daarnaast speelt de versterking van zorgsystemen in het voortgezet onderwijs en de versterking van de R MC-functie een grote rol.

\subsubsection{Sluitende aanpak o-tot 6-jarigen}

Met het inzicht dat achterstanden dikwijls hun oorsprong hebben in de vroege, voorschoolse ontwikkeling en het idee dat een vroege signalering en preventie van problemen uitval op latere leeftijd kunnen voorkomen, is vanaf eind jaren negentig van de vorige eeuw de aandacht gegroeid voor voorzieningen voor jonge kinderen (zie hoofdstuk 12). Het streven is om consultatiebureaus, peuterspeelzalen en kinderopvangvoorzieningen te versterken. Niet alleen door capaciteitsuitbreiding, maar ook door deskundigheidsbevordering van beroepskrachten en het vergroten van de bereikbaarheid van deze voorzieningen voor achterstandsgroepen. Veel aandacht gaat daarbij uit naar extra hulp en ondersteuning in het gezin en via de school, in het bijzonder naar opvoedingsondersteuning en ontwikkelingsstimulering ( $O \& O)$, voor-en vroegschoolse educatie (vve) en vroegtijdige signalering. $O \& O$ is gericht op het versterken van de opvoedingscompetenties van ouders en verzorgers en op het bevorderen van de ontwikkeling van de kinderen via spel. Het vve-beleid is gericht op kansenbevordering van peuters en kleuters uit risicogroepen om deel te kunnen nemen aan het onderwijs en op de langere termijn aan de samenleving. De vroegtijdige signalering is gericht op de onderkenning van problemen bij het kind of in de opvoeding die de ontwikkeling van het kind kunnen bedreigen, en op een snelle, adequate aanpak van deze problemen. Bij het vve- en o\&o-beleid en het beleid gericht op vroegtijdige signalering zijn verschillende sectoren betrokken, waaronder welzijn, onderwijs, jeugdgezondheidszorg en jeugdzorg.

\section{Box 4.6 Beleid gericht op o-6-jarigen}

Het beleid gericht op een sluitende aanpak van o- tot 6 -jarige kinderen krijgt vaak (gedeeltelijk) vorm via het onderwijsachterstandenbeleid, zo blijkt uit onderstaande portretten.

Er zijn in Appingedam zowel professionele peuterspeelzalen als peuterspeelzalen die werken met vrijwilligers. Bowendien participeert Appinged am in de Stichting Kinderopvang Noord-Groningen, Er wordt gewerkt met de projecten Opstapje en Opstap. Deze programma's zijn aanvankelijk opgezet voor allochtone kinderen en ouders, maar momenteel nemen er ook kinderen van een aantal autochtone gezinnen aan deel De thuiszorg berelkt via Ouder-Kindzorg bijna de gehele gnoep pasgeborenen en peuters. Deze instelling geeft ook opvoedingsondersteuning, onder andere in de vorm van de cursus Opvoeden zó!. Binnen de kinderopvang wordt aangegeven dat er wordt samengewerkt met peuterspeelzallen en het onderwijs, voornamelijk met betrekking tot individuele casuístiek. 


\section{Vervolg Box 4.6 Beleid gericht op 0-6-jarigen}

De gemeente Culemborg will, in het kader van het gemeentelijk onderwijsachterstandenbeleid, een toename van het aantal kinderen uit risicogroepen dat deelneemt aan voor- en vroegschoolse voorzieningen. Er is een aantal projecten, zoals Peuterplusprojecten, waarin wordt beoogd de drempel voor deelname aan het peuterspeelzaalwerk te verlagen. Verder wordt geprobeerd de kwaliteit van het peuterspeelzaalwerk te versterken door professionalisering en het aangaan van structurele contacten met basisonderwijs, consultatiebureaus en openbare bibliotheek. In het kader van thet o-6-jarigenbeleid worden ook opvoedcursussen aangeboden. Deze projecten zijn vooral gericht op Marokkaanse ouders.. Daarnaast zijn er projecten voor woonwagenbewoners en Molukkers. Hierbij wordt samengewerkt met provinciale steunfunctie-instellingen en landelijke zelforganisaties.

Het Leildse beleid gericht op de voor- en vroegschoolse periode maakt grotendeels deel uit van het onderwijsachterstandenbeleid. Er zijn projecten taalstimulering bij allochtone peuters, waarbij als toelatingseis deelname aan een Opstapje-project wordt gesteld om de betrokkenheid van ouders te garanderen. Voorts kennen andere peuterspeelzalen zogenaamde plusfuncties, waarbij extra aandacht wordt geschonken aan logopedie of sociaal-emotionele ontwikkeling. Ouders kunnen beslissen of de dossiers van de peuterspeelzalen worden doorgegeven aan het basisonderwijs en er wordt gewerkt aan een soortgelijk instrument voor de overdracht van gegevens van de kinderopvang naar het basisonderwijs. Ten slotte is er nog opvoedingsondersteuning, bijvoorbeeld in de vorm van opvoed bureaus, opvoedcursuissen (onder andere ouderpubercursussen) en Home-start.

Het beleid gericht op o- tot 6-jarige kinderen maakt in Spijkenisse deel uit van het bredere onderwijsachterstandenbeleid. Een belangrijk element van dit beleid is het aanbieden van projecten gericht op taalontwikkeling, zoals Opstapje en Opstap. Er is een discussie of het peuterwerk primair gericht moet zijn op de aanpak van ontwikkelingsachterstanden bij kinderen vit risicogezinnen of primair een algemene voorziening is die kinderen voorbereidt op het onderwijs. Tot op heden word thet peuterwerk vooral gezien als algemene voorziening, maar de wethouder wil met het peuterwerk nauwere afstemming realiseren met de Stap-projecten, wat een ommezwai naar een meer risicogerichte benadering zou betekenen. Een laatste element van het $0-6$-jarigenbeleid is de afstemming tussen peuterspeelzalen en basisonderwijs. Er zijn convenants tussen de betrokken partijen afgesloten om gegevens over te dragen indien bij kinderen bepaalde ontwikkelingsachterstanden zijn gesignaleerd. Bovendien wordt ernaar gestreefd de curricula van peuterwerk en onderwijs beter op elkaar af te stemmen. 
Ruim $80 \%$ van de onderzoeksgemeenten zegt desgevraagd een beleid gericht op a- tot 6-jarigen te hebben. De helft van deze gemeenten beschikt bovendien over een platform of netwerk dat specifiek gericht is op het o- tot 6 -jarigenbeleid. Bijna $70 \%$ van de 48 gemeenten met een o- tot 6-jarigenbeleid richt zich op alle 0 - tot 6 -jarigen in de gemeente en ruim $30 \%$ richt zich alleen op de risicokinderen in deze leeftijdsgroep. Het 0 - tot 6 -jarigenbeleid is in de praktijk dus niet uitsluitend doelgroepenbeleid.

Welke maatregelen nemen gemeenten om het algemene voorzieningenaanbod voor jonge kinderen te versterken en in hoeverre hebben zij projecten voor achterstandskinderen? De uitbreiding van de kinderopvang is de absolute nummer één (zie tabel 4.13). Het betreft hier een vrij algemeen doel, dat niet alleen de ontwikkeling van o- tot 6-jarigen behelst, maar vooral ook het faciliteren van de combinatie van arbeid en zorg. Het tweede en derde speerpunt - de vroegtijdige opsporing en signalering van problemen en de professionalisering van peuterspeelzalen - krijgen eveneens de nodige aandacht. Meer dan $60 \%$ van de onderzochte gemeenten besteedt hier aandacht aan.

Beduidend minder aandacht is er voor het onderbrengen van peuterspeelzalen in basisscholen. Ook de uitbreiding van het aantal peuterspeelzalen blijkt in veel gemeenten geen speerpunt te zijn. Niet zozeer de fysieke samensmelting van schoolse en voorschoolse voorzieningen en de uitbreiding daarvan, maar de professionalisering van voorschoolse voorzieningen in het kader van de vroegsignalering staat hoog op het prioriteitenlijstje van gemeenten.

\section{Tabel 4.13}

Beleidsaandacht voor 0-6-jarigen, 2001 (in procenten)

\begin{tabular}{|c|c|c|c|c|}
\hline & veel aandach: & enge andacht & geen andachit & (in) \\
\hline uitbreiding kinderopwang & 79 & 21 & 0 & (48) \\
\hline professionalisering peuterspeelzalen. & 64 & 33 & 2 & (45) \\
\hline $\begin{array}{l}\text { vroegtijdige opsporing, signalering van } \\
\text { problenien }\end{array}$ & 62 & 36 & 2 & (47) \\
\hline $\begin{array}{l}\text { verbetering voorschool se educatie, bv } \\
\text { voorschool }\end{array}$ & 60 & & & \\
\hline sluitende aanpako-6-jarigen. & 57 & 41 & 2 & (46) \\
\hline toename bereik bij doe Igroepkinderen & 56 & 36 & 9 & (45) \\
\hline opvoedingsondesteuning & 53 & 43 & 4 & (47) \\
\hline $\begin{array}{l}\text { betere dessieroverdracht peuterspeelzalenibasis- } \\
\text { onderwijs }\end{array}$ & 50 & 41 & 9 & (44) \\
\hline $\begin{array}{l}\text { methodische afstemming peuterspeelzalen ibasis } \\
\text { onderwijs }\end{array}$ & & 47 & 14 & \\
\hline betrokkentieid ouders uit doelgroep vergroten & 35 & 54 & 11 & (46) \\
\hline uitbreiding aantal peuterspelzaien & 24 & 42 & 33 & (45) \\
\hline $\begin{array}{l}\text { peuterspeelzalen onderbrengen in } \\
\text { basisscholen }\end{array}$ & 23 & 35 & 42 & (43) \\
\hline
\end{tabular}


Accenten in het jeugdbeleid

Geconstateerd werd dat bijna $60 \%$ van de onderzochte gemeenten haar jeugdbeleid als algemeen preventief typeert, wat wil zeggen dat het beleid zich richt op alle jeugd. lets meer dan de helft van de gemeenten beschouwt haar jeugdbeleid (tevens) als gericht preventief met als doel het voortijdig voorkomen van problemen onder risicogroepen jeugd. Curatief beleid voor jongeren met meervoudige problemen komt minder frequent voor. Er ligt, met andere woorden, een sterk accent op algemeen preventief en gericht preventief jeugdbeleid. Opvallend is echter wel dat er geen verband is tussen deze twee beleidstypen. Zij staan los van elkaar. Het lokale jeugdbeleid wordt, kortom, gekenmerkt door twee beleidssporen: één gericht op alle jeugd en één op risicogroepen.

Er worden weinig verschillen gevonden tussen stedelijke en minder stedelijke gemeenten als het gaat om algemeen preventieve maatregelen. De versterking van het algemene voorzieningenaanbod wordt in alle typen gemeenten van belang geacht. Wel zijn er duidelijke verschillen tussen de stedelijkheidstypen als het gaat om gericht preventieve en curatieve maatregelen. Stedelijke gemeenten voeren in het algemeen vaker beleid dat betrekking heeft op risicogroepen dan minder stedelijke gebieden.

Het blijkt dat bij het lokale jeugdbeleid in de meeste gemeenten - al dan niet expliciet - een leeftijdsgrens van 18 jaar wordt aangehouden. In vergelijking met het vorige onderzoek is met name de belangstelling voor 4-Ir-jarigen toegenomen. Er blijkt geen verband te zijn tussen kinder- en tienerbeleid. Gemeenten die veel aandacht hebben voor I2-minners richten zich niet noodzakelijkerwijs op 12-plussers en andersom. Ook deze beleidstypen staan los van elkaar, wat onder meer betekent dat er lang niet altijd een doorgaande beleidslijn is van de basisschool naar het voortgezet onderwijs.

De grote aandacht voor kinderen en tieners onder de 18 jaar kan niet los worden gezien van de inhoudelijke prioriteiten die worden gelegd in het jeugdbeleid van de onderzochte gemeenten. Bij kinderen gaat veel belangstelling uit naar opvang, opvoeding en thuissituatie. Vergeleken met 1998 staan deze thema's nu vaker op de beleidsagenda. Bij tieners richt de aandacht zich vooral op de vrijetijdsbesteding en op veiligheid. Voor beide leeftijdsgroepen geldt bovendien dat een grote nadruk wordt gelegd op het belang van onderwijs. De belangstelling voor thema's die vooral jongeren van I8 jaar en ouder aangaan, is beduidend geringer. Met name jongerenhuisvesting, maar ook arbeid en inkomen krijgen naar verhouding weinig aandacht.

Op basis van deze schets van de accenten in het jeugdbeleid kan de vraag of er sprake is van maatwerk in het lokale jeugdbeleid zeker niet zonder meer negatief beantwoord worden. Gemeenten waar de groep kwetsbare jeugd ook in relatief opzicht groot is, hebben doorgaans meer aandacht voor risico's en problemen bij jeugdigen in hun 
beleid. Het beleid van de meer stedelijke gemeenten kenmerkt zich doorgaans door een meer probleemgerichte benadering dan het beleid van minder stedelijke gemeenten. Daa rentegen blijkt ook dat er een grote gemeenschappelijke noemer is in de door gemeenten genoemde speerpunten. Deze staan vaak ook hoog op de agenda van de nationale overheid. Op de relatie tussen nationaal en lokaal beleid zullen we in de hoofdstukken $x_{2}$ en 13 terugkomen.

\section{Sperifieke beleidsthema's}

\section{Jeugd en veiligheid}

Een meerderheid van de onderzochte gemeenten voert een jeugd- en veiligheidsbeleid. Een aanzienlijke minderheid heeft geen beleid op dit terrein geformuleerd. De prioriteiten waar het meeste belang aan wordt gehecht in het kader van dit beleid zijn het regengaan van de overlastproblematiek en van het geweld op straat. Deze prioriteiten zijn duidelijk gericht preventief van aard. Aan algemene veiligheidsmaatregelen die betrekking hebben op alle jongeren, en bijwoorbeeld gericht zijn op de verkeersveiligheid, wordt doorgaans minder belang gehecht.

\section{Afstemming jeugdzorg en lokaal jeugdbeleid}

Een grote meerderheid van de bestudeerde gemeenten stemt haar lokale jeugdbeleid af op het provinciale beleid over jeugdzorg. Meer dan $40 \%$ van de onderzochte gemeenten doet dit vaak, een even groot aantal af en toe. Het afstemmen van de jeugdzorg en het lokale jeugdbeleid staat al langer op de lokale beleidsagenda, zo blijkt uit het onderzoek uit 1999 (Gilsing 1999). Een vergelijking tussen de resultaten van toen en mu laat zien dat er in 200 duidelijk meer afstemming plaatsvindt dan in 1998 . Toch heeft op dit moment maar $40 \%$ van deze gemeenten te maken met een regiovisie waarin de verhouding tussen het provinciale beleid omtrent jeugdzorg en het gemeentelijke jeugdbeleid is geregeld. Als we daarentegen kijken naar het voorzieningenniveau dan blijkt dat ongeveer driekwart van de gemeenten een (buurt)netwerk jeugdhulpverlening heeft. Bovendien bieden Bureaus Jeugdzorg de nodige ondersteunende activiteiten aan voorzieningen als consultatiebureaus en het onderwijs. De indruk ontstaat dat er op voorzieningenniveau veel gebeurt, maar dat op beleidsniveau de afstemming tussen jeugdzorg en lokaal jeugdbeleid in veel gemeenten beter kan.

\section{Afstemming jeugdbeleid en onderwijsbeleid}

Bij het onderwerp 'afstemming jeugdbeleid en onderwijsbeleid' is aandacht besteed aan twee thema's: de brede school en voortijdig schoolverlaten (vsv). Eenderde van de onderzochte gemeenten heeft op het moment van onderzoek één of meer operationele brede scholen en bijna de helft van de bestudeerde gemeenten is bezig met de oprichting daarvan. De doelstelling van waaruit deze gemeenten vertrekken bij de oprichting van de brede school is in de eerste plaats de ontwikkeling van kinderen. Het gaat om het vergroten van hun sociale competentie en om het bestrijden van 
achterstanden. Deze prioriteiten sluiten aan bij de visie van de vNG op de brede school (plek waar voorzieningen samenkomen met het oog op de bevordering van de ontwikkeling van kinderenj. Niettemin zeggen de meeste gemeenten die brede scholen aan het ontwikkelen zijn dat dit niet alleen scholen met veel achterstandsleerlingen betreft.

Met betrekking tot het voortijdig schoolverlaten geeft meer dan een kwart van de gemeenten aan dat zij geen eigen beleid heeft en dat het vsv-beleid geheel is ondergebracht bij het RMC. Bijna driekwart heeft een usv-beleid, waarvan $65 \%$ in samenwerking met het RMC en minder dan $10 \%$ los van het RMC. De prioriteit waar het meeste belang aan wordt gehecht in het kader van het vsv-beleid is de versterking van de leerplichthandhaving, versterking van zorgsystemen en de versterking van de $\mathrm{RMC}$-functie (sluitende aanpak van uitvallers). Deze accenten corresponderen eveneens grotendeels met de prioriteiten die worden gelegd in het VNG-project Lokaal jeugdbeleid.

Sluitende aanpak o- tot 6-jarigen

De meeste onderzochte gemeenten hebben een o- tot 6-jarigenbeleid. Het grootste deel van de gemeenten met een o- tot 6-jarigenbeleid richt zich op alle o- tot 6-jarigen $(70 \%)$ en de overige $30 \%$ richt zich alleen op o- tot 6 -jarige risicokinderen. In het kader van het 0 - tot 6 -jarigenbeleid wordt veel aandacht gegeven aan de uitbreiding van de kinderopvang, de professionalisering van het peuterspeelzaalwerk, het verbeteren van vve en de vroegtijdige opsporing van problemen en achterstanden. Deze prioriteiten sluiten aan bij de knelpunten die in het Bestuursakkoord Nieuwe Stijl (BANS) worden gesignaleerd.

Als we de thema's in ogenschouw nemen, dan kunnen we zeggen dat de vier thema's door het VNG-project Lokaal jeugdbeleid met succes op de agenda van het lokale jeugdbeleid zijn geplaatst. Ook hier komen we nog op terug in hoofdstuk 12. 
I Meer recent wordt in het jeugdbeleid gesproken van algemeen preventief, curatief en repressief jeugdbeleid; zie bijwoorbeeld Operatie Jong (2003). Deze indeling komt inhoudelijk in grote lijnen overeen met de indeling die in dit onderzoek wordt gehanteerd.

2 Het initiatief ontstaat in Groningen en in Rotterdam. Inmiddels zijn er diverse projecten opgezet en zijn er diverse namen voor dit type school in omloop. Brede school is daar eén van. Andere namen zijn vensterschool, community school, wijkschool, bredesamenlevingsschool, magneetschool, plusschool (voor een overzicht, zie Dawson en Zunderdorp 2002).

3 Daarbij dient gerealiseerd te worden dat de omvang van de jeugdwerkloosheid ten tijde van de dataverzameling aanzienlijk geringer was dan bij het verschijnen van deze studie. 


\section{$5 \quad$ Het betrekken van de jeugd bij lokaal jeugdbeleid}

\subsection{Inleiding}

Het decentrale karakter van grote delen van het jeugdbeleid is mede ingegeven door de gedachte dat het voor lokale overheden eenvoudiger is om de jeugd bij de vormgeving en uitvoering van het jeugdbeleid te betrekken. De jeugd is immers niet alleen object van het jeugdbeleid, maar ook een belangrijke belanghebbende partij. Om het beleid zo goed mogelijk af te stemmen op de jeugd is het van belang dat er overleg met jongeren plaatsvindt. Dit standpunt werd ook door de verschillende overheden vastgelegd in het Bestuursakkoord Nieuwe Stijl (BANS) van rg99. Jongeren moeten niet alleen de mogelijkheid krijgen om mee te doen, maar ook om mee te praten en mee te beslissen over zaken die hen aangaan en die voor hen van belang zijn, zo verklaarden het rijk, provincies en gemeenten in dit akkoord. Eén van de criteria die richtinggevend zijn voor het jeugdbeleid van landelijke en lokale overheden is dan ook: 'samen met de jeugd'.

De vragen die in dit hoofdstuk centraal staan, zijn dan ook direct gerelateerd aan het nabijheidsargument. Hoe gaan gemeenten om metjeugdparticipatie in het kader van het lokale jeugdbeleid? Trachten zij actief de jeugd te betrekken, en zo ja, op welke wijze? Deze vragen worden onderzocht met behulp van documentanalyse en de enquête onder de gemeentelijke ambtenaren. In paragraaf 5.2 wordt ingegaan op de beleidsmatige aandacht die er is voor participatie. Vervolgens wordt gekeken op welke thema's en leeftijdsgroepen het participatiebeleid zich richt $(\$ 5.3)$ en welke instrumenten worden ingezet ter bevordering van participatie (\$ 5.4). Paragraaf 5.5 beschrijft de manier waarop jeugdigen geïnformeerd worden over het jeugdbeleid van hun gemeente en hoe de gemeente zicht houdt op de jeugd. In paragraaf 5.6 worden de verschillende aspecten die verbonden zijn aan jeugdparticipatie op elkaar betrokken. We besluiten dit hoofdstuk met een samenvatting en conclusie $(\$ 5.7)$. Ook in dit hoofdstuk illustreren de bevindingen uit het kwalitatieve onderzoek de resultaten van het kwantitatieve onderzoek.

\subsection{Aandacht voor jeugdparticipatie}

Hebben gemeenten in hun jeugdbeleid aandacht voor jeugdparticipatie? Uit de enquête onder ambtenaren komt naar voren dat een grote meerderheid - $88 \%$ van de in totaal 60 onderzochte gemeenten - aangeeft beleidsdoelen te hebben geformuleerd omtrent 'jeugdparticipatie'. De overgrote meerderheid ( $(91 \%)$ daarvan zegt dit te doen omdat zij het van belang vindt dat de jeugd (meer) betrokken is bij het gemeentelijke beleid (tabel 5.x). Bovendien wil 40\% van de gemeenten ook instellingen aanmoedigen om jongeren te betrekken bij hun beleid. De $12 \%$ van de gemeenten die geen 
beleid hebben geformuleerd ten aanzien van jeugdparticipatie, behoort voor het overgrote deel tot de weinig en niet-stedelijke gemeenten. De aandacht voor jeugdparticipatie in de breedte lijkt, kortom, aanzienlijk. Het belang ervan wordt duidelijk onderkend door gemeenteambtenaren.

Tabel 5.1

Jeugdparticipatie als beleidsdoel van de gemeente, 2001 ( $n=53$ i in procenten)

\begin{tabular}{|c|c|}
\hline de gemeente wil jeugd meer bij het gemeentelijke beleid betrekken & 91 \\
\hline de gemeente wil jeugd stinulleien meer matschappelifk actief te worden & 55 \\
\hline de gemeente wil instellingen stimuleren om jeugdigen in hun beleid te betreikken & 42 \\
\hline anders & 6 \\
\hline
\end{tabular}

Brons SCP (UB amblenaren zoo)

Aan jeugdparticipatie, en dan in het bijzonder aan de betrokkenheid van jongeren bij de (lokale) politiek en het jeugdbeleid, worden in het landelijke jeugdbeleid doorgaans twee mogelijke functies toegekend (Gilsing 20or; Savornin Lohman 200I; Zeijl 2003; BANS r999a, 200r). Allereerst wordt gewezen op de ontwikkelings- of educatieve functie van jeugdparticipatie. Door deelname van de jeugd aan het beleid te stimuleren, zouden jongeren zich (meer) betrokken voelen bij de samenleving, zich vaardigheden zoals zelfsturing eigen maken en zich ontwikkelen tot bewuste burgers.

Daarnaast wordt gewezen op het belang dat inspraak door de jeugd heeft voor het jeugdbeleid zelf. Door met jongeren te praten kan inzicht verkregen worden in de problemen, wensen en behoeften wan deze groep en kan het beleid hier zoveel mogelijk op worden toegesneden. Dit is de instrumentele functie van jeugdparticipatie. Deze instrumentele functie speelt in de overwegingen bij decentralisatie een rol.

Welke functie dichten gemeenten toe aan de participatie van jeugd in beleid? Door de jeugdbeleidnota's van de verschillende gemeenten nader te bestuderen, is nagegaan in hoeverre beleidsmatig invulling wordt gegeven aan jeugdparticipatie en welke redenen in dit verband worden aangedragen. Er is gekeken of jeugdparticipatie aan de orde komt in jeugdbeleidnota's, wat ervan wordt verwacht en of er concrete acties zijn ingezet. Bij deze documentanalyse zijn de nota's bestudeerd van de 36 gemeenten waar na 1998 relevante documenten zijn verschenen.

Uit tabel 5.2. blijkt dat in 3 I van de 36 nota's $(86 \%)$ aandacht wordt besteed aan jeugdparticipatie. Dat laat onverlet dat in maar 24 nota's expliciet wordt beschreven welke concrete acties op dit punt zullen worden ingezet. Het belang dat in jeugdnota's wordt toegekend aan jeugdparticipatie wordt dus meestal wel, maar niet altijd vertaald in concrete plannen. 
Tabel 5.2

Aandacht voor jeugdparticipatie in beleidsnota's jeugdbeleid, 2001 ( $n=36$; in procenten')

\begin{tabular}{|c|c|c|}
\hline participatige anan de onde in de nota? & nee & 14 \\
\hline rohting wan de participatle & Informatie van jongeren aan de gemeente & 10 \\
\hline & informatie van de gemeente aan jongeren & 3 \\
\hline & tweer ichtingsverkeer & 77 \\
\hline & niet gespecificeerd & 10 \\
\hline perspectef van de participatie & ontwikkelingsgericht & 6 \\
\hline & instrumenteel & 35 \\
\hline & zowel ontwikkelingsgerichtals instrumenteel & 42 \\
\hline & niet genoemd & 14 \\
\hline actes nuet letrekting tot participatie? & nee & 32 \\
\hline & ja & 68 \\
\hline
\end{tabular}

Het perspectief van waaruit jeugdparticipatie benaderd wordt, is in bijna de helft van de gevallen tweeledig. Aan jeugdparticipatie wordt zowel een instrumentele als een ontwikkelingsfunctie toebedeeld. Het gaat in deze nota's dus zowel om het verbeteren en op maat maken van het jeugdbeleid, als om het aanbieden van leerervaringen aan jeugdigen door hen mee te laten werken aan en mee te laten denken over het jeugdbeleid. Het ontwikkelingsperspectief wordt nauwelijks exclusief gehanteerd als legitimering. Het instrumentele perspectief komt daarentegen wel regelmatig alleen voor. In meer dan eenderde van de beleidsdocumenten wordt jeugdparticipatie uitsluitend benaderd vanuit dit perspectief. Het belang van jeugdparticipatie wordt dan hoofdzakelijk gezien in termen van het afstemmen van het jeugdbeleid op de problemen en behoeften van jeugdigen.

In ruim driekwart van de nota's wordt jeugdparticipatie opgevat als tweerichtingsverkeer. Het gaat zowel om informatie die de gemeente aan jongeren verstrekt, als om informatie en ideeën die jongeren aan de gemeente geven. Slechts in een klein deel van de bestudeerde nota's wordt jeugdparticipatie als eenrichtingsverkeer gezien, waarbij ofwel jongeren worden geacht de gemeente te informeren ofwel de gemeente jongeren dient te informeren. 


\section{Box 5.1 Het belang van jeugdparticipatie}

De meeste gemeenten hechten veel belang aan jeugdparticipatie, zoals blijkt uit onderstaande voorbeelden.

In de Appingedammer nota komt het thema 'jeugdparticipatie' niet aan de orde. Desondanks is duidelijk dat de gemeente de jeugd meer bij het gemeentebeleid will betrekken en instellingen wil stimuleren om dat ook te doen. De jeugd wordt op dit moment betrokken bij het gemeentebeleid door middel van een jeugdiraad en schoolbezoeken door de wethouder. De wethouder vertelt dat er ieder jaar een kindergemeenteraad is met vertegenwoordigers uit groep 8 , waarin plannen worden gepresenteerd en verdedigd. Eén plan wordt dan gekozen en uitgevoerd en de kinderen worden zelf betrokken bij de uitvoering. De plannen worden echter niet gebruikt als beleidsinput. Er vindt geen gerichte informatieverstrekking plaats over zaken in de gemeente die voor jeugd van belang zijn. Wel is er sprake van ad-hocparticipatie rond concrete voorzieningen, die soms worden aangelegd op initiatief van jongeren.

In Leiden maakt jeugdparticipatie een belangrijk onderdeel uit van het jeugdbeleid. Het jeugdbeleid is opgehangen aan vijf thema's, waar het thema "Jeugd in beeld" er één van is. Het beleid rond dit thema is gericht op versterking van de betrokkenheid van jeugd bij het gemeentelijke beleid. Informatie aan jeugd over het beleid en over het voorzieningenaanbod voor de jeugd wordt door de gemeente gezien als een noodzakelijke voorwaarde voor participatie. Er is dan ook een internetsite, een 'digitale hangplek' voor jeugd en een jongerengids. Dit is een computernetwerk waar informatie te verkrijgen is over activiteiten in de stad. Jongeren kunnen hier tevens hun vragen en opmerkingen kwijt. Het netwerk is bereikbaar via bibliotheken, onderwijsinstellingen of buurthuizen. Verder wordt informatie verstrekt via instellingen die betrokken zijn bij het jeugd beleid. Ook stelt de gemeente jaarlijks een budget vast voor jongeren. De jongeren kunnen voorstellen doen voor aanwending van het budget en worden zoveel mogelijk betrokken bij de uitvoering van de plannen.

In een paar stadsdelen zijn kinderwijkraden opgericht die problemen helpen signaleren en oplossen. Ook wordt een jongerenpanel opgericht en zullen met regelmaat jongerenraadplegingen plaatswinden over gemeentelijke plannen. Er is op dit moment wel een jongerengemeenteraad, maar die functioneert nauwelijks. In het algemeen blijkt het lastig georganiseerde inspraak voor jongeren van de grond te krijgen.

De gemeente Culemborg acht het niet mogelijk een goede regie te voeren in het jeugdbeleid zonder daar de jongeren nadrukkelijk bij te betrekken. Participatie van jongeren wordt dan ook als een vereiste gezien en moet een structurele plaats krijgen in het gemeentelijke jeugdbeleid. Er is een jongerenadviesgroep die ondersteund wordt door, en samengesteld is vanuit het sociaal-cultureel werk. Formeel geeft zij gevraagd en 


\section{Vervalg Box 5.1 Het belang van jeugdparticipatie}

ongevraagd advies; zij wordt bijwoorbeeld bij het aanwijzen en inrichten van hangplekken geraadpleegd. Ondanks het belang dat het college van $B \& W$ hecht aan participatie, is er geen structureel overleg tussen de jongerenadviesgroep en de gemeente. Het sociaal cultureel werk heeft aangegeven dat formele participatie in gemeentelijk beleid jongeren afschrikt deel te nemen aan de jongerenadviesgroep. Dit is cok de reden waarom de jongerengemeenteraad geen succes is geworden.

De gemeente Heeze-Leende vindt het belangrijk dat de jeugd daadwerkelijk betrokken wordt bif het ontwikkelen van een goed samenhangend jeugdbeleid. In het kader van het opstellen van de nota over het jeugdbeleid, is er in thet basisonderwijs daarom een participatieproject geweest. Kinderen van basisscholen hebben de burgemeester brieven en tekeningen gestuurd met hun mening over het leven in de gemeente Heeze-Leende. Daarnaast heeft het Brabants Steunpunt Jeugdbeleid (BS) een project uitgevoerd waarin 40 jongeren tussen 13 en 25 jaar werden geïnterviewd, onder andere gericht op de prioriteiten in de Nota Jeugdbeleid. Er is ook wel eens gepraat over meer structurele participatie en hierin heeft de gemeente de landelijke projectgroep Ontwikkeling lokaal preventief jeugdbeleid (OLPJ) geconsulteerd. Dit heeft ertoe geleid dat de gemeente in concrete gevallen de jeugd raadpleegt, bijvoorbeeld over de jongerenruimte, maar dat er geen permanent orgaan is opgericht.

Naast het ontplooien van eigen initiatieven wil $42 \%$ van de onderzoeksgemeenten instellingen stimuleren om de jeugd bij hun beleid te betrekken. Het onderwijs maar ook maatschappelijke instellingen, zoals sportverenigingen en sociaal-cultureel werk, zouden jongeren de mogelijkheid moeten bieden om mee te praten over zaken die voor hen van belang zijn. Aan de ambtelijke sleutelfiguren is gevraagd of de gemeente bij het verstrekken van subsidies aan dergelijke instellingen als voorwaarde stelt dat zij jongeren moeten betrekken bij hun beleid . $17 \%$ van de gemeenten zegt deze voorwaarde altijd te stellen. Bijna $60 \%$ van de gemeenten stelt zulke voorwaarden nooit. De overige gemeenten doen dit soms wel en soms niet.

Veel gemeenten zijn in de afgelopen jaren wijkgericht gaan werken. Veel problemen worden op wijkniveau aangepakt en opgelost. Daarwoor is een deel van de gemeentelijke taken en verantwoordelijkheden overgedragen aan de betreffende wijken. Aan de ambtenaren is gevraagd of er bij het overleg op wijkniveau op wordt gelet dat jeugdigen als groep vertegenwoordigd zijn. Ruim $60 \%$ van de gemeenten zegt hier soms op te letten.

Veel gemeenten blijken dus belang te hechten aan participatie van jeugdigen in het beleid. Een aantal van deze gemeenten geeft het beleid met berrekking tot participatie echter geen concrete vorm. Verder blijkt dat waar het gaat om participatie in 
instellingen en op wijkniveau er meer gemeenten zijn die zich terughoudend opstellen. Het participatiebeleid wan een fors deel van de gemeenten beperkt zich tot het gemeentelijke niveau.

\subsection{Leeftijdsgroepen en thema's}

Op welke groepen jeugdigen richt de aandacht zich bij jeugdparticipatie? En op wellke terreinen wordt inspraak door de jeugd met name belangrijk gevonden? De resultaten van de enquête onder ambtenaren laten zien dat het participatiebeleid zich niet even sterk op alle leeftijdsgroepen richt. Bepaalde leeftijdsgroepen krijgen beduidend meer aandacht dan andere. Uit tabel 5.3 blijkt dat tieners in de leeftijd van 12 tot 18 jaar de meeste aandacht krijgen. Driekwart van de gemeenten richt zich sterk op deze leeftijdsgroep. Er is maar één gemeente die aangeeft niet of nauwelijks aandacht te besteden aan deze jongeren.

Tabuell $5 \cdot 3$

Gerichtheid op leeftijdsgroepen bij het betrekken van de jeugd, 2001 (in procenten)

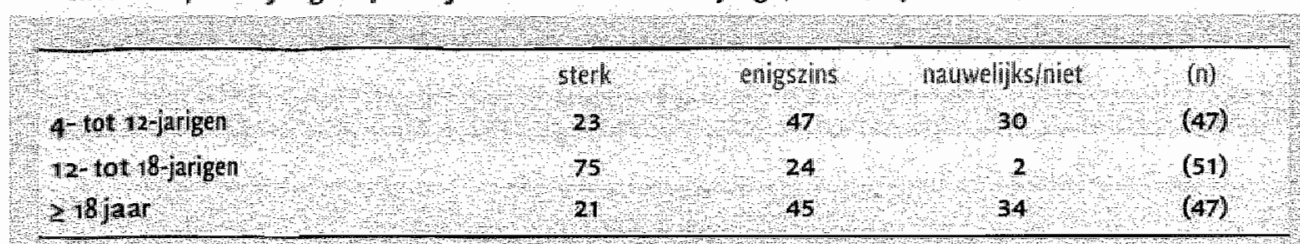

Bron Scp(ds-ambtennaren $200 \mathrm{~d})$

De aandacht voor kinderen van 4 tot 12 jaar en voor jongeren van 18 jaar en ouder is beduidend geringer. Deze leeftijdsgroepen komen er naar verhouding bekaaid af. Rond $20 \%$ van de gemeenten is sterk op deze leeftijdsgroepen gericht, terwijl ongeveer eenderde van de gemeenten aangeeft niet of nauwelijks aandacht te besteden aan inspraak door deze leeftijdsgroepen. Deze conclusie wordt ook getrokken door de BANS-bezoekcommissie. Deze commissie bezocht veertien gemeenten en constateert dat er in de afgelopen jaren veel is geïnvesteerd in inspraak door tieners. De commissie is van mening dat het van belang is dat in de toekomst meer aandacht uitgaat naar inspraak door kinderen, bijvoorbeeld als het gaat om het speelruimtebeleid (BANS-bezoekcommissie 2002: $\mathrm{I}_{4}$ ). Over de relatief geringe aandacht voor jeugd van 18 jaar en ouder doet de commissie in haar rapport geen uitspraak.

Bijna alle gemeenten willen jeugdigen betrekken bij zaken die te maken hebben met vrijetijdsbesteding en (buurt) voorzieningen, zo laat tabel 5.4 zien. De ambtelijke sleutelinformanten van de gemeenten verwachten vooral op deze terreinen input van de jeugd. Op de tweede plaats staat veiligheid en openbare orde. Meer dan driekwart van de gemeenten wil de jeugd betrekken bij het beleid hieromtrent. Beduidend minder belang wordt gehecht aan inspraak door de jeugd in het beleid omtrent huisvesting, opvoeding, opvang en arbeid en inkomen. Rond $20 \%$ van de gemeenten 
betrekt jongeren bij het beleid over huisvesting en opvoeding en rond $15 \%$ van de gemeenten betrekt de jeugd bij kwesties over opvang en arbeid/inkomen. Het is opvallend dat het hier thema's betreft die met name betrekking hebben op kinderen (opvoeding en opvang) en oudere tieners en jong volwassenen (huisvesting, arbeid). De relatief geringe aandacht voor participatie van met name oudere leeftijdsgroepen heeft vermoedelijk te maken met het beperkte belang dat in het lokale jeugdbeleid wordt gehecht aan deze terreinen (zie hoofdstuk 4 ).

Tabel 5.4

Levensterreinen waarop de jeugd bij] het beleid betrokken wordt, $2001 \quad(n=53$; in procenten)

\begin{tabular}{|c|c|}
\hline wijetijdsbesteding/(buurt)vaorzienimgen & 98 \\
\hline velligheid /openbare or de & 77 \\
\hline gezondheid (lichamelijk/geestelijk) & 32 \\
\hline onderwijs/sctioling & 26 \\
\hline (jongeren)huisvesting/woonruimte & 21 \\
\hline opvoeding en thuissituatie & 19 \\
\hline kinderdag - en buitenschoolse opwang & 17 \\
\hline arbeid/inkomen & 15 \\
\hline
\end{tabular}

\subsection{Instrumenten ter bevordering van jeugdparticipatie}

Verschillende studies hebben aangetoond dat het bereiken van jongeren als het gaat om jeugdparticipatie doorgaans niet eenvoudig is. Landelijk jeugdonderzoek heeft laten zien dat de interesse van jongeren voor politiek doorgaans gering is, al is hun interesse voor maatschappelijke vraagstukken, zoals criminaliteit en het milieu, wel aanzienlijk (vgl. Wittebrood 1995). Verder suggereren de resultaten van landelijk onderzoek dat jongeren doorgaans minder gebruikmaken van de inspraakmogelijkheden die zij tot hun beschikking hebben dan volwassenen, ondanks dat de meerderheid van de jongeren vindt dat zij meer inspraak zouden moeten krijgen in het beleid van gemeenten en ondanks dat het bevorderen van jeugdparticipatie een belangrijk speerpunt is van het jeugdbeleid. $7 \%$ van de jongeren tussen de $\mathrm{I} 2 \mathrm{en}$ I8 jaar in Nederland heeft in de afgelopen drie jaar meegedaan aan een jeugddebat of jongerenbijeenkomst, $5 \%$ heeft deel uitgemaakt van een jeugdpanel of jeugdraad en $4 \%$ heeft de laatste drie jaar een inspraakavond bezocht (Zeijl 2003: II2). Daarmee is de participatiegraad onder jongeren lager dan die onder volwassenen (SCP 2002: 229; zie ook Zeijl 2003: (I2). Het lijkt er op dat jongeren inspraak wel belangrijk vinden, maar dat zij zelf niet altijd bereid zijn actief mee te doen. De constatering van de BANS-bezoekcommissie (2002) dat op dit moment vooral de zogenoemde 'mondige jeugd' of 'beroepsjeugd' betrokken is bij inspraakavonden en jeugdraden bevestigt dit vermoeden. Dit roept onder meer de vraag op welke wegen gemeenten bewandelen om de jeugd te betrekken. 
Aan ambtenaren is gevraagd hoe zij jongeren op de hoogte stellen van en interesseren voor jeugdparticipatie (zie tabel 5.5). Verreweg de meeste gemeenten ( $91 \%)$ die beleid op het gebied van jeugdparticipatie voeren, trachten jongeren te bereiken via jongerenorganisaties of het jongerenwerk. De school is nummer twee. Bijna driekwart van de onderzochte gemeenten tracht de jeugd te bereiken via het onderwijs. lets minder gebruik wordt gemaakt van het internet en van sportverenigingen of culturele instellingen, al wendt toch nog een aanzienlijk aantal gemeenten deze middelen en voorzieningen aan $(36 \%-46 \%)$. Bovendien maakt $30 \%$ van de gemeenten gebruik van andere mogelijkheden om jongeren te interesseren voor jeugdparticipatie. Het gaat hier om rekrutering via gemeenteambtenaren, wijkbijeenkomsten, een meer persoonlijke benadering en door gebruikmaking van het sociaal-cultureel werk.

\section{Tabel 5.5}

Wegen waarlangs jeugd voor gemeentelijk beleid geïnteresseerd wordt, 2001 ( $n=53$; in procenten)

\begin{tabular}{lc}
\hline via jongerenorganisaties of jongerenwerk & 83 \\
via scholen & 66 \\
via jongeren ontmoetingsplaatsen (JOP's) & 70 \\
via een Jangeren informatie punt (JIP) & 36 \\
via de pers (lokale radio, $t$, dag- of weekbladen) & 36 \\
via internet & 28 \\
via sportwerenigingen of culturele instellingen & 28 \\
anders & 30
\end{tabular}

Bron Sco (1) B arnbtenaren zoon)

\section{Box 5.2 Het betrekken van de jeugd}

Dat gemeenten zich richten op verschillende leeftijdsgroepen en diverse strategieën aanwenden om jongeren te bereiken blijkt onder meer als we kijken naar de gemeenten Vlissingen, Groningen, Spijkenisse en Voorburg.

12-18-jarigen staan centraal in het jeugdparticipatiebeleid van de gemeente Vlissingen. Participatie van jeugdigen zou volgens de gemeente niet beperkt moeten blijven tot meedenken over gemeentelijk beleid, maar organisaties zouden ook jongeren bij hun bestuur moeten betrekken. De gemeente wil voor de leeftijdsgroep 4-12-jarigen al een voedingsbodem kweken voor participatie en demacratisch burgerschap. Participatie door jongeren wordt ook belangrijk geacht in het kader van preventie van jeugdcriminaliteit. In de praktijk blijkt jeugdparticipatie een moeilijk proces te zijn. Eén van de respondenten van uitvoerende instellingen geeft aan dat jongeren geen verantwoordelijkheid willen nemen, niet namens anderen willen spreken, enzovoort. Er zijn well kennismakingsdagen met de gemeente geweest die hebben geleid tot de oprichting van een jeugdgemeenteraad. Daarnaast wordt jeugd betrokken als het gaat om leefbaar- 


\section{Vervolg Box 5.2 Het betrekken van de jeugd}

heid en wijkvoorzieningen. Er zijn bijvoorbeeld inspraakavonden met een collegelid. De afgelopen jaren heeft de gemeente Groningen in het kader van participatie door jongeren geëxperimenteerd met paneldiscussies. De informatie uit deze panels leidt tot verdieping van het inzicht in de belevingswereld van jongeren. De gemeente legt hiertoe de richting van het beleid woor aan jeugd en ouders en vraagt om feedback. De paneldiscussie over de startnotitie De jeugd en de toekomst is hier een voorbeeld van. Tijdens deze discussie is er over het integrale jeugdbeleid van gedachten gewisseld met kinderen, jongeren, ouders; leerkrachten en begeleiders. De gemeente Groningen wil ook op buurt- en wijkniveau de jeugd betrekken bij het beleid dat voor hen van belang is.

Participatie van jeugdigen is één van de hoofddoelstellingen in het jeugdbeleid van de gemeente Spijkenisse. Dit krijgt vooral vorm door jongeren te betrekken bij datgene wat er voor hen in de openbare ruimte wordt gerealiseerd. Zo zijn er met jongeren convenants afgesloten over het organiseren van bewonersavonden voor omwonenden vain een hangplek en over het opruimen van rommel op hangplekken. Daarnaast wil de gemeente jeugd betrekken bij beleid met betrekking tot opvoeding en thuissituatie, veiligheid, onderwijs en arbeid. De vormen waarin jeugd bij het beleid worden betrokken zijn groepsgesprekken, panels en interviews. Om de participatie van jongeren beter te kunnen ondersteunen, wordt het jongerenwerk in de gemeente specifiek getraind. Verder wordt gepoogd de jeugd te bereiken via scholen en sportverenigingen of culturele instellingen. Er is sprake van een instrumentele benadering van participatie: als het het beleid ten goede komt, wordt de jeugd betrokken. Rond concrete beleidsplaninen wordt naar een passende manier gezocht om de wensen van jongeren te integreren. Om die reden voelt de wethouder weinig voor een jeugdraad, die wel kort bestaan heeft, maar geen succes was. Door één van de respondenten wordt jeugdparticipatie gekwalificeerd als een 'politielk item', gezien de grote aandacht die het ondanks het beperkte belang krijgt.

Uit onderzoek van de gemeente komt naar voren dat jongeren nauwelijks weten water in Voorburg te doen is. De gemeente vindt informatieverstrekking over de verschillende mogelijkheden voor jeugdigen in Voorburg echter heel belangrijk en heeft het als een van de beleidsprioriteiten aangemerkt. Het idee dat hierachter zit is dat 'kennis van' het 'deelnemen aan' verhoogt. Om de informatieverstrekking te verbeteren is er een Promoteam opgericht dat bestaat uit jongeren en dat zich bezig houdt met de uitgave van een jongerenkrant. De oprichting van dit team is het resultaat van een aantal jeugddebatten die door de gemeente waren georganiseerd. Kritiek hierop vanuit de instellingen is dat de jongeren waar zij mee te maken hebben zich helemaal niet aangesproken voelen om mee te doen aan zo'n debat. Jongeren uit een achterstandssituatie worden moeilijker bereikt en de participatie van jongeren verwordt tot een middle-classgebeuren. 
Concluderend kunnen we zeggen dat de onderzochte gemeenten aangeven doorgaans meerdere wegen te bewandelen om jongeren te bereiken. Niet alleen formele structuren (jeugdvoorzieningen), maar ook informele structuren (internet, media) worden angewend om de jeugd te bereiken, aldus de ambtenaren jeugdbeleid.

Wat zijn dan de vormen waarmee de participatie van jeugdigen gestalte moet krijgen? Meer dan de helft van de gemeenten maakt gebruik van groepsgesprekken/interviews om van de jeugd te horen hoe zij denkt over bepaalde zaken in het gemeentelijke beleid (tabel 5.6). Daarnaast heeft bijna $40 \%$ van de onderzochte gemeenten een jeugdpanel of jeugdraad. Opvallend is dat de categorie 'anders' hier tamelijk groot is: $42 \%$ van de gemeenten heeft dit antwoord ingevuld. Deze gemeenten regelen inspraak onder meer via enquêtes, videoboodschappen, de jongerenkrant of via het internet, zo blijkt. Verdere analyses maken duidelijk dat eenderde van de gemeenten slechts één inspraakvorm hanteert. Meer dan de helft van de gemeenten maakt gebruik van meerdere vormen. Een belangrijke vraag blijft in dit verband wat er uiteindelijk gebeurt met de resultaten van dergelijke interviews en panels. Hebben jongeren bijvoorbeeld de indruk dat ze serieus genomen worden en dat hun ideeën aandacht krijgen? Of haken zij af omdat zij het gevoel hebben dat er niks met hun inbreng wordt gedaan? Deze vragen komen aan de orde in hoofdstuk to.

\section{Tabel 5.6}

Vormen om jeugd bij het gemeentelijke beleid te betrekken, 2001 ( $n=53$; in procenten)

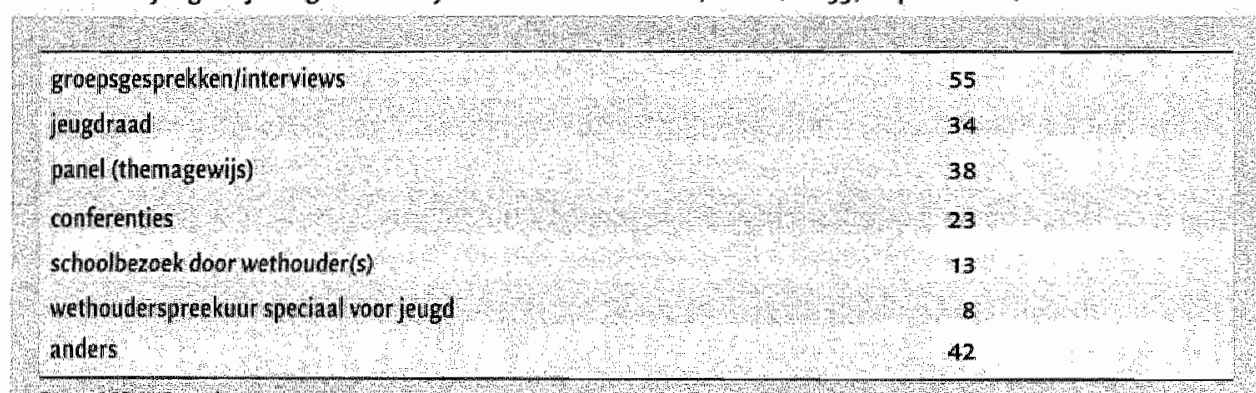

BronsG (L B anibensen 2002$)$

\subsection{Zicht op de jeugd en informatie aan de jeugd}

Naast het betrekken van de jeugd bij specifieke kwesties kan de gemeente ernaar streven (meer) zicht te krijgen op de leefsituatie van de jeugd in haar gemeente, teneinde haar beleid beter af te kunnen stemmen op de problemen of behoeften van jeugdigen. Het gaat dan om het raadplegen van jeugdigen met een puur instrumenteel motief. 
Tabel 5.7

Methoden om zicht te krijgen op de leefsituatie en wensen/behoeften van lokale jeugd, 2001 ( $n=60$; in procenten)

\begin{tabular}{|c|c|}
\hline periodieke registraties en matingen onder jeugdigen & 37 \\
\hline het organiseren yan gespreksen met groepjes jeugdigen & 52 \\
\hline een alig onderzoek onder jeugdigen & 47 \\
\hline geen methode & 12 \\
\hline anders & 30 \\
\hline
\end{tabular}

Bron, SCP (y) ambtenaren 2002)

Van de ondervraagde gemeenten geeft $88 \%$ aan onderzoek te doen naar de leefsituatie van de jeugd (zie tabel 5.7). De meest gehanteerde methode is het organiseren van gesprekken met groepjes jeugdigen, gevolgd door het doen van een eenmalig onderzoek onder de jeugd in de gemeente. Periodieke registraties en metingen onder jeugdigen, het zogenoemde monitoren van de jeugd, wordt eveneens frequent toegepast, vooral door (zeer) sterk stedelijke gemeenten, wat niet los gezien kan worden van de grote investering in tijd en geld die dergelijke onderzoeken doorgaans vergen.

$30 \%$ van de gemeenten wendt andere technieken aan dan die genoemd worden in tabel 5.7. Het gaat hier om het openstaan voor signalen van sleutelfiguren, het gebruikmaken van bestaande registraties of gegevens van de GGD-monitor en het gebruiken van informatie die afkomstig is van de jongerenraad of kinderraad uit de gemeente.

Naast het zicht krijgen op de leefsituatie en de wensen en behoeften van kinderen en jongeren kan de gemeente de jeugd informeren over zaken die voor hen van belang zijn, bijvoorbeeld over werken, wonen en school, maar ook over geld, drugs en over rechten en plichten. Als we kijken naar tabel 5.8 dan blijkt dat een minderheid van de gemeenten $(22 \%)$ geen woorzieningen treft om kinderen en jongeren te informeren. De meeste gemeenten spelen informatie door aan jongeren via instellingen of het internet. Opvallend is dat ruim een vijfde van de gemeenten de categorie 'anders' heeft ingevuld. Nadere exploratie van deze categorie leert dat deze gemeenten onder andere gebruik maken van de gemeente- of jongerengids, van folders en flyers en van de website van de gemeente om jongeren te informeren. 
Tabel 5.8

Methoden om jongeren gericht te informeren, $2001(n=57$; in procenten)

\begin{tabular}{|c|c|}
\hline va instell hingendie betrokken zin bij thet jeugdbeleid & 52 \\
\hline Ya een special op/eugdigen gerichte internetsite & 27 \\
\hline Wa een Jongeren Informatie Punt ollP) & 32 \\
\hline Via huis aan-huis verspreide bilader & 27 \\
\hline via gerichte roorlichtingscampagnes & 23 \\
\hline Via lesorieven/uideo's n het onderwijs & 13 \\
\hline Wa eenjeugdkrant & 10 \\
\hline anders & 22 \\
\hline 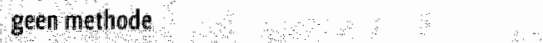 & 22 \\
\hline
\end{tabular}

Brons sep (GB amblenargn 2002 )

\subsection{Participatie-index}

Op basis van de verschillende aspecten die in dit hoofdstuk zijn besproken, is met behulp van de techniek van principale-componentenanalyse één dimensie gevonden voor het betrekken van de jeugd. ${ }^{x}$ Deze dimensie geeft op een samenvattende wijze weer of gemeenten meer of minder gericht zijn op jeugdparticipatie. Gemeenten die geen beleid hebben dat op jeugdparticipatie is gericht, zijn van de analyse uitgesloten. In tabel 5.9 staan de resultaten van de principalecomponentenanalyse. De component die gevonden is, verklaart $43 \%$ van de variantie en de ladingen van alle variabelen zijn hoog genoeg om te kunnen spreken van één schaal. Hoe hoger de lading van een aspect op deze component is, hoe zwaarder deze weegt in de berekening van de score. Dit betekent bijvoorbeeld dat het aantal methoden waarop de gemeente jongeren informeert, een grotere invloed heeft op de dimensiescore dan het aantal leeftijdsgroepen waarop het participatiebeleid sterk is gericht. De gemiddelde score op de dimensie is $\mathrm{o}$, de minimumscore is $-1,8$ en de maximumscore is 2,8 . Hoe hoger de score, hoe sterker een gemeente tracht jeugdigen bij het beleid te betrekken.

\section{Tabel 5.9}

Principale-componentenanayse "betrekken van de jeugd', $2001(n=53)$

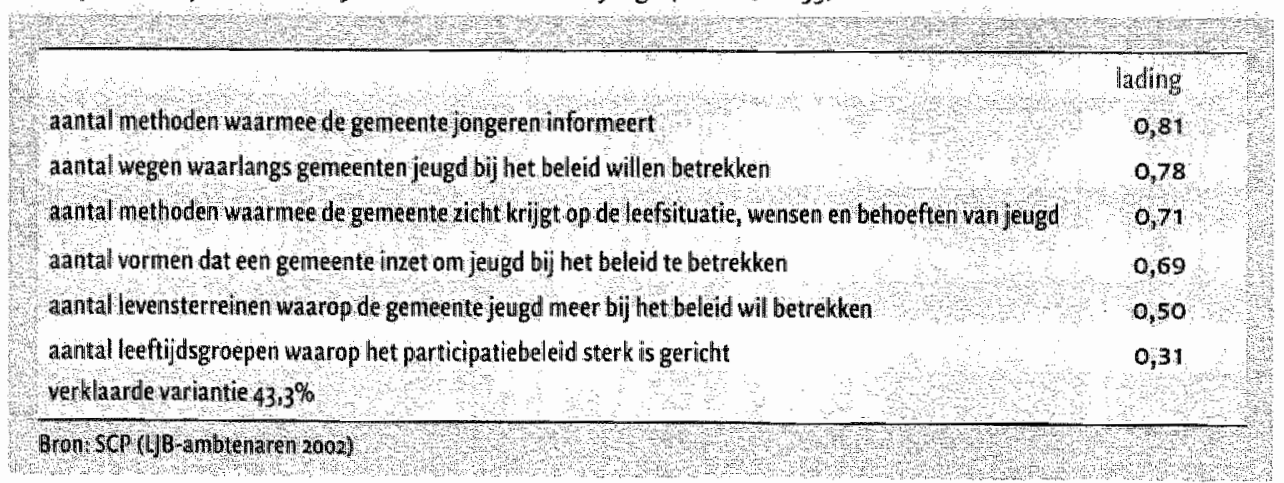


In tabel 5.ro zijn de scores op de participatiedimensie afgezet tegen de stedelijkheidsklasse van gemeenten. De scores zijn daartoe opgedeeld in drie klassen: een lage score (lager dan $-0,5$ ), een gemiddelde score (tussen $-0,5$ en 0,5 ), en een hoge score (hoger dan 0,5 ). $38 \%$ van de onderzoeksgemeenten heeft een score in de laagste klasse, wat betekent dat zij veel minder dan gemiddeld gericht zijn op het betrekken van de jeugd. Eenderde van de gemeenten heeft een dimensiescore rond het gemiddelde, en van $28 \%$ van de gemeenten kan gezegd worden dat zij duidelijk meer dan gemiddeld aandacht hebben voor de participatie van de jeugd.

Tabel 5.10

Dimensiescore 'betrekken van jeugd', naar stedelijkheid, 2001 (in procenten)

\begin{tabular}{|c|c|c|c|c|}
\hline & (zeer) sterth stedelik & matig stedelijli & weing rntat-stedetill & total \\
\hline$\leqslant-0,5$ & 4,18 & 47 & 56 & 38 \\
\hline$-0,5$ toto, 0,5 & 32 & 27 & 44 & 34 \\
\hline$>0,5$ & 50 & 27 & 0 & 28 \\
\hline (n) & (22) & (1s) & (16) & (53) \\
\hline
\end{tabular}

Bron. SCP ( B B anbitenaren 2002$)$

Er is een duidelijk verband tussen de stedelijkheid en de score op de jeugdparticipatiedimensie. De helft van de (zeer) sterk stedelijke gemeenten scoort in de hoogste klasse, wat betekent dat deze gemeenten op veel manieren en terreinen met jeugdparticipatie bezig zijn. Er is niet één weinig tot niet-stedelijke gemeente die in deze klasse geplaatst kan worden. Meer dan de helft van de weinig/niet-stedelijke gemeenten scoort in de laagste klasse. De conclusie mag duidelijk zijn: hoe stedelijker een gemeente, hoe meer en hoe breder zij jeugd bij haar beleid tracht te betrekken.

\subsection{Samenuatting en conclusies}

Zowel uit de nota's jeugdbeleid als uit de vragenlijst onder ambtenaren blijkt dat er veel beleidsmatige aandacht is voor jeugdparticipatie. Het grootste deel van de onderzochte gemeenten erkent het belang van jeugdparticipatie en heeft beleid op dit terrein geformuleerd. In de regel, zo blijkt, wordt jeugdparticipatie vooral nagestreefd omdat het goed is voor het beleid (het instrumentele motief) en in mindere mate omdat het goed is voor jongeren (de ontwikkelingsfunctie). De gemeenten willen vooral de mening van jongeren horen over vrijetijds- en buurtvoorzieningen en over zaken met betrekking tot veiligheid en openbare orde. Deze keuze is consistent met de leeftijdsgroep waarop gemeenten zich richten, te weten de 12-17-jarigen. De belangstelling voor inspraak door kinderen en oudere tieners is bij gemeenten doorgaans kleiner. De onderzochte gemeenten bijiken in het algemeen minder behoefte te hebben aan het betrekken van de jeugd bij zaken als arbeid en inkomen en bij kinderopvang en buitenschoolse opvang. 
Er zijn verschillende wegen waarlangs gemeenten de jeugd willen bereiken en voor het beleid willen interesseren. Veel gemeenten maken hiervoor gebruik van jongerenorganisaties of het jongerenwerk, gevolgd door het straathoekwerk, jongerenontmoetingsplekken en scholen. De inspraakvorm die gemeenten het meest gebruiken is het houden van groepsgesprekken of interviews. Daarnaast wordt gebruikgemaakt van jeugdpanels en -raden. Opvallend is dat veel gemeenten aangeven dat ze een andere dan de in de vragenlijst genoemde methode gebruiken om de jeugd bij het beleid te betrekken. Het gaat hier om zaken als het houden van enquêtes of het uitbrengen van een jongerenkrant. Dit doet vermoeden dat gemeenten actief zoeken naar manieren om jeugd bij het beleid te betrekken.

De vraag die we aan het begin van dit hoofdstuk stelden, luidde: trachten gemeenten actief de jeugd te betrekken bij hun jeugdbeleid? Het blijkt dat een zeer ruime meerderheid van de gemeenten dat inderdaad doet. De inspanningen tussen gemeenten wisselen weliswaar sterk, maar $88 \%$ van de onderzoeksgemeenten voert beleid om de jeugdparticipatie te versterken. Het is duidelijk dat de factor 'stedelijkheid' een belangrijke variabele is als het gaat om de mate waarin het beleid omtrentjeugdparticipatie vorm heeft gekregen. Stedelijke gemeenten hebben op dit terrein vaker doelstellingen geformuleerd dan minder stedelijke gemeenten. Ook hebben zij doorgaans meer aandacht voor inspraak door I8-plussers, bewandelen zij doorgaans meer wegen om jongeren te interesseren en te motiveren voor jeugdparticipatie, maken zij vaker gebruik van verschillende inspraakvormen en gebruiken zij meer methoden om de jeugd in hun gemeente te informeren. 
I De volgende aspecten zijn in de analyse opgenomen: het aantal levensterreinen waarop de gemeente jengd meer bij het beleid wil betrekken ( $\$ 5.3$ ), het aantal leeftijdsgroepen waarop het participatiebeleid sterk gericht is $(\$ 5.3)$, het aantal wegen waarlangs gemeenten jeugd bij het beleid willen betrekken ( $\$ 5.4)$, het aantal vormen dat de gemeente inzet om jeugd bij het beleid te betrekken $(\$ 5.4)$, het aantal methoden waarmee gemeenten jongeren informeren $(\$ 5.5)$ en het aantal methoden waarmee de gemeente zicht krijgt op de leefsitwatie van de jeugd (\$ 5.5). 


\section{De gemeente als sturende actor in het lokale jeugdbeleid}

\section{$6.1 \quad$ Inleiding}

Gemeenten worden geacht de 'regie' over het lokale jeugdbeleid te voeren. Althans, dat is de opvatting van de nationale overheid in de door haar voorgestane bestuurlijke rolverdeling tussen de verschillende overheden. De ervaren noodzaak van lokale regie komt woort uit het inzicht dat vele actoren op het lokale niveau zijn betrokken bij 'de jeugd'. Het is aan de gemeente om samenwerking en afstemming tussen deze actoren te bewerkstelligen en om heldere doelen te formuleren vanuit een gedeelde probleemanalyse, die richting geven aan het handelen van de bij het jeugdbeleid betrokken actoren. De gemeente is daarmee regisseur van het lokale jeugdbeleid. In hoofdstuk 3 is de regie over externe actoren al kort aan de orde geweest als onderdeel van de staat van het jeugdbeleid. Daar bleek dat twee derde van de onderzoeksgemeenten zichzelf tot doel had gesteld de samenwerking tussen gemeente en instellingen te structureren, het aanbod van verschillende instellingen op elkaar af te stemmen en de samenwerking tussen instellingen te stimuleren.

De term regie is natuurlijk een metafoor, en wordt veelvuldig gebruikt in beleidsnota's. In de wetenschappelijke literatuur wordt het begrip veel minder gebezigd. Daar gaat het over netwerksturing, netwerkmanagement of governance. In dit hoofdstuk sluiten we daarbij aan en zullen we het over de sturende rol wan gemeenten hebben. ${ }^{x}$ Deze rol zullen we in dit hoofdstuk beoordelen op de mate waarin hij bijdraagt aan de voorwaarden voor een effectief beleid, te weten een op de lokale situatie toegespitst beleid, integrale beleidswoering en slagvaardigheid.

De vraag of de gemeentelijke sturing bijdraagt aan maatwerk wordt beantwoord door te bezien in hoeverre gemeenten in de beleidsworming lokale informatie gebruiken door in die fase van de beleidscyclus lokaal opererende actoren te betrekken die te maken hebben met jeugd.

De vraag of de gemeentelijke sturing bijdraagt aan integralle beleidsvoering, beantwoorden we door te kijken naar het gebruik van een samenhangende, richtinggevende beleidsvisie als sturingsinstrument in hetjeugdbeleid. Bovendien kijken we naar de wijze waarop gemeenten de samenwerkingsrelaties tussen actoren trachten te regelen door beleidsnetwerken rond het jeugdbeleid in te richten en te onderhouden. Het zorgdragen voor de uitvoering van beleid conform het geformuleerde beleid beschouwen wij hier als een element wan integrale beleidswoering.

Slagvaardigheid is een kenmerk van beleid dat te maken theeft met de inrichting van het beleidsproces, en dan met name van de beleidsuitvoering en -evaluatie. We zullen zien hoe gemeenten trachten deze processen te sturen en wat dat voor gevolgen heeft voor het vermogen slagvaardig op te treden. 
De vraag in dit hoofdstuk is dus op welke wijze gemeenten het jeugdbeleid trachten te sturen. Zijn er netwerken rond het jeugdbeleid geformeerd, en zo ja, op welke wijze? Deze vraag komt in paragraaf 6.2 aan de orde. In paragraaf 6.3 wordt ingegaan op de beleidsworming en is de vraag in hoeverre gemeenten het voor netwerksturing belangrijke beleidsinstrument van de beleidsvisie gebruiken, en hoe dit door de overige actoren wordt ervaren. Met betrekking tot de beleidsuitvoering is vooral van belang hoe de gemeente deze stuurt, en met name wat dit voor gevolgen heeft voor de (kans op) afwijkingen van het geformuleerde beleid. Hierop wordt in paragraaf 6.4 ingegaan. Tot slot komt in paragraaf 6.5 de beleidsevaluatie an bod. Heeft de beleidsevaluatie een plaats in het jeugdbeleid, en zo ja, hoe krijgt deze vorm?

De wijze waarop de gemeenten hun sturende rol vormgeven, zal in dit hoofdstuk waar relevant worden afgezet tegen de stedelijkheid van de gemeente. Verondersteld wordt dat met de stedelijkheid van de gemeente de complexiteit van de bestuurlijke arena toeneemt, wat hogere eisen stelt aan de gemeentelijke sturing. Bovendien zijn meer stedelijke (in het algemeen: grotere) gemeenten beter toegerust om de sturende rol op zich te nemen. Zij beschikken over meer ambtelijke capaciteit en staan doorgaans sterker ten opzichte van andere bij het jeugdbeleid betrokken actoren. De wijze waarop de gemeenten hun sturende rol vormgeven, wordt bovendien afgezet tegen de mate waarin het jeugdbeleid in 200 r ontwikkeld was (staat van het jeugdbeleid, zie hoofdstuk 3). Sturing is een van de aspecten van de staat van het jeugdbeleid, dus men mag aannemen dat gemeenten met een hoge staat van het jeugdbeleid zich intensiever met hun sturende rol bezighouden dan gemeenten met een lage staat wan het jeugdbeleid.

De gegevensbronnen voor dit hoofdstuk zijn het onderzoek onder ambtenaren in 2002, het onderzoek onder uitvoerende instellingen in $2002 \mathrm{en}$, in beperkte mate, de documentanalyse 2002. ${ }^{2}$ De gegevens uit het instellingenonderzoek worden op verschillende plaatsen geaggregeerd naar het gemeentelijke niveau. Om daarbij uit te sluiten dat de invloed van een enkele instelling op de geaggregeerde gemeentelijke score al te groot is, zijn gemeenten waar minder dan drie instellingen aan het onderzoek hebben meegewerkt van de analyse uitgesloten. Dit beperkt het aantal gemeenten waarover uitspraken kunnen worden gedaan tot 63 , en in gevallen waar relaties worden gelegd met het onderzoek onder ambtenaren tot 53 . In afzonderlijke boxen illustreren de bevindingen uit de negen gemeenten van het kwalitatieve onderzoek de kwantitatieve resultaten.

\subsection{Beleidsnetwerken rond lokaal jeugdbeleid}

Het vormen van beleidsnetwerken en het onderhouden daarvan is een van de instrumenten die actoren ter beschikking staan wanneer zij het gedrag van andere actoren trachten te sturen. ${ }^{3}$ Het is bij uitstek een instrument dat bijdraagt aan een integrale beleidsvoering, omdat het de samenwerking tussen de bij een bepaald beleidsterrein betrokken actoren tracht te structureren. Beleidsnetwerken kenmerken zich door 
hun gerichtheid op bepaalde beleidsproblemen of -programma's, door de samenwerking van verschillende actoren en door enige duurzaamheid (vgl. Hufen en Ringeling 1990: 6).

Eerder onderzoek (Gilsing et al. 2000) wees uit dat rond het jeugdbeleid van grote gemeenten verschillende netwerken, platforms, werk- of projectgroepen opereren, die gevormd zijn rond thema's of leeftijdsgroepen, of rond het jeugdbeleid in bepaalde delen van de gemeente. Sommige netwerken bleken zich te beperken tot beleidsworming - beleidsstrategische netwerken - terwijl andere louter een taak in de uitvoering bleken te hebben - uitwoeringsnetwerken. Maar meestal bleken netwerken beide taken in zich te verenigen. In de slotbeschouwing van dat onderzoek is gepleit voor een kritische doorlichting van bestaande netwerkstructuren. Die aanbeveling werd ingegeven door de veelal grote aantallen netwerken in de grote steden. De taakafbakening tussen deze netwerken bleek niet zelden onhelder. Er was vaak sprake van overlap of van onvoldoende afstemming tussen netwerken. Er kon gesproken worden van inefficiënte netwerkstructuren, die een belemmering vormden voor een integrale en slagvaardige beleidsvoering. Een van de aandachtspunten voor de kritische doorlichting was de scheiding van netwerken naar beleidsstrategische en uitwoerende taken. Ook werd gepleit voor de samenstelling van netwerken langs een eenduidig criterium, zoals leeftijdsgroepen of thema's. Een eenduidig indelingscriterium zou overlap tussen netwerken kunnen voorkomen, waardoor tevens bereikt wordt dat de inspanningen van instellingen beperkt worden tot participatie in minder netwerken en dat de belasting voor hen wordt gereduceerd. In deze paragraaf gaan we in op de netwerkstructuur rond het lokale jeugdbeleid.

\subsubsection{Aantallen netwerken}

De eerste vraag betreft het aantal netwerken dat functioneert rond het jeugdbeleid. Aan de ambtenaren is gevraagd aan te geven welke netwerken of platforms er in hun gemeente zijn, wat de samenstelling is van die netwerken en welke positie zij in het beleidsproces innemen. In de vragen lijst zijn deze netwerken omschreven als groepen waarin verscheidene werkvelden vertegenwoordigd zijn, waar de gemeente in principe een rol in speelt of heeft gespeeld en die (meer of minder) regelmatig bijeenkomen. Dat betekent dat naar louter ambtelijke platforms niet is gevraagd; deze zijn in hoofdstuk 3 aan de orde geweest. Alle opgegeven netwerken zijn ingedeeld in acht veel voorkomende, naar werkveld onderscheiden typen.

Door de ambtenaren van 60 onderzoeksgemeenten zijn in totaal 178 netwerken genoemd, dus gemiddeld bijna drie netwerken per gemeente. Daarbij past de kanttekening dat het hier on een minimum aantal gaat. Het werkelijke aantal is hoger, omdat iedere gemeente per naar werkveld onderscheiden type er hoogstens één kon opgeven. Vooral van een aantal typisch uitvoerende netwerken (buurtnetwerken, zorgadviesteams in het onderwijs) zijn er echter vaak meer per gemeente. In tabel 6.x is het aantal netwerken per gemeente weergegeven. In $15 \%$ van de gemeenten functioneren geen netwerken rond het lokale jeugdbeleid. Het aandeel onderzoeksge- 
meenten waar drie of meer netwerken functioneren, bedraagt bijna $60 \%$. Er is één gemeente met negen netwerken, en er zijn drie gemeenten met acht netwerken.

Tabe: 6.:

Aantal netwerken rond jeugdbeleid per gemeente, naar stedelijkheid, $200 t$ (percentage gemeenten)

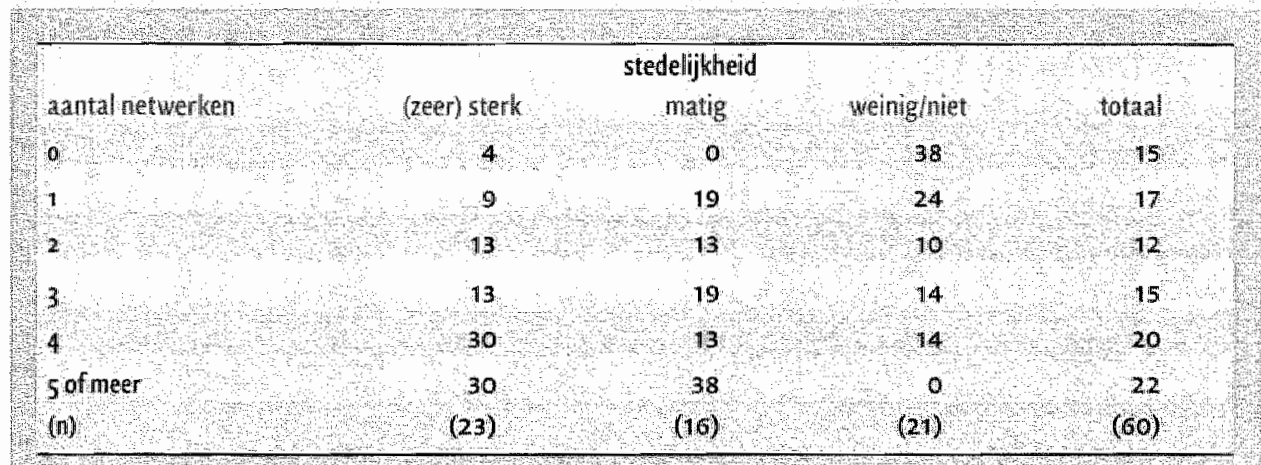

Bron SCP ( B ambienaren zoo2)

\subsubsection{Werkvelden van netwerken}

Met wat voor zaken houden de netwerken in de onderzoeksgemeenten zich bezig? In tabel 6.2 is een overzicht opgenomen van het aantal netwerken per onderscheiden werkveld. ${ }^{4}$ De meest voorkomende netwerken zijn de zogenoemde buurtnetwerken jeugdhulpverlening, of netwerken met een soortgelijke taak. Deze netwerken zijn gericht op de vroegtijdige onderkenning van risico's en problemen in opvoeding en ontwikkeling; opdat in een vroeg stadium geïntervenieerd kan worden. Bijna driekwart van de onderzoeksgemeenten heeft dergelijke netwerken. In twee derde van de gemeenten met buurtnetwerken zijn deze werkzaam in delen van de gemeente, in een derde bestrijken de buurtnetwerken het territorium van de hele gemeente. Netwerken rond jeugd en veiligheid zijn te vinden in zo'n twee vijfde van de onderzoeksgemeenten - overwegend (zeer) sterk stedelijke gemeenten. In vier op de tien onderzoeksgemeenten opereert een platform jeugdbeleid, waarmee gedoeld wordt op een netwerk dat in principe het brede terrein van het jeugdbeleid bestrijkt en waarin het gehele jeugdbeleid van de gemeente aan de orde is. Bijna even veel gemeenten kennen een netwerk voor het beleid gericht op o- tot 6 -jarigen, of, meer specifiek, het beleid rond voor- en vroegschoolse educatie. Overige netwerken komen beduidend minder voor. 
Tabel 6.2

Netwerken rond lokaal jeugdbeleid, naar werkveld, $2001(n=60)$

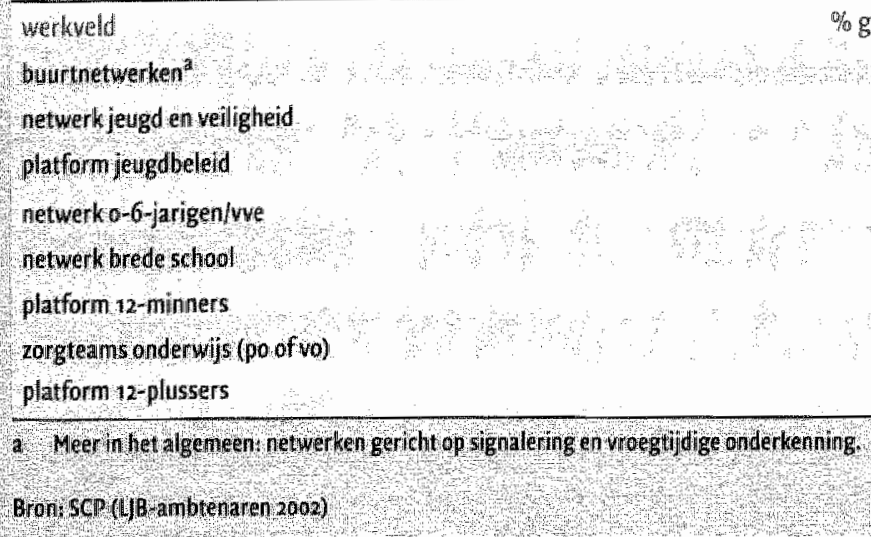

Op basis van naar werkveld onderscheiden typen netwerken is per gemeente bekeken of er een eenduidig indelingscriterium aan te wijzen is - wat nog niet betekent dat dit ook bewust is gehanteerd bij de instelling en samenstelling van netwerken. In ruim $60 \%$ van de 39 gemeenten met ten minste twee netwerken is een dergelijk criterium aan te wijzen. In twee derde van deze gemeenten is gekozen voor een thematische indeling, in eenderde voor een indeling naar leeftijdsgroepen. In ruim eenderde van de gemeenten met twee of meer netwerken is geen eenduidig indelingscriterium aanwijsbaar. Een indeling langs territoriale lijnen is vooral aan de orde waar het buurtnetwerken betreft, en is als zodanig niet uit de gegevens te destilleren, omdat er maximaal één buurtmetwerk per gemeente geteld wordt. Wel is er een enkele keer sprake van een gebiedsgebonden netwerk rond het thema jeugd en veiligheid. Een eenduidig indelingscriterium, dat zou kunnen leiden tot een efficiënte netwerkstructuur, is dus in een meerderheid van de onderzoeksgemeenten aan te wijzen.

\section{Box 6.1 Netwerken rond het jeugdbeleid}

De netwerkstructuren verschillen sterk per gemeente. Sommige gemeenten hebben een overkoepelende stuurgroep, andere niet. In sommige gevallen is er naast de stuurgroep nog een groot aantal andere netwerken met uiteenlopende bevoegdheden. Onderstaande portretten geven een indicatie van deze verscheidenheid.

De gemeente Culemborg heeft een regiegroep jeugdbeleid ingesteld. Deże regiegroep bestaat uit de coördinerende portefeuillehouder, een coördinator integraal jeugdbeleid, een lid van het managementteam en vertegenwoordigers van het voortgezet onderwiijs, het basisonderwijs, de welzijnsinstelling, de politie, het Bureau jeugdzorg en het maatschappelijk werk. De regiegroep regisseert de samenhang en samenwerking in het aanbod van activiteiten, waarbij het streven is te werken op een projectmatige 


\section{Vervolg Box 6.1 Netwerken rond het jeugdbeleid}

manier waarin alle disciplines zijn vertegenwoordigd. Verder ontwikkelde en begeleidde de regiegroep onder andere de netwerken $12+$ en $12-{ }_{\text {, }}$ de opvoedingsondersteuning, de vestiging van het JIP, de onderwijsondersteuning en projecten in de sfeer van overlastbestrijding.

Groningen kent een aantal overleggen rond het jeugdbeleid, zowel op bestuurlijk, ambtelijk als uitvoerend niveau. Op bestuurlijk niveau gaat het om besluitvormingsnetwerken waar de gemeente deel wan uitmaakt, zoals het lokale driehoeksoverleg tussen gemeente, politie en Openbaar Ministerie, of de regiegroep Jeugdzorg. Op ambtelijk niveau gaat het om de Regiegroep Integraal Jeugdbeleid, die als taak heeft om het jeugdbeleid zo te organiseren dat de inhoudelijke doelstellingen worden gehaald, dat de samenthang tussen de verschillende onderdelen wan het jeugdbeleid bewaakt wordt en dat de samenhang in de aampak wordt verbeterd. Op uitvoerend niveau wordt woorgesteld am de Stuurgroep o-12 jaar en de Werkgroep Jeugd en Veiligheid samen te laten gaan in een nieuw op te richten Uitvoeringsplatform Integraal Jeugdbeleid. Dit platform bevordert de samenhang in de uitvoering van het integrale jeugdbeleid. Vanuit én van de uitvoerende instellingen wordt aangegeven dat de gemeente kaders aanreikt die de handelingsruimte voor participanten definiëren. Daarnaast is er ruimte vaor beleidsinitiatieven van onderaf.

Rond het jeugd- en onderwijsachterstandenbeleid opereren in Leiden tal van netwerkachtige arrangementen, maar er is geen overkoepelende stuurgroep jeugdbeleid. De arrangementen komen tot uiting in verschillende vormen, zoals stuurgroepen (besluitvormend), regiegroepen (adviserend) en werkgroepen en begelleidingscommissies (actief rond de uitvoering). Een probleem dat door een aantal respondenten van uitvoerende instellingen wordt gesignalleerd, is de onduidelijkheid over wie met welke bevoegdheden aan bepaalde overlegvormen deelneemt. De lijnen zijn niet altijd duidelijk, het is niet helder met welk mandaat vanuit de eigen instelling deelnemers hun inbreng leveren. Ook de betrokkenheid van de gemeente is niet altijd helder vormgegeven: namens welke dienst of afdeling levert een ambtenaar een bijdrage, en vanuit welke rol gebeurt dat?

In Utrecht is er een stedelijke Adviesgroep Jeugdbeleid geînstalleerd die tot taak heeft stedelijk jeugdbeleid te ontwikkelen en voor afstemming tussen alle betrokken diensten, wijken en organisaties zorg te dragen. Hierin zîtten zowel ambtenaren als professionals uit het veld. Daarnaast wordt de Expertgroep Jeugd, waarin professionals uit het veld zitten, twee à drie keer per jaar om advies gevraagd. Er zal ook een 'Taskforce jeugd en ouders" ingesteld worden, die specifieke voorzieningen voor jeugd moet benoemen op het terrein van welzijn, sport en spel, gezondheidszorg en kunstzinnige vorming. De werkgroep die dit gaat doen bestaat uit deskundigen vanuit de gemeente en maatschappelijke organisaties. 


\section{Vervolg Box 6.1 Netwerken rond het jeugdbeleid}

Een van de uitgangspunten voor de regie in Utrecht is: "uitvoering van het beleid gebeurt op wijkniveau, tenzij.. In 1998 is een begin gemaakt met de vorming van Wijkregiegroepen Jeugd, De wethouder geeft aan dat de regierol voor hem bestaat uit het leggen van verbanden, met name op wijkniveau, De wijk is de voedingsbodem om ook centraal beleid te formuleren. Het gaat om het samen brengen van partijen.

\subsubsection{Positie netwerken in beleidsproces}

Wat is de positie van de netwerken in het beleidsproces? Bijna de helft van alle ( 178 ) netwerken heeft een tweeledige taak in het beleidsproces, dat wil zeggen: zij hebben zowel beleidsstrategische als uitwoerende taken. In ruim een kwart is sprake van louter beleidsstrategische netwerken, terwijl een kwart uitvoeringsnetwerken betreft. Bijna de helft van de gemeenten $(45 \%)$ kent geen uitwoerende netwerken en ruim eenderde $(37 \%)$ geen beleidsstrategische netwerken. In bijna de helft van de gemeenten $(48 \%)$ bestaan ten minste twee netwerken met een tweeledige positie in het beleidsproces.

Gezien de aanbeveling over de kritische doorlichting van netwerkstructuren is de vraag van belang of er in gemeenten met veel netwerken een scherpe taakafbakening is tussen beleidsstrategische en uitvoerende netwerken. In ongeveer de helft van de gemeenten met vier of meer netwerken blijken, bezien naar hun positie in het beleidsproces, alle drie de varianten voor te komen: zowel beleidsstrategische, uitwoerende als tweeledige netwerken. De ideaaltypische combinatie van enerzijds beleidsstrategische en anderzijds uitvoerende netwerken blijkt in slechts een op de tien gemeenten met netwerken jeugdbeleid voor te komen. Geconstateerd moet worden dat netwerken rond het jeugdbeleid zich vaak nog zowel met beleidsformulering als met beleidsuitvoering bezighouden en dat er slechts weinig gemeenten zijn waarin netwerken naar hun positie in het beleidsproces ontvlochten zijn. Dat kan tot problemen leiden, omdat het voor (vooral grotere) instellingen niet altijd duidelijk is op welk niveau een vertegenwoordiger van de instelling moet worden afgevaardigd: iemand die primair in de uitvoering bezig is, of iemand die op bestuurlijk of kaderniveau de instelling kan committeren aan bepaalde afspraken.

\subsubsection{Betrokken actoren}

Wat heeft de netwerkvorming op lokaal niveau nu voor consequenties voor de belasting van betrokken actoren? Tabel 6.3 wijst uit dat een aantal actoren in meer dan de helft van de 166 netwerken waarvan de samenstelling bekend is, vertegenwoordigd is. Het betreft het sociaal-cultureel werk, het primair onderwijs, de afdeling jeugdgezondheidszorg van de GGD, en de politie. Actoren die in relatief weinig netwerken deelnemen zijn justitie, de verslavingszorg, sportorganisaties, woningbouwcorporaties, de gemeentelijke sociale dienst, de maatschappelijke opvang en de Centra voor Werk en Inkomen. 
Tabel 6.3

Deelname actoren in netwerken, 2001

\begin{tabular}{|c|c|c|c|c|}
\hline artomen & $\begin{array}{l}\text { alle metwerken } \\
(\%, n=166)\end{array}$ & $\begin{array}{l}\text { gemuiddeld aantal } \\
\text { newwerken per } \\
\text { gerneente }(n=51)\end{array}$ & $\begin{array}{l}\text { tein minste drie } \\
\text { netwerken } \\
(0, n=34)\end{array}$ & $\begin{array}{l}\text { geentand } \\
\text { netwerk } \\
(\mathrm{w}, \mathrm{n}-\mathrm{s})\end{array}$ \\
\hline social cultureel welzijnswerk & 63 & 2, & 65 & 20 \\
\hline primair onderwijs & 61 & 2,0 & 50 & 8 \\
\hline eugdgezondheidszorg/GGD & 60 & 1,9 & 53 & 16 \\
\hline politie & 52 & 1,7 & 32 & 8 \\
\hline Bureau/Jeugdzorg & 49 & 1,6 & 41 ? & 26 \\
\hline consultatiebureau/thuiszorg & 49 & 1,6 & 32 & 18 \\
\hline tongeren/straathoekwerk & 48 & 1,6 & 41 & 20 \\
\hline algemeen maatschappelijk werk & 45 & 1,5 & 32 & 24 \\
\hline peuterspeelzalwerk & 44 & 1,5 & 24 & 26 \\
\hline voortgezet anderwijs & 43 & 1,4 & 29 & 26 \\
\hline knderopvang & 41 & 1,3 & 18 & 28 \\
\hline Opyoedingsondiersteuning & 24 & 0,8 & 9 & 51 \\
\hline bureautal, & 23 & 0,8 & औ & 45 \\
\hline justitie. & 14 & 0,5 & 6 & 67. \\
\hline verslawngszorg & 11 & 0,4 & 3 & 71 \\
\hline sportorganisatie/vereniging & 10 & 0,3 & 3 & 77 \\
\hline woning bouwcorporaties & & 0,3 & स्व & 77 \\
\hline sociale dienst & 8 & 0,3 & 3 & 77 \\
\hline maatschappelike opvang & 7 & 0,2 & $6+6$ & 84 \\
\hline $\begin{array}{l}\text { Centrum woorwerk en inkomen } \\
\text { gerniddeld aantal deelnemers }\end{array}$ & 7,1 & 0,2 & ${ }^{0}$ & 84 \\
\hline
\end{tabular}

Bron SCP (J B - anibtenaren voov)

De belasting van de verschillende actoren is ook in beeld gebracht door het gemiddelde aantal netwerken per gemeente te berekenen waaraan een actor deelneemt. Dit is (in de tweede kolom van tabel 6.3) gedaan voor de 5 I gemeenten met netwerken rond het jeugdbeleid. Het zo geschetste beeld komt goeddeels overeen met dat van de eerste kolom. Het sociaal-cultureel werk, het primair onderwijs en de afdelingen Jeugdgezondheidszorg ( $\mathrm{JGz}$ ) van de GGD nemen in gemiddeld zo'n twee netwerken deel, zelfs wanneer gemeenten met niet meer dan één netwerk in de analyse worden betrokken (zoals hier het geval is). Politie, jongeren- en/of straathoekwerk, Bureau Jeugdzorg, consultatiebureau/thuiszorg, maatschappelijk werk, peuterspeelzaal-

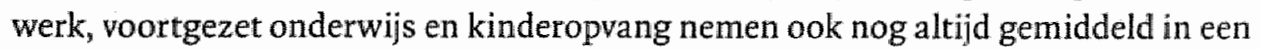
tot twee netwerken deel. De overige organisaties zijn gemiddeld in minder dan één netwerk vertegenwoordigd. 


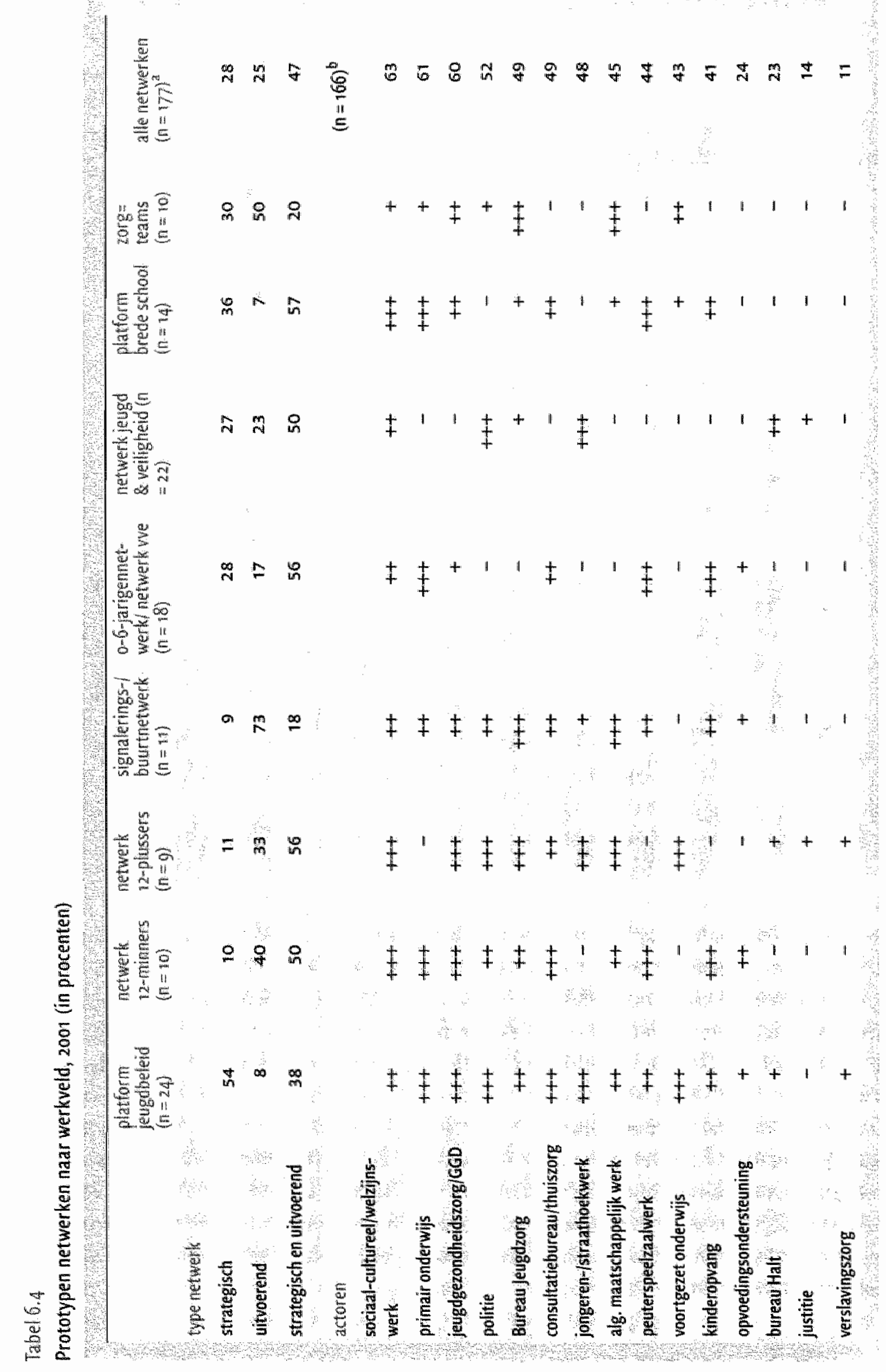




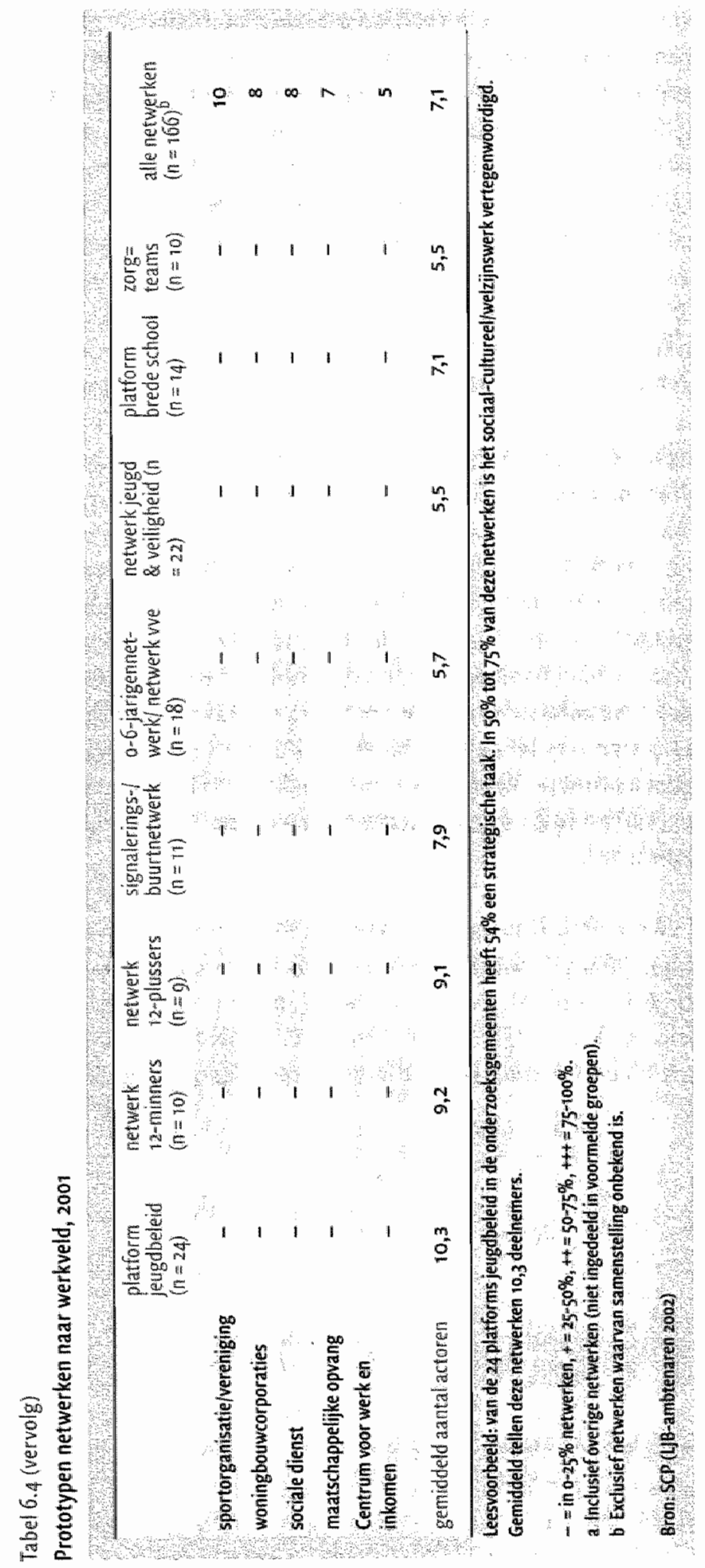


De gemiddelde deelname hangt ongeveer recht evenredig samen met het aantal gemeenten waarin de actoren in drie of meer netwerken deelnemen. Dit aantal heeft vanzelfsprekend alleen betrekking op de 34 onderzoeksgemeenten waarin ten minste drie netwerken rond het jeugdbeleid functioneren. Voor het sociaal-cultureel werk speelt een dergelijke deelname in maar liefst twee derde van deze gemeenten. Het primair onderwijs en de JGZ nemen in de helft van deze gemeenten deel aan drie of meer netwerken, het Bureau Jeugdzorg en het jongeren-/straathoekwerk doen dit in $40 \%$ van deze gemeenten.

Tot slot kunnen we kijken naar het percentage gemeenten waarin actoren in geen enkel netwerk vertegenwoordigd zijn. Dit is gedaan voor de 51 onderzoeksgemeenten met netwerken.

Het percentage is het laagst bij de politie en het primair onderwijs. Deze actoren zijn in slechts $8 \%$ van de gemeenten in geen enkel netwerk vertegenwoordigd.

Hoe zien de onderscheiden netwerken (zie tabel 6.2) er in de lokale praktijk nu doorgaans uit? In tabel 6.4 is per naar werkveld onderscheiden netwerktype getracht een typering te geven. Wat is doorgaans de positie in het beleidsproces en welke actoren nemen er meestal in deel? Vooral de platforms jeugdbeleid en de netwerken I2- en $12+$, en in iets mindere mate de signalerings- of buurtnetwerken blijken gemiddeld een brede samenstelling te kennen. Verder valt op dat alleen de platforms jeugdbeleid overwegend een strategische functie hebben. De signalerings- of buurtnetwerken zijn in hoofdzaak uitvoerend en in de overige netwerken worden strategische en uitvoerende functies gecombineerd.

Tabel 6.4 maakt de relatief $z$ ware belasting van een aantal actoren nog eens duidelijk. Welzijnsinstellingen zijn in de meeste onderscheiden typen netwerken vaak of zelfs bijna altijd vertegenwoordigd. Dat geldt ook, zij het in iets mindere mate, voor het basisonderwijs en de jeugdgezondheidszorg. Voor het basisonderwijs geldt dat het relatief veel participeert in netwerken die strikt genomen niet het onderwijs betreffen. 


\subsubsection{Classificatic van netwerkvorming}

In deze paragraaf wordt bekeken of het mogelijk is tot een classificatie van gemeentelijke netwerkvorming te komen. Deze classificatie geeft een overzicht van de wijze waarop gemeenten hun rol in de netwerkvorming uitoefenen. Daarnaast kan de classificatie gebruikt worden om de sturende rol van de gemeente in de beleidsworming, -uitvoering en -evaluatie te verklaren. Deze classificatie kan dan gebruikt worden in hoofdstuk 7 bij de constructie van een typologie van het lokale jeugdbeleid. Voor de ontwikkeling van deze typologie worden de volgende kenmerken van de netwerkvorming gebruikt: het aantal netwerken en het aantal actoren in drie of meer netwerken.

In de eerste plaats wordt bezien of er sprake is van enige netwerkvorming van betekenis. Vanzelfsprekend is dat niet het geval in gemeenten zonder netwerken, maar ook in gemeenten waar één (type) netwerk actief is dat niet als een breed platform jeugdbeleid is te typeren, is nauwelijks sprake van serieuze netwerkvorming. Deze gevallen worden aangeduid als 'geen netwerkvorming'. In de tweede plaats onderscheiden we gemeenten met één netwerk dat fungeert als breed platform voor het jeugdbeleid. In deze gevallen spreken we van eenvoudige netwerkvorming. Bovendien worden tot deze categorie de gemeenten gerekend waar twee of meer netwerken voorkomen, maar waarbij voor geen of voor maximaal één actor sprake is van deelname aan ten minste drie netwerken, of, als er slechts twee netwerken in de gemeente werkzaam zijn, deelname aan beide netwerken. Tot slot zijn er de gemeenten met meerdere netwerken waarbij voor meer dan één actor geldt dat deze aan drie of meer netwerken deelneemt, of aan twee in het geval van twee netwerken. Dit wordt aangeduid als complexe netwerkvorming.

\section{Tabel 6.5}

Classificatie van netwerkworming rond lokaal jeugdbeleid, 2001

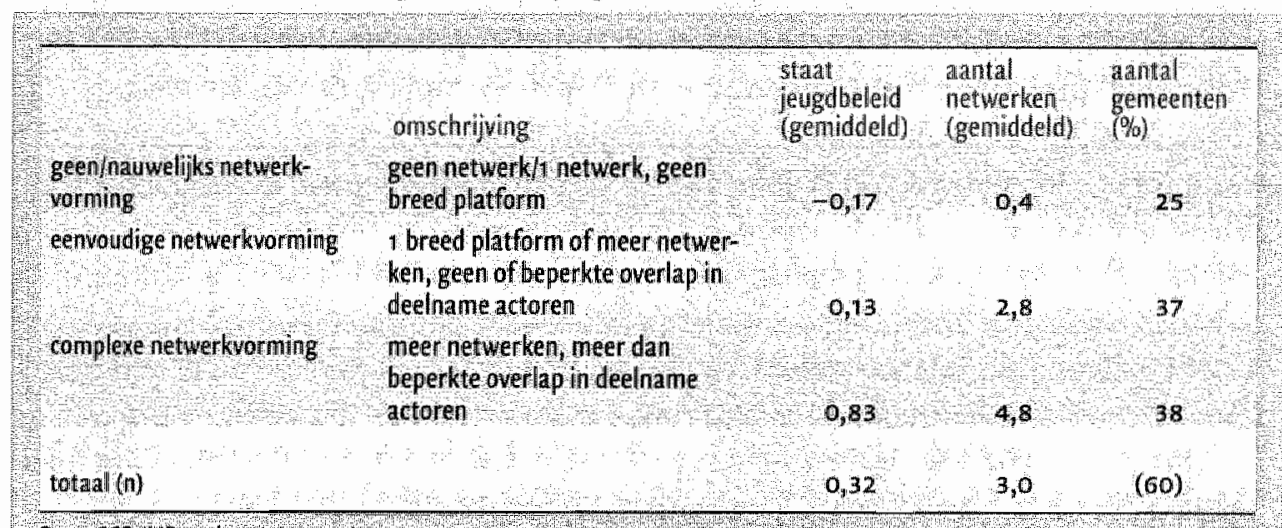

Bron, SCP (IB-amblenaren 2002)

In tabel 6.5 is weergegeven hoe het type netwerkvorming zich verhoudt tot de ontwikkeling van het jeugdbeleid in 200I. Er blijkt sprake van een duidelijke samenhang. Hoe complexer de netwerkvorming, hoe verder het beleid ontwikkeld is (en vice versa). Dat het aantal netwerken toeneemt met de complexiteit van de netwerk- 
vorming is vanzelfsprekend, omdat het een kenmerk betreft dat gebruikt is in de samenstelling van de typologie. Toch blijkt dat er geen gemeenten zijn met meer dan vier netwerken die de overlap in deelname voor de actoren beperkt houden.

\subsubsection{Conclusie}

In veruit de meeste gemeenten vindt netwerkvorming rond het jeugdbeleid plaats, wat in beginsel de integrale beleidsvoering ten goede komt Als we de netwerkstructuren rond het lokale jeugdbeleid in zijn geheel in ogenschouw nemen, dan is echter een aantal kanttekeningen te plaatsen bij de rol van gemeenten als de sturende actor in het proces van netwerkvorming. In veel gemeenten waar meerdere netwerken rond het jeugdbeleid aanwezig zijn, wordt een aantal actoren zwaar belast. Als daarbij in ogenschouw wordt genomen dat een aantal van deze actoren in het algemeen op regionale schaal opereren - politie, Bureau Jeugdzorg, JGZ, thuiszorg - plus het feit dat een aantal (uitvoerings)netwerken in de praktijk vaker voorkomen dan uit deze enkelvoudige telling blijkt, wordt deze conclusie alleen maar versterkt. Bovendien is er vaak geen heldere taakafbakening tussen netwerken. In een relatief beperkt aantal gemeenten is door het ontbreken van een eenduidig indelingscriterium de kans op overlap relatief groot. De complexiteit van de netwerkstructuren heeft mogelijk nadelige gevolgen voor het vermogen een slagvaardig jeugdbeleid te voeren.

\subsection{Beleidsvorming: de beleidsvisie als sturingsinstrument}

Een beleidsvisie, waarin in grote lijnen de doelen van het beleid zijn geformuleerd, is een belangrijk sturingsinstrument. Zo'n beleidsvisie kan andere actoren min of meer committeren aan de beleidsdoelen van de sturende actor (Klijn en Teisman 1992: 44; Gilsing et al. 2000: 12, I10-III). Een uitgewerkte beleidsvisie geeft richting aan het handelen van de verschillende bij het beleid betrokken actoren en aan het overleg in netwerken. Een beleidsvisie hangt samen met de percepties van het beleidsprobleem (Torenvlied r995:326). Het draagt bij aan de structurering van de samenwerking tussen instellingen en daarmee aan een integrale beleidswoering. In deze paragraaf wordt ingegaan op de rol van de beleidsvisie als sturingsinstrument in het jeugdbeleid: hebben gemeenten een visie, is deze richtinggevend voor instellingen, bestaat er consensus over de prioriteiten, en is de visie op interactieve wijze tot stand gekomen?

Een ander aspect van de beleidsvorming dat in deze paragraaf wordt behandeld, is de mate waarin de gemeente andere actoren betrekt bij het proces van beleidsvorming. De veronderstelling is dat het in ruime mate betrekken van andere actoren leidt tot een grotere beschikbaarheid van lokaalspecifieke informatie, waardoor het beleid beter op de lokale situatie kan worden toegespitst (maatwerk).

\subsubsection{Aanwezigheid visie}

De eerste vraag die in deze paragraaf behandeld wordt, is of gemeenten een visie op het jeugdbeleid hebben ontwikkeld. Deze vraag is voorgelegd aan de ambtelijke sleutelinformanten. Zo'n visie is daarbij omschreven als een beleidskader waarin de verschillende onderdelen van het jeugdbeleid in hun onderlinge samenhang worden 
gezien. Tabel 6.6 geeft weer in hoeverre gemeenten (zeggen) een visie ontwikkeld (te) hebben. Ruim $70 \%$ van de gemeenten zegt over een samenhangende visie op het jeugdbeleid te beschikken. De aanwezigheid van een visie hangt samen met de mate van beleidsontwikkeling in 20or (de staat wan het jeugdbeleid, zie hoofdstuk 3): hoe verder het beleid ontwikkeld is, hoe groter de kans om een beleidsvisie aan te treffen.

\section{Tabel 6.6}

Aanwezigheid visie op jeugdbeleid, naar stedelijkheid gemeenten, 2001 (in procenten)

\begin{tabular}{|c|c|c|c|c|}
\hline & (zeet) sterk & matig & weinghiet & totaal \\
\hline geen visie ontwikkeld & 13 & 25 & 550 & 29 \\
\hline wisie ontwikkeld & 87 & 75 & 50 & 71 \\
\hline (n) 13 & (23) & (16) & (20) & (59) \\
\hline
\end{tabular}

Brons SP (HB B amblenaren 20on)

Dezelfde vraag is gesteld aan de instellingen die bij het jeugdbeleid betrokken zijn. De instellingen konden aangeven of zo'n visie er was in de betreffende gemeente, en zo niet, of er plannen bestonden een visie te ontwikkelen. De antwoorden van de instellingen zijn geaggregeerd naar het gemeentelijke niveau, zodat het mogelijk is per gemeente uitspraken te doen. ${ }^{5}$ Het blijkt dat er een redelijk sterke samenhang bestaat tussen de 'gemiddelde opvatting' van instellingen en het antwoord van de ambtenaar of er een visie is: in gemeenten waar de ambtenaar aangeeft dat er een visie is, wordt dit ook relatief vaak gezien en erkend door de instellingen.

\section{Box 6.2 Sturing en beleidsformulering}

Vit de voorbeelden in deze box blijkt dat gemeenten op de nodige problemen stuiten bij het vormgeven van de regierol. De mate waarin het beleid geformuleerd is speelt daambij een rol.

De gemeentelijke regie in Appingedam bestaat vooral uit het op gang brengen van overleg tussen uitvoerende instellingen. Er is budgetfinanciering en de gemeente streeft ernaar steeds meer prestatieafspraken met instellingen te maken. Eén van de vertegenwoordigers van een uitvoerende instelling vindt evenwel dat er geen sprake is van een gemeentelijk jeugdbeleid: er is geen totaalconcept, geen visie. Wat er is zijn losse initiatieven. Er vindt dan wel overleg plaats met verschillende instellingen, maar er ontstaat geen eenheid, omdat iedereen vanuit een eigen invalshoek blijft redeneren. Een andere res pondent zou graag zien dat de gemeente de accenten in het jeugdbeleid voor éen of meer jaren zet.

De regietaak wordt in de nota jeugdbeleid van de gemeente Heeze-Leende slechts kort genoemd. De wethouder geeft evenwel aan dat het jeugdbeleid min of meer toevallig tot 


\section{Vervolg Box 6.2 Sturing en beleidsformulering}

stand is gekomen. Dit zou moeten veranderen. Gedacht zou kunnen worden aan een evaluatie van de startnota jeugdbeleid, waarna op basis daarvan tot een meer integrale nota kan worden gekomen met daarin aandacht voor de nog ontbrekende zaken. Oak vanuit de instellingen klinkt thet geluid dat de behoefte aan eenduidig gemeentelijk beleid toeneemt. Eén van de aanbevelingen uit de startnota jeugdbeleid is dat er in de gemeente permanente aandacht moet zijn voor het jeugdbeleid. Bij elk beleidswoomemen moet de vraag. gesteld worden wat de gevolgen hiervan kunnen zijn voor de jeugd. Alle medewerkers zijn verantwoordelijk voor het structureel rekening houden met de jeugd. De sectorhoofden moeten hierwoor ook verantwoordelijkheid dragen. In Heeze-Leende ontbreekt het aan een adequaat metwerk van instanties , bijwoorbeeld woor peuterspeelzalen, kinderopvang en basisonderwijs. Daardoor is het beleid te veel ad hoc. Erwordt vooral vanuit welzijn aan het jeugdbeleid gewerkt. Volgens één van de respondenten van uitvoerende instellingen heeft het jeugdbeleid geen hoge prioriteit bij de gemeente en is de voortgang traag.

De Vlissingse wethouder en ambtenaar zien beiden een regierol voor de gemeente weggelegd, waarbij het gaat om de sturing van instellingen door de gemeente. Ze vinden dat de regierol op sommige gebieden nog niet zo goed wordt aangepakt. In de nota's wordt op het gebied van regie veell nadruk gelegd op samenhang en afstemming van het beleid, zowel intern als extern. Eén van de middelen om de regierol waar te maken is door gebruik te maken van subsidiecontracten met uitvoerende instellingen. Uit de interviews met vertegenwoordigers van ü̈tvoerende instellingen blijkt dat de afstemming en samenwerking zowel met betrekking tot instellingen als met betrekking tot de ambtelijke organisatie een knelpunt is. Instellingen missen een structureel kader voor het beleid, lange termijn doelstellingen en visie van de gemeente. Andere knelpunten zijn de trage besluitvorming, het bestaan van verschillende geldstromen en het idee dat de gemeente weinig zicht heeft op de praktijk.

Het jeugdbeleid in Voorburg is door de gemeente in samenspraak met uitvoerende instellingen en na een behoefteonderzoek onder jongeren wan $12-18$ jaar opgesteld. In 1997 is hiervoor de basis gelegd toen er een inventarisatie werd verricht van problemen onder jongeren en van maatregelen die reeds werden genomen. Voor de ontwikkeling en verdere uitwoering van het jeugdbeleid is een aantal initiatieven tot samenwerkingsverbanden genomen en is een aantal nieuwe activiteiten gesubsidieerd. Vanuit de uitwoerende instellingen wordt opgemerkt dat de gemeente "het veld" meer zou moeten sturen, er wordt een helikoptervisie gemist. De gemeente werkt richting de instellingen met budgetsubsidies en productafspraken. Hoe deze afspraken worden nagekomen is aan de instellingen, waardoor zij een grote mate van beleidsvrijheid kennen. De nota jeugdbeleid heeft wel een positieve invloed gehad op het werk, zo stellen de respondenten vanuit de uitvoerende instellingen. Voor een deel is er erkenning van activiteiten die toch al gedaan werden. Het opnemen wan deze activiteiten in de nota betekent tevens een legitimatie ervan. 


\subsubsection{Richtinggevendheid visie en consensus over visie}

In hoeverre is de ontwikkelde visie richtinggevend voor de uitvoerende instellingen? Op een driepuntsschaal, die loopt van 'ja' (1) via 'deels wel, deels niet' (2) tot 'nee' (3), konden de instellingen aangeven in hoeverre de visie als richtinggevend ervaren is (zie tabel 6.7). Het grootste deel van de instellingen ( $59 \%$ ) ervaart de visie ten dele als richtinggevend, en nog eens $39 \%$ ervaart hem als richtinggevend zonder meer. Slechts een zeer beperkt aantal instellingen ziet de gemeentelijke visie niet als richtinggevend. De gemiddelde score onder alle instellingen was $\mathrm{r}, 6$. Kijken we naar het gemeentelijke niveau, dan zien we dat in $40 \%$ van de gemeenten de score van de instellingen gemiddeld 1,5 of lager is, wat betekent dat in deze gemeenten de meeste instellingen de visie als zonder meer richtinggevend zien. Slechts in $5 \%$ van de gemeenten is het gemiddelde oordeel van de instellingen hoger dan 2, dat wil zeggen, minder dan gedeeltelijk richtinggevend.

\section{Tabel 6.7}

Mate warin instellingen beleidsvisie als richtinggevend ervaren, 2001 ( $n=246$; in procenten)

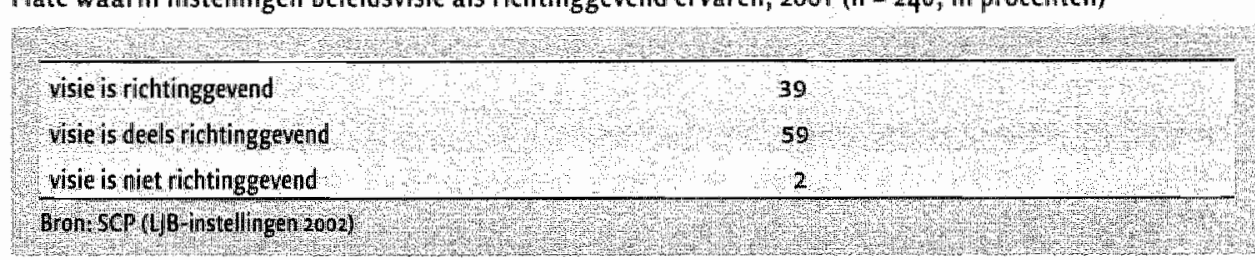

Stemmen de instellingen in met de prioriteiten die in de visie zijn opgenomen? Van de instellingen die deze vraag wilden of konden beantwoorden $(80 \%$ van de instellingen die zeggen dat de gemeente een visie heeft of zal krijgen), stemt bijna een op de zes volledig in met de in de visie neergelegde prioriteiten. De overgrote meerderheid $(84 \%)$ is het eens op hoofdlijnen en $\mathrm{I} \%$ zegt het niet eens te zijn met de prioriteiten in de beleidsvisie. Een vijfde van de instellingen die zeggen dat de gemeente een visie heeft of zal krijgen, gaf aan de vraag niet te kunnen beantwoorden ondat het hen nog niet duidelijk is welke prioriteiten in de visie worden gesteld, of, stelliger, omdat er naar hun mening geen prioriteiten worden gesteld. Voor deze instellingen is de visie op het jeugdbeleid in ieder geval voorlopig van beperkte waarde.

\subsubsection{Betrokkenheid bij ontwikkeling visie}

Om een op de lokale situatie toegespitst beleid te voeren, is het van belang optimaal gebruik te maken van de aanwezige kennis en informatie over de lokale situatie. Daarom is de vraag gesteld of andere actoren dan de gemeente betrokken zijn geweest bij de ontwikkeling van de visie. Aan de ambtenaren die aangaven dat de gemeente over een beleidsvisie beschikt, is gevraagd of en op welke wijze bij de ontwikkeling daarvan andere actoren zijn betrokken. In totaal zijn acht verschillende mogelijkheden voorgelegd (zie tabel 6.8). Alle gemeenten geven aan dat ze op ten minste één manier andere actoren hebben betrokken. Opvallend is dat in ongeveer de helft van de gemeenten met een visie gesprekken daarover met jongeren zijn gevoerd. Dat duidt erop dat een aanzienlijk aantal gemeenten de jeugd bij de beleids- 
formulering zegt te betrekken. Twee derde van de gemeenten heeft drie of meer van de acht instrumenten ingezet bij de visieontwikkeling. Het vaakst zijn andere actoren betrokken door het formeren van een voorbereidende werkgroep met deelname van instellingen, soms met betrokkenheid van jongeren, soms zonder die betrokkenheid. Daarnaast is instellingen relatief vaak de mogelijkheid geboden bilateraal te reageren op de visieontwikkeling.

\section{Tabel 6.8}

Betrokkenheid van niet-gemeentelijke actoren bij ontwikkeling visie lokaal jeugdbeleid, 2001

$(n=45$; percentage gemeenten)

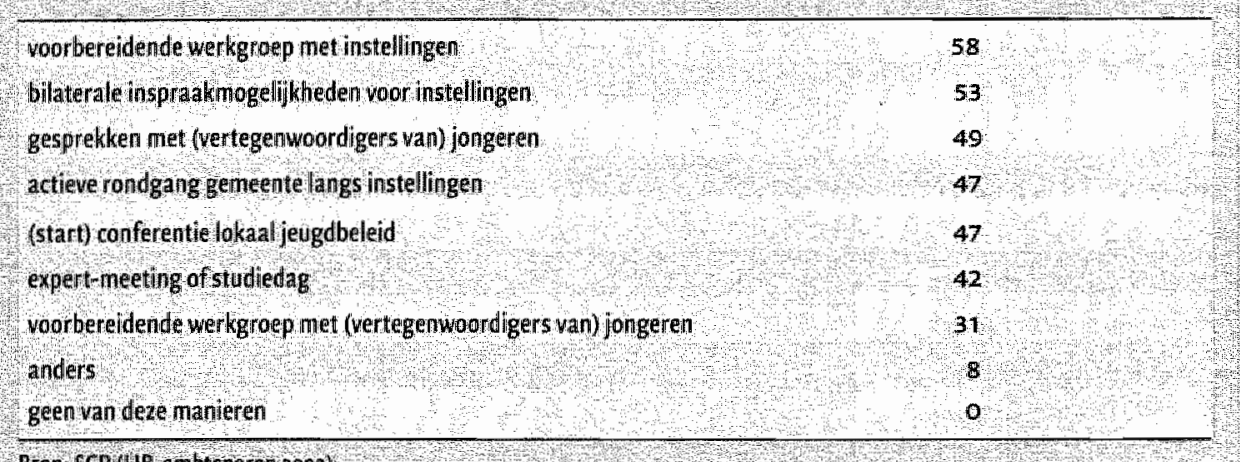

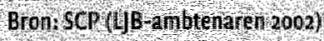

Van de $37 \mathrm{r}$ instellingen uit de 72 gemeenten die meegewerkt hebben aan het instellingenonderzoek geeft in totaal $59 \%$ aan betrokken te zijn bij de formulering van het lokale jeugdbeleid in de betreffende gemeente (zie tabel 6.9). Hiervan is het overgrote deel ook betrokken bij de beleidsuitvoering. Ongeveer een op de tien instellingen is alleen betrokken bij de beleidsformulering en niet bij de uitvoering. Een kleine $20 \%$ is alleen betrokken bij de uitvoering, terwijl nog eens ruim $20 \%$ aangeeft niet of nauwelijks bij het jeugdbeleid van de betreffende gemeente betrokken te zijn. In de minder stedelijke gemeenten zijn in het algemeen minder typen actoren (van de tien typen die in het instellingenonderzoek voorkomen) bij het jeugdbeleid betrokken dan in de meer stedelijke gemeenten. Dit werd ook al geïndiceerd door het geringere aantal netwerken in de weinig tot niet-stedelijke gemeenten. De mate van betrokkenheid van andere actoren bij zowel beleidsformulering als -uitvoering hangt ook samen met de ontwikkeling van het jeugdbeleid: in de gemeenten waar het jeugdbeleid het verst ontwikkeld is, zijn gemiddeld meer instellingen bij zowel formulering als uitvoering betrokken dan in gemeenten met een minder ver ontwikkeld jeugdbeleid. 
Tabel 6.9

Betrokkenheid instellingen bij lokaal jeugdbeleid, $2001(n=363 ;$ in procenten)

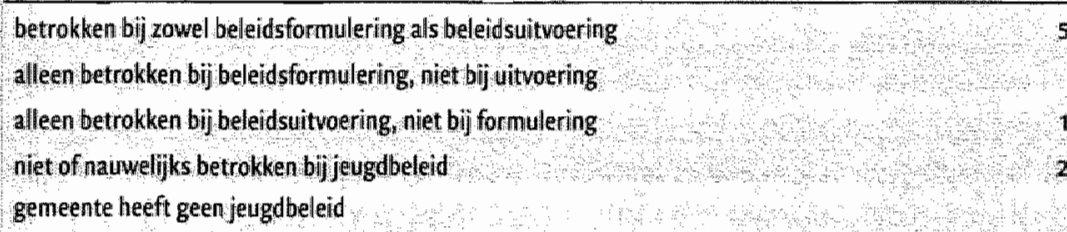

50

9

18

22

1

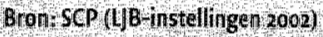

Wat vinden de bij de beleidsformulering betrokken instellingen nu van het functioneren van de werkgroepen die zich met de voorbereiding van het jeugdbeleid bezighouden? Het oordeel is gemengd. Zo'n $70 \%$ van de instellingen is weliswaar van oordeel dat de platforms goed functioneren, maar twee derde van deze groep vindt ook dat de platforms naar verhouding weinig resultaat opleveren. Overigens onderhouden de meeste instellingen bilaterale contacten met gemeenten over zaken die gerelateerd zijn aan de beleidsontwikkeling. Deze contacten behelzen onder meer de uitwisseling van gegevens met de gemeente over de leefsituatie van de jeugd en de afstemming met de gemeente over problemen die dienen te worden aangepakt.

De betrokkenheid van instellingen bij de beleidsformulering leidt er bovendien toe dat zij zich vaker helemaal of grotendeels kunnen vinden in datgene wat de gemeente in de uitwoering van hen vraagt. $79 \%$ van deze instellingen heeft hier met de gemeente consensus over, terwijl dat percentage bij de instellingen die niet betrokken zijn bij de beleidsformulering $48 \%$ is. Dit onderstreept het belang van interactieve beleidsworming als sturingsinstrument.

\subsubsection{Conclusie}

Veel gemeenten hebben een visie op het jeugdbeleid, die door de meeste betrokken instellingen in ieder geval ten dele, en soms ook als sterk richtinggevend wordt gezien. Bovendien is er in de meeste gevallen ten minste op hoofdlijnen consensus tussen instellingen en gemeente over deze visie. De kanttekening daarbij is dat een aanzienlijk deel van de instellingen ofwel aangeeft dat de gemeente geen visie heeft dan wel dat zij daar niet van op de hoogte zijn ( $22 \%$ ), ofwel aangeeft dat in de gemeentelijke visie (nog) geen prioriteiten ten aanzien van het jeugdbeleid zijn. gesteld ( $5 \%$ van alle instellingen). Op het gemeentelijke niveau hebben we echter kunnen concluderen dat in slechts $5 \%$ van de gemeenten de instellingen de richtinggevendheid van de visie sceptisch beoordelen. De meeste gemeenten trachten door een min of meer richtinggevende visie de integrale beleidsvoering te versterken.

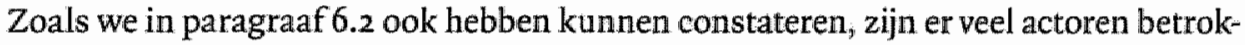
ken bij het lokale jeugdbeleid. Een meerderheid van deze actoren heeft een rol in de beleidsformulering. Ook jongeren worden in een aanzienlijk aantal gemeenten gehoord. We kunnen daardoor in ieder geval zeggen dat gemeenten trachten de 
lokaal aanwezige informatie aan te wenden in de beleidsworming, waardoor het jeugdbeleid beter op de lokale situatie kan worden toegespitst.

\subsection{Beletasuitvoering}

Vanuit het perspectief van integrale beleidsvoering is het wenselijk dat de uitvoering van het beleid wordt gecoördineerd. Torenvlied (1996:4) definieert beleidsuitvoering als 'de omzetting van de uitkomst van collectieve besluitvorming, dat wil zeggen het politieke besluit, in handelingen van één of meer uitvoerende organisaties'. In dit onderzoek zijn de uitkomsten van collectieve besluitvorming neergelegd in de doelen en maatregelen van het jeugdbeleid. De afspraken hierover zijn vaak in beleidsnetwerken of in samenspraak tussen de gemeente en andere actoren tot stand gekomen, zo hebben we in de paragrafen 6.2 en 6.3 gezien. In deze paragraaf gaan we in op de sturing door de gemeente van deze handelingen. We kijken naar de afspraken die gemeenten met uitvoerders maken en naar de beleidswrijheid die instellingen in de beleidsuitwoering genieten. Daarbij gaan we er vanuit dat een zekere handelingswrijheid voor de uitvoerders de slagvaardigheid in het beleid ten goede komt. Bovendien is van belang of instellingen in hun uitvoerende handelingen afwijken van het geformuleerde beleid: 'Per organisatie vormen deze handelingen de beleidsprestatie die de organisatie levert. (...) Wanneer de beleidsprestatie verschilt van het politieke besluit, is er sprake van een beleidsafwijking.' (Torenvlied rg96:4)

\subsubsection{Aansturing van de beleidsuitvoering}

Maken de gemeenten afspraken met de instellingen over de te leveren bijdrage aan het jeugdbeleid, ofwel de te leveren beleidsprestaties? Van de 258 instellingen die in de 72 onderzoeksgemeenten betrokken zijn bij de uitvoering van het jeugdbeleid, heeft een grote meerderheid $(8 \mathrm{r} \%)$ afspraken gemaakt met de gemeente over de bijdrage van de instelling aan dat beleid. Als we naar het gemeentelijke niveau kijken, dan zegt in $79 \%$ van de gemeenten ten minste twee derde van de instellingen dat zij dergelijke afspraken met de gemeente hebben. Dit gebeurt relatief vaak in gemeenten met een naar verhouding ver ontwikkeld jeugdbeleid. De afspraken zijn op verschillende wijzen vastgelegd, zoals in projectplannen, subsidiecontracten, gemeentelijke nota's of convenants. In een klein deel van de gevallen zijn de afspraken niet schriftelijk vastgelegd.

Hoe komen dergelijke afspraken tot stand? Ligt het initiatief bij de gemeente, of neemt de instelling het voortouw? Meestal (in twee derde van de gevallen) zijn deze afspraken tot stand gekomen op gezamenlijk initiatief van instelling en gemeente. In veel gevallen is dus - in ieder geval volgens de instellingen - sprake van interactiviteit bij het opstellen van implementatieplannen. In de afspraken die tussen instellingen en gemeenten zijn gemaakt, zijn in het algemeen doelstellingen opgenomen. Bij slechts ro\% van de afspraken is dat niet het geval. In de helft van deze afspraken zijn kwantitatief geformuleerde doelstellingen opgenomen. 
Leiden deze afspraken ertoe dat voor de instellingen duidelijk is wat de gemeente nu precies van hen verwacht? Voor een aanzienlijke minderheid van de instellingen zijn de verwachtingen van de gemeente slechts gedeeltelijk $(32 \%)$ of zelfs helemaal $(8 \%)$ niet duidelijk. Voor de meerderheid van de instellingen zijn de verwachtingen grotendeels $(45 \%)$ of zelfs volstrekt ( $12 \%$ ) duidelijk. Op gemeentelijk niveau vinden we dat in $40 \%$ van de gemeenten de gemiddelde instellingsscore op deze variabele 2,5 of lager is, wat betekent dat daar ten minste de helft van de instellingen de gemeentelijke verwachtingen ten aanzien van de beleidsprestaties van de instelling niet of slechts ten dele duidelijk vindt.

Hoe schatten instellingen nu hun eigen beleidsvrijheid in bij de uitvoering van hun bijdrage aan het lokale jeugdbeleid? Van de instellingen die bij de uitvoering betrokken zijn, zegt $8 \mathrm{r} \%$ over een grote of redelijk grote mate van beleidswrijheid in de uitvoering te beschikken. Slechts $5 \%$ van de instellingen vindt de beleidsvrijheid tamelijk klein of heel klein. ${ }^{6}$

\subsubsection{Beleidsafwijkingen in de uitvoering}

Wanneer de beleidswoorkeuren van uitvoerders afwijken van de uitkomsten van collectieve besluitvorming zullen zij eerder geneigd zijn om in de uitvoering van dat beleid af te wijken (Torenvlied I996). Of uitwoerders die het oneens zijn met het geformuleerde beleid daar daadwerkelijk van afwijken, hangt af van een aantal factoren. Ten eerste speelt het belang dat men hecht aan de eigen beleidswoorkeur een rol. Is dat groot, dan is de prikkel om van het geformuleerde beleid af te wijken ook groter. Ten tweede speelt de eigen controlegevoeligheid een rol. Hieronder wordt verstaan de inschatting van de kans om gesanctioneerd te worden voor het afwijkende gedrag, waarbij ook de omvang van de sancties een rol speelt. Wordt die kans hoog ingeschat, dan maakt dat de kans op beleidsafwijkingen kleiner. Eenderde factor is de mate waarin besluitvormers in staat zijn controle uit te oefenen op uitvoerders door middel van selectie, administratieve procedures en sancties. Deze factor heeft direct te maken met de politieke sturing. Als er een sterke politieke sturing bestaat, is de kans op beleidsafwijkingen kleiner.

Om beleidsafwijkingen te bepalen, wordt ingegaan op de doelrealisatie door instellingen. Voor de kans op beleidsafwijkingen kijken we naar de samenhang daarvan met de mate van consensus tussen gemeente en instelling over het beleid, met het belang dat de instelling toekent aan haar bijdrage aan het jeugdbeleid, met de gevoeligheid van de instelling voor toezicht door de gemeente, en met de ervaren politieke sturing vanuit de gemeente. Op die manier wordt inzicht verkregen in de vraag wat voor de gemeente belangrijke sturingselementen zijn in het uitvoeringsproces.

Aan de instellingen is gevraagd of de doelen van het lokale jeugdbeleid, voorzover deze binnen het werkveld van de instelling vallen, gerealiseerd worden. Deze vraag naar doelrealisatie is gebruikt om vast te stellen in hoeverre er sprake is van beleids- 
afwijkingen. Immers, als doelen niet gerealiseerd worden, is dat een afwijking van het geformuleerde beleid. Een opmerkelijk groot deel van de instellingen (ruim een op de vijf) geeft aan niet te weten of de doelen gerealiseerd worden, wellicht omdat het te vroeg is om dat aan te geven. Van de instellingen die zich hier wel een mening over vormen, zegt $13 \%$ dat de doelen volgens planning worden gerealiseerd, en $20 \%$ dat de doelen wel worden gerealiseerd, maar met vertraging (tabel 6.10 ). $61 \%$ denkt dat de doelen slechts ten dele zullen worden gerealiseerd en nog eens $5 \%$ dat ze helemaal niet zullen worden bereikt. Ruim $80 \%$ van de instellingen die het aandurven een inschatting te maken van de doelrealisatie denkt dus dat zij van het geformuleerde beleid zullen afwijken. Volgens een minderheid komt deze beleidsafwijking woort uit vertraging, de meeste instellingen wijzen op het slechts gedeeltelijk halen van de doelstellingen.

\section{Tabel 6.10}

Inschatting mate van doelrealisatie op het eigen werkweld door instellingen, 2001 ( $n=251$; in procenten)

doelen volgens planning gerealiseerd
doelen met vertraging gereal seerd
doelen deels gerealliseerd
doeten niet gerealiseend

Bronsce (JB intellingen 2002 )

In de theorie van Torenvlied ( $\left(9 g^{6} 6\right)$ is de cruciale factor voor het al dan niet optreden van beleidsafwijkingen de mate waarin de uitvoerende instelling zich kan vinden in het geformuleerde beleid. Deze vraag is op twee manieren aan de instellingen voorgelegd. In de eerste plaats is gevraagd of men het eens is met de in de beleidsvisie opgenomen prioriteiten. In paragraaf 6.3 bleek al dat, als er een gemeentelijke beleidsvisie is, deze door vrijwel alle instellingen geheel of in grote lijnen gesteund wordt. In de tweede plaats is gevraagd naar de consensus tussen gemeente en instelling over de bijdrage van de instelling aan de uitvoering van het jeugdbeleid. Ook hierover bestaat in het algemeen consensus: ruim $70 \%$ van de instellingen die betrokken zijn bij de uitvoering van het jeugdbeleid is het helemaal of in grote lijnen met de gemeente eens over de door de instelling te leveren bijdrage. Bijna 30\% is het daar maar ten dele $(2 \mathrm{i} \%)$ of nauwelijks of niet $(8 \%)$ met de gemeente over eens. Als de mate van consensus over de beleidsvisie en over de bijdrage van de instelling aan het jeugdbeleid worden samengenomen, blijkt een vijfde van de instellingen het op ten minste een van beide punten niet of slechts ten dele eens te zijn met de gemeente, terwijl $6 \%$ het op beide punten volledig eens is met de gemeente (zie tabel 6.II). 


\section{Tabel 6.11}

Consensus tussen instellingen en gemeente over visie en over bijdrage instelling, 2001 ( $n=197$; percentage instellingen)

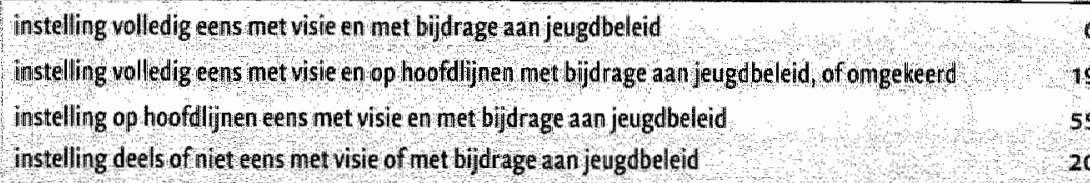

Bron. S CP (Y) Bnstellingen 2002 )

De verwachting is dat instellingen die het (gedeeltelijk) oneens zijn met de gemeente over ofwel de beleidsprioriteiten ofwel de concrete bijdrage van de instelling aan het jeugdbeleid, in sterkere mate denken van het beleid af te zullen wijken. Uit tabel 6.12 blijkt dat een dergelijk verband inderdaad bestaat. Instellingen die het (volledig of in hoofdlijnen) eens zijn met de gemeente verwachten vaker dat de doelen zullen worden gerealiseerd, terwijl instellingen die het (deels) oneens zijn met de gemeente vaker aangeven dat de doelen op hun werkveld slechts ten dele of niet zullen worden gerealiseerd. Met andere woorden: de kans op beleidsafwijkingen is bij consensus over het beleid kleiner dan bij meningsverschillen over de visie of over de te leveren beleidsprestaties.

\section{Tabel 6:2}

Doelrealisatie (beleidsafwijkingen) naar consensus tussen gemeente en instelling, 2001 (in pracenten) ${ }^{7}$

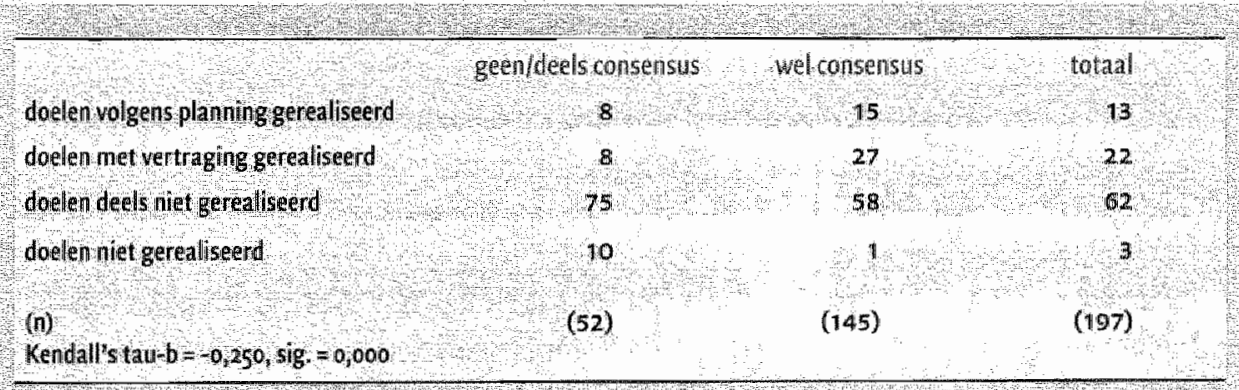

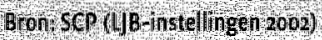

\section{Box 6.3 Belleidsuitvoering en -evaluatie}

Veel gemeenten stoeien met het toezicht op uitvoeringsprocessen en met de beleidsevaluatie, De meest stedelijke gemeenten lijken het verst te zijn in de effectevaluatie, hoewel dat ook daar problemen met zich meebrengt.

In de gemeente Appingedam is er ten aanzien van monitoring nog niets structureel geregeld. Wel leggen alle scholenveel gegevens vast door middell van leerlingvolg- 


\section{Vervolg Box 6.3 Beleidsuitvoering en -evaluatile}

systemen. De gemeente geeft aan te wachten op een model voor monitoring van het beleid in de grote steden dat door de Vereniging van Nederlandse Gemeenten (VNG) wordt ontwikkeld en voor kleinere gemeenten geschikt zall worden gemaakt. De effecten van het jeugdbeleid worden op onderdelen geëvalueerd. Instellingen rapporteren mondeling en schriftelijk aan de gemeente. Erwordt gewerkt aan een systeem van brede evaluatie, waarin bekeken wordt of meetbare doelstellingen worden gehaald. Het formuleren van meetbare doelstellingen is volgens de wethouder lastig; toch wordt er getracht zoveel mogelijk kerncijfers te krijgen. Volgens een respondent van één van de instellingen lag de nadruk vroeger meer op inhoud, doelstellingen en doelgroepen, en dat gaf aanknopingspunten voor meer inhoudelijk overleg. Volgens haar ligt de nadruk nu erg op cijfers, omdat de wethouder daar erg aan hecht.

Het Culemborgse beleid wordt in grote lijnen door de regiegroep (zie box 6.1) geëvalueerd, zo blijkt uit de nota jeugdbeleid. De wijze van evalueren verschilt per project, en is ook afhankelijk van de vraag of er vooraf meetbare doelstellingen zijn geformuleerd. In het geval van kwalitatieve doelen is het toetsingskader vaak impliciet en dat maakt evaluatie lastig. Met name in deze gevallen is de regiegroep afhankelijk van de kwaliteit van de informatie zoals die door de uitvoerders geleverd wordt. De wethouder plaatst in algemene zin vraagtekens bij de mogelijkheden voor gemeenten om uitvoeringsprocessen te monitoren en resultaten te evalueren. Ook de ambtenaar zet vraagtekens bij de evaluatiepraktijk: als je het goed wilt doen, moet je externe bureaus inhuren omdat intern de kennis en capaciteit niet aanwezig is. Het inhuren van externen is echter veel te kostbaar en gaat ten koste van bijvoorbeeld het woortzetten wan succeswolle projecten. Een algemeen knelpunt bij projectmatig werken is de financiering ervan. Er is niet altijd geld om succesvolle projecten woort te zetten. Dat is woor de betrokkenen frustrerend.

Eén van de respondenten van uitvoerende instellingen in Groningen geeft aan dat zijn instelling wordt gesubsidieerd op basis van een begroting. Aan die begroting ligt een budgetovereenkomst ten grondslag waarin productiecijfers staan. Het gaat hierbij om het aantal contacten, de duur van de contacten, het aantal allochtonen en verplichtingen in het kader van specifieke projecten of jaarprogramma's.

Het Groningse beleid wordt gevolgd door onder andere herhaalde metingen. Deze vinden sinds 1996 plaats en zijn gericht op de leeftijdsgroep 10-16-jarigen. Voor deze monitor wordt van verschillende bronnen gebruikgemaakt, zoals de jeugdpeiling, bestaande registraties, de trendrapportage jeugd, uitgaven wan het Sociaal en Cultureel Planbureau (SCP) en ander onderzoek, gesprekken met deskundigen en beleidsevaluaties en werkdocumenten van instellingen. 


\section{Vervolg Box 6.3 Beleidsuitwoering en -evaluatie}

De ambtenaar van de gemeente Spijkenisse geeft aan dat projecten worden geëvalueerd. De informatie die nodig is voor een evaluatie wordt geleverd door sleutelinformanten bij instellingen en binnen de gemeente, projectverslagen en soms door een externe evaluatie. Een knelpunt in de evaluatie is volgens de ambtenaar het gebrek aan kwantitatief materiaal.

Eén van dle uitvoerenden vindt dat er wat betreft evaluatie weinig door de gemeente gestuurd wordt. De gegevens worden niet systematisch doorgewerkt. Tegelijkertijd geeft de respondent aan dat de ambtenaar veel weet uit andere dan de officiële bronnen, em ook stuurt langs andere wegen dlan langs de formele evaluatie. Een jeugdmonitor is in woorbereiding.

De gemeente Utrecht poogt in het algemeen kwalitatieve en kwantitatieve doelen te stellen, maar is realistisch in de termijn waarop resultaten te zien zijn van het beleid: dat heeft tijd nodig. Er wordt goed bijgehouden hoe "het gaat" met het jeugdbeleid en dit komt onder andere terug in het jaarlijkse programma voor de jeugd. Begin 1998 verscheen het rapport Monitor jeugdproblematiek, een eerste nulmeting van de "staat van de jeugd' in de stad. Die nulmeting en de daarbij ontwikkelde methodiek bieden de mogelijkheid om regelmatig te meten welke veranderingen zich voordoen in de situatie van de jeugd. Regelmatig wordt er een Jeugd Utrecht Peiling (JUP) gehouden, waarin de jeugd van Utrecht wordt gevraagd naar haar mening over jeugdzaken, zoals school en werk, veiligheid en vrije tijd. De ambtenaar geeft aan dat er nog niet altijd duidelijke doelen en resultaten zijn geformuleerd en dat daarom niet duidelijk is wat er geèvalueerd moet worden.

Uit de interviews met uitvoerenden komt naar voren dat evaluatie niet altijd gericht is op de inhoud, maar met name ook op het proces, op de organisatievorm of op de resultaten in cijfers. Eén van de respondenten geeft aan dat de projecten over het algemeen beter gecontroleerd worden dan de reguliere activiteiten. Zij zijn door hun specifieke doelstellingen, methodiek en middelen makkelijker te evalueren.

De evaluatie van het Vlissingse beleid is nog niet zo sterk ontwikkeld. Dit komt met name omdat niet duidelijk is wat de doelstellingen zijn die geëvalueerd moeten worden en wat als 'beginpunt' moet worden genomen. Daarnaast wordt in eén van de nota's ook gesteld dat van een 'eindevaluatie' geen sprake kan zijn. Er kan hooguit iets gezegd worden over de voortgang. De vergelliking tussen momentopnames moet houvast geven omtrent de wenselijkheid van bijsturing van het beleid en daartoe zouden de registratievormen uniform moeten zijn. De wethouder geeft aan dat de evaluaties tot nu toe met name kwalitatief van aard zijn. De ambtenaar geeft aan dat een van de knelpunten bij evaluatie de effectiviteitmeting is van welzijnsvoorzieningen zoals een skatebaan of een incidenteel voetbaltoernooi. De inspanning om die effecten te meten staat in geen verhouding tot het rendement van dergelijke metingen. 
In de inleiding van deze subparagraaf $(6.4 .2)$ is gesteld dat de kans dat instellingen die het niet eens zijn met de prioriteiten van de gemeente afwijken van het geformuleerde beleid, samenhangt met drie factoren. Die kans wordt groter naarmate het belang toeneemt dat de instelling aan het beleid toekent, naarmate de kans op sancties bij beleidsafwijkingen hoger wordt ingeschat; en naarmate de kracht van de politieke sturing toeneemt. Deze drie factoren komen hierna aan de orde.

In de eerste plaats is de instellingen gevraagd hoe groot zij het belang achten van de bijdrage van de instelling aan het welslagen van het jeugdbeleid. Bijna zeven op de tien instellingen die bij de uitvoering van het jeugdbeleid betrokken zijn, achten het belang van hun bijdrage groot. Ruim een kwart acht het belang groot noch klein, terwijl $3 \%$ aan de eigen bijdrage een marginaal belang toekent. Er is op dit punt evenwel geen significant verschil gevonden tussen instellingen die het eens zijn met de gemeente over de hoofdlijnen van beleid en hun bijdrage aan de uitvoering enerzijds en instellingen die hierover geen of gedeeltelijke consensus met de gemeente hebben anderzijds. Daarom kan niet worden aangetoond dat het belang dat men toekent aan de eigen bijdrage woor het welslagen van het jeugdbeleid een rol speelt bij het realiseren van beleidsafwijkingen door uitvoerende instellingen.

Om de percepties te bepalen die instellingen hebben van de kans op sancties bij beleidsafwijkingen, ofwel hun controlegevoeligheid, is een schaal gemaakt die een aantal aspecten omvat. Deze aspecten zijn: de perceptie van het toezicht door de gemeenten op afspraken die gemaakt zijn over te leveren beleidsprestaties, de perceptie van de sanctiemogelijkheden van de gemeente, de perceptie van de bereidheid van de gemeente die sanctiemogelijkheden in te zetten, de vraag of en door wie er een evaluatie plaatsvindt van de bijdrage die de instelling levert aan het jeugdbeleid, en de vraag of de instelling over haar bijdrage moet rapporteren aan de gemeente.

De frequentieverdelingen van deze afzonderlijke variabelen en van de samengestelde schaal zijn opgenomen in tabel 6.x3. De perceptie van instellingen van de controleen sanctiemogelijkheden bij de gemeente is vooral hoog als het gaat om de evaluatie van de beleidsprestaties door of met de gemeente, en op het punt van verplichte rapportages aan gemeenten. Bij het laatste punt is het echter opmerkelijk te noemen dat liefst $40 \%$ van de instellingen zegt dat zij niet aan de gemeente hoeft te rapporteren over de beleidsprestaties. Op de schaal van controlegevoeligheid scoort ruim eenderde van de instellingen hoog, en $10 \%$ scoort laag.

Het blijkt dat ook de perceptie van de kans op sancties en van het toezicht niet samenhangen met het realiseren van beleidsafwijkingen, ook niet als daarbij rekening wordt gehouden met de vraag of er al dan niet consensus bestaat tussen instelling en gemeente. 
Tabel6.13

Controlegevoeligheid bij instellingen, indicatoren en schaal, 2001 (percentage instellingen)

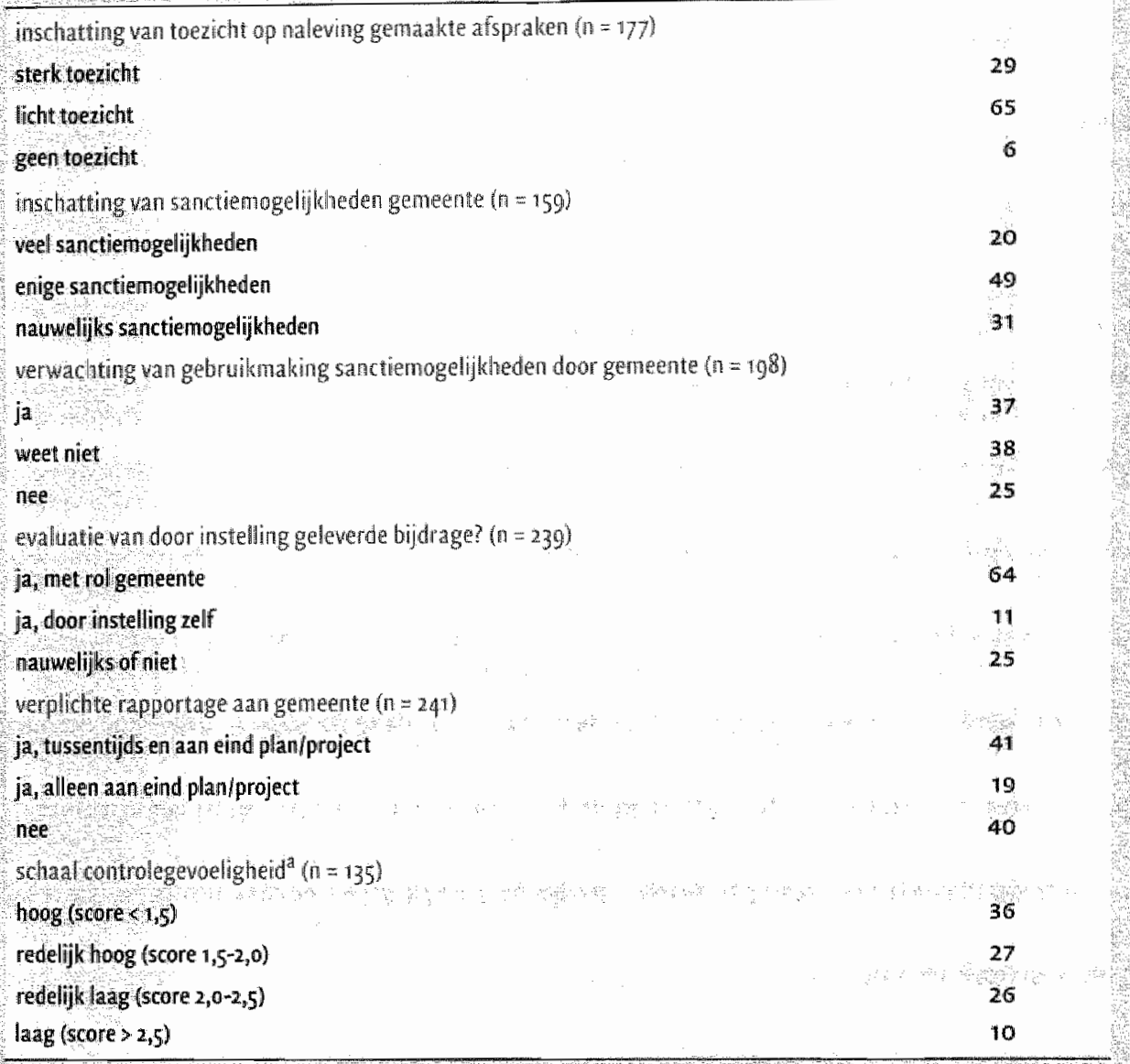

a. schall van 1 tot 3 ; som van itemscores/ 5 , Cronbach's alpha $=0,68$; hoe lager de score; hoe hoger de controlegevoeligheid Bron SCP (1) Binstellingen zooz)

Tot slot is de instellingen gevraagd naar de politiek-bestuurlijke aandacht voor de bijdrage die de instelling levert aan de uitwoering van het jeugdbeleid. Deze vraag. is gebruikt als indicator voor de (ervaren) politieke sturing. Bijna een kwart van de instellingen heeft de indruk dat de verantwoordelijke wethouder veel aandacht heeft voor datgene wat de instelling bijdraagt aan het jeugdbeleid. Een kleine $15 \%$ schat de aandacht vanuit het college van B\&W laag in. Bij de aandacht vanuit de gemeenteraad zijn de verhoudingen omgekeerd: bijna een kwart schat de aandacht laag in, en $1.4 \%$ heeft de indruk dat er veel aandacht is in de gemeenteraad. Deze percepties wan politieke sturing blijken samen te hangen met de ingeschatte kans op beleidsafwijkingen: bij de instellingen die het (deels) oneens zijn met de gemeente bestaat er een negatieve relatie tussen de perceptie wan politieke sturing enerzijds en de kans op beleidsafwijkingen anderzijds. Met andere woorden: als instellingen het (deels) 
oneens zijn met de gemeente over het gevoerde beleid, dan geldt: hoe hoger de politiek-bestuurlijke aandacht, hoe kleiner de kans op beleidsafwijkingen.

\subsubsection{Conclusie}

Een groot aantal gemeenten stuurt de uitvoering van het jeugdbeleid niet al te strak. De meeste instellingen ervaren een grote tot redelijk grote beleidsvrijheid bij de uitoefening van hun uitvoerende rol in het jeugdbeleid. Bovendien ervaart in een aanzienlijke minderheid van de gemeenten de meerderheid van de instellingen de verwachtingen van de gemeente als niet of slechts ten dele duidelijk. Dit ondanks het feit dat in circa vier op de vijf gemeenten afspraken bestaan tussen gemeente en instellingen over de door de instelling te leveren beleidsprestaties, en deze afspraken in de meerderheid van de gevallen op gezamenlijk initiatief van instelling en gemeente tot stand zijn gekomen. Aan de ene kant is de eigen ruimte voor professionals om de uitwoering van beleid vorm te geven positief voor de slagvaardigheid. Aan de andere kant kan voorall de onduidelijkheid omtrent de te leveren beleidsprestaties een bedreiging zijn voor een integrale beleidswoering vanwege de kans op beleidsafwijkingen. De overheersend losse vorm van sturing leidt er in ieder geval dan ook niet toe dat er geen beleidsafwijkingen in de uitwoering optreden. Liefst twee derde van de instellingen geeft aan dat de beleidsprestaties slechts gedeeltelijk (de meerderheid) of zelfs niet geleverd worden. Uit de verdere analyses blijkt dat de aanwezigheid van consensus tussen instellingen en gemeente over zowel de visie als de te leveren prestaties door de instelling de kans op beleidsafwijkingen vermindert. Als consensus ontbreekt, dan is sterke politieke sturing een instrument dat de kans op beleidsafwijkingen doet afnemen. In algemene zin blijkt er dus een (negatieve) relatie te bestaan tussen deze elementen van integrale beleidsvoering en de kans op beleidsafwijkingen.

\subsection{Beleidsevaluatie}

Als laatste onderdeel van de beleidscyclus behandelen we in deze paragraaf hoe gemeenten in het lokale jeugdbeleid omgaan met beleidsevaluatie. Evaluatie van het gevoerde beleid wordt als een noodzakelijke voorwaarde gezien om vast te kunnen stellen of doelen worden gerealiseerd. Eventueel kan op basis daarvan het beleid worden bijgesteld. Evaluatie is een belangrijk instrument om slagvaardig beleid te kunnen voeren. Het draagt bij aan de bewaking van de voortgang van het beleid en geeft daarmee aanleiding tot eventuele bijstellingen van beleid.

Evaluatie kan gericht zijn op de resultaten van genomen beleidsmaatregelen, maar ook op de organisatie van beleidsprocessen. Doorgaans wordt daarom een onderscheid gemaakt tussen proces- en effectevaluatie. Procesevaluatie is gericht op zaken als de samenwerking tussen verschillende actoren, de aansturing van de uitvoering en andere aan het beleidsproces gerelateerde zaken. Effectevaluatie is daarentegen gericht op de resultaten die het beleid heeft voortgebracht, waarbij doorgaans getracht 
wordt de resultaten te relateren aan het gevoerde beleid. In dit onderzoek is naar het voorkomen van beide soorten evaluatie gevraagd.

\subsubsection{Evaluatie volgens ambtenaren}

Driekwart van de onderzoeksgemeenten doet niet aan procesevaluatie (tabel 6.14). Er bestaat een sterk verband met de staat van het jeugdbeleid in 20oI: hoe verder het jeugdbeleid ontwikkeld is, hoe groter de kans dat het beleidsproces rond het jeugdbeleid wel wordt geëvalueerd.

Tabel 6.14

Uitwoering van proces- en effectevaluatie door gemeenten, $2001(n=60$; in procenten)

procesevaluatie
nee/mog niet
ja
effectevaluatie
nee/nog niet
op onderdelen
ja, totale jeugdbeleid

Brons SCP ( (B B ambtenaren 2002$)$

Effectevaluatie van het jeugdbeleid komt volgens de ambtenaren vaker voor. In bijna de helft van de onderzoeksgemeenten worden in ieder geval van onderdelen van het jeugdbeleid de effecten geëvalueerd. In $5 \%$ wordt zelfs het totale jeugdbeleid op zijn effecten geëvalueerd. Dit betekent tegelijkertijd dat in bijna de helft van de onderzoeksgemeenten de effecten van het jeugdbeleid in het geheel niet worden beoordeeld. Dit door ambtenaren geschetste beeld komt redelijk overeen met het beeld dat oprijst uit de analyse van beleidsdocumenten. In bijna $40 \%$ van de na 1998 verschenen nota's jeugdbeleid wordt geen aandacht besteed aan beleidsevaluatie. In de overige nota's gebeurt dat wel, hoewel er in bijna de helft daarvan geen concrete werkwijze voor de evaluatie is opgenomen. In de meeste gemeenten waar ambtenaren aangeven dat het jeugdbeleid niet op effecten wordt geëvalueerd, is daar in de nota's ook niets over terug te vinden. De samenhang met de staat van het jeugdbeleid in 200 is sterk. Van de gemeenten met een staat van het jeugdbeleid in de hoogste van drie klassen, evalueert $80 \%$ het beleid op effecten. Van de overige gemeenten doet slechts eenderde dit.

Bijna alle gemeenten die het jeugdbeleid geheel of gedeeltelijk op effecten evalueert, noemen het verslag of de rapportage van instellingen over hun bijdrage aan het jeugdbeleid als meest gebruikte bron daarvoor (tabel 6.15). Twee derde van de gemeenten maakt daarnaast gebruik wan bestaande registraties. Actief eigen onderzoek in de vorm van een enquête onder doelgroepen of gesprekken met doelgroepen 
of met deskundigen komt voor in minder dan de helft van de gemeenten die aan effectevaluatie doen. Er is specifiek gevraagd naar het gebruik van een jeugdmonitor, c.q. herhaalde metingen ten behoeve van de effectevaluatie. Van de gemeenten die aan effectevaluatie doen, werkt bijna de helft met een jeugdmonitor. Bovendien heeft eenderde van de gemeenten die aan effectevaluatie doen een jeugdmonitor in voorbereiding.

Tabe! 6.15

Door gemeenten gehanteerde methoden bij effectevaluatie, $2001 \quad(n=32$; in procenten)

\begin{tabular}{|c|c|}
\hline rapportage/werslag door instellingei & 97 \\
\hline gebruikmaking bestaande regisiraties & 66 \\
\hline monitor & 44 \\
\hline schriftelijke vragenlist onder jeugdigen & 41 \\
\hline gesprekken met daelgroepen & 35 \\
\hline gesprekken met deskundigen & 31 \\
\hline
\end{tabular}

Bron SCP (4B Bambtenaren 2002)

Vier vijfde van de gemeenten met een jeugdmonitor heeft dit instrument na het jaar 2000 in gebruik genomen. De eerste onderzoeksgemeenten zijn hiermee begonnen in 1996. De monitor is dus een relatief nieuw beleidsinstrument. De onderwerpen die in de monitor aan de orde komen, variëren in het algemeen niet tussen gemeenten. In steeds meer dan driekwart van de gemeenten maken de volgende onderwerpen deel uit van de monitor: onderwijs, risicogedrag, veiligheidsbeleving, gezondheidssituatie, leefsituatie in algemene zin, en het oordeel over en de wensen ten aanzien van wrijetijdsbesteding. ${ }^{8}$ Bijna twee derde van de monitoren is gericht op de gehele jeugd, dus zowel 12 -minners als 12 -plussers. In eenderde gaat het alleen om I2-plussers, terwijl monitoren alleen gericht op 12-minners onder de onderzoeksgemeenten nauwelijks voorkomen. In veruit de meeste monitoren wordt gebruikgemaakt van enquêtes onder de jeugd. Daarnaast wordt relatief vaak gebruikgemaakt van bestaande registraties. Gesprekken, zowel met (vertegenwoordigers van) de doelgroep als met deskundigen, worden in het kader van de monitor veel minder vaak gebruikt.

\subsubsection{Evaluatie volgens instellingen}

Op de vraag of de instelling moet rapporteren aan de gemeente over de door haar geleverde bijdrage aan het jeugdbeleid, antwoordt $40 \%$ van de instellingen dat dat niet hoeft (zie tabel 6.13). Daarbij zijn instellingen in de minder stedelijke gemeenten oververtegenwoordigd. Nog eens $4 \mathrm{r} \%$ zegt zowel tussentijds als na het realiseren van de bijdrage te moeten rapporteren. $20 \%$ van de instellingen zegt dat dit alleen na afloop van het project vereist is.

Van de instellingen die een rol spelen in de uitwoering van het jeugdbeleid zegt bijna twee derde dat de door haar geleverde bijdrage samen met de gemeente wordt 
geëvalueerd (zie eveneens tabel 6.r3). Ir\% geeft aan dat de geleverde bijdrage alleen binnen de eigen instelling wordt beoordeeld, en een kwart dat er geen evaluatie plaatsvindt. In gemeenten met een relatief weinig ontwikkeld jeugdbeleid wordt de evaluatie van de bijdrage van de instelling volgens de gemiddelde opvatting van de instellingen naar verhouding vaak door alleen de instelling verricht, terwijl in de gemeenten met een relatief ver ontwikkeld jeugdbeleild de evaluatie beduidend vaker in samenwerking met de gemeente plaatsvindt.

\subsubsection{Conclusie}

Beleidsprocessen rond het jeugdbeleid worden in een beperkt aantal gemeenten geëvalueerd, terwijl evaluatie daarvan wel moet worden gezien als een belangrijke bijdrage aan het vermogen om slagvaardig beleid te voeren. Effectevaluatie vindt in meer gemeenten plaats, waarbij instellingen in bijna alle gemeenten een belangrijke informatiebron zijn. Toch hoeft een aanzienlijke minderheid van de instellingen niet te rapporteren aan gemeenten en vindt bij een kwart geen gemeentelijke evaluatie van de instellingsbijdrage aan het jeugdbeleid plaats.

\subsection{Samenvatting en conclusies}

De centrale vraag in dit hoofdstuk was op welke wijze gemeenten trachten het jeugdbeleid te sturen en welke gevolgen dit heeft voor het vermogen van gemeenten om een op de lokale situatie toegespitst, integraal en slagvaardig jeugdbeleid te voeren. Hier vatten we de bevindingen nog eens kort samen.

\section{Maatwerk}

Het blijkt dat de meeste gemeenten veel actoren, waaronder jongeren, betrekken bij de formulering van het jeugdbeleid. Rond het jeugdbeleid blijken vele beleidsnetwerken te opereren. In $85 \%$ van de gemeenten zijn dergelijke netwerken actief, en het gemiddelde aantal naar werkveld onderscheiden typen netwerken in die gemeenten bedraagt 3,5. Het feitelijke gemiddelde aantal netwerken ligt hoger, omdat voor verschillende typen meer netwerken voorkomen. Hoe stedelijker de gemeente, hoe groter het aantal netwerken, zo blijkt. Ook een ruime meerderheid van de in dit onderzoek ondervraagde instellingen zegt betrokken te zijn bij de beleidsformulering. Veel gemeenten maken dus gebruik van de lokaal aanwezige informatie die relevant kan zijn voor een op de lokale situatie toegespitst jeugdbeleid.

\section{Integrale beleidswoering}

Het bestaan van vele netwerken rond het lokale jeugdbeleid met daarin doorgaans de participatie van vele actoren zegt ook iets over de integrale beleidswoering. Gemeenten slagen er doorgaans in om actoren vanuit verschillende sectoren (onderwijs, zorg, welzijn, veiligheid) bij elkaar te brengen in beleidsnetwerken. Dat betekent dat veel gemeenten niet vanuit een sectorale invalshoek naar het jeugdbeleid kijken. 
Een ruime meerderheid van de onderzoeksgemeenten heeft een beleidsvisie ontwikkeld. Door de meeste bij het jeugdbeleid betrokken instellingen wordt deze als richtinggevend ervaren. Bovendien blijkt dat een visie er relatief vaak toe leidt dat er tussen de gemeente en de instellingen consensus is over de bijdrage die de instellingen aan het jeugdbeleid moeten leveren. Die consensus is ook sterker naarmate de instellingen meer bij de ontwikkeling van het beleid zijn betrokken. We kunnen stellen dat veruit de meeste gemeenten met behulp van een richtinggevende visie tot een integraal jeugdbeleid trachten te komen.

De meeste instellingen maken met de gemeenten afspraken over hun bijdrage aan het jeugdbeleild, vooral in gemeenten waarin het jeugdbeleid ver ontwikkeld is. Meestal zijn deze afspraken voorzien van doelstellingen. Desondanks zegt twee vijfde van de instellingen dat het niet of niet voldoende duidelijk is wat de gemeente van de instelling verwacht. Verder is opmerkelijk dat ruim $80 \%$ van de instellingen zegt over een (redelijk) grote mate van beleidsvrijheid in de uitvoering te beschikken. Dit suggereert dat vooral afspraken worden gemaakt over de doelen (het 'wat') en in mindere mate over de wegen waarlangs die doelen bereikt dienen te worden (het 'hoe'). Deze wijze van sturing in de uitwoering verhindert niet dat er van het geformuleerde beleid wordt afgeweken: twee derde van de instellingen zegt de gevraagde beleidsprestaties slechts gedeeltelijk of zelfs niet te leveren. De kans op beleidsafwijkingen neemt af naarmate er meer consensus is tussen gemeente en instellingen; bij de afwezigheid van consensus neemt deze kans af door de aanwezigheid van sterke politieke sturing.

\section{Slagvaardigheid}

De vele beleidsnetwerken rond het lokale jeugdbeleid leiden ertoe dat een aantal actoren zwaar belast wordt. Het sociaal-cultureel werk, het primair onderwijs en de jeugdgezondheidszorg zijn in gemiddeld twee beleidsnetwerken per gemeente vertegenwoordigd, en in meer dan de helft van de gemeenten zelfs in drie of meer netwerken. Ook andere actoren, zoals de politie, de Bureaus Jeugdzorg, de consultatiebureaus en het jongerenwerk zijn bovengemiddeld in de netwerken vertegenwoordigd. Wellicht dat dat ook verklaart waarom een groot deel van de instellingen zegt dat de betrokken heid bij werkgroepen rond de beleidsworming naar verhouding weinig resultaat oplevert. Vooral voor actoren die op regionale schaal opereren, zoals de politie en de Bureaus Jeugdzorg, dreigt een onevenredige belasting die voortvloeit uit de deelname in beleidsnetwerken lokaal jeugdbeleid. Dit pleit eens te meer voor een 'zuinige' opzet van de netwerkstructuur per gemeente. In een aantal gemeenten bestaat de kans dat de complexiteit van de netwerkstructuur de slagvaardigheid rond het jeugdbeleid nadelig beinnloedt.

De evaluatie van wat er van het beleid terechtkomt, wordt door de helft van de onderzoeksgemeenten ter hand genomen, en dan vooral door gemeenten met een relatief ver ontwikkeld jeugdbeleid. Dat betekent meteen ook dat het in de helft van de onder- 
zoeksgemeenten nog niet gebeurt. Deze effectevaluatie gebeurt nog vooral door middel van de rapportages van instellingen, hoewel geconstateerd kan worden dat het instrument van de jeugdmonitor in opkomst is. Evaluatie van beleidsprocessen komt in slechts een beperkt aantal in hoofdzaak (zeer) sterk stedelijke gemeenten voor. Ook het tussentijds rapporteren over de voortgang van de beleidsuitvoering wordt door de gemeente van een minderheid van de bij het jeugdbeleid betrokken instellingen verlangd.

De slagvaardigheid rond het lokale jeugdbeleid wordt in principe positief beïnvloed door de ruimte die aan professionals in de beleidsuitvoering wordt gegund. De meeste instellingen ervaren hierbij een grote tot redelijk grote beleidsvrijheid, waardoor zij binnen bepaalde kaders flexibel kunnen reageren op gewijzigde omstandigheden in de beleidsomgeving. 
I Over de specifieke positie van overheden in beleidsnetwerken, zie De Bruijn et al. (I993: 26-27).

2 In. tegenstelling tot eerdere hoofdstukken vindt geen wergelijking plaats met 1998 , omdat in dat jaar het onderwerp geneentelijke regie een relatief ondergeschikte plaats had in het onderzoek.

3 Het is belangrijk de benadering van netwerken als sturingsinstrumenten te onderscheiden van de benadering wan netwerken als analysecategorie. In dit laatste perspectief bestaan netwerken als empirische fenomenen, zonder dat zij 'opgericht' zijn. In hoofdstuk $\mathrm{I}$ hebben we deze laatste aangeduid als beleidsarena's.

4 Bij het indelen is gebruikgemalakt van de mogelijkheid die gemeenten hadden om voor een aantal inhoudelijke thema's die in de vragenlijst aan de orde lkwamen (zie $\$ 4.3$ ) aan te geven of daar een netwerk omheen geformeerd was. Daarnaast is gelet op de meest voorkomende werkvelden wan de netwerken, wat niet heeft kunnen verhinderen dat er toch een relatief omvangrijke groep 'divers' is, uiteenlopend wan werkgroepen rond (de oprichting van) een jongerencentrum tot een platform jeugdparticipatie. Ook wordt in een (beperkt) aantal gemeenten het Op Overeenstemming Gericht Overleg (oogo) genoemd dat in het kader van het onderwijsachterstandenbeleid bestaat.

5 Nogmaals dient opgemerkt te worden dat, om de gemiddelde opvatting per gemeente niet te laten bepalen door één of twee instellingen, gemeenten waar minder dan drie instellingen gereageerd hebben, uitgesloten zijn van de analyse. Daardoor resteren 53 gemeenten.

6 Het beeld dat ambtenaren schetsen van de beleidsvrijheid van instellingen komt op het eerste gezicht overeen met dat van de instellingen. Van de ambtenaren zegt $75 \%$ dat instellingen een grote of redelijk grote beleidswrijheid hebben. $2 \%$ dicht de instellingen een tamelijk kleine beleidsvrijheid toe. Als evenwell de samenhang per gemeente wordt bekeken (waarbij alleen de gemeenten betrokken zijn waarvan minimaal drie instellingen aan het onderzoek hebben meegewerkt), dan valt op dat er tussen de inschatting van de ambtenaar en de gemiddelde opvatting van de instellingen geen relatie bestaat. De gemiddelde score van de instellingen schommelt dicht rond de twee (zie vorige alinea), ongeacht de opvatting van de ambtenaar uit de betreffende gemeente. Wel bestaat er een verband tussen de inschatting van de ambtenaren over de beleidswrijheid van de instellingen en de stedelijkheid van de gemeente: de ambtenaren uit de (zeer) sterk stedelijke gemeenten dichten de instellingen wat vaker een relatief geringe beleidswrijheid toe dan ambtenaren uit de minder stedelijke gemeenten.

7 De rijtotalen van tabel 6.12 komen niet geheel overeen met de percentages in tabel 6.10. Dit wordt veroorzaakt door het geringere aantal instellingen waarover in tabel 6.12 getapporteerd kan worden.

8 Andere onderwerpen komen in een enkele gemeente aan bod. Genoemd worden: participatie, fysieke omgeving, jeugdzorg, arbeid, gebruik van voorzieningen en drugsgebruik. Het is niet altijd duidelijk hoe deze thema's zich onderscheiden van de in de tekst genoemde thema"s. 


\section{Intermezzo: typologie van het lokale jeugdbeleid}

\subsection{Inleiding}

Dit hoofdstuk heeft tot doel om op basis van de diverse aspecten van het jeugdbeleid die behandeld zijn in de hoofdstukken 3 tot en met 6, te komen tot een typologie van het jeugdbeleid. Deze typologie kan inzichtelijk maken hoe de verschillende aspecten van het jeugdbeleid zich tot elkaar verhouden. De belangrijkste reden is evenwel dat de beleidstypologie gebruikt kan worden om verschillen in beleidsuitkomsten te verklaren. Is het zo dat bepaalde typen jeugdbeleid tot meer positieve resultaten leiden dan andere? Dit hoofdstuk, dat als een intermezzo kan worden gezien tussen de hoofdstukken die aan de ene kant het beleidsproces en de beleidsinhoud behandelen en aan de andere kant de beleidsuitkomsten, beschrijft de werkwijze die gevolgd is bij de constructie van de typologie.

\subsection{Constructie van de beleidstypologie}

De beleidstypologie is op exploratieve wijze tot stand gekomen. Dat wil zeggen dat de verschillende aspecten uit de voorgaande hoofdstukken waarop duidelijke verschillen waarneembaar zijn tussen de gemeenten, zullen worden gebruikt om tot de typologie te komen. Er is nadrukkelijk niet gekozen voor een theoretische constructie vooraf van verschillende beleidstypen, omdat dat tot empirische classificatieproblemen zou kunnen leiden. De aspecten die betrokken worden bij het ontwerpen van een typologie zijn de volgende: de staat van het jeugdbeleid (zie hoofdstuk 3 ), de dimensiescore betrekken van de jeugd (zie hoofdstuk 5) en diverse procesmatige aspecten die relevant bleken: het type netwerkworming, de aanwezigheid van een beleidsvisie, de mate van consensus tussen gemeente en instellingen, en de mate van politieke sturing in het jeugdbeleid (zie hoofdstuk 6 ). In houdelijke kenmerken van het beleid (zie hoofdstuk 4) worden niet in de constructie van de typologie betrokken omdat het niet mogelijk bleek om op een zinvolle wijze onderscheid te maken naar verschillende typen beleidsinhoud.

In totaal zijn er zes aspecten van het jeugdbeleid op basis waarvan gepoogd is een typologie te ontwikkelen. Vijf daarvan hebben direct te maken met de wijze waarop de gemeenten invulling geven aan hun rol als sturende actor in het lokale jeugdbeleid. Dit zijn: de staat van het jeugdbeleid, het type netwerkvorming, de aanwezigheid van een beleidsvisie, de mate van consensus tussen gemeente en instellingen, en de mate van politieke sturing in het jeugdbeleid. Het betrekken van jeugd is een duidelijk afzonderlijk aspect, dat weliswaar ook met sturing te maken heeft, maar dat daarnaast een inhoudelijke beleidskeuze in zich draagt. Om die reden was het ook bij de constructie van de typologie in het vorige onderzoek een afzonderlijk 
aspect (Gilsing 1999). De typologie wordt dus enerzijds gevormd door sturingsaspecten en anderzijds door de mate waarin gemeenten de jeugd bij het beleid betrekken.

Het is in de eerste plaats zinvol om nader te onderzoeken hoe de vijf sturingsaspecten met elkaar samenhangen en om na te gaan of zij wellicht zijn te reduceren tot een geringer aantal onderliggende factoren of dimensies van de sturingsrol van gemeenten. In tabel 7.I worden de samenhangen tussen de verschillende aspecten van de sturingsrol weergegeven. Er blijkt een duidelijke en positieve samenhang te bestaan tussen de mate van politiek-bestuurlijke aandacht voor het jeugdbeleid en de mate waarin er consensus is tussen gemeente en instellingen over datgene wat de instellingen worden verwacht bij te dragen aan het jeugdbeleid. Hoe meer politiek-bestuurlijke aandacht, hoe groter de mate van consensus. Daarnaast hangt de staat van het jeugdbeleid sterk samen met de aanwezigheid van een beleidsvisie en met het type netwerkvorming in de gemeente. Hoe hoger de staat van het jeugdbeleid, hoe groter de kans dat er - volgens de ambtenaren - ook een beleidsvisie is, en hoe omvattender en complexer de netwerkvorming rond het jeugdbeleid. Voor het overige bestaan er geen (significante) samenhangen tussen de verschillende sturingsaspecten.

Tabel 7.1

Samenhangen tussen verschillende aspecten sturing gemeente, 2001

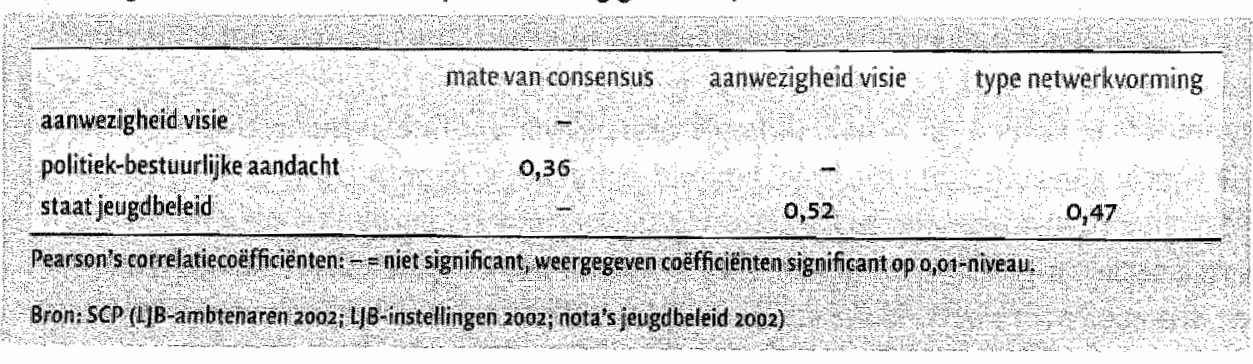

Om het patroon van de sturingsaspecten nader in beeld te brengen, is een principalecomponentenanalyse verricht. Deze techniek maakt het mogelijk de onderliggende dimensies van empirisch waargenomen zaken aan het licht te brengen. In tabel 7.2 staan de resultaten van de niet-geroteerde factoroplossing. De resultaten bevestigen (logischerwijze) de bevindingen wan tabel 7.I: er zijn twee groepen sturingsaspecten. De eerste bestaat uit de staat van het beleid, de aanwezigheid van een visie, en het type netwerkvorming. De tweede groep wordt gevormd door de politiek-bestuurlijke aandacht en de mate van consensus. De factoroplossing in tabel 7.2 is zo duidelijk dat het mogelijk is te spreken van twee sturingsdimensies. De eerste is aan te duiden als voorwaardelijke sturing: de ontwikkeling van beleid, de aanwezigheid van een visie en de vorming van netwerken zijn op te vatten als voorwaarden voor effectieve sturing van het jeugdbeleid. De tweede dimensie is te benoemen als materiële sturing. Zowel de mate van politiek-bestuurlijke aandacht als de mate van consensus betreffen zaken die in het proces van sturing voortdurend aan de orde zijn. Zou deze materiële sturing ontbreken, dan zouden processen als de uitvoering en evaluatie van het beleid uiteindelijk in het gedrang komen. 
Tabel 7.2

Factoroplossing principalle-componentenanalyse sturingsaspecten, 2001

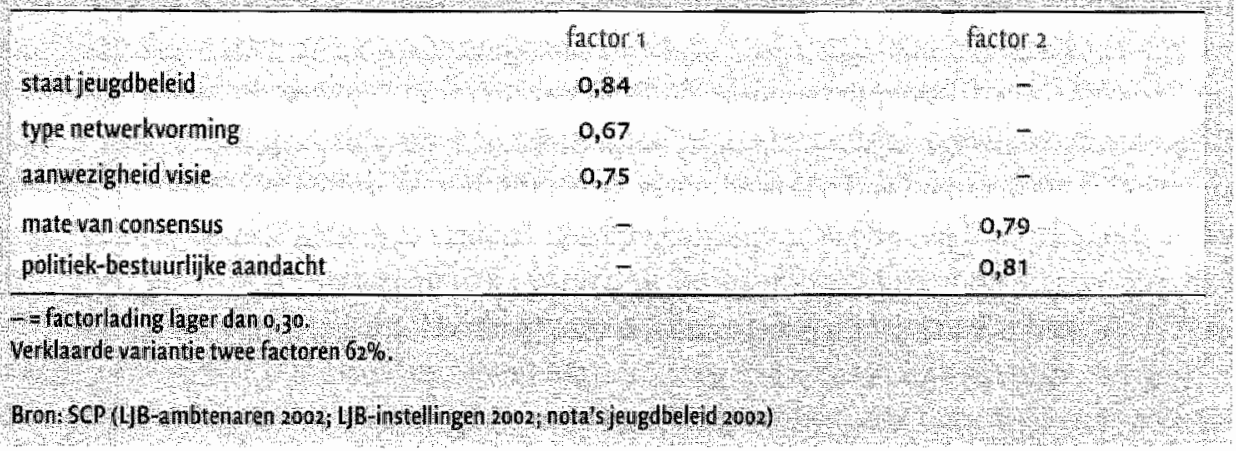

Met het oog op de ontwikkeling van de typologie kunnen de vijf sturingsaspecten dus teruggebracht worden tot twee dimensies. Voor wat betreft de eerste dimensie, de voorwaardelijke sturing, is daarbij als volgt te werk gegaan. Er is een nieuwe variabele geconstrueerd met drie mogelijke waarden: zwakke woorwaardelijke sturing, gemiddelde voorwaardelijke sturing en sterke voorwaardelijke sturing. Om de voorwaardelijke sturing als sterk te beoordelen, moet in lieder geval sprake zijn van een beleidsvisie (wat in het merendeel van de gemeenten het geval is). Zonder beleidsvisie kan er, gezien het belang van de visie als sturingsinstrument, geen sprake zijn van sterke voorwaardelijke sturing. Daarnaast moet op minimaal een van beide andere aspecten een score behaald zijn in de hoogste van drie categorieën, terwijl op geen van deze aspecten in de laagste categorie gescoord mag worden. Gemeenten die aan deze voorwaarden voldoen, krijgen de score 'sterke voorwaardelijke sturing'. Als op twee van de drie aspecten in de laagste categorie wordt gescoord, wordt de voorwaardelijke sturing getypeerd als zwak. In de overige gevallen is sprake van gemiddelde voorwaardelijke sturing. In tabel 7.3 is de frequentieverdeling van de dimensie voorwaardelijke sturing gerapporteerd. Van $42 \%$ van de gemeenten kan gezegd worden dat zij het jeugdbeleid in voorwaardelijke zin sterk sturen, wan $38 \%$ dat dit in gemiddelde mate gebeurt, en van $20 \%$ dat de voorwaardelijke sturing zwak is.

\section{Tabel 73}

Dimensie voorwaardelijke sturing, frequentieverdeling, 2001 ( $n=60$; in procenten)

zwakke voorwardelijke sturing
gemiddelde vaorwaardelijkesturing
sterke voorwa ardelijke sturing

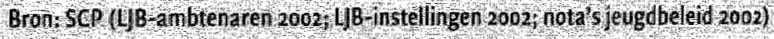

De dimensie materiële sturing is berekend door de variabele politiek-bestuurlijke aandacht te transformeren van een driepunts- naar een vierpuntsschaal, zodat deze vergelijkbaar wordt met de variabele mate van consensus. Vervolgens zijn beide 
variabelen bij elkaar opgeteld en gedeeld door twee, waardoor een nieuwe variabele materiële sturing ontstaat met een vierpuntsschaal. Omdat het hier gaat om variabelen die komen uit het onderzoek onder uitwoerende instellingen, zijn de scores voor de variabele materiële sturing alleen berekend voor gemeenten waarvan meer dan drie uitvoerende instellingen gerespondeerd hebben. In tabel 7.4 is de frequentieverdeling voor deze dimensievariabele opgenomen, waarbij de scores in drie klassen zijn ingedeeld. De grenzen voor deze klassen liggen bij het gemiddelde minus, respectievelijk plus een half keer de standaardafwijking. In deze indeling kenmerkt het beleid van $31 \%$ van de onderzoeksgemeenten zich door zwakke materiële sturing, eveneens $31 \%$ door sterke materiële sturing, en $38 \%$ door gemiddelde materiële sturing.

Tabel 7.4

Dimensie materiële sturing, frequentieverdeling, 2001 ( $n=61$; in procenten)

zwakke materiête sturing
gemiddelde materiéle sturing
sterke materièle sturing

Bron SCP (4B anbtenaren 2002; UB (nstellingen 2002)

$7 \cdot 3$

De beleidstypologie

Daarmee zijn nu drie dimensies voorhanden voor de ontwikkeling van een beleidstypologie: voorwaardelijke sturing, materiële sturing en het betrekken van de jeugd. Met behulp van clusteranalyse komen we op basis van deze dimensies tot drie clusters, of wel drie typen jeugdbeleid.

Het eerste cluster kenmerkt zich doordat bijna alle gemeenten die ertoe behoren de meest sterke vorm van woorwaardelijke sturing kennen. Verder scoren de elf gemeenten uit dit cluster zonder uitzondering hoog op de dimensie 'betrekken van jeugd'. Op het punt van materiële sturing is geen eenduidig beeld te schetsen. De gemiddelde score van de gemeenten in dit cluster wijkt op dit punt niet noemenswaardig af van het totale gemiddelde, maar tussen de gemeenten bestaan er aanzienlijke verschillen. De scores variëren van sterke tot $z$ wakke materiële sturing. Het beleidstype van de gemeenten in dit cluster duiden we, in navolging van het onderzoek uit 1999, aan als interactief: een ver ontwikkelde gemeentelijke rol op het gebied van voorwaardelijke sturing (beleidsontwikkeling, visie, netwerkvorming) en een in vergelijking met andere gemeenten sterk op het betrekken van jongeren gericht beleid.

Het tweede cluster onderscheidt zich nauwelijks van het eerste op het gebied van voorwaardelijke sturing. Ook in dit cluster scoort een ruime meerderheid in de hoogste categorie van deze dimensie, en geen enkele in de laagste categorie. Het beleid van deze twintig gemeenten is echter veel minder sterk gericht op het betrekken van 
jeugd. Zonder uitzondering scoren de gemeenten op dit punt lager dan de gemeenten uit het eerste cluster, en in het algemeen ook fors lager. Ook in dit tweede cluster varieert de materiële sturing sterk. Hoewel veel gemeenten op deze dimensie in de middelste van drie categorieën scoren, zijn er ook gemeenten met een zwakke respectievelijk een sterke materiële sturing. Het beleidstype van de gemeenten in dit cluster duiden we, eveneens in navolging van het onderzoek uit 1999, aan als actief: sterk ontwikkelde voorwaardelijke sturing, gecombineerd met een beleid dat gemiddeld of matig gericht is op het betrekken van jeugd.

Het derde cluster tot slot onderscheidt zich zowel op het punt van voorwaardelijke sturing als op het punt van het betrekken van jeugd van de andere clusters. Gemiddeld genomen is de voorwaardelijke sturing minder sterk, met bijna de helft van de veertien gemeenten in de laagste categorie. Tevens scoren veruit de meeste gemeenten uit dit cluster laag op de dimensie betrekken van jeugd. Ook hier zijn de scores op het punt van materiële sturing sterk uiteenlopend. Dit beleidstype wordt net als in het onderzoek van 1999 als passief bestempeld: zwak tot gemiddelde voorwaardelijke sturing, in beperkte mate gericht op het betrekken van jeugd.

In tabel 7.5 worden deze typen gepresenteerd. In totaal zijn voor 45 onderzoeksgemeenten de gegevens op de drie dimensies beschikbaar.

\section{Tabel 7.5}

Typen jeugdbeleid, naar gemiddelde scores (en standaardafwijkingen) op dimensies typologie, $2001 \quad(n=45)$

\begin{tabular}{|c|c|c|c|c|}
\hline 2 & $\begin{array}{l}\text { voorwarder } \\
\text { gike striritg }\end{array}$ & 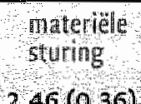 & Wet ellken van & of gemeenten \\
\hline Wype is interactief belleid & $2,73(0,65)$ & $2,46(0,36)$ & $1,49(0,56)$ & 324 \\
\hline type 2 artief beleid & $2,65(0,49)$ & $2,39(0,32)$ & $0,06(0,48)$ & 44 \\
\hline type 3 passief beleid & $1,57(0,51)$ & $2,40(0,45)$ & $0,97(0,43)$ & 31 \\
\hline
\end{tabular}

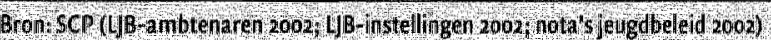

Tot slot wordt de samenhang tussen het in gemeenten voorkomende beleidstype en de stedelijkheid van die gemeenten bekeken (zie tabel 7.6). Zoals te verwachten is er een duidelijk verband tussen de stedelijkheid en het type jeugdbeleid. In de (zeer) sterk stedelijke gemeenten komt een passief beleidstype weinig voor. De gemeenten die deel uitmaken van het cluster interactief beleid zijn in grote meerderheid (zeer) sterk stedelijk. De minst stedelijke gemeenten komen in dit cluster niet voor. Zij zijn daarentegen oververtegenwoordigd in het cluster passief beleid. Hiertoe behoort ook nog eenderde van de matig stedelijke gemeenten. Het actieve beleidstype komt in de drie onderscheiden stedelijkheidsklassen in ongeveer gelijke mate voor. 
Tabel 7.6

Beleidstype naar stedelijkheid gemeente, 2001 (in procenten)

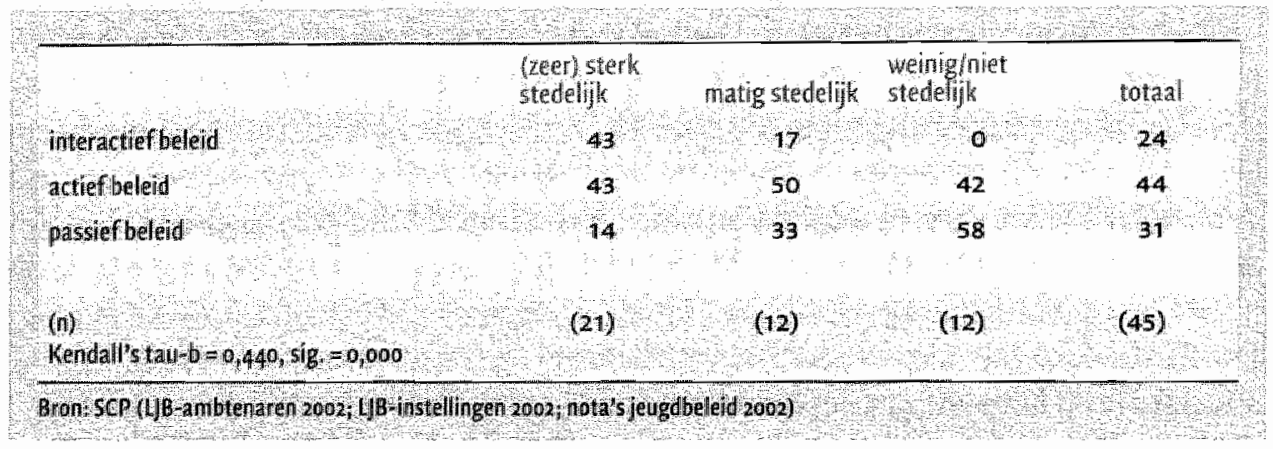


8.1. Inleiding

De belangrijke positie van gemeenten in het jeugdbeleid is voor een belangrijk deel ingegeven door de gedachte dat gemeenten beter dan andere bestuurslagen in staat zijn een effectiefjeugdbeleid te realiseren. In dit hoofdstuk gaan we in op een van de manieren om naar de uitkomsten van het jeugdbeleid te kijken. Dat doen we door de bij het beleid betrokken actoren om hun oordeel te vragen. Hoe denken zuj over de mate van doelbereiking en hoe oordelen zij over verschillende inhoudelijke delen en procesmatige aspecten van het gevoerde beleid? In dit hoofdstuk zal op deze vragen worden ingegaan.

Om te bezien of de verschillende aspecten van beleid en kenmerken van gemeenten ertoe doen bij de beoordeling door actoren, zullen beleidstypen en typen gemeenten daarbij steeds vergeleken worden. Leiden bepaalde typen beleid tot meer positieve beoordelingen? Zijn er typen beleid die het in de ogen van de uitvoerders minder goed doen? Deze vraag komt in iedere paragraaf aan de orde. Door de oordelen van de instellingen te aggregeren naar het gemeentelijke niveau is het mogelijk de samenhang tussen beleidstypen, kenmerken van gemeenten en de intersubjectieve beoordeling te bekijken. In deze analyses worden alleen gemeenten betrokken waarvan ten minste drie instellingen gerespondeerd hebben.

Zoals in hoofdstuk 2 is uiteengezet, zijn in de 72 onderzoeksgemeenten vertegenwoordigers van tien uitvoerende instellingen benaderd met een schriftelijke vragenlijst. Daarnaast zijn de ambtenaren jeugdbeleid gevraagd hun oordeel te geven over verschillende aspecten van het jeugdbeleid. Zowel aan de vertegenwoordigers van instellingen als aan de ambtenaren is een oordeel gevraagd over de mate van doelbereiking in het jeugdbeleid en over een aantal aspecten van het jeugdbeleid die te maken hebben met wat er daadwerkelijk is gerealiseerd. In iedere paragraaf wordt gekeken naar de samenhang tussen de oordelen wan instellingen en ambtenaren.

Een mogelijk bezwaar tegen deze benadering van beleidsuitkomsten betreft de betrouwbaarheid van de data (Hambleton en Thomas 1995: I4). Immers, de ondervraagde respondenten zijn voor het overgrote deel in meer of mindere mate betrokken bij het jeugdbeleid, en zijn daarmee belanghebbend. Dit probleem wordt deels ondervangen door een onderscheid te maken tussen actoren die niet en actoren die wel bij het jeugdbeleid betrokken zijn. Een andere mogelijkheid om dit probleem te ondervangen is door een onderscheid aan te brengen naar type actor. De diverse typen actoren 
zijn immers in verschillende mate betrokken bij het jeugdbeleid. Is het bijvoorbeeld zo dat respondenten uit het peuterspeelzaalwerk in het algemeen positiever oordelen dan respondenten wan het Bureau Jeugdzorg? Deze vragen komen in elke afzonderlijke paragraaf aan de orde.

In paragraaf 8.2 komt allereerst de evaluatie van de mate van doelbereiking aan de orde. De oordelen over het jeugdbeleid en de resultaten daarvan komen in paragraaf 8.3 aan bod. De conclusies van dit hoofdstuk staan in paragraaf 8.4.

\subsection{Oordelen over de mate van doelbereiking}

Tabel 8.r bevat de oordelen van de instellingen over de doelbereiking in het jeugdbeleid. Deze oordelen zijn in hoofdstuk 6 gebruikt als een indicator van de beleidsafwijking. Het oordeel dat de instellingen daarover geven is niet rooskleurig. Meer dan de helft $(56 \%)$ van de instellingen zegt dat de doelen op het werkveld van de instelling slechts ten dele gerealiseerd zullen worden. $5 \%$ zegt dat de doelen op het eigen werkveld niet gehaald worden. Van alle instellingen gelooft ongeveer een op de drie dat de doelen bereikt zullen worden, maar binnen deze groep denkt tweederde dat dat later zal gebeuren dan volgens de planning mag worden verwacht. Dat betekent dat in totaal slechts een op de acht instellingen inschat dat de doelen op het eigen werkveld volgens de planning gehaald zullen worden.

\section{Tabel 8.:}

Oordelen instellingen over doelrealisatie, 2002 ( $n=276$; in procenten)

\begin{tabular}{|c|c|}
\hline doelrealisatie volgens planning & 12 \\
\hline doelrealisatie met vertraging & 19 \\
\hline gedeeltelijke doelirealisatie & 56 \\
\hline geen doelrealisate & 5 \\
\hline geen doelen geformulteerd & 9 \\
\hline
\end{tabular}

Brons(r (4B-instellingenvoo)

\subsubsection{Naar type instelling}

Denken de verschillende typen instellingen stelselmatig anders over de mate van doelbereiking op hun werkveld? Alhoewel er verschillen bestaan tussen de verschillende typen instellingen, zijn deze op de vierpuntsschaal niet dusdanig groot dat zij significant zijn (zie tabel 8.2). Alleen de Regionale meld- en coördinatiepunten voortijdige schoolverlaters ( $\mathrm{RMC}$ 's) zijn duidelijk optimistischer dan andere instellingen. Dit wekt enige verwondering gezien de als hardnekkig geschetste problematiek van het voortijdig schoolverlaten waar de RMC's mee te maken hebben. Een mogelijke verklaring is dat de respondenten namens de RMC's in alle gevallen werkzaam zijn als ambtenaar bij ofwel de gemeente om wiens jeugdbeleid het gaat, 
ofwel de centrumgemeente in de betreffende RMC-regio, waardoor zij zich meer dan vertegenwoordigers van non- of paragouvernementele instellingen bij het gemeentelijke beleid betrokken voelen. Deze verklaring wordt ondersteund door de bevinding dat het oordeel van instellingen over de mate van doelbereiking samenhangt met de mate en wijze van betrokkenheid bij het jeugdbeleid. Instellingen die zowel bij de formulering als de uitvoering van het beleid betrokken zijn, schatten de kans op doelrealisatie hoger in dan instellingen die alleen bij de formulering of de uitvoering betrokken zijn. Instellingen die niet betrokken zijn bij het jeugdbeleid, beoordelen de doelbereiking op hun eigen beleidsterrein het minst positief.

\section{Tabel 8.2}

Oordelen over mate van doelbereiking, naar type instelling, 2002 (gemiddelde score op schaal 1-4, $1=$ doelen volgens planning, $2=$ doelen met vertraging, $3=$ gedeeltelijke doelbereiking, $4=$ geen doelbereiking)

\begin{tabular}{|c|c|c|}
\hline & gemiddelde score & (n) \\
\hline thuiszorg/consultatiebureau & 3,00 & (31) \\
\hline voortgezet onderwijs & 2,95 & (22) \\
\hline primair onderwis & 2,89 & (18) \\
\hline peuterspeelzaalwerk & 2,85 & (27) \\
\hline welzijnjeugd-en jongerenwerk & 2,83 & (29) \\
\hline Bureau Jeugdzorg & 2,83 & (30) \\
\hline kinderopvang & 2,81 & (27) \\
\hline politie, jeugdzaken & 2,80 & (41) \\
\hline GGDIJGZ & 2,63 & (35) \\
\hline $\mathrm{RMC}$ & 2,31 & (16) \\
\hline totaal & 2,80 & $(276)$ \\
\hline
\end{tabular}

Bron SeP (QjB-instellingen 2602)

\subsubsection{Naar type jeugdbeleid}

Verwacht mag worden dat het gevoerde jeugdbeleid van invloed is op de inschatting van de doelrealisatie: naarmate het beleid meer is ontwikkeld en er actiever gestuurd wordt, neemt de kans op doelbereiking toe. In tabel 8.3 worden de per gemeente gemiddelde oordelen van instellingen over de mate van doelbereiking in het jeugdbeleid afgezet tegen respectievelijk de stedelijkheid van de gemeente, het beleidstype en de mate van voorwaardelijke en materiële sturing. De stedelijkheid van de gemeente blijkt niet van invloed te zijn. Ook het type beleid en de mate van voorwaardelijke sturing leiden niet tot uiteenlopende oordelen over de mate van doelbereiking. Dat geldt wel voor de mate van materiële sturing. In gemeenten met een sterke materiële sturing - sterke politieke sturing en een hoge mate van consensus - zijn instellingen gemiddeld positiever over de mate van doelbereiking dan in gemeenten met een zwakke materiële sturing. De verwachtingen omtrent de invloed van beleidsontwik- 
keling en sturing op de inschatting van de doelbereiking komen daarmee slechts gedeeltelijk uit.

Tabel 8.3

Oordelen van instellingen over mate van doelbereiking, naar beleidskenmerken en naar stedelijkheid gemeente, 2002 (gemiddelde score op schaal $1-4,1=$ doelen volgens planning, $2=$ doelen met ver traging, 3 = gedeeltelijke doelbereiking, 4 = geen doelbereiking)

\begin{tabular}{|c|c|c|}
\hline$\therefore$ & gervindelde score & (n) significantie verschillen tussen instellingen \\
\hline stedelinheid & 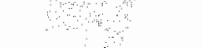 & \\
\hline (zeen) sterk & 2,59 & \\
\hline matig & 2,60 & \\
\hline nauwelijks/niet & 2,67 & \\
\hline totad & 2,62 & (63) \\
\hline type beled & & \\
\hline interactief & 2,53 & \\
\hline actief & 2,56 & \\
\hline passief & 2,73 & \\
\hline rotaal & 2,61 & $(45)$ \\
\hline Woorwatrdelijkes & 4 & 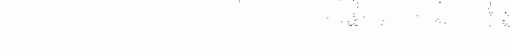 \\
\hline zwals & 2,55 & \\
\hline gemiddeld & 2,03 & \\
\hline sterk & 2,57 & \\
\hline totaal & 2,59 & (53) \\
\hline materide sturing & 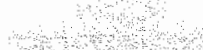 & 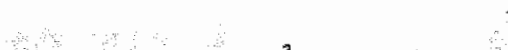 \\
\hline walt & 2,77 & $a$ \\
\hline gemiddeld & 2,67 & 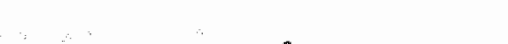 \\
\hline sterk & 2,39 & 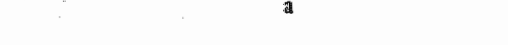 \\
\hline total & 2,62 & (61) \\
\hline
\end{tabular}

\subsubsection{Oordelen van ambtenaren}

Ook de ambtenaren is gevraagd een oordeel te geven over de mate van doelbereiking in het jeugdbeleid. Deze vraag is niet alleen gesteld voor het totale jeugdbeleid, maar tevens voor de verschillende beleidsthema's die in hoofdstuk 4 zijn behandeld. Tabel 8.4 geeft een overzicht van de resultaten. ${ }^{I}$ In het algemeen zijn de ambtenaren wat positiever gestemd over de doelbereiking in het totale jeugdbeleid dan de instellingen over de doelbereiking op hun werkveld $(2,34$ tegen 2,80 , zie tabel 8.2). Er zijn verschillen in de oordelen over de mate van doelbereiking in het jeugdbeleid tussen de verschillende stedelijkheidsklassen, maar deze zijn niet significant. Het meest positief zijn de ambtenaren over de doelbereiking in het beleid gericht op jeugd en veiligheid. 
Minder positief zijn zij over de doelbereiking in het o- tot 6-jarigenbeleid en het beleid gericht op het tegengaan van voortijdig schoolverlaten. In het algemeen zijn de meest stedelijke gemeenten het minst positief over de mate van doelbereiking. Alleen bij het beleid gericht op het voortijdig schoolverlaten is er sprake van een significant verband met stedelijkheid. Een uitzondering geldt verder het beleid gericht op de realisatie van brede scholen. Hierover zijn naast de meest stedelijke ook de minst stedelijke gemeenten veel minder positief dan de matig stedelijke gemeenten. Er blijken nauwelijks relaties te bestaan tussen de oordelen van ambtenaren over de mate van doelbereiking en de kenmerken van het gevoerde beleid.

\section{Tabel 8.4}

Oordelen van ambtenaren over mate van doelbereiking, naar stedelijkheid gemeente, 2001 (gemiddelde score op schaal $1-4,1=$ doelen volgens planning, $2=$ doelen met vertraging, 3 = gedeeltelijke doel bereiking, 4 = geen doelbereiking)

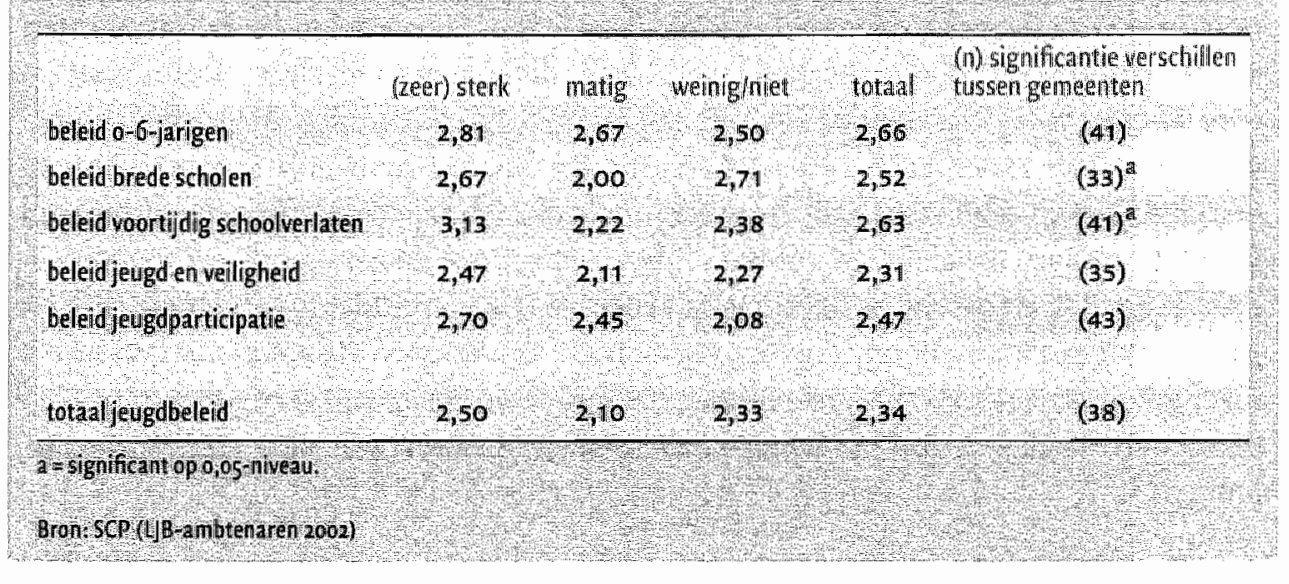

\subsubsection{Conclusies}

Instellingen zijn over de mate van doelbereiking op hun werkveld pessimistischer dan ambtenaren jeugdbeleid en dan de RMC-ambtenaren over de doelbereiking in het totale jeugdbeleid. De mate van materiële sturing blijkt het oordeel van instellingen in positieve zin te beïnvloeden. Het grotere optimisme bij ambtenaren geldt vooral het jeugd-en veiligheidsbeleid en het participatiebeleid. Met name over het o-6-jarigenbeleid en de aanpak van het voortijdig schoolverlaten zijn de ambtenaren relatief somber. Zij zijn opmerkelijk genoeg ook minder positief dan hun RMC-collega's over de doelbereiking bij de annpak van het voortijdig schoolverlaten. Er blijkt nauwelijks samenhang te bestaan tussen het beleidstype van de gemeente waarvoor een ambtenaar werkzaam is en zijn of haar oordeel over de doelbereiking. 
In deze paragraaf staan de oordelen van instellingen en ambtenaren over het jeugdbeleid en de resultaten daarvan centraal. Om te beginnen worden in tabel 8.5 de oordelen van de instellingen over het gevoerde jeugdbeleid gepresenteerd, uitgesplitst naar type instelling.

\subsubsection{Totaalbeeld}

Het meest positief - maar met iets meer dan een zesje, om in rapporttermen te spreken, evengoed zuinig - oordelen de instellingen over de toespitsing van het jeugdbeleid op de lokaalspecifieke situatie, ofwel over de vraag of er in het jeugdbeleid sprake is van maatwerk. Ook de afstemming en samenwerking tussen instellingen en de netwerksturing door de gemeente worden met gemiddeld iets meer dan een zes gewaardeerd. Deze aspecten van het jeugdbeleid betreffen de beleidsformulering (maatwerk) en de netwerksamenwerking en -sturing. De oordelen over de resultaten van het jeugdbeleid zijn gemiddeld lager. Het realiseren van een sluitende aanpak voor de diverse leeftijdsgroepen scoort een zes met een dikke min. Nog lager scoort de mate waarin moeilijk bereikbare doelgroepen ook daadwerkelijk bereikt worden: gemiddelde een vijf en een half. De meer procesmatige aspecten "afstemming tussen jeugd- en onderwijsbeleid" en 'inhoudelijke sturing door de gemeente' scoren beduidend lager dan de overige procesmatige aspecten. Het gemiddelde totaaloordeel over het jeugdbeleid komt uit op een zes, wat vertaald kan worden als voldoende, niets meer en niets minder. Overigens blijken de diverse oordelen van vertegenwoordigers van instellingen over het beleid en de resultaten ervan onderling sterk samen te hangen. ${ }^{2}$

\subsubsection{Naar type instelling}

Zijn er verschillen in de manier waarop verschillende typen instellingen oordelen over de uiteenlopende aspecten van het jeugdbeleid? Op bijna alle aspecten bestaan er significante verschillen in beoordeling (zie tabel 8.5), behalve bij maatwerk en bij het bereik onder moeilijk bereikbare doelgroepen, hoewel zich op deże punten hetzelfde patroon manifesteert dat zichtbaar is bij de overige aspecten. Op bijna alle aspecten geldt dat de RMC's zich het meest positief uitlaten over het jeugdbeleid. De verklaring hiervoor zou kunnen zijn dat de RMC-respondenten werkzaam zijn bij gemeenten en meer dan andere respondenten direct hebben bijgedragen aan de vormgeving van het jeugdbeleid. Daarnaast zijn de Bureaus Jeugdzorg in het algemeen positief over het jeugdbeleid, net als het voortgezet onderwijs en de politie. Bijna zonder uitzondering negatief zijn in het bijzonder de kinderopvang en - in mindere mate - het peuterspeelzaalwerk. Ook de instellingen voor thuiszorg en de consultatiebureaus zijn in het algemeen negatiever dan andere instellingen. Instellingen die in hoofdzaak betrokken zijn bij het beleid gericht op o- tot 6-jarigen oordelen negatiever over de verschillende aspecten van het jeugdbeleid dan instellingen die betrokken zijn bij het beleid gericht op de jeugd ouder dan 12 jaar. 


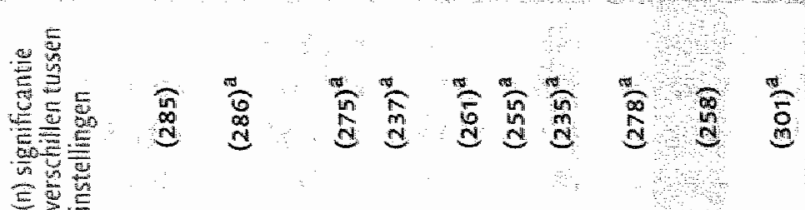

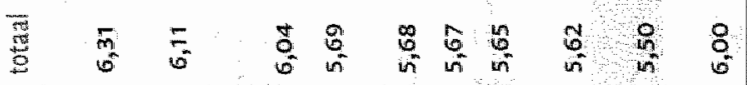

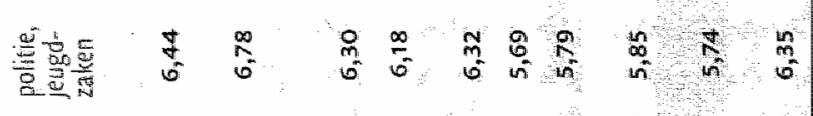

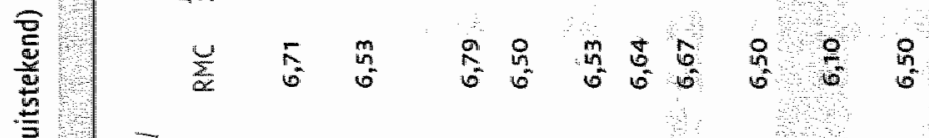

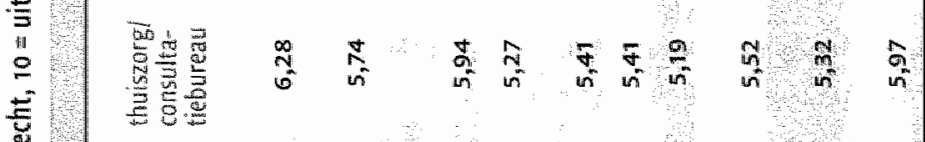

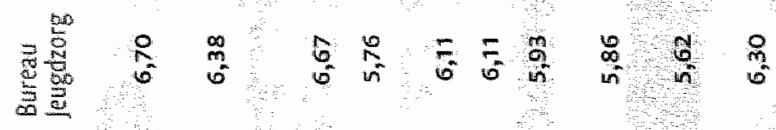

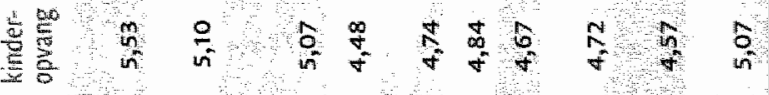
爱 है

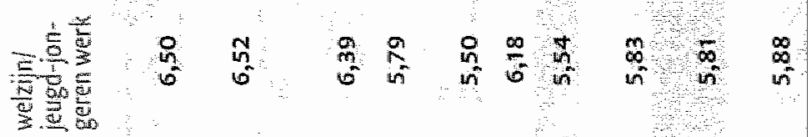

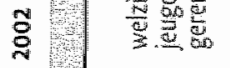

点产

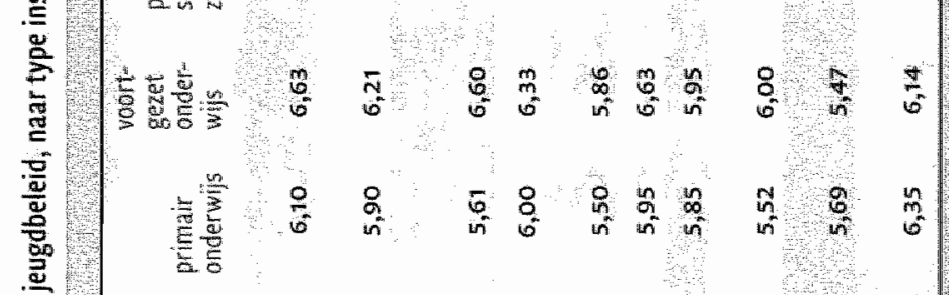

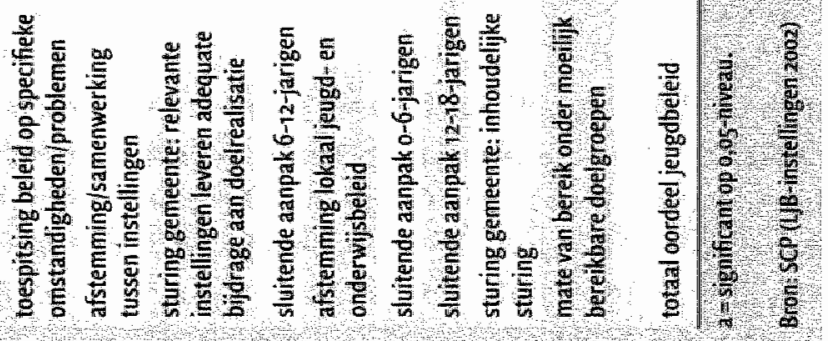




\subsubsection{Naar betrokkenheid bij het jeugdbeleid}

In tabel 8.6 zijn de oordelen over verschillende aspecten van het jeugdbeleid gekoppeld aan de betrokkenheid. Uit deze tabel komt duidelijk naar woren dat instellingen die niet of nauwelijks bij het jeugdbeleid zijn betrokken gemiddeld een beduidend negatiever beeld hebben dan instellingen die zowel bij de formulering als bij de uitwoering wan het jeugdbeleid betrokken zijn. Ook instellingen die alleen bij de uitvoering betrokken zijn, en dus niet bij de formulering, oordelen op alle aspecten gemiddeld negatiever dan de wel bij de formulering betrokken instellingen, zij het in mindere mate dan de in het geheel niet betrokken instellingen. Instellingen die alleen bij de formulering betrokken zijn, hebben gemiddeld een relatief positief oordeel over verschillende aspecten. Zij scoren echter ook op een aantal aspecten onder het gemiddelde oordeel.

\section{Tabel 8.6}

Oordelen instellingen over resultaten lokaal jeugdbeleid, naar betrokkenheid bij jeugdbeleid, 200.2 (gemiddelde score op schaall $1-10: 1=$ slecht, $10=$ uitstekend)

\begin{tabular}{|c|c|c|c|c|c|c|}
\hline & $\begin{array}{l}\text { fornulering } \\
\text { entutwoering }\end{array}$ & $\begin{array}{l}\text { alleen } \\
\text { formule- } \\
\text { ring }\end{array}$ & $\begin{array}{l}\text { aleen } \\
\text { ditvoering }\end{array}$ & $\begin{array}{l}\text { niet/ } \\
\text { nawweliks } \\
\text { betroken }\end{array}$ & toraal & $\begin{array}{l}\text { (n) significante } \\
\text { yerschillen hassen } \\
\text { instellingen }\end{array}$ \\
\hline $\begin{array}{l}\text { toespitsing beleid op specifieke } \\
\text { onstandighedenv problemen }\end{array}$ & 6.79 & 6.67 & 5.57 & 494 & 630 & $(283)^{a}$ \\
\hline $\begin{array}{l}\text { afsteming/samenwerking } \\
\text { tussen instellingen }\end{array}$ & 6,68 & 6,22 & 5,61 & 4,36 & 6,110 & $(284)^{\mathrm{a}}$ \\
\hline $\begin{array}{l}\text { sturing gemeenter relevante } \\
\text { instellingen leveren adequate } \\
\text { bijdrage aan doelrealisatie }\end{array}$ & 6,52 & 6,46 & 5,45 & 4,50 & 6,04 & $(274)^{2}$ \\
\hline sluitende anpak $6-12$-jarigen & 6,04 & 5,60 & 5,20 & 4,77 & 5,69 & $(235)^{2}$ \\
\hline sluitende aanpak o- 6-jarigen & 6,11 & 5,56 & 5,34 & 4,44 & 5,67 & $(254)^{2}$ \\
\hline $\begin{array}{l}\text { afstemming lokaall jeugd-en } \\
\text { onderwijsbeleid }\end{array}$ & 6,18 & 5,89 & 4,74 & 4,27 & 5,67 & $(260)^{a}$ \\
\hline sluitende anpak $12-18$ - wrigen & 6,01 & 5,46 & 4,91 & 4,97 & 5,65 & $(233)^{2}$ \\
\hline $\begin{array}{l}\text { sturing gemeente inhoudelijke } \\
\text { sturing } \\
\text { mate van berelk onder moeilit }\end{array}$ & 6,09 & 5,52 & 5,00 & 4,43 & 5,61 & $(276)^{a}$ \\
\hline bereikbare doelgroepen & 5,79 & 5,46 & 5,07 & 4,77 & 5,50 & $(256)^{\mathrm{a}}$ \\
\hline total oordeel jeugdbeleid & 6,45 & 6,30 & 5,59 & 4,68 & 6,00 & $(299)^{2}$ \\
\hline
\end{tabular}

Het is niet zo dat de typen instellingen die het minst of het meest positief zijn over het jeugdbeleid daar ook het minst sterk respectievelijk het sterkst bij betrokken zijn. De RMC-respondenten achten zichzelf gemiddeld het minst betrokken, maar zijn het meest positief. Kennelijk speelt meer dan hun betrokkenheid hun institutionele positie een rol. Bij de kinderopvang lijkt er wel een verband tussen de gemiddeld relatief geringe betrokkenheid en de lage beoordeling te bestaan. Van andere typen 
instellingen kan niet gezegd worden dat de mate van hun betrokkenheid bij het jeugdbeleid hun beoordeling beînvloedt.

\subsubsection{Naar type jeugdbeleid}

Het ligt in de verwachting dat het gevoerde jeugdbeleid invloed heeft op hoe de doelbereiking wordt ingeschat, en voor de oordelen over het beleid en de resultaten daarvan geldt dat in versterkte mate. Hoe verder het beleid is ontwikkeld en hoe sterker de voorwaardelijke en materiële sturing, hoe positiever de oordelen zullen zijn. In tabel $8.7 \mathrm{zijn}$ de resultaten opgenomen van multivariate analyses, waarin ook de stedelijkheid als achtergrondkenmerk van gemeenten is meegenomen. De stedelijkheid van de gemeente blijkt geen rol te spelen in de beoordeling van het beleid. Bij bijna alle genoemde aspecten speelt de mate van materiële sturing een rol, soms alleen, soms met het beleidstype of met de mate van voorwaardelijke sturing. Hoe sterker de materiële sturing door de gemeente, hoe positiever het (gemiddelde) oordeel. Het realiseren van maatwerk - beleid toegespitst op de lokale situatie - wordt het beste verklaard door zowel het beleidstype als de mate van materiële sturing. Met andere woorden: bij een interactief beleidstype en een sterke mate van materiële sturing wordt het jeugdbeleid het meest als maatwerk beoordeeld. De evaluatie van de procesmatige sturing - zorgen dat relevante instellingen een bijdrage leveren - en het realiseren van een sluitende aanpak van o- tot 6 -jarigen worden woor een redelijk deel verklaard door de mate van voorwaardelijke en materiële sturing. Opvallend genoeg spelen de genoemde kenmerken als zij worden samengenomen geen rol bij het verklaren van verschillen in het totaaloordeel over het jeugdbeleid. De mate van materiële sturing hangt hier wel bivariaat mee samen.

\section{Tabel 8.7}

Verklaring van aordelen van instellingen over resultaten jeugdbeleid, multivariate analyse, 2002

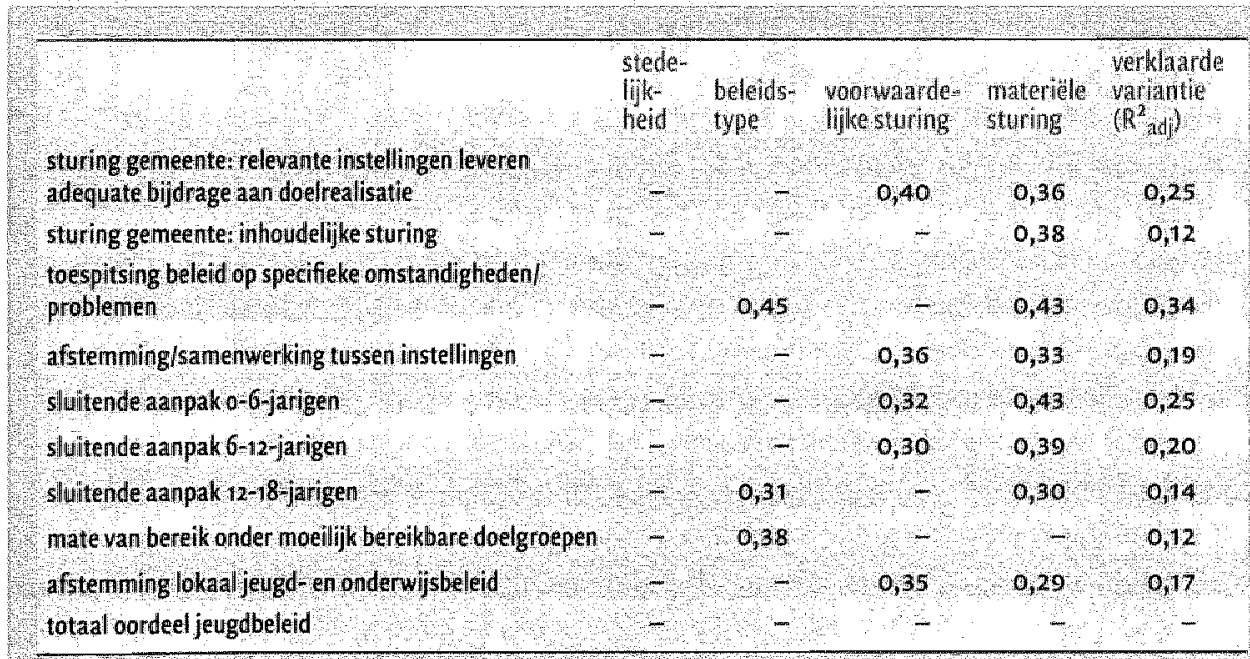

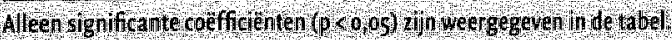




\subsubsection{Oordelen van ambtenaren}

Ook de verschillende oordelen van a mbtenaren blijken onderling samen te hangen, hoewel wat minder sterk dan bij de instellingen. ${ }^{3}$ Uit tabel $8.8 \mathrm{blijkt}$ dat het oordeel van ambtenaren gemiddeld wat milder is dan dat van instellingen. Verder komt grosso modo hetzelfde beeld naar voren: ook ambtenaren oordelen (betrekkelijk) positief over de vraag of er sprake is van maatwerk en over de eigen sturing. Het verschil is dat ambtenaren, in tegenstelling tot instellingen, relatief tevreden zijn over de inhoudelijke sturing. De ambtenaren zijn het wel weer eens met de instellingen over de relatief lage waardering van de inhoudelijke resultaten van het jeugdbeleid: de sluitende aanpak van de verschillende leeftijdsgroepen en het bereik van moeilijke doelgroepen. Deze aspecten scoren lager dan de eerder genoemde meer procesmatige aspecten van het jeugdbeleid. De ambtenaren is gevraagd naar hun oordeel over de mate waarin de relevante gemeentelijke afdelingen en diensten oog hebben voor het jeugdbeleid. Ambtenaren blijken daarover niet enthousiast te zijn. Verder valt op dat ambtenaren van de meest stedelijke gemeenten op de meeste punten positiever oordelen dan die van de minst stedelijke gemeenten, terwijl de matig stedelijke gemeenten een tussenpositie innemen die meestal dichter tegen de meest stedelijke gemeenten aan ligt dan tegen de minst stedelijke. Ondanks dit tamelijk consistente patroon zijn de verschillen echter maar in drie gevallen significant.

\section{Tabel 8.8}

Oordelen van ambtenaren over resultaten jeugdbeleid, naar stedelijkheid gemeente, 2001 (gemiddelde score op schaal $1-10: 1=$ slecht, $10=$ uitstekend)

\begin{tabular}{|c|c|c|c|c|c|}
\hline & $\begin{array}{l}\text { geer } \\
\text { sterk }\end{array}$ & matig & weing & totaal & $\begin{array}{l}\text { (n) significantive } \\
\text { werschillen tussen } \\
\text { anstellingen }\end{array}$ \\
\hline $\begin{array}{l}\text { toespitsing beleid op specifieke amstandigheden } \\
\text { problemen }\end{array}$ & & & & & \\
\hline $\begin{array}{l}\text { sturing gemeente relevante instellingen leveren } \\
\text { adequate bijdrage andoelrealisatie }\end{array}$ & 6,96 & 7,00 & 6,05 & 6,64 & $(59)^{\mathrm{a}}$ \\
\hline afstemming lokal/geugd d en onderwis isbeleid & 6,91 & 6,71 & 6,00 & 6,53 & (58) \\
\hline sturing gemeente: Inhoudelijke sturing & 6,61 & 6,20 & 5,76 & $6,20$. & $(59)^{\mathrm{a}}$ \\
\hline stuitende aanpak 0-6-Jarigen & 6,48 & 6,31 & 5,81 & 6,19 & $(57)$ \\
\hline sluitende aanpak 6 - 2-jarigen & 6,30 & 5,92 & $5 ; 67$ & 5,98 & $(57)$ \\
\hline sluitende aanpak 12 18-jarigen & 6,39 & 6,14 & 5.29 & 5,93 & $(58)^{\mathrm{a}}$ \\
\hline afdelingen hebben oog voor jeugdbeleid & 6,30 & 5,73 & 5,52 & 5,88 & $(59)$ \\
\hline mate van berelk onder moelijk bereikbare doelgroepen & 6,00 & 5,73 & 5,14 & 5,63 & (59) \\
\hline totaal oordeel jeugdbeleid & 6,66 & 6,61 & 6,00 & 6,41 & $(56)$ \\
\hline
\end{tabular}


De oordelen van ambtenaren zijn, net als die van instellingen, betrokken in een multivariate analyse (zie tabel 8.9). Daaruit blijkt dat de verschillende kenmerken van het beleid een rol spelen in de beoordeling van (de resultaten van) het beleid. De mate van voorwaardelijke sturing speelt bij de helft van de aspecten een rol: hoe sterker deze vorm van sturing, hoe positiever het oordeel van de ambtenaar. De andere kenmerken van het beleid zijn voor een beperkter aantal aspecten van belang, maar wel steeds in de verwachte richting.

Tabel 8.9

Verklaring van oordelen van ambtenaren over resultaten jeugdbeleid, multivariate analyse, 2001

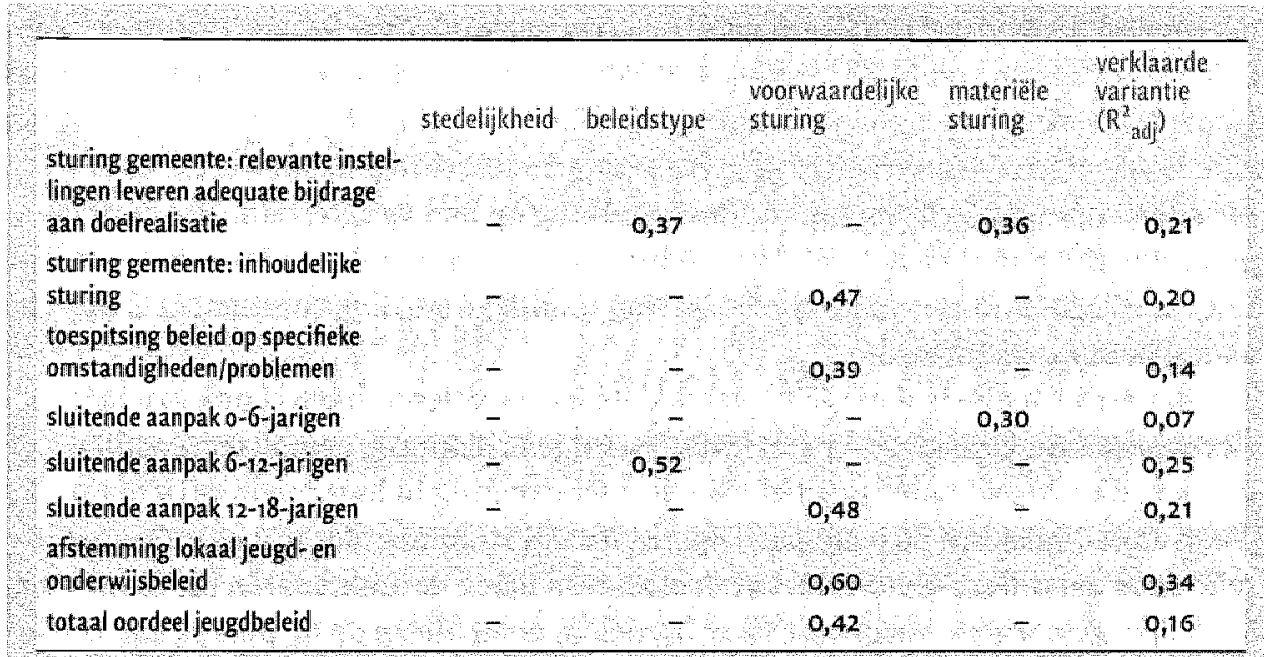

Alleen significante coefficienten $(p<0,05)$ in ineergegeven in de tabl

Brons SCP (LB-ambtenaren 2002)

Op het niveau van gemeenten blijkt dat er op bijna alle aspecten een samenhang bestaat tussen het oordeel van de ambtenaren en dat wan de instellingen. Het sterkst. is de samenhang bij het totaaloordeel over het jeugdbeleid. ${ }^{4}$

\subsubsection{Conclusies}

Het meest opvallend aan de beoordeling van het lokale jeugdbeleid en de resultaten ervan is dat de meeste procesmatige aspecten (maatwerk, netwerksturing- en samenwerking) positiever worden beoordeeld dan de inhoudelijke resultaten. Zowel bij de instellingen als bij de ambtenaren is dit patroon waarneembaar. Verder is opvallend dat de oordelen over de resultaten samenhangen met kenmerken van het gevoerde beleid, en niet met de stedelijkheid van de gemeente. Tot slot is het duidelijk geworden dat de oordelen van instellingen in sterke mate bepaald worden door hun betrokkenheid bij het beleid: instellingen die bij zowel formulering als uitvoering zijn betrokken, oordelen veruit het meest positief. 
In dit hoofdstuk is ingegaan op de vraag hoe bij het lokale jeugdbeleid betrokken actoren de effectiviteit van dat beleid beoordelen. Dat is gedaan door deze actoren te vragen naar hun inschatting van de doelbereiking en naar hun oordeel over het beleid en de resultaten.

Ruim de helft van de bij het jeugdbeleid betrokken instellingen denkt dat de doelstellingen op het eigen werkterrein hooguit gedeeltelijk worden gehaald. Ongeveer eenderde denkt dat de doelstellingen gehaald worden, hoewel de meerderheid van deze groep denkt dat dat later zal gebeuren dan gepland. Instellingen die meer bij de beleidsformulering en/of -uitwoering betrokken zijn, schatten de doelbereiking doorgaans wat zonniger in dan instellingen die niet of nawwelijks bij het beleid betrokken zijn. Verder zijn er weinig verschillen tussen typen instellingen, hoewel de RMC's opvallend optimistisch zijn over de doelbereiking op hun werkterrein. Het door de gemeente gevoerde beleid is slechts van beperkt belang voor de oordelen van instellingen. Alleen de mate van materiële sturing (politieke sturing, consensus) is op een aantal punten van invloed.

Ambtenaren jeugdbeleid oordelen gemiddeld iets positiever, hoewel ook van hen slechts een minderheid denkt dat de doelen volgens planning gerealiseerd zullen worden. Zij zijn met name positief over de doelbereiking in hun beleid gericht op jeugd en veiligheid en op jeugdparticipatie, terwijl zij somberder zijn over de doelbereiking in het o-6-jarigenbeleid. In het algemeen lijken de ambtenaren uit de minder stedelijke gemeenten wat positiever te oordelen, maar alleen op de punten van brede scholen en voortijdig schoolverlaten zijn deze verschillen significant.

Instellingen oordelen relatief positief over het beleid, met name over de mate waarin het beleid is toegespitst op de lokale situatie en over de procesmatige aspecten van de gemeentelijke sturing. De inhoudelijke kant van die sturing beoordelen zij gemiddeld als onvoldoende. Hetzelfde geldt voor de resultaten van het beleid. Ook hier zijn zij gemiddeld minder over te spreken. Het totaaloordeel over het jeugdbeleid is gemiddeld een zes. Het valt op dat vooral instellingen die bij het o-6-jarigenbeleid zijn betrokken het beleid en de resultaten zuinig beoordelen. Dit sluit aan bij de sceptische inschatting die ambtenaren maken van de doelbereiking in dat beleid. Ook ten aanzien van de oordelen over het beleid en de resultaten ervan vinden we dat de instellingen die zowel betrokken zijn bij de formulering als bij de uitwoering van het beleid, het meest positief oordelen, gevolgd door de instellingen die alleen betrokken zijn bij de beleidsformulering. Instellingen die niet of nauwelijks bij het jeugdbeleid zijn betrokken, oordelen het meest negatief. Verder blijkt dat de oordelen van instellingen positief worden beïnvloed door met name de materiële sturing (politieke sturing, consensus), en in iets mindere mate de voorwaardelijke sturing (beleidsontwikkeling, netwerkvorming, visie). Hoe sterker de sturing, hoe positiever het oordeel. 
Ambtenaren zijn ook op dit punt wat positiever dan instellingen, maar hun oordelen komen in grote lijnen overeen met die van instellingen. Het oordeel van ambtenaren wordt in positieve zin beïnvloed door de mate van voorwaardelijke sturing.

Al met al moeten we concluderen dat zowel ambtenaren als instellingen in meerderheid zeer zuinig oordelen over de resultaten en de doelbereiking in het jeugdbeleid. Actieve gemeentelijke sturing, zowel materieel als voorwaardelijk, heeft doorgaans een positieve invloed. Die sturing wordt gemiddeld krap voldoende beoordeeld, met uitzondering van de inhoudelijke sturing. Over het maatwerk dat in het lokale jeugdbeleid wordt geleverd, zijn de beleidsactoren het meest positief, hoewel nog steeds relatief zuinig. Tot slot springt het $0-6$-jarigenbeleid eruit. Hierover tonen de betrokken instellingen en de ambtenaren zich gereserveerd. 
I In tabel 8.4 wordt alleen gerapporteerd over de gemeenten die op het betreffende terrein doelen hebben geformuleerd, wat de reden vormt voor de relatief lage $n$ in de laatste kolom.

2 In een principale-componentenanalyse hebben alle oordelen een minimale factorlading van 0,77 op de eerste factor, die $73 \%$ van de variantie verklaart.

3 In een principale-componentenanalyse hebben alle oordelen een minimale factorlading van 0,55 op de eerste factor, die $60 \%$ wan de variantie verklaart.

4 Pearson's $R=0,45, p=0,00$ I $(n=48)$. 


\section{$9 \quad$ Resultaten van lokaal jeugdbeleid}

\subsection{Inleiding}

In hoofdstuk 8 zijn de bij het beleid betrokken actoren aan het woord geweest over het jeugdbeleid. Vanzelfsprekend geven zij een subjectief beeld van het beleid en van de resultaten. In dit hoofdstuk wordt getracht de resultaten van het jeugdbeleid op een meer objectieve wijze te schetsen. In hoofdstuk 2 is al aangegeven dat de 72 onderzoeksgemeenten zijn benaderd met de vraag of zij voor een aantal indicatoren cijfers konden verstrekken voor zowel het jaar 1998 als het jaar 200r. Daarnaast zijn, waar mogelijk, centrale databronnen gebruikt. De cijfers over het jaar 1998 fungeren als een soort nulmeting, omdat vanaf dat tijdstip het jeugdbeleid van de onderzoeksgemeenten is gevolgd. Het jaar $200 \mathrm{r}$ is gekozen als tweede meetpunt. De keuze voor 2001 was vooral pragmatisch: de dataverzameling werd verricht in 2002. Door naar de scores op twee momenten te kijken, is het mogelijk de ontwikkeling vast te stellen die gemeenten op de indicatoren hebben doorgemaakt. Door deze ontwikkeling te relateren aan kenmerken van het jeugdbeleid zou het wellicht mogelijk zijn iets te zeggen over bepaalde kenmerken die een positieve dan wel een negatieve invloed op de beleidsresultaten hebben. Bij de ontwikkeling van dit onderzoek is steeds benadrukt dat dergelijke pogingen om beleidsuitkomsten te verklaren door herhaling van het onderzoek aan kracht zullen winnen. Hoe langer de periode waarover beleidsinformatie beschikbaar is en hoe langer de periode waarin ontwikkelingen op de verschillende uitkomstenindicatoren kunnen worden vastgesteld, hoe robuuster de uitspraken over de relaties tussen beleid en beleidsuitkomsten kunnen zijn. In dit opzicht weerspiegelt dit hoofdstuk de eerste poging daartoe, die noodgedwongen beperkt is tot een relatief korte periode. Dat noopt tot allerlei slagen om de arm met betrekking tot de mogelijkheid causale verbanden te leggen en met betrekking tot noties over de incubatietijd van (sociaal) beleid: in hoeverre mag van beleid dat in r 998 is ingezet resultaat verwacht worden in 200I, zeker als het gaat om een beleidsterrein dat niet zelden effecten op langere termijn nastreeft?

In hoofdstuk 2 is al bericht over de tegenvallende resultaten van de dataverzameling bij gemeenten en deels ook bij centrale bronnen. In dit hoofdstuk komen daarom veel minder indicatoren aan de orde dan oorspronkelijk beoogd. Tabel $9 . \mathrm{I}$ bevat een overzicht van de indicatoren die wel aan de orde komen. De beschikbare indicatoren zijn ingedeeld naar vijf voor het lokale jeugdbeleid belangrijke thema's, die voor het grootste deel ook in hoofdstuk 4 aan de orde zijn gekomen. Voor iedere indicator is aangegeven of het de output wan beleid betreft (ook wel intermediair effect of prestatie), of de outcome (ook wel finaal effect of effect, vgl. Financiën 2002: 17). 
Tabel 9.1

Output en outcome indicatoren lokaal jeugdbeleid

\begin{tabular}{|c|c|c|c|}
\hline beleidsthema & $\begin{array}{l}\text { butpuly } \\
\text { outcome }\end{array}$ & inditator & bron \\
\hline voortidge cinval & outcome & $\begin{array}{l}\text { aandeel jeugdigen van } 15-24 \text { jaar met ABW- } \\
\text { WW uitkering in het totale aantal } 15^{-24^{-}} \\
\text {jarigen }\end{array}$ & CBS \\
\hline \multirow[t]{2}{*}{ jeugd en velligheid } & outcome & $\begin{array}{l}\text { aandeel minderjarig gehoorde verdachten } \\
(12-17 \text { jaar) in het totale aantal } 12-17 \text {-jarigen }\end{array}$ & CBS \\
\hline & output & $\begin{array}{l}\text { Halt-afdoeningen als percentage van } 12-17- \\
\text { jarigen }\end{array}$ & Halt \\
\hline sluitende anpalk o-6-jarigen & output & $\begin{array}{l}\text { aandeel peuters dat consultatiebureau } \\
\text { bezoekt in het totale aantal 0-3-jarigen }\end{array}$ & $\begin{array}{l}\text { thuiszorg- } \\
\text { organisaties }\end{array}$ \\
\hline ondermijsachiterstanden & outcome & $\begin{array}{l}\text { gemiddelde scores Cito-eindtoets basis- } \\
\text { onderwijs }\end{array}$ & Cito \\
\hline maatscliappelijke participatie & outcame & aandeel jeugdigen lid van bibliotheek & $\begin{array}{l}\text { NBLC-kennis- } \\
\text { centrum }\end{array}$ \\
\hline
\end{tabular}

\subsection{Overzicht van de resultaten}

Tabel 9.2 biedt een overzicht van het beschikbare materiaal. De laatste kolom van de tabel, die betrekking heeft op de ontwikkeling tussen r 998 en 200r, bevat gegevens over de gemeenten waarvan voor beide jaren gegevens beschikbaar zijn. De kolonmen waarin over de afzonderlijke jaren gerapporteerd wordt, gaan in bijna alle gevallen over een groter aantal gemeenten.

\section{Tabel 9.2}

Gemiddelde scores indicatoren beleidsuitkomsten, 1998, 2001 (en procentueel verschil (n))

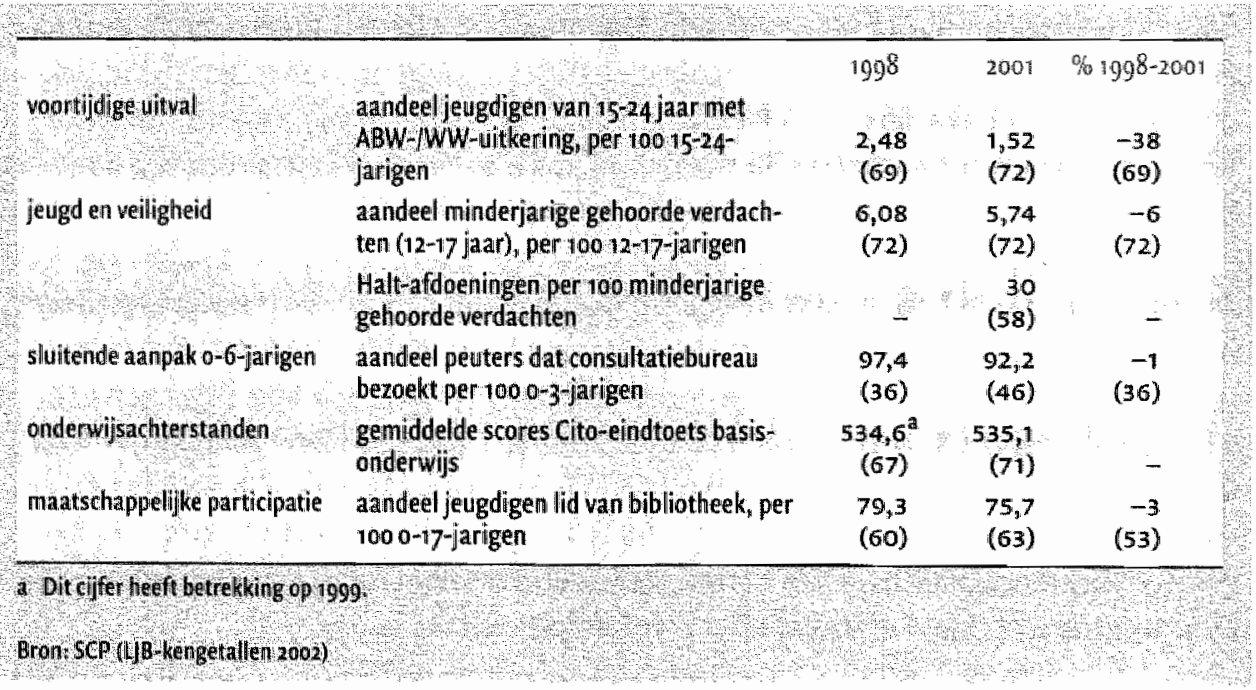


Het aandeel jeugdigen met een uitkering in het kader van de Werkloosheidwet (ww) of de Algemene bijstandswet (ABW) is tussen 1998 en 2001 per gemeente gemiddeld met $38 \%$ teruggelopen. In 200 lag het gemeentelijke percentage jeugdige werklozen op gemiddeld I,52, tegen 2,48 drie jaar eerder. Dit komt overeen met de landelijke trend. In 1999 ontving $4,53 \%$ van de 15 -24-jarigen een $A B w$ - of Ww-uitkering, in 2001 was dat $3,75 \% .{ }^{1}{ }^{2}$ Overigens is de dalende trend in 2002 tot stilstand gekomen (CBS 2003a: 93) en is er in 2003 sprake van een toenemende jeugdwerkloosheid (CBS 2003c).

Op het gebied van jeugd en veiligheid zijn twee indicatoren beschikbaar: het percentage minderjarige gehoorde verdachten onder $12-17$-jarigen en het aantal Halt-afdoeningen per roo minderjarige gehoorde verdachten. Het percentage minderjarige gehoorde verdachten is in de periode 1998-200I gemiddeld per gemeente iets afgenomen. Ook deze trend komt overeen met landelijke cijfers (CBS 2003b). Per 100 I2-I7-jarigen zijn in 200I per gemeente gemiddeld bijna zes personen gehoord wegens verdenking van het plegen van een strafbaar feit. Er bestaat een relatie met de stedelijkheid van de gemeente: in de meest stedelijke gemeenten ligt het percentage tegen de 8 , in de matig stedelijke gemeenten rond het gemiddelde, en in de minst stedelijke gemeenten tegen de 4 . Overigens neemt de toename tussen 1998 en $200 \mathrm{r}$ van het aandeel minderjarige gehoorde verdachten af met de stedelijkheid. Het is onduidelijk of het gemiddeld min of meer stabiele niveau van het percentage minderjarige gehoorde verdachten te maken heeft met een gelijk gebleven aantal strafbare feiten die door jongeren zijn gepleegd, met versterkte opsporingsinspanningen bij gedaalde criminaliteit, of met minder sterke opsporingsinspanningen bij gestegen jeugdcriminaliteit. In ieder geval lijkt er een verband te bestaan tussen het aandeel minderjarige gehoorde verdachten en de intensiteit van de opsporing. Wittebrood (2000a; 2000b: 185) maakt namelijk aannemelijk dat de door haar gesignaleerde toename in het aandeel minderjarige gehoorde verdachten het gevolg is van toegenomen aandacht van politie en justitie voor jeugdcriminaliteit.

Voor de Halt-afdoeningen zijn alleen gegevens over zoor beschikbaar. Deze cijfers zijn gepercenteerd over het aantal minderjarige gehoorde verdachten, omdat de Halt-afdoening als geschikte straf wordt gezien voor jongeren die voor het eerst met politie en justitie in aanraking komen en niet al te ernstige strafbare feiten hebben gepleegd (Wittebrood 2003). Het aandeel Halt-afdoeningen vormt daarom geen indicator van de omvang van de jeugdcriminaliteit, maar van de wijze van strafoplegging. Gemiddeld werden in $200 r$ per gemeente 30 van de roo minderjarige gehoorde verdachten met een afdoening door het Bureau Halt gestraft.

Voor de sluitende aanpak van o- tot 6-jarigen kan worden beschikt over de indicator 'percentage 0-3-jarigen dat het consultatiebureau bezoekt'. Dit percentage is in de 36 onderzoeksgemeenten waarvan voor beide jaren cijfers bekend zijn, nagenoeg gelijk gebleven. Het bereikpercentage ligt in deze gemeenten in 1998 zeer hoog met 97 . In 
2001, voor welk jaar over gegevens van meer gemeenten kan worden beschikt, ligt het percentage op 92. Dit komt overeen met bevindingen van het Centraal Bureau voor de Statistiek, dat voor heel Nederland in $200 \mathrm{r}$ een percentage vond van rond de 90 (CBS 2003a: 55). In dit onderzoek zijn geen significante samenhangen met de stedelijkheid van de gemeenten aangetroffen, net zo min als er een relatie bestaat tussen de stedelijkheid en de tussen 1998 en 2001 gerealiseerde ontwikkeling in bereik.

De enige indicator die betrekking heeft op het onderwijs laat tussen I998 en 200 r geen echte veranderingen zien. De gemiddelde Cito-score is in zoor weliswaar iets hoger dan in r999, maar aan de omvang van de stijging kan geen grote betekenis worden toegekend.

Het aandeel jeugdigen dat lid is van een bibliotheek is tussen r 998 en $200 \mathrm{r}$ gemiddeld per gemeente licht afgenomen. Dat past in de eerder door het Sociaal en Cultureel Planbureau (SCP) wastgestelde trend. Tussen 1995 en 1999 zou het aandeel 12- tot Ig-jarigen dat woor eigen gebruik boeken leent uit de bibliotheek gedaald zijn van $73 \%$ naar $68 \%$. In de leeftijdscategorie van 6 tot 12 jaar is het aandeel in dezelfde periode licht gestegen van $81 \%$ maar $83 \%$ (Huysmans en De Haan 2003: 84).

\subsection{Resultaten en beleidskenmerken}

Worden de resultaten die gemeenten volgens de in dit hoofdstuk gehanteerde indicatoren boeken teweeggebracht door het gevoerde beleid? Om deze vraag te beantwoorden zijn de verschillende typen beleid (passief, actief, interactief), de verschillende vormen van sturing en - als achtergrondkenmerk van gemeenten - de stedelijkheid gerelateerd aan de scores die gemeenten in $200 \mathrm{r}$ op de verschillende indicatoren hadden, en aan de verschilscores tussen 1998 en 2001.

\section{Tabel 9.3}

Beleidskenmerken en beleidsresultaten: multivariate analyse (gestandaardiseerde regressiecoëfficiënten)

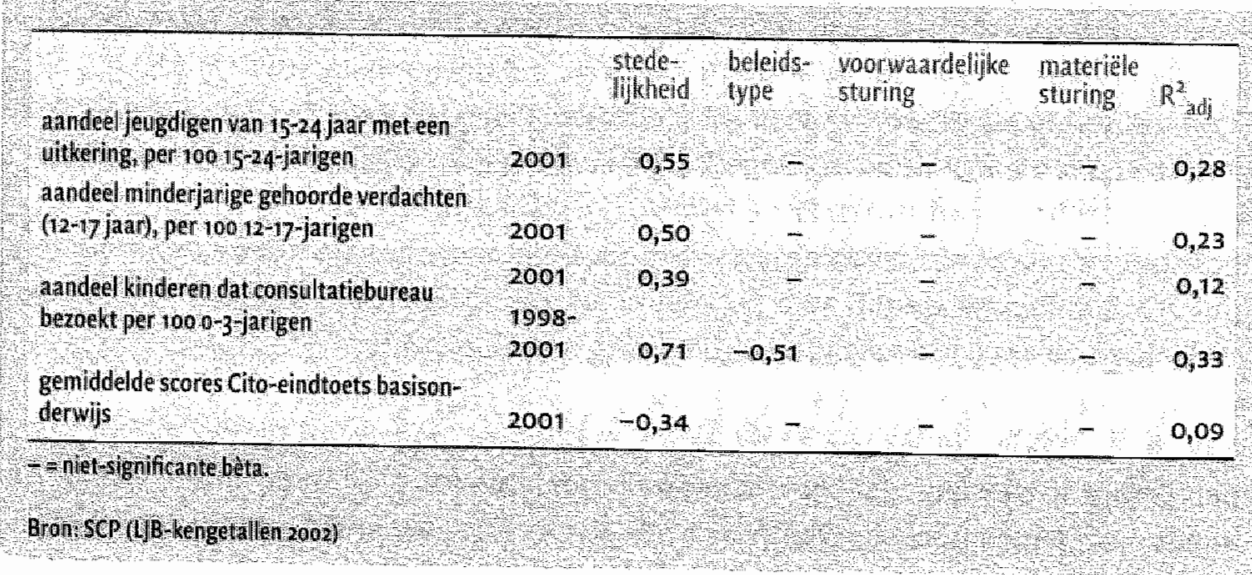


In de multivariate analyse resteert op een beperkt aantal indicatoren de invloed van beleidskenmerken (zie tabel 9.3). De stedelijkheid van de gemeenten blijkt bij al deze indicatoren van invloed. Hoe stedelijker de gemeente, hoe hoger het aandeel jongeren met een uitkering, hoe hoger het aandeel minderjarige gehoorde verdachten, en hoe hoger het aandeel kinderen dat het consultatiebureau bezoekt. Bovendien hangt het verschil tussen het aandeel kinderen dat in 1998 en in 2001 het consultatiebureau heeft bezocht, positief samen met de stedelijkheid: in meer stedelijke gemeenten is dit aandeel gemiddeld sterker gestegen dan in minder stedelijke gemeenten. De gemiddelde score op de Cito-toets is in de minder stedelijke gemeenten hoger dan in de meer stedelijke gemeenten.

Gecontroleerd voor de stedelijkheid van gemeenten is er bij een enkele indicator sprake van invloed van beleidskenmerken. Opmerkelijk genoeg laat dit enige geval een effect zien dat omgekeerd is aan het verwachte effect. Hoe meer het beleid ontwikkeld is, des te lager is de toename in het aantal kinderen dat het consultatiebureau bezoekt - hoewel stedelijkheid een groter effect heeft. Het is lastig deze bevinding te interpreteren. Mogelijk is de indicator te specifiek om beinvloed te worden door de meer algemene kenmerken van het jeugdbeleid.

Er blijken slechts in beperkte mate samenhangen te bestaan tussen de oordelen van beleidsactoren over de resultaten ( $z$ ie hoofdstuk 8) en de resultaten die, afgemeten aan de ontwikkeling op de in dit hoofdstuk gepresenteerde indicatoren, in het jeugdbeleid geboekt zijn.

\subsection{Samenuatting en condusies}

De belangrijkste conclusie van dit hoofdstuk is dat veel gegevens die - in ieder geval vanuit nationaal perspectief - relevant zijn voor het jeugdbeleid, niet of slechts in een beperkt aantal gemeenten voorhanden zijn. Bovendien blijken de gehanteerde definities tussen gemeenten te verschillen. Om die reden is het hast ondoenlijk iets over de resultaten van het lokale jeugdbeleid te zeggen, laat staan verbanden te lleggen met het gevoerde beleid. We moeten constateren dat dit onderzoek op dit punt mislukt is; dat is vervelend voor dit onderzoek. Daarnaast is deze constatering ook van betekenis voor het lokale jeugdbeleid. Het blijkt immers niet mogelijk om op basis van objectieve cijfers iets over de resultaten van het jeugdbeleid te zeggen. Dergelijke informatie over de resultaten is alleen op deelterreinen beschikbaar, en dan nog lang niet altijd op gemeentelijk niveau. Om uiteindelijk uitspraken te kunnen doen over de effectiviteit van bepaalde typen lokaal jeugdbeleid, zal toch juist op het niveau van de gemeente de relatie tussen resultaten en beleid moeten worden gelegd. Dat blijkt helaas niet goed mogelijk op basis van de in 2002 bij gemeenten en centrale databronnen aanwezige gegevens. 
I De verschillen in de hoogte van de landelijke en gemeentelijke percentages hebben te maken met het feit dat bij de berekening van de gemiddelde gemeentelijke percentages het aantal inwoners niet wordt meegewogen. Het gemiddelde gemeentelijke percentage wan stad A met 10\% werklozen op een bevolking van r.000.000 inwoners en gemeente $B$ met $x \%$ werklozen op een bevolking van rooo inwoners bedraagt 5,5. Het aandeel werklozen in deze twee gemeenten samen bedraagt echter $9,99 \%$.

2 De gegevens zijn ontleend aan CBS StatLine en CBS 2003 b, en door de auteur bewerkt. 
10.1 Inleiding

Wat vinden jongeren zelf nu eigenlijk van het jeugdbeleid van de gemeente waarin zij wonen? Het beantwoorden van deze vraag is de derde manier waarop we in dit onderzoek naar de uitkomsten van het beleid kijken. De vraag is in de eerste plaats natuurlijk interessant omdat jongeren het object van jeugdbeleid zijn en dat beleid veelal gericht is op de verbetering van hun positie en leefsituatie. Daarom mag verondersteld worden dat een 'succesvol' jeugdbeleid tot een positief oordeel van jongeren leidt. De vraag is in de tweede plaats van bellang omdat de gedachte leeft dat gemeenten door hun korte afstand tot burgers, c.q. jongeren, beter dan andere bestuurslagen in staat zouden zijn de doelgroep van het beleid erbij te betrekken. Dit zou een positieve invloed moeten hebben op de effectiviteit van het jeugdbeleid. Veel gemeenten hebben zich dan ook nadrukkelijk ten doel gesteld hun jeugdbeleid (mede) te baseren op de wensen en behoeften van jongeren (zie hoofdstuk 5).

In hoofdstuk 2 is al kort uiteengezet op welke wijze jongeren in het onderzoek zijn betrokken. In negen gemeenten zijn steeds zo'n 60 jongeren geïnterviewd door jongeren die deel uitmaakten van een Jongeren Inspectie Team (JIT). Bovendien hebben de JTT's gesproken over de gemeente en hun jeugdbeleid, en over de resultaten van de interviews. In paragraaf I0.3 worden de resultaten van de interviews gepresenteerd. Ze zullen worden geïllustreerd en verlevendigd met fragmenten uit de JiT-besprekingen. In paragraaf 10.4 worden de bevindingen samengevat en beschouwd. Maar allereerst komt in paragraaf 10.2 de gevolgde werkwijze nader aan de orde.

10.2 De werkwijze van de Jongeren Inspectie Teams

Voor dit deel van het onderzoek is gebruikgemaakt van de door Stichting Alexander ${ }^{1}$ ontwikkelde methode van Jongeren Inspectie Teams (JIT's). Deze methode maakt het mogelijk jongeren beleid te laten evalueren en beoordelen. Zij zijn zelf actief betrokken bij het ontwikkelen en uitvoeren van het onderzoek. Het JIT-onderzoek is uitgevoerd in de negen onderzoeksgemeenten die betrokken zijn in het kwalitatieve onderzoek naar lokaal jeugdbeleid (zie hoofdstuk 2).

In de negen gemeenten zijn ambtenaren jeugdbeleid verzocht om mee te werken aan het onderzoek door informatie over het jeugdbeleid te verstrekken en door namen beschikbaar te stellen van personen binnen instellingen, die een rol zouden kunnen spelen in de werving van jongeren. Langs deze weg zijn in iedere gemeente tien tot twintig jongeren in de leeftijd van is tot 21 jaar geselecteerd waarmee een panelgesprek is gehouden over het lokale jeugdbeleid en over de voor de jeugd aan- 
wezige voorzieningen. De onderwerpen van deze gesprekken waren steeds dezelfde: gemeente in het algemeen, vrije tijd, school, werk, wonen, veiligheid, hulp bij vragen en problemen, en inspraak van jongeren. Uit deze groep jongeren zijn de leden van het IIT geselecteerd, waarbij gestreefd is naar een gemengde samenstelling wat betreft sekse, schooltype en etniciteit. In de gemeente die fungeerde als pilotgemeente is van dit stramien afgeweken en is gestart met een panelgesprek met de vijf jongeren die uiteindelijk het JIT zouden gaan vormen. In deze gemeente was het doel zo snel mogelijk tot een standaardvragenlijst te komen die als basis kon worden gebruikt in de andere gemeenten. Bij het ontwikkelen van deze standaardvragenlijst waren ook onderzoekers van het Sociaal en Cultureel Planbureau (SCP) en Stichting Alexander betrokken. Uitgangspunt bij het ontwikkelen van de vragenlijst was dat de interviews maximaal vijftien minuten mochten duren.

De leden van de JIT's hebben voorafgaand aan het afnemen van de interviews een bijeenkomst gehad waarin de standaardwragenlijst werd aangevuld op basis van de lokale situatie en specifieke wensen. Tevens namen zij deel aan een interviewtraining. Vervolgens nam ieder JIT-lid zo'n twaalf tot wijftien interviews af bij andere jongeren uit de gemeente. De JIT-leden mochten zelf hun respondenten selecteren, die tussen de 12 en 21 jaar oud moesten zijn. Wel werden zij geacht de selectie te spreiden naar sekse, schooltype en etniciteit. ${ }^{2}$ De resultaten van de interviews zijn door ieder JrT beschouwd en besproken, wat heeft geleid tot een eindrapportage per gemeente. De teamleden ontvingen voor hun inzet bij het onderzoek een vrijwilligersvergoeding.

Uiteindelijk zijn er in de negen gemeenten 504 interviews gehouden. Voor een verslag van het veldwerk wordt verwezen naar de bijlage $D$. In een aantal gemeenten hebben de JIT's hun bevindingen gepresenteerd aan en besproken met het gemeen-
tebestuur.

De belangrijkste voordelen van de JIT-methode zijn dat jongeren een grote rol spelen in de beoordeling van het beleid. Zij zijn betrokken bij de ontwikkeling van vragenlijsten en bij de interpretatie van de resultaten. Bovendien blijken jongeren die gevraagd worden zich door een andere jongere te laten enquêteren bijna allemaal bereid mee te werken, waardoor de non-respons minimaal is. Naast deze voordelen kent de JIT-methode ook beperkingen. In de eerste plaats is er geen sprake van 'professionele' interviewers. Ondanks de interviewtraining heeft het enthousiasme van de interviewers ertoe geleid dat soms tijdens het interview vragen en antwoordmogelijkheden werden toegelicht op niet geheel neutrale wijze. In de tweede plaats hebben de JrT-leden zelf respondenten gezocht, waardoor niet alleen de samenstelling van de responsgroepen tussen gemeenten nogal verschilt - wat ook te maken heeft met de verschillende bevolkingssamenstellingen van de gemeenten - maar waardoor bovendien de samenstelling van de responsgroep in sommige gemeenten wat eenzijdig is. In de derde plaats beperkte de tijd die per interview was uitgetrok- 
ken het aantal vragen. In samenhang met het aantal onderwerpen dat de jongeren wilden behandelen in de vragenlijst leidde dit tot een wat oppervlakkige vragenlijst. Tot slot is de JIT-methode met name geschikt voor jongeren vanaf $\mathrm{I} 2$ jaar, terwijl het jeugdbeleid zich ook op de groep van $\mathrm{I} 2$ jaar en jonger richt. Daardoor blijft een deel van het jeugdbeleid buiten beeld.

\subsection{Jongeren over hun gemeente: resultaten}

Uit eerder onderzoek is gebleken dat veel jongeren vinden dat zij meer inspraak moeten krijgen in het gemeentelijke jeugdbeleid en in beslissingen over de buurt of wijk waarin $z$ ij wonen. Slechts iets meer dan eenderde van de jongeren vindt dat de gemeente waarin zij wonen voldoende doet voor de jeugd (Zeijl 2003: II4). Gemeenten hebben - overigens net als het rijk - een enigszins negatief imago bij jongeren. Gemeenten houden geen rekening met jongeren en hebben niet de intentie met hen in contact te treden. Tegelijkertijd wordt de gemeente door jongeren wel als een belangrijke actor gezien als het gaat om voorzieningen voor de jeugd (Bruggeman 2000). In het algemeen geldt dat de plaats die politiek en beleid innemen in de belevingswereld van jongeren gerelativeerd moet worden (Zeijl 2003; Wittebrood 1995).

Wat verwachten jongeren van hun gemeentebestuur? In de JIT-interviews werd hen gevraagd de twee in hun ogen belangrijkste zaken te noemen waarvan zij vinden dat de gemeente er verantwoordelijk voor is. Tevens konden de jongeren aangeven of zij vinden dat de gemeente op een reeks van onderwerpen voldoende doet woor jongeren (zie tabel ro.I). Als het gaat om de verantwoordelijkheden van de gemeente springen twee zaken eruit: uitgaan en veiligheid/criminaliteit. Ten minste $40 \%$ van de jongeren vindt dit tot de belangrijkste taken van de gemeente behoren als het gaat om jongerenaangelegenheden. Andere relatief veel genoemde zaken zijn sport en spel en activiteiten voor jongeren op straat. Met uitzondering van sport en spel behoren deze meest genoemde verantwoordelijkheden ook tot de zaken waarvan relatief veel jongeren vinden dat de gemeente er tekortschiet. Dit laatste geldt overigens ook voor het tegengaan van discriminatie, maar dit thema behoort volgens slechts $10 \%$ van de jongeren tot de belangrijkste verantwoordelijkheden van de gemeente. We kunnen constateren dat jongeren vinden dat op terreinen die zij belangrijk vinden en waar zij iets van de gemeente verwachten, de gemeente niet aan hun wensen en verwachtingen voldoet.

\section{Box vo.1 Algemeen oordeel en veriwachtingen ten aanzien van gemeente}

\section{Culembong}

Ongeveer $58 \%$ van de ondervraagde jongeren is positief over Culemborg in het algemeen, Deze jongeren vinden dat er voldoende voor jongeren wordt gedaan. Het is rustig in Culemborg en er zijn niet veel problemen. Verder zijn er leuke winkels en is het 


\section{Vervolg Box 10.1 Algemeen oordeel en verwachtingen ten aanzien van gemeente}

er gezellig. De jongeren die negatief zijin over Culemborg vinden dat er niets te doen is voor jongeren. Bovendien vinden ze dat het te lang duurt voordat de gemeente iets doet.

De gemeente geeft hun geld uit aan onzin, daar kunnen ze beter bijvoorbeeld een speeltuintje voor de kinderen maken. (jongen, 16 jaar)

De ondervraagde jongeren noemen 'veiligheid en criminaliteit' het vaakst a/s belangrijk thema waarop jongeren liets van de gemeente zouden mogen verwachten ( $48 \%$ ). Ruim de helft vindt dat de gemeente voldoende doet op dat gebied. "Uitgaan' wordt ook door veel jongeren genoemd bij de vraag wat de gemeente moet doen voor jongeren. Slechts $20 \%$ vindt dat de gemeente op dit terrein genoeg doet. Ook "sport en spel" en 'culturele voorzieningen' vinden jongeren belangrijk (respectievelijk $22 \%$ en 20\%), maar de meeste jongeren vinden dat de gemeente al voldoende doet op die gebieden (respectievelijk $75 \%$ en $83 \%$ ). Op de vraag wat de gemeente Culemborg voor jongeren zou moeten doen, maar in de praktijk te weinig doet, worden mogelijkheden voor uitgaan; activiteiten voor jongeren, hangplekken, jeugdcentra, enzovoort het meest genoemd.

\section{Spijkenisse}

Meer dan de helft van de jongeren uit zich negatief over de gemeente Spijkenisse. Ze vinden het saai. Vooral op het gebied van vrije tijd is er niet veel te beleven.

Sommige mensen klagen over hangjangeren, maar er is gewoon niks te doen. Dus dan kan je ook niks anders doen dan rondhangen. (meisje, 13 jaar)

De JIT-lieden weten uit eigen ervaring dat de gemeente wel het één en ander doet. Maar kennelijk is dit niet genoeg om jongeren tevreden te stellen. Hier komt volgens het JIT bij dat de gemeente jongeren ook niet voldoende informeert over wat ze voor hen doet. Jongeren zijn daardoor vaak niet op de hoogte. De jongeren die uitgesproken positief zijin over de gemeente $(32 \%$ ) vinden het gezellig. Alles wat je nodig hebt is in de buurt a anwezig en ze vinden dat er redelijk veel gedaan wordt met wensen van inwoners. De belangrijkste zaken die de gemeente voor jongeren moet regelen vinden de jongeren uitgaan ( $55 \%$ ), veiligheid en criminaliteit $(47 \%)$ en activiteiten voor jongeren op straat $(28 \%)$. Dit zijn tevens de zaken waarvan veel jongeren vinden dat de gemeente niet voldoende onderneemt: De gemeente doet volgens de meeste de jongeren wel voldoende op de gebieden 'school" (93\%) en 'culturele voorzieningen' $(80 \%)$.

\section{Vlissingen}

Vlissingen is een leuke gemeente vinden de ondervraagde jongeren, maar vooral voor ouderen en jonge gezinnen. Voor jongeren ontbreekt er nogal wat. Jongeren die zich negatief uitllateri over Vlissingen missen faciliteiten die specifiek voor hen bedoeid zij.jn. Er zijn beperkte uitgaansmogelijkheden en weinig activiteiten en ontmoetingsplekken voor jongeren op straat of in jongerencentra. Positief aan Vlissingen vinden de jongeren dat iedereen iedereen kent, dat het gezellig en relaxed is en dat het centrum mool en schoon is. 


\section{Vervolg Box 10.1 Algemeen oordeel en verwachtingen ten aanzien van gemeente}

Volgens $46 \%$ van de ondervraagde jongeren is weiligheid het allerbelangrijkste wat de gemeente voor jongeren moet regelen. Van de ondervraagde jongeren vindt minder dan de helft ( $44 \%$ ) dat de gemeente voldoende doet op ditt gebied.

veiligheid is puwr een taak van de gemeente. Dat is hun verplichting. Uitgaan is geem uerplichting wan de gemeente om te regelen. (jongen, 18 jaar)

Uitgaan wordt door $4.2 \%$ van de ondervraagde jongeren een belangrijke gemeentelijke taak gevonden; $10 \%$ vindt dat de gemeente nu voldoende doet op dat gebied. Ten slotte worden 'spartvoorzieningen' door $3^{6 \%}$ van de geënquêteerden genoemd. Een ruime meerderheid $(71 \%)$ vindt dat de gemeente hier voldoende aan doet.

Op de vraag waar de gemeente echt tekortschiet, noemen jongeren het vaakst uitgaansgelegenheden, zoals discotheken en cafés. Ook de uitbreiding van het winkelaanbod wordt vaak genoemd. In iets mindere mate wordem speelplekken, activiteiten voor jongeren en kinderen, en hangplekken of een buurthuis genoemd.

\section{Voarburg}

Op de vraag wat jongeren van de gemeente Voorburg vinden, geeft $4 \%$ van then een negatief antwoord. Voorburg is saai, er zijn alleen maar dingen te doen voor jonge kinderen en bejaarden en voor jongeren is er weinig. Een meerderheid van $59 \%$ van de jongeren geeft aan dat ze de gemeente Voorburg leuk vindt. Deze jongeren vinden het gezellig in Voorburg en volgens hen heerst er een relaxte sfeer. Het JIT vindt het opvallend dat zoveel jongeren positief over Voorburg oordelen. Zij denken dat dit komt omdat er ook veel jongeren tussen de 12 en 13 jaar geinterviewd zijn. Deze jongeren kijiken volgens het JiT nog niet zo goed om zich heen, gaan nog niet uit en zijn tevreden met de speelgelegenheden die er zijn.

De belangrijkste zaken die de gemeente woor jongeren moet regelen zijn volgens de jongeren "uitgaan" ( $42 \%$ ), hangplek/clubhuis $(30 \%)$, veiligheid/criminaliteit ( $26 \%$ ) en sport en spel $(22 \%)$. Concreet vinden veel jongeren dat de gemeente meer zou moeten doen aan een (overdekte) hangplek, een clubhuis of ontmoetingsplek en een uitgaanscentrum/discotheek.

Als je om je heen kijkt zie je dat er niet veel te doen is. (meisje, 15 jaar)

Er moet iets komen in de buurt, een overdekt jeugdhonk. (jongen, 16 jaar) 
Tabel 10.1

Belangrijkste zaken waarvoor gemeente volgens jongeren werantwoordelijk is, 2002 ( $n=504)$ en opvatting over taakuitoefening door gemeente $(n=494-501)$

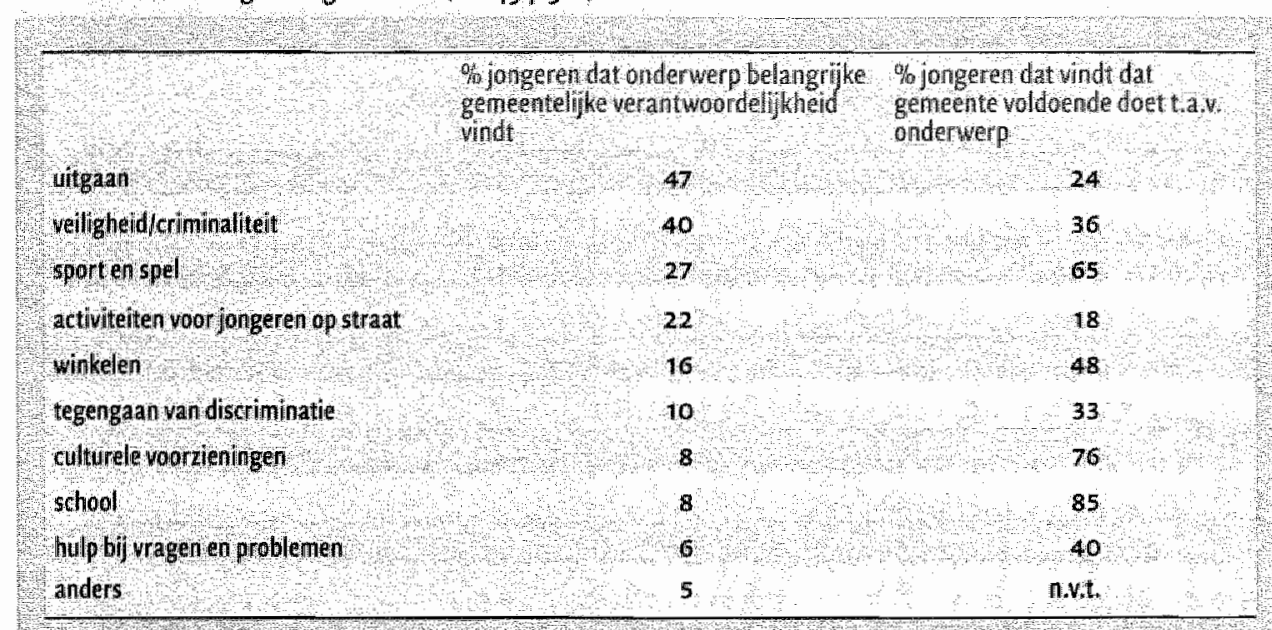

Bron SCP(11Bdongereninspectioteans 2002)

Uit tabel to.I wordt al duidelijk dat veel van de onderwerpen waarbij jongeren verwachtingen hebben van hun gemeente betrekking hebben op vrijetijdsbesteding. Dit onderwerp kwam in de enquêtes nader aan de orde. De jongeren werd gevraagd in hoeverre zij belang hechten aan verschillende vormen van vrijetijdsbesteding (zie tabel ro.2). Opmerkelijk is dat jongeren meer belang blijken te hechten aan algemene voorzieningen als winkels, disco's en sportcentra dan aan specifieke jongerenvoorzieningen. Daarmee is niet gezegd dat jongeren deze specifieke zaken onbelangrijk vinden: het jongerenwerk wordt nog altijd door $60 \%$ van de jongeren gewaardeerd, evenals hangplekken en trapveldjes.

In het vervolg op de vraag naar het belang dat jongeren hechten aan de verschillende vormen van vrijetijdsbesteding is hen gevraagd of zij vinden dat zij in hun gemeente voldoende keuze hebben om de dingen te doen die ze graag zouden willen doen. $61 \%$ van de jongeren oordeelt negatief over de keuzemogelijkheden. Als de vraag wordt toegespitst op de eigen wijk, stijgt dit percentage tot $8 \mathrm{r}$. Ten slotte vindt slechts $17 \%$ van de jongeren dat de gemeente voldoende rekening houdt met de wensen van jongeren op het gebied van vrijetijdsbesteding. 
Belang van verschillende vormen van/voor zieningen voor vrijetijdsbesteding, 2002 ( $(1)=497-501$; in procenten)

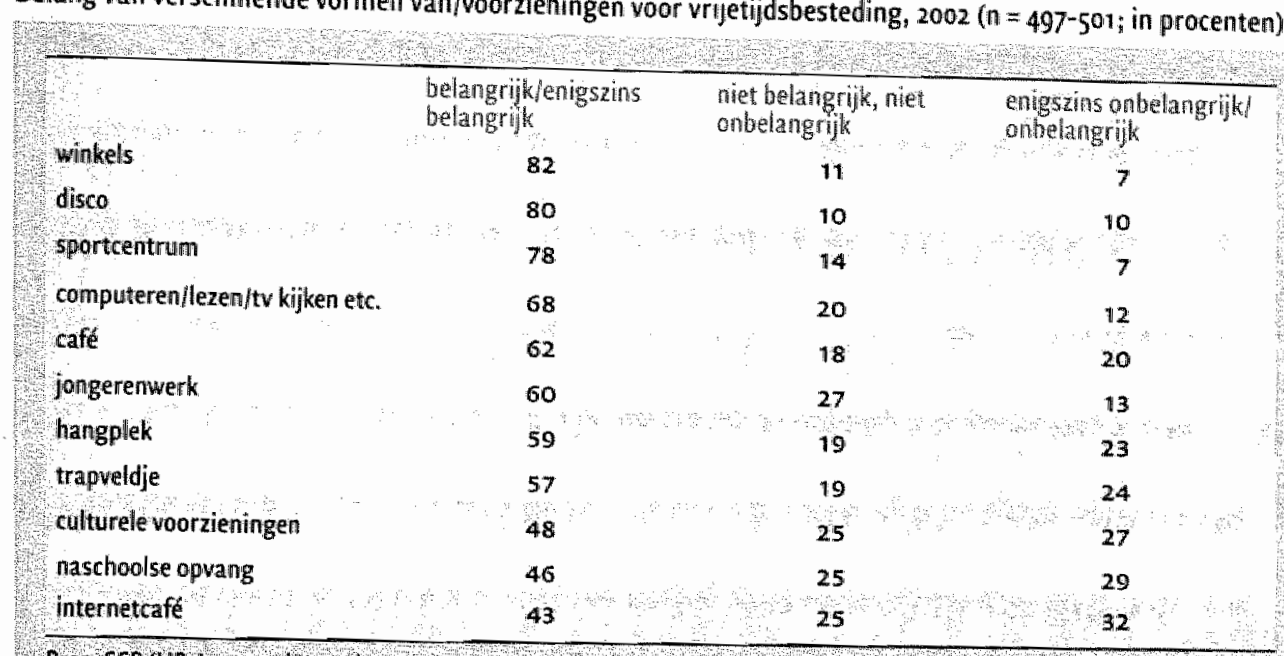

Brons se (UB 10 gereninspectieteams 2002)

\section{Box vo.2 Vrijetijdsbesteding}

\section{Appingedam}

Discobezoek wordt door $90 \%$ van de jongeren als een (heel) belangrijke vorm van vrijetijdsbesteding gezien, $83 \%$ vindt winkels (heel) belangrijk en $81 \%$ een sportvereniging. Slechts $7 \%$ van de jongeren geeft aan dat er genoeg mogelijkheden zijn om de vrije tijd leuk te besteden in Appingedam en maar $5 \%$ vindt dat er voldoende te doen is in de eigen wijk.

Een twaalfjarige kan genoeg te doen hebben in zijn of haar wijk, maar de andere $95 \%$ gaat niet meer van de glijbaan, bij wijze uan spreken dan. (meisje, 18 jaar)

Geen van de ondervraagde jongeren vindt dat de gemeente genoeg rekening houdt met de wensen van jongeren!

Dat zegt genoeg, dat is het enige wat je erover kunt zeggen. De jeugd roept om hulp hier. Van er is hier niks, help ons, doe iets! Ik denk dat de gemeente hier ook wel van zall schrikken. Dit zijn nog maar 58 mensen en er zijn nog veel meer jongeren in Appingedam. (meisje, 18 jaar)

De jongeren van het IIT zijn aan de ene kant blij dat de cijfers zo duidelijk zijn, want 'nu kan de gemeente ook zien dat het menens is', maar aan de andere kant zegt het IIT dat deze vraag duidelijk maakt dat jongeren zich alleen voelen staan tegenover de gemeente.

\section{Gironingen}

Als mogelijkheid voor vrijetijdsbesteding vinden Groningse jongeren een disco (heel) belangrijk; dit wordt door $93 \%$ van de onderwraagde jongeren genoemd. Daarnaast 


\section{Vervollg Box 10.2 Vrijetijdsbesteding}

worden 'winkels' heel belangrijk gevanden ( $83 \%$ ) en 'computeren thuis, tv kijken, lezen, etc' $(81 \%)$. Minder belangrijk vinden de jongeren 'naschoolse activiteiten' $(30 \%)$. De meeste jongeren $(71 \%)$ vinden dat ze genoeg keuze hebben om de activiteiten die ze in hun vrije tijd willen doen ook daadwerkelijk te doen. Jongeren die positief zijn vinden datt er altijd wel wat te doen is in de stad. Jongeren die negatiefzijn vinden onder andere dat de uitgaansmogelijkheden beperkt zijn en dat er niet genoeg te doen is voor jongeren op straat.

Over de mogelijkheden om vrije tijd door te brengen in de eigen wijk is men minder tevreden; twee derde van de jongeren geeft aan dat er niet genoeg te doen is. lets meer dan de helft van de jongeren vindt dat de gemeente hierbij niet genoeg rekening houdt met de wensen van jongeren. Ze vinden bijwoorbeeld dat het lang duurt voordat er iets gebeurt voor jongeren en dat er alleen rekening wordt gehouden met jongeren die overlast geven. De $\|$ lT-leden merken op dat de gemeente het op sommige plekken beter doet dan op andere plekken. Zo wordt Vinkhuizen genoemd als een wijk waar meer activiteiten woor jongeren worden georganiseerd en waar plekken zijn om elkaar te ontmoeten.

Het is een leuke buurt, je wordt niet lastig gevallen, rustig. (jongen) In mijn wijk wonen veel mensen met verschillende culturen bij elkaar. Het nadeel hiervan is dat sommige mensen je niet accepteren omdat je er anders uitziet en dat is niet leuk. (meisje, ${ }^{6}$ jaar)

\section{Spijkenisse}

Omdat er meer meisjes dan jongens zijn geënquêteerd, vermoedt het JIT Spijkenisse dat hierdoor de resultaten enigszins vertekend zijn. Meisjes winden een voetbalveld en een skatebaan minder belangrijk dan bijvoorbeeld winkelen.

Als ik het mag zeggen: woor een meisje uind ik hier niks te doen hoor, in Waterland. (meisje, 16 jaar) Leeftijd kan volgens de JIT-leden ook uitmaken: onder de 15 jaar vind je een discotheek, café of hangplek waarschijnlijk minder belangrijk. Die dingen zijn toch voor wat oudere jongeren. Een ruime meerderheid $(55 \%)$ van de jongeren vindt dat ze niet genoeg keuze heeft om bovenstaande leuke dingen te doen.

Eigenlijk doe je buiten hetzelfde als binnen: gewoon niks. Je kan buiten niksen en je kan binnen miksen, want er is gewoon niks. (meisje, 16 jaar)

Als het gaat over de eigen wijk is dit percentage nog hoger: $81 \%$ vindt dat er niet genoeg (leuke) mogelijkheden voor vrijetijdsbesteding zijn in de eigen wijk.

M'n ouders hebben ook zoiets van:ja, je gaat niet elke quond een andere wijk in. (meisje, 13 jaar)

Uit tabel ro.I kwam ook naar voren dat veiligheid en criminaliteit een thema is waarop jongeren het nodige van de gemeente verwachten. Dat jongeren veiligheid een belangrijk thema vinden, komt ook naar voren als hen gevraagd wordt naar het belang dat zij hechten aan zaken die te maken hebben met school. Dan blijkt dat de veiligheid op en rond de school het vaakst genoemd wordt: liefst $66 \%$ hecht hier veel 
belang aan, en nog eens $29 \%$ enigszins. Daarmee steekt weiligheid duidelijk uit boven andere onderwerpen die te maken hebben met school; het op een na meest genoemde thema is 'hulp bij problemen'. $47 \%$ van de jongeren hecht hier veel belang aan, en $36 \%$ enigszins.

De grote betekenis die jongeren toekennen aan veiligheid heeft ongetwijfeld te maken met de onveiligheidsgevoelens die bij veel van hen heersen: $44 \%$ voelt zich soms onveilig in de eigen gemeente en $7 \%$ voelt zich vaak onveilig. Bijna twee derde van de jongeren is in staat onveilige plekken in de gemeenten aan te wijzen en/of mijdt deze. Overigens is bijna de helft van de jongeren het (enigszins) eens met de stelling dat het gemeentebestuur voldoende doet om de gemeente veilig te maken en te houden, terwijl ongeveer eenderde het hier (enigszins) mee oneens is. Over de veiligheid op en rond school zijn jongeren beduidend positiever: $89 \%$ vindt het er veilig.

\section{Box 10.3 Veiligheid}

\section{Gironingen}

Bijna twee derde van de ondervraagde jongeren voelt zich zelden of nooit onveilig in Groningen. Toch vindt maar $44 \%$ van de jongeren dat de gemeente voldoende doet om Groningen veilig te maken en te houden. De jongeren die de inzet van de gemeente positief beoordelen, zeggen dat er genoeg bewaking is, dat de politie vaak door de buurt rijdt en dat ze niet weten wat de politie nog meer zou kunnen doen.

Bij ons in Vinkhuizen heb je een wijkagent, Cor. Dat is een strakke vent. (jongen, 18 jaar)

De jongeren die negatief zijn vinden dat er te weinig politie is, dat die zich met verkeerde dingen bezig houdt en te laat komt als er wat aan de hand is. Als jongeren zich onveilig voelen, dan is dat meestal in het donker, of wanneer ze alleen zijn. Onveilige plekken zijn bijwoorbeeld parkjes, steegjes of junkieplaatsen en er wordt ook een aantal wijken genoemd.

Meer dan $60 \%$ van de jongeren is het niet eens met de stelling dat de politie naar jongeren luistert. Zij vinden dat jongeren door de politie vaak niet serieus worden genomen, dat er al conclusies worden getrokken voordat je iets kunt zeggen.

\section{Heeze-Leende}

De meeste jongeren $(64 \%)$ voelen zich veilig in Heeze-Leende. Ongeveer $50 \%$ vindt dat de gemeente voldoende doet om Heeze-Leende veilig te maken en te houden. Jongeren die zich wel eens onveilig voelen, hebben dat gevoel vaak 's avonds, in het donker, bij de rotonde en bij andere jongeren.

Paffen, stoer doen, drinken, harde muziek dradien op straat en soms veruelende opmerkingen maken. Dan voel je je toch niet veilig. (meisje, 14 jaar)

Daar zitten dan een man of 15 zo. Een paar van die mennekes, die zitten daar met auto's en 20 , muziek hard. Een beetje bakkesen. Niemand durft er voorbij te fietsen. (jongen, 18 jaar) Meer dan $40 \%$ van de jongeren kan onveilige plekken noemen in de gemeente. 


\section{Vervolg Box 10.3 Veiligheìd}

Dit zijn vaak bepaalde straten, maar ook een bank in één van de dorpen is een aantal keer genoemd. De jongeren die vinden dat de gemeente niet genoeg doet op het gebied van veiligheid vinden dat er te weinig politie is, die bovendien op het verkeerde moment komt.

\section{Vlissingen}

De meeste jongeren $(62 \%)$ voelen zich zelden of nooit onveilig in Vlissingen. Het JIT denkt dat mensen in Vlissingen heel goed weten waar het onveilig is en daar niet heen gaan. Er wordt een aantal plekken genoemd waarvan wordt gezegd dat ze niet veilig zijn en die je beter kunt mijden. Wel kan over al die plekken volgens het IIT gediscussieerd worden: het gaat om het gevoel van onveiligheid en dat verschilt per persoon. Met de stelling 'de gemeente doet voldoende om Vlissingen veilig te maken en te houden" is een kleine meerderheid ( $55 \%$ ) van de jongeren het eens; $27 \%$ is het hier mee oneens. Over het algemeen vindt iedereen het wel veilig hierzo, maar er kan wel wat ineer gedaan worden. (jongen, 18 jaar)

In de toelichting die door de jongeren bij hun antwoord op de stelling wordt gegeven, blijkt echter dat de meeste opmerkingen negatief van aard zijn. Jongeren noemen dat er te weinig politie op straat loopt en dat er te veel wordt getolereerd. Daarnaast geven ze aan dat er wel veel plannen zijn, maar dat je daar in de praktijk weinig van merkt.

In de interviews is de inspraak in en betrokkenheid bij het gemeentelijke beleid nadrukkelijk aan de orde geweest. In de eerste plaats is de jongeren gevraagd of zij wel eens contact hebben met de gemeente (zie tabel 10.3). Als het gaat om interactieve contacten, dan blijkt dat $2 \mathrm{r} \%$ van de jongeren wel eens mee heeft gewerkt aan een interview, $14 \%$ aan een groepsgesprek en $9 \%$ aan een debat. Ruim de helft van de jongeren is op geen enkele wijze met de gemeente in contact geweest en ruim een kwart op één van de in de tabel genoemde wijzen.

\section{Tabel 10.3}

Contacten met de gemeente, 2002 (percentage jongeren)

\begin{tabular}{lr}
\hline uragenlijst & 38 \\
interview & 21 \\
groepsgesprek/panel & 14 \\
debat & 9
\end{tabular}

Bron SCP (10-Jongereniuspectieteams 2002)

Van de jongeren die aangaven op enigerlei wijze contact te hebben gehad met de gemeente, zegt een op de vijf dat dit contact goed was. $44 \%$ beoordeelt het contact als redelijk, $28 \%$ als matig of slecht, en ro\% heeft geen mening. 


\section{Box 10.4 Inspraak en participatie}

\section{Appingedam}

Het valt de jIT-leden op dat jongeren niet vaak aan inspraakmogelijkheden wan de gemeente meedoen.

Het is zeer slecht want we hebben geen inspraak en ook geen hoop omdat wij wit ervaring weten dat er nu nog niks gebeurd is. Zij zeggen dan van het komt goed; het komt goed. En we draaien ons orn we zien geen verandering. Misschien doen ze er we! wat aan, maarja, het is nu voor ons eerst zien en dan gelowen. Ik hoop dat wij in het gesprek met de gemeente verder komen. (meisje, 18 jaar)

Daartegenover staat dat de meerderheid van de jongeren die wel eens hebben gebruikgemaakt van inspraakmogelijkheden van de gemeente daar positief over is. Ruim eenderde van de jongeren vindt dat de beste manier om in contact te komen met de gemeente is om dit te doen via actieve jongeren die al contact hebben met de gemeente.

\section{Spïjkenisse}

Een groot aantal jongeren heeft wel eens contact gehad met de gemeente door middel van een interview, vragenlijst, gesprek met een ambtenaar of gesprek met een jongerenwerker/buurtbeheerder of politiemedewerker. Het grootste deel van de jongeren $(80 \%)$ vindt dit contact redelijk tot goed.

Als ze ons laten meebeslissen en meepraten, dan kan het allemaal veranderen en verbeteren. (meisje, 16 jaar)

De beste manier om in contact te komen met de gemeente is volgens een kwart van de jongeren via actieve jongeren die al contact hebben met de gemeente.

De لIT-leden beseffen dat de gemeente aandacht en geld moet besteden aan alle bevolkingsgroepen en niet uitsluitend aan jongeren. Maar dit neemt volgens hen niet weg dat de gemeente te weinig rekening houdt met jongeren. De teamleden denken dat de gemeente dat eigenlijk zelf ook wel weet.

Ik denk dat de gemeente donders goed weet dat zij niet genoeg rekening houdt met jongeren. Ze weten het zelf wel. (lid jiT)

\section{Utrecht}

Het IIT-Utrecht oordeelt dat jongeren niet genoeg inspraak hebben als het gaat om onderwerpen die voor hen belangrijk zijn. Een grote meerderheid van de ondervraagde jongeren heeft dit bijwoorbeeld aangegeven bij het onderwerp vrijetijdsvoorzieningen in de eigen wijk. Jongeren zijn ook een belangrijke doelgroep von de stad. Als jongere kan je het zelf het beste zien wat belangrijk is voor jou. Beter dan al die mensen die in de gemeente zitten te vergaderen. (meisje) 


\section{Vervolg Box 10.4 Inspraak en participatie}

Het JIT vindt het opvallend dat veel jongeren $(67 \%)$ wel eens een gesprek in de wijk hebben gehad met iemand van de gemeente. Daarnaast heeft $61 \%$ van de jongeren wel eens een vragenlijst met betrekking tot de gemeente ingevuld en $47 \%$ heeft wel eens over de eigen wensen gepraat met een jongerenwerker, buurtbeheerder of politiemedewerker. Meer dan de helft van de jongeren vond het contact met de gemeente redelijk tot goed. Jongeren achten de beste kanalen om in contact te komen met de gemeente jongerenwerkers; buurtbeheerders en politiemensen ( $24 \%$ ) of actieve jongeren die al contact hebben met de gemeente $(22 \%)$.

Op de vraag of de gemeente rekening houdt met de wensen van jongeren, antwoordt $61 \%$ negatief. Redenen hiervoor zijn onder andere dat de gemeente te veel doet wat ze zelf wil, dat er geld te kort is, dat jongeren niet serieus worden genomen en dat de gemeente haar beloftes niet nakomt.

Wat vinden jongeren de beste manier om in contact te komen met de gemeente? Uit een aantal mogelijkheden mochten de jongeren de naar hun mening meest geschikte manier aangeven (zie tabel 10.4). Het meest in het oog springt dat jongeren het meeste zien in zogenoemde zaakwaarnemers. Actieve jongeren die al bekend zijn met de gemeente worden het meest genoemd als geschikte manier om de belangen van jongeren bij de gemeente onder de aandacht te brengen. Andere manieren worden veel minder vaak genoemd.

\section{Tabel 10.4}

Beste manier voor contact fussen jongeren en gemeente, 2002 (n= 492 ; in procenten)

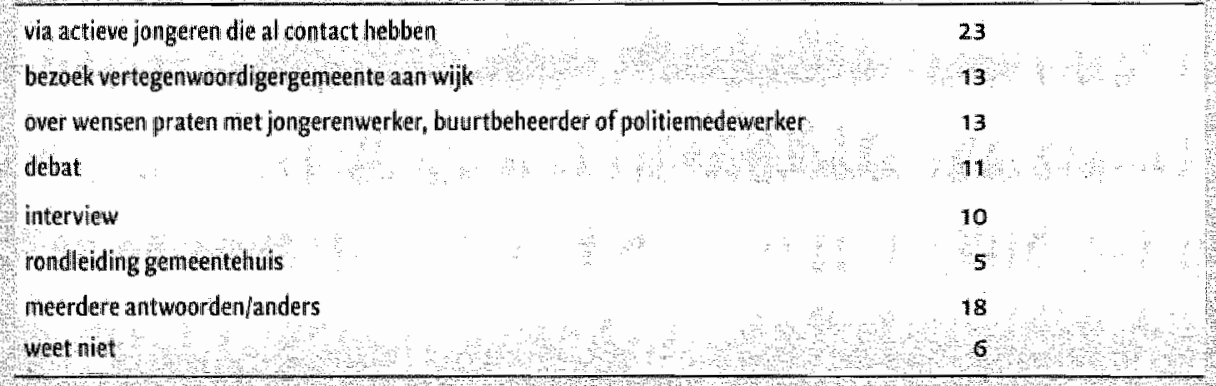

Bron SCP (BB B ongerennspectieteams 2002)

Tot slot is de jongeren de vraag voorgelegd of zij vinden dat de gemeente rekening houdt met de wensen van jongeren. Het aandeel jongeren dat deze vraag negatief beantwoordt, laat aan duidelijkheid niets te wensen over: $73 \%$ vindt dat de gemeente geen rekening houdt met de wensen van jongeren. 
Over het algemeen lijken de jongeren uit verschillende gemeenten niet zoveel van elkaar te verschillen in hun mening over het jeugdbeleid. Steeds weer duikt hetzelfde beeld op: rond de $50 \%$ van de jongeren uit zich negatief over de gemeente, de andere helft oordeelt positief. Met name uitgaan en veiligheid worden belangrijke thema's gevonden waarbinnen de gemeente iets voor jongeren moet regelen. Veel jongeren vinden dat ze geen inspraak hebben in het jeugdbeleid en dat de gemeente niet voldoende rekening houdt met hun wensen.

Het is helaas lastig de gegevens over het jeugdbeleid van een gemeente te koppelen aan het oordeel van jongeren uit die gemeente. Het kan zijn dat een gemeente veel projecten heeft in het kader van preventief veiligheidsbeleid, maar dat jongeren daar schijnbaar niets van merken. Dit roept ook de vraag op in hoeverre het jeugdbeleid dat een gemeente voert, zichtbaar is of zichtbaar kan zijn voor jongeren. Jongeren lijken het beleid te beoordelen op wat ze zien: uitgaansmogelijkheden, hangplekken, politie op straat. Gemeenten zijn vaak bezig met zaken die voor jongeren minder zichtbaar zijn, zoals het voorkomen van achterstanden en uitval. Deze zaken zijn vaak gericht op specifieke doelgroepen zoals (allochtone) peuters of voortijdige schoolverlaters. Daarnaast is het de vraag of jongeren de gemeente herkennen in zaken waar ze mee te maken hebben. In de JrT's kwam dit bijvoorbeeld aan de orde in vragen van jongeren over wat de gemeente met school te maken heeft en in een opmerking dat een bepaalde (door de gemeente gesubsidieerde) welzijnsstichting wel iets voor jongeren doet maar de gemeente niet. De gemeente lijkt in ieder geval voor een deel van de jongeren iets te zijn wat abstract is en ver weg staat.

In alle gemeenten wordt door jongeren 'uitgaan' genoemd als één van de twee belangrijkste zaken die de gemeente voor jongeren moet regelen. De keuze voor 'uitgaan' ligt in zekere zin wel voor de hand: het is een onderwerp waar jongeren veel mee bezig zijn en waar veranderingen woor hen ook direct zichtbaar zijn. Daarnaast wordt in zeven van de negen gemeenten "veiligheid en het tegengaan van criminaliteit' genoemd als belangrijke gemeentelijke taak. Ruim de helft van de ondervraagde jongeren geeft aan zich wel eens of zelfs vaak onveilig te voelen. Ook rond school wordt veiligheid als een belangrijk thema gezien. "Veiligheid" is in vergelijking met 'uitgaan' een meer abstract onderwerp. Een onderwerp ook dat lijkt te passen binnen deze tijdgeest waarin veel over (on)veiligheid en waarden en normen gepraat wordt. In een gemeente gaven jongeren aan dat een gevoel van (on)veiligheid een heel subjectieve ervaring is. Uit de antwoorden die jongeren geven lijkt het gevoel van (on)veiligheid en de mening of de gemeente genoeg doet op dit gebied, samen te hangen met de houding ten opzichte van de politie en de gemeente. Jongeren die vinden dat de gemeente niet voldoende aan veiligheid doet, geven aan dat ze niet serieus worden genomen, dat er niets verandert en dat de politie toch niets doet. Jongeren die vinden dat de gemeente wel genoeg aan veiligheid doet, zeggen dat de politie 
haar best doet en dat de gemeente doet wat ze kan. Onveilig voelen jongeren zich vooral op donkere, stille plekken. Voor veel jongeren lijkt een gevoel van veiligheid dan ook verband te houden met zichtbare zaken, zoals meer politie op straat en betere verlichting.

De jongeren uit de verschilllende gemeenten blijken het ook redelijk eens te zijn over terreinen waarop de gemeente niet voldoende voor hen doet: 'uitgaan' en 'activiteiten voor jongeren op straat' springen er uit. We kunnen constateren dat jongeren vinden dat op terreinen die zij belangrijk vinden en iets van de gemeente verwachten, de gemeente niet aan hun wensen en verwachtingen voldoet. Op deze gebieden willen jongeren blijkbaar meer (keuze)mogelijkheden hebben dan er bestaan. Dit laatste punt is interessant. Zijn bepaalde voorzieningen er niet, of voelen jongeren zich niet aangesproken door die voorzieningen? Bij het JIT in Leiden was er een meisje dat dit duidelijk aangaf: 'Je hebt de Burcht en een skatebaan. Maar op die plekken staat maar één soort jongeren. Bij de Burcht staan de gothic-achtige personen. En op de skatebaan alleen maar skaters.' Blijkbaar delen jongeren plekken, activiteiten en andere jongeren in bepaalde groepen in. Dit roept de vraag op of sommige activiteiten niet bij voorbaat 'besmet' zijn omdat jongeren een beeld hebben van de activiteit en van het soort jongeren dat daaraan meedoet, wat ze vervolgens doet besluiten of ze daar zelf wel of niet bijhoren.

Over wat ze het liefste doen in hun vrije tijd zijn jongeren uit de verschillende gemeenten het ook eens: winkelen, naar de disco gaan en sporten zijn favoriet. Het lijkt erop alsof vooral 'uitgaan' iets is wat jongeren heel graag doen en waarvan ze vinden dat de gemeente niet genoeg voor hen doet.

Aangezien er aantoonbaar nogal wat verschillen bestaan tussen gemeenten wat betreft vrijetijdsvoorzieningen in het algemeen en uitgaansgelegenheden in het bijzonder, is het de vraag wat jongeren als 'normaal' beschouwen. Jongeren die wonen in een gemeente waar relatief veel te doen is - de meer stedelijke gemeenten - lijken namelijk even (on)tevreden als jongeren die wonen in een gemeente waar veel minder te doen is - de minst stedelijke gemeenten. Wat ervaren jongeren als 'basis' en wat ervaren ze als 'extra'? Met andere woorden: wat is het referentiekader waar jongeren van uitgaan en hoe bepalend is dit in hun oordeel over de gemeente? Kán de gemeente überhaupt ooit genoeg doen op sommige gebieden of zal de vraag van jorigeren het aanbod van de gemeente altijd overstijgen? $O p$ het gebied van vrijetijdsvoorzieningen lijkt het laatste het geval te zijn. Een nuancering is echter op zijn plaats. In een aantal grote steden geven jongeren aan dat er weliswaar in het centrum voldoende te doen is voor jongeren, maar dat ze daar in de wijken niet veel van merken. Fysieke en gevoelsmatige afstand spelen blijkbaar ook een rol in het oordeel over vrijetijdsvoorzieningen.

Een ruime meerderheid van de jongeren heeft nooit interactief contact gehad met de gemeente. De vraag is in hoeverre jongeren dat betreuren, want de meest genoemde 
geschikt geachte wijze om jongeren in contact te brengen met de gemeente is via toch al actieve jongeren, de zogenoemde zaakwaamemers. De constatering in hoofdstuk 5 dat vooral de zogenoemde beroepsjeugd bereikt wordt op inspraakavonden en jeugdpanels hoeft gezien deze bevinding niet noodzakelijkerwijs geproblematiseerd te worden. Dat geldt wel voor de overgrote meerderheid van de jongeren die vindt dat de gemeente onvoldoende rekening houdt met de wensen van jongeren. Kennelijk heeft de vele energie die een aantal gemeenten stopt in hun pogingen jeugd bij het beleid te betrekken bij jongeren niet geleid tot het gevoel gehoord te worden.

In het algemeen oordelen jongeren niet positief over het beleid van hun gemeente. Integendeel, zij zijn buitengewoon kritisch, ondanks het feit dat de onderwerpen waarop gemeenten jongeren vooral bij het beleid trachten te betrekken - vrijetijdsvoorzieningen en veiligheid, zie hoofdstuk 5 - aansluiten bij wat jongeren als belangrijk aanmerken. Kijken we echter alleen door de bril van jongeren naar de resultaten van het lokale jeugdbeleid, dan is duidelijk dat gemeenten de verwachtingen niet waarmaken. 
Noten

I Zie: http://www.st-alexander.nl

2 In Bijlage $\mathrm{D}$ is de totalle samenstelling van de respons opgenomen. 


\subsection{Inleiding}

In dit hoofdstuk maken we de balans op met betrekking tot de eerste centrale vraag van dit onderzoek:

In hoeverre bijken gemeenten in stant om een effectiefjeugdbeleid tot stand te brengen? We zullen de bevindingen over het lokale jeugdbeleid gebruiken om de onderzoeksvragen te beantwoorden die in hoofdstuk I zijn geformuleerd om een antwoord op de eerste centrale vraag te krijgen. Deze acht onderzoeksvragen zullen achtereenvolgens aan de orde komen. Allereerst gaan we in op de ontwikkeling van een specifiek jeugdbeleid door gemeenten (S II.2), vervolgens komen de resultaten van het jeugdbeleid aan de orde ( $\left(\mathrm{II}_{3}, 3\right.$ ), en daarna een aantal bestuurlijke voorwaarden voor een effectiefjeugdbeleid ( $\$$ I. 4 ). In de slotparagraafvan dit hoofdstuk (\$ Ir.5) wordt een antwoord op de eerste centrale vraag geformuleerd.

\subsection{De ontwikkeling van een lokaal jeugdbeleid.}

Onderzoeksuraag 1: In hoeverre hebben gemeenten een specifiek jeugdbeleid ontwikkeld? Om deze vraag te beantwoorden, hebben we naar verschillende aspecten van de beleidsontwikkeling gekeken. In de eerste plaats de beleidsformulering, dat wil zeggen de vraag in hoeverre gemeenten jeugdbeleid in de zin van doelen en maatregelen kennen. In de tweede plaats is op een aantal manieren gekeken naar een van de belangrijke kenmerken van het jeugdbeleid, te weten de integrale beleidsvoering. Een specifiek jeugdbeleid veronderstelt dat over de muren van traditionele beleidssectoren wordt gekeken en dat verschillende beleidsthema's met elkar verbonden worden. We hebben daarom gekeken naar de breedte van het beleid, naar de politieke en ambtelijke coördinatie en samenwerking, en naar de samenwerking met actoren die niet tot de gemeentelijke organisatie behoren. Als laatste element van de beleidsontwikkeling is gekeken naar de gemeentelijke aandacht voor beleidsevaluatie.

In 200 zijn er nog maar weinig gemeenten die geen specifiek jeugdbeleid hebben geformuleerd. ${ }^{x}$ Ongeveer een op de zeven gemeenten heeft geen expliciete doelstellingen ten aanzien van de jeugd, of heeft deze doelstellingen versnipperd over traditionele beleidssectoren als welzijn, zorg en onderwijs. Bijna 60\% van de gemeenten heeft uitgewerkte doelstellingen in het jeugdbeleid; in de meeste van deze gemeenten zijn het kwalitatieve doelstellingen, terwijl in een minderheid de doelstellingen in kwantitatieve zin zijn uitgewerkt.

In ongeveer vier op de vijf gemeenten bestrijkt het jeugdbeleid ten minste vier van acht voorgelegde thema's [zoals onderwijs, gezondheidszorg, veiligheid, arbeid en inkomen) en in bijna de helft zelfs zeven of acht, zo blijkt uit gemeentelijke beleids- 
nota's jeugdbeleid. In de meeste gemeenten kan in dit opzicht dus gesproken worden van een integraal jeugdbeleid.

Dergelijk breed jeugdbeleid vergt politiek-bestuurlijke en ambtelijke coördinatie en samenwerking. Op politiek-bestuurlijk niveau wordt er indien nodig in zo'n $60 \%$ van de gemeenten in de regel weliswaar afgestemd tussen leden van het college, maar in de meeste gemeenten gaat de regel matige samenwerking niet verder dan dat. Het gezamenlijk formuleren van doelen of het koppelen van budgetten komt in hooguit eenderde van de gemeenten vaak voor. In $40 \%$ van de gemeenten wordt op geen enkele manier geregeld politiek-bestuurlijk samengewerkt. Wel kennen de meeste gemeenten $(83 \%)$ een vorm van ambtelijke coördinatie. Regelmatige ambtelijke samenwerking komt in meer gemeenten voor dan politiek-bestuurlijke samenwerking, maar ook onder ambtenaren gaat dit in een meerderheid van de gemeenten niet verder dan afstemming. De conclusie is dat de breedte van het jeugdbeleid in lang niet alle gevallen ondersteund wordt door met name samenwerking op politiekbestuurlijk niveau.

De meeste gemeenten tonen zich wel ambitieus als het gaat om het reguleren van de samenwerking met instellingen die met jeugd van doen hebben, en hebben hiertoe op verschillende punten doelen gesteld. Slechts een kwart van de gemeenten heeft op dit vlak geen doelen.

Tot slot blijkt dat ruim eenderde van de gemeenten de effecten van het jeugdbeleid evalueert door administratieve gegevens te registreren en/of door een periodieke meting onder jongeren te verrichten.

De verschillende aspecten van beleidsontwikkeling zijn opgenomen in een samenvattende maat, de staat van het jeugdbeleid. Deze maat maakt het mogelijk uitspraken te doen over de voortgang van de beleidsontwikkeling in de tijd, en tussen gemeenten. Het blijkt dat de gemiddelde beleidsontwikkeling tussen 1998 en 2001 in eenderde van de gemeenten is toegenomen. Dit heeft vooral te maken met de ontwikkelingen op het gebied van beleidsformulering en de breedte van het beleid. De gemiddelde toename van de beleidsontwikkeling in die periode doet veronderstellen dat de ontwikkeling van het lokale jeugdbeleid na $200 \mathrm{r}$ is doorgegaan. Verwacht mag worden dat het aantal gemeenten met een specifiek jeugdbeleid na 200 r verder is toegenomen en dat dit beleid bovendien gemiddeld verder ontwikkeld is.

Samengevat hebben de meeste Nederlandse gemeenten in 200 r een specifiek jeugdbeleid ontwikkeld en dat aandeel is in de jaren na 2001 naar verwachting gegroeid. Bij de ontwikkeling van het jeugdbeleid blijven met name de integrale beleidsvoering op politiek-bestuurlijk niveau en de bepaling van beleidseffecten achter. Steeds meer gemeenten hebben echter uitgewerkte doelen in een breed geformuleerd jeugdbeleid. 
11.3.1 Onderzoeksvraag 2: Hoe hebben de scores op voor het jeugdbeleid relevante output-en outcome-indicatoren zich ontwikkeld in de periode van 1998 tot en met 2001?

Helaas hebben we moeten constateren dat deze vraag slechts voor een zeer beperkt aantal van de voorziene indicatoren is te beantwoorden. Dat heeft ermee te maken dat de meeste gemeenten niet over gegevens voor beide jaren beschikken als het gaat om de indicatoren waarvan de gegevens niet centraal worden geregistreerd. Hiervan blijken ambtenaren jeugdbeleid zich overigens lang niet altijd bewust. Het onderzoek is daarom beperkt tot vijf indicatoren waarvan woor beide jaren gegevens uit centrale bronnen aanwezig zijn. Op vier indicatoren zijn de veranderingen tussen 1998 en 200 r per gemeente gemiddeld gering. Een uitzondering vormt de indicator 'percentage 15 -24-jarigen met een ABW- of Ww-litkering'. Dit percentage is tussen 1998 en 2001 per gemeente met gemiddeld $3^{8}$ gedaald. Waarschijnlijk heeft dit meer te maken met conjuncturele economische ontwikkelingen dan met het gevoerde jeugdbeleid. Tussen verschillende beleidskenmerken en de ontwikkelingen in scores op de indicatoren worden in dit onderzoek op gemeentelijk niveau geen relaties gevonden. Dat kan overigens ook te maken hebben met de relatief korte periode waarin het beleid effect kon sorteren.

\subsubsection{Onderzoeksuraag 3: Hoe beoordelen jeugdigen het jeugdbeleid van de gemeente waarin zij woonachtig zijn?}

In het algemeen oordelen jongeren niet positief over het beleid van hun gemeente. Integendeel, zij zijn buitengewoon kritisch, ondanks het feit dat de onderwerpen waarop gemeenten jongeren vooral bij het beleid trachten te betrekken - vrijetijdswoorzieningen en veiligheid - aansluiten bij wat jongeren als belangrijk aanmerken. Niettemin vindt een zeer ruime meerderheid van de jongeren uit de negen gemeenten die bij het kwalitatieve onderzoek betrokken waren dat de gemeente geen rekening houdt met hun wensen. Bovendien oordeelt een groot deel van deze jongeren dat de gemeente te weinig doet op een aantal punten die te maken hebben met thema's die door jongeren zijn aangemerkt als belangrijk voor het gemeentelijke beleid: vrijetijdsvoorzieningen en veiligheid. De meeste jongeren vinden hun gemeentebestuur onvoldoende responsief ten opzichte van hun wensen en behoeften.

Kijken we dus alleen door de bril van jongeren naar de resultaten van het lokale jeugdbeleid, dan lijkt het alsof gemeenten de verwachtingen niet waarmaken. De kritische bejegening door jongeren kan genuanceerd worden door een verwijzing naar het bredere opinieklimaat van de laatste jaren waarin burgers negatiever staan. ten opzichte van bestuur en politiek (Dekker et al. 2004). 
11.3.3 Onderzoeksvraag 4: Hoe beoordelen bij het jeugdbeleid betrokken actoren de resultaten van het jeugdbeleid van de gemeente waar zij een rol in spelen?

Zowel ambtenaren als vertegenwoordigers van instellingen die bij het lokale jeugdbeleid zijn betrokken, beoordelen de resultaten van dat beleid relatief mager; de oordelen over het beleid zelf zijn gemiddeld wat hoger, waarover in paragraaf II. 4 meer. De gemiddelde rapportcijfers voor de resultaten liggen doorgaans beneden de zes, een ciffer dat algemeen gezien wordt als de grens tussen voldoende en onvoldoende. Voegen we daarbij de vaak sceptische inschatting van de doelbereiking in het jeugdbeleid - de overheersende teneur is dat doelen slechts deels of te laat worden gehaald - dan is de conclusie gerechtvaardigd dat de bij het beleid betrokken actoren vrij somber zijn over de effectiviteit van het lokale jeugdbeleid. Deze conclusie geldt in minder sterke mate voor gemeenten met een actieve sturende rol in het jeugdbeleid.

\subsection{Voorwaarden voor een effectiefjeugdbeleid}

\subsubsection{Onderzoeksuraag 5: In weike mate is er in het lokale jeugdbeleid sprake van} maatwerk, dat wil zeggen: op de lokale situatie toegespitst beleid?

Tussen de onderzoeksgemeenten bestaan duidelijke inhoudelijke verschillen in het jeugdbeleid. Deze inhoudelijke verschillen kunnen niet louter verklaard worden uit de stedelijkheid van gemeenten. In dat opzicht kan er dus niet gesproken worden van eenvormig lokaal jeugdbeleid. Kijken we echter naar de hoofdaccenten in het beleid, dan zien we dat in veel gemeenten dezelfde keuzes worden gemaakt. Veruit de meeste gemeenten volgen zowel een algemeen preventief als een gericht preventief spoor, terwijl een curatieve aanpak in veel mindere mate voorkomt. Bovendien is in veel gemeenten sprake van een doorgaande beleidslijn voor de jeugd tot I2 jaar, en is er daarnaast een beleidslijn voor de jeugd van $\mathrm{I} 2$ tot I 8 jaar. Van beleid gericht op de oudere jeugd ( $8+$ ) is - in ieder geval in het kader van het jeugdbeleid - in veel minder gemeenten sprake. Verschillen komen vooral naar voren in de mate waarin het beleid is ontwikkeld en de mate waarin en de wijze waarop de jeugd betrokken wordt, en veel minder in de beleidsinhoud. Wel blijken er tussen meer en minder stedelijke gemeenten inhoudelijke verschillen te zijn in de aandacht voor gericht preventief beleid. De meer stedelijke gemeenten zetten zich op dit gebied meer in dan de minder stedelijke gemeenten, wat waarschijnlijk samenhangt met de - ook relatief - grotere omvang van de groep probleemjeugd en/of risicojeugd in deze gemeenten. De beleidskeuzen van gemeenten lijken deels ook samen te hangen met de ambities en intenties van de centrale overheid. Hierop komen we in de hoofdstukken $\mathrm{I}_{2}$ en $\mathrm{r} 3$ terug.

Het beschikken over lokaal-specifieke informatie is een vereiste om het beleid toe te snijden op lokaal-specifieke omstandigheden. We hebben al gezien dat cijfermatige informatie in veel gemeenten op lang niet alle deelterreinen van het jeugdbeleid voorhanden is. Dat maakt het eens te meer van belang om verschillende actoren in het proces van beleidsvorming te betrekken, waaronder de jeugd zelf. Het betrekken van de jeugd staat nog steeds hoog op de agenda van gemeenten. Zij benaderen 
jeugdparticipatie vooral vanuit een instrumenteel perspectief, dat wil zeggen: vanuit de gedachte dat jeugdparticipatie hen beter in staat stelt maatwerk te realiseren.

Lokaal-specifieke informatie kan ook verkregen worden van in de gemeente werkzame instellingen. De betrokkenheid van instellingen bij de vorming van het jeugdbeleid is gewaarborgd in de uitgebreide netwerkvorming rond dat beleid. Er zijn weinig onderzoeksgemeenten zonder netwerken ( $15 \%$ ) en de gemeenten met netwerken hebben gemiddeld drie en een half netwerk. In twee derde van deze laatste groep is een deel van de netwerken betrokken bij de beleidsworming. Gezien de in het algemeen brede samenstelling van de netwerken lijken deze gemeenten te kunnen rekenen op voldoende lokaal-specifieke informatie. Overigens betekent dat ook dat iets minder dan de helft van alle onderzoeksgemeenten geen netwerken met strategische taken kent. In deze gemeenten moet de informatievergaring anders verlopen. Het blijkt dat als gemeenten een visie op het jeugdbeleid hebben ontwikkeld (wat voor de meeste geldt), in praktisch alle gevallen lokale instellingen bij deze ontwikkeling betrokken zijn. In het algemeen kan worden gesteld dat gemeenten hun jeugdbeleid in ieder geval op interactieve wijze trachten vorm te geven.

Overigens betekent dat nog niet dat die informatie goed gebruikt wordt. In een onderzoek naar het gemeentelijke jeugd- en veiligheidsbeleid in het kader van het grotestedenbeleid constateren Denters et al. (199gb) dat het vooral schort aan een adequate analyse van problemen in hun onderlinge samenhang. Bovendien wijzen zij op het gevaar van eenzijdig samengestelde beleidsnetwerken, die worden gedomineerd door ambtenaren en professionals van bepaalde instellingen: 'Professionals beschikken per definitie over een gemeenschappelijk fonds aan professionele kennis en vaardigheden op basis van een veelal langdurige specialistische opleiding en intensieve training. Vaak is er ook sprake van een gedeelde beroepsethiek.' (Denters et al. rg9gb: Ir3) Deze eenzijdige blik zou het vermogen om tot maatwerk te komen negatief kunnen beïnvloeden.

Vertegenwoordigers van instellingen en ambtenaren is gevraagd hun oordeel te geven over een aantal aspecten van het jeugdbeleid, waaronder de mate waarin het beleid is toegespitst op de lokaal-specifieke omstandigheden en problemen. Van alle aspecten waarover instellingen konden oordelen zijn zij op dit punt het meest positief of, zo men wil, het minst negatief. Het gemiddelde oordeel van 6,3 op een schaal van I tot en met ro ligt maar net boven het middelpunt van die schaal - in rapportcijfers een krappe voldoende. Ook de ambtenaren jeugdbeleid hebben een relatief positief oordeel over de vraag of gemeenten maatwerk hebben gerealiseerd.

Om terug te komen op de onderzoeksvraag: of gemeenten maatwerk realiseren is lastig te zeggen. In ieder geval lijken zij een redelijke inspanning te plegen om het jeugdbeleid op interactieve wijze vorm te geven door informatie te vergaren bij zowel instellingen als jongeren. Jongeren zelf zijn echter niet te spreken over de responsiviteit van het gemeentelijke jeugdbeleid. Een grote meerderheid vindt dat gemeenten onvoldoende rekening houden met hun wensen. Instellingen daarentegen, en dan 
vooral die instellingen die bij de beleidsvorming worden betrokken, geven het jeugdbeleid op dit punt het voordeel van de twijfel. Zonder dat dit leidt tot volledige beleidsuniformiteit lijken de beleidskeuzen bij gemeenten echter ook voor een aanzienlijk deel beïnvloed door de agenda van de verschillende bij het jeugdbeleid betrokken ministeries (vgl. Kwekkeboom 1994: 140-I 4I).

\subsubsection{Onderzoeksvraag 6: in hoeverre is het lokale jeugdbeleid te typeren als integraal?}

De vraag of er sprake is van integrale beleidsvoering is op een aantal manieren beantwoord. In de eerste plaats is gekeken naar de inhoudelijke breedte van het jeugdbeleid. Het gemiddelde aantal thema's dat in het jeugdbeleid aan de orde komt, bedroeg in 2001 bijna zes van in totaal acht mogelijke thema's. Gezien de toename van dit gemiddelde van 4,5 in 1998 naar 5,7 in 200 is het zeker niet uit te sluiten dat het na 200 r verder is gestegen. De waargenomen groei in de breedte heeft te maken met de toegenomen ontwikkeling van het jeugdbeleid. Hoe verder het beleid is uitgewerkt, hoe meer beleidsvelden in het jeugdbeleid aandacht krijgen, zo bleek al uit het onderzoek wan 1999 (Gilsing 1999). Vanuit het oogpunt van integrale beleidsvoering is deze ontwikkeling positief te waarderen. De verschillende thema's in het jeugdbeleid hangen vaak inhoudelijk samen, waardoor het jeugdbeleid gebaat is bij een omvattende, integrale aanpak. Of, om het voorzichtiger te stellen, het jeugdbeleid is in ieder geval gebaat bij het goed doordenken van de mogelijke samenhangen tussen bij het jeugdbeleid betrokken beleidssectoren.

Een dergelijke benadering van het jeugdbeleid komt ook tot uiting in de netwerken die in de meeste gemeenten rond het jeugdbeleid bestaan en waarin doorgaans verschillende actoren participeren. Bovendien zijn in de meeste gemeenten meerdere netwerken actief. Als er netwerken zijn dan is het gemiddelde antal dirie en een half. Ook dit zegt ook iets over de integrale beleidswoering. Gemeenten blijken er doorgaans in te slagen om actoren uit verschillende sectoren (onderwijs, zorg, welzijn, veiligheid) bij elkaar te brengen in beleidsnetwerken. Dat betekent dat veel gemeenten niet vanuit een sectorale invalshoek naar het jeugdbeleid kijken.

Een beleidsvisie is een belangrijk instrument voor de sturing van dergelijke netwerken. Het kan de integraliteit van het beleid bevorderen doordat het samenhang brengt en van daaruit richting geeft aan het handelen van beleidsactoren. Het blijkt dat de meeste gemeenten een visie hebben, die bovendien door instellingen als richtinggevend wordt ervaren. Ook in andere opzichten - zoals het creëren van consensus - blijkt de beleidsvisie een belangrijk sturingsinstrument. Consensus tussen gemeente en instellingen gaat samen met een geringere kans op afwijkingen van het geformuleerde beleid in de beleidsuitvoering. Meer in het algemeen blijkt de kracht waarmee gemeenten het beleid en het beleidsnetwerk sturen positief samen te hangen met de oordelen over het beleid en de resultaten. We kunnen stellen dat veruit de meeste gemeenten met behulp van een richtinggevende visie tot een integraal 
jeugdbeleid trachten te komen. Niettemin wordt de inhoudelijke sturing door instellingen gemiddeld als onvoldoende ervaren.

Wat wel opvalt aan de netwerkvorming rond het lokale jeugdbeleid is dat er in een aantal gemeenten veel netwerken zijn en de netwerkstructuur er complex is. Het blijkt dat vaak niet gesproken kan worden van een 'zuinige' netwerkstructuur: er is niet altijd sprake van een heldere verdeling van taken en verantwoordelijkheden tussen netwerken, en evenmin is de positie die netwerken in het beleidsproces innemen altijd eenduidig (zie ook Gilsing et al. 2000). Daarmee lijkt het erop alsof gemeenten er moeite mee hebben de integraliteit in het jeugdbeleid op een efficiënte wijze te organiseren. We komen hierop terug bij de beantwoording van de onderzoekswraag naar slagvaardigheid (\$ II.4.3).

Een ander aspect van de sturende rol van gemeenten is de politieke sturing. De politiek-bestuurlijke aandacht blijkt van belang voor de kans op beleidsafwijkingen in het geval er tussen gemeente en instelling geen of beperkte consensus bestaat. In die gevallen geldt dat de kans op beleidsafwijkingen afneemt naarmate de politiekbestuurlijke aandacht voor het jeugdbeleid toeneemt. De meeste bij het jeugdbeleid betrokken actoren geven aan dat de aandacht voor het jeugdbeleid van het college niet sterker of zwakker is dan die voor andere beleidsterreinen. Vanuit de raad is de aandacht iets minder, maar niet abnormaal laag.

Naast de samenwerking met actoren buiten de gemeentelijke organisatie is ook de interne afstemming en samenwerking van belang voor een integrale beleidsvoering. Op het punt van de politiek-bestuurlijke samenwerking wordt er doorgaans, ondanks de aanwezigheid van een coördinerende wethouder, door leden van het college nog steeds relatief weinig gedaan. Hetzelfde geldt min of meer voor de ambtelijke samenwerking. In de meeste gemeenten wordt het jeugdbeleid op ambtelijk niveau gecoördineerd - alleen in sommige kleine gemeenten gebeurt dit niet - maar de samenwerking tussen ambtenaren is in lang niet alle gemeenten de regel. Ook oordelen veel ambtenaren jeugdbeleid dat de bij het jeugdbeleid betrokken afdelingen weinig oog voor dit beleid hebben.

Een punt van specifieke aandacht is de afstemming tussen het lokale jeugdbeleid en de (provinciaal aangestuurde) jeugdzorg. In dit verband wordt vaak gesproken van een ketenaanpak, waarbij de jeugdzorg de laatste schakel in de keten kan zijn. Jeugdzorg vormt een aanvulling op het algemene voorzieningenaanbod. Wanneer de algemene voorzieningen onvoldoende zijn toegerust om bepaalde problemen van jongeren aan te pakken, dan dienen deze jongeren te worden doorverwezen naar de jeugdzorg. In het onderzoek van 1999 (Gilsing r9g9) bleek de afstemming tussen het lokale beleid en de jeugdzorg in weel gemeenten niet zonder problemen. Ook in dit onderzoek ontbreekt het in de meeste gemeenten aan een gezamenlijke visie van gemeente en jeugdzorg op de wijze waarop lokale voorzieningen en de jeugdzorg het beste kunnen samenwerken. 
Samenvattend kunnen we over de integrale beleidsvoering zeggen dat in een fors deel van de gemeenten de afstemming en samenwerking binnen de eigen organisatie beperkt is, terwijl het beleid inhoudelijk gemiddeld breed is. De netwerkstructuren rond het jeugdbeleid zijn in een behoorlijk aantal gemeenten omvangrijk en complex. Dit betekent enerzijds dat het beleid niet alleen breed geformuleerd is, mar. dat er ook een breed scala aan andere actoren bij betrokken is, en anderzijds dat de integralle beleidsvoering wordt bedreigd. De meeste gemeenten hebben wel een beleidsvisie die richting geeft aan de samenwerking met instellingen, wat de integrale beleidswoering in beginsel ten goede komt, maar tegelijkertijd is het oordeel van instellingen over de inhoudelijke sturing gemiddeld mager. Tot slot blijkt de afstemming met de provinciale jeugdzorg in veel gemeenten nog problematisch. De conclusie moet zijn dat gemeenten weliswaar veel investeren om tot een integrale beleidsvoering te komen en dat dit ook blijkt uit de min of meer integrale beleidsformulering, maar dat dit in zijn uitwerking nog wel de nodige tijd en energie zal kosten (vgl. Kwekkeboom I994: 143; Kwekkeboom 1997; Turkenburg 2003: 170; Fleurke 2003; De Groot 2005).

\subsubsection{Onderzoeksuraag 7: In hoeverre is het lokale jeugdbeleid te typeren als slaguaardig?}

Een zekere beleidsvrijheid in de uitvoering is van belang om adequat in te spelen op veranderende omstandigheden, om zo het zicht op realisatie van de beleidsdoelen niet te verliezen. Ruim vier op de vijf instellingen geeft aan over een grote of redelijk grote vrijheid in de beleidsuitwoering te beschikken. Dat betekent niet dat instellingen hun gang kunnen gaan. In de meeste gevallen ( $60 \%$ zijn er afspraken gemaakt over wat van uitvoerders wordt verwacht. Kennelijk betreft het vaak afspraken die meer betrekking hebben op wat er bereikt dient te worden dan op de wijze waarop dat gebeurt. In die zin kunnen uitvoerders slagvaardig opereren. Dat neemt niet weg dat voor $40 \%$ van de uitvoeringsrelaties geldt dat het voor de uitvoerder niet of onvoldoende duidelijk is wat de gemeente verwacht. In deze gevallen is de beleidsvrijheid zo groot dat de realisatie van verwachte beleidsprestaties in gevaar komt.

Niet bevorderlijk woor de slagvaardigheid is het gebrek aan tussentijdse evaluaties (60\% van de instellingen zegt dat deze niet plaatsvinden, ook niet in de vorm van een tussentijdse rapportage). Er wordt gaandeweg de uitvoering relatief weinig gekeken naar de voortgang en naar de vraag of het beleid misschien bijstelling behoeft. Dit komt in zekere zin de beleidswrijheid van instellingen ten goede, maar aan de andere kant zijn er weinig prikkels woor uitvoerders orn het eigen beleid kritisch te bezien en indien nodig bij te stellen.

Een laatste opmerking over de slagvaardigheid betreft de inefficiënte en overvloedige netwerkvorming. In de meeste gemeenten maken weel actoren op de een of andere manier deel uit van deze netwerken. De netwerkvorming neemt in omvang en complexiteit toe naarmate het jeugdbeleid verder ontwikkeld is. Het blijkt dat vaak niet 
gesproken kan worden van een 'zuinige' netwerkstructuur. De taakafbakening tussen netwerken is niet altijd helder, evenmin als de positie die netwerken in het beleidsproces innemen. Dit heeft onder andere tot gevolg dat op sommige instellingen een groot beroep wordt gedaan om deel te nemen aan beleidsnetwerken. Hoewel instellingen die bij beleidsstrategische netwerken zijn betrokken, aangeven dat deze in het algemeen goed functioneren, vinden zij ook relatief vaak dat de netwerken naar verhouding weinig opleveren. Dat verklaart waarschijnlijk ook waarom instellingen de afstemming en samenwerking tussen instellingen en de sturing van de gemeente zuinigjes waarderen met een zeer krappe voldoende. Een zuinige inrichting van netwerken, waarbij taken goed afgebakend worden en overlap wordt vermeden, zou de slagvaardigheid ten goede kunnen komen. Het lijkt erop alsof er een zekere spanning bestaat tussen de wens integraal beleid te voeren enerzijds en het vermogen slagvaardig beleid te voeren anderzijds.

11.4.4 Onderzoeksuraag 8: In hoeverre is het lokale bestuur toegankelijk voor maatschappelijke actoren, in het bijzonder jeugdigen, als het gaat om lokaal jeugdbeleid?

Bij de beantwoording van onderzoeksvraag 5 over maatwerk is al ingegaan op de vraag of en hoe gemeenten de jeugd trachten te betrekken bij het jeugdbeleid. Het grote belang dat gemeenten hieraan hechten, vertaalt zich niet in tevredenheid bij de jeugd over de mate waarin zij zich betrokken voelen. In de negen gemeenten waarin jongeren ondervraagd zijn, geeft steeds een (soms zeer ruime) meerderheid van hen te kennen dat de gemeente onvoldoende rekening houdt met hun wensen en problemen. Bovendien zijn er relatief weinig jongeren die participeren in het jeugdbeleid, ook als hun deelname vergeleken wordt met de participatiegraad onder volwassenen (SCP 2002: 229; Zeijl 2003: 112).

Het is de vraag of de ambities van rijk, provincies en gemeenten op het gebied van jeugdparticipatie niet te hooggespannen zijn. De opvatting van een groot deel van de jongeren dat hun stem te weinig doorklinkt in het jeugdbeleid, rechtvaardigt weliswaar die hoge ambities, maar tegelijkertijd moet geconstateerd worden dat grote delen van het jeugdbeleid voor de meeste jeugdigen slechts beperkt zichtbaar zijn. Jongeren willen vooral meepraten over zaken die te maken hebben met vrijetijdsbesteding en veiligheid, en niet over de hele breedte van het jeugdbeleid. Bovendien blijkt dat jongeren hun stem vooral willen laten horen via zogenoemde zaakwaarnemers, jongeren die toch al actief zijn. Veel jongeren zitten niet te springen om zelf bij het jeugdbeleid betrokken te worden. Dit gegeven zou nadrukkelijker meegewogen moeten worden bij de formulering van ambities op het gebied van jeugdparticipatie in het beleid.

De toegankelijkheid van het lokale bestuur voor de overige actoren is hiervoor ook al uitgebreid aan de orde geweest. Vooral via de beleidsnetwerken zijn veel instellingen bij het jeugdbeleid betrokken en hebben toegang tot de gemeente. Slechts een klein deel 
van de instellingen die bij het beleid betrokken zijn, vindt dat de gemeente voor hen moeilijk toegankelijk is als het gaat om jeugdbeleid.

\subsection{Conclusie: de effectiviteit van lokaal jeugdbeleid}

Als we de balans opmaken met betrekking tot de effectiviteit van het lokale jeugdbeleid, de belangrijkste overweging om belangrijke delen van het jeugdbeleid in handen van gemeenten te leggen, dan moeten we constateren dat de bevindingen van dit onderzoek er niet op wijzen dat het beleid van de meeste gemeenten voldoet aan de voorwaarden voor effectief beleid. Op het punt van maatwerk is het oordeel zuinig. Hoewel gemeenten er veel aan doen lokale informatie te vergaren, lijkt er ook sprake van een zekere beleidsuniformiteit. Er wordt veel moeite gedaan om integraal beleid te voeren, maar de opbrengsten daarvan zijn onduidelijk. Er is een aantal factoren dat het slagvaardig optreden kan belemmeren, en integrale beleidswoering is daar zeker een van. De breedte van het beleidsterrein, het grote aantal betrokken actoren en de wens om veel zaken samenhangend aan te pakken belemmeren het vermogen slagvaardig op treden. Tot slot is de betrokkenheid van de jeugd bij het beleid beperkt. Over de mate waarin gemeenten in het lokale jeugdbeleid aan de verwachtingen voldoen, bestaat daarom gerede twiffel.

Gezien deze bevindingen is het niet verwonderlijk dat er de nodige scepsis is over de resultaten van het jeugdbeleid, zowel bij betrokken beleidsactoren als bij jongeren. Hoewel we deze scepsis niet kunnen staven met 'harde' cijfers van maatschappelijke ontwikkelingen, is het duidelijk dat al deze actoren zeer gereserveerd zijn over de resultaten van het jeugdbeleid.

De vraag die vervolgens aan de orde is, luidt: doet het lokale jeugdbeleid er eigenlijk wel toe? Die vraag dient bevestigend te worden beantwoord. Het blijkt namelijk dat een actieve sturing van de gemeente, die onder meer tot uiting komt in de mate van ontwikkeling van het jeugdbeleid, de netwerkvorming, de aanwezigheid van een beleidsvisie en de mate van consensus tussen gemeente en instellingen, positief samenhangt met de oordelen van ambtenaren en instellingen over de resultaten van het lokale jeugdbeleid. Hoewel de invloed van de gemeentelijke sturing beperkt is, doet deze er dus wel degelijk toe. 
Noot

I Ook ander onderzoek wijst op een forse toename wan het aantal gemeenten met een specifiek jeugdbeleid in het laatste decennium; vgl. Noorda et al. 1996; Claassen 1996; Dijkman 1997; Wiebing en Van Lankvelt 1999; Kwekkeboom et al. 2002: 137-138. 
Deel III

De invloed van nationaal beleid op

lokaal jeugdbeleid 


\section{Het nationale jeugdbeleid}

\subsection{Inleiding}

Het lokale jeugdbeleid voldoet slechts ten dele an de verwachtingen die ten grondslag liggen aan decentralisatie, zo is in hoofdstuk II geconstateerd. De vraag is hoe deze discrepantie tussen verwachtingen en bevindingen verklaard kan worden. Het ligt voor de hand om te kijken naar de rol van het nationale jeugdbeleid. De tweede centrale vraag van dit onderzoek luidde dan ook:

Op welke wijze tracht de centrale overheid het lokale jeugdbeleid te beïnvloeden en wat betekent dat voor de mogelijkheden die gemeenten hebben om een effectief jeugdbeleid tot stand te brengen?

Aan deze centrale vraag zijn drie onderzoeksvragen gekoppeld:

9 Wat waren van 1998 tot en met 2001 de doelen in het nationale beleid ten aanzien van jeugd en in hoeverre werd aan gemeenten en lokale actoren een rol toegekend in het realiseren van die doelen?

10 Welke instrumenten zette de nationale ovetheid in de periode van 1998 tot en met 2001 in om gemeenten en andere lokale actoren te ondersteunem bij of te faciliteren in het realiseren van die doelen?

11 In hoeverre kan het nationale jeugdbeleid van 1998 tot en met 2001, in terment van doelen en instrumenten, gezien worden als een belemmering dan wel een stimulans voor het ontwikkelen van eetn op de lokale situatie toegesneden integraal, slagvaardig en effectieflokaal jeugdbeleid?

In dit hoofdstuk trachten we een antwoord op deze drie onderzoekswragen te vinden. In hoofdstuk $I$ is uitgebreid ingegaan op de wijze waarop dat zal gebeuren. Hieronder is deze werkwijze nog eens kort samengevat.

\section{Doelen van nationaal beleid}

Het is belangrijk doelen te onderscheiden die het lokale beleidsproces betreffen (throughput), doelen die in het beleid te behalen prestaties betreffen (output) en doelen die de maatschappelijke positie van jeugd en/of hun opvoeders betreffen (outcome). Output en outcome hebben te maken met beleidsinhoudelijke doelen, throughput met procesmatige doelstellingen. De veronderstelling is dat nationaal beleid waarwan de doelen op outcome-niveau zijn geformuleerd de meeste vrijheid laat aan gemeenten en dus het vermogen om tot maatwerk en een integrale en slagvaardige beleidsvoering te komen het minst belemmert. Doelen op outcome-niveau kunnen overigens wel effect hebben op het vermogen tot maatwerk. Voor doelen op outputniveau geldt dat zij al in wat sterkere mate interfereren met de lokale beleidswrijheid; ook hier geldt dat vooral het aspect van maatwerk. Doelen in het nationale beleid op 
throughput-niveau perken de lokale beleidsruinte echter het sterkst in. Ze beïnvloeden vooral het vermogen tot een integrale en slagvaardige beleidsvoering te komen.

\section{Instrumenten van nationaal beleid}

De kenmerken van nationale beleidsinstrumenten zijn van invloed op het lokale vermogen tot maatwerk, integrale beleidsvoering en slagvaardigheid. De vier onderscheiden kenmerken zijn het instrumenttype, de generieke of specifieke toepassing ervan, de mate van uitwoeringsregulering, en het object van sturing. Deze kenmerken bepalen de verruimende of beperkende werking van een instrument. De veronderstelde invloed van de kenmerken is samengevat in tabel $12 . x$. Naast de beleidsinstrumenten zijn er zogenoemde bestuursinstrumenten en vormen van constituerende sturing. Dit zijn instrumenten die de werking van beleidsinstrumenten inkaderen of faciliteren. In de analyse worden zij, omdat zij niet direct gericht zijn op gedragsbeinvloeding van lokale actoren, niet beoordeeld op hun invloed op het lokale jeugdbeleid.

Het beoordelingskader fungeert in dit onderzoek als hulpmiddel om de werking van nationale instrumenten 'op de hand' te wegen. Het is niet mogelijk om verruimende en beperkende werkingen van een instrument rekenkundig bij elkaar op te tellen of van elkaar af te trekken. De invloed van een instrument wordt, gegeven zijn kenmerken, steeds beargumenteerd, waarbij het beoordelingskader uit tabel I2.I als hulpmiddel dient. Het is bijvoorbeeld duidelijk dat een forse financiële prikkel een meer verruimende invloed heeft op het vermogen tot maatwerk dan de specifieke toepassing van een instrument of dan informatie.

Tabel 12.1

Invloed van beleidsinstrumenten op aspecten van het lokaal jeugdbeleid ${ }^{a}$

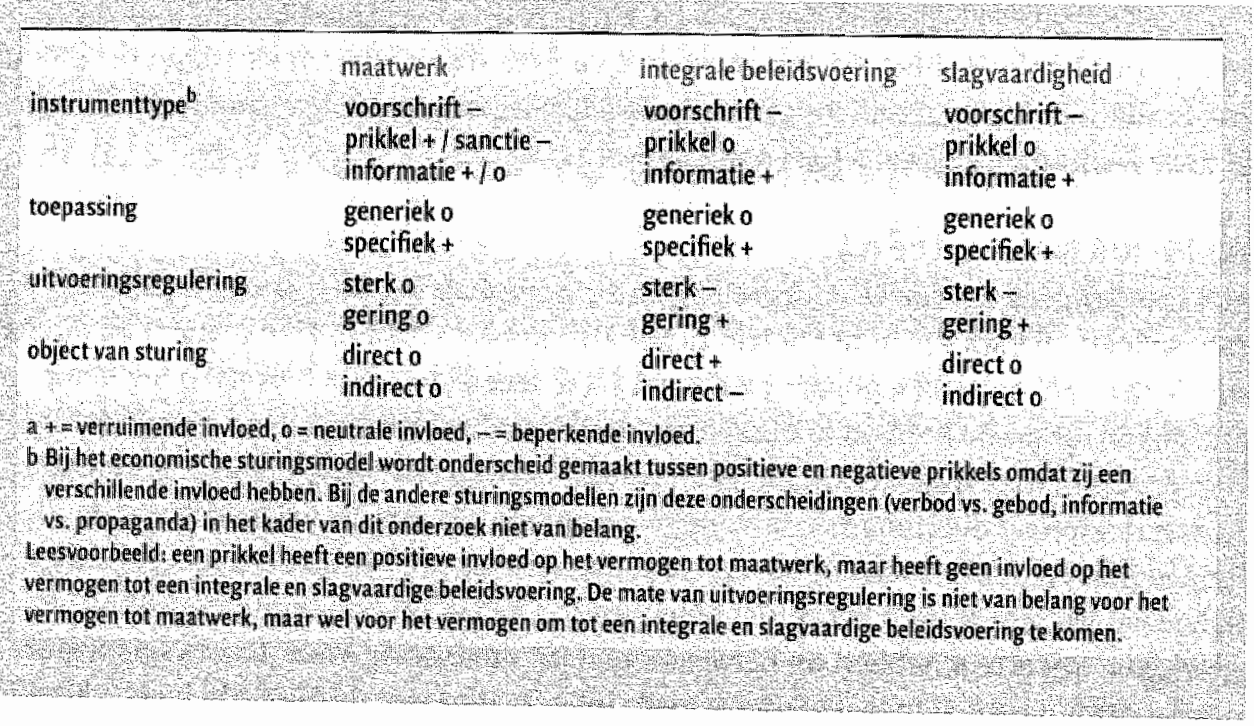


Dit hoofdstuk bevat naast de gebruikelijke literatuurverwijzingen ook veel verwijzingen naar Tweede-Kamerstukken (TK), documenten van het ministerie van Binnenlandse Zaken en Koninkrijksrelaties (BZK) en andere ministeries waaronder ocw en wws, de Staatscourant en het Staatsbliad. Deze publicaties zijn te vinden in de lijst Geraadpleegde documenten.

Alle bedragen worden in dit hoofdstuk weergegeven in de munteenheid die gebruikt werd in de periode voór 2002 - de onderzoeksperiode -, de gulden.

\subsubsection{Werkwijze bij de analyse van het nationale jeugdbeleid}

Een belangrijke vraag is natuurlijk hoe het jeugdbeleid van de nationale overheid zich laat kennen. Waaruit bestaat dat beleid eigenlijk? In zekere zin zou betoogd kunnen worden dat 'het' nationale jeugdbeleid niet bestaat. Verschillende departementen voeren beleid dat van invloed is op jeugd en zij doen dat lang niet altijd onder de noemer van jeugdbeleid. Slechts het coördinerende ministerie van Volksgezondheid, Welzijn en Sport (vws) heeft het expliciet over jeugdbeleid. Indien alleen dat beleid als het nationale jeugdbeleid wordt gezien, blijft het grootste deel van het beleid dat van invloed is op de jeugd buiten beschouwing. Een andere mogelijkheid is om tot het jeugdbeleid al dat beleid te rekenen dat direct gericht is op de jeugd, waarbij de precieze definitie van jeugd nog even buiten beschouwing wordt gelaten. Vanuit het perspectief van het rijk, en in het bijzonder vanuit de ambities die bijvoorbeeld in Regie in de jeugdzorg (WvC en Justitie 1994) zijn geformuleerd, is een dergelijke brede definitie meer passend. Immers, de nationale overheid stelt zich nadrukkelijk ten doel de verschillende op de jeugd gerichte beleidsinitiatieven op elkaar af te stemmen, met een coördinerende rol voor het ministerie van vws.

Er is echter erg veel nationaal beleid dat van invloed is op de jeugd. Ondat het in dit onderzoek gaat om de relatie tussen nationaal en lokaal beleid, komt alleen nationaal beleid aan de orde dat direct of indirect van invloed is op de rol van gemeenten als regisseur van het lokale jeugdbeleid. Deze beperking betekent bijwoorbeeld dat sectoraal onderwijsbeleid dat louter gericht is op directe gedragsbeïnvloeding van schoolbesturen of-directies met betrekking tot het onderwijsproces, in dit hoofdstuk niet aan de orde komt, tenzij het van invloed is op de relaties tussen onderwijsinstellingen en gemeenten in de beleidsarena rond het jeugdbeleid.

Een tweede afbakening betreft de periode. Omdat het in dit hoofdstuk gaat om nationaal beleid dat van invloed is op het gevoerde lokale jeugdbeleid in de periode I998-200I, wordt voor het nationale beleid dezelfde periode als uitgangspunt genomen. Dat betekent dat beleidsdoelen en -maatregelen die in deze periode van kracht waren of dit geworden zijn, worden meegenomen in de beschrijving. Het gaat dus nadrukkelijk ook om beleid dat vór de periode r998-200r tot stand is gekomen en dat toen nog steeds van kracht was. 
De wijze waarop het onderzoek naar de inhoud van het lokale jeugdbeleid is verricht (zie hoofdstuk 4 ) is in dit hoofdstuk leidend voor de beschrijving van het nationale beleid. Dat maakt het mogelijk per 'onderdeel' van het lokale jeugdbeleid uitspraken te doen over het relevante nationale beleid. Dat perspectief op de inhoud van het lokale jeugdbeleid is in figuur 12.1 schematisch weergegeven. De horizontale balk geeft het instrumentele aspect van het lokale jeugdbeleid weer, te weten de sturende rol van de gemeente in het jeugdbeleid. Daarbij gaat het onder meer om het tot stand brengen van samenhang tussen de inhoudelijke pijlers uit het schema en om het bevorderen van de participatie van jeugdigen in het beleid. De acht inhoudelijke pijlers dekken het jeugdbeleid in de breedte. Deze inhoudelijke pijlers zijn ook aan bod gekomen in het onderzoek naar de inhoud van het lokale jeugdbeleid. Zij vertegenwoordigen een aantal mogelijke aandachtsvelden in het lokale jeugdbeleid. Per onderdeel van het schema wordt in afzonderlijke paragrafen ingegaan op het voor gemeenten relevante rijksbeleid. De paragrafen worden steeds afgesloten met een samenvatting en een tabel waarin de bevindingen worden samengevat.

Het beleid van de rijksoverheid is ingedeeld naar de pijlers waarin het het beste past. Soms is er sprake van overlap, omdat beleid tot meer pijlers gerekend kan worden. Dit beleid wordt dan bij de betreffende pijlers vermeld, maar het wordt slechts bij één pijler uitvoeriger behandeld. Veelomvattende beleidsprogramma's als het grotestedenbeleid (GSB) en het Bestuursakkoord Nieuwe Stijl (BANS) zijn verdeeld over de pijlers en komen daarnaast in de paragraaf over regie aan de orde ( $($ I2.3.I). Facetbeleid, zoals het integratiebeleid, wordt waar van toepassing eveneens per pijler behandeld.

Het nationale beleid voor de periode $1998-2001$ is geïnventariseerd door in eerste instantie de rijksbegrotingen van de bij het jeugdbeleid betrokken departementen te 'screenen' op aangekondigd beleid, en op verwijzingen naar lopend beleid. Het betreft de begrotingen van de ministeries van Volksgezondheid, Welzijn en Sport (vws), Onderwijs, Cultuur en Wetenschap (ocw), Binnenlandse Zaken en Koninkrijksrelaties (BZK), Justitie en Sociale Zaken en Werkgelegenheid (SZW) voor de jaren 1998 tot en met 2002 . Vanuit de verwijzingen in de begrotingen is getracht een beter beeld te krijgen van de beleidsinitiatieven door te zoeken naar wet- en regelgeving in Staatsblad en Staatscourant, en naar beleidsnota's, beleidsbrieven en memories bij de behandeling van wet- en regelgeving, die door de regering aan de Eerste of Tweede Kamer werden verstrekt. Als deze officièle overheidspublicaties onvoldoende inzicht gaven, is voor zover beschikbaar gebruikgemaakt van secundaire literatuur, zoals beleidsevaluaties. 
Figuur 12.*

Schematische weergave gemeentelijk jeugdbeleid

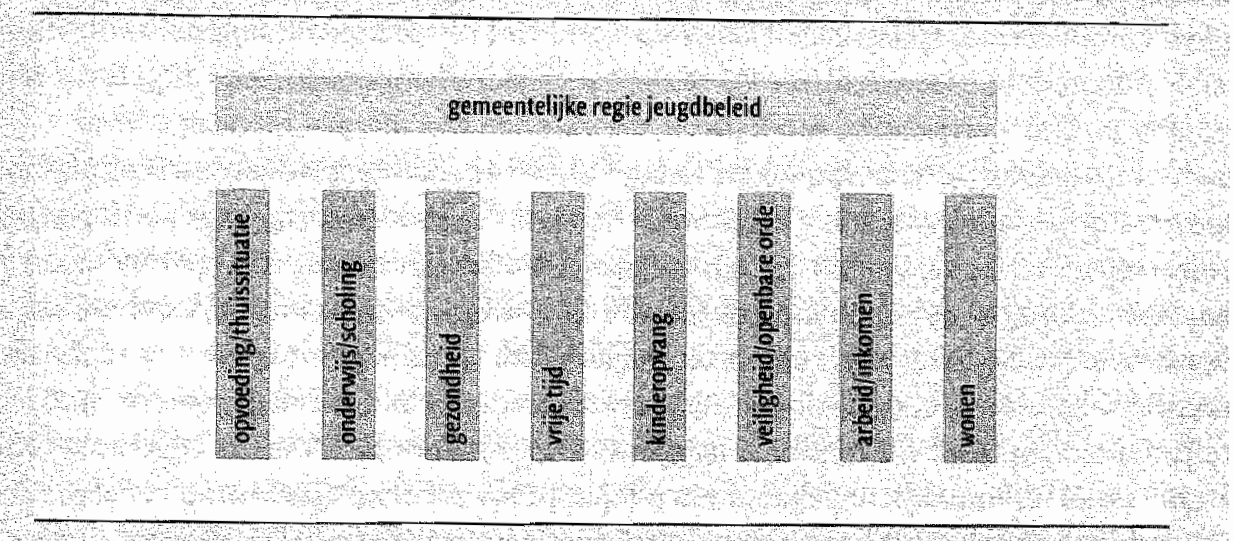

Tot slot: het achterhalen van beleidsdoelen is geen eenvoudige zaak. Doelen zijn vaak niet expliciet aangegeven, zijn vaag geformuleerd of worden gepresenteerd als voornemens of ambities (vgl. Bressers en Klok 1998: 188-r9o). In dit hoofdstuk hanteren we een ruime opvatting van beleidsdoelen: ook ambities of voornemens om iets te bereiken of tot stand te brengen worden gezien als beleidsdoelen. Een ander punt is dat doelstellingen elkaar kunnen overlappen of dat zij hiërarchisch geordend zijn. Vanwege de complexiteit en omvang van het nationale jeugdbeleid komt deze ordening van doelen niet systematisch aan de orde. Het zou een aanzienlijke aanvullende onderzoeksinspanning vergen om met name de hiërarchische ordening van beleidsdoelen in beeld te brengen. Soms is een dergelijke ordening expliciet aangegeven, maar vaker is deze impliciet of in het geheel onduidelijk, omdat er vanuit veel verschillende beleidskaders naar het jeugdbeleid gekeken wordt. Een reconstructie is dan gekunsteld en hoeft niet noodzakelijk recht te doen aan de intenties van beleidsmakers.

\subsection{Het nationale jeugdbeleid}

\subsubsection{Gemeentelijke regie in het jeugdbeleid}

Doelen van het nationale beleid

Het algemene doel van het nationale jeugdbeleid, zoals geformuleerd door het ministerie van vws (zie de vws-begrotingen van $1998 \mathrm{t} / \mathrm{m}$ 200r: TK 1997/r998a, TK I998/1999a, TK 1999/2000a, TK 2000/200ra), is het bevorderen van kansen van jeugdigen en het tegengaan van uitval. Daartoe acht men het noodzakelijk dat de maatschappelijke positie van de jeugd wordt versterkt en dat de participatie van de jeugd wordt bevorderd. Deze algemene doelstelling is uitgewerkt in de Beleidskaders 
jeugdzorg (en de daaraan gekoppelde voortgangsrapportages), die met ingang van 1995 steeds voor een periode van vier jaar worden vastgesteld en fungeren als het richtinggevende kader woor het jeugdbeleid. ${ }^{I}$ In de respectievelijke beleidskaders wordt het preventieve jeugdbeleid steeds als een van de speerpunten genoemd. Dit beleid zou gericht moeten zijn op de al eerder genoemde hoofddoelstellingen van het jeugdbeleid - vergroting van kansen, voorkomen van uitval - en deze vooral moeten realiseren door de draagkracht (sociale steun, competenties) van jeugdigen te vergroten, door maatschappelijke participatie en sociale binding te bevorderen, en door in specifieke gevallen de draaglast (eisen, 'leefwereldstressoren') te verminderen. Voorzieningen op met name lokaal niveau worden verantwoordelijk gehouden voor de totstandkoming van een preventief aanbod, waarbij gemeenten een regierol vervullen. Voor de tweede periode van het grotestedenbeleid is een algemene doelstelling geformuleerd die hierbij aansluit (BZK 1998 ). Voor het domein Opgroeien in de stad is als uiteindelijk te behalen maatschappelijk resultaat geformuleerd dat alle jongeren op school zitten en een startkwalificatie halen of aan het werk zijn.

In de notitie Perspectief voor jeugdigen, kansen voor gemeenten (Vws 1995) heeft de nationale overheid getracht de gemeentelijke regierol in het lokale jeugdbeleid nader te duiden. Belangrijke elementen daarin zijn een eenduidige visie op het jeugdbeleid met daaraan gekoppelde concrete doelen, het zicht hebben op de jeugd in de gemeente, het betrekken van jeugd bij het beleid en de aansturing van voorzieningen, gebaseerd op de principes van vraaggericht werken en 'ketenverantwoordelijkheid'. De lokale visie op het jeugdbeleid wordt verondersteld gestoeld te zijn op de algemene doelen uit het richtinggevende kader: het bevorderen van kansen en het voorkomen van uitval. Later (onder andere in de Welzijnsnota 1999-2002 (TK 1998/1999b) en BANS 1999a) wordt de doelstelling verbijzonderd: bij het lokale jeugdbeleid dienen jeugdigen en hun opvoeders actief betrokken te worden, er is sprake van een balans tussen algemeen beleid, gerichte preventie en probleemgericht beleid, er wordt tijdig ingespeeld op risicofactoren en -situaties en er is een sluitend aanbod van voorzieningen dat aansluit op de vraag van jeugdigen en hun opvoeders.

De ambitie van het rijk ten aanzien van de regierol van gemeenten geldt de gehele periode tot en met 200I (en ook daarna). In tal van andere beleidsnota's en in toelichtingen bij wet- en regelgeving wordt verwezen naar de gemeentelijke regierol, in het bijzonder waar het gaat om de afstemming tussen verschillende (lokale en regionale) voorzieningen of beleidsinitiatieven. Wel is in 1999 het doel aangescherpt (TK 1998/1999b): alle gemeenten zouden in 2002 een actief jeugdbeleid moeten voeren. In het Bestuursakkoord Nieuwe Stijl van mei 2000 (BANS 200I), waarin rijk, provincies en gemeenten gezamenlijke afspraken hebben gemaakt over het jeugdbeleid, is ook de gemeentelijke regierol aan de orde gekomen. Hierover is afgesproken dat gemeenten een gemeentelijke beleidsnotitie jeugd opstellen waarin zij hun visie formuleren, ingaan op de staat van de jeugd, en doelstellingen, maatregelen en beoogde resultaten opnemen. In de nota dient onder andere de wijze waarop de afstemming met de 
arbeidstoeleiding, politie en justitie, opvang en jeugdzorg georganiseerd wordt aan de orde te komen. Uitgangspunt van het gemeentelijke beleid is dat dit gericht is op alle jeugdigen in de gemeente en in het bijzonder op de preventie van problemen en de aanpak daarvan. Met nadruk wordt het belang van afstemming met de jeugdzorg genoemd. Het gemeentebestuur maakt daarover afspraken met de provincie.

Samengevat kunnen de ambities van het rijk ten aanzien van de regierol van de gemeente worden gezien als een drietrapsraket. In de eerste plaats, op het outcomeniveau, hebben gemeenten een beleid dat tot doel heeft de kansen van jeugdigen te bevorderen en uitval te voorkomen. In de tweede plaats, en dan hebben we het over de te leveren prestatie, kenmerkt het gemeentelijke beleid zich door een balans tussen een algemene, een gericht preventieve en een probleemgerichte benadering, en door een sluitende aanpak. Tot slot zijn er op het niveau van throughput een aantal procesdoelstellingen: concrete doelformulering op basis van een visie die aansluit bij de hoofddoelstellingen van het nationale beleid, een vraaggerichte werkwijze en betrokkenheid van de jeugd, zicht op de leefsituatie van de jeugd en afstemming van beleid met de provinciale jeugdzorg. vws heeft de rol van coördinerend departement.

\section{Instrumenten van het nationale beleid}

Een belangrijk instrument van het rijk is het richtinggevende kader voor het jeugdbeleid, door vws voor het eerst geformuleerd in 1995 (vws et al. 1995). In dat kader zijn de verwachtingen ten aanzien van de lokale regierol geschetst. Het beleidskader heeft echter geen wettelijke basis, wat betekent dat de gemeenten niet gehouden zijn mee te werken aan de ambities van het rijk. Dat lijkt veranderd met de afspraken die gemaakt zijn in het overhedenoverleg van december 1999 , in het kader van het Bestuursakkoord Nieuwe Stijl (BANS r999a). Daarbij heeft de belangenvertegenwoordiger van de Vereniging van Nederlandse Gemeenten ( $\mathrm{VNG}$ ), zich gecommitteerd aan afspraken met het kabinet over de bestuurlijke inrichting van het jeugdbeleid, waaronder afspraken over de gemeentelijke regierol. Formeel zijn echter ook deze afspraken voor afzonderlijke gemeenten niet bindend. De vNG is slechts gehouden de afspraken bij haar leden onder de aandacht te brengen.

Het richtinggevende kader heeft daarnaast ook de functie om de afstemming in het op jeugdigen gerichte beleid van de verschillende departementen te versterken. Via het beleidskader geeft vws invulling aan haar coördinerende taak. Een sterkere coördinatie op rijksniveau moet eveneens bijdragen aan de facilitering van gemeentelijke regie.

Tot welk type beleidsinstrumenten behoren het richtinggevende beleidskader en het bestuursakkoord? In beide documenten wordt veel gesproken in termen van 'gemeenten zijn verantwoordelijk voor ...', 'gemeenten dragen zorg voor ...', enzowoort. Dergelijk taalgebruik suggereert dat de instrumenten bindend zijn voor gemeenten. Zoals we al opmerkten, is dat niet het geval. De instrumenten moeten daarom tot het communicatieve sturingsmodel worden gerekend. $\mathrm{Zij}$ roepen 
gemeenten op tot bepaalde acties en verschaffen informatie over mogelijkheden om het lokale jeugdbeleid in te richten. In dat opzicht vergroten zij de handelingsruimte voor gemeenten om het beleid op de lokale situatie toe te spitsen. Zij hebben hoegenaamd geen invloed op het vermogen tot integraal en slagvaardig beleid, omdat de aangereikte informatie vooral betrekking heeft op outcome- en output-doelstellingen.

Met een deel van de gemeenten heeft de nationale overheid (i.c. BzK) wel bindende afspraken gemaakt. Het betreft de gemeenten die deel uitmaken van het grotestedenbeleid. Daarbij kan onderscheid worden gemaakt naar de naar inwonertal gemeten vier grootste gemeenten $\left(G_{4}\right)$ en een aantal middelgrote gemeenten die op grond van bepaalde (probleem)indicatoren zijn geselecteerd. ${ }^{2}$

In de eerste GSB-periode, I994-1999, is gekozen voor een projectmatige aanpak, waarbij de steden steeds per project een projectvoorstel indienen (BZK I995a; BZK I995b). De projecten zijn gericht op een integrale aanpak van problemen, met zoveel mogelijk beleidsruimte voor de steden. De steden zijn verantwoordelijk voor de regie. Twee van de vijf clusters zijn van belang voor het jeugdbeleid; jeugd en veiligheid, en onderwijs, zorg en opvang. Deze clusters kennen ieder een aantal specifieke doelstellingen, die in de paragrafen van de betreffende pijlers besproken worden.

In de tweede GSB-periode, $1998-2004$, is gekozen voor een meerjarige programmatische aanpak (BZK 1998; vgl. BZK 2002; TK 1998/1999c). Op basis van een soort beleidskader van de nationale overheid ontwikkelen de steden meerjarenplannen, die door het rijk onder meer aan de inhoudelijke doelen van het rijksbeleid en aan de mate van integraliteit worden getoetst. Daarna worden tussen steden en nationale overheid overeenkomsten voor de gehele periode gesloten, waarin het rijk een financiële verplichting aangaat en de steden zich verplichten de doelstellingen te realiseren. Belangrijk element is het versterken van de regierol van de steden. De steden dienen zich aan het eind van de periode eenmalig te verantwoorden voor de behaalde resultaten en voor de besteding van de rijksbijdrage. Tussentijds wordt de voortgang met behulp van verschillende instrumenten gevolgd. De rolverdeling kan als volgt worden samengevat: het rijk bepaalt de doelstellingen op hoofdlijnen, de steden maken deze concreet voor hun eigen beleid en zoeken bijpassende beleidsinstrumenten. Deze rolverdeling moet bijdragen aan meer samenhang en integraliteit in de beleidsuitvoering.

Een van de drie pijlers van het GSB in deze tweede periode is de sociale pijler. Doelstellingen in deze pijler zijn de verbetering van de aansluiting tussen onderwijs en arbeidsmarkt, het versterken van de sociale infrastructuur en het verbeteren van de veiligheid, waaronder de veiligheid op scholen. In de beleidsbrief van juni 1999 (TK $1998 / \mathrm{rg} 99 \mathrm{c}$ ) wordt aangegeven dat de inzet binnen de sociale pijler in eerste instantie gericht is op het domein 'perspectieven bieden aan jeugd in de stad'. Voor een deel krijgen gemeenten de beschikking over een grotere beleidsvrijheid door de bundeling van specifieke uitkeringen in een brede doeluitkering, en over extra middelen voor bepaalde doeleinden. In de behandeling van de afzonderlijke pijlers wordt ingegaan op de diverse aspecten van het voor de jeugd relevante grotestedenbeleid. 
De overeenkomsten in het grotestedenbeleid zijn niet afgedwongen door de nationale overheid. Het GSB is te zien als een prikkel voor gemeenten op een aantal terreinen beleid te ontwikkelen en behoort daarom tot het economische sturingsmodel. Omdat de doelstellingen in de beleidskaders van het rijk door gemeenten dienen te worden owergenomen, beperkt dit de ruimte voor maatwerk, ondanks de ruimte die er voor elke gemeente bestond om het landelijke beleidskader grotestedenbeleid in een eigen beleidsplan uit te werken. Het grotestedenbeleid leidt door de bundeling van specifieke uitkeringen wel tot een groter vermogen van de steden om integraal en slagvaardig beleid te voeren.

Gemeenten zijn in de ontwikkeling van hun jeugdbeleid vanaf 1995 ondersteund door twee opeenvolgende projecten. Het eerste, het project Ontwikikeling lokaal preventief jeugdbeleid (OLPJ) kent onder meer als taken het lokale jeugdbeleid te stimuleren en te ondersteunen, bij gemeenten draagvlak te creëren voor preventief jeugdbeleid, en zorg te dragen voor informatie aan en communicatie met gemeenten en (lokale) voorzieningen voor jeugdigen. De projectgroep oLPJ heeft zich in de periode 1995 -r 998 geconcentreerd op drie thema's: participatie, regie en het lokaal agenderen van jeugdbeleid. Rond elk thema zijn in tien pilot-gemeenten projecten uitgevoerd. Daarnaast is voor elk thema een aantal publicaties verschenen met als doel gemeentelijke beleidsmakers te ondersteunen. Het project is in 1998 afgerond met een eindadvies aan de nationale overheid over de verdere ondersteuning van het lokale jeugdbeleid (OLPJ 1998a en r998b).

Het tweede project met als doel gemeenten in de ontwikkeling van het jeugdbeleid te ondersteunen, is het VNG-project lokaal jeugdbeleid. Dit project moet ertoe bijdragen dat eind 2002 zoveel mogelijk gemeenten een actief jeugdbeleid hebben ontwikkeld. Het project tracht dit te realiseren door de uitwisseling van ervaringen tussen gemeenten te faciliteren, door informatievoorziening en door op maat gesneden, gerichte steun voor afzonderlijke gemeenten. De thema's waarop ondersteuning plaatsvindt, zijn de gemeentelijke regierol, participatie van de jeugd, aansluiting tussen lokaal jeugdbeleid en jeugdzorg, afstemming van lokaal onderwijsbeleid en jeugdbeleid en jeugd, en veiligheid. In een later stadium is daar een sluitende aanpak van o- tot 6 -jarigen aan toegevoegd. Het project was ondergebracht bij een apart projectbureau binnen de vNG. Het is voor de periode $1999-2002$ voor 3 miljoen gulden per jaar gefinancierd door vws. In aanvulling daarop verschafte $\mathrm{BZK}$ voor de periode 2000-2002 ook een jaarlijkse subsidie van 3 miljoen gulden (Van Westering 2003: II). ${ }^{3}$ Uit de evaluatie van het VNG-project bleek dat een zeer groot deel van de Nederlandse gemeenten is bereikt (Koops en Gilsing 2003).

Beide ondersteuningstrajecten zijn bij uitstek instrumenten waarmee informatie is overgedragen. Ze hebben in hoofdzaak betrekking op het lokale beleidsproces en op de operationalisering van bepaalde beleidsdoelen. Het VNG-project heeft daarnaast door gerichte ondersteuning van individuele gemeenten voorzien in de specifieke inzet van deze communicatieve sturing. De trajecten hebben daardoor vooral bijgedragen aan het vermogen van gemeenten een integraal en slagvaardig beleid te voeren. 
De rijkssoverheid heeft ook getracht de gemeentelijke regierol te versterken door het invoeren van een aantal wetten, respectievelijk het doorvoeren van wetswijzigingen op het gebied van onderwijs. Met name de Wet gemeentelijk onderwijsachterstandenbeleid (Wet GOA) is van invloed op de regiemogelijkheden van gemeenten. In de notitie die aan deze decentralisatie ten grondslag ligt (OCenW I995: 5-6; zie ook TK 1994/1995a) wordt gesteld:

"Lokaal onderwijsbeleid kan een wezenlijke bijdrage leveren aan nog meer samenwerking en samenhang op lokaal niveau. Daarbij gaat het niet alleen om samenwerking binnen het onderwijs, maar juist ook om de afstemming met andere beleidsterreinen, zoals lokaal jeugdbeleid en veiligheidsbeleid. Doel is een integrale lokale aanpak, gericht op zaken als het voorkomen van uitval en de zorg dat geen jongere de school verlaat zonder startkwalificatie. (...) Een succesvolle aampak vraagt om intensieve samenwerking tussen scholen en andere instellingen. Te denken valt onder meer aan de schoolbegeleidingsdienst, welzijnsinstellingen, de Riagg, algemeen maatschappelijk werk, de jeugdgezondheidszorg, jeugdhulpverlening, justitie en politie, het arbeidsbureau en het centrum vakopleiding en ook woningbouwverenigingen en de sociale dienst.'

Ruimere bevoegdheden voor gemeenten in het onderwijsbeleid zouden bijdragen aan het totstandkomen van een dergelijke "succesvolle" aanpak. Op de inhoudelijke aspecten van deze decentralisatie wordt nader ingegaan in de paragraaf over onderwijs (\$ $12.3 \cdot 3)$.

Het is duidelijk dat deze decentralisatie tot het juridische sturingsmodel dient te worden gerekend. Niettemin en ondanks de sterke binding aan regels van de uitvoering vergroot het de vrijheid van gemeenten zowel bij de doelformulering als bij de inrichting van het beleidsproces. De decentralisatie van het onderwijsbeleid heeft daarom in beginsel een verruimend effect op de vrijheid wan gemeenten tot maatwerk en tot een integraal, slagvaardig beleid te komen.

De invoering van de Wet op de jeugdzorg per I januari 2005 vindt zijn oorsprong in het regeringsstandpunt Regie in de jeugdzorg (wvc en Justitie r994). Daarin wordt per regio een eenduidige toegang tot de jeugdzorg voorzien. Bij deze eenduidige toegang, die in de jaren na 1994 gestalte heeft gekregen in de opkomst van de Bureaus Jeugdzorg, is het belangrijk dat de afstemming tussen de regionale jeugdzorg en het lokale jeugdbeleid goed geregeld is. Ondanks het feit dat de Wet op de jeugdzorg pas in 2005 van kracht is geworden, hebben de voorbereidingen op de wet door onder meer de oprichting van de Bureaus Jeugdzorg en de totstandkoming van zogenoemde regiovisies hun invloed gehad op de regiemogelijkheden van gemeenten. Eén van de systeemeisen die aan de regiovisies wordt gesteld is dat daarin de relatie tussen de jeugdzorg enerzijds en het lokale jeugdbeleid, het (speciaal) onderwijs, de arbeidsvoorziening en de gezondheidszorg anderzijds wordt beschreven. In het Beleidskader preventieve en curatieve jeugdzorg 1997-2000 (vws et al. 1996) wordt het streven ('richtinggevende afspraak') geformuleerd dat er in r 998 'een brede aanwezigheid' van 
regiovisies zou zijn. In 1997 heeft de regering een standpunt geformuleerd over de procesmatige en inhoudelijke eisen waaraan regiovisies zouden moeten voldoen. In I 999 is in het eerste BANS over het jeugdbeleid afgesproken dat het Interprovinciaal Overleg ( $\mathrm{PPO}$ ) en de VNG bij provincies en gemeenten aandringen op expliciete afspraken over deze afstemming in de regiovisies. 'Een regiovisie bevat bindende afspraken die overheden, verzekeraars, justitiële vertegenwoordigers en gemeenten met elkaar maken (...)' (vws et al. 1996: 62). De provincie heeft het initiatief bij het opstellen van regiovisies. In het Doorstartconvenant voor de tweede periode van het grotestedenbeleid neemt het rijk de verplichting op zich om voorwaarden te creëren waaronder de steden een sluitende aanpak kunnen realiseren, onder andere door instrumenten te ontwikkelen om de samenwerking te bevorderen tussen instellingen die opereren op regionaal en op lokaal niveau (BZK 1998). Daarbij wordt met name verwezen naar het terrein van de jeugdzorg, de AWBZ-zorg en justitiële diensten zoals het Openbaar Ministerie, de kinderbescherming en de reclassering.

Ook voor de regiovisie geldt dat het nationale beleid geen bindend karakter heeft, waardoor het als een vorm van informatievoorziening dient te worden aangemerkt. Tegelijkertijd beperken de procesmatige en inhoudelijke eisen aan de regiovisie en het feit dat niet de gemeente maar de provincie initiatiefnemer (regisseur) is, de ruimte voor gemeenten om tot integraal, slagvaardig beleid te komen.

In de beleidsbrief Brede scholen (TK I999/200ob) wordt het concept van de brede school gezien als een geschikt instrument om de samenhang tussen onderwijs, welzijnswerk, politie en andere instellingen te versterken. Met andere woorden: de brede school is een instrument dat gemeenten kunnen gebruiken in hun gemeentelijke regie. De rijksoverheid ondersteunt de ontwikkeling van brede scholen door communicatie en onderzoek, deels via lopende beleidsinitiatieven als de voor-en vroegschoolse educatie, het gemeentelijk onderwijsachterstandenbeleid en het VNGproject lokaal jeugdbeleid. De financiering van brede scholen wordt nadrukkelijk aan gemeenten overgelaten.

Omdat we dit instrument hier behandelen in het kader van de gemeentelijke regiefunctie, zien we de aangereikte informatie vooral als een versterking van het vermogen tot integraal en slagvaardig beleid en voor een deel (het onderzoek) als constituerend instrument.

Tot slot ondersteunt het rijk de regiefunctie van gemeenten door onderzoek en monitoring, waarvan de resultaten worden meegedeeld aan gemeenten. De monitoring van de regiefunctie van gemeenten vond onder meer plaats door middel van dit onderzoek naar lokaal jeugdbeleid. Verder zijn er bijvoorbeeld plannen ontwikkeld voor een interactieve lokale jeugdmonitor, die zicht moet geven op de jeugd, zijn er methodieken ontwikkeld die het mogelijk maken vraaggericht preventief te werken, en zijn instrumenten ontwikkeld waarmee gemeenten sturing kunnen geven aan het vraaggericht werken van voorzieningen. 
De onderzoeken en monitoren kunnen, voor zover ze daadwerkelijk van de grond zijn gekomen, op zichzelf als constituerend worden beschouwd, terwijl de informatie die daarover aan gemeenten en andere lokale actoren wordt verstrekt (methodiekontwikkeling) en die vooral betrekking heeft op het beleidsproces, het vermogen tot slagvaardig en integraal beleid bevordert.

\section{Overzicht en conclusie}

In tabel 12.2 is een overzicht opgenomen van het nationale beleid ten aanzien van de gemeentelijke regierol in het jeugdbeleid. In de tabel zijn de instrumenten niet direct gekoppeld aan één doel, maar aan een groep doelstellingen, omdat de verschillende instrumenten verschillende doelen dienen en de doelen door verschillende instrumenten gerealiseerd moeten worden. De doelen zijn in twee groepen verdeeld. De ene groep betreft de inhoudelijke aspecten wan de regierol, de tweede groep de procesmatige doelen van de regierol.

Twee van de drie instrumenten die gekoppeld zijn aan de inhoudelijke doelen van de regie (outcome en output) hebben geen bindend karakter. $Z$ ij verschaffen gemeenten informatie over de te stellen doelen in het jeugdbeleid en vergroten de hoeveelheid informatie die gemeenten kunnen gebruiken om het beleid op de lokale situatie toe te snijden. Zij hebben geen effect op het gemeentelijke beleidsproces. Het instrument dat slechts voor een klein deel van de gemeenten van toepassing is, het grotestedenbeleid, is een prikkel. Omdat het de keuze van beleidsdoelen door gemeenten in sterke mate beïnvloedt, heeft het een negatief effect op het vermogen maatwerk te realiseren. Tegelijkertijd heeft dit instrument door de bundeling van specifieke uitkeringen en door vergroting van de financiële ruimte een positief effect op het vermogen een integraal en slagvaardig beleid te voeren.

De instrumenten die gericht zijn op de gemeentelijke regie als proces behoren overwegend tot het communicatieve sturingsmodel. Zij verschaffen gemeenten informatie over hoe verschillende aspecten van de gemeentelijke regie versterkt kunnen worden, en verruimen daardoor de handelingsmogelijkheden en daarmee het vermogen om een integraal en slagvaardig beleid te voeren. Deze instrumenten hebben geen noemenswaardig effect op het vermogen tot maatwerk. Uitzondering hierop vormen de regiovisies, die aan allerlei inhoudelijke en procesmatige eisen moeten voldoen en daardoor een negatief effect hebben op het vermogen tot integraal en slagvaardig beleid. Het enige juridische en daardoor zwaarwegende instrument is de decentralisatie van het onderwijsbeleid. Dit heeft op alle drie de aspecten van het lokale jeugdbeleid een positieve invloed.

In het algemeen werkt het nationale beleid ten aanzien van de regierol niet beperkend voor gemeenten. De belangrijkste uitzondering is het grotestedenbeleid, waar de nationale overheid een sterke vinger in de pap houdt bij het formuleren van beleidsdoelstellingen. Voor de steden staat daar een grotere vrijheid in de uitvoering tegenover. 


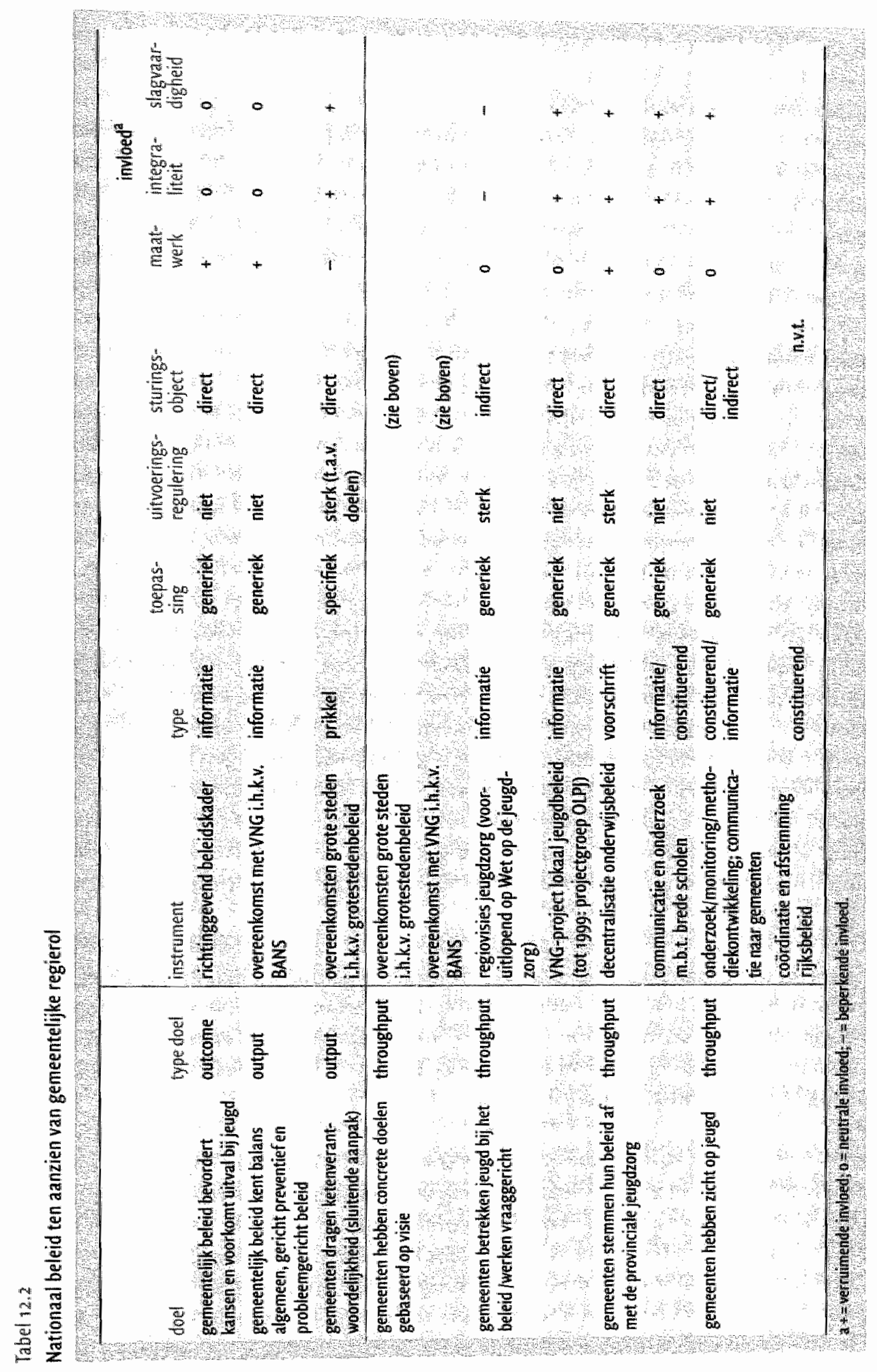




\subsubsection{Opvoeding en (opgroeien in) thuissituatie}

\section{Doelen wan het nationale beleid}

Deze pijler van het jeugdbeleid betreft de thuisomgeving van jeugdigen en is gericht op factoren die van invloed zijn op de opvoedingsomgeving en de thuissituatie waarin kinderen zich ontwikkelen. Veel van dergelijk beleid wordt aangeduid als opvoedingsondersteuning en ontwikkelingsstimulering [O\&O). Ook beleid gericht op vroegtijdige signalering van risico's en problemen in de ontwikkeling en in de opvoedingsomgeving wan kinderen behoort tot deze pijler.

In de Welzijnsnota 1995-1998 (vws 1994) is opvoedingsondersteuning een van de programma's in het kader van het thema preventie. Het doel van dit programma is 'inzicht (te verkrijgen) in een adequaat aanbod aan opvoedingsondersteuning naar inhoud en structuur, in de bestuurlijke voorwaarden om tot een adequaat aanbod te kunnen komen, en in de voorwaarden voor implementatie op landelijke schaal in het kader van lokaal, geïntegreerd jeugdbeleid'. Kennelijk is het doel impliciet om tot een landelijk dekkend aanbod van opvoedingsondersteuning te komen, dat gerealiseerd wordt op lokaal niveau. In april 1998 verscheen de vws-beleidsbrief Naar een solide basis (TK 1997/I998b). De ondertitel van de beleidsbrief is veelzeggend: 'Opvoedingsondersteuning en ontwikkelingsstimulering als bijdrage aan het voorkomen van maatschappelijke uitval en jeugdcriminaliteit'. Het doel is om op lokaal niveau een samenhangend, effectief aanbod van opvoedingsondersteuning en ontwikkelingsstimulering tot stand te brengen, met name in zogenoemde achterstandswijken. Daartoe zou het structurele aanbod van de algemene voorzieningen moeten worden versterkt en aangevuld met een specifiek aanbod. In de beleidsbrief over Niet-vrijblijveride vormen van opvoedingsondersteuning van Justitie uit juni 2000 (TK I999/200oc) neemt het kabinet zich voor om, indien nodig, ouders nadrukkelijker aan te spreken op hun rol als opvoeder en daartoe de contacten met justitie en politie beter te benutten.

In de vws-begroting voor 1999 (TK 1998/1999a) wordt de vroegtijdige signalering én aanpak van problemen in de ontwikkeling en opvoeding als een van de centrale punten in het jeugdbeleid genoemd, waarbij er een belangrijke doorverwijzende rol is weggelegd voor consultatiebureaus, instellingen kinderopvang en peuterspeelzalen. De vroegtijdige signalering dient het mogelijk te maken dat (dreigende) achterstanden op jonge leeftijd worden aangepakt.

In de afspraken die in het kader van het Bestuursakkoord Nieuwe Stijl zijn gemaakt, is een aantal ambities geformuleerd die passen in de pijler 'opvoeden en thuissituatie'. In het BANS wordt gesproken over een sluitende aanpak van o- tot 6-jarigen:

'(...) de overheden (spreken) af nog in deze kabinetsperiode (1998-2002, rg) overal in Nederland structurele versterking van het samenhangende aanbod voor kinderen van o tot 6 jaar en hun ouders te realiseren. In concreto moet dit ertoe leiden dat aan alle kinderen optimale ontwikkelingsmogelijkheden en een goede 
toerusting voor het basisonderwijs wordt geboden, met bijzondere aandacht voor kinderen die iets extra's nodig hebben. Doordat ieder kind met enige regelmaat een of meerdere van de algemene voorzieningen bezoekt en de betrokkenheid van ouders wordt gestimuleerd, kunnen risico's voor de ontwikkeling van kinderen tijdig worden gesignaleerd en kunnen ouders die de opvoedingstaak tijdelijk als belastend ervaren ondersteuning op maat krijgen. (...) De gemeente heeft hierbij een regisserende functie.' (BANS xg9ga: $\mathrm{xI}$ ).

Ook in het beleid dat gericht is op de integratie van etnische minderheden (BZK) worden doelen op dit gebied geformuleerd (TK I998/rg9gd; TK 1998/rg99e). Deze komen overeen met de hierboven genoemde doelen, met dien verstande dat de doelen in het integratiebeleid vanzelfsprekend van toepassing zijn op de jeugd en hun ouders die tot de beleidscategorie etnische minderheden behoren.

De ambities van de nationale overheid ten aanzien van opvoedingsondersteuning, ontwikkelingsstimulering en vroegtijdige signalering dienen, zo veel is duidelijk uit de verschillende nota's, op het lokale niveau te worden gerealiseerd. Ze zijn allen geformuleerd als door gemeenten te leveren beleidsprestaties (output).

\section{Instrumenten van het nationale beleid}

In de Welzijnsnota 1995-19g8 (vws I994) is een programma Opvoedingsondersteuning opgenomen. 4 Dit programma bestaat uit experimenten op zeven locaties en is vooral gericht op de doelgroep allochtone gezinnen. In de experimenten worden 'de bestuurlijke vormgeving en de inhoudelijke invulling beproefd en onderzocht' (vws 1994: 30). De experimenten zijn ondersteund door het Nederlands Instituut voor Zorg en Welzijn (NIZW). De opgedane ervaringen 'kunnen de basis vormen voor een bredere implementatie' (NIZW: 30), waarbij het beleid ingebed zou kunnen worden in het bredere jeugdbeleid. Voor de experimenten is in de periode 1995 -1998 3 miljoen gulden per jaar beschikbaar gesteld. De experimenten zijn in 1997 afgerond. De bevindingen hebben een rol gespeeld in de beleidsbrief o\&O Naar een solide basis (vgl. vws 1998: 52). De experimenten zijn een duidelijk voorbeeld van constituerende sturing, ze zijn immers gericht op het genereren van kennis die in toekomstig beleid kan worden gebruikt.

De Welzijnsnota 1995-1998 kent ook het deelprogramma o-18-jarige allochtonen, dat grotendeels gericht is op ontwikkelingsstimulering bij allochtone kinderen. In de periode $1994-1998$ heeft $v$ ws ongeveer 13 miljoen gulden per jaar uitgetrokken om de invoering van zogenoemde Stap-programma's te stimuleren. Voor een deel zijn deze op gemeentelijk niveau uitgevoerde programma's door het rijk gefinancierd: er was sprake van cofinanciering door rijk en gemeenten. Ook konden gemeenten gratis gebruikmaken van ondersteuning door de landelijke stichting die de methodieken ontwikkelde en is gratis materiaal verstrekt. 5 Aan de cofinanciering zijn voorwaarden gesteld met betrekking tot de aantallen deelnemende kinderen en de herkomst van de kinderen. De omvang van de financiering door vws is in de tijd aflopend om de kansen op structurele voortzetting van de programma's te vergroten. Gemeenten 
kunnen kiezen uit een aantal door vws vastgestelde programma's; andere programma's komen niet voor de regeling in aanmerking. De uitvoering van de regeling werd intensief gevolgd door de ondersteunende stichting, terwijl de verantwoordingsplicht aan vws beperkt was.

In de vws-begroting voor 1999 wordt aangegeven dat de ontwikkeling en evaluatie van programma's voor met name jonge kinderen voltooid is of zich in de laatste fase bevindt, en dat vanaf 1998 geen stimulering van nieuwe projecten meer plaatsvindt (TK 1998/1999a).

Door de cofinancieringsstructuur is dit programma aan te merken als economisch beleidsinstrument dat de handelingsmogelijkheden van gemeenten verruimt. De gevolgen voor het vermogen een integraal en slagvaardig beleid te voeren zijn gering; dit komt vooral door de beperkte mate van uitvoeringsregulering.

Een versterking van het structurele aanbod van algemene voorzieningen, aangevuld met specifieke voorzieningen, is noodzakelijk om de doelstellingen uit de vws-beleidsbrief o\&o Naar een salide basis (TK I997/I9g8b) te realiseren. De keuze om de (lokale) algemene voorzieningen te versterken wordt echter doorgeschoven naar een volgend kabinet. In de brief zijn 'voorwaardenscheppende maatregelen' aangekondigd: betere afstemming tussen landelijke aanbieders van programma's, methodiek-ontwikkeling en -toetsing, monitoring, intra- en interdepartementale coördinatie, intensivering van communicatie tussen gemeenten en landelijke overlegstructuren, en verbetering van de landelijke infrastructuur voor steunfuncties. In de vws-begroting voor 1999 is het voornemen opgenomen om te overleggen met de VNG over de wijze waarop bevorderd kan worden dat binnen het gemeentelijke beleid de nodige aandacht zal worden gegeven aan de uitvoering van deze plannen, waarbij de mogelijkheden die de groei van het Gemeentefonds biedt, zullen worden benut (TK 1998/1999a). In hoofdzaak zijn deze instrumenten echter niet gericht op gedragsbeïnvloeding van lokale actoren. Daarmee zijn zij voornamelijk constituerend van aard en hebben dus geen directe gevolgen voor het beleidswormende vermogen van gemeenten.

In de Welzijnsnota 1999-2002 (TK 1998/1999b) worden in vier Nederlandse gemeenten experimenten (pilots) aangekondigd met het programma Communities that Care (Ctc). De experimenten maken deel uit van het deelprogramma Leefbarheid en sociale samenthang op buurt- en wijkniveau uit die nota. De ctc-programma's zijn nadrukkelijk gericht op het voorkomen van probleemgedrag onder jongeren, zoals jeugddelinquentie en schooluitval. De aanpak richt zich ook nadrukkelijk op de omgeving waarin jongeren zich ontwikkelen en opgevoed worden, en is te zien als een breed preventieprogramma. Daarnaast is er het project Opuoeden en opgroeien in de wijk (O\&O op wijkniveau), dat uitgevoerd wordt in het kader van het Welzijnsnota-deelprogramma Netwerken rond jeugd en gezin, en waarin het doel is om de regie van de gemeente op het gebied van o\&o te versterken en om het aanbod van o\&O-voorzieningen te verbeteren. Dit zou bereikt moeten worden door een integraal instrumentarium voor de wijk en voor de versterking van de wijkstructuur te ontwikkelen. ${ }^{6}$ In het kader van dit project zijn in drie gemeenten pilots uitgezet. 
Beide experimentele projecten zijn bedoeld om kennis op te doen voor latere beleidsontwikkeling en zijn dus constituerend van aard. Dat betekent ook dat ze geen directe gevolgen hebben voor het beleidswormende vermogen van gemeenten, met uitzondering van de zeven pilot-gemeenten.

In 200 r wordt door vws de (Tijdelijke) regeling vroegsignalering afgekondigd (Staatscourant 20ora). Om (dreigende) achterstanden van jonge kinderen op vroege leeftijd aan te pakken worden consultatiebureaus gefaciliteerd om extra inspanningen te leveren. De regeling loopt vooruit op de wijziging van de Wet Collectieve Preventie Volksgezondheid ( $W C P V)$, waarmee gemeenten verantwoordelijk worden voor de gehele jeugdgezondheidszorg voor o-rg-jarigen. De tijdelijke regeling oormerkt de rijksmiddelen voor enkele specifieke taken die de rol van consultatiebureaus moeten versterken. De regeling vereist dat de middelen globaal worden ingezet voor de volgende taken:

- versterking van het bereik van de vroegsignalering door extra inspanningen om ouders te motiveren het consultatiebureau te bezoeken, onder meer via zogenoemde outreaching;

- actieve doorverwijzing van kinderen met een (dreigende) taalontwikkelingsachterstand, met name toeleiding naar voorschoolse voorzieningen;

- ondersteuning van ouders van jonge risicokinderen;

- samenwerking met andere hulpverleners (Bureau Jeugdzorg, GGD) en deelname in netwerken met peuterspeelzalen en basisscholen om een sluitende aanpak in het o-6-jarigenbeleid mogelijk te maken;

- gegevensregistratie;

- deskundigheidsbevordering.

Per GGD-regio wordt een gemeente aangewezen waaraan de uitkering wordt verstrekt; deze gemeente dient het beleid af te stemmen met de overige gemeenten in de betrokken regio en overleg te voeren met de in de regio werkzame thuiszorgorganisaties over de taakuitvoering en de wijze van bekostiging. 7 De coördinerende gemeente moet met de uitkering alle thuiszorgorganisaties bereiken die in de regio werkzaam zijn. Zij mag maximaal 20,000 gulden besteden aan aanloopkosten. Ook draagt zij zorg voor de registratie door consultatiebureaus op kwartaalbasis van:

- het aantal jonge kinderen dat in het verzorgingsgebied woont en het aantal dat in het betreffende kwartaal is bereikt;

- het aantal kinderen dat in een kwartaal is aangemerkt als risicokind, plus de motivering daarvan;

- het aantal kinderen bij wie in een kwartaal een (verhoogd risico op) taalachterstand is gesignaleerd en het aantal kinderen dat om die reden is doorverwezen naar voor- of vroegschoolse voorzieningen of intensieve educatieve programma's;

- het aantal van de in het voorgaande punt genoemde kinderen dat daadwerkelijk gebruik heeft gemaakt van de betreffende voorzieningen. 
Deze gegevens worden jaarlijks door de coördinerende gemeente gerapporteerd aan vws met daarbij een inhoudelijk verslag met aandacht voor de aard, duur en omvang van activiteiten die de gemeente heeft ondernomen om de taken uit de regeling te vervullen. Ook wordt er gerapporteerd over de besteding van de uirkering. Vanaf 200 is voor de duur van de regeling 35 miljoen gulden per jaar beschikbaar. De hoogte van de uitkering is mede afhankelijk van het aandeel gewichtenleerlingen in het basisonderwijs. ${ }^{8}$ Vanwege de urgentie dient men al in 200 I met het uitvoeren van de taken te beginnen. Bij wijziging van de wCPV wordt de tijdelijke regeling daarin geïntegreerd, in eerste instantie door een specifieke uitkering. ${ }^{9}$ In principe worden de middelen na drie jaar overgeheveld naar het gemeentefonds, tenzij evaluatie anders uitwijst. De (coördinerende) gemeenten hebben een maand de tijd om een uitkering aan te vragen. ${ }^{\mathrm{IO}}$ De coördinerende gemeenten zijn verantwoordelijk voor het doen van de aanvraag.

De regeling behoort tot de economische sturingsinstrumenten. De verruiming van de financiële mogelijkheden heeft in principe positieve gevolgen voor de mogelijkheden tot maatwerk. De hoge mate van uitvoeringsregulering beperkt echter het vermogen tot een integraal en slagvaardig beleid. Opmerkelijk is ook de korte termijn die gemeenten is vergund om een aanvraag in te dienen.

In het kader van de ambities die door de overheden in het BANS geformuleerd zijn (BANS r999a: 57-59), is afgesproken dat gemeenten die ambitie trachten te realiseren door een gemeentelijk plan van aanpak op te stellen voor het beleid dat op o- tot 6-jarigen is gericht. Het plan dient gebaseerd te zijn op de specifieke lokale omstandigheden en te leiden tot de ontwikkeling van een structurele aanpak voor o- tot 6-jarigen op wijkniveau. Uitgangspunten daarbij zijn:

- aan de aanpak ligt een visie op het gewenste voorzieningenaanbod ten grondslag die gebaseerd is op de vraag bij jeugdigen, c.q. hun ouders, en die leidt tot doelstellingen en maatregelen;

- er is sprake van een effectieve en doelmatige samenwerkingsstructuur tussen instellingen en voorzieningen;

- er is sprake van een vraaggerichte werkwijze;

- de effecten van het beleid worden systematisch gevolgd.

De VNG zal het totstandkomen van dit beleid bij haar leden stimuleren, waar nodig samenwerking tussen gemeenten stimuleren en bevorderen dat gemeenten ervaringen uitwisselen. De nationale overheid zal nagaan hoe gemeenten gefaciliteerd kunnen worden en zorgt voor interdepartementale afstemming van relevante beleidsinitiatieven. In het BANS van 2000 (BANS 200I) is besloten de zogenoemde BANS-bezoekcommissie in te stellen, die de verschillende overheden zou moeten stimuleren zich in het jeugdbeleid op de BANS-afspraken te baseren. De commissie is in januari 200 ingesteld en heeft in 2002 verslag van haar bevindingen uitgebracht (BANS-bezoekcommissie 2002). 
Zoals in paragraaf I2.3.I al is opgemerkt heeft het BANS de pretentie meer te zijn dan een vrijblijvende afspraak tussen overheden. Vanuit het perspectief van gemeenten is het echter geheel vrijblijvend. Het verschaft gemeenten informatie over mogelijke te volgen strategieën en behoort daarom tot de communicatieve beleidsinstrumenten. ${ }^{\text {II }}$

De sluitende aanpak in het o- tot 6 -jarigenbeleid was dan ook een van de inhoudelijke thema's in het VNG-project lokaal jeugdbeleid. Door themamiddagen, workshops en (individuele) consultaties zijn gemeenten ondersteund in de ontwikkeling en vormgeving van een sluitende aanpak (zie Van Westering 2003). Het vNG-project is een communicatief beleidsinstrument dat het vermogen van gemeenten om een slagvaardig en integraal beleid te voeren verruimt.

In de beleidsbrief over Niet-vrijblijvende vormen van opvoedingsondersteuning spreekt de nationale overheid, c.q. het ministerie van Justitie het voornemen uit om een aantal acties te ondernemen die het mogelijk maken ouders aan te spreken op hun verantwoordelijkheid in de opvoeding. Daarin spelen justitie en politie een belangrijke rol ( $T K$ I I999/2000c). De belangrijkste voornemens die direct betrekking hebben op het lokale beleid zijn:

- het activeren van bestaande richtlijnen voor onder meer politie, justitie en Haltbureaus over het systematisch betrekken en aanspreken van ouders op hun verantwoordelijkheid voor wangedrag van hun kinderen;

- het experimenteren met family group conferences bij Halt-bureaus en eventueel de politie;

- het stimuleren van geregelde contacten (netwerkvorming) tussen politie en justitie enerzijds en (ouders uit) etnische minderheidsgroepen anderzijds.

De experimenten zijn constituerend van aard. De overige twee maatregelen zijn gericht op niet-gemeentelijke actoren uit de lokale beleidsarena. Hoewel verschillend van aard (juridisch respectievelijk communicatief), versterken ze de functionele (sectorale) benadering van problemen, waarbij de overige actoren uit de lokale beleidsarena niet zijn betrokken. Dit heeft in beginsel een negatief effect op het beleidsvormende vermogen van de gemeente. De maatregelen hebben geen effect op het vermogen van de betreffende actoren om slagvaardig op te treden, omdat aan deze actoren geen extra instrumenten worden aangereikt.

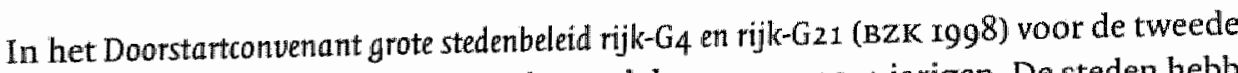
GSB-periode zijn afspraken gemaakt rond de zorg voor 0-4-jarigen. De steden hebben zich verplicht resultaatafspraken te maken met de ketenvoorzieningen rond $0-4$-jarigen, zoals consultatiebureaus, peuterspeelzalen, de kinderopvang en het opvoedingssteunpunt. Steden voeren de regie over de totstandkoming van de keten en over de beleidsuitvoering. Daardoor kan de deelname van kinderen aan voorschoolse voorzieningen worden vergroot. In de stedelijke programma's worden de te behalen tussentijdse en eindresultaten vastgelegd. Als mogelijke indicatoren voor het welslagen van het beleid worden de verhoging van de deelname van het aantal 0-4-jarige risicokinderen aan voorschoolse programma's en de vroegtijdige signalering van ontwikkelingsbedreigende situaties en gedragingen genoemd. 
Het grotestedenbeleid is in paragraaf ${ }_{12.3 .1}$ al aan de orde geweest. Daar hebben we geconstateerd dat het tot de economische instrumenten behoort. Het beperkt echter de ruimte voor maatwerk vanwege de sterke inbreng van de rijksoverheid in de doelformulering. Door de bundeling van specifieke uitkeringen leidt het GSB wel tot een groter vermogen van de steden om integraal en slagvaardig beleid te voeren.

\section{Overzicht en conclusie}

Om de doelstelling van vroegtijdige signalering te realiseren heeft het rijk gekozen voor een economisch sturingsmodel. Gemeenten zijn financieel geprikkeld om in de vroegsignaleringsfunctie te voorzien. Hoewel dit instrument door de extra financiële middelen die gemeenten verwerven als zij er gebruik van maken, aangeduid moet worden als verruimend, heeft de opzet van de regeling ook een beperkende kant. De regeling schrijft gemeenten vrij uitvoerig voor wat zij moeten doen met de beschikbare gelden en hoe zij te werk moeten gaan in de uitwoering van de regeling.

Het realiseren van een sluitende aanpak wordt door het rijk nagestreefd door communicatieve sturing. Gemeenten zijn in de periode vanaf de totstandkoming van de (niet bindende) BANS-afspraken uitgebreid en op verschillende manieren geïnformeerd over de wijze waarop een sluitende aanpak onder hun regie tot stand zou kunnen komen. Alleen de $\mathrm{G}_{25}$ zijn geprikkeld om bindende afspraken te maken over de zorg voor 0-4-jarigen, waaronder een sluitende aanpak.

Het doel om ouders bij geconstateerde problemen nadrukkelijker aan te spreken op hun rol als opvoeder is in beleidsmaatregelen omgezet door het ministerie van Justitie. Er is gekozen voor instrumenten die niet direct gericht zijn op de lokale overheid, maar op de actoren in de justitiële hoek.

In de vele beleidsnota's en beleidsbrieven van de rijksoverheid over deze pijler wordt vaak verwezen naar de experimenten Communities that Care en O\&O in de wijk. De door dèze dôcumenenten gewekte indruk dat het om breed toegepast beleid gaat, is onjuist: in de praktijk gaat het om zeven, in de meeste gevallen grotere, gemeenten. Gezien het experimentele karakter van de projecten is dat niet vreemd, maar dit karakter en de beperkte toepassing van de projecten komen lang niet altijd (even duidelijk) naar voren, waardoor het lijkt of veel meer gemeenten de genoemde experimenten uitvoeren.

Tabel 12.3 biedt een overzicht van beleidsdoelen en -instrumenten van de nationale overheid voor de pijler 'opvoeding/thuissituatie'. Alle doelen zijn op output-niveau geformuleerd, zodat de gemeentelijke beleidsvrijheid grotendeels in tact blijft. Alleen het vermogen tot maatwerk wordt er enigszins door beperkt. Bij de instrumenten valt op dat het hoofdzakelijk constituerende en informatieve beleidsinstrumenten zijn. Uitzonderingen vormen drie prikkels waarvan er een in 1998 is beëindigd, en een voorschrift dat betrekking heeft op een niet-gemeentelijke actor. Het is vooral de Tijdelijke regeling uroegsignalering die de ambitie van de nationale overheid moet waarmaken. Deze maatregel verruimt het gemeentelijke vermogen tot maatwerk, maar beperkt door zijn hoge mate van uitvoeringsregulering het vermogen tot een integraal en slagvaardig beleid te komen. 
We moeten constateren dat de ambities van de nationale overheid in beperkte mate worden ondersteund door instrumenten die het beleidsvormende vermogen van gemeenten significant verruimen. 


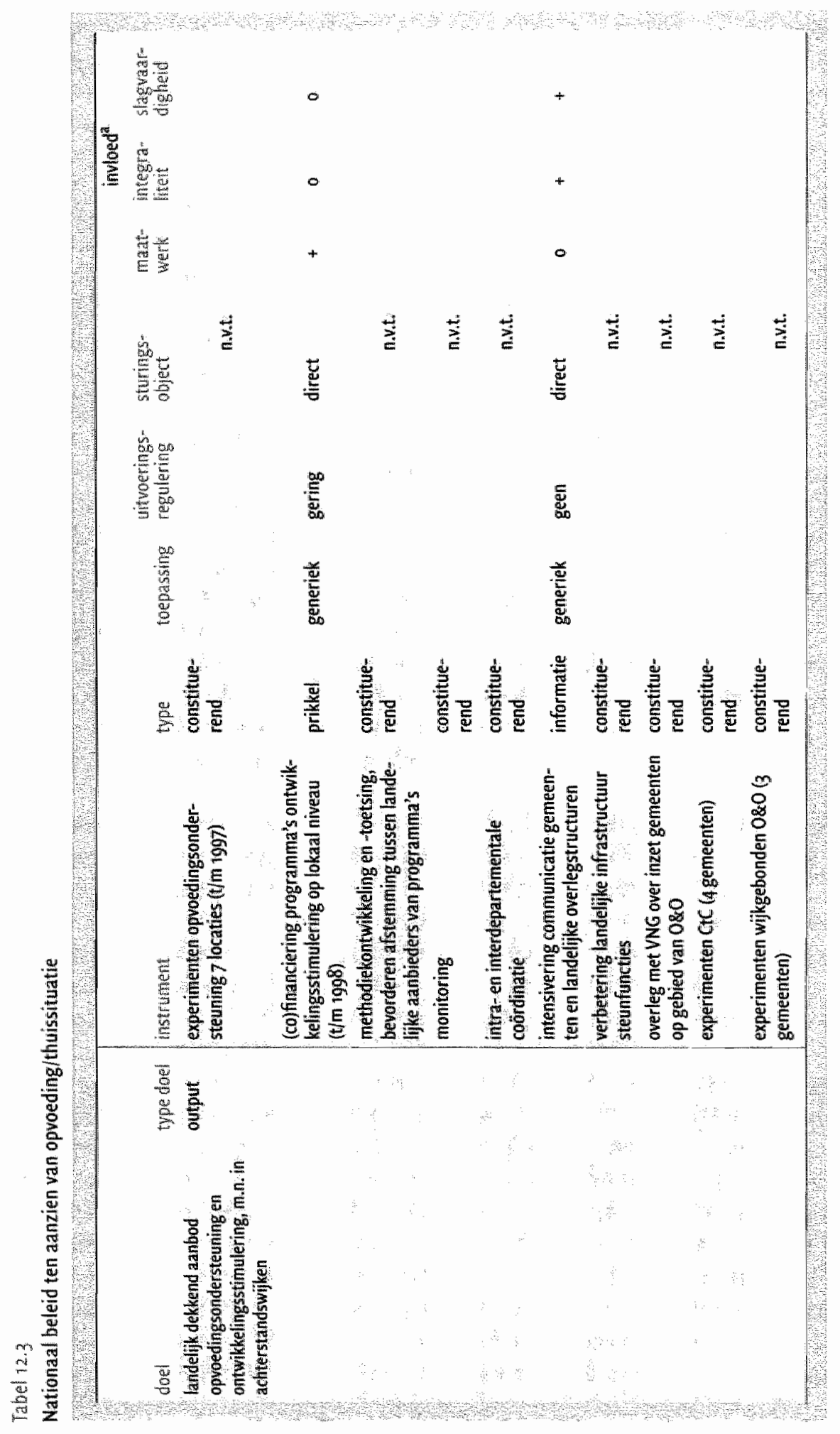




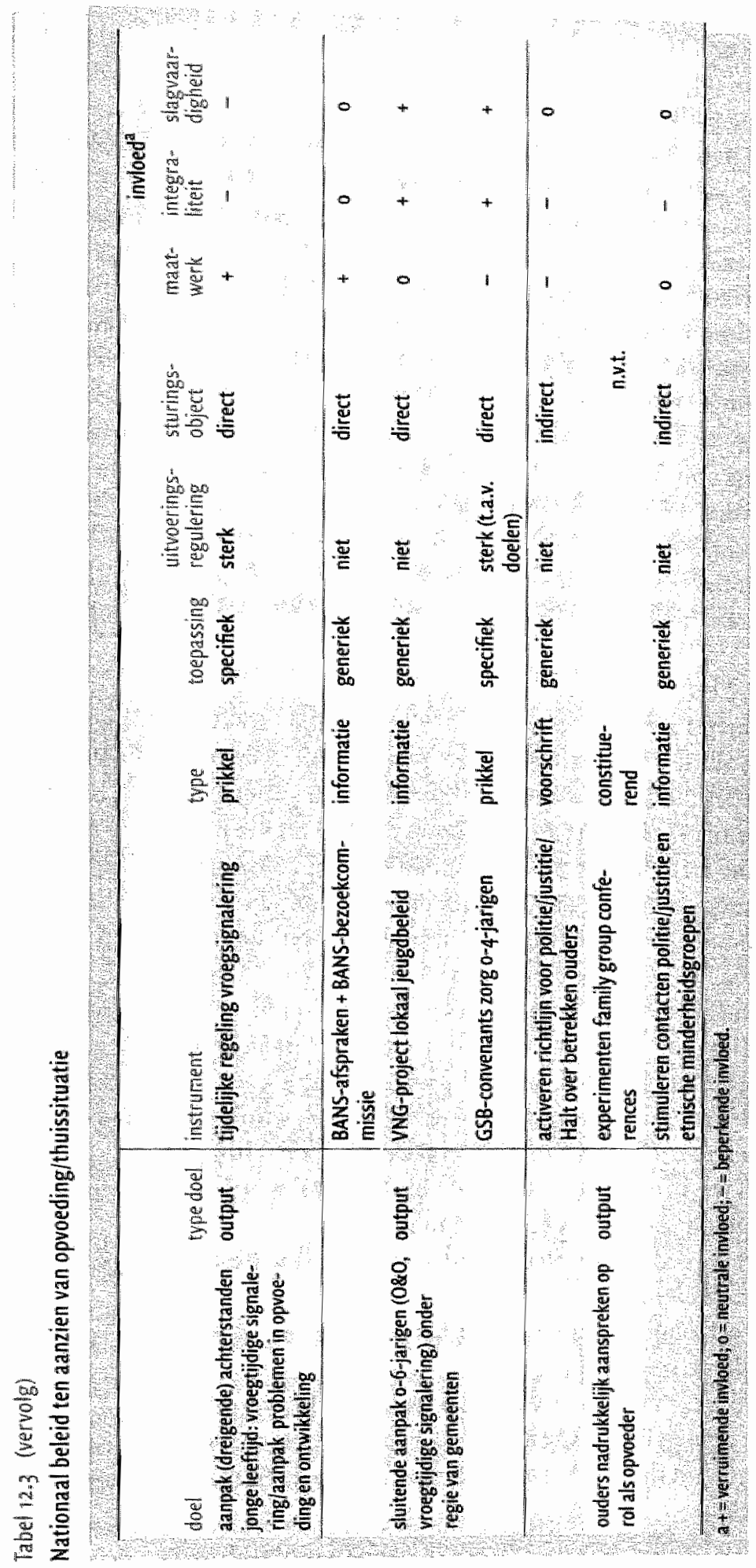




\subsubsection{Onderwijs en scholing}

Doelen van de nationale overheid

In paragraaf 12.3.I is al ingegaan op de decentralisatie van het onderwijsbeleid zoals die vanaf de helft van de jaren negentig heeft plaatsgevonden. In die paragraaf werd decentralisatie gezien als een instrument om op lokaal niveau tot een integrale aanpak van problemen te komen en zo te voorkomen dat leerlingen voortijdig uitvallen en het onderwijs verlaten zonder startkwalificatie. In de begroting van ocw voor 1998 (TK $1997 / \mathrm{rgg} 8 \mathrm{C}$ ) is het nog eens herhaald: het doel van het rijksbeleid op het terrein van het primair onderwijs is het versterken van de samenhang en samenwerking op lokal niveau, binnen het onderwijs en tussen het onderwijs en andere beleidsterreinen. De gemeente treedt daarbij op als makelaar en coördinator. Op het terrein van voortgezet onderwijs wordt het beleid waarbij gemeenten een toenemende verantwoordelijkheid krijgen voor een samenhangende zorg voor de jeugd, voortgezet. Onderwijsbeleid draagt bij aan het bevorderen van ontplooiingskansen in brede zin. In deze paragraaf wordt ingegaan op de inhoudelijke ambities van de decentralisatie. Daarnaast komt een aantal andere doelen op het gebied van onderwijs en scholing aan de orde.

In 1997 is de Wet inzake het gemeentelijk onderwijsachterstandenbeleid (Staatsblad r997a) vastgesteld. ${ }^{12}$ Het doel van de wet is een effectieve aanpak van onderwijsachterstanden. In de wet wordt onder die achterstanden verstaan 'die negatieve effecten op de leer- en ontwikkelingsmogelijkheden van leerlingen hebben en die het gevolg zijn van sociale, economische en culturele omstandigheden'. Van sommige leerlingen zijn de problemen zo complex dat begeleiding alleen vanuit de school niet voldoende is. Er is een samenhangende aanpak nodig van onderwijsinstellingen samen met andere instellingen zoals het welzijnswerk, de geestelijke gezondheidszorg en de jeugdhulpverlening. Gemeenten krijgen hierin een coördinerende rol, waardoor individuele scholen en instellingen beter in staat zijn hun eigen kerntaak te verrichten, waar nodig in onderlinge samenhang. In het Landelijk beleidskader 1998-2002 (Staatsblad 1997b), dat als referentiekader dient voor gemeentelijk beleid, worden de algemene doelstellingen geconcretiseerd in een aantal operationele doelstellingen:

- de startcondities van leerlingen bij entree in de basisschool worden verbeterd, onder meer op het gebied van de Nederlandse taal;

- achterstanden op het gebied van de Nederlandse taal bij allochtone en autochtone leerlingen worden bestreden;

- de verwijzing van doelgroepleerlingen ${ }^{\mathrm{r} 3}$ naar het (voortgezet) speciaal onderwijs wordt zo veel mogelijk verminderd;

- het aantal voortijdige schoolverlaters wordt zo veel mogelijk verminderd;

- doelgroepleerlingen nemen deel aan vormen van voortgezet, secundair beroepsen hoger onderwijs zo veel mogelijk overeenkomstig niet-doelgroepleerlingen met soortgelijke capaciteiten;

- lokale ontwikkelingen worden gevolgd en geregistreerd (monitoring). 
Sommige van deze doelstellingen zijn verder uitgewerkt in op zichzelf staand beleid. De eerste doelstelling is verder uitgewerkt in de beleidsbrief Voor-en uroegschoolse educatie (TK I999/200oe). Daarin stellen wws en OCw zich ten doel alle kinderen in een achterstandssituatie te bereiken en hen optimale ontwikkelingskansen te bieden, opdat hun taal-en ontwikkelingsachterstand aan het begin van hun schoolloopbaan aanzienlijk gereduceerd wordt.

De vierde doelstelling komt ook naar voren in het plan van aanpak Voortijdig school verlaten (TK I9g8/r999g) van ocw. ${ }^{14}$ Meer concreet wordt in dit plan van aanpak het doel geformuleerd om voor jongeren die voorwaarden te scheppen waaronder zij de voor hen hoogst haalbare en meest passende onderwijs- en/of arbeidsmarktpositie kunnen bereiken. Mochten zij in het onderwijstraject daarnaartoe uitvallen, dan moeten de jongeren worden teruggeleid naar school of doorgeleid naar een arbeidsplaats in combinatie met een leertraject. In het plan wordt een aantal eisen aan gemeentelijk beleid gesteld, die als afgeleide doelen kunnen worden gezien.

De eerste eis is dat het uiterste wordt gedaan om leerlingen in het onderwijs te houden, dat onderwijsprocessen worden afgestemd op het leer- en ambitieniveau van de leerlingen en dat daadwerkelijk wordt toegeleid naar vervolgonderwijs of arbeidsmarkt. Het gaat om preventie binnen het onderwijs, door onder meer zorg(breedte)teams, social teams en leerlingbegeleiding. Dit preventiebeleid dient aan te sluiten bij de functie van het Regionaal Meld- en Coördinatiepunt voortijdige schoolverlaters (RMC). Verder speelt de gemeente een ondersteunende en coördinerende rol bij het realiseren van een doorgaande lijn vmbo-roc en richt zij zich op het versterken wan de verantwoordelijkheid die scholen nemen voor het afleveren van gekwalificeerde leerlingen.

De tweede eis uit het plan is dat op lokaal en/of regionaal niveau gegevens van de voortijdige schoolverlaters beschikbaar moeten zijn. Hiervoor is een sluitend systeem van melding en registratie nodig. Deze eis heeft te maken met de activiteiten die voortvloeien uit de Leerplichtwet en uit het RMc-beleid.

De derde eis uit het plan is een specifieke benadering van de moeilijkst bereikbare groep, de zogenaamde risicojongeren. Op dit punt wordt aansluiting gezocht bij het grotestedenbeleid. Het gaat erom dat grote gemeenten:

- zelf maatregelen nemen en projecten opzetten om risicojongeren te bereiken en met hen wegen uit te stippelen voor aansluiting bij normale ontwikkelingspatronen;

- hun bestaande instrumentarium in het kader van achterstandsbeleid, jeugdbeleid, welzijnsbeleid, arbeidsmarktbeleid e.d. specifiek aanwenden ten gunste van risicojongeren;

- inspanningen coördineren die (kunnen) worden gedaan door scholen, jeugdzorg, arbeidsvoorziening, politie en justitie, het lokale bedrijfsleven en de eigen gemeentelijke diensten.

Prioriteit daarbinnen ligt bij de groep risicojongeren: jongeren die niet in het bezit zijn van een vbo/mavo-diploma, geen werk hebben en geconfronteerd worden met meervoudige problematiek, waaronder (dreigende) aanraking met politie en justitie. 
Uit de beleidsbrief Brede scholen ( $T K$ I999/200ob) valt op te maken dat OCW en vws de ontwikkeling van brede scholen - die bij het uitbrengen van de briefal gaande is - als positief zien en willen stimuleren, hoewel er geen directe doelstelling wordt geformuleerd (zie ook § 12.3.I). 'Brede scholen zijn voor heel Nederland mogelijk, en voor scholen in risicowijken welhaast een must. (...) Het kabinet ziet het ontstaan van brede scholen als een veelbelovende ontwikkeling.'. Het rijk leidt uit een aantal relevante intersectorale beleidskaders een aantal prioritaire doelstellingen voor brede scholen af. Dit zijn:

- vergroting van de deelname door achterstandskinderen aan programma's vooren vroegschoolse educatie;

- de aanpak van voortijdig schoolverlaten (vsv);

- het bevorderen van de veiligheid van kinderen in en om de school en in de buurt;

- het realiseren van longitudinale en intersectorale samenhang in het aanbod voor de jeugd;

- het vergroten van de ontwikkelingsmogelijkheden van de jeugd;

- de snelle onderkenning en behandeling van kinderen die zijn aangewezen op de jeugdzorg.

Het stimuleren van de totstandkoming van brede scholen waarin aan een of meer prioritaire doelstellingen wordt gewerkt, lijkt een impliciete doelstelling van het rijksbeleid te zijn. Dat wordt bevestigd in de convenants tussen rijk en grote steden voor de tweede periode van het GSB (BZK r998).

In 1995 is de campagne 'De veilige school' gestart, gericht op het vergroten van de sociale competentie van leerlingen, het planmatig en deskundig omgaan met incidenten en calamiteiten op school en de zorg voor veilige voorzieningen in het schoolgebouw en zijn omgeving (vgl. Mooij 200r). Naast het oogmerk om het leefklimaat op scholen zo veilig mogelijk te maken, had de campagne ook (het versterken van) de preventie van voortijdig schoolverlaten tot doel.

De doelen die in het grotestedenbeleid zijn geformuleerd, komen voor een belangrijk deel overeen met de hierboven genoemde doelstellingen. In de eerste periode gelden een integrale aanpak van onderwijsachterstanden, het voorkomen van uitval en de zorg dat geen jongere de school verlaat zonder startkwalificatie als doelstellingen (BZK 1995a; BZK 1995b). In de tweede periode kent het GSB drie pijlers: een fysieke, een economische en een sociale ( $\mathrm{BZK}$ 1998). In de economische pijler geldt als een van de (proces)doelen dat de nationale overheid en de steden zich inzetten om de aansluiting tussen onderwijs en arbeidsmarkt te versterken; dit zou de jeugdwerkloosheid onder met name voortijdige schoolverlaters moeten voorkomen. Ook het bevorderen van de veiligheid in en rond scholen wordt in de economische pijler als doelstelling genoemd. De sociale pijler kent een domein 'Opgroeien in de stad'. Het te behalen maatschappelijke resultaat is globaal gelijk aan dat van de eerste GSBperiode, namelijk de deelname van alle jongeren aan het onderwijs opdat zij een startkwalificatie behalen dan wel aan het werk zijn. De concrete doelstelling op het 
gebied van onderwijs is om een sluitend netwerk in en rond de school te organiseren, om zo ontwikkelingsbedreigende situaties en gedragingen te voorkomen en terug te dringen. De brede school is hiervoor een geschikt instrument. Steden zouden de regie moeten voeren en resultaatafspraken moeten maken met instellingen die tot het netwerk behoren. Als mogelijke indicatoren voor het beleid worden onder meer genoemd de verhoging van de leerprestaties in de basisvaardigheden en de vermindering van het aantal jongeren dat zonder startkwalificatie aantreedt op de arbeidsmarkt.

Aan de tien doelen in de pijler 'onderwijs/scholing' valt op dat de helft op outcomeniveau is geformuleerd. Nog eens drie hebben betrekking op de output en twee op de throughput. Deze verdeling doet vermoeden dat gemeenten een behoorlijke mate van beleidsvrijheid hebben. Bij de behandeling van beleidsinstrumenten zullen we dit nader toetsen.

Instrumenten van de nationale overheid

Gemeentelijk onderwijsachterstandenbeleid (GOA)

Voor het gemeentelijk onderwijsachterstandenbeleid heeft ocw wet-en regelgeving ontworpen. De GOA-wetgeving werd van kracht op I augustus 1998 (Staatsblad I997a). Belangrijke elementen in het GOA zijn de coördinerende rol van gemeenten, een specifieke uitkering aan gemeenten en een landelijk beleidskader (LBK) waarin inhoudelijke doelstellingen voor het lokale beleid worden geformuleerd (zie onder Doelen van de nationale overheid in deze paragraaf). De coördinerende gemeentelijke rol wordt behalve door de specifieke uitkering mogelijk gemaakt door gemeenten de regie te geven over de inzet van de zogenoemde gewichtenmiddelen door de scholen. ${ }^{15}$

De GOA-wetgeving bepaalt dat iedere gemeente die meer dan 250.000 gulden per jaar ontvangt aan specifieke uitkeringen en gewichtenmiddelen wettelijk verplicht is een onderwijsachterstandenplan vast te stellen. ${ }^{16}$ Gemeenten die minder ontvangen zijn niet planplichtig; als zij wel een plan opstellen, hoeft dat niet te voldoen aan de vereisten uit de wet. Intergemeentelijke planvorming is uitdrukkelijk toegestaan. Om de samenhang tussen verschillende lokale beleidsterreinen te bevorderen kan het plan deel uitmaken van een breder lokaal plan waarin de visie van de gemeente op een samenhangend lokaal onderwijsbeleid is neergelegd. Het plan wordt door de gemeenteraad voor vier jaren vastgesteld, nadat eerst het zogeheten Op Overeenstemming Gericht Overleg (OOGO) is gevoerd met het bevoegde gezag van alle in de gemeente gelegen scholen voor basisonderwijs, (voortgezet) speciaal onderwijs en woortgezet onderwijs. De procedure hiervoor dient te worden geregeld in een aparte gemeentelijke verordening. Het plan bevat zo veel mogelijk in meetbare termen geformuleerde en uitgewerkte doelstellingen. Het vormt het kader voor het verrichten van activiteiten die in het GOA worden bekostigd. Het plan heeft een verplichtend karakter, maar laat ruimte voor een schoolspecifieke uitwerking. Het regelt de inzet van de middelen die scholen voor achterstandsbestrijding ontvangen, de inzet van 
gemeentelijke middelen en de wijze waarop scholen verantwoording afleggen aan het gemeentebestuur. Ook wordt de wijze van evaluatie geregeld.

Op grond wan de Gemeentewet oefent de gemeente integraal toezicht uit op de naleving van het plan. De gemeente heeft alleen sanctiemogelijkheden voor de inzet van de specifieke uitkering en van de eigen gemeentelijke middelen. De rijksinspectie houdt toezicht op de inzet van de overige, schoolgebonden middelen. Gemeenten hebben hierbij een signaleringsrol ten opzichte van de inspectie. De nationale overheid kan middelen geheel of gedeeltelijk inhouden als de gemeente haar wettelijke verplichtingen niet nakomt.

In de wet wordt een landelijk beleidskader voorzien, dat als referentiekader fungeert voor de gemeentelijke plannen. Het LBK wordt vastgesteld bij algemene maatregel van bestuur (AMvB). Dit instrument geeft het rijk de mogelijkheid prioriteiten aan te geven voor een periode van vier jaar. Deze vormen het uitgangspunt voor het uitwerken van lokale doelstellingen. Concreet betekent dit dat in het lokale plan bij de analyse van de lokale situatie aan alle LBK-doelstellingen aandacht moet worden besteed. Het LBK verwoordt niet alleen de doelstellingen van het rijk, maar geeft ook de wegen aan waarlangs die doelen op het lokale niveau gerealiseerd kunnen worden. In het LBK 1998-2002 (Staatsblad r997b) zijn de volgende doelstellingen met bijbehorende uitwerking opgenomen:

I Voor-en vroegschoolse educatie. De startcondities van leerlingen bij entree in de basisschool worden verbeterd door:

a) samenwerkingsrelaties tussen scholen, peuterspeelzalen en kinderopvang om ontwikkelingsachterstanden te voorkomen, waarbij aansluiting plaatsvindt bij de activiteiten van consultatiebureaus;

b) deskundigheidsbevordering bij genoemde voorzieningen, met aandacht voor:

i. informatie-uitwisseling over toekomstige leerlingen in het basisonderwijs;

ii. versterking van de kwaliteit van educatieve activiteiten in voorschoolse voorzieningen;

iii. gebruik in peuterspeelzalen van programma's en instrumenten die op (taal)ontwikkeling zijn gericht;

iv. ondersteuning van ouders door gezinsgerichte programma's.

2 Beheersing van de Nederlandse taal, gericht op taalachterstanden, in samenwerking met scholen en andere instellingen. Daarbij wordt aandacht besteed aan de volgende aspecten:

a. gezamenlijke eersteopvangvoorziening voor onderinstromers en zij-instro mers ${ }^{17}$, eventueel samen met andere gemeenten;

b. afstemming tussen eerste opvang en vervolgactiviteiten op het gebied van NT2, en tussen NT2 en regulier onderwijs in Nederlandse taal;

c. stimulering van het gebruik van buitenschoolse programma's Nederlandse taal;

d. deskundigheidsbevordering van leraren met het oog op eerste opvang; 
e. beheersing van de Nederlandse taal door moeders, door basiseducatie en opvoedingsondersteuning.

3 Vermindering van de verwijzing naar speciale voorzieningen. Er worden zo min mogelijk doelgroepleerlingen verwezen naar het (woortgezet) speciaal onderwijs, in lijn met de doelstellingen van het Weer-Samen-Naar-Schoolbeleid (WSNs) en van het leerwegondersteunend en praktijkonderwijs in mavo/vbo. Daarbij wordt aandacht besteed aan de volgende aspecten:

a. afstemming van GOA-activiteiten met samenwerkingsverbanden wsNs en met samenwerkingsverbanden volvso;

b. samenwerking van scholen met medische kleuterdagverblijven, jeugdwelzijnsinstellingen, jeugdhulpverlening, politie, justitie, jeugdgezondheidszorg en Riagg bij de hulpverlening aan leerlingen met sociaal-emotionele problemen; c. inzet van expertise uit genoemde niet-onderwijsinstellingen in het onderwijs; 4 vermindering van schooluitval, in samenwerking met lokale partners. Aspecten daarvan zijn:

a. stroomlijning van de aansluiting tussen basisonderwijs en voortgezet onder wijs;

b. informatie-uitwisseling over leerlingen;

c. uitlijning van activiteiten met de activiteiten in het kader van de RMC-functie (zie verderop);

d. samenhang met regionale ontwikkelingen in het kader van vernieuwd voorbereidend beroepsonderwijs en mavo.

5 Evenredige deelname aan onderwijs. Lokaal worden initiatieven genomen om de deelname van doelgroepleerlingen aan vormen van voortgezet, secundair beroepsonderwijs en hoger onderwijs meer overeen te laten komen met die van niet-doelgroepleerlingen met overeenkomstige capaciteiten.

6 Monitoring. Registratie van ten minste:

a. in-, door-en uitstroom van (doelgroep)leerlingen in scholen voor primair onderwijs, (voortgezet) speciaal onderwijs, voortgezet onderwijs, secundair beroepsonderwijs en hoger onderwijs;

b. verwijzing naar (voortgezet) speciaal onderwijs;

c. verzuim en uitval van leerlingen.

De invoering van de GOA-wet is begeleid door een intensief voorlichtings- en ondersteuningstraject van de VNG, op basis van de LBK-doelstellingen. Dit traject is gefinancierd door ocw.

In 2000 intensiveert oCw het GOA met het actieprogramma voor ariderwijskansenscholen (TK r999/200of; TK 1999/2000g; TK r999/2000h). Er zijn daardoor extra middelen beschikbaar voor een schoolspecifieke aanpak op basisscholen met meer dan $70 \%$ gewichtenleerlingen. ${ }^{18}$ De toekenning daarvan verloopt deels via gemeenten. In 2000 gaat het alleen om de $\mathrm{G}_{4}$, in 200 r volgt uitbreiding naar de $\mathrm{G}_{25} 5$ en de overige gemeenten met meer dan 100.000 inwoners lallemaal op basis van convenants tussen rijk en gemeenten). ${ }^{x}$ De gemeenten voeren de regie in dit onderwijskansenbeleid en 
sluiten "bestuursarrangementen" met scholen, waarmee zij de acties van de scholen coördineren. De scholen worden door gemeenten geselecteerd op basis van onder meer inspectierapporten en bevatten afspraken over maatregelen die op de scholen moeten worden genomen, over de verantwoordelijkheden van de gemeente en over de te behalen resultaten in termen van leerprestaties en schoolloopbanen. Gemeenten zien toe op de uitvoering, lossen problemen in de uitvoering op in overleg met. de betrokkenen en evalueren de afspraken over de te behalen resultaten. De plannen die de gemeenten opstellen op basis van de convenants met respectievelijk de $\mathrm{G}_{4}$ en de overige grote gemeenten worden getoetst op het gebruik van inspectie-rapportages bij de selectie van scholen, op het overleg dat over de selectie met schoolbesturen is gevoerd, op de inbedding in het GOA, en op de uitwerking van doelstellingen, het tijdpad, de monitoring en de evaluatie.

De gemeenten zijn daarnaast verantwoordelijk voor een gestructureerd aanbod van voor- en vroegschoolse educatie, voor een integraal lokaal taalbeleid, voor een aanpak gericht op voortijdig schoolverlaten, voor een samenhangende inzet van beschikbare middelen, voor de prioritaire inzet van de schoolbegeleidingsdiensten en voor de ondersteuning van de school door andere instellingen (genoemd worden maatschappelijk werk, bibliotheken en politie). Een aantal maatregelen is sterk schoolgerelateerd, zoals die op het gebied van taal en rekenen. ${ }^{20}$ Daarnaast zijn er maatregelen die van direct belang zijn voor gemeenten:

- voor- en vroegschoolse educatie (zie verderop in deze paragraaf);

- informatie- en communicatietechnologie (ICT). Voor het grootste deel betreft het de toerusting van scholen ${ }^{2 \mathrm{I}}$, maar er wordt ook verwezen naar de Bijdrageregeling 'Digitaal trapveld' (Staatscourant 2000a), die de $\mathrm{G}_{3}$ o voorziet van een bijdrage voor het realiseren van locaties in aandachtswijken waar inwoners gebruik kunnen maken van ICT. Hiervoor is in totaal een bedrag van ongeveer 20 miljoen gulden beschikbaar;

- gemeenten bekijken samen met scholen hoe deze beter kunnen samenwerken in de overgangsfase van leerlingen van het primair naar het voortgezet onderwijs. Concreet gaat het om een doorlopend leerlingvolgsysteem en om de onderwijsvorm waarin leerlingen in het voortgezet onderwijs les krijgen;

- voortijdig schoolverlaten. Hierbij wordt verwezen naar reeds lopend beleid (zie verderop in deze paragraaf).

Verder is er een ondersteuningsstructuur bij het onderwijskansenbeleid, met onder meer een expertisenetwerk voor scholen en leerkrachten, extra aandacht voor scholing van leerkrachten en werkconferenties en trainingen voor directies van scholen. Bovendien is er een projectgroep Onderwijskansen ingesteld, die de uitvoering van de schoolspecifieke aanpak coördineert. Deze groep bestaat uit lokale vertegenwoordigers en vertegenwoordigers van $O C w$. Tot slot is er een bestuurlijk overleg, het Landelijk Overleg Onderwijskansen, gericht op de bestuurlijke samenwerking tussen betrokken partijen. 
Het nationale beleid ter bestrijding van onderwijsachterstanden krijgt deels gestalte via juridische sturing (GOA) en deels via economische sturing (onderwijskansen). ${ }^{22}$ Het GOA is wettelijk geregeld, en in de onderwijskansenaanpak worden gemeenten gebonden in convenants tussen rijk en gemeenten. Er zijn echter belangrijke verschillen tussen beide aanpakken. Het GOA laat gemeenten enige vrijheid in de lokale vertaling van het landelijk beleidskader, hoewel er een behoorlijke mate van uitvoeringsregulering is. ${ }^{23}$ Bovendien kampt het GOA met het 'pacificatiecompromis' (Mentink 2004: 225), waarin de achterstandsmiddelen voor een groot deel naar de scholen gaan maar wel moeten worden ingezet voor gemeentelijk beleid. Het onderwijskansenbeleid is veel dwingender voor gemeenten en sluist een deel van de financiële middelen rechtstreeks naar scholen, wat de regie door gemeenten bemoeilijkt. Waar het GOA overwegend het beleidsvormende vermogen van gemeenten in ieder geval op het gebied van maatwerk verruimt, heeft het onderwijskansenbeleid vooral een beperkende invloed.

\section{Voortijdig schoolverlaten}

De bestrijding van het voortijdig schoolverlaten is een van de doelstellingen uit het LBK die verder zijn uitgewerkt in afzonderlijk nationaal beleid. Uitgangspunt in dit beleid is de Leerplichtwet uit ${ }_{9} 699$. Deze wet legt gemeenten de verplichting op om te controleren of volledig en partieel leerplichtige jongeren staan ingeschreven op een school en of ze die school regelmatig bezoeken. Als (ouders van) jongeren niet aan de leerplicht voldoen, kan de gemeente maatregelen treffen. Met de wijziging van de wet in 1994 (Staatsblad I994) wordt de gemeente geacht bij het uitoefenen van het toezicht samen te werken met andere gemeenten en met andere 'diensten en instellingen'.

Het in r994 ingezette beleid rond het Regionale Meld- en Coördinatiepunt voortijdige schoolverlaters vormt op twee punten een aanvulling op de leerplichtwet. Het heeft in tegenstelling tot die wet ook betrekking op niet-leerplichtigen. Daarnaast vormt in plaats van de verplichtingen van individuele burgers de samenwerking tussen gemeenten, onderwijs- en andere maatschappelijke instellingen het uitgangspunt. In 1995 is het Tijdelijk besluit regionale meld- en coördinatiefunctie voortijdig schoolverlaten (Staatsblad 1995) van kracht geworden, waarin de samenwerking en krachtenbundeling van scholen op regionaal niveau een belangrijke plaats inneemt, door een sluitende aanmelding en registratie en door zo veel mogelijk aansluitende verwijzing. ${ }^{24} \mathrm{Er}$ is niet voor gekozen om een apart RMC-loket te creëren, maar om de hieraan gekoppelde functies op te dragen aan de gemeente, c.q. de leerplichtambtenaar. Met de ontwikkeling van de RMC-functie worden bestaande activiteiten en geldstromen gebundeld. De concrete invulling wordt aan de regio's overgelaten om voldoende recht te doen aan de verantwoordelijkheden van de diverse actoren die daar actief zijn, zo wordt in de toelichting op de regeling gesteld.

Uitgaande van de verantwoordelijkheid van individuele gemeentebesturen wordt in het Besluit een regionale aanpak door de samenwerkende gemeenten in regio's 
volgens de Wet gemeenschappelijke regelingen (WGR) nagestreefd. Door een regionaal actieplan in te dienen (op te stelllen volgens een in de Bijlage van het besluit opgenomen formulier), kan de regionale contactgemeente een subsidie aanvragen voor het verbeteren van de regionale infrastructuur. Het regionale actieplan dient in ieder geval een kwantitatieve beschrijving van de regionale problematiek en een kwantitatieve verplichting inzake het terugdringen daarvan voor de periode 1995 -I997 te bevatten. Er moeten regionale afspraken worden gemaakt en activiteiten en geldstromen dienen te worden gebundeld. In een effectrapportage worden de besteding van de subsidie en de daarmee bereikte resultaten verantwoord.

Concreet is de contactgemeente verantwoordelijk voor:

- het maken van afspraken met onderwijsinstellingen en andere betrokken organisaties in de regio over de inzet en verantwoordelijkheid bij de aanpak van het voortijdig schoolverlaten;

- de totstandkoming van een regionaal netwerk van de genoemde organisaties;

- de organisatie en coördinatie van regionale melding, registratie en doorverwijzing;

- de coördinatie van de totstandkoming van het regionale actieplan;

- de coördinatie van het opstellen van een effectrapportage.

Het Besluit draagt de gemeentebesturen op om het beleid van de WGR-regio's gelegen binnen een RBA-gebied (Regionaal Bestuur voor de Arbeidsvoorziening) zo veel mogelijk af te stemmen. In totaal is voor de periode r $994-199724$ miljoen gulden beschikbaar.

Het Tijdelijk besluit is later met een jaar verlengd tot $1998 \mathrm{en}$ is daarna zo goed als ongewijzigd overgegaan in een Tijdelijke regeling en uiteindelijk per I januari 2002 in een Wet (Staatsblad 20ora). De overlap tussen het RMC-beleid en de Leerplichtwet op het gebied van leerplichthandhaving is door de invoering van de wet verdwenen (TK I I999/2000i). ${ }^{25}$

De leerplichtambtenaar is de verbindende figuur tussen de school en de gemeente. Er is een apart Actieplan voor de leerplicht (opgenomen in het plan van aanpak Voortijdig schoolverlaten, TK r998/r99gg) opgesteld. Dit actieplan bevat een mix van maatregelen, die deels gericht zijn op de versterking van de leerplichtfunctie. Zo vindt men het belangrijk dat de gemeentelijke leerplichthandhaving en de gemeentelijke taken in RMC-verband zo veel mogelijk aan elkaar gekoppeld worden. Ook wordt de verzuimregistratie op scholen versterkt en wordt het Openbaar Ministerie (OM) aangezet om zorg te dragen voor meer aandacht voor en uniformiteit in de justitiële afhandeling van verzuim. Voor een ander deel gaat het in het Actieplan om meer flankerende maatregelen, zoals de ontwikkeling van een cursusaanbod voor ouders van verzuimers en de aanscherping van verzuimpreventie door scholen.

Het plan van aanpak Voortijdig school verlaten uit r999 (TK I998/1999g) sluit aan op het landelijk beleidskader gemeentelijk onderwijsachterstandenbeleid (LBK GOA). Ook in dit beleid wordt de regie aan gemeenten toegekend. De nationale overheid (ocw) heeft als primaire taak doelen en kaders te formuleren en - in samenspraak met gemeenten - aan te geven welke resultaten bereikt moeten worden. Verder neemt $z i j$ 
de belemmeringen voor gemeenten weg. Voor de grote steden worden de beoogde resultaten vastgelegd in maatwerkconvenants. In het plan van aanpak wordt een aantal eisen geformuleerd waaraan voldaan moet worden om de beleidsdoelstelling te realiseren (zie Doelen van de nationale overheid in $\$ 12.3 .3$ ). Het gaat onder andere om preventie binnen het onderwijs, door inzet van bijvoorbeeld zorg(breedte)teams, social teams en leerlingbegeleiding. Gemeenten hebben een coördinerende rol in het betrekken van buitenschoolse instellingen bij problemen van leerlingen. Dit preventiebeleid dient aan te sluiten bij de RMC-functie. Verder speelt de gemeente een ondersteunende en coördinerende rol bij het realiseren van een doorgaande lijn vmbo-roc en richt zij zich op het versterken van de verantwoordelijkheid die scholen nemen om gekwalificeerde leerlingen af te leveren.

Door de Bijdrageregeling sociale integratie en veiligheid (Staatscourant I99ga) uit de tweede GSB-periode, die mede tor doel heeft het voortijdig schoolverlaten te verminderen en tegen te gaan, ontvangen de $G_{25}$ een brede doeluitkering. Voorwaarde is dat het beleid is opgenomen in het stedelijk GSB-plan en dat het voldoet aan de in de regeling gestelde voorwaarden. Die voorwaarden betreffen, naast de doelen waaraan de uitkering mag worden besteed, een aantal eisen die aan de gemeentelijke plannen worden gesteld:

- een beschrijving van de problematiek en van de omvang en de samenstelling van groepen waarop het beleid gericht is;

- een indicatieve begroting;

- van streefcijfers voorziene maatregelen;

- duiding van de relatie met ander gemeentelijk beleid: de inzet van GoA-middelen, de RMC-functie, de Wet inschakeling werkzoekenden (Wiw) (zie $\$$ 12.3.9), het CRIEM-beleid (Criminaliteit in relatie tot integratie van etnische minderheden, zie $\$$ 12.3.8), de jeugdzorg en de inzet van middelen uit de Europese structuurfondsen;

- duiding van de wijze waarop lokale en regionale onderwijs-en welzijnsinstellingen en bewonersorganisaties zijn betrokken in de beleidsvorming en welke afspraken er met deze organisaties zijn gemaakt.

De plannen moeten worden goedgekeurd door het rijk. De steden legen achteraf inhoudelijk en financieel verantwoording af. Gemeenten wordt gevraagd de volgende prestatiegegevens te leveren:

- het aantal leerlingen dat in een kalenderjaar het onderwijs verlaat zonder startkwalificatie, als percentage van de uitstroom van dat jaar, en afgezet tegen het streefbeeld;

- het aantal herplaatste leerlingen dat het onderwijs in een kalenderjaar heeft verlaten en in het kader van de RMC-functie in dat jaar is teruggeleid naar een onderwijsinstelling, of is doorgeleid naar een alternatief leer/werktraject, of is doorgeleid naar een Wiw-traject, stuk voor stuk uitgedrukt als percentage van het totale aantal woortijdige schoolverlaters en afgezet tegen de streefcijfers. 
Voor de aanpak is 48 miljoen gulden beschikbaar. Dit budget wordt toegevoegd aan de brede doeluitkering 'Leefbaarheid en veiligheid' (zie \$ 12.3.8).

In 1998 is door ocw de Regeling pilot trajectbegeleiders (Staatscourant $\mathrm{rg9} 8 \mathrm{8a}$ ) ingesteld. Deze regeling heeft tot doel het aanstellen van trajectbegeleiders door RMC-contactgemeenten. Deze trajectbegeleiders zouden voortijdig schoolverlaters jonger dan I8 jaar (partieel leerplichtigen) moeten begeleiden naar een opleiding met arbeidsmarktperspectief of naar werk. De regeling betreft een eenmalige specifieke uitkering aan gemeenten, waarvoor in totaal 5 miljoen gulden beschikbaar is. Voor dat bedrag kunnen in totaal 42 trajectbegeleiders voor I fte worden aangesteld. Omdat gemeenten voor minimaal twee en voor maximaal acht begeleiders een uitkering kunnen ontvangen, is het aantal gemeenten dat gebruik kan maken van de regeling maximaal $2 r$. De aanvraag voor een uitkering dient onder meer een plan van aanpak en een begroting te bevatten. De overige gemeenten in de regio moeten instemmen met de aanvraag. Het plan van aanpak dient het volgende te omvatten:

- een schets van de regionale randvoorwaarden, waarbij ten minste aan de orde komt: de invulling van de RMC-functie, het beleid van de regio met betrekking tot de opvang van voortijdige schoolverlaters, de omvang van de groep voortijdige schoolverlaters jonger dan 18 jaar op $1 / 10 / 97$ en van de groep voortijdige schoolverlaters tot 23 jaar over het studiejaar $1997 / 1998$, en de samenwerking tussen organisaties;

- een afschrift wan de samenwerkingsovereenkomst tussen de contactgemeente en Regionale Opleidingencentra (ROC's);

- een afschrift van de samenwerkingsovereenkomst tussen de contactgemeente en het samenwerkingsverband vo/vso;

- een bereidverklaring van de contactgemeente om mee te werken aan kwalitatief onderzoek naar de opbrengsten van de regeling;

- de contactpersoon die in het kader van de regeling door de contactgemeente is benoemd;

- een indicatie van het aantal gesubsidieerde plaatsen en de omschrijving van de wijze waarop deze in het kader van de Wiw worden ingezet;

- een opgave van de inzet van eigen middelen door de regiogemeenten;

- een beschrijving van de opzet en werkwijze, met inbegrip van het aantal te benoemen trajectbegeleiders;

- een opgave van de plaats waar trajectbegeleiders hun werkzaamheden verrichten;

- een overzicht van de samenwerkingsrelaties met ondersteunende organisaties en met het bedrijfsleven in de regio;

- een beschrijving van de wijze waarop deze samenwerkingsrelaties worden ingezet om voortijdige schoolverlaters te ondersteunen;

- een beschrijving van de wijze waarop aandacht wordt besteed aan de specifieke problematiek van voortijdige schoolverlaters uit etnische minderheden. 
De aanvragen worden getoetst op deze punten. Als ze hieraan voldoen worden ze gerangschikt op basis van het aantal voortijdige schoolverlaters tot 18 jaar als aandeel van het totale aantal voortijdige schoolverlaters. Gemeenten die een uitkering krijgen voor het tweede spoor van het CRIEM-beleid (zie $\$ 12.3 .8$ ) komen niet in aanmerking voor de specifieke uitkering. Gemeenten leggen verantwoording af door een inhoudelijk verslag, waarbij zij aangeven hoeveel voortijdige schoolverlaters door de trajectbegeleiders zijn begeleid, wat hun leeftijd, sekse en etniciteit is, en of ze een opleiding hebben vervolgd of gestart dan wel werk hebben gevonden. Daarnaast verantwoorden gemeenten zich door een financieel verslag.

Tot slot heeft $\mathrm{CW}$ verschillende initiatieven genomen om het beleid rond voortijdig schoolverlaten (vsv) te ondersteunen. $Z o$ is er aandacht voor monitoring en evaluatie van het beleid en worden gemeenten voorzien van informatie over good practices via de jaarlijkse Almanak Voortijdig Schoolverlaten.

Afsluitend: het nationale beleid gericht op het voortijdig schoolverlaten kent diverse instrumenten (zie tabel 12.4 ). Een aantal daarvan (het RMC-beleid en het GSB) heeft door de extra financiële middelen die voor gemeenten ter beschikking komen in beginsel een verruimend effect op de handelingsmogelijkheden van gemeenten en daarmee op het vermogen tot maatwerk te komen. Tegelijkertijd kennen deze regelingen een dermate sterke uitvoeringsregulering dat het vermogen om integraal en slagvaardig beleid te voeren, wordt aangetast. De overige instrumenten hebben een wisselend effect op het gemeentelijke beleid. Vooral de integraliteit van dat beleid wordt door de beleidsinstrumenten voortijdig schoolverlaten onder druk gezet. Sommige van deze instrumenten versterken echter ook de positie van de betreffende actor, waardoor diens slagvaardigheid in principe wordt vergroot.

Voor- en vroegschoolse educatie (vve)

In het LBK GOA is het bevorderen van de voor-en vroegschoolse educatie een van de doelstellingen. Dit beleid, gericht op de reductie wan taal- en ontwikkelingsachterstanden bij kinderen in een achterstandssituatie aan het begin van hun schoolloopbaan, wordt verder uitgewerkt in de beleidsbrief Voor- en vroegschoolse educatie (TK I999/2000e) uit 2000. De voorgestelde aanpak kent verschillende sporen:

- alle kinderen uit de risicogroep (kinderen uit etnische minderheidsgroepen en autochtone kinderen met laagopgeleide ouders) moeten op zeer jonge leeftijd een intensief programma krijgen aangeboden in voorschoolse voorzieningen en in de eerste klassen van het basisonderwijs;

- daarvoor is het nodig dat (dreigende) ontwikkelingsachterstanden al op zeer jonge leeftijd worden gesignaleerd (zie ook de Tijdelijke regeling vroegsignalering, $\$$ I2.3.2);

- vervolgens worden ouders gemotiveerd om hun kind te laten deelnemen aan een voorschoolse voorziening en een intensief ontwikkelingsprogramma. Hierin spelen consultatiebureaus vanwege hun grote bereik een belangrijke rol; 
- daartoe dient er voldoende aanbod van intensieve programmaxs en voldoende aanwezigheid van professionele voorschoolse voorzieningen te zijn (het doel is om de gebruikelijke twee dagdelen die op peuterspeelzalen beschikbaar zijn voor het volgen van zo' $\mathrm{n}$ programma uit te breiden naar vier dagdelen);

- de gemeente regisseert, zodat er een sluitend aanbod en samenwerking ontstaat van in ieder geval consultatiebureaus, peuterspeelzalen en basisscholen;

- om ouders te betrekken wordt een link gelegd naar de volwasseneneducatie en inburgering en wordt nauwe samenwerking gezocht met zelforganisaties van minderheden.

Deze aanpak wordt uitgewerkt in de volgende, concrete maatregelen:

- substantiële capaciteitsuitbreiding van programma's voor kinderen uit de doelgroep;

- versterking van de voorzieningenketen voor jonge kinderen en vergroting van hun bereik. Daartoe worden afspraken gemaakt met gemeenten over de versterking van het peuterspeelzaalwerk en over een sluitende aanpak voor o-6-jarigen, worden consultatiebureaus verder geprofessionaliseerd en ondersteund zodat zij actief deelnemen aan netwerken van voorschoolse voorzieningen, worden met name allochtone ouders gestimuleerd om gebruik te maken van vve-voorzieningen, en worden gemeenten opgeroepen de financiële drempels voor peuterspeelzalen zoveel mogelijk weg te nemen;

- scholing, deskundigheidsbevordering en werving (nascholing door medewerkers van de onderwijsbegeleidingsdienst, post-hbo-opleiding voor de aansluiting vooren vroegschoolse educatie, enz.);

- ondersteuning van kwaliteit- en beleidsontwikkeling (vNG-project Lokaal jeugdbeleid, methodiekontwikkeling);

- monitoring en evaluatie.

In de beleidsbrief wordt een groot aantal beleidslijnen genoemd die relevant geacht worden voor het wve-beleid en waarmee afstemming gewenst is: GSB, GOA, BANS, Welzijnsnota, brede scholen, en integratiebeleid. Daarnaast is er een aantal belangrijke inhoudelijke ontwikkelingen waarmee rekening gehouden moet worden: de stimulering van de Stap-programma's, de ontwikkeling van de centrumgerichte programma's Kaleidoscoop en Piramide, het o\&o-beleid op basis van de beleidsnota Een solide basis (zie $\$$ 12.3.2), CRIEM (zie $\$$ 12.3.8), en de klassenverkleining in de onderbouw van het basisonderwijs.

De eerste vve-regeling is op $\mathrm{I}$ mei 2000 in werking getreden (Uitleg gele katern 2000 b). Aanvankelijk ontvingen 69 gemeenten met scholen met ten minste $70 \%$ gewichtenleerlingen een specifieke uitkering. Het doel was de deelname van het aantal 2-5-jarigen met grote (taal)achterstand aan effectieve voor- en vroegschoolse programma's te vergroten en zo (taal)achterstand in groep 3 van het basisonderwijs te voorkomen. Er is een aantal voorwaarden aan de programma's gesteld:

- ze dienen geschikt te zijn voor 2- en 3-jarigen en door te lopen tot en met groep 2 van de basisschool; 
- ze kennen een gestructureerde didactische aanpak;

- kinderen worden intensief begeleid;

- de programma's worden verzorgd door voldoende gekwalificeerd personeel;

- ze worden gegeven aan een voorschoolse instelling of een basisschool.

De regeling keert tot en met augustus 2002 jaarlijks een bedrag per leerling aan gemeenten uit, met een drempelbedrag van 30.000 gulden. Dit is volgens de regeling het bedrag dat een gemeente minstens nodig heeft om extra vve-beleid te ontwikkelen (het is bijvoorbeeld toereikend om een extra peuterspeelzaalleidster in te zetten voor vier dagdelen per week).

De regeling is gewijzigd in oktober 2000 (Uitleg gele katern 2000c). Door extra beschikbare middelen zijn met ingang van het schooljaar 2000/200I ook gemeenten met scholen met tussen de $50 \%$ en $70 \%$ gewichtenleerlingen in de regeling betrokken en zijn de toe te kennen bedragen per leerling verhoogd. In totaal vallen daardoor 172 gemeenten onder de regeling. Daarnaast is er een eenmalige uitkering voor de aanschaf van methodieken en materialen, plus een eenmalige uitkering voor investeringen in informatie- en communicatietechnologie (beide eveneens een bedrag per leerling).

De regeling kent een bestedingsverplichting: de middelen dienen te worden ingezet woor 2-en 3-jarigen en voor leerlingen in de eerste twee groepen van de basisschool. Met de middelen mogen personele uitgaven en onderwijsmaterialen en methodieken worden gefinancierd. Voor elke 30.000 gulden die een gemeente ontvangt, moeten vijftien kinderen uit de doelgroep deelnemen aan vve-programma's. Na afloop van de regeling (augustus 2002) zendt de gemeente een activiteitenverslag en een financiële verantwoording aan het ministerie, waaruit besteding conform de regeling moet blijken; in deze stukken rapporteert de gemeente over:

- de aard en omvang van de gesubsidieerde activiteiten;

- een vergelijking van de nagestreefde en gerealiseerde doelstellingen inclusief een toelichting op de verschillen;

- de benoeming van de doelgroepkinderen;

- het aantal en de toename van doelgroepkinderen bij het begin en het einde van de regeling;

- de gekozen vve-aanpak;

- de inzet van gekwalificeerde leidsters;

- de relatie met taalactiviteiten voor inburgering van oudkomers;

- de samenhang met overig sociaal beleid.

Met ingang van het schooljaar 2001/2002 is de Regeling opnieuw gewijzigd (Uitleg gele katern zoorb) door nieuwe extra middelen. Omdat de vve-middelen vanaf $\mathrm{I}$ augustus 2002 deel zouden gaan uitmaken van het GOA-budget, komen voor de aanvullende regeling alleen gemeenten in aanmerking die na die datum structureel GOA-middelen kunnen blijven inzetten voor vve. Daardoor krijgt de implementatie van vve in een groot aantal reeds gesubsidieerde gemeenten een extra impuis, terwijl in een groot aantal andere gemeenten gestart kan worden met de invoering en professionali- 
sering van vve. In de toelichting op de regeling wordt verwezen naar de Keuzegids vve, waarin vve-programma's worden beoordeeld op de criteria die in de regelingen worden gesteld. De conclusie in de Keuzegids is dat alleen de programma's Piramide en Kaleidoscoop aan alle criteria voldoen. Gemeenten moeten daarom voor deze programma's kiezen (VNG 200r). Het is niet duidelijk wat dat betekent voor gemeenten die eerder voor andere vve-programma's hebben gekozen. Voor het overige komen de bepalingen in deze regeling goeddeels overeen met de eerdere regelingen.

In de toelichtingen op de achtereenvolgende Regelingen wordt steeds weer gewezen op het belang van de gemeentelijke regierol, op het belang van een samenhangende aanpak en op het belang van bestuurlijke en inhoudelijke afstemming.

De vve-regelingen hebben voor gemeenten geen bindend karakter. Gemeenten die aan de criteria voor de aantallen gewichtenleerlingen voldoen, krijgen automatisch een uitkering van het rijk. Ze zijn weliswaar gehouden die uitkering te besteden volgens de voorschriften van de regeling, maar kunnen besluiten de gelden niet of anders te besteden en te wachten op de terugvordering van het rijk na de financiële verantwoording. Inzet van de middelen in overeenstemming met de regeling is dan ook facultatief en de regeling kan worden aangeduid als economisch beleidsinstrument.

Medio 1999 is het rijk gestart met het instellen van 'makelaars vve'. Deze makelaars ondersteunen en begeleiden lokale welzijns- en onderwijsinstellingen bij de implementatie van het vve-beleid (vgl. vNG s.a.). Zij maken onder meer vve-programma's toegankelijk, geven woorlichting en bevorderen de samenwerking tussen scholen en vve-voorzieningen. De makelaars vve zijn ondergebracht bij het vNG-project lokaal jeugdbeleid, waarbinnen zij een soort 'status aparte' hebben. Voor de bestuurlijke ondersteuning van gemeenten is in september 2000 het VNG-project Ondersteuning voor- en uroegschoolse educatie gestart. Hiermee werd beoogd gemeenten te ondersteunen bij de keuze van een doorgaande didactische aanpak en methodiek. Daarnaast was er aandacht voor deskundigheidsbevordering, ICT en de samenwerking tussen onderwijs- en welzijnswoorzieningen. In totaal stelde ocw voor de ondersteuning 7,4 miljoen gulden beschikbaar.

Het vve-beleid van ocw is sterk gericht op de verruiming van handelingsmogelijkheden van gemeenten door financiële prikkels. Tegelijkertijd is die extra handelingsruimte ingeperkt door de uitvoering van de vve-regelingen sterk te reguleren. Daarmee hebben de regelingen een positief effect op het vermogen tot maatwerk, maar een negatief effect op het vermogen tot integraal en slagvaardig beleid. De invoering van vve is wel sterk ondersteund, wat de negatieve effecten op integraliteit en slagvaardigheid mogelijk (deels) heeft weggenomen. 


\section{Overige instrumenten}

In de beleidsbrief Brede scholen (TK rg9g/200ob) neemt het rijk zich voor de ontwikkeling van brede scholen te ondersteunen door communicatie en onderzoek. Het rijk verwijst naar andere relevante beleidskaders waarvan gebruik kan worden gemaakt, zoals GOA en vve, en naar het VNG-project lokaal jeugdbeleid. In de begroting van OCW voor $200 \mathrm{r}$ worden brede scholen aangeduid als hét antwoord op lokale afstemmings-, coördinatie- en netwerkvraagstukken (TK 2000/200rb). De ontwikkeling ervan is, zo wordt in de begroting gesteld, mogelijk gemaakt door het decentralisatiebeleid van de nationale overheid. Deze acht de ontwikkeling van brede scholen echter een lokale aangelegenheid en ziet af van andere instrumenten dan communicatie en onderzoek. In het doorstartconvenant voor de tweede GSB-periode worden brede scholen genoemd als een belangrijk instrument om een sluitend netwerk in en om de school te creëren (BZK 1998). Nationale overheid en steden komen overeen dat het concept van de brede scholen aan de steden 'een inhoudelijke oriëntatie biedt'. De nationale overheid zet evenwel geen specifieke instrumenten in. Daardoor worden de handelingsmogelijkheden van gemeenten niet verruimd, maar wordt wel ondersteuning in de uitvoering geboden.

Twee andere beleidsterreinen die gedecentraliseerd zijn, maar die het jeugdbeleid slechts indirect raken, zijn de schoolbegeleiding (Staatsblad r997c) en de onderwijshuisvesting (Staatsblad r996). Voor beide terreinen wordt de decentralisatie ook gezien als een mogelijkheid om bij de inrichting van voorzieningen rekening te houden met het bredere onderwijs- of jeugdbeleid. Vooral met de aanzienlijke bedragen voor onderwijshuisvesting die gemeenten door de decentralisatie via het Gemeentefonds zijn gaan ontvangen, waardoor zij aanzienlijke beleidsvrijheid hebben gekregen (vgl. Mentink 2004), krijgen gemeenten een instrument in handen om het lokale onderwijsbeleid vorm te geven, met name bij de ontwikkeling van brede scholen. In paragraaf 12.3.I is al geconstateerd dat de decentralisatie positieve effecten heeft op het beleidsvormende vermogen van gemeenten.

De achtergrond van het beleid Onderwijs in Allochtone Levende Talen (OALT) is de gedachte dat goede kennis van de eigen taal en cultuur, naast beheersing van de Nederlandse taal, bijdraagt aan de oriëntatie van allochtonen op de Nederlandse samenleving (TK 1996/1997a; vgl. Turkenburg 2002). OALT wordt daarom verondersteld bij te dragen aan de emancipatie van allochtonen en hun participatie in de Nederlandse samenleving. Door het OALT-beleid kregen gemeenten een centrale rol en ontvingen ze een specifieke rijksuitkering (Staatsblad 1998a). Gemeenten die op I januari 1997 meer dan II60 minderjarige allochtone inwoners hadden, ontvingen een uitkering van 80,69 gulden per minderjarige allochtone inwoner (Staatsblad 1998b). Door de mogelijkheid het gemeentelijke OALT-plan in te bedden in het GOAplan, wat voor de hand ligt als gemeenten de OALT-middelen geheel of gedeeltelijk bestemmen voor de bestrijding van onderwijsachterstanden, kan OALT een rol spelen in het lokale jeugdbeleid. Later is dit gespecificeerd naar het geheel of gedeeltelijk 
bestemmen van OALT-middelen voor taalondersteuning van allochtone leerlingen in de eerste vier schooljaren ('we spreken van ondersteuning in de moedertaal', TK I996/1997b). 'Zo kan in het kader van het achterstandsbeleid de beheersing van de moedertaal ondersteunend zijn bij leeractiviteiten van het reguliere programma van de basisschool.' (EK 1997/1998). Als de OALT-middelen hier in zijn geheel voor bestemd worden, vervalt de verplichting om een OALT-plan op te stellen. Voor een dergelijke wijziging van de bestemming dienen allochtone ouders in de gelegenheid te worden gesteld hun mening kenbaar te maken, maar de uiteindelijke beslissing ligt bij de gemeente.

De stap om de inzet wan OALT-middelen facultatief te maken - waardoor we ze hier als een prikkel zien - vergroot de gemeentelijke handelingsruimte en daarmee het vermogen tot maatwerk. De mogelijkheid om het OALT-beleid in te passen in GOA vergroot bovendien het gemeentelijke vermogen tot integraliteit en slagvaardigheid.

In 1995 startte de rijksoverheid de campagne De veilige school, die gericht was op scholen uit het voortgezet onderwijs (vgl. Mooij 20oI). De campagne liep tot het voorjaar van 2000 . De belangrijkste doelen waren het doorbreken van het taboe om over geweld op school te spreken en preventie en bestrijding van geweld op school (TK I997/1998c). Daarnaast zou de campagne een bijdrage moeten leveren aan het vergroten van de sociale competentie van leerlingen, het planmatig en deskundig omgaan met incidenten en calamiteiten op school en de zorg voor veilige voorzieningen in het schoolgebouw en zijn omgeving. Hiermee werd niet alleen beoogd het leefklimaat op school zo veilig mogelijk te maken, maar ook om op deze manier te voorkomen dat leerlingen voortijdig van school gaan. Zie verder paragraaf I2.3.8 over veiligheid en openbare orde.

Het beleid dat gericht is op de beperking van de instroom van het speciaal onderwijs is indirect van belang voor het jeugdbeleid. Door dit zogenoemde Wert-Samen-NaarSchoolbeleid wordt er op regionaal niveau samengewerkt tussen het reguliere en het speciale basisonderwijs (OCW 2000). In deze samenwerkingsverbanden wordt de toegang tot en de verwijzing naar het speciale onderwijs geregeld, met als doel de instroom te beperken. Het wSNS-beleid is gericht op schoolbesturen en heeft voor hen een bindend karakter. Het kent een vrij sterke mate van uitvoeringsregulering. Het beleid heeft er onder meer toe geleid dat de interne zorgstructuren binnen het reguliere onderwijs zijn versterkt, wat mogelijk ook de vroegtijdige signalering en de aanpak van leer-, sociaal-emotionele en gedragsproblemen heeft versterkt. Ook de Bureaus Jeugdzorg zijn betrokken nadat daartoe in Iggg afspraken zijn gernaakt tussen vws en OCW. WSNS heeft geen effect op de handelingsmogelijkheden in de lokale beleidsarena, maar belemmert mogelijk wel een integrale en slagvaardige beleidswoering. De nationale overheid faciliteert de samenwerking tussen onderwijs en jeugdzorg onder meer door een financiële bijdrage aan een landelijk expertisecentrum te leveren. 
Tot slot was de afstemming tussen het lokale jeugdbeleid en onderwijsbeleid een van de vier inhoudelijke thema's in het vNG-project lokaal jeugdbeleid. Om gemeenten te ondersteunen zijn er themamiddagen, workshops en consultaties op maat georganisseerd. Ook het vve-beleid heeft aandacht gekregen in het vNG-project. Deze communicatieve instrumenten hebben een verruimende invloed op het gemeentelijke vermogen om tot een integraal en slagvaardig jeugdbeleid te komen.

\section{Overzicht en conclusie}

Ruim eenderde van de doelstellingen in de pijler onderwijs en scholing is te typeren als outcome-doelen: zij betreffen de maatschappelijke positie van de jeugd (zie tabel 12.4). De overige doelen hebben betrekking op concrete beleidsresultaten (output) en vooral ook op het beleidsproces (throughput).

Met name het beleid dat gericht is op de bestrijding van onderwijsachterstanden en het beleid gericht op de aanpak van voortijdige schoolverlaten kenmerken zich door een instrumentkeuze van het rijk die in bepaalde gevallen formeel weliswaar als verruimend is te typeren (vooral door de inzet van extra financiële middelen), maar die materieel een inperking van de gemeentelijke beleidsvrijheid met zich meebrengt door de vele en soms gedetailleerde eisen die in voorschriften aan het gemeentelijke beleid worden gesteld. Dat geldt niet alleen het vermogen van gemeenten om een integraal en slagvaardig beleid te voeren, maar ook het vermogen om een op de lokale situatie toegesneden beleid te formuleren. De Raad voor de Financiële Verhoudingen (RFV 2000) stelt voor het GOA dan ook dat een LBK OP gespannen voet staat met het uitgangspunt dat de gemeente de eerst verantwoordelijke is voor het beleid. Hetzelfde kan gezegd worden van een aantal instrumenten dat tot het economische sturingsmodel behoort. De prikkels in de vorm van specifieke uitkeringen verruimen de handelingsmogelijkheden van gemeenten, maar als gemeenten van de regelingen gebruik wensen te maken, worden ze geconfronteerd met nogal wat eisen waaraan de plannen en de later af te leggen verantwoording moeten voldoen.

Daarnaast valt op dat het rijksbeleid in deze pijler voor een deel sterk probleemgericht is. Het onderwijsachterstandenbeleid, het beleid dat erop gericht is de startcondities bij entree in het basisonderwijs te verbeteren, het beleid gericht op het voortijdig schoolverlaten onder probleemjongeren en het onderwijs in allochtone levende talen: voor al deze beleidsterreinen geldt dat alleen die gemeenten voor financiering in aanmerking komen waar naar het idee van de nationale overheid de problemen het grootst zijn. 


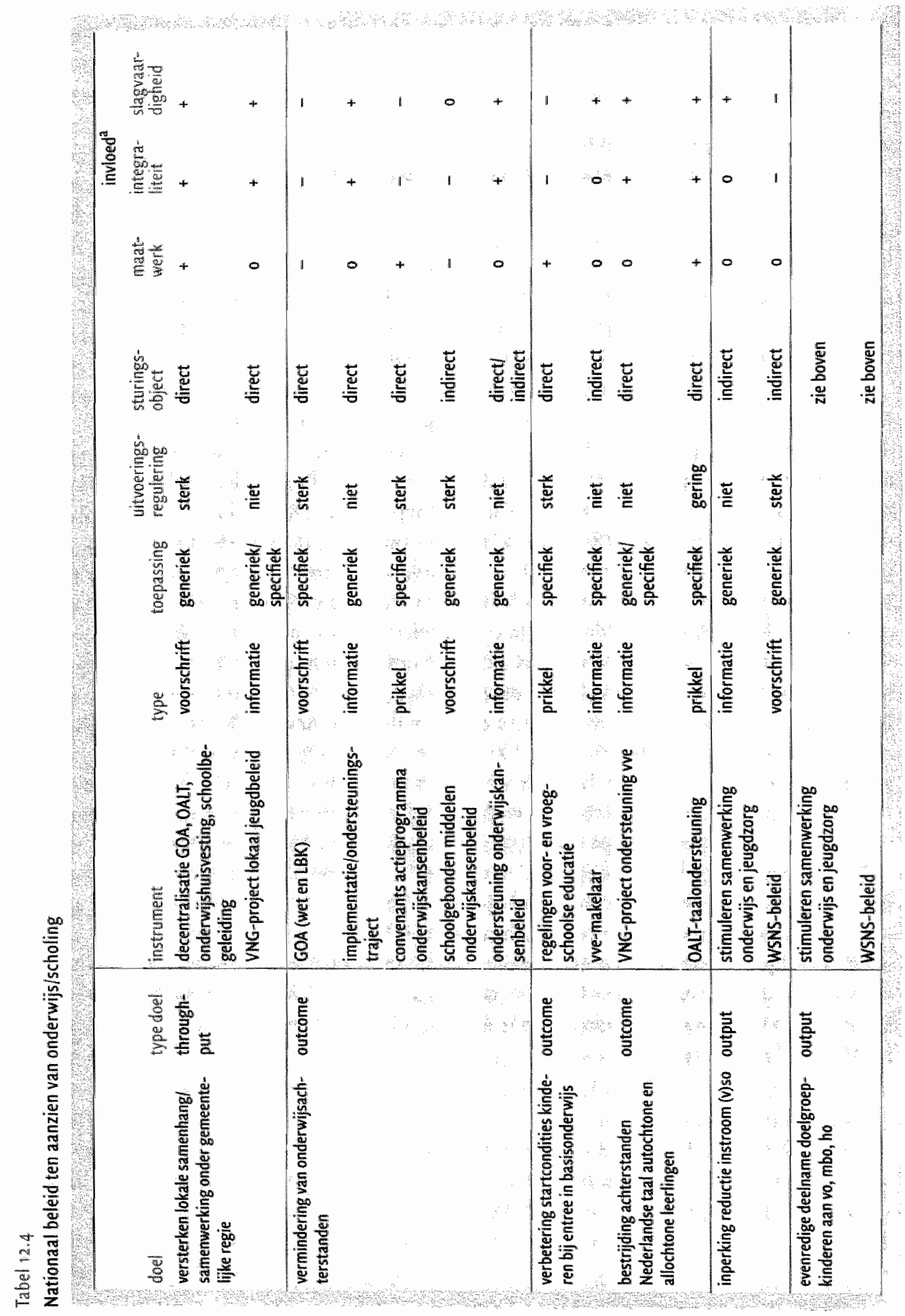




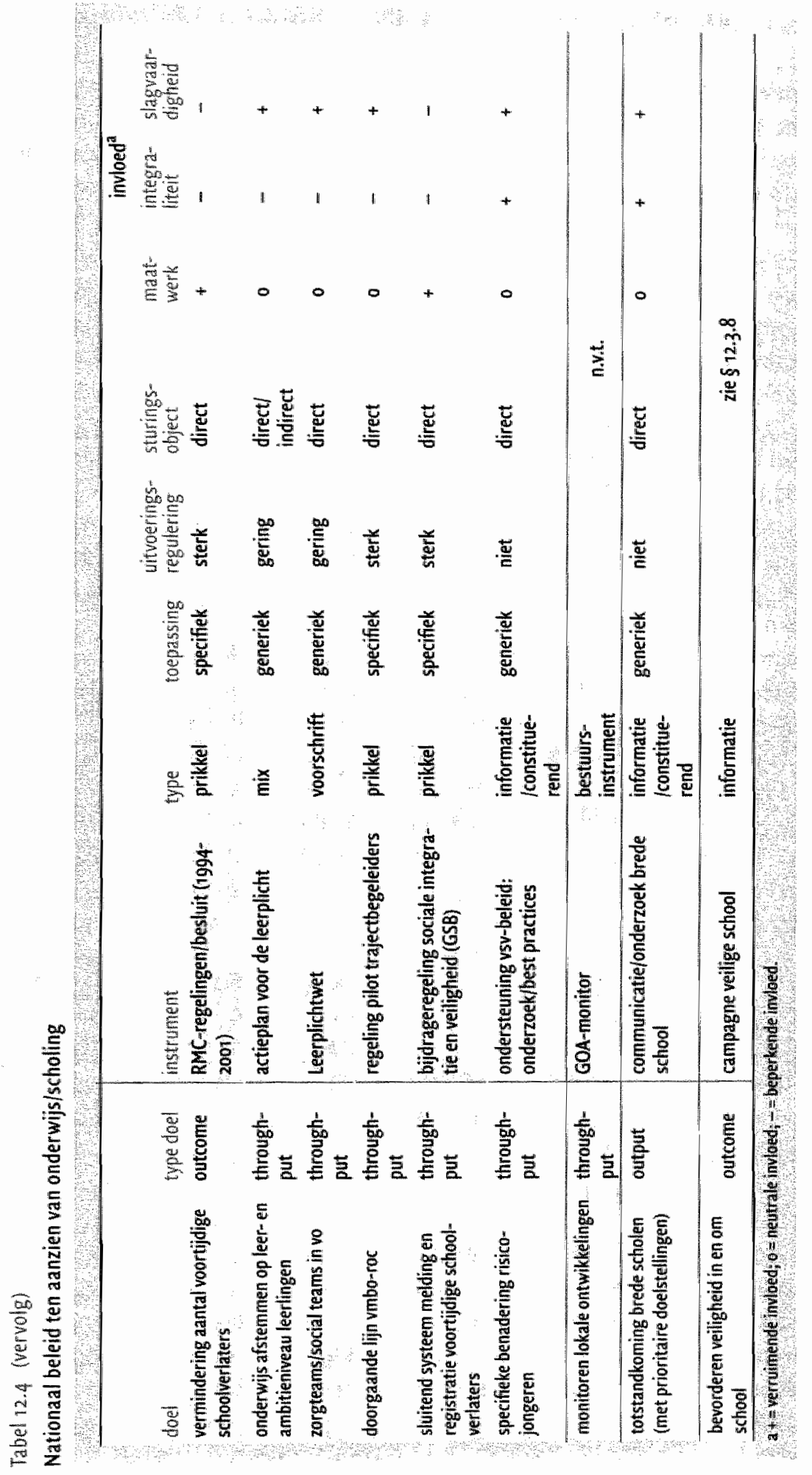




\subsubsection{Gezondheid}

Doelen van de nationale overheid

In 1997 verscheen een beleidsbrief van de rijksoverheid met daarin het besluit om gemeenten te stimuleren via een gemeentelijke nota gezondheidsbeleid te komen tot wederzijdse afstemming tussen het zorgbeleid en het jeugdbeleid (TK 1997/1998e). Verder werd het woornemen geuit met ingang van mei 1998 een standaardbasispakket jeugdgezondheidszorg te hanteren, dat kan worden aangevuld met een specifiek op de lokale situatie toegesneden pakket. Later, voor het eerst in de vws-begroting voor 2000 , wordt het streven geformuleerd te komen tot een ongedeelde jeugdgezondheidszorg voor 0-19-jarigen (TK 1999/2000a). Tot dat moment bestaat er in de jeugdgezondheidszorg de zogenoemde knip. De zorg voor 0-3-jarigen wordt daarbij uitgevoerd door consultatiebureaus van in totaal ongeveer 60 thuiszorgorganisaties en gefinancierd uit de Algemene Wet Bijzondere Ziektekosten (AWBZ). De gezondheidszorg voor 4-19-jarigen behoort tot de gemeentelijke verantwoordelijkheid, wordt uitgevoerd door de 5I GGD's en (met uitzondering van het rijksvaccinatieprogramma) gefinancierd uit het Gemeentefonds. In relatie met het voornemen tot een ongedeelde jeugdgezondheidszorg zou er een discussie over het basistakenpakket gevoerd moeten worden.

Ook hier wordt de beleidsmatige afstemming met andere gebieden zoals jeugdbeleid en jeugdzorg van groot belang geacht, omdat het zou moeten bijdragen aan meer continuiteit en samenhang in met name de zorg voor risicokinderen.

In de beleidsbrief Positionering Jeugdgezondheidszorg 0-19 jaar (TK I999/200oj) is dit voornemen verder uitgewerkt. De jeugdgezondheidszorg wordt gezien als een belangrijke voorziening in het lokale jeugdbeleid en zou daarin zelfs een centrale rol kunnen spelen. De zorg voor 0-3-jarigen (door consultatiebureaus) is een belangrijke vindplaats van vroegtijdige signalen. Daarom zouden zo veel mogelijk opvoeders met hun kinderen bereikt moeten worden door de consultatiebureaus. Na het vierde jaar wordt de rol van vindplaats overgenomen door de school. Ook aan de brede school (\$ 12.3.3) en aan opvoedingsondersteuning en ontwikkelingsstimulering (zie $\$ 12.3 .2)$ kan de jeugdgezondheidszorg een belangrijke bijdrage leveren.

In de vws-begroting voor 2002 wordt als doel van een ongedeelde jeugdgezondheidszorg de verbetering van de gezondheid van de jeugd genoemd (TK 2001/2002a). Daarnaast kan door specifiek beleid een hogere levensverwachting voor kinderen van ouders met een lage sociaal-economische status gecreëerd worden. Door verbetering van de vroegsignalering en in samenhang met het vve-beleid moet het aantal kinderen met leerachterstanden afnemen. Daarbij zouden ook andere actoren een rol moeten spelen. Belangrijk is de samenwerking tussen jeugdgezondheidszorg en andere voorzieningen, zoals het peuterspeelzaalwerk, de kinderopvang, het onderwijs en sport- en andere vrijetijdsvoorzieningen. Bij gesignaleerde problemen moet ook samengewerkt worden met voorzieningen als het algemeen maatschappelijk werk, de jeugdzorg en de Advies- en Meldpunten Kindermishandeling (AMK's). Hoewel deze samenwerking al op veel plaatsen vorm krijgt, kan deze worden verbreed en verbeterd. 
Instrumenten van de nationale overheid

Een van de weinige instrumenten die van belang is voor de pijler gezondheid, is de (Tijdelijke) regeling uroegsignalering (Staatscourant 20ora). Deze is besproken bij de pijler 'opvoeding en thuissituatie' in paragraaf 12.3 .2 . Verder is er in het kader van het bevorderen van een sluitende aanpak voor $0-6$-jarigen in het vNG-project lokaal jeugdbeleid aandacht geweest voor de rol die de jeugdgezondheidszorg daarin speelt. Voor het overige is het in de periode tot 2002 bij voornemens gebleven. Uiteindelijk is per $\mathrm{r}$ januari 2003 de Wet Collectieve Preventie Volksgezondheid gewijzigd, maar deze wijziging valt buiten het bestek van dit onderzoek. ${ }^{26}$ In de vws-begroting van 2002 wordt verder een basisconvenant tussen vws, vNG en de Landelijke Vereniging voor Thuiszorg (LVT) aangekondigd, waarin afspraken worden gemaakt over de financiering, registratie en kwaliteit van de jeugdgezond heidszorg (TK 200r/2002a). Er is enige financiële ruimte voor het subsidiëren van projecten ten behoeve van de gewijzigde WCPV en voor een landelijke ondersteuningsstructuur.

Om de toegankelijkheid te verbeteren is per r januari 1999 de toegangsbijdrage voor de ouder- en kindzorg (de jeugdgezondheidszorg voor 0-3-jarigen, lees: de consultatiebureaus) afgeschaft. De drempel wordt daardoor lager, met name voor de belangrijke doelgroep van jeugdigen en gezinnen in achterstandssituaties.

\section{Overzicht en conclusies}

Het overzicht van het nationale beleid in de pijler gezondheid laat zien dat het rijk in de periode 1998-200r meer doelen dan instrumenten kende (tabel 12.5). Met andere woorden: een aantal beleidsdoelen is in die periode niet voorzien van beleidsinstrumenten. De gewijzigde wCPv, die een aantal van de doelen in deze pijler zou moeten dienen, is pas in 2003 van kracht geworden. Verder moeten de eerste drie (throughput) doelen in de tabel worden gezien als intermediaire doelen om de twee laatstgenoemde (outcome) doelen te bereiken. Er is sprake van een hiërarchische ordening tussen deze throughput- en outcome-doelen. Naast algemene ondersteuning van het jeugdgezondheidszorgbeleid in de vorm van informatie die via het vNG-project lokaal jeugdbeleid wordt verstrekt, zijn er alleen instrumenten ingezet om het bereik van de consultatiebureaus te optimaliseren, respectievelijk om de vroegsignalering te verbeteren. De regeling vroegsignalering is in paragraaf $\mathbf{1 2 . 3 . 2}$ al aan de orde geweest omdat hij te maken heeft met zowel gezondheid als met opvoeding/thuissituatie. De afschaffing van de toegangsbijdrage ouder/kindzorg heeft slechts beperkt effect op het lokale jeugdbeleid. Het vermogen van de uitvoerder, in dit geval het consultatiebureau, om slagvaardig op te treden is door de afschaffing vergroot. 


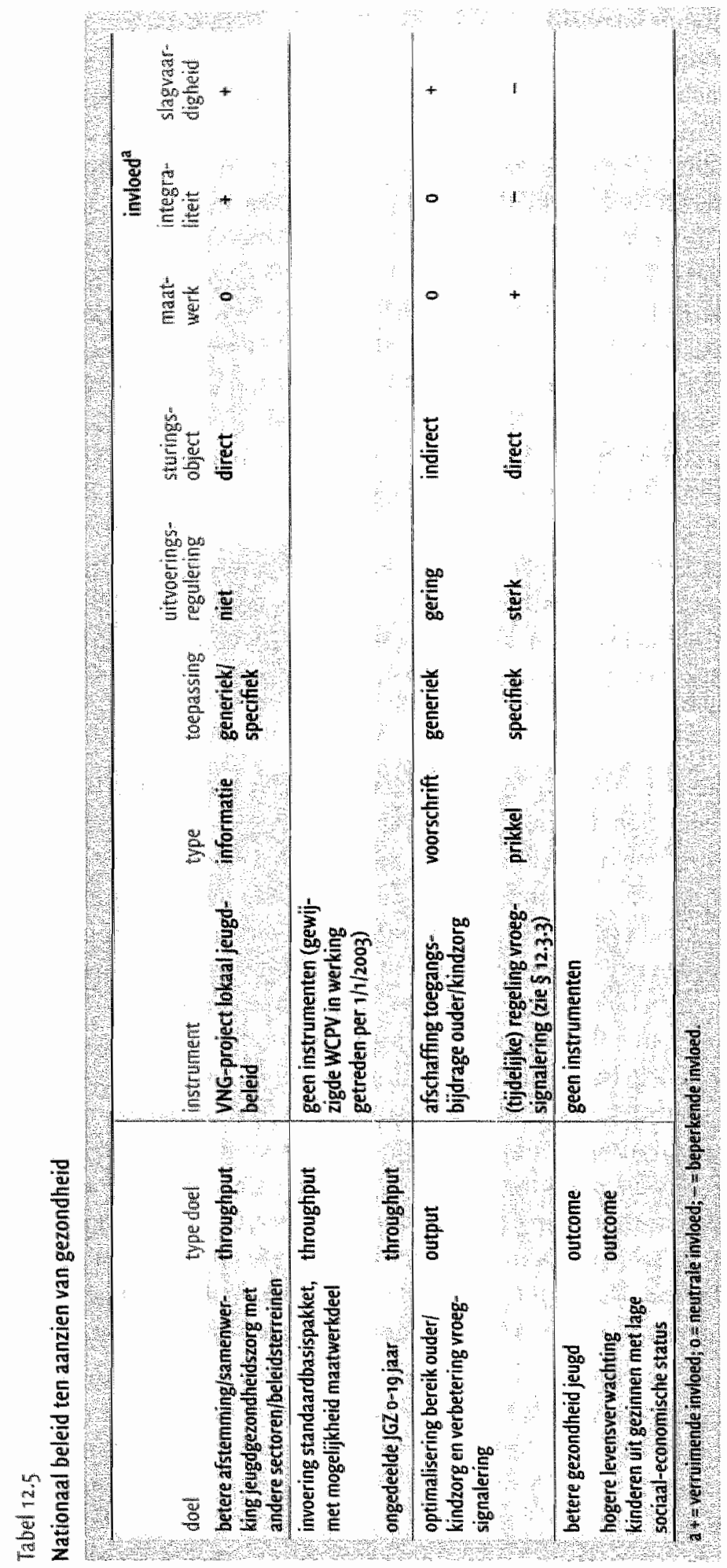




\subsubsection{Vrije tijd}

Doelen van de nationale overheid

Tot de pijler vrije tijd behoort het overheidsbeleid dat gericht is op de vrijetijdsbesteding van jeugdigen, dat wil zeggen: de tijd die zij buiten school of werk doorbrengen. Voor het gemeentelijke beleid gaat het dan om de gebieden sportparticipatie en cultuurparticipatie. Daarnaast behoort het creëren van gelegenheid voor jeugd om de vrije tijd in de publieke ruimte door te brengen tot deze pijler.

\section{Sport ${ }^{27}$}

In 1996 initieert vws het project Jeugd in beweging, met een aantal doelstellingen (TK r995/rg96a);

- het bevorderen van een actieve en gezonde leefstijl onder jeugdigen;

- het afstemmen van het sportaanbod van onderwijs-, jeugd-, sport en andere maatschappelijke organisaties;

- het actief betrekken van jongeren bij de keuze, opzet en organisatie van lichamelijke opvoeding, sport en bewegingsactiviteiten;

- het bevorderen van de maatschappelijke participatie en integratie van kwetsbare jongeren, allochtone jongeren én jongeren met een handicap door middel van sport en bewegingsactiviteiten.

Het laatste doel is ook van belang omdat sportactiviteiten kunnen bijdragen aan bijvoorbeeld hulpverlening of criminaliteitspreventie (TK 1996/1997C). In 1999 wordt het doel, in lijn met de eerdere doelstellingen, expliciet om de lokale sportinfrastructuur te versterken, om sport vanuit een integrale benadering in te zetten als een instrument voor sociaal beleid, en om dwarsverbanden te leggen met andere sectoren op het lokale niveau. Gemeenten en lokale organisaties zouden (verdere) initiatieven moeten ontplooien die bijdragen aan een duurzame verbetering van het lokale sportaanbod, indien mogelijk in samenwerking met andere sectoren. Tevens wordt getracht te bevorderen dat sportactiviteiten optimaal worden benut in het kader van andersoortige maatschappelijke projecten.

\section{Cultuut}

In de ocw-begroting voor 1999 worden jongeren als een van de specifieke doelgroepen van het cultuurbeleid genoemd (TK 1998/1999f). Ook wordt het belangrijk geacht onderwijs en cultuur dichter bij elkaar te brengen. In de beleidsnota Cultuur als confrontatie: uitgangspunten voor het cultuurbeleid 2001-2004 (OCW 1999a) wordt gesteld: 'Het is van cruciaal belang voor de samenleving maar ook voor de kunsten zelf om te investeren in aanbod van, voor en door de jeugd. Kunst stimuleert de fantasie en prikkelt de nieuwsgierigheid van jonge mensen. Kinderen moeten wegwijs worden gemakkt in de vele schoonheden die het leven en de kunsten in het bijzonder hebben voortgebracht. (...) Zo wordt een tegenwicht geboden voor de economisering, verzakelijking en commercialisering van de samenleving... Het bevorderen van de 
cultuurparticipatie van jeugdigen in brede zin is, hoewel niet met zoveel woorden geformuleerd, een ambitie die de nationale overheid in haar cultuurbeleid heeft ontwikkeld.

Voorzieningen in de publieke ruimte en overige vrijetijdsvoorzieningen Tot 20or heeft de nationale overheid (ministerie van Volkshuisvesting, Ruimtelijke Ordening en Milieu, vROM) geen beleidsdoelen geformuleerd voor de voorzieningen voor jeugdigen in de publieke ruimte. ${ }^{28}$ Evenmin zijn er doelstellingen met betrekking tot overige vrijetijdsvoorzieningen.

Instrumenten van de nationale overheid

\section{Sport}

In 1996 is de Stichting Jeugd in Beweging (JIB) door vws in het leven geroepen om de ambities van de nationale overheid te vervullen. 'Lokaal beleid' is daarin een van de programma's. Het accent daarvan ligt op het tot stand brengen van lokaal jeugdsportbeleid, 'met name op het onderdeel samenwerking van gemeentelijke diensten en lokale partners om zich met elkaar sterk te maken voor sportstimulering.' (Vollers en Hack 20oI: 25-26) Voor gemeenten zijn tien doelstellingen geformuleerd:

- organiseren van inspraak en betrokkenheid van jeugd;

- betere samenwerking tussen sportaanbieders;

- verbetering van bewegingsonderwijs op scholen;

- uitwisseling van ervaringen tussen gemeenten;

- afspraken met schooldirecties;

- aanspreken van ouders op gewenst gezond gedrag van kinderen;

- openstellen van sportclubs voor achterblijvers en niet-actieven;

- het betrekken van welzijn en hulpverlening;

- afsluiten van contracten met scholen en sportclubs;

$-25 \%$ meer actieve jeugd over drie jaar.

Alle gemeenten zijn in 1997 uitgenodigd om voorstellen voor plannen in te dienen, die gebaseerd moeten zijn op prioriteiten die op regionale bijeenkomsten door gemeenten zelf zijn bepaald. Van zeven gemeenten worden de plannen gehonoreerd: zij krijgen een financiële bijdrage om de plannen uit te voeren. Nog eens zes gemeenten en een samenwerkingsverband van vier gemeenten krijgen een bijdrage in de personeelskosten van een aan te stellen bewegingsconsulent. Alle gemeenten moeten zich bereid verklaren hun 'leerervaringen' te delen. Met de $\mathrm{G}_{4}$ zijn 'partnerships' opgezet, zodat deze een bepaald experimenteel project met financiële steun van Jів kunnen opzetten. In alle gemeenten is de voortgang van de projecten door monitoring gevolgd. Daarnaast is in nog een aantal andere gemeenten de haalbaarheid van bepaalde stimuleringsinstrumenten onderzocht, zoals een lokale jeugdsportpas en de verlengde schooldag. JIB heeft verder een aantal concrete producten ontwikkeld om gemeenten in hun beleid(sontwikkeling) te ondersteunen, zoals handreikingen, brochures, nieuwsbrieven en voorlichtingscampagnes. Ook zijn bijeenkomsten 
georganiseerd en is samenwerking gestimuleerd. JIB heeft tot in 2001 gefunctioneerd. In de laatste periode zijn de belangrijkste activiteiten overgedragen aan het Nederlands Instituut voor Sport en Bewegen (NISB).

In 1999 is door vws de Breedtesportimpuls aangekondigd (TK I998/I99gh). Hiermee wordt beoogd gemeenten en lokale organisaties initiatieven te laten ontplooien die bijdragen aan een duurzame verbetering van het lokale sportaanbod, indien mogelijk in samenwerking met andere sectoren. ${ }^{29}$ De breedtesportimpuls is gericht op versterking van de lokale sportinfrastructuur, het leggen van dwarsverbanden op lokaal niveau met andere sectoren - het aanstellen van iets soortgelijks als bewegingsconsulenten wordt bepleit - en het inzetten van sport als een instrument in het sociale beleid. Met betrekking tot de laatste doelstelling wordt opgemerkt dat sport een grote waarde kan hebben voor het onderwijs, de naschoolse opvang, criminaliteitspreventie, hulpverlening, revalidatie en gezondheidszorg. De jeugd wordt met name genoemd als kwetsbare groep die specifieke aandacht behoeft. De breedtesportimpuls krijgt concreet vorm in de Stimuleringstegeling breedtesport (Staatscourant rg9gb), die voorlopig een werkingsduur van acht jaar zou hebben. Gemeenten kunnen een aanvraag doen voor een breedtesportproject. Om in aanmerking te komen voor een uitkering gelden de volgende eisen:

- gemeenten dragen zelf ten minste $50 \%$ bij in de kosten van een project;

- er wordt per gemeente maximaal één keer een meerjarige uitkering verstrekt;

- gemeenten met minder dan ro.00o inwoners kunnen alleen samen met andere gemeenten een aanvraag indienen;

- in de aanvraag wordt een relatie gelegd tussen het breedtesportproject en overig gemeentelijk beleid;

- het project is innovatief en verschaft inzichten voor toekomstig beleid;

- het project is gericht op duurzame versterking van de breedtesport in de gemeente;

- het project is gericht op versterking van de lokale sociale infrastructuur;

- het projectplan wordt opgezet in overleg met lokale sportaanbieders en sporters;

- een project duurt minimaal drie en maximaal zes jaar;

- de hoogte van de uitkering is in de latatste twee jaren van het project aflopend;

- voor de grote steden geldt dat de projecten moeten worden ingebed in het grotestedenbeleid;

- na ieder projectjaar wordt door de gemeente(n) een inhoudelijk en financieel verslag uitgebracht.

In 1999 komen alleen gemeenten met meer dan 50.000 inwoners en provinciehoofdsteden in aanmerking, en vanaf 2000 alle gemeenten. De maximale hoogte van de uitkering wordt bepaald door het aantal projectjaren en het inwoneraantal van de gemeente en varieert van Iro.00o gulden voor gemeenten met minder dan ro.000 inwoners bij de minimale projectduur van drie jaar tot 2.887 .500 gulden voor gemeenten met meer dan 200.000 inwoners bij de maximale projectduur van zes jaar. 


\section{Cultuur}

Vanaf I 997 bestaat het door ocw geïnitieerde project Cultuur en school, dat tot doel heeft om onderwijs en cultuur dichter bij elkaar te brengen. Jaarlijks zijn financiële middelen beschikbaar voor culturele activiteiten die aansluiten op onderwijsprogramma's. ${ }^{30}$ Onder andere met grote gemeenten wordt samengewerkt aan een vraaggericht aanbod van cultuureducatieve projecten. Dit gebeurt op basis van convenants, waarbij de criteria waaraan het beleid moet voldoen, worden vastgelegd in een toetsingskader. Er is sprake van gezamenlijke financiering. In 1999 wordt geconstateerd dat het cultuur- en schoolbeleid verbreed en verankerd moet worden in het gemeentelijke beleid en minder gericht dient te zijn op losse projecten. In 2000 wordt het project opgenomen in het Actieplan culturbereik. ${ }^{3 \mathrm{I}}$ 'Investeren in jeugd' is een van de vijf doelstellingen in het beleidskader van dit actieprogramma. Er is nu sprake van convenants tussen het rijk enerzijds en de $\mathrm{G}_{4}$ en $\mathrm{G}_{2} 6$ anderzijds. De gemeenten ontvangen op basis van een door hen op te stellen programma een specifieke uitkering van het rijk, met de daaraan verbonden verplichtingen, waaronder een gemeentelijke financiële inzet die gelijk is aan de specifieke uitkering. In de programma's zijn de volgende zaken opgenomen:

- de doelstellingen;

- de wijze waarop het programma is ontwikkeld;

- de samenwerkingsverbanden;

- de visie op cultuurbereik;

- een sterkte-zwakteanalyse;

- de wijze waarop de doelstellingen zich in de actuele lokale of provinciale situatie laten vertalen;

- de waarborgen voor culturele kwaliteit;

- de te bereiken resultaten;

- de benodigde middelen.

Gemeenten die niet rechtstreeks in aanmerking komen om deel te nemen aan het actieplan, kunnen via een provinciaal programma betrokken worden. De stedelijke of provinciale programma's dienen gericht te zijn op publieksverbreding door middel van kwalitatieve, innovatieve en cultureel gedifferentieerde programmering. $Z$ ij worden opgesteld in samenspraak met lokale culturele instellingen.

Opmerkelijk is dat er in het cultuurbeleid van het rijk geen relaties worden gelegd met het jeugdbeleid. Omgekeerd vormt cultuur een marginaal onderdeel van het rijksjeugdbeleid (Van den Broek en Huysmans 2003: 65).

Voorzieningen in de publieke ruimte en overige vrijetijdsvoorzieningen De nationale overheid (VROM) kent geen beleidsinstrumenten voor voorzieningen in de publieke ruimte; het ministerie heeft in de betreffende periode ook geen beleidsdoelen. De beslissingsbevoegdheid over publieke voorzieningen voor jeugdigen ligt op lokaal niveau. Hetzelfde geldt in feite voor de overige vrijetijdsvoorzieningen: dit is bepaald in de Welzijnswet. Door de decentralisatie van het welzijnsbeleid hebben 
gemeenten grote vrijheid gekregen (Kwekkeboom et al. 2002). De middelen zijn opgenomen in het Gemeentefonds en derhalve vrij besteedbaar.

\section{Overzicht en conclusies}

Op het gebied van sportbeleid van gemeenten zijn aan de twee outcome-doelstellingen twee throughput-doelstellingen en een output-doelstelling gekoppeld (tabel 12.6). Er is gekozen voor een economisch sturingsmodel, waarbij opgemerkt dient te worden dat voor de prikkels slechts een beperkt aantal gemeenten in aanmerking is gekomen. De later ingevoerde breedtesportimpuls is op meer gemeenten van toepassing. Het sportbeleid heeft in beginsel positieve effecten op het beleidsvormende vermogen van gemeenten.

Op het gebied van cultuur is de belangrijkste doelstelling een maatschappelijk resultaat (outcome). De procesdoelstelling is daarvan afgeleid. Er is voor convenants tussen gemeenten (en provincies) en het rijk gekozen. Gemeenten zijn dus wel gebonden aan bepaalde afspraken, maar hadden zelf een inbreng in de totstandkoming van de afspraken. De mate van uitvoeringsregulering is echter hoog, waardoor het effect op het vermogen integraal en slagvaardig beleid te voeren beperkend is.

Op het gebied van jeugdvoorzieningen in de publieke ruimte heeft de nationale overheid tot 2002 geen beleid geformuleerd. 


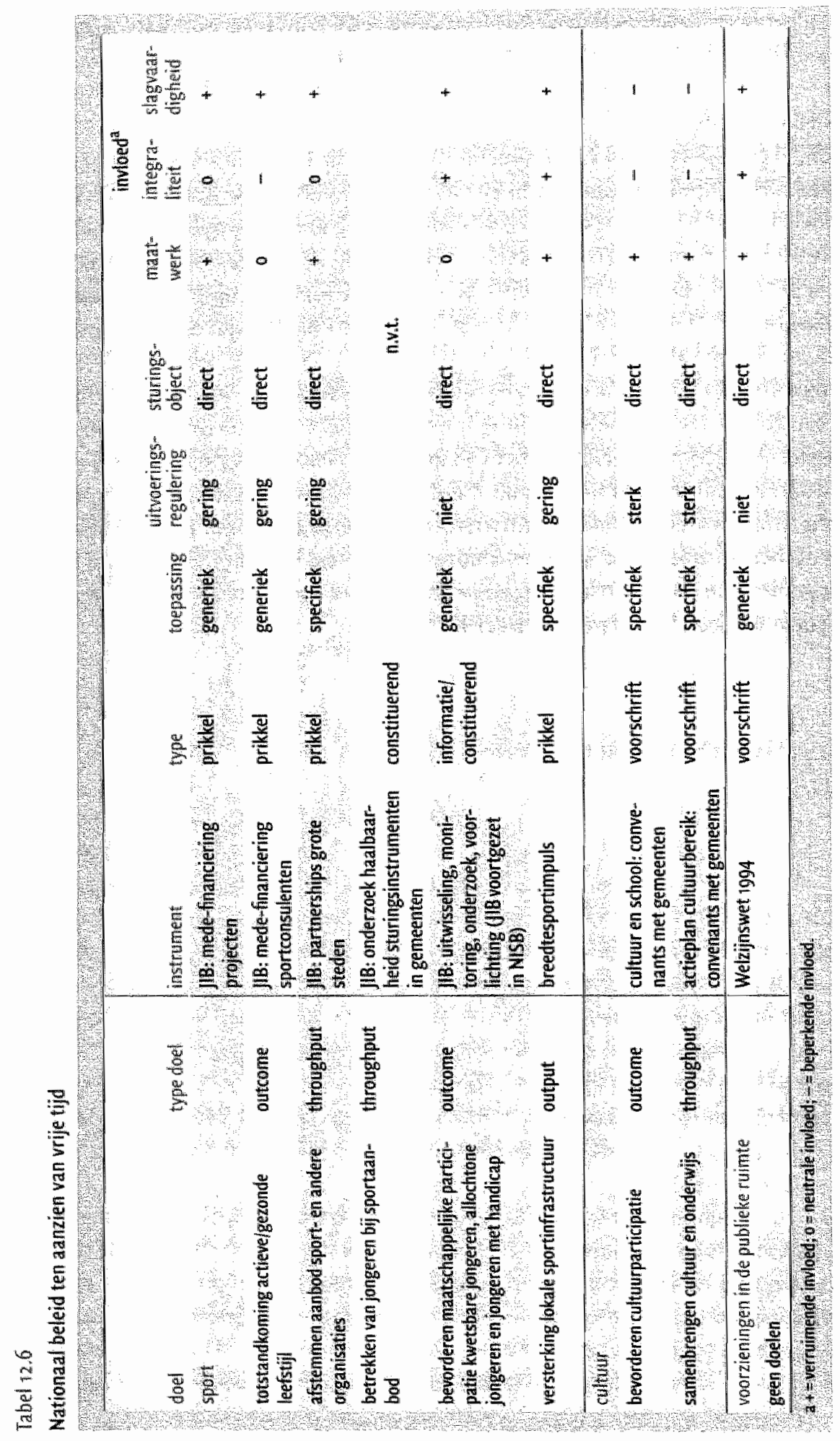




\subsubsection{Kinderopuang}

\section{Doelen van de nationale overheid}

De ambities van de nationale overheid in deze pijler zijn duidelijk: vanaf het begin van de jaren negentig van de vorige eeuw wordt een forse groei van het aantal plaatsen in de kinderopvang beoogd, aanvankelijk vooral in de kinderdagopvang (0-3-jarigen) en later ook in de buitenschoolse opvang (bso). Het doel van de uitbreiding is primair het ondersteunen van de arbeidsmarktparticipatie van ouders, maar de uitbreiding zou ook benut kunnen worden voor doelstellingen op bijvoorbeeld het terrein van het onderwijsachterstandenbeleid, zodat 'het gemeentelijk beleid gericht op buitenschoolse opvang op die manier ingebed (kan) worden in een integraal jeugd- en jongerenbeleid" (TK 1996/x997d). Ook bij de uitbreiding van de kinderdagopvang wordt nadrukkelijk gestreefd naar samenhang met de verdere ontwikkeling van het: jeugd-en onderwijsbeleid, zo wordt gesteld in de beleidsnota Kinderopuang uit 1999 (TK I998/rg9gi). Daarnaast wordt in de vws-begroting voor ig99 het doel geformuleerd om meer zicht te krijgen op wensen rond, behoeften aan en mogelijkheden van tieneropvang (TK I998/rg99a). Vanaf 1996 heeft het rijk bovendien het specifieke doel om de uitstroom van alleenstaande ouders uit de bijstand te bevorderen door hen kinderopvang aan te bieden. Vanaf eind jaren negentig wan de vorige eeuw is gestreefd naar een Wet kinderopvang ${ }^{32}$, waarin de gehele kinderopvang wettelijk verankerd zou worden. Deze is uiteindelijk in januari 2005 van kracht geworden.

\section{Instrumenten van de mationale overheid}

Het kinderopvangbeleid viel tot de inwerkingtreding van de Wet kinderopvang in januari 2005 onder de werking van de Welzijnswet. Dit betekent dat de rijkssoverheid verantwoordelijk is voor de landelijke functie: het ondersteunen en stimuleren van de uitvoering door gemeenten door onder andere onderzoek, experimenten en communicatie.

In de periode van 1990 tot en met 1995 zijn er diverse stimuleringsmaatregelen voor gemeenten, hoofdzakelijk gericht op uitbreiding van de opvang voor 0-3-jarigen. De middelen die beschikbaar waren voor deze stimuleringsmaatregelen zijn per I996 overgeheveld naar het Gemeentefonds (Staatscourant 1997a).

\section{Stimuleringsmaatregel buitenschoolse opvang 33}

In 1997 wordt de Tijdelijke stimuleringsmaatregel buitenschoolse opvang van kracht (Staatscourant 1997a). De maatregel voorziet in een uitkering aan gemeenten voor de opvangplaatsen die in de periode van 1997 tot 2000 worden gerealiseerd in de bso, voor zover deze plaatsen niet bekostigd worden op basis van andere regelingen zoals de Kinderopvangregeling Alleenstaande Ouders (KOA of WiW - waarover verderop in deze paragraaf meer). Beoogd wordt in totaal zo'n 20.000 extra bso-plaatsen te creëren. Het uitgangspunt is dat gemeenten zo veel mogelijk vrijheid wordt gelaten bij de vormgeving van hun stimuleringsbeleid. Gemeenten vervullen een belangrijke 
rol in verband met de raakvlakken die er bestaan met lokaal onderwijs- en jeugdbeleid en vanwege hun spilpositie krachtens de Welzijnswet. Belangrijke elementen in de buitenschoolse opvang zijn continuitteit in het aanbod, openingstijden die aangepast zijn aan arbeidstijden van ouders en aan schooltijden van kinderen, en een kwalitatief goed en veelzijdig aanbod. Het aanbod aan bso dient toezicht, opvoeding en verzorging te garanderen, met tegelijk een activiteitenprogramma voor alle leeftijdsgroepen, met (re)creatieve, culturele, educatieve en sportieve elementen. Een dergelijk aanbod kan voor kinderen van 8 tot 12 jaar bereikt worden door samenwerking met bijvoorbeeld het onderwijs, club- en buurthuiswerk, muziekschool, (sport)verenigingen of bibliotheek. ${ }^{34}$

Gezien een van de doelen van de regeling - aanbodvernieuwing - dient uitbreiding van de bso tot stand te komen in samenwerking met onderwijs-en welzijnsinstellingen (zoals leegstaande (onderwijs) locaties). De uitbreiding vergt daarom consensus met deze instellingen. Bezien kan worden in hoeverre kinderen die niet op opvang zijn aangewezen vanwege arbeidsparticipatie van de ouders, gebruik kunnen maken van het aanbod. Gemeenten worden uitgenodigd huishoudens met een laag inkomen en huishoudens uit de etnische minderheden te stimuleren tot gebruik. Bso kan ook een rol spelen in de bestrijding van onderwijsachterstanden; hoe dat zou moeten wordt in de regeling niet toegelicht. Bso zou dan echter wel deel uit moeten maken van het jeugdbeleid dat zich op deze groepen richt.

In totaal is voor de regeling x6o miljoen gulden beschikbaar. Daarvan is 1,5 miljoen bestemd voor het ondersteuningsaanbod door landelijke organisaties, de resterende 158,5 miljoen is voor de uitbreiding. Er worden ook bijdragen van ouders en werkgevers verwacht. De bijdrage per gerealiseerde plaats is $50 \%$ van de gemiddelde kostprijs. De bijdrage per plaats wordt daardoor 8000 gulden voor de gehele periode. Voor opvangplaatsen die boven het normaantal uren van ro50 tot I300 uitgaan (bij voorschoolse opvang, volledige vakantieopvang, langere openingsuren na schooltijd) wordt de bijdrage vermenigvuldigd met een factor $\mathrm{r}, 25$. Opvangplaatsen van minder dan to5o uur komen niet in aanmerking voor een bijdrage. Voor plaatsen in de gastouderopvang wordt een halve normbijdrage uitgekeerd.

De regeling is alleen van toepassing op plaatsen bij instellingen waarmee de gemeente een financiële relatie onderhoudt. Voor kleinere gemeenten kan het handig zijn samen te werken met andere gemeenten; de mogelijkheid daartoe wordt opengelaten. Het aantal gerealiseerde plaatsen waarvoor gemeenten een rijksbijdrage kunnen kriigen is per gemeente gemaximeerd; dit gebeurt in eerste instantie op basis van het aantal inwoners tot 20 jaar en daarnaast op grond van het aantal huishoudens met een laag inkomen en het aantal inwoners dat tot de etnische minderheden behoort. Daardoor komen grotere steden voor relatief meer plaatsen in aanmerking. Alleen bij onderuitputting van het totale budget zijn er per gemeente eventueel meer plaatsen te financieren. Gemeenten dienen op de aanvraag aan te geven of zij voor financiering wan deze extra plaatsen in aanmerking willen komen.

Er wordt één uitkering verstrekt voor de gehele periode. De uitkering mag besteed worden aan exploitatie en investeringen als het om plaatsen in de bso gaat, en aan 
bemiddeling, begeleiding en eventueel inventarisgoederen, die in eigendom blijven wan de organisatie, als het om gastouderopvang gaat. De gemeenten dienen een werantwoording te overleggen waaruit blijkt in hoeverre de uitkering is besteed aan het doel van de regeling. Overwogen wordt om een lump-sumuitkering mogelijk te maken, waarbij er niet meer wordt gekeken naar de feitelijke kosten van opvangplaatsen. Daarvoor is echter een wijziging van het Bekostigingsbesluit welzijnsbeleid noodzakelijk.

De regeling uit 1997 is gewijzigd in 1998 met de Wijziging Tijdelijke stimulleringsmaatregel buitenschoolse opvang ( $($ taatscourant $1998 \mathrm{c}$ ). De wijziging betreft een verhoging van de bijdrage per bso-plaats van 8000 naar 9300 gulden voor de gehele periode. De bijdrage per gastouderplaats blijft 4000 gulden. Bovendien wordt het aantal te financieren plaatsen met $\sigma_{349}$ uitgebreid. Om voor de extra plaatsen in aanmerking te komen, moeten gemeenten een nieuwe aanvraag indienen. De wijziging wordt structureel gefinancierd door het budget uit te breiden met 85 miljoen gulden per jaar, voor de periode van 1998 tot en met 2000.

In r999 wordt als gevolg van extra financiële middelen (zie TK 1998/1999i) de regeling opnieuw gewijzigd met de Wijziging Tijdelijke stimuleringsmaatregel buitenschoolse opvang (Staatscourant $1999 \mathrm{c}$ ). Beoogd wordt een capaciteitsuitbreiding te realiseren, die structureel wordt voortgezet. De belangrijkste wijzigingen zijn:

- de looptijd van de regeling wordt verlengd tot en met 2002;

- naast bso-plaatsen komen ook dagopvangplaatsen (voor 0-3-jarigen) in aanmerking voor financiering;

- in totaal gaat het om 71.000 plaatsen, inclusief de 26.000 bso-plaatsen die reeds zijn gefinancierd;

- het budget wordt verhoogd met in totaal ruim 600 miljoen gulden; 35

- de uitkering per plaats wordt verhoogd naar 1.968 gulden voor de hele periode, voor zowel kinderdagopvang als bso.

In de toelichting op de regeling wordt de wens geuit om meer transparantie te creëren in het proces waarbij gemeenten capaciteiten en budgetten aan instellingen toekennen. Een gelijke toegang voor verschillende aanbieders, bijvoorbeeld via openbare inschrijving, is wenselijk. Daarom wordt flankerend beleid gevoerd waarmee gemeenten worden ondersteund in het bevorderen van marktwerking.

Omdat van gemeenten een grote inspanning wordt gevraagd (uitbreiding met ca. $80 \%$ in drie jaar), biedt de regeling gemeenten maximale beleidsvrijheid om de uitbreiding naar lokale omstandigheden in te richten, zo wordt in de toelichting gesteld. Het kader waarbinnen de gemeenten opereren wordt bepaald door het aantal te realiseren plaatsen, de uitkering die daarvoor beschikbaar is en de einddatum van $3 \mathrm{I} / \mathrm{x} / 2002$. Gemeenten zijn vrij in het kiezen van een verhouding tussen te realiseren plaatsen bij kinderdagopvang en bso, en bij bedrijfs- en subsidieplaatsen, hoewel de vergoeding per plaats wel gebaseerd is op bepaalde verhoudingen (respectieve- 
lijk $40 \% / 60 \%$ en $45 \% / 55 \%$ ). Daardoor kunnen gemeenten bij afwijkingen duurder of goedkoper uit zijn. De reeds verleende uitkeringen worden verhoogd volgens de aangepaste bijdragehoogten. Middelen die resteren vanwege onderuitputting gaan bij voorrang naar de $\mathrm{G}_{25}$-gemeenten.

Op grond van het Bekostigingsbesluit Welzijnsbeleid wordt van gemeenten verlangd dat zij meewerken aan jaarlijks in te stellen onderzoeken naar de capaciteitsontwikkeling per jaar en eventueel ook naar de vernieuwing van de bso voor 8-12-jarigen en naar het vóórkomen van marktwerking. Het is de bedoeling de middelen op termijn over te hevelen naar het Gemeentefonds.

De volgende wijziging van de regeling volgt in 2000 (Staatscourant 2000b). Bij deze wijziging wordt de uitkering per gerealiseerde opvangplaats opnieuw verhoogd, nu naar 12.080 gulden per plaats. Bovendien komt er een extra rijksbijdrage van 4500 gulden voor bso-plaatsen die gerealiseerd zijn in 1997 en van 1500 voor plaatsen die in 1998 zijn gerealiseerd. Om hiervoor in aanmerking te komen, moeten gemeenten een extra aanvraag indienen. In de gewijzigde regeling wordt de verruiming van openingstijden gestimuleerd. Er kunnen extra plaatsen worden gerealiseerd als het aantal opvanguren van een plaats boven een bepaald aantal ligt. Tot slot vervalt de uitzondering voor plaatsen die gerealiseerd zijn op basis van de regeling-KOA (zie verderop in deze paragraaf); ook deze plaatsen komen in aanmerking woor een uitkering.

Als gevolg van nieuwe extra middelen wordt de regeling later in 2000 nog eens gewijzigd (Staatscourant 2000c). De extra middelen ( $20 \mathrm{mln}$. gulden) zijn deels bestemd voor verbetering van het toezicht en van de kwaliteit $(8,25 \mathrm{mln}$. gulden) en deels voor gemeenten die de gewenste uitbreiding snel kunnen realiseren ( $1 \mathrm{I}, 75 \mathrm{mln}$. gulden). Snelle uitbreiding wordt gedefinieerd als het realiseren van meer dan de helft van de beoogde uitbreiding eind $200 r$, een jaar voor het einde van de stimuleringsperiode. De bonus bedraagt maximaal 6500 gulden per versneld gerealiseerde plaats. Verder is nu het Bekostigingsbesluit welzijnsbeleid gewijzigd, waardoor het mogelijk is over te gaan op lump-sumfinanciering, zoals het voornemen al was bij de totstandkoming van de regeling in 1997. De kosten die de gemeente heeft gemaakt zijn daardoor niet meer van belang: ongeacht de hoogte daarvan wordt een bijdrage per gerealiseerde plaats uitgekeerd.

Twee weken later volgt de volgende wijziging, die opnieuw te maken heeft met extra budget ( $80 \mathrm{~min}$.), maar ook met de indexering van de gereserveerde middelen (Staatscourant 2000d). Het bedrag per plaats wordt verhoogd van 12.080 naar 12.372 gulden. Het extra budget komt opnieuw ten goede aan de snelle uitbreiders.

In december 2000 volgt weer een wijziging van de regeling (Staatscourant 2000e). Hierin wordt de besteding van de 8,25 miljoen gulden voor de verbetering van het toezicht en de kwaliteit geregeld. Per plaats wordt extra geld beschikbaar gesteld dat ten goede zou moeten komen aan de inspectie. Het rijk verwacht van de gemeenten dat 
zij de verhoging besteden aan de inspectie, uitgevoerd door de GGD'en. De GGD'en krijgen een overzicht van de gemeenten in hun werkgebied, waaruit blijkt hoeveel rijksbijdrage zij ontvangen ten behoeve van de inspectie. Na afloop van de uitbreidingsperiode moeten gemeenten rapporteren over de uitvoering van de inspectie, naast de rapportage over de uitbreiding van de kinderopvang.

De diverse regelingen hebben een verruimend effect op het vermogen tot maatwerk, maar de mate van uitvoeringsregulering verkleint de kans op een integraal en slagvaardig beleid. Die kans wordt weer iets groter door de communicatieve sturing via het ondersteuningstraject. De projecten en experimenten kwaliteitszorg en beleidsinformatie zijn instrumenten van constituerende aard.

Regeling kinderopuang en buitenschoolse opvang alleenstaande ouders Naast de zojuist behandelde stimuleringsregeling bso (en later ook kinderdagopvang), die afkomstig is van vws, is er vanaf 1996 de Regeling kinderopvang en buitenschoolse opuang alleenstaande ouders (Staatscourant $1997 \mathrm{~b}$ ) van $\mathrm{SZW}$. Er is tot en met 2002 sprake van opeenvolgende regelingen met steeds een looptijd van een jaar. ${ }^{36}$ De regeling is gericht op bevordering van de uitstroom van alleenstaande ouders uit de bijstand of uit een andere uitkering naar werk of scholing - dit wordt per geval door de gemeente beoordeeld. Het budget wordt verdeeld op basis van het aantal alleenstaande ouders met bijstand in een gemeente. Per gemeente wordt zo een maximaal subsidiebedrag vastgesteld. Op basis daarvan krijgen gemeenten per I maart van elk jaar een voorschot van 50\%, waarbij geen rekening wordt gehouden met de werkelijke behoefte. Voor $\mathrm{I}$ juni moeten gemeenten hun definitieve aanvraag indienen op basis van de feitelijk verwachte behoefte. Eventueel te hoge voorschotten worden dan teruggevorderd. Een voorwaarde is dat alleen extra platsen bovenop het aanbod per eind 1995 worden gesubsidieerd. Gemeenten zijn vrij de periode te bepalen waarin zij de subsidie handhaven voor ouders die uitstromen naar werk en om te bepalen of er een ouderbijdrage wordt geheven. De administratie van gemeenten moet een overzicht bevatten waaruit blijkt dat de subsidie ten goede is gekomen aan de doelgroep, dat het nieuwe plaatsen betreft, en dat deze bezer zijn geweest. De contracten met instellingen moeten deze gegevens bevatten.

In 1999 is de regeling op een aantal punten aangepast, mede naar aanleiding van de gemeentelijke wens tot vereenvoudiging (Staatscourant $1998 \mathrm{~d}$ ):

- er is een gewijzigde subsidiegrondslag. In plaats van 'bezette plaats' komt de 'overeenkomst met een instelling per individuele cliënt'. Daardoor hoeft de bezettingsgraad niet meer te worden gemeten;

- er is een gewijzigde indieningstermijn, waarmee wordt beoogd gemeenten sneller duidelijkheid te verschaffen;

- bij een subsidie lager dan 20.000 gulden is geen accountantsverklaring meer vereist;

- de additionaliteit van de plaats hoeft niet meer te worden aangetoond;

- de duur van de subsidie na uitstroom naar werk wordt beperkt. 
In 2000 worden de doelgroepen waarop de regeling betrekking heeft, uitgebreid met minderjarige alleenstaande ouders en met deelnemers aan sociale activering (Staatscourant rgggd).

Het budget dat met de regeling is gemoeid loopt geleidelijk op van 85 miljoen gulden in 1996 tot 150 miljoen in 2002.

De regeling is een economisch sturingsinstrument en heeft aanvankelijk een sterke en later een geringere mate van uitvoeringsregulering.

\section{Tieneropvang}

Op het gebied van tieneropvang is er het Programma Tieneropvang. Dit vws-programma, gericht op innovatie, heeft drie hoofddoelen:

I zicht krijgen op de behoeften en opvattingen van tieners en ouders;

2 praktijkervaring opdoen met de inhoud en organisatie van tieneropvang door projecten te ondersteunen, door onder andere te kijken naar de mogelijkheden tot inbedding in het lokale jeugd- en onderwijsachterstandenbeleid en naar de afstemming op en samenhang met sport-, onderwijs-, vrijetijds- en wijkvoorzieningen. Het NIZW heeft een aanbod ontwikkeld om de projecten te ondersteunen en dit aanbod wordt door een onafhankelijke instantie geëvalueerd;

3 een maatschappelijk en beleidsmatig perspectief voor de tieneropvang formuleren. Daartoe is in 2001 de commissie Tieneropvang in het leven geroepen (Staatscourant 200Ib).

De kern van het programma bestaat uit de projecten die onder de tweede doelstelling zijn genoemd en die met de Tijdelijke regeling innovatieve tieneropuangprojecten (Staatscourant 1999 e) van 1999 tot en met 2003 zijn gefinancierd. De resultaten hiervan zouden moeten bijdragen aan de besluitvorming over de toekomst van de tieneropvang. Uitkeringen zijn verstrekt voor de periode van 1999 tot en met 2003. In 1999 was 5 miljoen gulden beschikbaar, van 2000 tot en met 2002 ro miljoen per jaar, en in 2003 6,7 miljoen. Gemeenten kunnen per project een uitkering aanvragen, met oog voor een goede inbedding in lokaal beleid en een efficiënt gebruik van reeds voorhanden zijnde activiteiten en accommodaties. Gemeenten dragen daarbij ook een deel van de kosten. De rijksbijdrage is aan een maximum gebonden ( 3500 gulden per plaats) en bedraagt maximaal de helft van de exploitatiekosten; ook voor andere kostensoorten is de uitkering gelimiteerd. ${ }^{37}$ Bestaande projecten komen ook voor de regeling in aanmerking. De afrekening vindt eenmalig plaats na afloop van de projectperiode, op basis van de kosten die de gemeente werkelijk heeft gemaakt. Aan de projecten worden de volgende eisen gesteld:

- het project is gericht op leerlingen in het voortgezet onderwijs die niet ouder zijn dan I5 jaar;

- opvang vindt plaats op alle schooldagen en in een deel van de schoolvakanties, waarbij wordt aangesloten op school- en arbeidstijden;

- er is een goed evenwicht tussen ruimte voor zelfstandigheid en begeleiding. Er is gelegenheid om huiswerk te maken en op gezette tijden is er een activiteitenaanbod; 
- betrokkenheid van jongeren en ouders is essentieel, zowel bij de voorbereiding als bij de uitvoering;

- omwille van geïntegreerde en efficiënte opvang wordt gebruikgemaakt van of afgestemd met al aanwezige voorzieningen voor tieners, inclusief de bso voor 4-I 2-jarigen;

- projecten kennen een inkomensafhankelijke ouderbijdrage. Per project wordt de hoogte en de wijze van inning bepaald;

- de opvang vindt uiterlijk plaats met ingang van het schooljaar rg9g/200o.

Uit de aanvragen door gemeenten wordt een selectie gemaakt op basis van de volgende criteria:

- spreiding naar type gemeente (bijvoorbeeld grootte en stad/platteland);

- spreiding naar vormen van opvang en doelgroepen;

- spreiding naar aanbieders (kinderopvang, sociaal-cultureel werk, onderwijs);

- de mate waarin een project een bijdrage levert aan het programma, onder meer blijkend uit de bereidheid om informatie te leveren aan het NIZW en gebruik te maken van ondersteuning door het NIZW.

Het rijk kan besluiten minder plaatsen te financieren dan waarvoor een aanvraag is gedaan als alle in aanmerking komende aanvragen het voor de regeling beschikbare budget overstijgen en als aanvraag is gedaan voor grootschalige projecten die het innovatieve karakter van de regeling te boven gaan.

In 2000 is de regeling gewijzigd (Staatscourant 2000 ). Met de wijziging werd beoogd een zo groot mogelijk aantal van de 67 deelnemende gemeenten de mogelijkheid te bieden deel te blijven nemen. Zonder wijziging zouden de projecten in een aantal van deze gemeenten beëindigd moeten worden. Gemeenten die er niet in zijn geslaagd per $1999 / 2000$ te beginnen, krijgen de mogelijkheid uiterlijk aan het begin yan het schooljaar 2000/200r te starten. In uitzonderlijke gevallen worden andere dan inkomensafhankelijke ouderbijdragen toegestaan. De eis tot opvang op alle. dagen komt woor het schooljaar 1999/200o te vervallen.

Het is duidelijk dat de Regeling een economisch sturingsinstrument is, dat de mogelijkheden voor gemeenten om maatwerk te leveren vergroot. Het is de mate van uitvoeringsregulering die beperkend werkt voor het vermogen om tot een integraal en slagvaardig beleid te komen.

De commissie Tieneropvang heeft niet direct invloed op de handelingsmogelijkheden van lokale actoren en kan daarom worden beschouwd als een constituerend instrument.

\section{Overige instrumenten}

In de Wiw (zie $\$$ r2.3.8) is een structurele regeling voor kinderopvang opgenomen in het zogenoemde Gemeentelijk Werkfonds. Dit fonds voorziet in een basisbedrag per gerealiseerde dienstbetrekking of werkervaringsplaats, in een vooraf vastgesteld budget voor aanvullende kosten (met name voor personen die ver van de arbeidsmarkt af staan), in een jaarlijks budget voor scholing en financiële stimulansen, en in kinderopvang. 
Een aantal voornemens die in de beleidsnota Kinderopuang uit r999 (TK 1998/I999i) zijn geuit, zoals aanvullende fiscale faciliteiten voor ouders en werkgevers, een nieuw wettelijk systeem van ouderbijdragen en een stelsel gebaseerd op vraagfinanciering, zijn uiteindelijk pas gerealiseerd met de inwerkingtreding van de Wet kinderopvang in januari 2005 .

\section{Overzicht en conclusies}

Veruit de belangrijkste doelstelling van de nationale overheid op het gebied van de kinderopvang is geformuleerd op output-niveau: het realiseren van fors meer plaatsen in zowel de kinderdag- als de buitenschoolse opvang. Daartoe heeft het rijk vanaf de jaren negentig van de vorige eeuw fors geïnvesteerd om gemeenten te prikkelen de beoogde uitbreiding te realiseren. De regelingen zijn diverse malen aangepast omdat er extra geld beschikbaar kwam. Hoewel de capaciteitsuitbreiding ook tot doel had de relatie tussen de kinderopvang en het jeugdbeleid te versterken, lag het accent op het faciliteren van arbeidsmarktparticipatie. Voor dit laatste (outcome-)doel stonden aan gemeenten ook de KOA-regelingen en het gemeentelijk Werkfonds uit de Wiw ter beschikking. Het wordt uit de diverse regelingen niet duidelijk hoe de uitbreiding van de kinderopvang het jeugdbeleid zou moeten versterken. De concrete invulling van deze relatie wordt dus overgelaten aan gemeenten. De vraag is of het hoge tempo waarin de uitbreiding heeft plaatsgewonden, heeft bijgedragen aan een zorgvuldige afstemming van kinderopvang en jeugdbeleid door gemeenten.

Het is duidelijk dat het economische sturingsmodel veruit het belangrijkste type sturing was in de pijler kinderopvang (zie ook tabel 12.7). De handelingsmogelijkheden voor gemeenten op het gebied van kinderopvang zijn door de forse prikkels sterk uitgebreid. Het uitgangspunt in de uitbreidingsregelingen dat gemeenten maximale vrijheid in de uitvoering zouden moeten krijgen, is door de sterke mate van uitvoeringsregulering niet waargemaakt. 


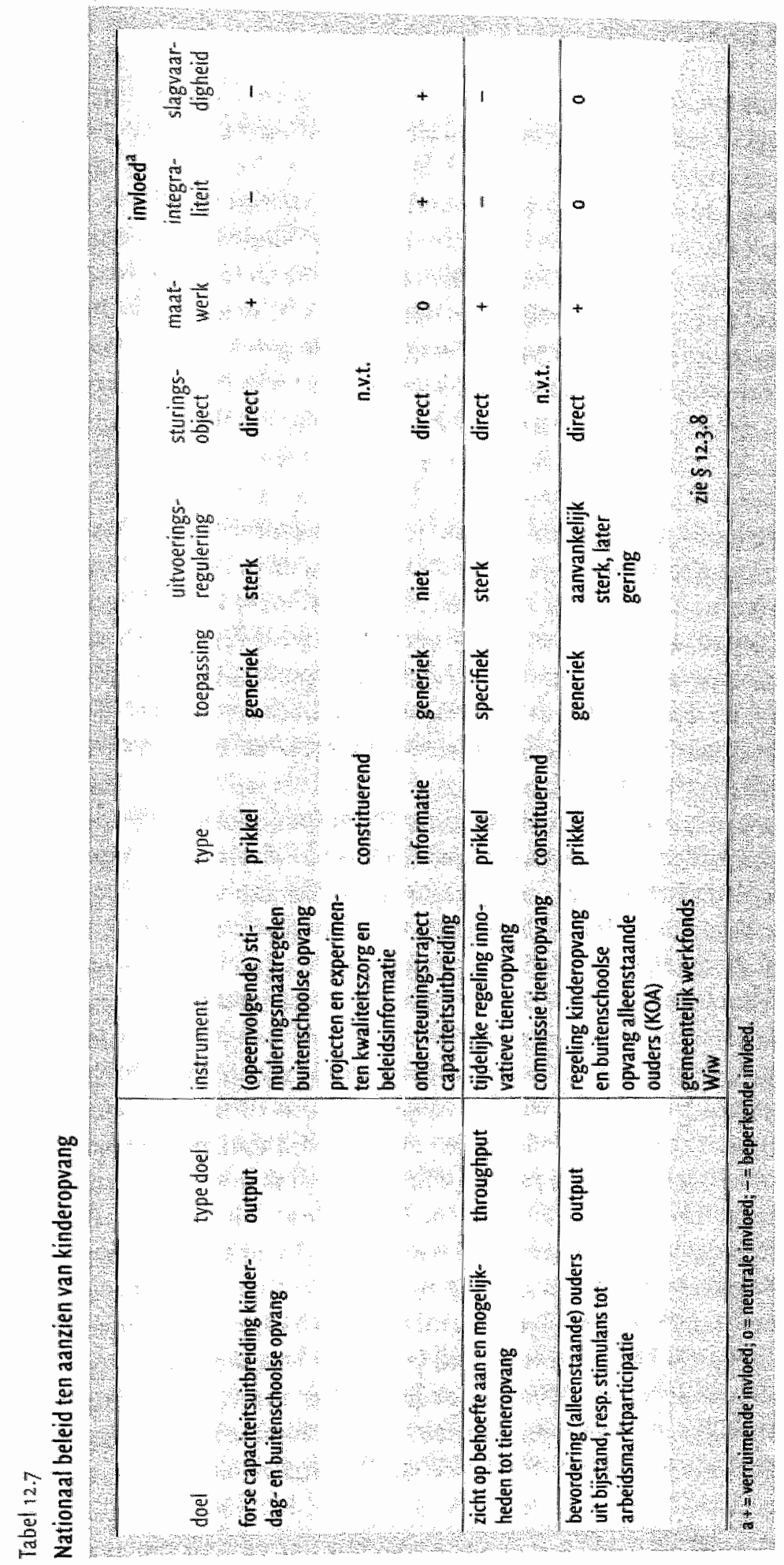




\subsubsection{Veiligheid en openbare orde}

\section{Doelen van de nationale overheid}

In het veiligheidsbeleid van de nationale overheid wordt vanaf 1995 prioriteit gegeven aan het thema jongeren en veiligheid:

"Er is een grote groep van jongeren die tussen wal en schip dreigt te raken.

Schooluitval, gebrek aan zinvolle vrijetijdsbesteding, gebrekkige integratie en werkloosheid, dreigen bij deze jongeren te leiden tot apathie en in toenemende mate tot vatbaarheid voor gedrag dat bijdraagt aan onveiligheidsgevoelens bij anderen, overlast en criminaliteit. De toekomst van vele jongeren staat op het spel en daarmee grote delen van onze samenleving. Het kabinet acht dit vooral wegens de omvang en het karakter van deze inbreuken onacceptabel.' (TK 1994/1995b: (3).

De aanpak van jeugddelinquentie 'moet zowel voorzien in een duurzame investering in het voorkomen van jeugdproblemen als in extra investeringen in een extra repressieve aanpak met een sterk socialiserend karakter.' (TK 1994/rg95b: I5). Belangrijk is een evenwichtige aanpak met als elementen pro-actie (het goed functioneren van algemene voorzieningen als onderwijs en sociaal-culturele voorzieningen), preventie (toegespitst op risico's) en repressie (de aanpak van criminaliteit en overlast). Specifieke aandacht voor de situatie van jeugd uit etnische minderheden, waaronder Antilliaanse jongeren, wordt gewenst geacht.

In de convenants voor de eerste GSB-periode zijn twee output-doelstellingen opgenomen die gezien kunnen worden als verbijzondering van de zojuist genoemde algemene outcome-doelstellingen (BZK 1995a; BZK 1995b). Het aantal jongeren dat met de politie in aanraking komt als gevolg van preventief en repressief beleid zou met $30 \%$ moeten dalen. Bovendien dient het aantal taakstraffen en Halt-afdoeningen jaarlijks met 10\% toe te nemen. In het doorstartconvenant tussen het rijk en de steden voor de tweede GSB-periode zijn geen nieuwe doelen op het gebied van jeugd en veiligheid opgenomen (BzK 1998). De programma's jeugd en veiligheid uit de eerste GSB-periode moeten 'met kracht' worden voortgezet, met dien verstande dat de jeugdcriminaliteit onder etnische minderheden meer aandacht dient te krijgen.

De algemene outcome-doelstellingen van het jeugd- en veiligheidsbeleid kennen bovendien een aantal afgeleide throughput-doelen. Zo zou de aansluiting tussen de verschillende schakels van de keten die gevormd wordt door thuissituatie, basisonderwijs, voortgezet onderwijs, arbeidsmarkt, jeugdbescherming, en politie en justitie verbeterd moeten worden. Om die reden, maar ook omwille van redenen als maatwerk en integraliteit, ligt het zwaartepunt bij het lokale bestuur. Vanwege de vereiste bijdrage wan diverse lokale organisaties en instellingen aan het beleid wordt een sterke lokale bestuurlijke regie verlangd. Daarnaast is er meer afstemming nodig tussen lokaal veiligheidsbeleid en (strafrechtelijk) handhavingsbeleid. 
Regelingen jeugd en veiligheid

$\mathrm{Na}$ het verschijnen van de nota Veiligheidsbeleid in 1995 ligt de nadruk in eerste instantie op het jeugd- en veiligheidsbeleid van de grote steden (TK 1994/I995b). ${ }^{38}$ In 1996 zijn in het kader van het grotestedenbeleid financieringstegelingen jeugd en veiligheid voor respectievelijk de $\mathrm{G}_{4}$ (Staatscourant $1996 \mathrm{a}$ ) en de $\mathrm{G}_{15}$ (Staatscourant 1996b) opgesteld door BZK en OCenW. De regelingen lijken sterk op elkaar. Op basis van beide regelingen levert de nationale overheid een bijdrage aan de financiering van stedelijk beleid, dat een uitwerking is van tussen de $\mathrm{G}_{4}$, respectievelijk de $\mathrm{G}_{5}$ en het rijk gesloten overeenkomsten. De steden stellen in overleg met in ieder geval het Openbaar Ministerie en de Raad voor de Kinderbescherming jaarlijkse actieplannen op. In deze plannen worden de output-afspraken (zie: Doplen van de nationale overheid aan het begin van deze paragraaf) uit de convenants uitgewerkt in concrete beieidsmaatregelen. De steden brengen jaarlijks verslag uit aan het rijk over de stand van zaken in de uitvoering en de mate van doelrealisering. Mede op basis hiervan komen zij tot een actieplan voor het volgende jaar. De gerapporteerde stand van zaken kan bovendien voor het rijk aanleiding vormen nadere afspraken met de betreffende gemeente te maken. Daarnaast leggen de gemeenten achteraf financieel verantwoording af over de besteding van de rijksbijdrage.

Voor dit beleid was in 19954 miljoen gulden beschikbaar. Dit bedrag zou oplopen tot 93 miljoen gulden structureel in 1999 . Daarvan is uiteindelijk 68 miljoen beschikbaar voor de brede doeluitkering 'jeugdketen', afkomstig uit de begrotingen van OCW en BZK. De overige 25 miljoen is bestemd voor reclassering en uitbreiding van taakstraffen, en is afkomstig van Justitie. Daarnaast zijn er extra middelen van Justitie voor justitiële opvang-en behandelplaatsen en voor versterking van het Openbaar Ministerie met het oog op de bestrijding van jeugdcriminaliteit. Ter versterking van de lokale regiefunctie wordt de lokale beleidsontwikkeling ondersteund door uitwisseling van kennis en methoden. In de voortgangsrapportage van het traject 'Jeugd en veiligheid' (TK 1995/r996b) wordt aangegeven dat van het totale bedrag van 244 miljoen gulden dat in de periode r $996-1999$ beschikbaar is voor jeugd en veiligheid, 200 miljoen ten goede komt aan de $\mathrm{G}_{4}$ en de Gr5. Daarnaast hebben de $\mathrm{G}_{4}$ in 1995 eenmalig een startbedrag van 4 miljoen gulden ontvangen.

Van 1997 tot en met 1999 zou dus in totaal 40 miljoen gulden beschikbaar zijn voor de rest van Nederland. De inzet daarvan is in 1997 geregeld door de Tijdelijke regeling inzet extra middelen Jeugd en Veiligheid (Staatscourant $1997 \mathrm{c}$ ). Uit de toelichting op de regeling blijkt dat slechts 16 miljoen beschikbaar is. Het doel van de regeling is een aantal gemeenten financieel te ondersteunen om een extra inspanning te doen op het gebied van jeugd en veiligheid. De gemeenten dienen zelf ten minste $50 \%$ van de projectkosten te financieren. Zij moeten een plan woor een periode van drie jaar maken. Dit plan bevat in ieder geval een kwantitatieve en kwalitatieve probleemanalyse en een daarop aansluitende anpak, meetbare doelstellingen, afspraken met 
derden over hun bijdrage, een begroting waarin de inzet van rijksmiddelen wordt verantwoord, en een voorziening voor de overd racht van de resultaten van het project aan andere gemeenten. Aanvragen moeten worden ingediend voor 9 juli 1997 (de regeling stond op 3 april 1997 in de Staatscourant). Als er meer geld wordt aangevraagd dan er beschïkbaar is, selecteren de ministers op basis van spreiding naar gemeentegrootte, doelgroepen, leeftijdsgroepen en soorten activiteiten, en op basis van de ernst van lokalle problemen. De gemeente wordt geacht te rapporteren over de gerealiseerde activiteiten en de daarmee samenhangende uitgaven, zodat inzicht wordt verkregen in de voortgang van het project, de behaalde resultaten en de realisering van de $50 \%$-bijdrage van de gemeente. De opstelling van het plan wordt apart begroot. In de toelichting bij de regeling wordt het belang van een integrale aanpak benadrukt, 'waarbij alle schakels van de jeugdketen betrokken worden'. Uit de evaluatie (Batelaan 2002) blijkt dat 39 gemeenten met in totaal 64 projecten van de regeling gebruik hebben gemaakt.

Eind 2000 kondigt het rijk de Eenmalige intensiveringsbijdrage jeugd en veiligheid (Staatscourant $2000 \mathrm{~g}$ ) af. Deze regeling is bestemd voor gemeenten met meer dan I00.000 inwoners die niet tot de GSB-gemeenten behoren, voor de (toen nog) partiële GSBgemeenten en voor gemeenten met een inwonertal tussen de 50.000 en 100.000 en ten minste $7 \%$ allochtone inwoners. Daarmee overlapt de regeling deels met de voortzetting van het CRIEM-beleid die een jaar eerder is doorgevoerd, en dan met name met het specifieke beleidsspoor (zie verderop in deze paragraaf). Voor zowel het jaar 2000 als het jaar 200 is 15 miljoen gulden beschikbaar. De in de bijlage genoemde gemeenten (22) hebben ongeveer drie weken de tijd om een aanvraag in te dienen waarin op hoofdlijnen is aangegeven op welke wijze de gemeente de (vastgestelde) bijdrage zal besteden aan de intensivering van het wijkveiligheidsbeleid in het kader van het jeugd- en veiligheidsbeleid. ${ }^{39}$ Ondersteuning en advisering is beschikbaar via onder meer het VNG-project lokaal jeugdbeleid. De gemeente dient de besteding van de middelen te verantwoorden.

In het algemeen hebben de regelingen jeugd en veiligheid een verruimende invloed op de mogelijkheden tot lokaal maatwerk. De mate van uitvoeringsregulering en - in het geval van de Eenmalige investeringsbijdrage - de korte reactietijd beperken echter het vermogen tot integraal en slagvaardig beleid.

Aanpak jeugdcriminaliteit

In de notitie Jeugdcriminaliteit (TK 1995/1996c) van het ministerie van Justitie uit 1995 staan onder andere beleidswoornemens rond criminaliteitspreventie. Daarin wordt verwezen naar de eerder besproken nota Veiligheidsbeleid (TK I994/I995 b), maar het gaat in de nota vooral om het beleid van Justitie. Preventie is dan vooral gericht op het voorkomen van recidive, en daarbij blijkt de invoering van de Halt-afdoening succesvol. Deze zal dan ook worden gecontinueerd. Verder wordt langs verschillende sporen het gebruik van softdrugs onder jeugdigen zo veel mogelijk ontmoedigd 
(aanscherping gedoogbeleid, drempels in verkoop van softdrugs, intensivering van de voorlichting). Justitie draagt bij aan methodiekontwikkeling op het gebied van signalisering, diagnose en preventie van veel voorkomende criminaliteit op scholen en stelt jaarlijks een lespakket criminaliteitspreventie beschikbaar. Er wordt melding gemaakt van tien projecten die verspreid zijn over het land en gericht zijn op methodiekontwikkeling voor de aanpak van hardekernjongeren (onder andere individuele trajectbegeleiding). In 1997 wordt bekeken of deze aanpak wordt uitgebreid.

Behalve criminaliteitspreventie wordt een aantal andere maatregelen voorgesteld. Ter versterking van de aandacht voor jeugd bij de politie worden (niet bindende) aanbevelingen opgesteld voor de minimale toerusting van 'jeugd-en zedenzaken' per regiokorps. Voorts wordt de jeugdreclassering landelijk ingevoerd, worden er per arrondissement platforms rond de jeugd ingericht waarin ten minste de Raad voor de Kinderbescherming, de reclassering en de gezinsvoogdij-instelling en bij voorkeur OM en politie deelnemen; daarnaast wordt de positie van de Raad voor de Kinderbescherming op strafrechtelijk terrein versterkt (onder meer door betere samenwerking op plaatselijk niveau met de politie bij de melding van processen-verbaal voor minderjarigen), wordt de jeugdfunctie van het Openbaar Ministerie versterkt (door de doorlooptijd van strafzaken tegen jeugdigen te verkorten, door de officier van justitie in het hele land de mogelijkheid te geven taakstraffen op te leggen, door een nieuwe landelijke richtlijn voor politiesepot in te voeren, en door betrokkenheid van het $O M$ bij het opstellen van de $\mathrm{GSB}$-convenants met $\mathrm{de}_{4}$ ), wordt de implementatie van taakstraffen versterkt en worden de justitiële jeugdinrichtingen uitgebreid en verbeterd. Tot slot wordt gewezen op de noodzaak van goede registratie, informatie en onderzoek, en worden hiertoe voorstellen ontwikkeld.

Een deel van de instrumenten uit de notitie Jeugdcriminaliteit versterkt de handelingsruimte van lokale actoren vooral als het gaat om maatwerk en slagvaardigheid. Het gaat woor een groot deel immers om versterking van lokale actoren langs functionele lijnen. Verder behoort een behoorlijk aantal instrumenten tot de constituerende en bestuursinstrumenten.

\section{Integraal veiligheidsprogramma}

In 1999 komt BZK met het Integraal veiligheidsprogramma (IVP) (TK 1998/1999j). Daarin wordt gesteld dat de regie in het lokale integrale veiligheidsbeleid bij gemeenten ligt, omdat zij op veel onderdelen van het veiligheidsbeleid al verantwoordelijkheden hebben. Het is de bedoeling dat de 'partners in veiligheid' op lokaal niveau afspraken maken om tot een sluitende aanpak van jongeren te komen en om de hulpverlening zo vroeg en zo effectief mogelijk vorm te geven.

Een van de beleidsthema's in het IVP is jongeren en veiligheid, met specifieke aandacht voor jongeren uit etnische minderheden. Het beleid rond jeugd en veiligheid (nota Veiligheidsbeleid, TK $1994 / \mathrm{ig} 95 \mathrm{~b}$ ) is geëvalueerd en wordt voortgezet, met als nieuwe zwaartepunten verjonging, verharding en de blijvende oververtegenwoordiging van allochtone jongeren. 
In het BANS is een aantal afspraken gemaakt over de verantwoordelijkheden van de verschillende bestuurslagen (BANS $1999 \mathrm{~b}$ ). Het rijk zal onder meer de knelpunten in de aanpak van jeugdcriminaliteit onderzoeken. Verder is belangrijk dat de provincies bij de ontwikkeling van regiovisies in de jeugdzorg verbanden leggen met "jeugd en veiligheid'. In het kader van het GSB zijn de doorstartconvenants met de grote steden belangrijk. Er is een interdepartementale commissie jeugd en veiligheid ter bevordering van de interdepartementale afstemming, die tevens de ambtelijke gesprekspartner is voor lokale besturen.

Met betrekking tot het proces is ook de positie van de gemeente als regisseur belangrijk, te midden van organisaties die met hun eigen verantwoordelijkheden op afwijkende territoriale niveaus opereren. Ter verbetering van deze complexe situatie zal het functioneren van de arrondissementsplatforms jeugdcriminaliteit worden gestimuleerd. In het Beleidsplan Nederlandse Politie, het BANS en GSB is vastgelegd dat in de beleidskaders van de veldorganisaties van de betrokken departementen (zoals het $O M$, de Raad voor de Kinderbescherming, de jeugdhulpverlening en de politie) niet-vrijblijvende afspraken over samenwerking zullen worden opgenomen. Om te bevorderen dat gemeenten een eigen plan van aanpak ontwikkelen, zullen zij worden gestimuleerd een actuele diagnose van de lokale situatie op te stellen.

In de eerste helft van rggg is de Stop-maatregel ingevoerd, bedoeld voor kinderen jonger dan 12 jaar die zich schuldig maken aan een 'Halt-waardig' delict. Dit is geen strafrechtelijke reactie, maar een pedagogische handreiking aan ouders. Deelname vindt plaats op vrijwillige basis en de maatregel wordt uitgevoerd door de Haltbureaus. De Halt-bureaus woeren de Halt-afdoening en de Stop-reactie uit onder verantwoordelijkheid van het Openbaar Ministerie. De kosten hiervan komen voor rekening van de nationale overheid. Daarnaast houden de 52 Halt-bureaus zich bezig met preventieve activiteiten, zoals advisering en voorlichting. Deze activiteiten vallen onder de verantwoordelijkheid van de bij het Halt-bureau aangesloten gemeenten, die ook de kosten ervan dragen. De organisatorische inbedding van de Halt-bureaus verschilt. In sommige gevallen zijn ze ondergebracht bij een gemeente, soms opereren ze als zelfstandige stichting en in weer andere gevallen zijn ze ondergebracht bij andere organisaties zoals het Bureau Jeugdzorg. Verder zijn er in het Halt-beleid verwijzingen naar het beleid omtrent voortijdig schoolverlaten en de leerplichthandhaving, het integratiebeleid, het onderwijsbeleid (onder andere de samenwerking tussen onderwijs en jeugdzorg, de veilige school in het primair onderwijs, praktijkgerichte leerwegen en schooladoptie), CRIEM (zie verderop in deze paragraaf), de pilot Communities that Care (zie $\$$ r2.3.2) en de GSB-convenants.

Omdat er veel raakvlakken zijn tussen lokaal veiligheidsbeleid en het (strafrechtelijk) handhavingsbeleid is afstemming met justitie noodzakelijk. Door de sterke oriëntatie in de voorafgaande jaren van justitie, c.q. het oM, op lokale problematiek (de arrondissementale platforms, Justitie in de buurt (Terpstra en Bakker 2002)), is de noodzaak van deze afstemming toegenomen.

De in het IVP aangekondigde maatregelen in het kader van het GSB hebben vorm gekregen in de Bijdrageregeling sociale integratie en veiligheid (Staatscourant I99ga, zie 
ook $\$(2.3 .5)$. Via deze regeling ontvangen de $\mathrm{G}_{25}$ een brede doeluitkering, die onder meer bestemd is voor het verbeteren van de leefbaarheid en de veiligheid van de leefomgeving, een integrale aanpak van jeugdcriminaliteit en de aanpak van voortijdig schoolverlaten..$^{\circ}$ Voorwaarde voor de uitkering is dat het beleid is opgenomen in het stedelijke GSB-plan en dat het voldoet aan de in de regeling gestelde voorwaarden. Het GSB-plan dient in ieder geval te bevatten:

- een beschrijving van de problematiek en van de omvang en de samenstelling van groepen waarop het beleid gericht is;

- de maatregelen en een indicatieve begroting;

- streefcijfers bij de maatregelen;

- de wijze waarop de relatie wordt gelegd met ander gemeentelijk beleid: de inzet van GOA-middelen, de RMC-functie, de inzet van middelen uit de Europese structuurfondsen ter bevordering van een leven lang leren en het tegengaan van voortijdig schoolverlaten;

- de wijze waarop lokale en regionale onderwijs- en welzijnsinstellingen en bewonersorganisaties zijn betrokken in de beleidsvorming en de afspraken die met deze organisaties zijn gemaakt.

De plannen dienen te worden goedgekeurd door het rijk. De steden leggen achteraf inhoudelijk en financieel verantwoording af.

Voor de $\mathrm{G}_{5}$ (de partiële GSB-steden) is er vanaf 2000 de Bijdrageregeling leefbaarheid partielle GSB-steden (Staatscourant $2000 \mathrm{~h}$ ). Deze regeling is gericht op versterking van de leefbaarheid en veiligheid in bepaalde stadswijken. Het thema jeugd en veiligheid wordt in de regeling niet genoemd.

\section{Beleidsplan Nederlandse Politie}

Hierboven is al gerefereerd aan het Beleidsplan Nederlandse Politie (BNP) (TK 19981 $199 \mathrm{gk}$ ). In het BNP is de aanpak van de jeugdcriminaliteit een van de thema's. Het doel is de politiële jeugdzorg kwalitatief en kwantitatief te verbeteren. Daartoe wordt geïnvesteerd in informatie-uitwisseling en samenwerking, bijvoorbeeld door het cliënt-volgsysteem jeugdcriminaliteit. Men acht het vanzelfsprekend dat er aansluiting bij het gemeentelijk integraal veiligheidsbeleid wordt gezocht. Verder wordt het jeugdspecialisme bij de politie verder versterkt, onder meer door de deskundigheid van politiemedewerkers te vergroten. Vanaf 1998 is voor de politiekorpsen 25 miljoen gulden per jaar extra beschikbaar voor jeugd en veiligheid. Bovendien komt een deel van de extra middelen uit het Regeerakkoord 1998 voor politie en justitie ten goede aan de aanpak van de jeugdcriminaliteit. De Inspectie voor de Politie zal in 2.001 onderzoeken of de beoogde verbetering van de politiele jeugdzorg is verbeterd.

Er bestaat een nauw verband tussen het IVP en het BNP. Het IVP is complementair aan het BNP doordat het toevoegt wat andere partners dan de politie aan de veiligheid kunnen bijdragen, zoals op het gebied van jeugdcriminaliteit. In de gemeentelijke veiligheidsplannen zouden de lokale politieprioriteiten moeten worden opgenomen. Daartoe wordt onder meer gewerkt aan de toekenning van een wettelijk inbrengrecht voor de gemeenteraad, om de gemeentelijke invloed op het politiebeleid te versterken. 
Criminaliteit in relatie tot integratie van etnische minderheden

In 1997 is met de nota Criminaliteit in relatie tot integratie van etnische minderheden (CRYEM) (TK rg97/rgg8f) een begin gemaakt met beleid dat specifiek gericht is op de jeugd uit etnische minderheden. De belangrijkste gedachte in die nota is dat beleid primair gericht moet zijn op preventie, door de integratie van etnische minderheden te verbeteren. Niettemin speelt het strafrecht een belangrijke rol bij zowel de preventie als de repressie van criminaliteit - het strafrecht blijft in de nota echter buiten beschouwing. Uitgangspunt is dat gemeenten een belangrijke positie innemen door de toegenomen ruimte die zij hebben - het gevolg van het terugtreden van de centrale overheid. Gemeenten moeten samenwerking tot stand brengen, doelstellingen op verschillende terreinen verknopen en een integraal aanbod realiseren. Het rijk heeft dan ook het voornemen om bij de uitwerking van het CRIEM-beleid gemeenten te betrekken.

CRIEM behelst een preventieve aanpak van marginaliseringsprocessen onder jongeren uit etnische minderheidsgroepen. 'Daarbij staat voorop, dat het kabinet niet zozeer uit is op nieuw beleid als wel op een herorienntatie van beleid en uitvoering waaraan een aantal cruciale keuzen ten grondslag ligt.' De aanpak is opgebouwd uit drie beleidssporen, die gericht zijn op:

$\mathrm{r}$ etnische jongeren die (dreigen) met het strafrecht in aanraking (te) komen vanwege lichtere vormen van criminaliteit. Zij krijgen individuele trajectbegeleiding (гтв). Ітв bestaat uit een op de jongere toegesneden programma, waarin wordt samengewerkt door welzijn, onderwijs, arbeidsmarkttoeleiding, politie en justitie. Ook zelforganisaties en ouders worden betrokken. De programma's hebben objectief te controleren doelen. Er moet één regisseur komen, maar er wordt niet uitgesproken wie of wat. De relatie met de repressieve aanpak (strafrecht, justitie, politie) is belangrijj;

2 het voorkomen van spijbelgedrag en voortijdig schoolverlaten, met name bij jongeren die nog niet in het criminele circuit zitten maar wel tot de potentiële risicogroep behoren. Daartoe wordt de RMC-functie (zie \$ 12.3.3) versterkt. Elementen daarvan zijn het relateren van voortijdig schoolverlaten aan spijbelgedrag, een sluitende aanpak in samenwerking met scholen en andere betrokken instanties, een goed registratiesysteem (ook met betrekking tot etniciteit), teruggeleiding van voortijdige schoolverlaters naar het onderwijs (eventueel met behulp van Bureaus Jeugdzorg en de voorziene Centra voor Werk en Inkomen, CWI's), op-maat-trajectbegeleiding naar de arbeidsmarkt voor voortijdige schoolverlaters die niet teruggeleid worden naar het onderwijs, en het betrekken van de jeugd(gezondheids)zorg;

3 beheersing van de Nederlandse taal door de voorschoolse jeugd om de uitgangspositie op de basisschool te verbeteren. Elementen van dit spoor zijn: aandacht van consultatiebureaus voor taalbeheersing, sociale ontwikkeling en opvoedingsproblematiek; concrete taalprogramma's; betrokkenheid van ouders; aandacht voor moeilijk bereikbare groepen en geïsoleerde gezinnen; eventueel intermediairs uit minderheidsgroepen; beter bereik en betere kwaliteit van voorschoolse voor- 
zieningen (met name peuterspeelzalen); streven naar structureel in plaats van projectenbeleid; formuleren van eenduidige doelstellingen; aanbrengen van een duidelijke regie; en versterking van het taalonderwijs in de onderbouw van de basisschool. Er wordt overwogen de leerplichtige leeftijd te verlagen tot 4 jaar. Het bredeschoolconcept biedt volgens de nota goede aanknopingspunten om deze aanpak te realiseren. Het is duidelijk dat dit spoor aansluit bij het $O \& O$-beleid (zie \$ I2.3.2) en het vve-beleid (zie $\$$ I2.3.3).

Onder verantwoordelijkheid van de nationale overheid en samen met een aantal grote gemeenten en minderhedenorganisaties worden de drie sporen uitgewerkt tot concrete beleidsprogramma's. De regie voor de uitwoering ervan berust bij de gemeenten. De uitvoering vindt plaats volgens regels die vooraf in overleg tussen alle betrokken partijen zijn vastgelegd.

In $x 999$ zijn er pilots gestart in zeven gemeenten, in 2000 is een achtste toegevoegd. De pilots werden voor twee jaar gefinancierd met in totaal 12 miljoen gulden. Daarnaast is het eerste beleidsspoor, de ITB, in 29 gemeenten (G25 +4 andere gemeenten) opgezet. Dit spoor wordt uitgevoerd door de afdelingen jeugdreclassering van de gezinsvoogdij-instellingen.

Het CRIEM-beleid krijgt een vervolg in 200 I (TK 2000/200rc). Gemeenten worden vier jaar lang (van 200I tot 2005) ondersteund bij de preventie van marginalisering en criminalisering van allochtone jongeren. Belangrijk is een balans tussen de zelfstandigheid van gemeenten enerzijds en ondersteuning door de overheid anderzijds (bedoeld wordt de rijksoverheid). Deze balans wordt bereikt door een tweedeling aan te brengen in het beleid:

- algemeen beleid voor alle gemeenten. Dit is gericht op de ontwikkeling van een instrument waarmee gemeenten hun instellingen kunnen doorlichten op hun toegankelijkheid voor allochtone jongeren, en op de ontwikkeling van handreikingen bij registratiekwesties. Daarnaast bestaat het algemene beleid uit voorlichting en uitwisseling en uit het stimuleren van centrumgemeenten om hun expertise delen met randgemeenten. Hiervoor is jaarlijks 5 miljoen gulden beschikbaar.

- specifiek beleid. In de G25 zijn de drie beleidssporen al ingevuld. Het is zaak dat het beleid verder wordt 'uitgerold' over andere gemeenten met relatief veel allochtonen. Deze gemeenten worden gefaciliteerd bij de vormgeving, structurering en aanvulling van hun beleid. Zestien van de Gr7 (niet-G25 met meer dan 60.000 inwoners én meer dan $7 \%$ allochtonen, en exclusief de pilot Bergen op Zoom) worden gefinancierd (Staatscourant 20orc). Per gemeente worden afspraken gemaakt over te behalen resultaten, zoals het aanvullen van ontbrekende delen in de keten, het realiseren van verbeterde ketensamenwerking, een groter bereik van allochtone jongeren door instellingen, een groter aantal allochtonen in ITB-trajecten, meer allochtone ouders bij opvoedingsondersteuning, enzovoort. De randvoorwaarden zijn dat de regie bij de gemeente ligt, dat activiteiten en projecten bijdragen aan een sluitende keten, dat doelgroepen participeren en dat er uitzicht is op structurele inbedding van activiteiten. De gemeenten worden vier jaar lang substantieel gefinancierd bij 
hun preventiebeleid en ITB. Eerst wordt de planvormingsfase gefinancierd en vervolgens, na toetsing van de plannen aan de randvoorwaarden, de uitvoeringsfase. Gemeenten krijgen intensieve ondersteuning bij de planworming door de inzet van extra menskracht. Halverwege en aan het eind van de periode rapporteren de gemeenten over de inhoudelijke voortgang en over de inzet van middelen, waarbij wordt ingegaan op de resultaatafspraken. Tussentijdse ondersteuning en bijsturing is mogelijk. Jaarlijks is $\mathrm{r} 4,5$ miljoen gulden beschikbaar.

- Daarnaast krijgen de acht pilotgemeenten uit het oorspronkelijke CRIEM-beleid nog drie jaar extra om hun beleid te optimaliseren en te continueren, en om het in te bedden in staand beleid. De hiervoor bestemde extra bijdrage van 12 miljoen gulden wordt in drie jaar afgebouwd.

- Tot slot is er een potje voor actuele kwesties of zaken die vragen om een experimentele aanpak. In totaal komt in dit kader ro miljoen gulden ten goede aan twintig $\mathrm{G}_{25}$-gemeenten die niet tot de CRIEM-pilotgemeenten behoren. Gemeenten kunnen voorstellen indienen, op voorwaarde dat die voorstellen samen met de doelgroep zijn ontwikkeld. De plannen worden beoordeeld op inhoud en relevantie.

Alle activiteiten die gemeenten in het kader van het CRIEM-vervolg ontwikkelen, moeten na 2004 ingebed zijn in het reguliere jeugd- en veilligheidsbeleid. De verantwoordelijkheid daarvoor ligt bij de gemeenten.

In totaal is jaarlijks 36 miljoen gulden beschikbaar. 25 miljoen gaat naar het hierboven beschreven beleid. Van de resterende Ir miljoen gaat 5 miljoen naar vve-beleid (en is met name bestemd voor het betrekken van moeilijk bereikbare ouders) en 6 miljoen naar de zeven Antillianengemeenten (zie verderop in deze paragraaf).

Overigens bestaat er naast de zogenoemde ITB-CRIEM zoals hierboven beschreven, ook nog de ITB voor hardekernjongeren. Deze aanpak past uitsluitend in een justitieel kader en is bedoeld als alternatief voor (een deel van een) detentie. ITB-harde kern wordt uitgevoerd door de voogdij-instellingen, die hiervoor van het rijk een bijdrage ontvangen (zie het extra-comptabel overzicht GSB in TK 1998/I999l). ITB-CRIEM is van toepassing op jongeren uit etnische minderheden die in aanraking komen met het strafrecht. Het is een lichtere aanpak dan de ITB voor hardekernjongeren.

\section{Bijdrageregeling Antillianengemeenten}

Om de groeiende overlast aan te pakken die wordt veroorzaakt door een relatief kleine groep kansarme Antilliaanse jongeren, komt de nationale overheid in $200 \mathrm{I}$ met de Bijdrageregeling Antillianengemeenten (Staatscourant 20ord). Deze regeling is bestemd voor zeven grote gemeenten die een groot aantal overlast veroorzakende, kansarme, Antilliaanse inwoners tellen in de leeftijd tussen 16 en 25 jaar. Voor vier jaar is in totaal 24 miljoen gulden beschikbaar, deels afkomstig uit het budget van het vervolg-CRIEM-beleid. De gemeenten moeten binnen twee weken een meerjarig plan overleggen dat gericht is op de integratie van Antilliaanse jongeren. ${ }^{4 \mathrm{r}}$ Het doel van het gemeentelijke beleid moet zijn de positie van Antilliaanse jongeren te verbeteren door maatregelen te treffen op het gebied van opvang, begeleiding en scholing. 
In het plan moet worden aangegeven op hoeveel Antilliaanse jongeren het beleid is gericht, welke maatregelen tegen welke kosten worden getroffen en welke prestaties er uitgedrukt in streefcijfers worden nagestreefd. Daarnaast bevat het plan een gedegen probleemanalyse met de urgente knelpunten. De aanpak dient integraal onderdeel uit te maken van het structurele beleid van de gemeente. Bij de planning en de uitwoering wordt de Antilliaanse gemeenschap betrokken en in het plan wordt aangegeven op welke wijze dat is gebeurd. De minister doet een beroep op de gemeenten om waar nodig met buurgemeenten samen te werken. De gemeente brengt jaarlijks (kwalitatief en kwantitatief) verslag uit over de uitvoering en de bereikte resultaten. $\mathrm{Na}$ afloop van de regeling wordt financieel verslag uitgebracht.

\section{Overige instrumenten}

Jeugd en veiligheid was een van de vier inhoudelijke thema's van het vNG-project Lakaal jeugdbeleid. Gedurende de looptijd van het project, van 1999 tot en met 2002, zijn gemeenten op verschillende manieren ondersteund in de vormgeving en uitvoering van hun jeugd-en veiligheidsbeleid.

Zoals in paragraaf 12.3 .3 al aangegeven, start $0 \mathrm{cw}$ in 1995 de campagne De veilige school, die gericht is op scholen in het voortgezet onderwijs (Mooij 20or). Met de campagne wordt niet alleen beoogd het leefklimaat op scholen zo veilig mogelijk te maken, maar ook om op deze manier te voorkomen dat leerlingen voortijdig van school gaan. De campagne liep tot het voorjaar van 2000 en kende een tweeledige doelstelling (zie Studulski en Hoogbergen 2002):

- het doorbreken van het taboe om over geweld in het onderwijs te spreken;

- het helpen van scholen bij het werken aan veiligheid.

De doelstellingen worden vertaald in drie pijlers: het vergroten van de sociale binding van leerlingen, het omgaan met incidenten en calamiteiten op school, en de zorg voor veilige voorzieningen in het schoolgebouw en zijn omgeving. Het accent ligt op sociale aspecten van veiligheid; de fysieke aspecten worden bestreken door de Arbowetgeving. Ter ondersteuning van scholen zijn een aantal instrumenten ontwikkeld, die scholen tegen geringe kosten kunnen aanschaffen. Scholen uit de GSB-gemeenten kunnen daarnaast een beroep doen op financiële ondersteuning bij het uitvoeren van hun plannen. Om hiervoor in aanmerking te komen, moeten zij een plan van aanpak indienen.

Het beleid krijgt in 1999 verder vorm met de notitie Veilightidsbeleid 2000-2003 voor $P O$, VO en BVE (OCW 1999b). In deze notitie zijn twee uitgangspunten geformuleerd voor het veiligheidsbeleid op scholen:

deel zijn van het kwaliteitsbeleid en de kwaliteitszorg van de school;

2

zijn met het lokale integrale veiligheidsbeleid van de gemeente. 
Gaande de campagne breidt deze zich langzaam uit naar het primair onderwijs. Vanaf 1999 is de campagne daar een feit (Diepeveen en Krooneman 2001; Studulski en Hoogbergen 2002). In de campagne primair onderwijs wordt een accent gelegd op pesten en op fysieke veiligheid, terwijl in de campagne voortgezet onderwijs veel aandacht bestaat voor de relatie tussen verzuim en voortijdig schoolverlaten en veiligheid.

Om de samenwerking op lokaal niveau te bevorderen is in het convenant voor de tweede GsB-periode de richtlijn opgenomen dat scholen moeten worden betrokken bij het lokale integrale veiligheidsbeleid (BzK 1998 ). Verder heeft het veiligeschoolbeleid relaties met het wSNs-beleid en met de ontwikkeling van brede scholen.

De campagne De veilige school is in 2000 overgedragen aan het transferpunt 'jongeren, school en veiligheid'. Het transferpunt biedt alle scholen (en gemeenten) gespecialiseerde hulp en ondersteuning bij vraagstukken over veiligheid.

\section{Overzicht en conclusies}

In tabel 12.8 is een overzicht opgenomen van de doelen en instrumenten van het rijksbeleid in de pijler veiligheid en openbare orde. Opvallend is dat de meeste doelen in globale termen zijn geformuleerd. Het is duidelijk dat er een zekere hiërarchische ordening in de doelen zit, waarbij het uiteindelijke doel het voorkomen van jeugddelinquentie is. Daarmee is het beleid in zijn doelstelling helder.

De instrumenten vallen in ieder geval op door hun hoeveelheid. Verder komt de complexiteit van de pijler veiligheid en openbare orde onder andere tot uiting in de relatief grote hoeveelheid instrumenten die niet direct op de gemeenten zijn gericht, maar wel indirect van belang zijn voor het lokale beleid. Dit is vooral beleid op het terrein van justitie en politie. Veel daarvan kan worden gerekend tot de constituerende en bestuursinstrumenten, omdat zij geen (direct) effect hebben op de handelingsmogelijkheden van lokale actoren. Zoals we ook bij andere pijlers hebben kunnen zien, beperkt het grotestedenbeleid in algemene zin de mogelijkheden tot maatwerk, maar vergroot het het vermogen tot integraliteit en slagvaardigheid. De werking van de diverse bijdrageregelingen is in de meeste gevallen omgekeerd: $z i j$ vergroten de handelingsmogelijkheden van gemeenten, maar hebben een beperkend effect op het vermogen tot integraal en slagvaardig beleid. Verder valt op dat voor het realiseren van de throughput-doelstellingen overwegend informatieve, bestuurs- en constituerende instrumenten worden ingezet. Dit zijn instrumenten die in het algemeen een verruimende respectievelijk geen invloed hebben op de handelingsruimte van lokale actoren.

De pijler veiligheid en openbare orde kent een behoorlijk aantal economische sturingsinstrumenten. Het is belangrijk nog eens te constateren dat deze prikkels, met uitzondering van de Tijdelijke regeling inzet extra middelen jeugd en veiligheid, slechts op een beperkt aantal gemeenten van toepassing zijn. Dat betekent dat de meeste Nederlandse gemeenten niet voor deze regelingen in aanmerking zijn gekomen. Hetzelfde geldt voor een aantal indirecte instrumenten, zoals Justitie in de buurt. De meeste 
gemeenten zijn door het rijk alleen ondersteund met communicatieve beleidsinstrumenten, die in het algemeen een beperkte verruimende invloed hebben gehad op de gemeentelijke handelingsmogelijkheden.

De pijler jeugd en veiligheid vertoont ook een zekere overlap met andere pijlers, zoals onderwijs en opvoeding en thuissituatie. Als het gaat om de preventie van jeugdcriminaliteit, dan komen deze pijlers al snel in beeld. Dit doet de vraag rijzen of bijwoorbeeld de voor- en vroegschoolse educatie (onderdeel van CRIEM) gezien moet worden als een bijdrage aan de algemene doelstelling van het jeugdbeleid om kansen te vergroten en uitval te voorkomen, of dat vve primair het doel van vermindering van de jeugdcriminaliteit dient. Hoewel beide perspectieven elkaar niet helemaal uitsluiten, maakt het voor de operationalisering van het beleid wel degelijk uit welk perspectief dominant is. ${ }^{42}$ Daarnaast wijst de Externe commissie CRIEM (s.a.) op de stigmatiserende werking van het plaatsen van vve in het perspectief van de aanpak van jeugdcriminaliteit. ${ }^{43}$ Hetzelfde geldt voor het beleid rond het voortijdig schoolverlaten en de vroegtijdige signalering. 


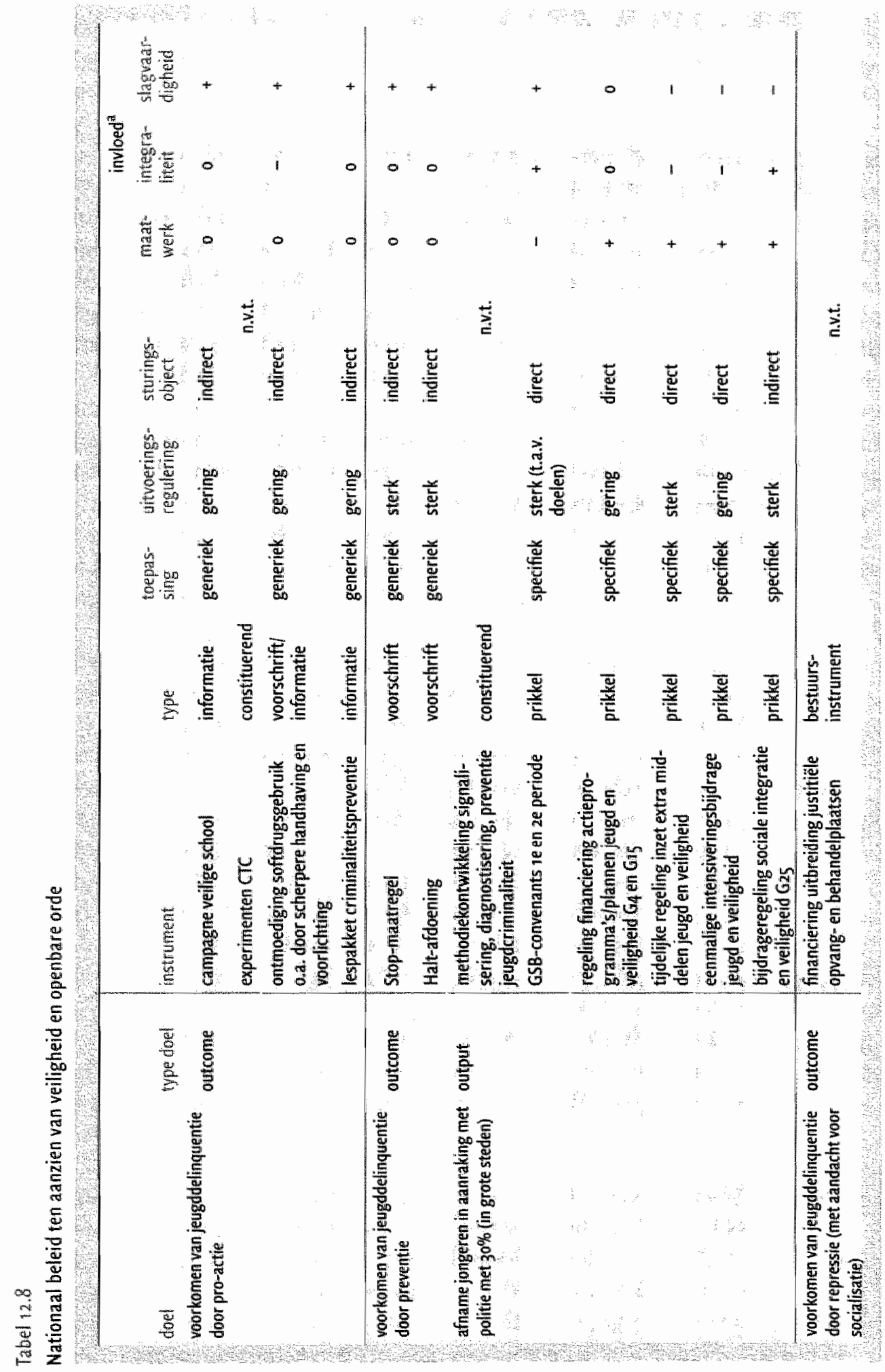




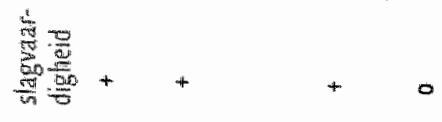

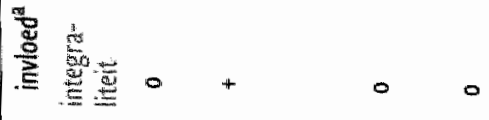

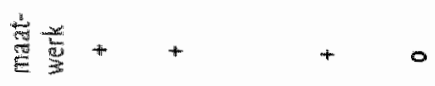

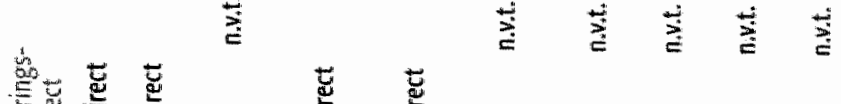

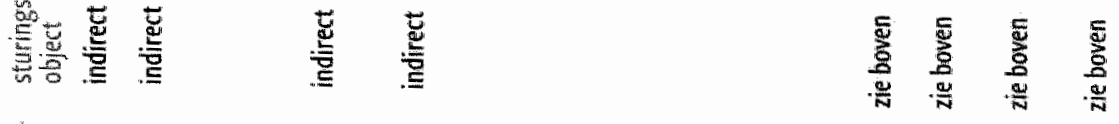

离

.

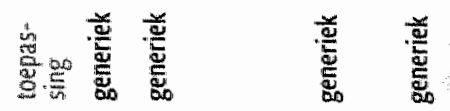

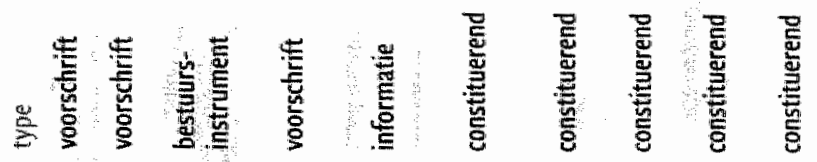

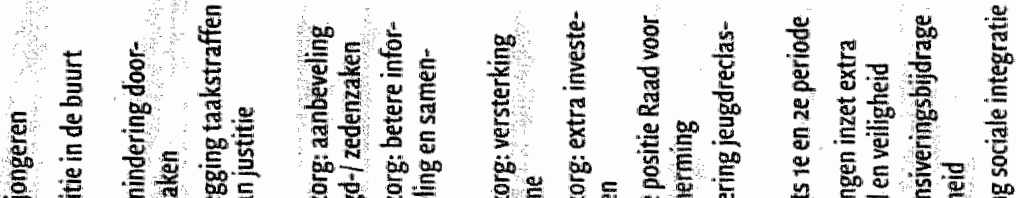

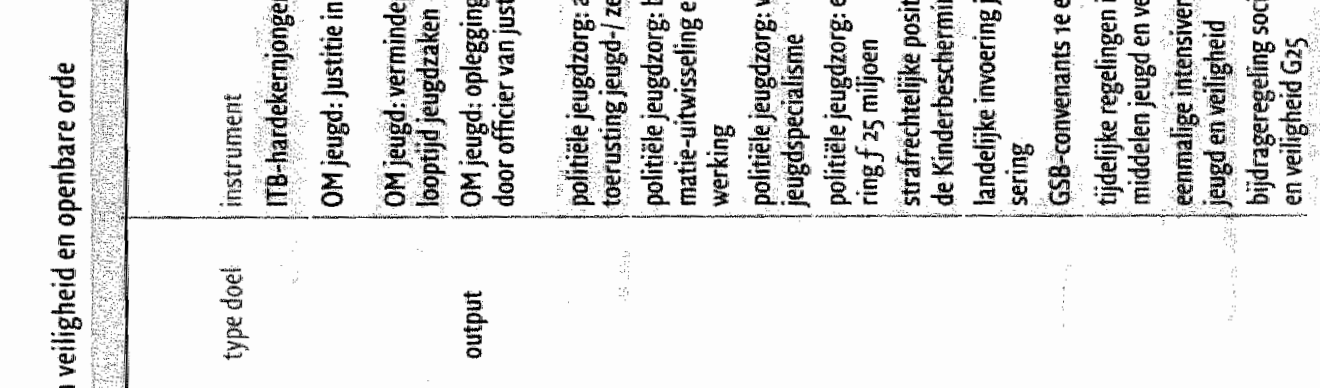

空

$\frac{50}{5}$

s.

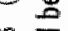

i

踏

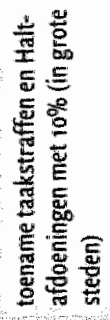




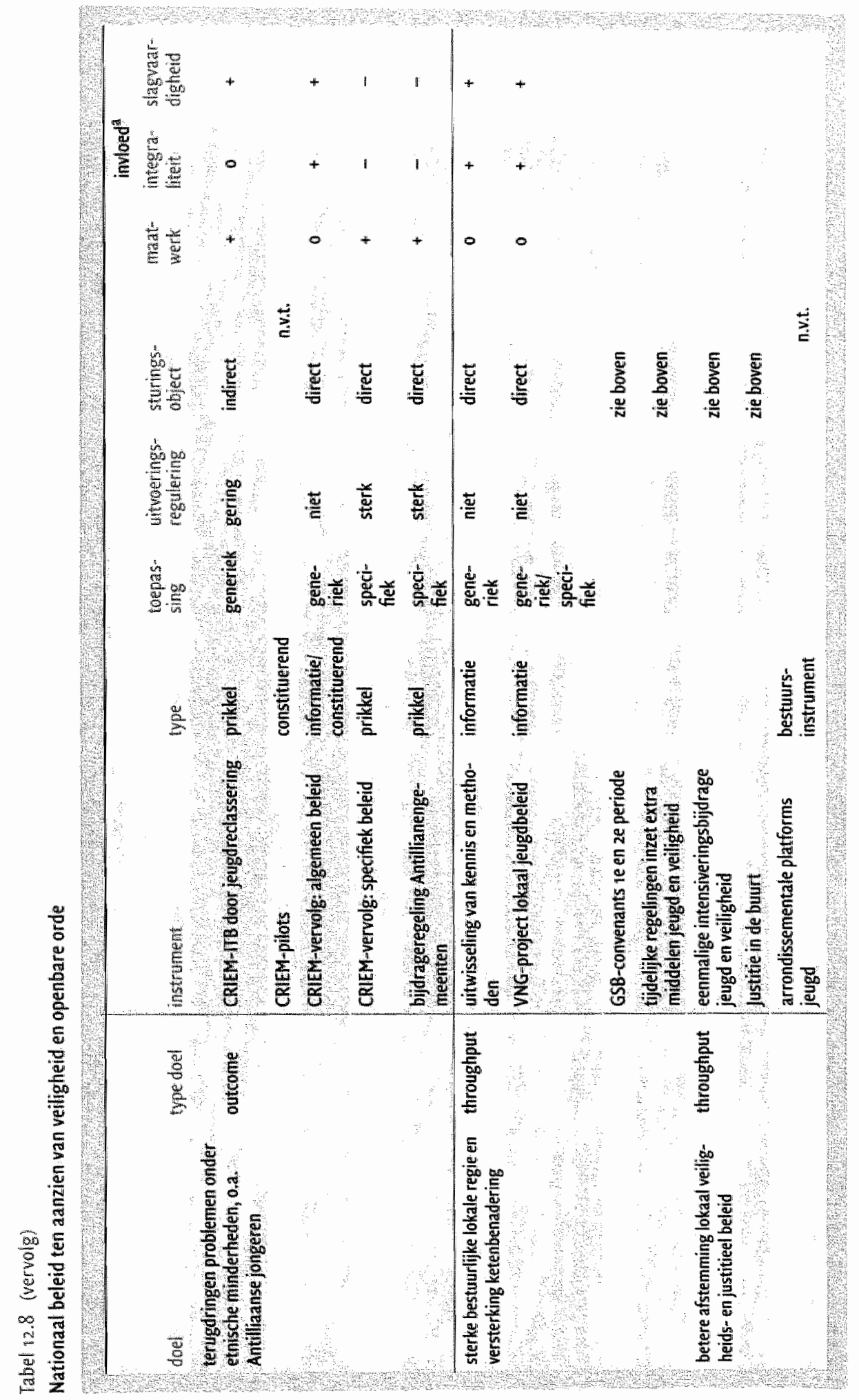




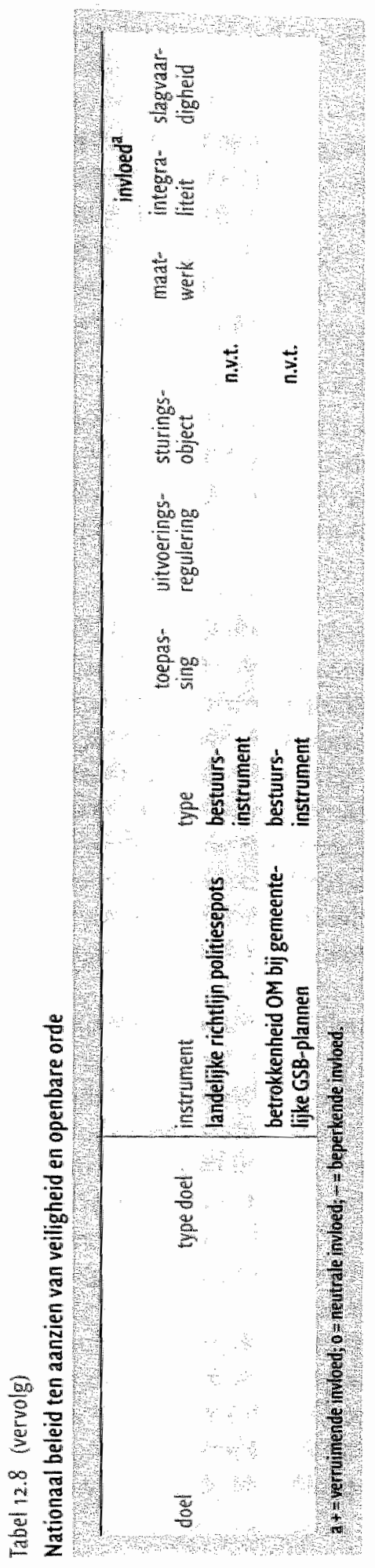

Het nationalejeugdueleid 301 


\section{.8 Arbeid en inkomen}

len van het nationale beleid

doel van het nationale beleid in deze pijler wordt treffend weergegeven door de edige titel van de Wet inschakeling werkzoekenden (Wiw): Regeling voor de totstandko$g$ van een gemeentelijk werkfonds voor voorzieningen ter bevordering van de toetreding tot het idsproces van langdurig werklozen en jongeren (Staatsblad I997d). Het beleid is erop icht alle jongeren die uit het onderwijs komen liefst zo snel mogelijk te laten deelten aan het arbeidsproces. Er moet een sluitende benadering zijn van jeugdwerksheid. Daarbij is een belangrijke rol weggelegd voor gemeenten.

vel in de eerste als in de tweede GSB-periode is de verbetering van de aansluiting sen scholing en arbeidsmarkt een nadrukkelijk doel van beleid (BZK I995a; BZK 5b; BZK 1998). In het Doorstattconvenant neemt het rijk de verplichting op zich om te ien hoe lastige schakels tussen school en arbeidsmarkt kunnen worden verbeterd.

trumenten van het nationale beleid 44

$t$ belangrijkste instrument om jongeren toe te leiden naar de arbeidsmarkt is de $w$, die begin 1998 in werking trad. In de Wiw is een aantal bestaande regelingen ntegreerd: de Banenpoolregeling uit 1990, de Jeugdwerkgarantiewet (JWG) uit $\|$, en een tijdelijke subsidieregeling voor de $\mathrm{G}_{4}$ met het doel de uitstroom uit nenpools en JWG naar reguliere arbeid of scholing te versterken. Een belangrijk el van de Wiw is om de bestaande wet- en regelgeving te vereenvoudigen, waaror de gemeentelijke beleidsvrijheid zou toenemen. De verschillende financieIgsstromen voor gemeenten zijn samengebracht in één brede doeluitkering, het meentelijk Werkfonds. Gemeenten zouden door de Wiw de mogelijkheid moeten ijgen een samenhangend instrumentarium te ontwikkelen voor de toeleiding van der meer jongeren naar de arbeidsmarkt.

: uitkering die gemeenten ontvangen voor het gemeentelijk Werkfonds bestaat uit ie onderdelen:

een basisbedrag van 57.000 gulden per gerealiseerde dienstbetrekking of arbeidsplaats, te declareren bij het rijk;

een vooraf vastgesteld budget voor aanvullende kosten van arbeidsplaatsen (met name bedoeld voor werklozen die ver van de arbeidsmarkt af staan en voor wie het basisbedrag niet toereikend is);

een jaarlijks budget voor scholing en financiële stimulansen, en voor kinderopvang (de KOA-middelen (zie $\$$ 12.3.6) maken geoormerkt deel uit van het Werkfonds). e Wiw schrijft voor dat de gemeente en de arbeidswoorzieningsorganisatie voor dere jongere (tot 23 jaar) die een uitkering bij de gemeente aanvraagt of die ingeshreven is als werkloos werkzoekende, een traject vaststellen dat gericht is op de ischakeling in het arbeidsproces. Binnen een jaar moet aan deze jongeren een ienstbetrekking worden aangeboden, tenzij zij nog voor minstens tg uur per week 
deelnemen aan voorzieningen die hun kans op inschakeling in het arbeidsproces vergroten, of als zij woor minstens $\mathrm{g} g$ uur per week elders een betrekking hebben.

De instrumenten die gemeenten onder meer ten dienste staan, zijn scholing en educatie, sociale activering, kinderopvang, detacheringen en werkervaringsplaatsen. Gemeenten worden geacht samen te werken met de arbeidswoorzieningsorganisatie (de latere Centra voor Werk en Inkomen) en de uitvoeringsinstanties sociale verzekeringen.

De nationale overheid ziet toe op een doelmatige en rechtmatige uitvoering van de Wiw.

Vanaf 9994 bestaat de zogenaamde regeling Stimuleringsprojecten allochtone groepen. Aanvankelijk zijn deze alleen gericht op werkloze Antilliaanse en Arubaanse jongeren. In 1998 komt er ook een regeling voor projecten gericht op werkloze Turkse en Marokkaanse jongeren (Schambach et al. 200r). Met ingang van 2001 is de regeling verbreed. Projecten gericht op werklozen uit andere etnische minderheidsgroepen komen voor een bijdrage in aanmerking. De leeftijdsbeperking van 18 tot $3^{\circ}$ jaar is losgelaten, WAO-ers ouder dan 40 jaar gaan tot de doelgroep behoren, evenals nietuitkeringsgerechtigde allochtone vrouwen. De projecten dienen aan de realisatie van de volgende doelstellingen bij te dragen: 45

- verbeteren van de aansluiting van etnische minderheden bij reguliere scholingsen arbeidsvoorzieningsinstellingen;

- bevorderen van de doorstroom van etnische minderheden naar werk en vergroten van het bereik van het reguliere gemeentelijke instrumentarium;

- ontwikkelen van methodieken waarmee etnische minderheden aansluiting kunnen vinden bij de arbeidsmarkt en reguliere toeleidende instellingen;

- bewerkstelligen dat reguliere instellingen specifieke aandacht besteden aan etnische minderheden;

- implementeren van de succesvolle ervaringen van stimuleringsprojecten in het reguliere activeringsbeleid.

De projectaanvragen worden gedaan door gemeenten. Een belangrijke voorwaarde is dat gemeenten ten minste de helft van de kosten van het project dragen. Verder zijn er voorwaarden gesteld aan het betrekken van relevante lokale instellingen en (zelf)organisaties of sleutelfiguren uit de gemeenschap bij zowel de opzet als de uitvoering van het project, aan de structurele inbedding van de methodiek bij gebleken succes, aan het leveren van gegevens voor een cliënt-volgsysteem aan een onderzoeksbureau dat belast is met de evaluatie, en aan de rapportage aan szw. Deze rapportages omvatten werkplannen en inhoudelijke en financiële tussenverslagen die op verschillende momenten moeten worden ingediend, en een inhoudelijk en financieel eindverslag. ${ }^{46}$ Van de Stimuleringsprojecten allochtone groepen is uiteindelijk door 28 gemeenten gebruikgemaakt; deze gemeenten hebben in totaal 44 projecten uitgevoerd (Mateman et al, 2004). Onder die gemeenten bevinden zich relatief veel GSB-gemeenten, ook omdat een deel van de regeling is ondergebracht in de pijler sociale infrastructuur van het grotestedenbeleid (TK 1999/2000k: 327). 
Een tijdelijke subsidieregeling geeft de $\mathrm{G}_{4}$ in de periode van 1998 tot en met 2000 extra middelen voor het activeren van bijstandscliënten, waaronder jongeren, naar Wiwactiviteiten en voor het bevorderen van de uitstroom uit Wiw-dienstbetrekkingen naar regulier werk (TK 1998/I999k: 8). De overige gemeenten kunnen gebruikmaken van de Stimuleringsregeling sociale activering (Staatscourant 200oi). Hiermee kunnen gemeenten nieuwe of extra projecten ontwikkelen om de moeilijke groep bijstandsgerechtigden te activeren en om hun sociale uitsluiting te verminderen. Tot de doelgroep behoren ook jongeren. De voorwaarden die aan de subsidie-uitkering worden gesteld, komen globaal overeen met die van de Stimuleringsprojecten allochtone groepen.

De aansluiting tussen onderwijs en arbeidsmarkt krijgt met name aandacht in het $\mathbb{R}$ MC-beleid (zie $\S \mathrm{I} 2.3 .3$ ), door het het aantal jongeren te verminderen dat zonder startkwalificatie aantreedt op de arbeidsmarkt.

\section{Overzicht en conclusies}

Het nationale beleid op het gebied van arbeid en inkomen heeft een doelstelling op outcome-niveau: de zo spoedig mogelijke deelname van schoolverlaters aan het arbeidsproces (zie tabel 12.9). Daartoe is het onder meer van belang dat de aansluiting tussen onderwijs en arbeidsmarkt wordt verbeterd. Dit is een meer procesmatige throughput-doelstelling.

De instrumenten waarmee getracht wordt het gedrag van lokale actoren, in dit geval de gemeente, te beïnvloeden, zijn divers. Belangrijk is het juridische instrument van de Wiw, dat gemeenten bepaalde taken oplegt en daarom het vermogen tot maatwerk beperkt. Tegelijkertijd laat de Wiw gemeenten veel ruimte in de wijze waarop de taken worden gerealiseerd, en dit heeft positieve gevolgen voor het vermogen tot integraal en slagvaardig beleid. Naast de Wiw is er een aantal economische instrumenten. Deze vergroten de handelingsmogelijkheden van gemeenten en daarmee het vermogen tot maatwerk, maar beperken de vrijheid in de uitvoering, waardoor zij een beperkende invloed hebben op het vermogen tot een integraal en slagvaardig beleid te komen.

Het RMC-beleid dat onder meer tot doel heeft de aansluiting tussen onderwijs en arbeidsmarkt beter te laten verlopen, is in paragraaf 12.3 .3 aan de orde geweest. 


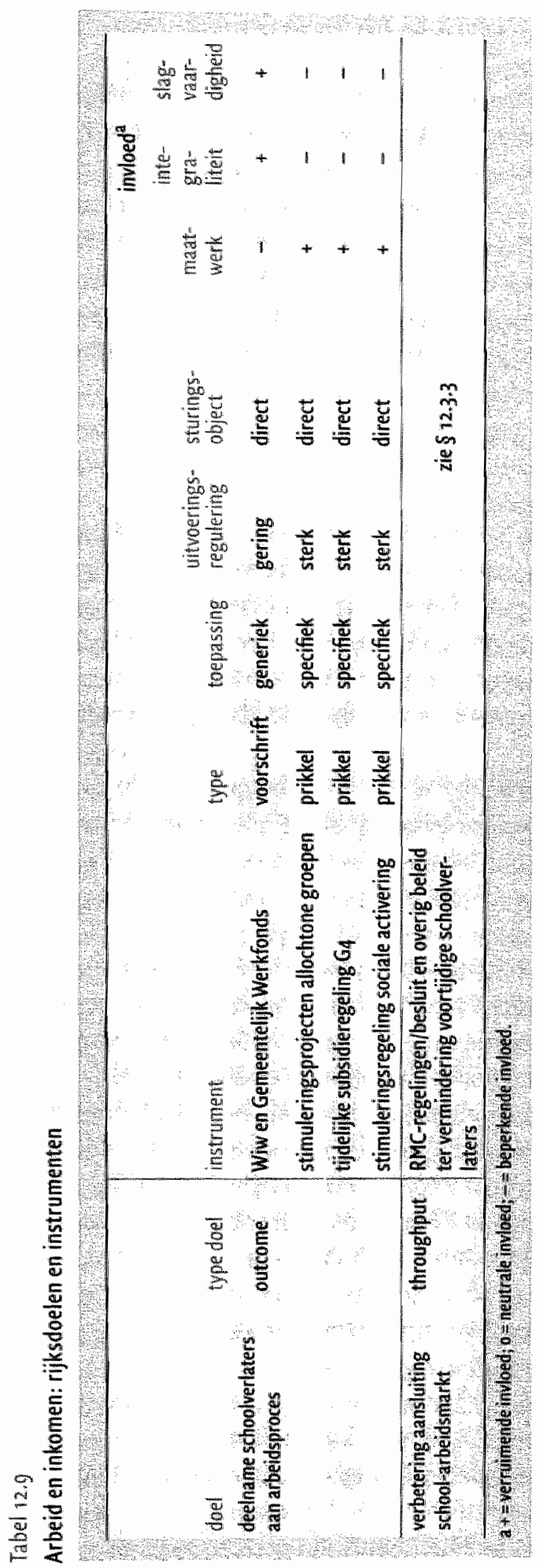

Het notionale jeudbeleid 305 


\subsubsection{Wonen}

We kunnen deze paragraaf kort houden. De nationale overheid heeft geen bellid met betrekking tot jongerenhuisvesting. In de nota Volkshuisvesting in de jaren negentig (TK $1988 / \mathrm{Ig} 89$ ) stelt VROM dat de bouw van nieuwe woningen woor jongeren een verantwoordelijkheid van gemeenten en opdrachtgevers is. De jongerentabel in de individuele huursubsidie is afgeschaft. Wel zal bevorderd worden dat er meer kamers zullen worden verhuurd, wat vooral de huisvesting van jongeren ten goede zal komen. In de Nota Wonen uit december 2000 ( $V R O M$ 2000) wordt terloops aandacht besteed aan studentenhuisvesting. Er wordt een onderzoek naar vraag en aanbod door ocw aangekondigd.

\subsection{Conclusies}

In dit hoofdstuk hebben we het nationale beleid dat relevant was voor het lokale jeugdbeleid in de periode van I 998 tot en met 2001 geïnventariseerd en geanalyseerd. We hebben getracht het nationale beleid te beoordelen op zijn beperkende of verruimende invloed op het beleidsvormende vermogen van lokale actoren, en hadden daarbij bijzondere aandacht voor de gemeente vanwege haar centrale rol in het lokale jeugdbeleid. In deze slotparagraaf proberen we de tweede centrale vraag van dit onderzoek te beantwoorden:

Op welke wijze tracht de centrale overheid het lokale jeugdbeleid te beïnvloeden en wat betekent dat voor de mogelijkheden die gemeenten hebben om een effectiefjeugdbeleid tot stand te brengen?

\section{Grote hoeveelheid nationaal beleid}

De analyse van het nationale beleid maakt in de eerste plaats duidelijk dat de hoeveelheid door de nationale overheid geproduceerd beleid in de relatief korte periode van 1998 tot en met 200 I groot is. Met uitzondering van het beleidsdomein wonen heeft de nationale overheid op alle onderscheiden inhovdelijke pijlers van het jeugdbeleid ten minste enkele, en vaak een behoorlijke hoeveelheid beleidsdoelen geformuleerd en instrumenten ingezet. Vooral bij de pijlers onderwijs, opvoeding/ thuissituatie en veiligheid en openbare orde is de hoeveelheid beleid groot. En in de pijler kinderopvang buitelen de wijzigingen in de regeling over elkaar heen. Vooral het aantal financiële prikkels moet voor met name wethouders en coördinerende ambtenaren jeugdbeleid soms lastig te overzien zijn geweest. Daarnaast was er sprake van een forse inzet van communicatieve sturingsinstrumenten. 47

... maar niet woor alle gemeenter

Bij deze constatering over de omvang van het nationale beleid past wel een tweetal kanttekeningen. In de eerste plaats is veel beleid niet gericht op het jeugdbeleid van alle gemeenten. Veel beleid, vooral het meer probleemgerichte jeugdbeleid, kent juridische en economische instrumenten die uitsluitend zijn gericht op gemeenten 
waarvan verondersteld wordt dat de problematiek er aanwezig respectievelijk relatief omvangrijk is. Dat neemt niet weg dat deze veelal grotere gemeenten met een forse hoeveel heid nationaal beleid worden geconfronteerd. Het is de vraag in hoeverre alleen al de omvang van het nationale beleid waar gemeenten 'iets mee moeten' een bedreiging vormt voor de integraliteit en slagvaardigheid in het lokale jeugdbeleid.

\section{... en het lijkt sams meer dan het is}

In de tweede plaats is er ook de schijn van beleid. In beleidsnota's en beleidsbrieven worden niet zelden reeksen beleidsmaatregelen opgesomd, waarvan de indruk wordt gewekt dat het om 'nieuw' beleid gaat. Dat blijkt niet altijd het gevall. Een goed voorbeeld daarvan is de nota over het integratiebeleid Kansen krijgen, kansen pakken (TK I998/I999d), waarin een compleet actieprogramma "jeugd van etnische minderheidsgroepen' plus bijbehorend uitvoeringsplan (TK Igg8/xg9ge) wordt gepresenteerd. In feite wordt echter een aantal beleidsmaatregelen op het gebied van vve, voortijdig schoolverlaten, jeugdgezondheidszorg, opvoedingsondersteuning, enzovoort, opgesomd. De nota's zelf bevatten nauwelijks nieuw beleid. Een ander voorbeeld is het Integraal Veiligheidsprogramma. Daarin worden rond het thema jongeren en veiligheid nauwelijks nieuwe instrumenten genoemd. Het programma omvat vooral een opsomming van 'oud' beleid. Het is dit opnieuw inkaderen of herordenen van staand belleid in nieuwe beleidsprogramma's die de suggestie van beleidsdrukte mede in de hand werkt.

Een andere uitingsvorm van de schijn van beleid treffen we minder vaak aan: het groter voorstellen van beleidsmaatregelen dan ze feitelijk zijn. Typische voorbeelden daarvan zijn de experimenten Communities that Care, os-o in de wijk en CRIEM. In deze gevallen gaat het om experimenten in een zeer beperkt aantal gemeenten. De experimenten zijn te typeren als constituerende instrumenten: ze hebben vooral een leerdoel ten behoeve van toekomstig beleid. Vanzelfsprekend zijn dergelijke experimenten daarom belangrijk, maar in veel beleidsbrieven en -nota's wordt de indruk gewekt dat het gaat om op grote schaal toegepaste beleidsprogramma's.

Tot slot moeten in dit verband de Bestuursakkoorden Nieuwe Stijl (BANS 1999a; BANS 20or) worden genoemd. Deze akkoorden zijn vaak afgeschilderd als belangrijke beleidsinstrumenten in het jeugdbeleid, omdat hiermee de verschillende overheidslagen zich zouden committeren aan gezamenlijke afspraken. ${ }^{48}$ Hierbij past echter de belangrijke kanttekening dat het BANs voor gemeenten op geen enkele manier bindend is. De gemeenten worden door hun belangenbehartiger, de vNG, aangezet om mee te werken aan het realiseren van de afspraken, maar zijn daartoe niet verplicht. De sterke kapitalisatic op BANs in veel beleidsnota's van de nationale overheid ('met de gemeenten is afgesproken dat ...') komt daarmee in een ander daglicht te staan. De akkoorden passen weliswaar in de nieuwe sturingsfilosofie van governance en hebben hun invloed op lokaal beleid (vgl. Kwekkeboom et al. 2002), maar zijn tegelijkertijd voor gemeenten vrijblijwend, daar waar vaak een andere indruk wordt gewekt. 49 
Invloed op het lokale jeugdbeleid

Wat is nu de (mogelijke) invloed van al dat nationale beleid op het lokale jeugdbeleid? In het algemeen kan gesteld worden dat betrekkelijk veel doelen van de nationale overheid geformuleerd zijn op output- of outcome-niveau. Dat wil zeggen dat deze beleidsinhoudelijke doelstellingen in beginsel gunstig zijn voor de handelingsruimte van lokale actoren. Voor elke pijler waarvoor de nationale overheid beleid heeft ontwikkeld, met uitzondering van de kinderopvang, is op zijn minst één outcome-doelstelling geformuleerd. Vaak gaan deze echter gepaard met één of meer output-doelstellingen. Kennelijk durft de nationale overheid het niet aan om het bij outcome-doelstellingen te laten. De nationale overheid vult daarmee haar kaderstellende rol niet alleen in door maatschappelijke effecten te verlangen van lokale actoren, maar ook door om concrete beleidsprestaties te vragen. De throughputdoelstellingen, die betrekking hebben op het beleidsproces, hebben bijna allemaal te maken met de invulling van de gemeentelijke regierol. Omdat men deze doelstellingen in het algemeen tracht te realiseren door communicatieve en dus meer vrijblijvende beleidsinstrumenten, is dat voor de beleidsruimte van lokale actoren niet problematisch. Integendeel: informatie over de wijze waarop de regierol op een effectieve manier kan worden vormgegeven kan deze rol alleen maar ten goede komen. Een uitzondering vormt het grotestedenbeleid, dat een aantal dwingende voorwaarden stelt aan de gemeentelijke regie. Daarover later meer.

\section{Gunstig voor maatwerk}

Veruit de meeste instrumenten hebben een verruimende of neutrale invloed op het vermogen van lokale actoren om tot maatwerk te komen. Deze instrumenten verruimen de handelingsmogelijkheden, respectievelijk perken deze mogelijkheden niet in. Vooral van de economische beleidsinstrumenten (prikkels) gaat een verruimende invloed uit. Dat komt omdat gebruikmaking van deze prikkels niet is af te dwingen en omdat de meeste van deze instrumenten ruinte laten voor een specifieke lokale invulling, weliswaar binnen de aangegeven kaders. Opnieuw vormt het grotestedenbeleid een uitzondering: door de steden een beleidskader voor te schrijven waarin de marges om van de nationale doelstelling af te wijken gering zijn, worden de mogelijkheden tot een op de lokale situatie toegesneden beleid beperkt.

\section{Ongunstig voor integraliteit en slaguaardigheid}

Als we echter kijken naar de invloed van de nationale beleidsinstrumenten op het vermogen tot integraliteit en slagvaardigheid, dan zijn de conclusies minder positief. Veel van de economische sturingsinstrumenten, en in mindere mate de juridische sturingsinstrumenten, hebben een beperkende invloed op het lokale vermogen tot integraliteit en vaak ook slagvaardigheid. In de meeste gevallen vloeit dit voort uit de mate van uitvoeringsregulering die de instrumenten kennen. Naast inhoudelijke en financiële verantwoordingseisen worden er niet zelden ook eisen gesteld aan de wijze waarop het lokale beleidsproces dient te worden georganiseerd. Verder is een behoorlijke hoeveelheid instrumenten gericht op andere actoren dan de gemeente. 
De functionele kaders die op deze wijze mede het bestuurlijke regime vormen waarbinnen deze andere actoren opereren, compliceren de regietaak van de gemeenten om tot een integraal jeugdbeleid te komen. Tegelijkertijd versterken dergelijke instrumenten vaak de positie van deze actoren, wat hun slagvaardigheid ten goede komt. Daarmee blijken vooral indirecte instrumenten een tweeslachtige werking te hebben: ongunstig voor een integrale beleidsvoering, gunstig voor slagvaardig beleid. Deze tweeslachtige werking is op een hoger niveau terug te voeren op de in hoofdstuk I behandelde spanning tussen territoriale en functionele decentralisatie.

Het vermogen om integraal en slagvaardig beleid te voeren wordt in de meeste pijlers wel versterkt door communicatieve beleidsinstrumenten. Deze instrumenten kunnen door lokale actoren vrijblijvend worden gebruikt en passen bij uitstek in de ondersteunende rol van de nationale overheid. Met name het VNG-project lokaal jeugdbeleid, dat voorzag in de intensieve ondersteuning van de gemeentelijke regierol in het lokale jeugdbeleid, is een goed voorbeeld van hoe deze ondersteunende rol kan worden vormgegeven.

\section{Export van departementale verkokering}

De verschillen in sturingsfilosofie tussen de meest bij het jeugdbeleid betrokken ministeries komen duidelijk naar voren uit de analyse van het nationale beleid (vgl. Bressers en Ringeling 1989 ; Veenswijk 1996 ). Het is duidelijk dat ieder ministerie zijn eigen tradities en gewoonten heeft in zijn relatie met het lokale bestuur. Het valt op dat de ministeries van BZK en Justitie de lokale actoren meer ruimte laten, waarbij Justitie tegelijkertijd ook kampt met de spanning tussen functionele en territoriale decentralisatie. De regeldichtheid bij OCw en vws is veel groter; lokale actoren hebben bij regelgeving van deze ministeries in het algemeen met een sterkere mate van uitvoeringsregulering te maken. Bovendien valt ocw op als departement dat relatief vaak voor juridische beleidsinstrumenten kiest, wat te maken heeft met de in artikel 23 van de Grondwet geregelde pacificatie tussen algemeen en bijzonder onderwijs (Mentink 2004). Deze verschillen in sturingsfilosofie hebben daardoor ook een verschillende werking op het beleidsvormende vermogen van lokale actoren. Het beleid van ocw en vws beperkt het lokale jeugdbeleid sterker dan het beleid van vooral BZK. Tegelijkertijd betekent de verschillende inzet van beleidsinstrumenten door ministeries dat lokale actoren met van elkaar afwijkende uitvoeringsregimes hebben te maken. In zekere zin is er sprake van export van de verkokering tussen ministeries naar het lokale niveau. We mogen aannemen dat dit de gemeentelijke regie compliceert en daarmee een negatief effect heeft op met name het vermogen tot een integrale beleidsvoering.

\section{Bijzondere werking van het grotestedenbeleid}

Hierboven is al ingegaan op de bijzondere positie van het grotestedenbeleid. Het GSB is, naast het juridische instrumentarium van het onderwijsachterstandenbeleid en de daaruit voortvloeiende onderwijskansenaanpak, het enige beieidsinstrument dat 
een beperkende invloed heeft op het lokale vermogen tot maatwerk. Dat leidt in de praktijk tot beleidsuniformiteit tussen de steden (ROB en RFV 2001; Denters 2000). De nationale overheid formuleert de beleidskaders met een aantal doelstellingen (output en outcome) waaraan de steden moeten werken. De steden hebben daarbij wel enige vrijheid om deze nationale beleidskaders in hun meerjarenontwikkelingsplannen te operationaliseren. In zoverre de doelstellingen op outcome-niveau zijn geformuleerd, kan echter worden gesteld dat het rijk invulling geeft aan zijn kaderstellende rol en dat de inbreuken op het lokale vermogen tot maatwerk dan maar voor lief dienen te worden genomen.

De eerste GsB-periode, die liep tot 1999 , kende een projectmatige aanpak waarin de beschikbare gelden steeds op basis van stedelijke projectvoorstellen werden verdeeld. Deze aanpak wordt later in een rapport van BZK (2002: 5) als volgt gekenmerkt: 'De steden verwelkomden het extra geld, maar verloren energie en slagkracht door de plicht telkens opnieuw projecten in te moeten dienen. Ook bij het rijk legde deze werkwijze een groot beslag op de beschikbare capaciteit. Mede daarom is er in GSB-I slechts beperkt voortgang geboekt met ontkokering en deregulering.' 'De tweede GSB-periode (van 1999 tot en met 2004) kende een meerjarige programmatische aanpak, waarin het rijk en de steden overeenkomsten woor de hele periode sloten. In de voor het jeugdbeleid relevante sociale pijler is een aantal regelingen gecreëerd waarmee diverse specifieke uitkeringen gebundeld zijn in een brede doeluitkering. Deze afzonderlijke regelingen hebben daardoor, in tegenstelling tot de meeste andere bijdrageregelingen, een verruimende invloed op het vermogen tot een integrale beleidswoering te komen. Niettemin heeft het grotestedenbeleid, en met name de sociale pijler, in zijn onderlinge samenhang bezien ook een beperkende invloed op het beleidswormende vermogen. De Sociaal-Economische Raad (SER) stelde in 2002 vast dat alleen al binnen de sociale pijler gemeenten over veertig regelingen verantwoording moeten afleggen (SER 2002: 23). Het Centraal Planbureau ( $\mathrm{CPB} 2000)$ spreekt van beleidsmatige versnippering en van fragmentatie in tientallen departementale regelingen in de sociale pijler (vgl. ROB en RFV 200I; Visitatierapport G2I 2002; Gilsing et al. 2001).

\section{Langdurige wetgevingstrajecten us. korte reactietijd voor gemeenten}

Een laatste punt met betrekking tot het nationale beleid zijn de langdurige wetgevingstrajecten. De Wet op de jeugdzorg, de wijziging van de wCPv en de Wet kinderopvang: het zijn voorbeelden van wetten die hun schaduw lang voor hun inwerkingtreding vooruit hebben geworpen, met vaak ook directe gevolgen voor het lokale jeugdbeleid. Zo is er in het kader van de Wet op de jeugdzorg lang sprake geweest van een verplichting tot overleg tussen provincie en gemeente over de posities van de Bureaus Jeugdzorg ten aanzien van het lokale jeugdbeleid, maar deze verplichting is uiteindelijk niet in de wet opgenomen. De situatie was voor lokale actoren daardoor lang onduideliijk. Hetzelfde kan worden opgemerkt over de door het rijk aangekondigde monitoren, zoals op het gebied van GOA, vve en jeugd. De totstandkoming van deze monitoren laat lang op zich wachten. De lange wetgevings- 
en beleidstrajecten staan bovendien in schril contrast met de termijnen die soms aan economische instrumenten als financieringsregelingen zijn gekoppeld. De termijn waarop gemeenten hun plannen bij het betreffende ministerie moeten inleveren, bedraagt soms niet meer dan een paar weken. Het is sterk de vraag of dergelijke termijnen het lokale jeugdbeleid ten goede komen.

\section{Conclusie: tweeslachtig nationaal beleid}

We moeten concluderen dat er sprake is van een tweeslachtig nationaal beleid. Enerzijds toont het rijk zich bewust van zijn kaderstellende rol ten opzichte van het lokale beleid, waarbij aan lokale actoren ruimte wordt gelaten de kaders in te vullen. Bovendien tracht zij vooral met economische beleidsinstrumenten het lokale vermogen om tot maatwerk te komen te verruimen. Daarnaast zet het rijk een fors aantal conmunicatieve beleidsinstrumenten in om bijwoorbeeld de gemeentelijke regie, gericht op de totstandbrenging van een integraal beleid, te versterken, en om de slagvaardigheid van afzonderlijke actoren te vergroten. Anderzijds is er de sterke mate van uitvoeringsregulering die veel instrumenten kenmerkt en die het lokale vermogen tot een integraal en slagvaardig beleid beperkt. Bovendien bemoeilijkt de versterking van de functionele kaders waarbinnen sommige actoren opereren de gemeentelijke regie in een toch al complexe bestuurlijke omgeving. Tot slot is het waarschijnlijk dat de grote hoeveelheid nationale beleidsdoelen en -instrumenten, met zijn vele verantwoordingsregels en proceseisen, het beleidsvormende vermogen van gemeenten beperken. 
1 Het eerste Beleidskader is het Beleidskader preventieve en curatieve jeugdzorg 1996-1999. Zie vws et al. 1995, vws et al. 1996, vws et al. 1997, vws et al. 1998, wws et al. 1999 .

2 Aanvankelijik de G15: Almelo, Amhem, Breda, Deventer, Eindhoven, Enschede, Groningen, Helmond, Hengello, "s-Hertogenbosch, Leetwarden, Maastricht, Nijmegen, Tilburg en Zwolle; in 1996 uitgebreid tot de GzI met Dordrecht, Haarlem, Heerlen, Leiden, Schiedam en Venlo. In 1999 werden 5 partiêle GsB-steden (G5) toegevoegd: Alkmaar, Amersfoort, Emmen, Lelystad en Zaanstad. G4 en G 2I vormen samen de G25; $\mathrm{G}_{21}$ en $\mathrm{G}_{5}$ de $\mathrm{G}_{2} 6$. Alle steden vormen samen de $\mathrm{G}_{3} 0$.

3 In 2000 werden ook door ocw middelen toegevoegd. Deze waren specifiek bestemd voor de ondersteuning van de implementatie van voor- en vroegschoolse educatie door gemeenten; zie verder paragraaf 12.3 .4 .

4 In het verslag over de uitwoering van de Welzijnsnota 1995-1998 (vws r998) blijkt dat het programma opwoedingsondersteuning is ingeschoven in het programma lokaal preventief jeugdbeleid.

5 Het aantal programma's is groot. Gelauff-Hanzon en De Gruijter (1999) geven een overzicht van elf voorschoolse en drie schoolse programma's. De ondersteuning door vws verschilde per programma.

6 Voor een beschrijving van de overeenkomsten en verschillen tussen $\mathrm{CtC}$ en $\mathrm{O} \& \mathrm{O}$ op wijkniveau, zie de evaluatie van Zunderdorp Beleidsadvies \& Management (2002).

7 Als de aangewezen gemeente geen aanvraag wil indienen, kan de minister een andere gemeente aanwijzen.

8 I8 miljoen gulden wordt verdeeld over GGD-regio"s op basis van het aantal jonge kinderen per $\mathrm{x} / \mathrm{x} / 2000$ en $\mathrm{x} 7$ miljoen gulden op basis van de gewichtenregeling van het ministerie van ocw. Voor de gewichtenregeling, zie noot 15 .

9 De regeling is dan ook verwallen per $1 / 1 / 2003$ (Staatscourant 2002).

ro Aanvragen voor het jaar 2001 dienden binnen te zijn voor $30 / 4 / 200 \mathrm{r}$; de regeling stond in de Staatscourant op 3 o/3/200r.

II Oorspronkelijk was het de bedoeling dat de VNG zich in het overhedenoverleg van mei zooo zou committeren aan de door gemeenten te behalen resultaten, maar hiervan is later klaarblijkelijk afgezien. Ook in het eerste geval zijn individuele gemeenten echter niet gebonden.

12 Feitelijk is dit een wet waarin een aantal onderwijswetten (onder meer de Wet op het basisonderwijs en de Wet op het voortgezet onderwijs) wordt gewijzigd ten behoeve van het gemeentelijk onderwijsachterstandenbeleid.

$x_{3}$ Leerlingen met gedragsproblemen, gerelateerd aan opvoedings- en sociaal-emotionele problematiek. In jargon: kinderen met leer-en opwoedingsmoeilijkheden - $(z)$ lonkinderen, moeilijk lerende kinderen - (z)mlk-kinderen, en in hun ontwikkeling bedreigde kleuters - iobk-kinderen.

14 Door de Europese Raad is in 2000 in Lissabon bovendien afgesproken dat de lidstaten het aandeel voortijdige schoolverlaters in 20 ro bebben gehalveerd.

15 Scholen ontwangen volgens een bepaalde sleutel gewichtenmiddelen voor het aandeel gewichtenleerlingen in hun leerlingenpopulatie. In de Gewichtenregeling basisonderwijs zijn criteria geformuleerd op grond waarvan basisscholen in aanmerking komen voor extra middelen voor personeelsformatie. Deze criteria zijn gebaseerd op een inschatting van de gemiddelde onderwijsachterstand van kinderen. In de regeling worden vier gewichten onderscheiden: van $\mathrm{I}, 9$ voor leerlingen met ouders uit etnische 
minderheidsgroepen én een laag beroeps- en opleidingsniveau, tot $\mathrm{I}, 25$ voor (grofweg) kinderen van autochtone ouders met een lage opleiding ( $\mathrm{x} K \mathrm{x} 997 / \mathrm{rg9} 8 \mathrm{~d}$ ).

I6 De inwerkingtreding van de wer leidde niet tot wijziging van de toekenning wan financiële middelen voor dit doel aan gemeenten. Zij ontvingen per $1 / 1 / 98$ als lump sum de bedragen die zij tot dat moment ook al ontwingen op basis van diverse regelingen en beschïkingen die in de wet GoA werden ondergebracht (0.a. NT2- en gebiedsmiddelen, en eventueel projectmiddelen).

17 Met onderinstromers wordt gedoeld op leerlingen die in groep $x$ van de basisschool beginnen. Zij-instromers komen in een hogere groep het basisonderwijs binnen.

18 Zie noot 15 .

Ig Voor de $\mathrm{G}_{4}$ is voor 2000 en $200 \mathrm{r}$ in total 33,5 miljoen gulden beschikbaar, voor de G2r en roo+-gemeenten in $200 \times 15$ miljoen gulden. Vanaf 2002 volgt uitbreiding naar alle gemeenten met basisscholen met meer dan $70 \%$ gewichtenleerlingen (Uitleg gele katern 2002).

20 Zie bijvoorbeeld Financiële impuls voor basisscholen met veel achterstandsleerlingen (Uitleg gele katern 2000a).

2. Zie Regeling financiële impuls voor ICr-toepassingen op scholen met veel achterstandsleerlingen in het basis- en het (voortgezet) speciaal onderwijs (Uitleg gele katern 200ra).

22 Mentink (2004: 225) stelt dat de vraag of het LBK gemeenten "in rechte" bindt moeilijk te beantwoorden is, en daardoor voor veel onduidelijkheid heeft gezorgd.

23 Eerder is in tapporten van het Sociaal en Cultureel Planbureau (SCP) betoogd dat het GOA-model leidde tot een heldere afbakening van verantwoordelijkheden tussen rijk, gemeenten en instellingen ( $\mathrm{SCP}$ 1998; Gilsing et al. 2000: 107). Dat neemt niet weg dat de mate van uitvoeringsregullering een beperkende invloed heeft op het lokale vermogen om tot een integraal en slagvaardig beleid te komen.

24 Dit besluit komt wat betreft strekking en inhoud overeen met de Regeling regionale meld- en coördinatiefunctie voortijdig schoolverlaten uit 1994, toen is gekozen voor een regelling vanwege het spoedeisende karakter van de te bekostigen activiteiten (Staatscourant 1994).

25 De wet regelt alleen de melding van niet-leerplichtigen en de onderlinge afstemming van systemen voor leerplichtigen enerzijds en niet-leerplichtigen anderzijds. Daarnaast regelt de wet, net als het Tijdelijk besluit, de coördinatiefunctie van de contactgemeente. Een belangrijk nieuw element in de wet is dat er is gekozen voor "wettelijk geconditioneerde zelffregulering'. De meldplicht voor scholen van niet-leerplichtige schoolverlaters is nu wettelijk geregeld en geldt niet alleen woor de gemeenten die een specifieke uitkering aanvragen (via het Regionaal actieplan), maar voor alle gemeenten. Bowendien wordt alle gemeenten voorgeschreven regionaal samen te werken in een RMC-functie; de keuzevrijheid voor gemeenten om dit wel of niet te doen is in de Wet weggenomen. De regio-indeling wordt geregeld bij of krachtens AMvB (zie Staatsblad $200 \mathrm{rb})$ en sluit aan bij de indeling volgens de Wet gemeenschappelijke regelingen. Het bedrag dat ter beschikking staat is verhoogd naar $\mathrm{f} x 2$ miljoen per jaar.

26 In de WCPV is onder meer opgenomen dat gemeenten om de vier jaar een nota gezondheidsbeleid moeten uitbrengen, waarin ze expliciet aandacht besteden aan de jeugdgezondheidszorg. Daarnaast ontstaat voor gemeenten een wettelijke plicht om het basistakenpakket jeugdgezondheidszorg uit te voeren, walarvan de nadere definièring plaatsvindt via AMvB.

27 Zie ook Van der Poel (2003). 


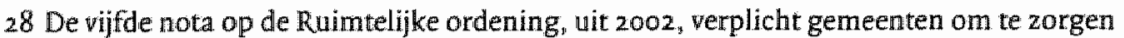
voor voldoende duurzame en weilig ingerichte ruimte, waarbij aan iedereen mogelijkheden worden geboden voor ontplooiing, ontmoeting en ontspanning. In het bijzonder dient daarbij aandacht te worden besteed aan de speelruimte die kinderen nodig hebben. Het rijk vindt dat gemeenten (en provincies) jeugdigen bij de inrichting van de openbare ruimte moeten betrekken (zie TK 2001/2002c).

29 Onder breedtesport wordt verstan: sportactiviteiten die op lokaal niveau plaatsvinden en die niet op beroepsmatig of op topsportaiveau worden uitgeoefend.

30 Zie http://www.cuituurnetwerk.nl/beleid, geraadpleegd op 2-rI-2004.

3I Zie http:/Www.minocw.nl/cultuurbeleid/notas/index.html, geraadpleegd op 3-II-2004.

32 Oorspronkelijk aangekondigd als de Wet basisvoorziening kinderopvang.

33 Naast de regelingen die gericht waren op de uitbreiding wan de kinderopvang, zijn er ook projecten en experimenten geweest die gericht waren op kwaliteitszorg en verbetering wan de beleidsinformatie (zie TK $1997 / 1998$ a). Vanwege hun sterk sectoralle karakter blijven deze experimenten hier verder buiten beschouwing.

34 Doordat de bso voor deze oudere kinderen vanwege de samenwerking met andere instellingen meer als uitwalsbasis dan als opvangplek zou fungeren, werd in de toelichting op de regeling vooruitgelopen op een aanpassing van het Tijdelijk besluit kwaliteitsregels kinderopwang, waarin werd geregeld dat het aantal kinderen ouder dan 8 jar in een groep van twee leiders groter mocht zijn dan in een groep kinderen van 4 tot 8 jaar. De financiering werd hierop aangepast. In r 998 werd een Ontwerp-besluit wijziging Tijdelijk besiluit kwaliteitsregels kinderopuang bekendgemaakt (Staatscourant I998b), maar dit is na overleg met partijen in de CAO-welzijn niet ingevoerd (zie Staatscourant I999c).

35 Het gaat in 1999 om 50 miljoen gulden, in $2000 \mathrm{om} 120$ miljoen, in $2001 \mathrm{om}$ r $70 \mathrm{mil}$ joen en in 2002 om 250 miljoen (TK 1999/2000a).

36 De kOA-regeling is ondergebracht in de Wet kinderopvang, die wan kracht is vanaf r januari 2005. Overigens werd aanvankelijk onderbrenging in de Wiw beoogd.

37 Investering: 4000 gulden per plaats; woorbereiding en ontwikkeling: 2000 gulden per plaats; en in totaal niet meer dan 75.000 gulden per project.

38 Voor een overzicht van het jeugd-en veiligheidsbeleid in het kader van het grotestedenbeleid, zie Van Aart et al. (1997).

39 Gemeenten moeten de plannen indienen voor $1 / 1 / 2000$, terwijl de publicatiedatum van de regeling $10 / 10 / 2000$ is. De betrokken gemeenten zijn geïnformeerd per brief van 4/ $\mathrm{ro} / 2000$ (zie de evaluatie door Assen et al. 2004).

40 In de cerste GSB-periode waren er de Regelingen impuls leefbartheid, weiligheid en stadseconomie voor respectievelijk de $\mathrm{G}_{4}$ (Staatscourant I995), de G.15 (Staatscourant 19g6c) en de G6 (Staatscourant I $997 \mathrm{~d}$ ). Deze regelingen waren onder meer gericht op de leefbaarheid en veiligheid wan de leefomgeving.

$4 \mathrm{I}$.De publicatiedatum van de regeling is $\mathrm{I} 8 / 5 / 200 \mathrm{r}$ en de plannen moeten uiterlijk $x / 6 / 200 \mathrm{I}$ zijn ingediend.

42 Zie de Externe commissie CRIEM (s.a.: r9-20), die spreekt van de ongewenste nevenschikking van doel (afglijden tot criminaliteit) en middel (integratie). Het eenzijdige accent op criminaliteit is volgens de commissie een belemmering voor integratie.

43 "Bij het derde beleidsspoor (wve, rg) is een zekere souplesse wan geest noodzakelijk om in de praktijk aan allochtone ouders van zeer jeugdige kinderen het verband tussen het voorkomen en tegengaan van achterstanden in de ontwikkeling van heel jonge kinderen en criminaliteit op latere leeftüjd te kunnen of durven uitleggen. ' (Externe commissie CRIEM S.a.: Ig). 
44 Voor de beschrijving van de Wiw is gebruikgemaakt van Dut (s.a., in het Handboek jeugdbeleid) en van de Schuurmans en Jordens-editie Nederlandse wetgewing (Van de Boom 1999).

45 Zle de website van SzW (geraadpleegd op 25/11/2004): http://home.szw.nl/navigatie/ dossier/dsp_dossier.cfm?set_id+r35\&link_id=23530

46 De voorwaarden zijn grotendeels ontleend aan een door SZW ter beschikking gestelde subsidiebeschïkking.

47 Het onderzoeksbureau EIM telt in haar voorstel voor een landelijke jeugdmonitor liefst 200 doelstellingen in het nationale beleid (EIM/100 2004). Hoewel het bij deze doelstellingen voor een deel gat om beleidsinstrumenten, geeft het aantal wan 200 wel een indicatie van de omvang van het nationale beleid.

48 Torenvlied en Akkerman (2004: 37) hebben het over soft policy instruments als efficiënte instrumenten om beleid over verschillende overheidslagen te coördineren.

49 Die vrijblijvendheid is ook in de evaluatie van het BANS geconstateerd: zie de verwijzingen daarnaar in TK 2004/2005a en in de brief van de VNG (2002). Tegelijkertijd wordt in de ledenbrieven van de VNG soms de indruk gewekt dat de B.ANS-afspraken voor gemeenten wel bindend zijn. Zie bijvoorbeeld de ledenbrief over jeugdbeleid van 24 januari 2000 (VNG 2000): 'De afspraken over deze criteria zijn niet vrijblijvend.' Bedoeld worden de vijf criteria waaraan lokaal jeugdbeleid zou moeten voldoen. 


\section{Slotbeschouwing: lokaal en nationaal beleid geconfronteerd}

\subsection{Inleiding}

In dit laatste hoofdstuk komen de twee lijnen van dit onderzoek bij elkaar: het lokale en het nationale jeugdbeleid. In paragraaf 13.2 vatten we nog eens zeer beknopt de belangrijkste bevindingen voor beide onderzoeksdelen samen. In paragraaf 13.3 staat de vraag centraal in hoeverre het nationale beleid daadwerkelijk heeft doorgewerkt in het lokale beleid. In paragraaf $\mathrm{I3.4}$ plaatsen we de bevindingen in het licht van de verhouding tussen de nationale overheid en lokale overheden. Hoe dient deze op het gebied van het jeugdbeleid nu gekenschetst te worden? Tot slot gaan we in de laatste paragraaf 13.5 in op alternatieve wijzen waarop de verhouding tussen beide bestuurslagen rond het jeugdbeleid zou kunnen worden vormgegeven.

\subsection{Beknopte samenvatting van de bevindingen}

Het uitgangspunt in dit onderzoek is de rol die gemeenten hebben gekregen bij het realiseren van de doelstellingen wan het nationale jeugdbeleid. Aan de toekenning van deze rol ligt een aantal overwegingen ten grondslag, waarmee in breder verband nut en noodzaak van decentralisatie wordt beargumenteerd. De veronderstelling is dat lokale overheden beter dan de nationale overheid in staat zijn een effectief en efficiënt beleid te vormen, waarbij tevens de toegankelijkheid voor burgers groot is. Omdat burgers daardoor makkelijker kunnen participeren in beleid, wat op zichzelf de legitimiteit van dat beleid vergroot, worden de mogelijkheden voor lokale overheden om een effectief beleid te voeren versterkt. Kortom: autonome taakuitoefening door gemeenten wordt verondersteld belangrijk te zijn voor een effectief beleid dat dicht bij de burger staat. In dit onderzoek staan deze argumenten voor een zelfstandige, democratisch gelegitimeerde gemeente centraal. We stellen de vraag in hoeverre gemeenten in hun jeugdbeleid in staat blijken de belangrijkste verwachting te realiseren: het voeren van een effectief beleid. Daarnaast hebben we de vraag opgeworpen hoe het beleid van de nationale overheid zich verhoudt tot deze verwachting. Met andere woorden: vormt het nationale beleid een stimulans of juist een belemmering voor gemeenten bij het voeren van een effectief jeugdbeleid, of doet het wellicht niet ter zake?

Effectief lokaal jeugdbeleid?

In hoofdstuk Ix is uitgebreid ingegaan op de bevindingen over het lokale jeugdbeleid, met als vraag of gemeenten in staat zijn een effectief jeugdbeleid te voeren. Hier volgt een beknopte samenvatting. 
In eerste instantie zijn we ingegaan op de vraag of gemeenten in de onderzoeksperiode van 1998-200I een specifiek op de jeugd gericht beleid hebben ontwikkeld. Het blijkt dat in 2001 een ruime meerderheid van de Nederlandse gemeenten dat heeft gedaan, waarbij de groei er in $200 \mathrm{r}$ nog niet uit was. De meeste gemeenten hebben uitgewerkte doelen in een doorgaans breed, en daarmee in ieder geval in zijn opzet integraal geformuleerd jeugdbeleid.

Naar het antwoord op de vraag of gemeenten een effectief jeugdbeleid voeren is in tweede instantie gezocht door op drie manieren te kijken naar de resultaten van het jeugdbeleid. In de eerste plaats hebben we gekeken naar de ontwikkeling op een aantal voor het jeugdbeleid relevante output- en outcome-indicatoren. Deze methode leverde echter weinig op, omdat gemeenten niet over adequate gegevens bleken te beschikken. De tweede manier waarop we naar de resultaten hebben gekeken, is door in iedere onderzochte gemeente een aantal bij het beleid betrokken actoren te laten oordelen over de resultaten van het jeugdbeleid. De conclusie daaruit is dat de betrokken actoren zeer zuinig oordelen. Doellen worden vaak niet, gedeeltelijk of te laat bereikt. De effecten van het jeugdbeleid worden door deze actoren als onvoldoende beoordeeld. Het derde perspectief op de uitkomsten is dat van de jeugd zelf. Het blijkt dat ook zij in het algemeen negatief oordeelt over het jeugdbeleid van haar gemeente.

De vraag naar de effectiviteit van het lokale jeugdbeleid hebben we in derde instantie trachten te beantwoorden door te onderzoeken of gemeenten aan een aantal noodzakelijke en faciliterende voorwaarden voor effectief beleid voldoen. Achtereenvolgens zijn we ingegaan op de toespitsing van het beleid op de lokale situatie (maatwerk), integrale beleidsvoering en het vermogen tot slagvaardig opereren.

Met betrekking tot de vraag naar maatwerk is de conclusie dat er wel degelijk verschillen zijn tussen gemeenten, en dat die ook samen lijken te hangen met de omvang van de lokale problematiek. In die zin kan worden gesproken van op de lokale situatie toegespitst beleid. Bovendien oordelen betrokken actoren relatief positief over de mate waarin het beleid is toegespitst op de lokale situatie en zijn er doorgaans veel actoren betrokken bij de beleidsvorming, wat de kans op maatwerk door de input van lokaalspecifieke informatie vergroot.

Op het punt van integraliteit is het oordeel minder positief. Gemeenten hebben grote moeite tot een integraal jeugdbeleid te komen, ondanks de inhoudelijk vaak brede beleidsformulering. De sturende rol van gemeenten, een noodzakelijke voorwaarde voor een integrale beleidsvoering, komt moeizaam uit de verf. Het belang van die sturende rol wordt nog eens onderstreept door de positieve samenhang tussen een aantal sturingsaspecten, zoals een beleidsvisie, en de oordelen wan beleidsactoren over de resultaten van het beleid.

Ook op het punt van slagvaardigheid leiden de onderzoeksbevindingen tot een kritisch oordeel. Weliswaar hebben instellingen vaak een redelijke mate van beleidsvrijheid in de uitvoering, toch is het bij een aanzienlijke minderheid onduidelijk wat 
de bijdrage van de instelling aan het lokale jeugdbeleid dient te zijn. Ook het gebrek aan tussentijdse evaluaties is niet bevorderlijk voor de slagvaardigheid, evenals de inefficiënte en overvloedige netwerkvorming rond het jeugdbeleid.

Tot slot is het lokale bestuur slechts beperkt toegankelijk. Weliswaar zijn beleidsactoren in ruime mate betrokken bij beleidsworming en -uitvoering, maar de jeugd zelf neemt, ondanks de inspanningen van gemeenten, een marginale positie in.

Samengevat is er alleen bij maatwerk reden voor een, weliswaar voorzichtig, positief oordeel. Aan de voorwaarden voor een effectief beleid wordt in het jeugdbeleid van veel gemeenten in slechts beperkte mate voldaan.

Al met al moeten we concluderen dat de verwachtingen over de mogelijkheden die gemeenten hebben om een effectief jeugdbeleid te voeren (nog) niet of maar ten dele uitkomen. De vraag die we vervolgens hebben gesteld is of deze bevinding samenhangt met de opstelling van de nationale overheid in het jeugdbeleid.

Nationaal beleid: belemmerend of stimulerend voor lokale actoren?

De nationale overheid tracht langs vele wegen het lokale jeugdbeleid te beïnvloeden. Is de wijze waarop de nationale overheid zich opstelt in het jeugdbeleid van invloed op het vermogen van gemeenten om tot een effectief jeugdbeleid te komen? In hoeverre beïnvloedt het rijksbeleid het gemeentelijke vermogen om tot maatwerk, tot een integrale en een slagvaardige aanpak te komen? Om die vraag te beantwoorden, hebben we het nationale beleid dat voor het lokale jeugdbeleid in de periode r998-20or relevant was, onderzocht en beoordeeld op de mate waarin zij invloed heeft op het beleidsvormende vermogen van gemeenten.

In hoofdstuk I hebben we beargumenteerd dat het nationale beleid recht dient te doen aan de positie van de gemeente als sturende actor (regisseur) in een complexe lokale beleidsarena. Voorzover de nationale overheid richting geeft aan het lokale jeugdbeleid, moet dat op hoofdlijnen gebeuren, met een zo groot mogelijke beleidsvrijheid voor gemeenten en andere lokale actoren om het jeugdbeleid overeenkomstig die hoofdlijnen vorm te geven.

De analyse van het nationale beleid leidt tot de constatering dat het beleid van de nationale overheid enerzijds gemeenten ruimte laat en ze stimuleert om, binnen zekere kaders, een op de lokale situatie toegespitst beleid te formuleren. Bovendien worden gemeenten bij het vormgeven van hun regisseursrol met informatie ondersteund. Anderzijds hebben vooral de voorschriften en specifieke uitkeringen door hun sterke mate van uitvoeringsregulering een beperkende invloed op de mogelijkheden van gemeenten om hun regisseursrol waar te maken. Daarnaast wordt de handelingsruimte van gemeenten beperkt doordat een deel van het nationale beleid gericht is op versterking van de positie van actoren waar de gemeente geen of beperkte zeggenschap over heeft. Dit nationale beleid langs functionele lijnen compliceert eveneens de regisseursrol van de gemeente, met name bij het bewerkstellin- 
gen van een integraal jeugdbeleid. Een derde bevinding aangaande het nationale beleid betreft de omvang ervan. Gemeenten, maar ook ander lokale actoren, zagen zich in de periode van 1998 tot 200 r geconfronteerd met een grote hoeveelheid beleidsdoelen en -instrumenten van de nationale overheid, die elkaar in hoog tempo opvolgden en die elkaar overlapten. In die zin is van een heldere kaderstelling door de nationale overheid geen sprake. Bovendien is de omgeving waarin gemeenten hun jeugdbeleid moeten vormgeven voortdurend in verandering.

\subsection{Doorwerking national beleid in iokaal jeugdbeletd}

De vorige paragraaf hebben we besloten met de veronderstelde invloed van nationaal op lokaal beleid. Maar wat kunnen we nu zeggen over de daadwerkelijke invloed? Is de veronderstelde invloed van het nationale beleid ook terug te vinden in het lokale beleid? Heeft het nationale beleid doorgewerkt in het lokale beleid? ${ }^{\mathrm{I}}$

\section{Jeugdbeleid op de agenda van gemeenten}

In de eerste plaats kunnen we constateren dat een integrale benadering van de jeugd onder regie van gemeenten een grote vlucht heeft genomen wanaf het moment dat de nationale overheid daar expliciet beleid op is gaan voeren. In het midden van de jaren negentig van de vorige eeuw heeft de nationale overheid haar standpunt over de bestuurlijke rolverdeling in thet jeugdbeleid geformuleerd, waarin aan gemeenten een belangrijke rol in het preventieve beleid werd toegekend. Op tal van manieren is getracht te stimuleren dat gemeenten deze rol zouden oppakken. Het meest in het oog springen de Beleidkaders jeugdzorg en de activiteiten van de OLPJ en later het VNG-project lokaal jeugdbeleid, maar ook de Bestuursakkoorden tussen rijk, IPO en VNG. Met het VNG-project, waarin gemeenten werden ondersteund, werd meer dan $90 \%$ van de gemeenten bereikt (Van Westering 2003). Het is ontegenzeggelijk zo dat het aantal gemeenten met een specifiek jeugdbeleid in het laatste decennium fors is toegenomen, getuige ook de aanzienlijke toename van het aantal gemeenten met een specifiek jeugdbeleid tussen 1998 en 20or. Het is zeer aannemelijk dat de initiatieven van de nationale overheid ertoe hebben geieid dat jeugdbeleid op de agenda van veel gemeentebesturen is gekomen. Veel gemeenten hadden voor die tijd geen specifiek jeugdbeleid, of ze hadden een jeugdbeleid dat zich tot jeugdwelzijnsbeleid beperkte. Zonder dat gesteld kan worden dat landelijk geformuleerde doelstellingen zonder veel problemen op lokaal niveau doorwerken, lijkt er op lokaal niveau wel een zekere internalisering van de nationale doelstelling van integraal, preventief jeugdbeleid door gemeenten te hebben plaats gevonden (vgl. Koppenjan et al. 200I: 466). Het nationale jeugdbeleid heeft daardoor ook een zekere symbolische betekenis gekregen (Edelman 1964; vgl. Yanow 1993; Korsten 1997). ${ }^{2}$

\section{Inhoudelijke agendasetting door de nationale overheid}

Het nationale beleid heeft in de onderzochte periode nadrukkelijk tot doel gehad het lokale jeugdbeleid inhoudelijk te sturen - overigens zonder dat dit, met uitzondering 
van het grotestedenbeleid en het onderwijsachterstandenbeleid, in beginsell negatieve gevolgen had voor het vermogen een op de lokale situatie toegespitst beleid te ontwikkelen.

\section{- Meer probleemgericht beleid in stedelijke gemeenten}

Dat de meer stedelijke gemeenten - met in het algemeen een omvangrijkere jeugdproblematiek (Gilsing 1999) - meer aandacht hebben voor probleemgericht beleid dan minder stedelijke gemeenten kan mede verklaard worden uit de probleemgerichte oriëntatie in het nationale beleid. De inhoudelijke sturing door de nationale overheid heeft namelijk onder meer plaats gevonden door economische instrumenten, waarvan de meeste zich kenmerkten door een probleemgerichte benadering: alleen gemeenten waarvan verondersteld werd dat zij meer dan gemiddeld met bepaalde maatschappelijke problemen te maken hadden, vielen onder de werking van deze instrumenten. Daarbij valt te denken aan het onderwijsachterstandenbeleid en het jeugd-en veiligheidsbeleid. Eenzelfde probleemgerichte oriëntatie vinden we in het grotestedenbeleid. Het is dus niet verwonderlijk dat deze meer stedelijke gemeenten in het algemeen meer dan minder stedelijke gemeenten aangeven dat $z i j$ in hun jeugdbeleid ook veel aandacht hebben voor probleemgericht beleid (ook aangeduid als gericht preventief beleid).

\section{- Doorwerking prikkels en voorschriften op lokale agenda}

Ook op een minder abstract niveau is deze doorwerking van juridische en economische sturingsinstrumenten waarneembaar. De sterke financiële prikkels voor alle gemeenten op het gebied van kinderopvang verklaren waarschijnlijk dat de kinderopvang het meest genoemde speerpunt is in het lokale jeugdbeleid (zie hoofdstuk 4). Ook andere thema's die door het nationale beleid gestimuleerd zijn door prikkels en voorschriften staan hoog op de agenda van gemeenten. Voorbeelden daarvan zijn de professionalisering van de peuterspeelzallen, het realiseren van aansluiting tussen peuterspeelzalen en basisonderwijs en van een sluitende aanpak van 0-6-jarigen, die alle gekoppeld kunnen worden aan de regelingen voor- en vroegschoolse educatie, de aanpak van onderwijsachterstanden en voortijdig schoolverlaten, en de vroegtijdige onderkenning van problemen bij kinderen. Bovendien heeft bijna de helft van de onderzochte gemeenten een afzonderlijke aanpak jeugd en veiligheid. Behalve de economische en/of juridische instrumenten die de nationale overheid op al deze terreinen heeft ingezet, hebben de meeste ervan ook expliciete aandacht gekregen in het VNG-project lokaal jeugdbeleid. De weinige gemeenten met aandacht voor de thema's arbeid en inkomen en jongerenhuisvesting kunnen verklaard worden uit de geringe omvang van het nationale beleid op deze thema's in die periode. Het heeft er dus alle schijn van dat het beleid van de nationale overheid zijn stempel drukt op de inhoudelijke agenda van het jeugdbeleid van veel gemeenten. In dat opzicht mogen we stellen dat de nationale overheid slaagt in zijn kaderstellende rol ten aanzien wan het lokale jeugdbeleid. 
Nationale beperking van lokale regiemogelijkheden

Dat veel gemeenten moeite hebben om tot een integraal en slagvaardig jeugdbeleid te komen, kan mogelijk worden verklaard uit de omvang en de aard van het nationale beleid, dat in beginsel een beperkende invloed heeft op de mogelijkheden van gemeenten om hun regisseursrol in een integraal en slagvaardig jeugdbeleid waar te maken. In het lokale beleid is er sprake van omvangrijke en complexe netwerkstructuren, de inhoudelijke sturing wordt door instellingen gemiddeld als onvoldoende ervaren en ook de sturing binnen de gemeentelijke organisatie verloopt moeizaam. Tot soortgelijke bevindingen komt Turkenburg (2003) ten aanzien van het onderwijsachterstandenbeleid.

De beperkende invloed van het nationale beleid op de gemeentelijke regierol blijkt ook uit de opvattingen van bij het jeugdbeleid betrokken instellingen (Gilsing 2003:

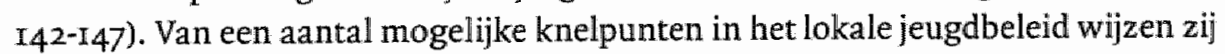
een aantal buiten de lokale beleidsarena gelegen factoren als relatief $z$ waarwegend aan. Dit zijn achtereenvolgens: onvoldoende capaciteit bij de Bureaus Jeugdzorg, de verschillende financieringswijzen van bij het jeugdbeleid betrokken instellingen en de schotten op rijksniveau. Samen met financiële schaarste en onvoldoende capaciteit bij eerstelijnsinstellingen wordt aan deze knelpunten de meest belemmerende werking toegekend. Gemeentelijke ambtenaren jeugdbeleid delen in grote lijnen deze opvattingen. De perceptie van belemmerende schotten op rijksniveau ondersteunt de export van de verkokering-these (vgl. Kwekkeboom 1994: 140-14r). Daardoor krijgen gemeenten te maken met coördinatie- en integratievraagstukken waarvoor de nationale overheid geen oplossing kent-ook wel aangeduid als de decentralisatieval. De gebrekkige capaciteit van de Bureaus Jeugdzorg is eveneens een extralokale factor, maar een die vooral met het provinciale jeugdbeleid te maken heeft.

De in hoofdstuk I besproken bestuurlijke complexiteit rond het lokale jeugdbeleid komt onder meer voort uit de verschillende financieringswijzen van bij het jeugdbeleid betrokken instellingen. Het gaat ten dele om instellingen waarover lokale overheden geen zeggenschap hebben en die langs functionele lijnen zijn gedecentraliseerd. Dit knelpunt weerspiegelt de spanning die bestaat tussen het integrale, territoriale bestuur en het bestuur langs functionele lijnen, en wordt door de Raad voor de Financiële Verhoudingen als volgt verwoord (RFV 2000: 59): 'gemeenten zijn in hun rol als regisseur in het jeugdbeleid aangewezen op de welwillende medewerking van alle betrokken partijen, zowel qua formuleren van de doelstellingen van het integrale beleid als het inzetten van de onder het beheer van vele afzonderlijke actoren staande financiële instrumenten in de gewenste (integrale) richting.'

\section{Klaarblijkelijk duidelijke invloed van nationaal beleid}

Het is meer dan aannemelijk dat het nationale beleid 'doorwerkt' in het lokale jeugdbeleid. Het heeft ertoe bijgedragen dat veel gemeenten een specifiek jeugdbeleid hebben ontwikkeld. Daarnaast beïnvloedt het nationale beleid de inhoudelijke 
beleidsagenda van gemeenten, terwijl het tegelijkertijd lokale beleidsprocessen frustreert. Bovendien wordt de lokale beleidsarena (onbedoeld) sterk gecompliceerd door de sturing van lokale actoren langs zowel territoriale als functionele lijnen. Terwiil aan gemeenten enerzijds een belangrijke positie in het jeugdbeleid wordt toegekend, wordt anderzijis het vermogen tot een effectief lokaal jeugdbeleid door het nationale beleid aangetast.

\subsection{De bestuurlike rolverdeling in het jeugdbeleid}

\section{Voorgestane bestuurlijke rolverdeling}

In de voorgestane bestuurlijke rolverdeling is er weliswaar sprake van vervlechting van het beleid wan de verschillende overheidslagen, maar blijft deze beperkt. De nationale overheid stelt, gecoördineerd door vws, de kaders. Lokale overheden hebben de ruimte om binnen deze kaders hun eigen beleid te ontwikkelen. Zij worden daarin ondersteund door de nationale overheid, die faciliteert, in novatie stimuleert en zorgdraagt voor monitoring. Er is dus sprake van duidelijk gescheiden verantwoordelijkheden. De vraag is of de voorgestane rolverdeling empirisch gezien gestalte heeft gekregen. Hoe kunnen we de bestuurlijke rolverdeling in het jeugdbeleid kenschetsen op basis van de in hoofdstuk 1 onderscheiden modellen van de relatie tussen nationale en lokale overheid? Is het nationale beleid zo georganiseerd dat gemeenten vooral als werktuig van het rijk fungeren, of is er sprake van een relatief zelfstandige positie van gemeenten? En in hoeverre kan gesproken worden van beleidsvervlechting?

Formeel lokale autonomie, materieel inmenging van rijk

Gemeenten hebben formeel een relatief zelfstandige positie op belangrijke onderdelen van het jeugdbeleid. Zij zijn formeel in hoge mate onafhankelijk van de nationale overheid in het formuleren van hun jeugdbeleid. De hoeveelheid juridische beleidsinstrumenten die ingrijpen in de formele zelfstandigheid van gemeenten is gering. Op het gebied van onderwijs is wel een aantal voorschriften voor gemeenten van kracht. De bevinding over de formele onafhankelijkheid sluit aan bij het onderzoek van Willemse (200I; vgl. Fleurke 2004) naar de mate waarin gemeenten een zelfstandige positie innemen in het Nederlandse staatsbestel. Daarin concludeert hij onder meer dat gemeenten in de afgelopen decennia in het vaststellen van hun beleidsprioriteiten zelden door het rijk zijn gestuurd.

We moeten op basis van dit onderzoek echter ook constateren dat de materiële zelfstandigheid van gemeenten geringer is. We hebben gezien dat het meer dan aannemelijk is dat de speerpunten en accenten in het lokale jeugdbeleid in ieder geval voor een belangrijk deel zijn ingegeven door het nationale beleid. Dat heeft zeker ook met de kenmerken van de veel gebruikte economische sturingsinstrumenten te maken. Het is voor gemeenten klaarblijkelijk lastig de verlokkingen van financiële prikkels, vooral als die van enige omvang zijn, te weerstaan, ook als deze een serieuze inbreuk op de lokale beleidsvrijheid vormen. 


\section{Gemeenten als werktuig van het rijk?}

Een belangrijke vraag is hoe we de wortels die het rijk gemeenten voorhoudt moeten waarderen. De gekozen vorm van specifieke uitkeringen suggereert dat gemeenten toch vooral als werktuig van het rijk worden gezien. Gezien de financiële verhoudingen tussen rijk en gemeenten, waarbij meer dan de helft van de gemeentelijke inkomsten niet vrij te besteden is, is het verder binden van gemeentelijke uitgaven toch vooral op te vatten als een verdere beperking van de zelfstandigheid van gemeenten, ondanks het feit dat zij niet gehouden zijn gebruik te maken van de instrumenten. Het rijk oordeelt kennelijk dat gemeenten niet over voldoende eigen middelen beschikken om het gevraagde beleid te ontwikkelen. Het wel ontwikkelen van dat beleid onder het afzien van gebruikmaking van de specifieke uitkering zou in het algemeen een aanzienlijk verder beslag op de vrij besteedbare gemeentelijke middelen betekenen.

\section{Zelfstandigheid ingeperkt door uitvoeringstegulering}

De relatieve gemeentelijke zelfstandigheid wordt materieel verder ingeperkt door de beperkende, zo niet belemmerende werking ervan op het gemeentelijke vermogen de regie te voeren. Waar het vorige punt vooral betrekking heeft op de beleidsworming door gemeenten, raakt dit punt vooral de beleidsuitvoering. ${ }^{3}$ De gedachte dat gemeenten beter dan de nationale overheid in staat zijn tot integraal beleid, wordt in gevaar gebracht door de sterke uitvoeringsregulering van de nationale overheid. In een toch al complexe bestuurlijke omgeving waarin hoge eisen worden gesteld aan de regie, vormt het nationale beleid een extra complicerende factor.

\section{Nauwelijks reductie van complexiteit}

Het nationale beleid blijkt bovendien niet bij te dragen aan het reduceren van de bestuurlijke complexiteit rond het jeugdbeleid, wat de regierol van gemeenten zou vereenvoudigen. Sterker nog: het nationale beleid draagt eerder bij aan de vergroting van die complexiteit. Voor een deel vindt de sturing door de nationale overheid plaats langs functionele lijnen, wat op gespannen voet staat met een zelfstandig integraal bestuur op territoriale basis. Gemeenten zien zich geconfronteerd met een grote hoeveelheid beleid, waarvan de doelstellingen elkaar deels overlappen. In veel nationale beleidsnota's wordt lippendienst bewezen aan het belang van lokale afstemming en aan dat van nationale coördinatie. De veelheid aan beleid druist daar echter lijnrecht tegenin. Het heeft er alle schijn van dat departementen niet in staat zijn het departementale belang te overstijgen. Zij lijken er vooral belang in te stelien hun eigen beleidsvoorkeuren te borgen, waarbij zij weinig oog hebben voor de (formeel) relatief zelfstandige positie van gemeenten. Daaruit blijkt dat de coördinatie op het nationale niveau niet toereikend is. Het gevolg is dat er eerder een toe-dan cen afname van complexiteit rond het lokale jeugdbeleid waarneembaar is.

\section{Samenuattend: sterke beleidsverulechting}

Het gaat te ver om te stellen dat de bestuurlijke verhoudingen rond het jeugdbeleid zich laten schetsen met behulp van het model van de eenheidsstaat, waarin gemeenten 
louter als uitvoerders van nationaal beleid worden gezien. Daarvoor beschikken gemeenten formeel over een te zelfstandige positie. Niettemin wordt deze positie sterk ondermijnd door rijksbeleid dat zich tot in details met uitvoering bemoeit, overstelpend is in zijn hoeveelheid en bovendien slecht wordt gecoördineerd. Het rijk maakt zijn kaderstellende rol niet waar, waardoor van de voorgestane bestuurlijke rolverdeling met zijn tamelijk scherpe verdeling van verantwoordelijkheden in werkelijkheid niets is terug te vinden. De verhoudingen kunnen daarom het best getypeerd worden als beleidsvervlechting, waarin verantwoordelijkheden niet helder zijn afgebakend en er sprake is van sterke wederzijdse afhankelijkheden. De complexiteit die mede door deze vervlechting optreedt, wordt verder versterkt door de verschillen in de mate van vervlechting tussen de deelterreinen van het jeugdbeleid.

\subsection{Epiloog: naar een effectiefjeugdbeleid}

\section{Bestuurlijke knelpunten: hoe nu verder in het jeugdbeleid?}

De vele ambities van de nationale overheid op het gebied van jeugdbeleid hebben de gemeenten in een lastige situatie gemanoeuvreerd. In de complexe bestuurlijke omgeving waarin zij verkeren, is het een moeilijke opgave de vele ambities waar te maken. De lasten die het coördineren en afstemmen van de regelingen van en afspraken met andere overheden met zich meebrengen, drukken zwaar. Een belangrijke uitkomst van dit onderzoek is dat de door gemeenten gepleegde inspanningen op het gebied van jeugdbeleid (in ieder geval nog) niet in verhouding lijken te staan tot de opbrengsten.

Door het rijk worden deze bestuurlijke knelpunten in de periode na $200 \mathrm{r}$ erkend. Concreet wordt onder meer het probleem van de bestuurlijke schaalproblematiek genoemd (Operatie Jong 2003 b: 17 ). Ook wordt erkend dat de afbakening van verantwoordelijkheden lang niet altijd helder is (Operatie long 2004a: 8). In een brief aan de Tweede Kamer van november 2004 spreekt de voor de coördinatie van het jeugdbeleid verantwoordelijke staatssecretaris van een 'ingewikkeld en verkokerd systeem (...). Dit systeem kent vele instanties, specialismen, benaderingen alsmede wettelijke en financiële kaders.' (TK 2004/2005 b: I). Goede samenwerking is niet gegarandeerd, wat bijdraagt aan een verkokerde in plaats van een integrale benadering van problemen, die bovendien diep verankerd is in de werkwijze van instellingen en in de wetteliike en financiële kaders waarbinnen zij opereren. Een belangrijke doelstelling van het tweede kabinet-Balkenende is dan ook te voorkomen dat kinderen en gezinnen tussen de wal en het schip raken door afstemmingsproblemen tussen departementen, bestuurslagen en jeugdzorginstellingen.

De paradox van lokale beleidsvrijheid enerzijds en de ambities van andere overheden die die vrijheid inperken anderzijds, lijkt ten minste voor een deel debet te zijn aan deze bestuurlijke knelpunten. Dit roept de principiële vraag op hoe verder te gaan in het jeugdbeleid. Deze vraag staat centraal in deze laatste paragraaf. 
Twee scenario's: integraal beleid of focus op urgente themass

Voor de toekomst van het jeugdbeleid zijn grofweg twee scenario's denkbaar. In het eerste scenario is de versterking van integraal beleid het belangrijkste doel. In het tweede scenario worden de ambities met betrekking tot integrale beleidswoering naar beneden bijgesteld en concentreert het jeugdbeleid zich op een aantal urgente thema's.

In het eerste scenario worden (blijven) gemeenten verantwoordelijk voor een integraal jeugdbeleid. Om de sturingskracht van gemeenten te versterken, blijft de nationale overheid zo veel mogelijk op de achtergrond. De bemoeienis van het rijk blijft beperkt tot het aanwijzen van gebieden waarop gemeenten beleid of voorzieningen moeten hebben, bijvoorbeeld via een richtinggevende Agenda voor de jeugd (Roes et al. 2002). Specifieke uitkeringen worden zo veel mogelijk gebundeld en ontdaan van uitvoeringsregels of gaan op in het gemeentefonds. ${ }^{4}$ Gemeenten verantwoorden zich over het jeugdbeleid horizontaal, dat wil zeggen, tegenover de lokale samenleving. Onderlinge vergelijking tussen gemeenten vindt plaats door het volgen van ontwikkelingen in het beleid op een beperkt alantal indicatoren. Deze indicatoren hebben betrekking op de maatschappelijke positie van de jeugd en niet op beleidsgerelateerde zaken. De indicatoren kunnen in een overhedenoverleg tussen gemeenten en rijk gezamenlijk worden vastgesteld. Het rijk heeft zogenoemde "systeemverantwoordelijkheid' en is aanspreekbaar wanneer de maatschappelijke resultaten onvoldoende zijn. Verder heeft het rijk een ondersteunende rol, die bestaat uit het ontwikkelen van monitorinstrumenten en methodieken en het stimuleren van innovaties. Aan het lokale beleid worden inhoudelijke noch procesmatige eisen gesteld, behoudens in de eerste plaats de door het rijk als belangrijk aangemerkte gebieden waarop gemeenten beleid dan wel voorzieningen dienen te hebben en in de tweede plaats het leveren van informatie met betrekking tot de indicatoren. Dit scenario lijkt op de sturingsfilosofie achter de in ontwikkeling zijnde Wet maatschappelijke ondersteuning (WMO) (Schoorl s.a.) en sluit aan bij het advies van de RMO (2002) over sturingsvraagstukken. ${ }^{5}$ Deze filosofie sluit tevens aan bij het recente pleidooi van de WRR (2004), waarin gepleit wordt voor meer vertrouwen in de relaties tussen beleidsactoren. In de huidige praktijk met de nadruk op controleren gat te veel tijd en energie op aan het afleggen van verantwoording. Ook Fleurke (2004) pleit voor horizontale in plaats van verticale verantwoordingsmechanismen.

In een verdergaande variant van dit eerste scenario wordt bovendien serieus gepoogd de bestuurlijke complexiteit rond het lokale jeugdbeleid te reduceren. In dit onderzoek is aangetoond dat de spanning tussen territoriaal en functioneel bestuur problemen oplevert voor de gemeente als sturende actor. De verschillende territoriale schaalniveaus waarop langs functionele lijnen bij het lokale jeugdbeleid betrokken partijen opereren, compliceren de coördinatietaak van gemeenten aanzienlijk. De GGD-regio's, politieregio's, RMC-regio's, de schaal waarop Bureaus Jeugdzorg opereren, het werkingsgebied van thuiszorgorganisaties (aanbieders van ouder-en 
kindzorg), de regionale samenwerking tussen gemeenten: zij vormen een bestuurlijke lappendeken, waarin de gemeente wordt verondersteld ordening aan te brengen. Daarbij verschillen de bevoegdheden van de gemeente per beleidsterrein, wat de zaak er niet eenwoudiger op maakt. Getracht zou moeten worden de spanning tussen functionele en territoriale decentralisatie te verminderen (vgl. Fleurke 2004: $1 \mathrm{I}-\mathrm{I} 2$ ). In de Code interbestuurlijke verhoudingen (2004) wordt dit probleem onderkend en wordt door kabinet, IPO en VNG een verkenning van het probleem aangekondigd. Vanuit het perspectief van een sterk integraal bestuur verdient een stroomlijning van de verschillende functionele regio-indelingen aanbeveling. De ROB (I99gb: 25) heeft al eens betoogd dat de bestaande functionele regio-indelingen toch al, vaak geen resultaat $z$ ijn van rationele besluitvorming. ${ }^{6}$

Het tweede scenario is pragmatischer dan het eerste. Het tempert de ambities op het gebied van integraal beleid en berust in de sterk vervlochten bestuurlijke verhoudingen. Het lokale jeugdbeleid beperkt zich tot een aantal pregnante problemen waarmee de jeugd te maken heeft, zoals voortijdig schoolverlaten en jeugddelinquentie. Voor die problemen wordt door relevante partijen, al dan niet onder regie van de gemeenten, een oplossing gezocht. Voor het overige krijgt het jeugdbeleid vorm in de traditionele beleidssectoren. De bemoeienis van de nationale overheid komt tot uiting in de functionele kaders van deze traditionele sectoren.

\section{Operatie Jong en beperking van de bestuurlijke complexiteit}

In deze laatste subparagraaf gaan we in op de vraag in hoeverre in de periode na 200 r aan de reductie van de bestuurlijke complexiteit rond het jeugdbeleid wordt gewerkt. Een belangrijk initiatief daaromtrent is de zogenoemde Operatie Jong, die vanaf 2003 bestaat. De Operatie Jong is onder meer gericht op de aanpak van de genoemde bestuurlijke knelpunten. Het doel van de Operatie Jong is het versterken van een op de jeugd gerichte aanpak om uitval van jeugdigen zoveel mogelijk te voorkomen (Operatie Jong 2004a: 6). De Operatie wordt door het kabinet geslaagd geacht als aan het einde van de kabinetsperiode deze uitval is teruggedrongen én als de belemmeringen zijn weggenomen die voortkomen uit de sturing van het rijk (ibid.: 8). In de Operatie Jong werken zes departementen samen, te weten vWS, OCW, BZK, sZW, Justitie en VROM. De Operatie kent een projectbureau dat onder leiding staat van een door de regering benoemde commissaris jeugd-en jongerenbeleid, die een 'aanjaagfunctie' heeft in het verhelderen van verantwoordelijkheden en het doorbreken van verkokering (ibid.: 9). Bovendien adviseert de commissaris de regering.

Eind 2004 is het Plan van Aanpak van de Operatie Jong vastgesteld (Operatie Jong 2004b). Hierin wordt een twaalftal concrete thema's uitgewerkt die moeten bijdragen aan het realiseren van voornoemde doelstellingen. Deels betreffen deze thema's de meer inhoudelijke kanten van het jeugdbeleid, zoals het maximaliseren van het maatschappelijke rendement van het onderwijs, de vroegsignalering en de zorgstructuren in en rond de school. Voor een ander deel zijn de thema's meer procesmatig van 
aard, zoals de ontwikkeling van een jeugdmonitor en het integrale toezicht jeugdzaken. Vanaf 2005 worden deze thema's daadwerkelijk aangepakt.

In een brief aan de Tweede Kamer met daarin het Plan van Aanpak (TK 2004/2005b) stelt de staatssecretaris dat er één zogenoemd themaoverstijgend knelpunt is: de sturing in het jeugdbeleid. De regie in het jeugdbeleid moet eenduidiger worden, het aantal samenwerkingsverbanden rond het jeugdbeleid dient te worden verminderd en er moet een duidelijke scheiding worden aangebracht tussen bestuurlijke en uitvoeringsregie. Bestuurlijke regie is een taak woor de gemeente en is gericht op het maken van generieke samenwerkingsafspraken met instellingen. Deze afspraken dienen de meer uitvoerende taken te faciliteren. De tweede regievorm, de uitvoeringsregie, dient in handen te komen van uitvoerende instellingen die een centrale positie in een bepaalde voorzieningenketen innemen. Met de aanpak van de sturingsproblematiek wordt vanaf 2005 voor een jaar in elf gemeenten en twee provincies geëxperimenteerd. Deze sluiten daartoe overeenkomsten met het kabinet (Operatie Jong 2005). De ervaringen leiden zonodig tot wijzigingen in de wettelijke en financiële kaders rond het jeugdbeleid.

In de Operatie Jong wordt dus gekozen voor de gemeente als verantwoordelijke actor voor een integraal preventief jeugdbeleid. Het gemeentebestuur staat immers dicht bij jongeren en hun opvoeders. Lokaal jeugdbeleid dient onderdeel te zijn van breder lokaal beleid (Operatie Jong 2004a: 7). In sommige thema's uit het Plan van Aanpak is deze benadering die aansluit bij het scenario van integraal beleid verder uitgewerkt. Dat geldt bijvoorbeeld voor het thema waarin een aantal gemeentelijke taken, bevoegdheden en verantwoordelijkheden verankerd worden in de toekomstige Wet op de maatschappelijke ontwikkeling (WMO). Het kabinet kiest op dit punt dus voor het scenario van integraal jeugdbeleid. Ook de overeenkomsten met gemeenten en provincies, gericht op de aanpak van sturingsproblemen " passen in dit scenario.

Tegelijkertijd moet echter geconstateerd worden dat het kabinet ook voor het scenario van de functionele benadering van het jeugdbeleid kiest. De plannen om de onderwijsachterstandsmiddelen die uitgekeerd worden aan gemeenten in de toekomst rechtstreeks door te sluizen naar scholen, vormen een aantasting van de positie van de gemeente als regisseur in het onderwijsachterstandenbeleid, terwijl dat beleidsterrein voor het jeugdbeleid als geheel van groot belang blijkt te zijin (Gilsing 1999).

Daarmee rijst de vraag voor welk scenario het rijk nu eigenlijk kiest als het gaat om de reductie van de bestuurlijke complexiteit rond het jeugdbeleid. Die vraag is te meer aan de orde omdat er in de Operatie Jong verder weinig aandacht is voor de bestuurlijke rolverdeling in het jeugdbeleid en de daarmee samenhangende sturingsvraagstukken. De meer fundamentele vraag over de wijze waarop het rijk zijn bemoeienis met het jeugdbeleid dient vorm te geven, wordt door de Operatie Jong. 
niet anders dan in algemene zin opgepakt. Vooralsnog is er nauwelijks sprake van een concrete aanpak van de bestuurlijke complexiteit rond het jeugdbeleid. Van een consequente keuze woor een van beide scenario's is geen sprake. Het valt daarom te betwijfelen of de bestuurlijke complexiteit in het jeugdbeleid in de nabije toekomst. gereduceerd zal worden. 
I Over het begrip doorwerking: zie De Lange 1995; Koppenjan et all. 200x; Van Houten 2004; Maarse 199:; Maarse en Moen rggr.

2 Edelman ( $1964: 20)$ zet de symbolische werking van politiek en beleid als volgt af tegen de conventionele benadering daarvan: "If the conventional study of politics concentrates on how people get the things they want through government, this books concentrates on the mechanisms through which politics influences what they want, what they fear, what they regard as possible, and even who they are."

3 Willemse (200r) en Fleurke (2004) beperken zich in hun onderzoeken nadrukkelijk tot: de beleidsformulering, waardoor zij de vraag naar de relatieve zelfstandigheid slechts voor een deel beantwoorden.

4 Zie de voorstellen van de commissie-Brinkman (Stuurgroep doorlichting specifieke uitkeringen s.a.). De sanering van specifieke uitkeringen ('gouden koorden") staat echter al sinds de jaren tachtig op de bestuurlijke agenda. Dat dergelijke woorstellen niet zo maar doorgang vinden, blijkt onder meer uit de reactie van de Rekenkamer (Algemene Rekenkamer 2005): het rijk moet matuurlijk wel toezicht kunnen houden: brede doeluitkeringen frustreren de verantwoordelijkheid van ministers voor hun eigen beleidsartikelen. Ook meerjarige verantwoordingen en single audit en single information staan op gespannen voet met vBтв en Comptabiliteitswet.

5 De geschetste problemen in de interbestuurlijke werhoudingen rond het jeugdbeleid worden in een breder kader erkend door de nationale overheid. In de in 2003 uitgebrachte kabinetsvisie Modernisering van de overheid (TK 2003/2004b) wordt de noodzaak erkend van een grotere beleidswrijheid voor gemeenten door minder op de gemeenten gerichte regelgeving en minder specifieke uitkeringen. Maar tegelijkertijd wordt geconstateerd (ibid.: II) dat "deze herijking van de interbestuurlijke betrekkingen geen eenvoudige opgave is. Zo blijkt het lastig te zijn om de kluwen aan verantwoordelijkheden, regels en geldstromen te ontrafelen tot een nieuw werkbaar geheell.' In de in nowember 2004 tussen rijk, IPO en VNG overeengekomen Code interbestuurlijke verhoudingen (2004: 28) staan de voornemens als volgt geformuleerd: 'Rijk, provincies en gemeenten richten zich de komende periode op: een verruiming van de decentrale beleidswrijheid zowel in bestuurlijke als in financiële zin, vermindering van centrale regels (deregulering en ontbureaucratisering), vermindering van gedetailleerd nedebewind en specifieke uitkeringen, vermindering van het verticale toezicht en leggen de nadruk op resultaten in plaats van processen. ${ }^{\circ}$ Het is echter de vraag in hoeverre er sprake is van een rituele dans. Ieder kabinet gaat met $\mathrm{VNG}$ en IPO om tafel om te praten over interbestuurliike verhoudingen (Toonen en Hendriks 1998 ).

6 Overigens speelt dit afstemmingsprobleem niet alleen op het gebied van jeugdbeleid. Ook bijvoorbeeld het ouderenbeleid en het beleid gericht op mensen met een beperking kennen dergelijke problemen. Mogelijk is de vorming van een regionale bestuurslaag, waarin veel van dergelijke regio-indelingen samenkomen, een oplossing voor de functionele schaalproblematiek. Dat zou dan gepaard kunnen gaan met de gelijktijdige opschalling van provincies naar vier of vijf landsdelen, zoals in 1963 al door Van Poelje (1963: 58) is gepropageerd (vgl. Van Nijendaal en Tetteroo 2003; ROB 2003). 
Summary 


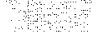




\section{Limits to local government \\ Dutch local youth policy and the impact of national policy}

In Dutch youth policy, several layers of government are involved. National government sets the general framework, the provincial authorities implement the curative youth care services and local government is responsible for developing a more preventive policy. In carrying out their policy tasks, provincial and local government operate within the frameworks set by national government and contribute to the achievement of national policy goals. Local government is expected to fulfil a role as 'régisseur' or director of local policy and to focus primarily on fostering cooperation between sectors such as education, healthcare, police, welfare and childcare services. This role of local government in youth policy, and the way it relates to the policy of national government, forms the basis for this study.

The decision to give local government an autonomous role in youth policy is based on the belief that local government is in a better position to pursue an effective and efficient policy. In addition, they are more accessible to the public, who can therefore be involved more easily in policymaking. This in turn can have a positive impact on the legitimacy and effectiveness of that policy. However, there is a certain tension between the autonomy of local government on the one hand and the role of national government and the dependence of local government on that national government on the other. What is the relationship between a decentralized youth policy and a simultaneous dependence on national government? Does local government occupy a relatively autonomous position with regard to youth policy, or is it mainly an implementing agent of government policy? What opportunities does local government have for pursuing effective youth policy within the assigned role division? What is the added value of national policy? This study seeks to provide an answer to these questions.

The study is based on two central questions:

I To what extent does local government prove to be able to establish an effective youth policy?

2 How does national government seek to influence local youth policy and what implications does this have for the opportunities of local government to establish an effective youth policy?

The study was carried out in 72 municipalities. 
Is local government able to pursue an effective youth policy? This question is answered in two ways. First the results of local youth policy are examined; this is followed by an exploration of a number of conditions that are necessary for and facilitate effective policy.

\section{Results of local youth policy}

The study looks at three aspects of the results of local youth policy:

I The trend in output and outcome indicators over time;

2 The intersubjective assessment of stakeholders;

3 The views of young people on the youth policy in their municipality.

\section{- Output and outcome indicators}

Output and outcome indicators were selected for a number of areas of youth policy. The aim was to gather information for both 1998 and 200 I to determine the developments in each municipality. For the majority of indicators, data are not recorded at central level, and therefore had to be obtained from local government. However, during the study it became obvious that only a very limited number of municipalities possesses data for both years. The study was therefore restricted to five indicators for which data were available from central sources for the two years in question. For four of these indicators, the changes between 1998 and 2001 in each municipality were generally small, and no correlations were found between the various policy characteristics and the development in the scores at municipal level. This may be connected with the relatively short period in which the policy was able to have an impact.

\section{- Intersubjective assessment by stakeholders}

Ten representatives of organisations that are typically involved in youth policy and the municipal official with responsibility for youth policy were interviewed about the results of the youth policy and the degree to which its objectives were being achieved. Both types of actors assessed the results of the policy as relatively poor, just around the mark. Moreover, they were often sceptical regarding the achievement of objectives: many actors think it highly likely that the objectives are being achieved only partially or too late. The actors involved in the policy are therefore fairly pessimistic regarding the effectiveness of local youth policy. It was noted that the views were somewhat more positive in municipalities that take on an active steering role in their youth policy.

\section{- Young people on youth policy in their municipality}

Young people in nine municipalities were interviewed about the local youth policy. In general, their opinions were critical. A very large majority feel that the municipality takes no account of their wishes and is inactive with regard to issues that they favour important, such as leisure facilities and safety. 
- Conclusion: scepticism regarding results and achievement of objectives Although the conclusions regarding the results of youth policy are not based on objective output or outcome data, it is clear that the actors involved, including young persons themselves, are very reticent on the results of youth policy. According to these stakeholders, local youth policy can generally not be considered as effective.

\section{Conditions for effective local youth policy}

This study also seeks to determine the effectiveness of local youth policy by examining whether the policy meets a number of necessary and facilitating conditions for effectiveness. These conditions are derived from the arguments used to support autonomy for local government in carrying out policy tasks:

I Integrated policy approach. Social issues, especially those concerning young people, often demand an approach involving several policy sectors. Liaison and coordination are then needed in order to achieve an effective policy. Local government plays a key role here;

2 Customisation. Policy is more effective if it is geared to the specific case and to the local situation, problems and needs;

3 Adaptability. The effectiveness of the policy is improved if implementers are able to respond timely and adequately to changes in the (social) circumstances under which policy goals have to be achieved;

4 Accessibility of local administration. Opportunities for citizens and civil-society organisations to influence policy help create a more responsive and therefore more customized and thus effective policy.

\section{- Integrated policy approach}

An answer was sought in several ways to the question whether there is an integrated policy approach. First the substantive scope of youth policy was examined. The average number of themes covered by youth policy was just under six out of a total of eight possible themes in 200I, compared with 4.5 in 1998 . From the perspective of an integrated policy approach, this can be regarded as a positive development. There is also evidence of an integrated policy approach in the many networks that exist around local youth policy, in which various actors from different sectors generally participate. Many municipalities thus do not approach youth policy from the perspective of a single policy sector.

A policy vision is an important instrument in steering networks. It can promote policy integration by creating cohesion, and from this basis it gives direction to the actions of policy actors. Most municipalities have a vision, which is generally perceived by the organisations involved as giving direction to their actions. Policy vision is also a key steering instrument for creating consensus. Consensus between local government and community-based organisations means there is less chance of deviations from the formulated policy. There is a positive correlation between how actively local government steers policy and the policy network on the one hand, and 
the opinions on that policy and its results on the other. Nevertheless, most organisations regard the steering by local government in terms of content as inadequate.

Internal coordination and cooperation are also important for an integrated policy approach. The cooperation between politicians and officials is generally limited, despite the presence of a coordinating alderman. In addition, youth policy is often coordinated at the level of council officials, but cooperation between officials is by no means the norm in most municipalities. Many council officials also hold the view that relevant local government departments pay little attention to youth policy.

The coordination between local youth policy and (provincially administered) curative youth care services deserves specific attention. Youth care services supplement general youth facilities. If these general facilities prove inadequate to tackle specific problems of young people, they are referred to the youth care services. In 1998 the coordination between local policy and the youth care services proved to be problematic in many municipalities. In $200 \mathrm{r}$ in most municipalities there was no joint vision shared by local government and youth care services on how local youth facilities and the youth care services could cooperate most effectively.

In summary, the degree of internal coordination and cooperation in most municipalities is limited, while the policy is in most cases broad in terms of its content. The network structures around youth policy are large and complex in many municipalities. The majority of municipalities have a policy vision which gives direction to the cooperation with local organisations, but those organisations are reticent on the content-based steering of the policy. The coordination with provincial youth welfare services is problematic in many municipalities.

\section{- Customisation}

Although there are some differences between municipalities as regards the content of their youth policy, their main characteristics are rather similar. The same applies for the age groups that are targeted by the policy. The main differences between municipalities relate to the degree of policy development and the extent to which young people are involved in that process. In terms of content, more and less urbanised municipalities differ in their degree of attention for 'risk groups'. The strongly urbanised municipalities undertake more than the less urbanised localities in this regard, probably because of the relatively large group of problematic and/or at-risk young people in these municipalities. The policy choices made by local government also appear to depend in part on the ambitions and intentions of national government. We shall return to this later in this summary.

In order to tailor policy to specific local circumstances, information on those circumstances is needed. As mentioned with regard to output and outcome data, in many municipalities only limited statistical information is available. Other sources 
are therefore important, such as actors working with young people and young persons themselves. Involving young people in the policy is high on the agenda of local government. The extensive networks that are formed around that policy guarantee the involvement of local organisations in the development of youth policy; only one in seven municipalities does not have such a network. The other municipalities have three or four networks on average. In two-thirds of these municipalities there is at least one network that is involved in policy formulation. The generally broad composition of the networks means that these municipalities have access to diverse information. In roughly half of all municipalities no networks are involved in the formation of policy, and information in these municipalities has to be gathered in a different way. If local government has developed a policy view - which is the case in around $70 \%$ of municipalities - local organisations are almost always involved in its development. Local government thus at least attempts to develop their youth policy interactively. This does not however mean that the information is necessarily used in an adequate manner.

Organisations and council officials were asked for their opinions on the extent to which customisation is achieved. Of all the aspects on which local organisations were asked to express a view, this aspect was evaluated most positively, or perhaps more accurately, least negatively: the average score comes barely up to the mark. Youth policy officials are also relatively positive in their opinions on the achievement of customisation.

To summarise, it is difficult to say whether local government achieves customisation. They appear to make reasonable efforts to develop youth policy interactively by gathering information from both local organisations and young people. However, young people themselves are not impressed by the responsiveness of local government. Local organisations, by contrast, especially those that are involved in policy formulation, generally give local government the benefit of the doubt on this point. The policy choices by local government do however appear to be partly influenced by the agenda of national government.

\section{- Adaptability}

A degree of freedom in the implementation of policy is important for an adequate response to changing circumstances. Many organisations report that they have a (reasonably) high degree of freedom in implementing the policy. This does however not mean that they can simply go their own way. In most cases agreements have been made on what is expected from those implementing the policy. Evidently these are often agreements about what should be achieved, rather than how this should be done, and in this sense policy implementers are given the freedom they need. Nonetheless, in $40 \%$ of cases it is unclear or insufficiently clear to the policy implementing body what local government expects. This puts the achievement of policy goals in jeopardy. 
The lack of interim evaluations is also not helpful here. A majority of organisations report that these do not take place. Fairly little attention is paid to the progress of policy implementation. To some extent this increases the policy freedom of organisations, but on the other hand there are few incentives for them to critically review their own policy and to make adjustments where necessary.

The inefficient and excessive network formation does also not contribute to the adaptive power of actors. In most municipalities a large number of actors are involved in networks, but the network structure is often less than clear-cut. The division of tasks between different networks is not always clear, nor is the position occupied by networks in the policy process. As a result, some organisations participate in several networks. Although organisations that are involved in strategic policy networks report that these generally function well, they also relatively frequently report that they are rather unproductive. Organisations are therefore critical in their judgment of the coordination and cooperation between local organisations and the steering of policy by the municipality. There appears to be a degree of tension between the desire for an integrated policy and the ability to develop and pursue an effective policy. The breadth of the policy domain, the many actors involved and the desire for a cohesive approach hinder the ability to act with adaptive power.

\section{- Accessibility}

Local government attaches a great deal of importance to involving young people in the development of policy, but this is not translated into a sense of genuine involvement among young people. In each of the nine municipalities where young people were interviewed, a majority (sometimes a very large majority) reports that local government takes insufficient account of their wishes and problems. Moreover, few young people participate in the formation of youth policy, also in comparison with the participation rate of adults. It also has to be concluded that large parts of youth policy remain obscure for most young people. Young people are mainly interested in sharing ideas on issues that relate to leisure time and safety, and are less interested in the entire breadth of youth policy. Moreover, young people want to be represented above all by young people who are already actively participating in politics.

\section{- Conditions for effective policy: conclusions}

In most municipalities, youth policy meets the conditions for effective policy only to a limited extent. When it comes to customisation, our conclusion is cautious. Although local government does a great deal to gather local information, there is certain policy uniformity across the different municipalities. A good deal of effort is also invested in creating an integrated policy, but the effects are unclear. Several factors can hinder effective action, including the integrated implementation of policy. Finally, young people are involved in the development of policy to only a limited extent. It is therefore not surprising that there is a degree of scepticism regarding the results of youth policy. 
Does local youth policy then actually matter? The answer is positive. An active steering role of local government, expressed in the development of policy, network formation, a policy vision and consensus between local government and local organisations, correlates positively with the views of local officials and local organisations on the results of local youth policy. Although the influence is limited, it does make a difference.

Is there a correlation between the findings on local youth policy and the attitude of national government? Does that attitude influence the ability of local government to pursue an effective youth policy? In order to answer these questions, national policy in the period 1998-20or was studied. An assessment framework was developed for this. The starting point is that a national policy should support the position of local government as the key actor (director) in a complex local policy arena. To the extent that national government gives direction to local youth policy, this should be limited to the main lines of policy, with maximum policy freedom being left to local government and other local actors for customisation.

\section{Objectives of national policy}

A relatively high proportion of national government objectives are formulated at output or outcome level. These policy objectives in principle don't affect the freedom of action of local actors. Outcome objectives are often accompanied by output objectives. National government thus fulfils its role of setting frameworks not only by demanding local actors to realize social changes, but also by requiring actual policy achievements. Throughput objectives, which relate to the policy process, almost all concern the municipal role as a director. Since these objectives are generally expected to be achieved through communicative and therefore non-compulsory policy instruments, this does not present a problem for the policy freedom of local actors.

\section{National instruments and customisation}

Far and away the majority of national policy instruments increase or have no effect on the ability of local actors to deliver customisation. Economic policy instruments (incentives) in particular tend to increase the freedom of action of local actors. In most cases use of these incentives is not compulsory and, within the set frameworks, most of these incentives leave scope for customisation.

National instruments and an integrated and effective policy approach Many economic policy instruments, and to a lesser extent legal instruments (regulations) limit the local opportunities for an integrated and adaptable local policy, usually because of the highly regulatory nature of such instruments. In addition to substantive and financial accountability requirements, requirements are often set 
regarding the way in which the local policy process must be organised. Further, a considerable number of so-called indirect instruments are focused on actors other than local government. Changes in the functional frameworks within which these other actors operate can complicate the steering task of local government. At the same time, these indirect instruments often strengthen the position of those other actors, increasing their autonomy. Indirect instruments thus have a double-edged effect: bad for integration, good for the adaptive power.

Furthermore, it is plausible that the 'export of ministerial compartmentalisation' complicates the municipal steering role and therefore has a negative impact on the ability of local government to pursue an integrated policy. Differences in the deployment of policy instruments between the various ministries involved increase the variety of administrative regimes within which local actors have to make their contribution to youth policy.

The ability to pursue an integrated and adaptable policy is strengthened by communicative policy instruments (information). Local actors can use these instruments without obligation, and they fit in perfectly with the supporting role of national government. The local youth policy project by the Association of Netherlands Municipalities ( $\mathrm{VNG}$ ), which provided intensive support for the steering role of local government, is a good example.

National policy overall

The amount of national policy produced between 1998 and. $200 x$ is extensive, especially in the fields of education, childcare and safety. Changes in childcare regulations followed each other rapidly. The number of financial incentives was so large that local administrators must have had difficulty seeing the wood for the trees. Communicative policy instruments were used intensively. There are some grounds for asking to what extent the sheer volume of national policy with which municipalities were expected to 'do something' posed a threat to the integration and adaptability of local youth policy. However, two further comments can be made on the large extent of national policy.

In the first place, much of this policy was not directed at all municipalities. In the main, youth policy designed to address problems contains instruments focusing specifically on municipalities where those problems are thought to be relatively widespread. These mostly larger municipalities are confronted with a considerable volume of national policy.

Secondly, there is the semblance of policy. Whole rafts of policy measures are summed up in policy memoranda and policy papers, creating the impression that this is 'new' policy. On closer examination, this proves not always to be the case. In fact, it is sometimes a matter of the repackaging or rearranging of existing policy in 
new policy programmes, creating the impression of a plethora of policy initiatives. Another manifestation of this semblance of policy is less common: presenting policy measures as bigger than they are in reality. Typical examples of this are experiments in a very limited number of municipalities, which are sometimes presented in policy memoranda as if they are policy programmes that are being deployed on a large scale. Finally, the new-style administrative agreements can be mentioned in this connection. These are often portrayed as important policy instruments in youth policy, as examples of initiatives in which the various layers of government commit themselves to joint agreements. While it is true that these agreements fit in with the new steering philosophy of 'governance' and do influence local policy, they are in no way binding for local government, contrary to the impression that is often created.

- Conclusion: double-edged national policy

National policy is double-edged. On the one hand national government shows an awareness of its role in setting the frameworks for local youth policy. It leaves scope to local actors and, mainly through economic policy instruments, seeks to increase the local capacity for custom solutions. The government also deploys a considerable number of communicative policy instruments to strengthen the steering role of local government and to increase the autonomy of the individual actors. On the other hand, many instruments are highly regulatory in their effect, and consequently tend to limit the local ability to pursue an integrated and adaptable policy. Moreover, the strengthening of the functional frameworks within which some actors operate makes it more difficult for local government to steer in what is already a complex administrative setting. Finally, it is likely that the large amount of national policy with its many accountability rules and process requirements limits local government in formulating an integrated and adaptable policy.

\section{Consequences of national policy for the effectiventess of local youth policy}

In the previous section, we focused on the presumed effect of national policy on local youth policy. What can be said about the real influence of national policy on local policy? Is the assumed double-edged action of national policy reflected in local policy?

Youth policy on the agenda of local govermment The idea of an integrated youth policy under the control of local government really began to take off from the moment that national government explicitly began pursuing policy to this end. The number of municipalities with a specific youth policy has accordingly increased sharply in the last decade. It is highly plausible that national government initiatives have contributed to this.

Determination of policy content by national government

National policy explicitly aims to influence the content of local youth policy. The 
fact that the more urbanised municipalities focus more on youth problems than less urbanised municipalities can be explained partly by the focus of national policy on addressing problems. The impact of national policy instruments can also be observed from another perspective. The strong financial incentives offered to all municipalities in the area of childcare probably explain the fact that this is the most frequently cited priority of local youth policy. Other national incentives and regulations are also high on the agenda of local government. The fact that only a small number of municipalities devote attention to themes such as employment and income and youth housing is probably due to the fact that there is little national policy focusing on these themes. In conclusion, it is very likely that national policy heavily influences the content of the local youth policy agenda. In this regard, national government succeeds in its frame-setting role.

\section{National limits on steering role of local government}

The fact that many municipalities have difficulty in achieving an integrated and adaptable youth policy can be explained from the extent and nature of national policy, which has a limiting effect on the ability of local government to steer local policy. Local policy is characterised by large, complex network structures, local organisations regard the steering by local government as generally inadequate, and the coordination of policy within local government itself turns out to be difficult. The constraining influence of national policy on local government steering is also reflected in the views of organisations involved in youth policy. They point to a number of factors that lie outside local government as being rather constraining in comparison with other factors: the inadequate capacity of youth care centres, the different methods of funding organisations and compartmentalisation at national. government level. Youth policy officials within local government broadly share these views. The perception that barriers between national government departments impede local policy reinforces the idea of the export of ministerial compartmentalisation. This confronts local government with coordination and integration problems for which national government offers no solution - the 'decentralization trap'. The administrative complexity surrounding local youth policy results among other things from the different ways of funding organisations. Some of these are organisations in which local government has no say and which are governed within a functionally organized, sectoral framework. This pinch point reflects the tensions that exist between integral, territorially organized administration and functionally organized administration.

\section{Conclusion: local administration constrained}

It is more than plausible that national policy affects local youth policy rather strongly. It has helped ensure that many municipalities have developed a specific youth policy. In addition, national policy influences the substantive policy agenda of local government, while at the same time it frustrates local policy processes. A further (unintended) effect of national policy is that the local policy arena is greatly 
interfered with the fact that local actors are steered along both territorial and functional lines. While local govermment has been attributed a key position in youth policy, national policy at the same time undermines the local ability to pursue an effective youth policy.

While it is true that the administrative role division that is advocated by national government involves a degree of interweaving of the policy of the various layers of government, this interweaving is in theory limited. National government, with the Ministry of Health, Welfare and Sport playing the coordinating role, sets the frameworks, and within those frameworks local government is given scope to develop its own policy, supported by national government. Has the advocated role division actually taken shape empirically? Is national policy organised in such a way that local government really enjoys a relatively autonomous position, or does it function mainly as a tool of national government? And to what extent is policy at the two levels of government interwoven?

It would be an exaggeration to suggest that local government is treated merely as implementing agent of national policy; its formal position is too independent for this. Nonetheless, this independence is greatly undermined by national government policy, which is greatly concerned - and in great detail - with the implementation of policy. This is promulgated in an overwhelming amount of policy measures that is moreover inadequately coordinated. National government is stretching its role of setting the frameworks, and as a result the advocated administrative role division, with its fairly clear formal division of responsibilities, is failing to materialise to any substantial degree. The relationship between the two layers of government can therefore be characterised as highly interwoven. Responsibilities are not clearly defined and there are strong mutual dependencies. The resulting complexity is further increased by differences in the degree to which responsibilities are interwoven in the various youth policy domains.

\section{Two scenarios to reduce complexity}

Broadly speaking, two scenarios can be imagined to reduce the complexity surrounding youth policy. In the first scenario, the emphasis is on strengthening policy integration. Local government is responsible for an integrated youth policy; in order to reinforce their capacity to steer and control policy, national government remains in the background as much as possible. Its involvement is limited to defining the areas where local government has to develop policy or provisions, for example via a Youth Agenda. Specific grants from national government are pooled as much as possible and freed from implementation rules, or they are absorbed into the freely disposable municipal funds. Local government is "horizontally' accountable for its youth policy, i.e. to the local community. Municipalities are compared with each 
other by monitoring policy developments using a limited number of indicators. These indicators measure the social position of young people rather than policy achievements and can be established jointly by local government and national government. National government is accountable if the social results are insufficient all along the line. In addition national government has a supporting role. Taking this first scenario a step further, serious attempts have to be made to reduce the administrative complexity surrounding local youth policy. The tension between territorially and functionally organized administration, which creates problems for local government as the steering actor, should be reduced.

In the second, more pragmatic scenario, the ambitions concerning integrated policy are lowered and youth policy is concentrated on a number of urgent themes. This scenario takes the highly interwoven administrative relations for granted. Local youth policy is limited to a number of key problems concerning young people, such as early school dropout and juvenile delinquency. A solution to these problems is sought by relevant parties, under the control of local government or otherwise. The remaining themes in youth policy are given shape in the traditional policy sectors. The involvement of national government is expressed in the functional frameworks set for these traditional sectors.

It is particularly the importance that is attached to an integrated youth policy that determines the choice between the two scenarios. This study makes clear that in the current administrative relations around youth policy it is difficult to realize an integrated local youth policy. 


\section{Literatuur}

Aart, H.A.P. van, et al. ( $(1997)$. Grote-stedenbeleid 1995-1996. Een tussentijdse evaluatie von de politiek-bestuwrlijke verhoudingen in het beleidsveld Jeugd en Veiligheid. Enschede: Universiteit Twente, Faculteit Bestuurskunde.

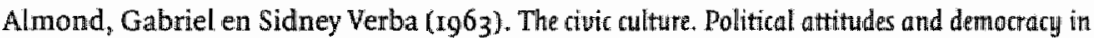
five nations. Princeton, N J: Princeton up.

Assen, Natalie, et al. (2004). Snelle impuls - duurame resultaten? Evaluatie van de EIB-regeling. Den Haag: sGio.

Baldersheim, Harald en Krister Stăhlberg (2002). "From guided democracy to multi-levell governance. Trends in central-local relations in the Nordic countries'. In: Local government studies (28) 3, p. 74-90.

Batelaan, H. (2002). Projecten jeugd en veiligheid in miet-GSB-gemeenten. Evaluatie van de Tijdelijke Regeling inzet extra middelen jeugd en veiligheid (1997-2000) (eindrapport). Ansterdam: Regio plan (Regioplan publikatienr. 452).

Batley, Richard en Gerry Stoker (red.) (r99I). Local govemment in Europe. Trends and developments. Houndmills, Basingstoke: Macmillan.

Beker, M. en E. Zeijl (2003). 'Slotbeschouwing beleidsinterventies'. In: E. Zeijl (red.), Rapportage jeugd 2002 (p. 2x7-224). Den Haag: Sociaal en Cultureel Planbureau (SCPpublicatie 2002/16).

Bekke, Hans A.G.M. (rggr). 'Experiences and experiments in Dutch local government". In: Richard Batley en Gerry Stoker (red.), Local government in Europe: trends and developments (p. 123-133). Houndmills, Basingstoke: Macmillan.

Bemelmans-Videc, Marie-Louise, Ray C. Rist en Evert Vedung (1998). Carrots, sticks and sermons. Policy instruments and their evaluation. New Brunswick: Transaction publishers.

Bleker, H. en W.M. van den Breemen ( $\left.\mathrm{g}^{8} 8_{3}\right)$. Macht in het bimnenlands bestuur. Eem theoretische en empirische verkenning van machts- on invloedsuerhoudingen tussen bestuurslagen. Deventer: Kluwer.

Bogt, T. ter, F.M en C.S. van Praag (I992). Jangeren op de drempel van de jaren negentig. Rijswijk/ Den Haag: Social en Cultureel Planbureau/vugA (Cahier 9o).

Bogt, T. ter, S. van Dorsselaer en W. Vollebergh (2003). Psychische gezondheid, risílogedrag en welbevinden van Nederlandse scholieren. Hesc Nederland 2002. Utrecht: Trimbos-institutut.

Bovaird, Tony, Ellke Löffler en Salvador Parrado-Dlez (red.) (2002). Developing local governance networks in Europe. Baden-Baden: Nomos (Local governance in Europe vol.l).

Brasz, H.A. ( 1960$)$ ). Veranderingen in het Nederlandse communalisme. De geneentabesturen als element in het Nederlandse stelsel van saciale beheersing. Assen: Van Gorcum.

Bressers, J.Th.A. (1988). 'Triangulatie in evaluatieonderzoek. Beleidseffectiviteit en waterkwaliteit'. In: W. Derksen, A.F.A. Korsten en A.F.M. Bertrand (red.), De praktijk uan onderzoek: problemen bij onderzokk van politiek, bestutur en beleid. Groningen: Wolters-Noordhoff.

Bressers, J.Th.A. en A.B. Ringeling (1989). 'Beleidsinstrumenten in drie arena"s. Beleidsvorming, witwoering en doorwerking'. In: Beleidswetenschap (3) In, p. 3-24.

Bressers, J.Th.A. en P-J. Klok (rog8). 'De inhoud van het beleid'. In: A. Hoogerwerf en M. Herweijer (red.), Overheidsbeleid. Een inleiding in de beleidswetenschap (p. 185-207). Alphen a/d Rijn: Samsom (zesde, geheel herziene uitgave).

Broek, Andries van den en Frank Huysmans (2003). 'Cultuur'. In: E. Zeijl (red.), Rapportage jeugd 2002 (p.6r-78). Den Haag: Sociaal en Cultureel Planbureau (scP-publicatie $2002 / 16)$. 
Bronneman-Helmers, H.M. (rggg). Scholen onder druk. Op zoek naar de taak van de school in een veranderende samenleving. Den Haag: Sociaal en Culrureel Plan-bureau (Sociale en Culturele Studies 28).

Bruggeman, D.A.G. (2000). De overheid in beeld. Beelder van jongeren aangaande de overheid als institut en als werkgever. Den Haag: Raad voor het Openbaar Bestuur.

Bruijn, J.A de en E.F. ten Heuvelhof (rggr). Sturingsinstrumenten voor de overheid. Over complexe netwerken en een tweede generatie sturingsinstrumenter. Leiden: Stenfert Kroese.

Bruijn, Hans A. en Hans A.M. Hufen (1998). "The traditional approach to policy instruments'. In: B. Guy Peters en Frans K. M. van Nispen (red.), Public policy instruments. Evaluating the tools of public administration (p. II-3r). Cheltenham: Edward Elgar.

Bruijn, J.A. de, W.J.M. Kickert en J.F.M. Koppenjan (1993). 'Inleiding. Beleidsnetwerken en overheidssturing". In: J.F.M. Koppenjan, J.A. de Bruijn en W.I.M. Kickert (red.), Netwerkmanagenemt in het openbaar bestuur. Over de mogetijkheden van overheidssturing in beleidsnetwerken (p. Ir-3o). Den Haag: vuGA.

Castenmiller, Peter (1988). Participatie in beweging. Ontwrikkelingen in politieke participatie in Nederland. Rijswijk: Sociaal en Cultureel Planbureau (scp-cahier 59).

Castenmiller, P. (1994). Onverschillige democratie. Betrakkenheid bij de lokale politiek. Amsterdam: Het Spinhuis.

CBS (2003a). Jeugd 2003, chifers en feiten. Voorburg/Heerlen: Centraal Bureau voor de Statistiek. CBS (2003b). Statistisch jaarboek 2003. Voorburg/Heerlen: Centraal Bureau woor de Statistiek.

CBS (2003C). CBS Persbericht PB03-153. Voorburg/Heerlen: Centraal Bureau voor de Statistiek.

CPB (2000). Op weg naar een effectiever grotestedenbeleid. Den Haag: Centraal Planbureau (Werkdocument I17).

Claassen, A. (r996). Lokaal jeugdbeleid in Gelderse gemeenten. Een onderzoek naar de stand van zaken. Nijmegen: Instituut voor toegepaste sociale wetenschappen.

Dagevos, J. en S. Hoff (2003). 'Arbeild'. In: T. Roes (red.), De sociale stant van Nederland 2003 (p. 55-78). Den Haag: Socialal en Culnureel Planbureau (sCP-publicatie 2003/12).

Dahl, R.A. en E.R. Tufte (1973). Size and democracy. Stanford: Stanford university press.

Dawson, M. en R. Zunderdorp (2002). Brede sthoal ontwikkeling in Nederland. Notitie ten behoeve van de brede dialoog over de kansen en risico's van de brede school ontwikkeling in Nedetland. Den Haag: Zunderdorp Beleidsadvies \& Management.

Dekker, Paw, Joep de Hart en Esther van den Berg (2004). "Democratie en civil society". In: In tet zicht vari de toekomst. Sociaal en Cultureel Rapport 2004. Den Haag: Sociaal en Cultureel Planburean.

Denters, S.A.H. (1989). "Gemeentelijke politiek". In: R.B. Andeweg, A. Hoogerwerf en J.1.A. Thomassen (red.), Politiek in Nederland. Alphen a/d Rijn: Samsom.

Denters, Bas (2000). 'Greep op het grotestedenbeleid. Observaties en stellingen'. In: Bestuurswetenschappen (54) 4, p. $277-287$.

Denters, S.A.H. en V. Veldheer (Ig98). 'Gemeentelijke taken. Historie en actualiteit'. In: A.F.A. Korsten en P.W. Tops (red.), Lakaal bestum in Nederland. Inleiding in de gemeentekunde (p. 66-76). Alphen a/d Rijn: Samsom.

Denters, S.A.H., H.M. de Jong en J.J.A. Thomassen (r9go). Kwaliteit van gemeenten. Eem onderzoek naar de relatie tussen de omvang van gemeenten en de kwaliteit van het lokale bestuw. Den Hag: vugA.

Denters, S.A.H., et al. (rg9ga). Preadvies. De regiefunctie in gemeenten. Den Haag: Raad wan het Openbaar Bestuur.

Denters, S.A.H., O. wan Heffen en H.M. de Jong (rg9gb). 'Grotestedenbeleid: proeftuin of procrustusbed? Gemeentelijk jeugd- en veiligheidsbeleid als casus'. In: Besturskunde (8) 3. P. IO6-II5. 
Denters, Bas en Lawrence Rose (2004). "Van lokale overheid tot onderdeel van het lokaal bestuur? (Serie 'Veranderend lokaal bestuur in vergelijkend perspectief'). In: Bestuurswetenschappern (58) 5, p. 373-390.

Derksen, W. (1985). 'Centrale sturing van lokale waarden'. In: M.A.P. Bovens en W.J. Witteveen (red.), Het schip van staat. Beschouwingen over recht, staat en sturing (p. 237260). Zwolle: Tjeenk Willink.

Derksen, W., J.A. wan der Drift, R. Giebels en C. Terbrack (1987). De bestuurskracht wan kleine gemeenten. Beleidsrapport. Leiden/Amsterdam: Onderzoekscentrum Sturing van de samenleving RU Leiden/Stichting voor economisch onderzoek UvA.

Diepeveen, Marlies en Peter Krooneman (2001). De veilige school. Een evaluatieonderzoek in het primait onderwijs (eindrapport). Ansterdam: Regioplan (Regioplan publicatienr. OA-24-256).

Doelen, F.C.J. van der (rg8g). Beleidsinstrumenten ent enetgiebesparing. De toepassing en effectiviteit van voorlichting en subsidies gericht op energiebesparing in de industrie uan 1977 tot 1987 (diss. Twente). Enschede: Universiteit Twente

Doelen, F.C.J. van der en P-J. Klok (I998). 'Beleidsinstrumenten'. In: A. Hoogerwerf en M. Herweijer (red.), Overheidsbeleid. Een inleiding in de beleidswetenschap (p. 209-227). Alphen a/d Rijn: Samsom (zesde, geheel herziene uitgave).

Driessen, $G_{n}$ en J. Doesborg (2003). Voor- en vroegschoolse educatie en cognitieve en niet-cognitieve competenties van jonge kinderen. Nümegen: Instituut voor toegepaste sociale wetenschappen.

Dulk, C.J. den, H. van de Stadt en J.M. Vliegen ( 1992$)$. "Een nieuwe maatstaf voor stedelijkheid. De omgevingsadressendichtheid'. In: CBs, Maandstatistiek bevolking, juli 1992, p. I4-27.

Dut, E.M.J. (s.a.). 'Werk en inkomen'. In: Handboek jeugdbeleid (p. A 3.1-1-A 3.I-31). Den Haag: Elsevier overheid.

Dijkman. Theo (1997). Lokaal jeugdbeleid in Utrechtse gemeenten. Een onderzoek naar de stand wan zaken. Nijmegen: Instituut woor toegepaste sociale wetenschappen.

Edelman, Murray ( 1964$)$. The symbolic uses of politics. Urbana: University of Illinois Press.

Eggink, E. en J.L.T. Blank (20or). Verstandig verzorgd. Een empirisch onderzoek naar de efficiëntie vam de intramurale zorg voor verstandelijk gehandicapten. Den Haag: Sociaal en Cultureel Planbureau (SCP-publicatie 2001/4).

EIM/100 (2004). Monitor jeugdbeleid. Dummy en achtergrondrapportage (eindrapport). Zoetermeer: ElM/roo.

Elsinga, E. (1985). Politieke participatie in Nederland. Een onderzoek naar ontwikkelingen in poititieke participatic in Nederland gedurende de jaren zeventig (diss. Twente). Amsterdam: cT-press.

Elzinga, D.J. en G.H. Hagelstein ( 1998 ). 'Centralisatie en decentralisatie'. In: A.F.A. Korsten en P.W. Tops (red.), Lokaal bestuur in Nederland. Inleiding in de gemeentrelande (p. Io7-12r). Alphen a/d Rijn: Samsom.

Fortuin, Kees (1998). Sociale infrastructulir, regie en ketenverantwoordelijkheid in de grote stederi. Utrecht: Verwey-Jonker Instituut.

Fleurke, E. (2003). 'Nabeschouwing'. In: Sjoerd Karsten et all. (red.), Het gemeentelijkt onderwijsarhterstanden beleid nader beschouwd (p.rr7-r32). Amsterdam, sco-Kohnstamm Instituut.

Fleurke, F. (2004). Over de bestuurlijke verhouding tussen hat Rijken de gemeente. Brief uan de gemeente aun het rijk. Den Haag: Commissie Autonomie voor de VNG, 22 mei 2004.

Fleurke, F., R. Huist en P.J. de Vries (r997). Decentraliseren met beleid. Een keuristick. Den Haag: Sdu.

Gelauff-Hanzon, C. en M. de Gruijter (Ig9g). Venworvenheden en perspectief. o- tot 18 -jarige allochtonenbeleid. Den Hatag: ministerie van wws.

Gilsing, Rob (r999). Lokasl jeugdbeleid. Een inventariserend onderzoek. Rijswijk/Den Haag: Sociaal en Cultureel Plambureau/Elsevier bedrijfsinformatie (scp-cahier 16I). 
Gilsing, Rob (2001). 'Involving young people. Two perspectives on youth participation in local government.' In: P. Salustowicz (red.), Civil society and social development. Proceedings of the $6^{\text {Th }}$ biennial European IUCISD Conference in Krakow 1999 (p. 213-228). Bern: Peter Lang.

Gilsing, Rob (2003). Beleid in de groei. Voortgang en uitkamsten van het lokale jeugdbeleid.

Den Haag: Sociaal en Cultureel Planbureau ( $\mathrm{SCP}$-onderzoeksrapport 2003/15).

Gilsing, Rob, et al. (r999). Onderzoek naar lokaal sociaal beleid. Den Haag: Sociaal en Cultureel Planbureau ( $(\mathrm{SCP}$-Werkdocument 58 ).

Gilsing, Rob, et al. (2000). Knelpunten in het stedelijk jeugdbeleid. Den Haag: Sociaal en Cultureel Planbureau (scp-onderzoeksrapport 2000/8).

Gilsing, Rob, Vic Veldheer en Marianne Vorthoren (200r). 'De betekenis van de sociale pijler in het grotestedenbeleid'. In: R.P. Hortulanus en J.E.M. Machielse (red.), Op het snijulak van de fysieke en saciale leffomgeving. Het Sociaal debat 3 (p. 23-36). Den Haag: Elsevier.

Goldsmith, Michael (2002). 'Central control over local government - a Western European comparison'. In: Local government studies (28) 3, P. 91-112.

Goldsmith, Mike ( 2005). 'A new intergovernmentalism? Changing intergovernmental relations in federal and unitary states'. In: Bas Denters and Lawrence E. Rose (red.), Comparing local governance. Trends and developments. Houndmills, Basingstoke: Palgrave Macmillan, p. 2.28-245.

Goldsmith, Mike en Ken Newton ( 1983 ). 'Central-local government relations. The irresistible rise of centralised power". In: West European politics (6), p. 216-233.

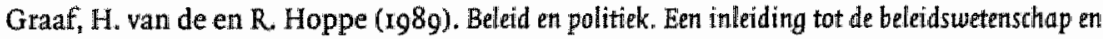
de beleidskunde. Muiderberg: Coutinho.

Groenendijk, J.G. (r998). 'Local policymaking under fiscal centralism in the Netherlands. Consequences for local environmental policy*. In: Environment and planning c: government and policy (16), p. 173-189.

Groot, Ronald de (2005). 'Effecten van decentralisatie van onderwijsbeleid naar gemeenten en de keuze voor territoriale of functionele decentralisatie'. In: Bestuurswetenschappen (59) $r$, p. 52-73.

Hagelstein, G.H. (1993). 'De verhouding tussen algemeen en functioneel bestuur. Naar bestuur op mat'. In: Functioneel bestuur (p. 1-36) (met bijdragen van $\mathrm{G}_{n} \mathrm{H}$. Hagelstein et al.). Zwolle: Tjeenk Willink (Publicaties van de staatsrechtkring 4).

Hambleton, $R$. en $H$. Thomas (1995). "Urban policy evaluation - the contours of the debate'. In: R. Hambletom en $H$. Thomas (red.), Urban policy evaluation. Challenge and change ( $\mathrm{p} .1-20)$. Londen: Paul Chapman publishing,

Hanf, Kenneth (r978). 'Introduction'. In: Kenneth Hanf en Fritz W. Scharpf (red.), Interorganizational policy making. Limits to coordination and central control (p. 1-15). London: Sage.

Heffen, Oscar van, Walter Kickert en Jacques Thomassen (2000). "Introduction. Multi-level and multi-actor governance'. In: Oscar van Heffen, Walter J.M. Kickert en Jacques J.A. Thomassen (red.), Governa nice in modern society. Effects, change and formation of government institutions (p. 3-1r). Doordrecht: Kluwer academic publishers.

Hennekens, H.Ph.A.M. (2000). 'De gemeente verbouwd, niet versterkt''. In: Bestuurskunde (9) 2, p. $62-66$.

Herweijer, L. (2003). 'Voorschoolse voorzieningen en brede scholen'. In: E. Zeill (red.), Rapportage jeugd 2002 (p. 175-I96). Den Haag: Sociaal en Cultureel Planbureau (scPpublicatie 2002/16).

Hesse, Joachim Jens en Laurence J. Sharpe (199I). "Local government in international perspective. Some comparative observations". In: Joachim Jens Hesse (red.), Local government and urban affairs in international perspective. Antalyses of twenty western industrialised countries (p. 603-62r). Baden-Baden: Nomos. 
Heuvel, J.H.J. van den (1998). Beleidsinstrumentatie. Sturingsinstrumenten woor het overheidsbeleid. Utrecht: Lemma.

Hood, Christopher C. (Ig83). The tools of government. Chatham, New Jersey: Chatham House Publishers.

Hoogerwerf, A. (I980). 'Relaties tussen centrale en lokale overheden in Nederland'. In: Beleid \& Maatschappij (7) r., p. 330-346.

Houten, Gijs van (2004). Is er meer nodig in de metall? De doorwerking van de aonbevelingen wit het social akkoord 'Er is meer nodig' in de coo Metalelektro als exemplaar van de coherentie tussen verschillende niveuas in stelsels van gelaagde besluitvorming. Utrecht: Universiteit Utrecht, i.s.m. ministerie van szw.

Hufen, J.A.M. en A.B. Ringeling (red.) (rg9o). Beleidmetwerken. Overheids-, semi-overheids-en particuliere organisaties in wisselwerking. Den Haag: VUGA.

Hupe, P.L. (1990). 'Intenties in interacties'. In: J.A.M. Hufen en A.B. Ringeling (red.), Beleidsnetwerken. Overheids-, semi-overheids- en particuliere organisaties in wisselwerking (p. 223234). Den Haag: vuga.

Hupe, Peter en Míchael Hill (2004). "Het meerlagenvraagstuk in het onderzoek naar beleidsprocessen'. In: Belleidswetenschap $(18)$, p. $62-85$.

Hupe, D.L. en E.H. Klijn ( 1997 ). De gemeente als regisseur varn het preventief jeugdbeleid. Rotterdam: Erasmus universiteit, vakgroep bestuurskunde.

Huysmans, F. en J. de Haan (2003). 'Media en ict'. In: E. Zeijl (red.), Rapportage jeugd 2002 (p. 79-102). Den Haag: Sociaal en Cultureel Planbureau (SCP-publicatie 2002/16).

John, Peter (200I). Lacal governance in. Western Europe. London: Sage.

Kalders, P, J. wan Erp en K. Peters (2004). 'Overheid in spagaat: over spanningen tussen. verticalle en horizontalle sturing'. In: Bestuurskunde (13) 8, p. 338-346.

Kesteren, J.H.M. van en A.F.A. Korsten (1993). 'Welzijnsbeleid. Oefening in functionele complementariteit?' In: A.J.A. Godfroil en N.J.M. Nelissen (red.), Verschuivingen in de besturing van de samenleving (p. 439-47x). Bussum: Coutinho.

Kickert, W.J.M. (rg93a). 'Conclusies en discussie'. In: W.J.M. Kickert (red.), Veranderingen in management en organisatte bij de rijksoverheid (p. 297-306). Alphen a/d/ Rijn: Samsom H.D. Tjeen Willink.

Kickert, W.J.M. (1993b) "Inleiding'. In: W.J.M. Kickert (red.), Veranderingen in management en organisatie bij de rijksoverheid (p. 15-32). Alphen a/d/ Rijn: Samsom H.D. Tjeen Willink.

King, David ( $\mathrm{rg} 84$ ). Fiscal tiers. The economics of multi-level government. Londen: George Allen and Unwin.

KJijn, E.H. en G. Teisman (1992). "Besluityorming in netwerken. Een theoretische beschouwing over het analyseren en verbeteren van beleidsprocessen in complexe beleidsstelsels'. In: Bestuurswetenschap i, p. 32-51.

Kolk, H. van der (r997). Electoralle controle. Lokale verkiezingent en respontsiviteit uan politici (diss. Twente). Enschede: Twente University Press.

Koops, H. en R. Gilsing (2003). 'Evaluatie vNG-project Lokaal jeugdbeleid'. In: $\mathrm{X}$. van Westering (red.), Einduerslag project Lokaal jeugdbeleid 1999-2002. Einduerslag van het project lokaal jeugdbeleid vam de VNG. Den Haag: Vereniging van Nederlandse Gemeenten.

Koot, W. en E. Dobbinga (2004). 'Vertraagde vernieuwing. De weerbarstigheid van departementale culturen". In: Bestuurskunde (13) 3, p. mo-rr8.

Koppenjan, J.F.M., J.A.M. Hufen en J.H.Th. Kramer (200I). 'Centrale visie en lokale praktijk. Barrières en kansen in het gemeentelijk verkeers- en vervoersbeleid. In: Bestuursujetenschappen (55) 6, P. 454-479.

Korsten, A.F.A. (1997) " Bestuurlijke vernieuwing in Nederlandse gemeenten: een illusie?' In: Beleidswetenschap (II) I, p. 4r-54. 
Kuhry, B. en V. Veldheer (2004). Maten voor gemeenten 2004 . Een andlyse van de prestaties van de lokale oterheid. Den Haag: Sociaal en Cultureell Planbureau (SicP-onderzoeksrapport 2004(5).

Kwekkeboom, M.H. (1994). Rapportage welzijnswerk, Deel 4. De rol van de gemeente in het ouderembeleid. Rijswijk: Sociaal en Cultureel Planbureau (SCP-cahier 107).

Kwekkeboom, M.H. (I997). De ontwikkeling van een lokaal beleid woor ouderen en gehondicapten. Rijswijk: Sociaal en Cultureel Planbureau (Welzijnsbeleid in de lokale samenleving 6, scp-cahier 138):

Kwekkeboom, $R$, T. Roes en V. Veldheer (2002). De werkelijkheid van de Welzijnswet. Verkenning van de werking van de Welzijnswet op lokaal, provinciaol en landelijk niveau. Den Haag: Sociaal en Cultureel Planbureau (SCP-onderzoeksrapport 2002/r2).

Lane, Jan-Erik (1993). The public sector. Concepts, models and approaches. Londen: Sage.

Langbroek, P.M. (1988). Machtenstheiding en decentralisatic. Een onderzoek nact de rechtsuerhowding tussen centrale en decentrale overheidsotganen in Nederland (diss. Twente). Enschede: Faculteit der Bestuurskunde, Universiteit Twente.

Lange, Marice de (1995). Besluituorming rond strategisch ruimtelijk beleid. Verkenning en toepassing van doorwerking als beleidswetenschappelijk begrip (diss. Nijmegen). Amsterdam: Thesis publishers.

Lelieveldt, Herman (1999). Wegen naar macht. Politieke participatie en toegang van het maatschappelijk middenveld op lokaal niveau (diss. Nijmegen). Amsterdam: Thela thesis.

Maarse, J.A.M. (Ig9r). 'Hoe valt de effectiviteit van beleid te verklaren?, deel $\mathrm{x}$ : Empirisch onderzoek'. In: J.Th.A. Bressers en A. Hoogerwerf (red.), Beleidsevaluatie (p. 222-135). Alphen ald Rijn: Samsom H.D. Tjeenk Willink.

Maarse, J.A.M. en J. Moen (Iggr). 'Instrumenten van beleid'. In: Bieleidswetenschap (5) 2, p. 132-r47".

Mateman, Sander, et al. (2004). Evaluatie Stimuleringsprojecten allachtone groepen (eindrappost). Amsterdam / Leiden: Regioplan/Research voor beleid.

Mentink, D. (2004). Omstreden gemeentelijk anderwijsbeleid. Over grondwetsuitleg en het primaat van de wetgever, in het bijzonder met betrekking tot de decentralisatie van het onderwijsachterstandenbeleid en de huisvestingsvoorzieningen. Den Haag: Elsevier overheid.

Michels, A.M.B. (2002). 'Een halue eeuw overheidssturing'. In: Beurijdende kaders. Sturen op verantwoordelijkheid (p. 115-139). Den Haag: R.Mo/Sdu (Advies 24).

Mooij, Ton (20or). Veilige scholen ert (pro)socioal gedrag in het voortgezet onderwijs. Evaluatie van de campugne 'de veilige school'. Nijmegen: Instituut voor toegepaste sociale wetenschappen.

Netten, Xenia (200o). Lokaal jeugdbeleid. Inhoudsanalyse van beleidsdocumenten (stageverslag Sociaal en Cultureel Planbureau).

Noorda, J.I., et al. (1996). Resultaten nulmeting ontwikkeling loknal preventiefjeugdbeleid. Amsterdam: Instituut Jeugd en Welzijn/Van Dijk, Van Soomeren en Partners.

Nijendaal, Gerber van en Patrick Tetteroo (2003). 'Bestuurlijke modellen voor de regio'. In: Auke J. van Dijk (red.), Laag voor laag. Aspecten van regionalisering (p. 43-49). Den Haag: Raad voor het Openbaar bestuur.

Oberon (2002). Brede scholen in Nederland: jaarbericht 2002. Utrecht: Oberon.

Osborne, David en Ted Gaebler (1992). Reinventing government. How the entrepreneurial spirit is transforming the public sector, Reading, Mass: Addison-Wesley.

Osterkamp, Rigmar en Markus Eller (2003). 'Functional decentralisation of government activity'. In: CESifo DICE Report 3/2003: Joumal of institutional comparisons (6) 3, p. $3^{6-42}$.

Owens, Jeffrey en Giorgio Panella (red.) (199I). Local government. An international perspective. Amsterdam: Elsevier. 
Page, Edward C. (uggI). Localism and cemtralism in Europe. Oxford: Oxford university press.

Page, Edward C. en Michael J. Goldsmith (red.) (rg87). Central and local government relations. A comparative analysis of West European unitary states. London: Sage (Modern Politics Series Vol. 13).

Pennen, A.W. van der, et al. (1995). Welzijnsbeleid in de lokale sumenieving. Een verkemnende studie in drie gemeenten. Rijswijk: Sociaal en Cultureel Planbureau (Rapportage welzijnswerk 5 , ScP-cahier Irgl.

Pierre, Jon en B. Guy Peters (2000). Governance, politics and the state. Houndmills, Basingstoke: Macmillan.

Poel, Hugo van der (2003). 'Ontwikkelingen in het sportbeleid'. In: Koen Breedveld (red.), Rapportage sport 2003 (p.35-69). Den Haag: Sociaal en Cultureel Planbureau (scp-publicatie 2003/4).

Poelje, G.A. van (I95I). 'Met ledige handen. Enkele algemene opmerkingen in het jaar van het eeuwfeest der Gemeentewet'. In: WNG, Gedenkboek ter gelegentheid wan het honderdjarig bestacn van de Gemeentewet (p. 82-133). Den Haag: Vereniging van Nederlandse Gemeenten.

Poelje, G.A. van (1963). Hedendaugs gemeentewezen. Alphen ald Rijn: Samsom.

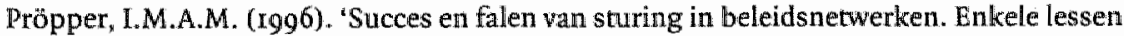
ten behoeve van een theoretisch model'. In: Beleidswetenschap (ro) 4, p. 353-357.

Pröpper, Igno, Bart Litjens en Ester Weststeijn (2004). Lokale regie uit macht of onmacht? Onderzokk naar optimalisering van de gemeentel ijke regiefunctie. Vught: Partners en Pröpper.

Puts, J.H.L. en G.M.L.M. Wever (1998). Jeugdvoorzieningen in beeld. Een instrument voor het inventariserem van het lokale aanbod vaor de jeugd. Rijswijk: Ontwikkeling lokaal preventief jeugdbeleid.

Raadschelders, J.C.N. (I990). Plaatselijke bestuurlijke ontwilkkelingen $1600-1980$. Een historischbestuurskundig onderzoek in vier Noord-Hollandse gemeenten (proefschrift Rijksuniversiteit Leiden). Den Haag: vNG-uitgeverij.

Rhodes, R.A.W. (rg97). Understanding governance. Policy networks, governance, reflexivity and accountability. Maidenhead: Open Uniwersity Press.

RBB (r995). Functioneel bestuur in organieke kaders. Den Haag; Raad voor het binnenlands bestuur.

RFV (2000). Jaarrapport 1999 Raad voor de Financiële Verhoudingen. Den Haag: Raad voor de Financiële Verhoudingen

R.MO (2002). Bewrijdende kaders. Sturen op verantuwordelijkhed. Den Haag: Raad voor Maatschappelijke Ontwikkeling/Sdu (Advies 24).

ROB (r999a).. Op het toneel en achter de coulissen. De regiefunctie van gementen. Den Haag: Raad voor het Openbaar bestuur.

ROB (I999b). Het bestuurlijkk kraakbern. Den Haag: Raad woor het Openbaar bestuur.

ROB (2003). Legio voot de regio. Bestum urlijke antwoorden op regionale praagstukkem. Den Haag: Raad voor het Openbaar bestuur.

ROB en RFV (2000). De kunst van het overlaters. Maatwerk in decentralisatie. Den Haag: Raad voor het Openbaar bestutr en Raad woor de Financiële Verhoudingen.

ROB en RFV (2001). Steden zonder muren. Toekomst van het grotestedenbeleid. Den Haag: Raad voor het Openbaar bestuur en Raad voor de Financiële Verhoudingen.

Roes, Theo, et al. (1987). Gemeente, butger, klant. Rijswijk: Sociaal en Cultureel Planbureau ( $S C P-s t u k w e r k 4 x$ ).

Roes, Theo, Rob Gilsing en Elke Zeifl (2002). Noar eer agenda voor de jeugd. Voorsteller voor een positief lokaal jeugdbeleid. Den Haag: Sociaal en Cultureel Planburean (SCP-werkdocument 87).

Savornin Lohman, P.M. (2001). "Jeugdparticipatie', In: Handbock jeugdbeleid (p. A5.4.1A 5, 4.18). Den Haag: Elsevier. 
Schafer, J.L. (1999). Multiple imputation of incomplete multivariate data under a normal model, version 2.03. Geraadpleegd in maart 2003 via www.stat.psu.edu/ -jls/misoftwa.html. Schambach, Rixt, Jaap Bouwmeester en Mechtelien wan der Aalst (2001). Stimuleringsprojecten voor Turkse en Marokkaanse jongeren. Eindevaluatie. Den Haag: ministerie van Sociale Zaken en Werkgelegenheid.

Scharpl, Fritz W. (1978). 'Interorganizational policy studies. Issues, concepts and perspectives'. In: Kenneth Hanf en Fritz W. Scharpf (red.), Interarganizational policy making. Limits to coordination and central control (p. 345-370). London: Sage.

Scharpf, Fritz W. Bernd Reissert en Fritz Schnabel (r978). 'Policy effectiveness and conflict awoidance in intergovernmental policy formation'. In: Kenneth Hanf en Fritz W. Scharpf (red.), Interorgamizational policy making. Limits to coordination and central control (p. 57-112). London: Sage.

Schnabel, P. (200r). "Bedreven en gedreven. Een heroriëntatie op de rol van de rijksoverheid in de samenleving'. In: Verkenningent bouwstemen voor toekomstig beleid. Den Haag: Sdu.

Schoorl, André (s.a.). 'De Wet maatschappelijke ondersteuning'. In: Handboek lokaal sociaal beleid (p. A 3.1-I-A 3.1.8). Den Haag: Elsevier overheid.

Schuyt, C.J.M. (1995). Kuetsbare jongeren en hurn toekomst. Beleidsadvies gebaseerd op literatuurverkenning. Rijswijk: ministerie van Volksgezondheid, Welzijn en Sport.

SCP (1985). Jongeren in de jaren tachtig. Een beschrijwende studie naar maatschappelijke kenmerken en denkbeelden wan jongeren. Rijswijk: Sociaal en Cultureel Planbureau.

SCP (I998). Sociale en Culturele Verkenningen 1998. Rijswijk/Den Haag: Sociaal en Cultureel Planbureau/Elsevier bedrijfsinformatie (SCP-cahier ${ }_{449}$ ).

SCP (2002). Sociaal en Culturel Rapport 2002. Den Haag: Sociaal en Cultureel Planbureau.

SER (2002). Steden op koers. Advies over het grotestedenbeleid. Den Haag: Sociaal-Economische Raad (advies nr, 02/03)

Sharpe, L.). (Ig88). "The growth and decentralisation of the modem democratic state'. In: European joumal of political research ( 160$), \mathrm{p} \cdot 365-380$.

Simonis, J.B.D. en P.B. Lehning (I987). 'Een pluriforme beleidswetenschap'. In: P.B. Lehning en J.B.D. Simonis (red.), Handboek beieidswetenschap. Meppei: Boom.

Studulski, Frank en Miek Hoogbergen (2002). Veiligheid als woorwaarde. Werken aan een structureel weiligheidsbeleid op school, 1995-2001. Utrecht: Sardes.

Tatenhove, J. van en P. Leroy (rg95). 'Beleidsnetwerken. Een kritische analyse'. In: Beleidswetenschap (9) 2, p, 128-145.

Terpstra, J. en I. Bakker (2002). Met recht lokaal. Evaluatie van Jusititie in de butrt. Enschede: IPIT.

Toonen, Theo A.J. ( $198 \mathrm{r})$. "Gemeentelitke invloed in een vervlochten bestuur. De relaties tussen nationale en lokale owerheden'. In: Beleid en Maatschappij (8) II, p. 334-342.

Toonen, Theo A.J. (1987), Denken over binnenlands bestuwr. Theorieen van de gedecentraliseerde enheidsstant bestuurskundig beschouwd (diss. Rotterdam). Den Haag: vUGA.

Toonen, Th. (rg93). 'Bestuur en beleid'. In: J.W. van Deth (red.), Handboek politicologie (p. 250-28i ). Assen: Van Gorcum.

Toonen, Th.A.J. (1998). 'De geneente in de gedecentraliseerde eenheidsstaat'. In: A.F.A. Korsten en P.W. Tops (red.), Lokaal bestuur in Nederlond. Inleiding in de gemeentekunde (p. 35-46). Alphen a/d Rijn: Samsom.

Toonen, Theo A.I. (2000). "Administrative conditions to institutional politics. Federalism in an unitary state'. In: Oscar wan Heffen, Walter J.M. Kickert en Jacques J.A. Thomassen (red.), Governance in modern society. Effects, change and formation of government institutions (p. 203-222). Dordrecht: Kluwer academic publishers.

Toonen, Th.A.J. en F. Hendriks (I998). 'Gemeenten en hogere overheden'. In: A.F.A. Korsten en P.W. Tops (red.), Lokaal bestuur in Nederland. Inleiding in de gemeentekunde (p. 122-134). Alphen ald kijn: Samsom. 
Torenvlied, René (r 995$)$. "De inbedding van beleidswisies in beleidsnetwerken". In: Beleidswetenschap (9) 4, p. 3.23-341.

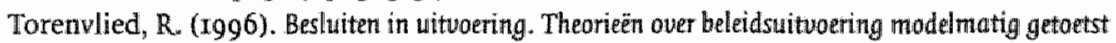
op sociale vernieuwing in drie gemeenten (diss. Groningen). Amsterdam: Thesis publishers.

Torenvlied, René en Agnes Akerman (2004). "Theory of 'soft' policy implementation in multilevel systems with an application to social partnership in the Netherlands'. In: Acta Politica (39) I, p. 3I-58.

Turkenburg, Monique (1999). Germeentelijk onderwijsachterstandenbeleid. Een inhoudelijke en bestuurlijke typering. Den Haag: Sociaal en Cultureel Planbureau/Elsevier bedrijfsinformatie (SCP-cahier 164 )

Turkenburg, Monique (2002). Taal lokaal. Gemeentelijk onderwijs in allochtone levende talen (OALT). Den Haag: Sociaal en Cultureel Planbureau (SCP-publicatie 2002/9).

Turkenburg, Monique (2003). Het gemeentelijk onderwijsactiterstandenbeleid halverwege de eerste planperiode (1998-2002). Het beleidspraces in viffien gemeenten. Den Haag: Sociaal en Cultureel Planbureau (SCP-onderzoeksrapport 2003/10).

Vedung, E. (I997). Public policy antd program evaluation. New Brunswick: Transaction publishers.

Veenswijk, Marcel (1996). Departementale cultuur, IJzeren kaoi, bron van versplintering of politiek werktuig? (diss. Rotterdam) Delft: Eburon.

Veenswijk, M. en W.J.M. Kickert (1993). 'Departementale cultuur'. In: W.J.M. Kickert (red.), Veranderingen in management en organisatie bij de rijksoverheid (p.237-253). Alphen a/d/Rijn: Samsom H.D. Tjeen Willink.

Veldheer, V. (1994). Kantelend bestuur. Ondezzoek naar de ontwikkeling wan taken van het lokale bestuur in de periode $1851^{-1985}$ (diss. Leiden). Rijswijk: Sociaal en Cultureel Planbureat (Sociale en Culturele Studies 20).

Veldheer, Vic, et al. (1994). Het lokale profiel. De identiteit van gemeenten en de rol van de butget. Rijswijk: Sociaal en Cultureel Planbureau (SCP-cahier II5).

Vollers, Jan en Henk Hack (200r). 'Programma lokaal beleid'. In: Beleidswerantwoording Jeugd in beweging 1996-2001. Arnhem: Stichting Jeugd in beweging.

Westering, Y. van (2003). Einduerslag project Lokaal jeugdbeleid 1999-2002. Einduerslag wan het project lokaal jeugdbeleid van de vNG. Den Haag: Vereniging van Nederlandse Gemeenten.

Wiebing, H.P. en E. van Lankvelt (1999). Nata van preventie. Inventarisatie van het lokaal preventief jeugdbeleid in 12 Limburgse gemeetten, beleidsrapportage. Maastricht: PBW.

Willemse, $\mathbb{R}$. (200r). Het bestanspecht van de Nederlandse gemeente. Eigen initiatief en integraal besturer in de periode 1960-1996 (diss. vu Amsterdam). Delft: Eburon (Binnenlands bestuur in verandering 7 ).

Winter, M. de (1995). Kinderen als medeburgets. Kinder-en jeugdparticipatie als ma atschappelijk opuoedingsperspectief. Maarssen: Elsevier/De Tijdstroom.

Wittebrood, K. (x995). Politieke socialisatie in Nederland. Een onderzaek naar de veruerving en ontwikkeling van politieke houdingen van havo-en wwo-leetlingen (diss. Nijmegen). Amsterdam: Thesis publishers.

Wittebrood, K. (2000a). 'Problemgedrag onder jongeren'. In: K. Wittebrood en S. Keuzenkamp (red.), Rapportage jeugd z 000 . Trajecten van jongeren naar zelfstandigheid (p. I67-193). Den Haag: Sociaal en Cultureel Planbureau (SCP-publicatie 2000/7).

Wittebrood, K. (200ob). 'Trends in jeugdgeweld'. In: Justitiele verkenningen (26) I, P. 2I-34.

Wittebrood, K. (2003). 'Preventieve en strafrechtelijke interventies ter voorkoming van jeugdcriminaliteit'. In: E. Zeijl (red.), Rapportage jeugd 2002 (p. 197-216). Den Haag: Sociaal en Cultureel Planburean (SCP-publicatie 2002/I6).

Wouden, R. van der et al. (1994). Evaluatie sociale vernieuwing. Het eindrapport. Rijswijk/Den Haag: Sociaal en Cultureel Planbureau/vUGA (SCP-cahier IOg). 
WRR (2004), Wetenschappelijke Raad voor het Regeringsbeleid. Bewijzen van goede dienstwerlening. Amsterdam: Amsterdam University Press.

Yanow, Dvora (1993). 'The communication of policy meanings. Implementation as interpretation and text'. In: Policy sciences (2.6), p. 4r-6r.

Zeijl, Elke (2003). 'Politieke en maatschappelijke participatie'. In: E. Zeijl (red.), Rapportage jeugd 2002 (p. 103-124). Den Haag: Sociaal en Cultureel Planbureau (scP-publicatie 2002/16).

Zeijl, Elke, et al. (2003). Rapportage jeugd 2002. Den Haag: Sociaal en Cultureel Planbureau (SCP-publicatie 2002/:6).

Zeiil, Elke, et al. (2005). Kinderen in Nederland. Den HaaglLeiden: Sociaal en Cultureel Planbureau/TNo Kwaliteit wan leven (SCR-publicatie 2005/4). 


\section{Geraadpleegde documenten}

Algemene Rekenkamer (2003). Handreiking normen woor netwerksturing. Den Haag: Allgemene Rekenkamer.

Algemene Rekenkamer (2005). Brief aan de Voorzitter van de Tweede Kamer d.d. 13/0r/2005, betreffende Reactie op eind rapport Stuurgroep doorlichting specifieke uitkeringen (commissie-Brinkman). Den Haag: Algemene Rekenkamer (kenmerk 4006422 R.

BANS (rg99). Bestuursakkoord Nieuwe Stijl. Jengdbeleid in Ba(la)ns. Afspraken van rijk, provincies en gemeenten over een gezamenlijk jeugdbeleid. Den Haag: ministerie van Binnenlandse Zaken en Koninkrijksrelaties/Vereniging van Nederlandse Gemeenten Interprovinciaal Overleg.

BANS (Ig9gb). Bestuursakkoord Nieuwe Stijl. Ouetheden over toekamst. Den Haag: ministerie van Binnenlandse Zaken en Koninkrijksrelaties/Vereniging van Nederlandse Gemeenten/ Interprovinciaal Overleg.

BANS (2001). Bestuursakkoord Nieuwe Stijl. Jeugdbeleid in Ba(la)ns II. Afspraken van rijk, provincies en gemeenten over een gezamenlijk jeugdbeleid. Den Haag: ministerie van Binnenlandse Zaken en Koninkrijksrelaties/Vereniging van Nederlandse Gemeenten/Interprovincial Overleg.

BAN S-bezoekcommissie (2002). Bans in het land. Eindrapportage Bans-bezoekcommissie jeugdbeleid. Den Haag: ministerie van Volksgezondheid, Welzijn en Sport.

Boom, C.E.M. van de (1999). Wet inschakeling werkzoekenden. Nederlandse wetgeving Editie Schuurman en Jordens, ro8b. Deventer: Kluwer.

BzK (I995a). 'Convenant $G_{4}$ '. Geraadpleegd op http://www.minbzk.nl/grote_steden/grotestedenbeleid/publicaties/convenant_g4, op 23 november 2004 .

BZK (I995b). 'Convenant Gr5'. Geraadpleegd op http://www.minbzk.nl/grote_steden/grotestedenbeleid/publicaties/convenant_gI5, op 23 november 2004 .

BZK (1998). Doorstartconventant grote stedenbeleid rijk-G4 en rijk-G21. Den Haag: ministerie van Binnenlandse Zaken en Koninkrijksrelaties.

BZK (2002). Steden op stoom: tussenstand grotestedenbelleid 1994-2002. Den Haag: ministerie van Binnenlandse Zaken en Koninkrijksrelaties.

Code interbestuurlijke verhoudingen (2004). "Code interbestuurlijke verhoudingen'.

EK (1997/1998). Wijziging van enkele onderwijswetten in werband met het onderwijs in allachtone levende talen en enkele technische toepassingeth. Memorie van Antwoord. Eerste Kamer, vergaderjaar $1997 /$ I 998,25176, nr.167b.

Externe commissie CRIEM (s.a.). Op weg noar een andere cultuut: de eerste stap(pen) gezet. Advies van de Externe Commissie CRIEM.

Financiën (2002). Regleling prestatiegegevens en evaluatieonderzoek rijksoverheid. Den Haag: ministerie van Financiền.

Ocw (1995). Lokaal onderwijsbeleid. Den Haag: Sdu.

ocw (1999a). Cultuur als confrontatie: uitgangspunten voor het culturbeleid 2001-2004.

Den Haag: Sdu.

OCW (1999b). Veiligheidsbeleid 2000-2003 voor PO, vo en BVE. Zoetermeer: ministerie van

Onderwijs, Cultuur en Wetenschappen (kenmerk vo/TAB/1999/43846).

OCW (2-000). Voortgangsrapportage Weer samern maar school. Zoetermeer: ministerie van $O C e n W$ (kenmerk PO/KB-Oo/I407I).

OLPJ ( $1998 \mathrm{a}$ ). Jeugdbeleid windt zijn weg: eindwerslag van de projectgroep Ontwikkeling lokad preventief jeugdbeleid. Rijswijk: oLPI. 
OLy] (r9g8b). Verder werken aun lokaal jeugdbeleid. Eindadvies van de projectgroep Ontwikkeling lokad preventiefjeugdbeleid. Rijswijk: OLPJ.

Operatie Jong (2003a). Operatie Jong. Samen werken aum integraal jeugdbeleid (I) $x$.

Den Haag/Zoetermeer: ministeries wan BZK, Justitie, SZw en vws, ocw.

Operatie Jong (2003b). Praete van de jeugdagenda. Den Haag/Zoetermeer: ministeries van. EZK, Justitie, szw en wws, OCW.

Operatie Jong (2004a). Operatie Jong. Sterk en resultatgaticht woor de jeugd. Den Haag: Operatie long.

Operatie Jong (2004b). 12 Thema's van Operatie Jong. Plannen van aanpak. Den Haag: Operatie Jong.

Operatie Jong (2005). 'Kabinet selecteent gemeenten voor nieuw lokaal jeugdbeleid' (persbericht vrijdag 21 januari 2005 , nummer 2 ). Den Haag: Operatie Jong.

Staatsblad (1994). "Wet van wo maart 1994, houdende wijzigingen van de Leerplichtwet 1969 en enkele andere wetten'. In: Staatsblad 1994, 255.

Staatsblad (1995). 'Besluit van 22 maart 1995, houdende voorschriften in verband met het werstrekken aan gemeenten van middelen in verband met het opzetten van een regionaal meld- en coördinatiepunt ter bestrijding van het voortijdig schoolverlaten door leerplichtige en niet-leerplichtige leerlingen" (Tijdelijk besluit regionale meld-en coördinatiefunctie voortijdig schoolverlaten). In: Staatsblad 1995, r6g.

Staatsblad (1996). "Wet van 4 juli 1996 , houdende wijziging van de Wet op het basisonderwijs, de Interimwet op het speciaal onderwijs en het voortgezet speciaal onderwijs, alsmede de Wet op het voortgezet onderwijs in verband met de decentralisatie van de huisvestingswoorzieningen'. In: Stantsblad 1996, 402.

Staatsblad (I997a). 'Wet van 15 mei I997 tot wijziging van onder meer de Wet op het basisanderwijs, de Interimwet op het speciaal onderwijs en het voortgezet speciaal onderwijs en de Wet op het voortgezet onderwijs inzake het gemeentelijk onderwijsachterstandenbeleid' (Gemeentelijk onderwijsachterstandenbeleid). In: Staatsblad 1997, 237.

Staatsblad (1997b). "Besluit van 28 augustus 1997 , houdende vaststelling van het landelijk beleidskader inzake het gemeentelijk onderwijsachterstandenbeleid en wijziging van enkele besluiten' (Besluit landelijk beleidskader gemeentelijk onderwijsachterstandenbeleid). In: Statatsblad 1997, 431 .

Staatsblad (1997c). "Wet wan 15 mei 1997 tot wijziging wan onder meer de Wet op het basisonderwijs, de Interimwet op het speciaal onderwijs en het voortgezet speciaal onderwijs en de Wet op het voortgezet onderwijs inzake schoolbegeleiding' (regeling schoolbegeleiding). In: Statatsblad 1997, 25.2.

Staatsbiad (1997d). 'Wet vain 4 december 1997, houdende regeling voor de totstandkoming van een gemeentelijk werkfonds voor voorzieningen ter bevordering van de toetreding tot het arbeidsproces van langdurig werklozen en jongeren" (Wet inschakeling werkzoekenden). In: Staatsblad 1997, 760.

Statsblad (1998a). "Wet wan 5 maart I998, houdende wijziging van enkele onderwijswetten in werband met het onderwijs in allochtone levende talen en enkele technische aanpassingen.' Stamteblad 1998,148 .

Staatsblad (1998b). 'Besluit van 2 juni r 998 tot wijziging van enkele algemene maatregelen van bestuur naar aanleiding van het totstandbrengen van een Wet op het primair onderwijs en een Wet op de expertisecentra en toevoeging van een tweede deel aan de Wet op het voortgezet onderwijs en in verband met het onderwijs in allochtone levende talen?. In: Stautsblad 1998,413 .

Staatsblad (200ra). Wet van 6 december 200 r tot wijziging van de Wet op het voortgezet onderwijs, de Wet educatie en beroepsonderwijs en de Wet op de expertisecentra in verband met de invoering van de verplichting voor het bevoegd gezag tot het melden van 
voortijdige schoolverlaters die niet meer leerplichtig zijn, alsmede van de verantwoordelijkheid van de gemeente voor het bestrijden wan voortijdig schoolverlaten" (regels inzake regionale meld- en coördinatiefunctie voortijdig schoolverlaten). In: Stactsblad 2001,636 .

Staatsblad (200rb). ${ }^{\text {B }}$ Besluit van 7 december 2001 , houdende wijziging van de regio-indelling en regels voor de berekening en betaling van de specifieke uitkering woor de regionale meld- en coördinatiefunctie voortijdig schoolwerlaten' (Besluit regionale meld- en coördinatiefunctie voortijdig schoolverlaten). In: Stactsblad 2001, 650 .

Staatscourant (1994). 'Regeling regionale meld- en coördinatiefunctie voortijdig schoolverlaten'. In: Staatscourant, 20 juli 1994, 136, p. $12-14$.

Staatscourant (1995). 'Regeling impuls leefbaarheid, veiligheid en stadseconomie'. In: Statscourant, 2 I december $1995 \times 249$, p. Ix.

Staatscourant (I996a). 'Regeling Financiering Actieprogramma's Jeugd en Veiligheid 1996-1999'. In: Staatscourant, 23 mei r996, 97, p. rI.

Staatscourant ( $(9966)$ ). 'Regeling financiering actieplannen jeugd en veiligheid 1996 -rog9 Gi5'. In: Staatscourant, 29 nowember Ig96, 232, p. 8 .

Staatscourant (I996c). "Regeling impuls leefbaarheid, veiligheid en stadseconomie Gr5". In: Staatscourant, 29 november I9g6, 232, p. 8.

Staatscourant (1997a). 'Tijdelijke stimuleringsmaatregel buitenschoolse opvang'. In: Staatscourant, 8 oktober 1997,194, p. 8.

Staatscourant ( $1997 \mathrm{~b}$ ). 'Regeling kinderopvang en buitenschoolse opvang alleenstaande ouders $1997^{\circ}$. In: Staatscourant, 28 februari 1997,42, p. 8.

Staatscourant (rg97c). "Tijdelijke Regeling inzet extra middelen Jeugd en Veiligheid". in: Statscourant, 3 april $\mathrm{r}_{997}, 65$, p. 14 .

Staatscowrant (r997d). "Regeling impuls leefbaarheid, veiligheid en stadseconomie $\mathrm{G} 6$ '. Itr: Staatscourant 20 november 1997,225, p. 8 .

Staatscourant (1998a), 'Regeling pilot trajectbegeleiders'. In: Staatscourant, 9 oktober 1998 , 196, p. 10 .

Staatscourant ( $(1998 \mathrm{~b})$. 'Ontwerp-besluit wijziging Tijdelijk besluit kwaliteitsregels kinderopvang'. In: Staatscouramt, 2 april 1998,64 , p. II.

Staatscourant (1998c). "Wijziging Tijdelijke stimuleringsmaatregel buitenschoolse opwang:. In: Stautscourant, rr mei 1998,87, p. 8.

Staatscourant (1998d). 'Regeling kinderopvang en buitenschoolse opvang alleenstaande ouders 1999'. In: Staatscourant, 30 december 1998,249 , p. 20.

Staatscourant (r99ga). 'Bijdrageregeling sociale integratie en veiligheid'. In: Stctatscourant, I6 juil $1999,162, \mathrm{p} .8$.

Staatscourant (rgg9b). 'Stimuleringsregeling breedtesport'. In: Statscourant, 19 november I999, 229, p. 6 .

Staatscourant (1999C). "Wijziging Tijdelijke stimuleringsmaatregel buitenschoolse opvang". In: Staatscourant, r8 oktober 1999, 199, p. I4.

Staatscourant (r.999d). "Regeling kinderopvang en buitenschoolse opvang alleenstaande ouders $2000^{\circ}$. In: Statutscouramt, 28 december $1999,250, p \cdot 40$.

Staatscourant (ig9ge). 'Tijdelijke regeling innovatieve tieneropvangprojecten'. In: Stautscourant, 23 februari 1999,36, p.7.

Staatscourant (2000a). 'Bijdrageregeling 'Digitaal trapveld'. In: Staatscourant, 25 april 2000 , 80, p. 8.

Staatscourant (200ob). "Wijziging Regeling uitbreiding kinderopvang en buitenschoolse opvang". In: Staatscourant, 24 juli 2000,140, p. 10.

Staatscourant (200ac). 'Regelling uitbreiding kinderopvang en buitenschoolse opvang'. In: Statatscourant, 15 september 2000 . 179 , p. ro. 
Staatscourant (200od). "Wijziging Regeling uitbreiding kinderopvang en buitenschoolse opvang'. In: Staatscourant, 27 september 2000,187 ; P. Ir.

Staatscourant (200ae). "Wijziging Regeling uitbreiding kinderopvang en buitenschoolse opvang'. In: Stautscourant, II december 2000,240 , p. II.

Staatscourant (200of). 'Wijziging Tijdelijke regeling innowatieve tieneropvangprojecten'. In: Staatscourant, 21 juli 2000,139 , p. 8.

Staatscourant (2000g). 'Eenmalige intensiveringsbijdrage jeugd en veiligheid'. In: Staatscourant ro oktober 2000,196, p. 8 .

Staatscourant (2oooh). "Bijdrageregeling leefbaarheid partiële GsB-steden". In: Staatscoutant, 27 april 2000,82, p. 10.

Staatscourant (2000i). 'Stimuleringsregeling sociale activering'. In: Stantscourant, 8 februari 2000,27, P. 13 .

Staatscourant (200ra). "(rijdelijke) regeling vroegsignalering". In: Staatscourant, 30 maart 2001,64, p. 24.

Staatscourant (200 rb). 'Regeling commissie-Tieneropvang'. In: Stantscourant, 20 maart 200 , 56 , p. Io.

Statscourant (200rc). 'Bijdrageregeling preventiebeleid $2001-2004$ voor jongeren uit etnische minderheidsgroepen'. In: Stautscourant, 28 november 200I, 23 I, p. 9 .

Staatscourant (200rd). 'Bijdrageregeling Antillianengemeenten'. In: Stalatscourant, 18 mei $200 \mathrm{r}, 96, \mathrm{p} .8$.

Staatscourant (2002). 'Beëindiging (tijdelijke) regeling vroegsignalering'. In: Staatscourant. 5 december 2002,235, p. 25 .

Stuurgroep doorlichting specifieke witkeringen (s.a.). Eindrapport stuurgroep doorlichting specifieke aitkeringen.

TK (Ig8o/198I). Decentralisatie van rijkstaken. Tweede Kamer, vergaderjaar rg8o/198I, 16492, nrs. I-2 (Decentralisatienota).

TK (rg88/1989). Nota volkshuisvesting in de jaren negentig. Tweede Kamer, pergaderjaar I988/1989, 2069i, nr. 3 .

TK ( $1992 / 1993)$. Bijzondere commissie vraagpunten decentralisatie. Over decentralisatie is mog nooit een vers geschreven. Tweede Kamer, vergaderjaar I992/I993, 2I427, nrs. 42-43.

TK (1994/1995a). Bestuurlijke vernietwing in het onderwijs. Brief van de staatssecretaris van Onderwijs, Cultuur en Wetenschappen. Tweede Kamer, vergaderjaar I994/1995, 23309, nir. 12.

TK (r994/1995b). Nota Viligheidsbeleid 1995-1998. Brief wan de staatssecretaris met Nota veiligheidsbeleid $1995-1998$. Tweede Kamer, vergaderjaar $1994 / \mathrm{Kg} 95,24225$, nrs. I-2.

TK (1995/1996a). Vaststelling uan de begroting wan de witgawen en de ontuangsten van het ministerie wan Volksgezondheid, Welzijt en Sport (xvi) woor het jaar 1996 . Brief van de staatssecretarissen van Volksgezondheid, Welzijn en Sport en van Onderwijs, Cultuur en Wetenschappen. Tweede Kamer, vergaderjaar r $995 / 1996,24400$ Xv1, nr. 59 .

rk (1995/1996b). Veiligheidsbeleid 1995-19.98. Brief van de staatssecretaris van Binnenlandse Zaken. Tweede Kamer, vergaderjaar $1995 \mathrm{irg96} 6,24225$, nr. 4 (voortgangsrapportage van het traject 'Jeugd en Veiligheid').

TK (1995/1996c). Jeugdcriminaliteit. Brief van de staatssecretaris van Justitie. Tweede Kamer, vergaderjaar $1995 / 1996,24485$, Mr. I.

TK (I996/1997a). Wijziging van de Wet op het basisonderwijs en de Interimuet op het speciaal onderwijs en het voortgezet speciaal ondenwijs in verband met het onderwijs in allochtone levende talen. Memorie van Toelichting. Tweede Kamer, vergaderjaar $1996 / 1997,25176, \mathrm{nr}_{*} 3$. 
TK (1996/1997b). Wijziging uan de Wet op het Basisondenwijs en de Interimwet op Het speciaal onderwijs en het voortgezet speciaal anderuigs in verband met het onderwijs in allochtone levende talen. Nota naar aanleiding van het verslag. Tweede Kamer, vergaderjaar I996/s997, 25176, nr. 5 . TK (1996/1997 c). Sportbeleid. Brief van de staatssecretaris van Volksgezondheid, Welzijn en Sport en Nota. Tweede Kamer, wergaderjaar $1996 / 1997,25125$, nrs. 1-2.

TK (1996/1997d). Buitenschoolse opvang. Brief wan de minister van Sociale Zaken en werkgelegenheid. Tweede Kamer, vergaderjaar 1996/1997, 25457, nr. I (besteding wan de extra middelen ten behoeve van de buitenschoolse opvang).

TK (1997/19g8a). Vaststelling begrating var de uitgaven en de ontvarysten van thet ministerie van Volksgezondheid, Welzijn en Sport (xvi) voor het jaar 1998. Memorie van Toelichting en Bijlam gen. Tweede Kamer, vergaderjaar $1997 / \mathrm{rg9} 8,25600 \mathrm{XVI}$, nrs. 2-3.

TK (1997/I998b). Opvoedingsonderstewning en ontwikkelingstimulering. Brief van de staatssecretaris van Volksgezondheid, Welzijn en Sport. Tweede Kamer, vergaderjaar I997/Ig98, 25980 , nr. I (beleidsbrief 'Naar een solide basis').

TK (r997/1998c). Vaststel ling begroting van de witgaven ery de ontuangsten van het ministerie wan Onderwijs, Cultuur en Wetenschappen (viii) woor het jaar 1998. Memorie van Toelichting en Bijlagen. Tweede Kamer, vergaderjaar r997/I998, 25600 vrrr, nrs , 2-3.

TK (rg97/r998d). Gewichtenregeling basisonderwijs. Brief van de staatssecretaris voor Onderwijs, Cultuur en Wetenschappen. Tweede Kamer, vergaderjaar $1997 / 1998,25844$, nur. I.

TK (1997/I998e). Jeugdzorg 1998-2001. Brief van de minister van Volksgezondheid, Welzijn en Sport. Tweede Kamer, vergaderjaar $1997 / \mathrm{L} 998,256 \mathrm{Ig}$, nr. 3 (standpunt bij het onderzoeksrapport Op weg naar volwassenheid *. Evaluatie jeugdgezondheidszorg Ig96).

TK (1997/rg98f). Criminaliteit in relatie tot integratie van etnische minderheden. Brief van de ministers van Binnenlandse Zaken en van Justitie. Tweede Kamer, vergaderjaar I997/1998, 25726, nr. I.

$\mathrm{TK}$ (I997/I998g). Vaststelling begroting van de uitgaven en de ontvangsten van het ministerie van Binnenlandse Zaken (vii) uoor het jaar 1998. Memorie van Toelichting en Bijlagen. Tweede Kamer, wergaderjaar 1997/1998, 25600 vII, nrs. 2-3.

TK (1997/1998h). Vaststelling begroting uan de uitgaven en de ontvangsten van het ministerie van Sociale Zakert en Werkgelegenheid (xv) voor het jaat 1998 . Memorie van Toelichting en Bijlagen. Tweede Kamer, vergaderjaar $1997 / 1998,25600 \mathrm{xV}$, nrs. 2-3.

TK (1997/rgg8i). Vaststelling begroting van de uitgoven en de antuangsten vam het ministerie van Justitie (vi) voor het jaar 1998. Memorie van Toelichting en Bijlagen. Tweede Kamer, vergaderjaar $1997 /$ rg98, 25600 vi, nrs. $2-3$.

TK (I998/rg9ga). Vaststelling begroting vant de uitgaven en de ontwangsten wan het ministerie van Volksgezondheid, Welziji en Sport (xui) yoor het jaar 1999. Memorie van Toelichting en Bijllagen. Tweede Kamer, vergaderjaar $1998 / 1999,26200$ XVI, nrs. 2-3.

TK (rg98/1999b). Welzijnsnota I999-2002. Tweede Kamer, vergaderjaar 1998/1999, 26477, nir. 2.

TK (1998/1999c). Grotestedenbeleíd. Brief van de minister voor Grote steden- en integratiebeleid. Tweede Kamer, vergaderjaar I998/1999, 2 1062, nr. 7 .

TK (r998/1999d). Integratiebeleid 1999-2002. Brief van de minister woor Grote steden- en integratiebeleid. Tweede Kamer, vergaderjaar 1998/1999, 26333, nrs. I- 2. (brief met nota Kansen krijgen, kansen pakken, Integratiebeleid $1999-2002)$.

TK (1998/1999e). Integratiebsleid 1999-2002. Brief van de minister woor Grote steden- en integratiebeleid. Tweede Kamer, vergaderjaar 1998/1999, 26333, nr. 4 (plan van uitvoering van de nota Kansen krijgen, karsen pakken, Integratiebeleid 1999-2002).

TK (Igg8/r999f). Vaststelling begroting van de uitgaven en de ontwangsten van het ministerie van Onderuijs, Cultuur en Wetenschappen (viii) voor het jaar 1999. Memorie van Toelichting en Bijlagen. Tweede Kamer, vergaderjaar I998/1999, 26200 virr, nrs. 2-3. 
TK (1998/1999g). Plan Voortijdig school verlaten. Tweede Kamer, vergaderjaar y9g8/1999, 26695 , ar. 2 .

TK (1998/1999h). Breedtesport. Brief van de staatssecretaris van Wolksgezondheid, Welzijn en Sport. Tweede Kamer, vergaderjaar $1998 / 1999,26632$, nr. I (Breedtesportimpuls).

TK (1998/I999i). Nota Kinderopuang. Tweede Kamer, vergaderjaar $1998 / 1999,26587$, nr. 2. TK (1998/rg9gi). Integrad veiligheidsprogramma. Brief van de staatssecretaris van Binnenlandse Zaken en Koninkrijksrelaties. Tweede Kamer, vergaderjaar $1998 / \mathrm{rg99}, 26604$, nr. I.

TK (rg98/1999k). Beleidsplan Nederlandase Politie 1999-2002. Brief van de ministers van Binnenlandse Zaken en Koninktijksrelaties en van Justitie. Tweede Kamer, vergaderjaar 1998/1999, 26345, nix. I.

TK (1998/r999l). Vaststelling begroting van de witgaven en de ontuangsten van het ministerie van Binnenlandse Zaken en Koninkrijkstelaties (vii) voor het jaar 199g. Memorie van Toelichting en Bijlagen. Tweede Kamer, vergaderjaar $1998 /$ r999, 26200 VII, nrs. 2-3.

TK (1998/1.999m). Vaststelling begroting uan de uitgaven en de ontuangstem varn het ministerie van Saciale Zaken en Werkgelegenheid (xv) voor her jaar 19g9. Memorie van Toelichting en Bijlagen. Tweede Kamer, vergaderjaar $x 998 / 1999,26200 \mathrm{xv}$, nrs. 2-3.

TK (I998/rog9n). Vaststelling begroting van de uitgaven en de ontuangsten wan het ministerie van Justitie (vi) voor het jaar 1999. Memorie van Toelichting en Bijlagen. Tweede KKamer, vergaderjaar $1998 / 1999,26200 \mathrm{VI}$, nrs. 2-3.

TK. (1999/2000a). Vaststelling begroting van de uitgaven ent de ontvangsten van het ministerie van Volksgezondheid, Welzijn en Sport (xvi) voor het jaar zooo. Memorie van Toelichting en Bijlagen. Tweede Kamer, vergaderjaar $1999 / 2000$, 26800 XVI, nrs. 2-3.

TK (I999/200ob). Brede scholer. Brief van de staatssecretarissen van Onderwijs, Cultuur en Wetenschappen en van Volksgezondheid, Welzijn en Sport. Tweede Kamer, vergaderjaar $1999 / 2000,26999$, ne. I.

TK (1999/2000c). Niet-uriblijuende vormen van opvoedingsondersteuning. Brief wan de staatssecretaris van Justitie. Tweede Kamer, vergaderjaar I999/2000, 27197, nr. I.

TK (x999/200od). Vaststelling begroting wan de witgaven en de ontwangsten van het ministerie van Onderwijs, Cultu ur en Wetenschappen (viii) veor het jaar 2000. Memorie van Toelichting. Tweede Kamer, wergaderjaar 1999/2000, 26800 VIII, nr. 2.

TK (r999/2000e). Voor- en uroegschoolse educatie. Brief van de staatssecretarissen van Volksgezondheid, Welzijn en Sport en van Onderwijs, Culturur en Wetenschappen. Tweede Kamer, vergaderjaar $1999 / 2000,27190$, nr. I.

TK (199g/20oof). Aunpak onderwijsachterstandem. Brief van de staatssecretaris van Onderwijs, Cultuur en Wetenschappen. Tweede Karner, vergaderjaar r999/2000, 27020, nir. I4 (uitwerking notitie 'Onderwijskansen').

TK (1999/200og). Aanpak onderujjachterstanden. Brief van de staatssecretaris van Onderwijs, Cultuur en Wetenschappen. Tweede Kamer, vergaderjaar I.999/2000, 27020, nir. 23 (eerste voortgangsrapportage Uituerking Onderwijskansenbeleid).

TK (I999/2000h). Aanpak onderwijsachterstanden. Brief van de staatssecretaris van Onderwijs, Cultuur en Wetenschappen. Tweede Kamer, vergaderjaar $1999 / 2000,27020$, nr. $3 \mathrm{I}$ (tweede voortgangsrapportage Uitwerking Onderwijskansenbeleid).

TK (r.99/20ooi). Wijziging van de Wet ap het voortgezet onderwijs, de Wet educatie en beroepsonderwijs en de Wet op de expertisecentra in verband met de invoering vart de werplichting voor het. bevoegd gezag tot het melden van voontijdige schoolverlaters die niet meet leerplithtig zijn, alsmede van de verantwoordelijkheid van de gemeente voor het bestrijden van woortijdig schoolverlaten (reggel's inzake regionale meld en coôrdinatie-functic voortijdig schoolverlatenl. Memorie van Toelichting. Tweede Kamer, vergaderjaar 1999/2000, 27206, nr. 3 .

TK (1999/2000j). Positionering Jeugdgezondheidszorg 0-19 jaar. Briefvan de staatssecretaris van Volksgezondheid, Welzijn en Sport. Tweede Kamer, vergaderjaar I999/2000, 27004, nr. I. 
TK (1999/2000k). Vaststelling begroting van de uitgaven en de ontvangsten van het ministerie wan Binnemlandse Zaken en Koninkrijksrelaties (vii) voor het joar 2000. Memorie van Toelichting. Tweede Kamer, vergaderjaar 1999/2000, 26800 VII, nr. 2.

TK (rg99/200ol). Vaststelling begroting van de witgaven en de ontwangstem van het ministerie van. Sociale Zaken en Werkgelegenheid (xw) voor het jaar 2000. Memorie van Toelichting en Bijlagen. Tweede Kamer, vergaderjaar 1999/2000, $26800 \mathrm{xv}$, nrs. $2-3$.

TK (1999/2000m). Vaststelling begroting van de uitgaven en de ontvangsten van het ministerie van Justitie (vi) voor het jaar 2000. Memorie van Toelichting en Bijlagen. Tweede Kamer, vergaderjaar $1999 / 2000,26800$ vi, nrs. 2-3.

TK (200o/200ia). Vaststelling begroting wan de uitgaven en de ontuangsten van het Ministerie van Volksgezondheid, Welzijn en Sport (xvi) woor het jaar zo01. Memorie van Toelichting. Tweede Kamer, vergaderjaar 2000/200I, 25600 XVI, nr. 2.

$\mathrm{TK}(2000 / 200 \mathrm{rb})$. Vaststelling begroting uan de uitgaven en de ontuangsten wan het ministerie van. Onderwijs, Cultuur en Wetenschappen (viii) voor het jaar 2001. Memorie van Toelichting. Tweede Kamer, vergaderjaar 2000/2001, 27400 vinl, nr. 2.

TK (2000/200Ic). Criminaliteit in relatie tot integratie van etnische minderheden. Brief van de minister voor Grote Steden- en Integratiebeleïd. Tweede Kamer, vergaderjaar $2000 / 2001,25726$, nr. 9 .

TK (2000/200Id). Vaststelling begroting van de uitgaven en de ontuangsten van het ministerie van Binnenlandse Zaken en Koninkrijksrelaties (vii) woor het jaar 2001. Memorie van Toelichting. Tweede Kamer, vergaderjaar 2000/200r, 27400 VII, nr. 2.

TK (2000/2001e). Vaststelling begrating van de uitgaven en de ontuangsten van het ministerie vant Sociale Zaken en Werkgelegentheid $(x v)$ voor het jaar 2001. Memorie van Toelichting en Bijlagen. Tweede Kamer, vergaderjaar $2000 / 200$, $27400 \mathrm{XV}$, nrs. 2-3.

$\mathrm{rK}$ (2000/200rf). Vaststelling begroting van de uitgaven en de ontuangsten van het ministerie van Justitie (vi) voor het jaar 2001. Memorie van Toelichting en Bijlagen. Tweede Kamer, vergaderjaar 2000/200r, 27400 VI, nrs. 2-3.

TK (2001/2002a). Vaststelling begroting van de uitgaven en de ontuangsten uan het ministerie van. Volksgezondheid, Welzijn en Sport (xvi) woor het jaar 2002 . Memorie van Toelichting. Tweede Kamer, vergaderjaar $2001 / 2002,25600 \mathrm{XVI}, \mathrm{nr} .2$.

TK (2001/2002b). Vaststelling begroting van de uitgaven en de ontwangsten van het ministerie van Onderwijs, Cultuur en Wetenschappen (wiii) woor het jaar 2002. Memorie van Toelichting. Tweede Kamer, vergaderjaar 2001/2002, 28000 virI, nr. 2.

TK (2001/2002c). Organiseren van opuoeding en ontwikkeling uan jeugd. Brief van de staatssecretaris van Volksgezondheid, Welzijn en Sport. Tweede Kamer, vergaderjaar 2001/2002, 28369 , nir. $x$.

TK (2001/2002d). Vaststelling begroting van de uitgaven ent de ontwangsten van het ministerie uan Binnemlandse Zaken en Koninkrijksrelaties (vii) voor het jaar 2002 . Memorie van Toelichting. Tweede Kamer, vergaderjaar 200r/2002, 28000 vII, nr. 2 .

TK $(2001 / 2002 e)$. Vaststelling begroting van de uitgaven en de ontuangsten van het mintsterie van. Sociale Zaken en Werkgelegenheid (xw) voor het jaar 2002. Memorie van Toelichting. Tweede Kamer, vergaderjaar $2001 / 2002,28000 \mathrm{XV}, \mathrm{nr} .2$.

TK (200I/2002f). Vaststelling begroting van de witgaven en de ontuangsten van het ministerie vath Justitie (vi) voor het jaar 2002. Memorie van Toelichting. Tweede Kamer, vergaderjaar $2001 / 2002,28000 \mathrm{VI}_{1}$, nt. 2 .

TK (2002/2003a). Vaststelling begroting uan het ministerie van Vollksgezondheid, Welzijn en Sport (xwi) voor het jaar 2003 . Memorie van toelichting. Tweede Kamer, vergaderjaar 2002/2003, 28600 XVI, nr. 2 .

TK $(2002 / 2003$ b). Tussen beleid en uitvoering. Lessen uit recent onderzoek van de Algemene Rekenkamer. Tweede Kamer, vergaderjaar $2002 / 2003,2883$ I, nr. 2. 
TK (2003/2004a). Vaststelling van de begrotingsstaat van het ministerie van Volksgezondheid, Welzijn en Sport (xvi) voor het jadr 2004. Memorie van Toelichting. Tweede Kamer, vergaderjaar 2003/2004, 29200 XVI, nr. 2.

TK (2003/2004b). Modernisering van de overheid. Brief van de minister voor Bestuurlijke vernieuwing en koninkrijksrelaties. Tweede Kamer, vergaderjaar 2003/2004, 29362, nr. I

TK (2004/2005a). Vaststelling van de begrotingsstaten varn het mimisterie van Binnenlandse Zaken en Koninkrijksrelaties (vii) voor het jaar 2005. Brief van de minister van Binnenlandse Zaken en Koninkrijksrelaties. Tweede Kamer, vergaderjaar 2004/2005, 29800 VII, nr.15 (brief minister over de Code interbestuurlijke verhoudingen).

TK (2004/2005b). Jeugdagenda. Brief van de staatssecretaris van Volksgezondheid, Welzijn en Sport. Tweede Kamer, vergaderjaar 2004/2005, 29284, nr. 5 (brief bij Plannen van anpak jeugdagenda).

Uitleg gele katern (20ooa). 'Financiële impuls voor basisscholen met veel achterstandsleerlingen". In: Uitleg gele katern, 29 november 2000,28 , p. II-I3.

Uitleg gele katern (2000b). 'Regeling voor-- en vroegschoolse educatie'. In: Uitleg gele katern, 19 april $2000,11-12$, p. 10-16.

Uitleg gele katern (200oc). 'Regeling voor- en vroegschoolse educatie'. In: Uitleg gele katern, Ir oktober 2000,24, p. II-17.

Uitleg gele katern (200ra). "Regeling financiële impuls voor ICT-toepassingen op scholen met veel achterstandsleerlingen in het basis- en het (voortgezet) speciaal onderwijs'. In: Uitleg giele katern, 2 I november $200 \mathrm{~T}, 27$, p. $4^{-6}$.

Uitleg gele katern (200rb). 'Aanvullende regeling uitbreiding voor- en vroegschoolse educatie (VVE)'. In: Uitleg gele katern, 25 juli 200r, I8a deel r, p. 54-60.

Uitleg gele katern (2002). 'Regeling verbreding onderwijskansenbeleid'. In: Uitleg gele katerm, (22 mei 2002), 12, p. 9-15.

Visitatierapport G2I (2002). De vele gezichten uarn het grotestedenbeleid. Visitatierapport G21 grotestedembeleid 2001. Den Haag: B\&A-groep.

VNG (r999). vNG-project Lokaal jeugdbeleid 1999-2002. Den Haag: Vereniging van Nederlandse Gemeenten.

VNG (2000). Jeugdbeleid. Ledenbrief Vereniging van Nederlandse Gemeenten. Den Haag: Vereniging van Nederlandse Gemeenten (nr. Lbr.00/03).

VNO (20Or). Knelpurtem in de vie-regeling. Ledenbrief Vereniging van Nederlandse Gemeenten. Den Hidag: Vereniging wan Nederlandse Gemeenten (nr. Lbr.ox/68).

VNG (2002). Gemeenten en interbestuurlijke samenwerking. Brief aan minister-president, minister van Algemene Zaken. Den Haag: Vereniging van Nederlandse Gemeenten (vNGkenmerk CB/2002002768).

VNG (s.a.). Onderzoek naar stand wan zaken WVE-beleid van gemeenten 2000-2002.

Den Haag: Vereniging van Nederlandse Gemeenten (project lokaal jeugdbeleidd).

vrom (2000). Nota Wonten. Mens"n, wensen, wonen. Den Haag: ministerie van Volkshuisvesting, Ruimtelijke Ordening en Milieuhygiëne.

vws (1994), Naar eigen verthogen. Welzijnsnota 1995-1998. Rijswijk: ministerie van Volksgezondheid, Welzijn en Sport.

vws (1995). Perspectief voor jeugdigen, kansen voor gemeenten. Startdoctment lokaal preventiefjeugdbeleid. Rijswijk: ministerie van Volksgezondheid, Wellzijn en Sport.

vws (1998). De terugblik. Welzijnsnota $1999-2002$ deel $A$, het verslag over de periode 1995 -1998.

Rijswijk: ministerie van Volksgezondheid, Welzijn en Sport.

vws, Justitie en ocw (1995). Beleidskader preventieve en curatiene jeugdzorg 1996-1999.

Rijswijk/Den Haag/Zoetermeer: ministerie van VwS/ministerie van Justitie/ministerie van ocw. 
vws, Justitie, ocw, szw en BiZa (r9g6). Beleidskader preventieve en curaticve jeugdzorg 19972000. Rijswijk/Den Haag/Zoetermeer: ministerie van vws/ministerie van Justitie/ministerie van SZW/ministerie van BiZa/ministerie van ocw.

vws, Justitie, ocW, szW en BiZa (1997). Voortgangsrapportage beleidskader jeugdzorg. Rijksverslagen 1996 en rijksmeerjarenplannen 1998-2001. Rijswijk/Den Haag/Zoetermeer: ministerie van VWS/ministerie van Justitie/ministerie van SZW/ministerie van BiZa/ministerie van ocw.

vws, Justitie, OCW, szW en BZK (I998). Voortgangsrapportage beleidskader jeugdzorg 1999-2002. Rijswijk/Den Haag/Zoetermeer: ministerie van vws/ministerie wan Justitie/ministerie van $\mathrm{SZW} /$ ministerie van $\mathrm{BZK} /$ ministerie van ocW.

wws, Justitie, ocw, szw en BiZa (r999). Voortgangsrapportage beleidskader jeugdzorg 2000-2003. Den Haag/Zoetermeer: ministerie wan Wws/ministerie van Justitie/ministerie van $\$ Z W /$ ministerie van $\mathrm{BZK} /$ ministerie van $0 \mathrm{CW}$.

wvc (1993). Jeugd verdient de toekomst. Nota intersectoraal jeugdbeleid. Rijswijk: ministerie van Welzijn, Volksgezondheid en Cultuur.

wvc en Justitie (rg94). Regie in de jeugdzorg. Standpunt wan de ministers van Welzijn, Volksgezondheid en Cultuur en Justitie. Rijswijk/Den Haag: ministerie van wvc/ministerie van Justitie. Zunderdorp Beleidsadvies \& Management (2002). Advies Communities that care en o\& O op wijkniveau. Den Haag: Zunderdorp Beleidsadvies \& Management. 


\section{Bijlage A Gebruikte databestanden}

Interviews lokaal jeugdbeleid (ILJ 19g8)

Ten behoeve van het project Lokaal jeugdbeleid zijn interviews afgenomen in 74 gemeenten en 4 deelgemeenten over de inhoud van het lokale jeugdbeleid en de participatie van jongeren.

\begin{tabular}{|c|c|}
\hline Doelpopulatie & N L-gemeenten \\
\hline Soort onderzoek & enquête \\
\hline Entiteiten & gemeenten \\
\hline Steekproefmethode & $\begin{array}{l}\text { aselecte steekproef met stratificatie naar sociaal-econo- } \\
\text { mische achterstand (2) en stedelijkheidsklasse (5) }\end{array}$ \\
\hline Opdrachtgever & Sociaal en Cultureel Planbureau (SCP) \\
\hline Uitwoerder veldwerk & Instituut voor Toegepaste Sociale Wetenschappen (ITS) \\
\hline Veldwerkperiode & oktober - december 1998 \\
\hline Verslagperiode & r998 \\
\hline Frequentie & eenmalig \\
\hline Verzamelmethode & mondelinge vragenlijst \\
\hline Berichtgever & ambtenaren \\
\hline Steekproefomvang & $\begin{array}{l}8 \text { gemeenten per stratum: } 74 \text { gemeenten en } 4 \text { deelge- } \\
\text { meenten (één stratum bevat slechts } 2 \text { gemeenten) }\end{array}$ \\
\hline Respons & 7 I gemeenten en 3 deelgemeenten \\
\hline
\end{tabular}

Zie Bijlage Cr voor de vragenlijst en Bijlage B voor de steekproef.

Nota's lokaal jeugdbeleid 1998

Documentanalyse op enkele concrete punten van de woor het jeugdbeleid relevante en beschikbare beleidsdocumenten. Deze punten betreffen: de mate waarin doelstellingen zijn geformuleerd, de thema's die aan de orde komen, de leeftijdsgroepen die aandacht krijgen, de dominante benadering in het jeugdbeleid (algemeen-preventief, gericht-preventief, curatief), de speerpunten in het jeugdbeleid en eventuele doelgroepen van beleid.

\section{Lokaal jeugdbeleid (LJB)}

Op verzoek van het ministerie van Volksgezondheid, Welzijn en Sport (vws) voert het Sociaal en Cultureel Planbureau sinds 1998 onderzoek uit naar het jeugdbeleid in Nederlandse gemeenten, als onderdeel van het onderzoek Lokaal Sociaal Beleid (LSB). De rapportage heeft enerzijds het doel het lokale jeugdbeleid te volgen (monitorfunctiej en anderzijds te komen tot een evaluatie van het beleid. Bij dit laatste doel gaat het om de relatie tussen het gevoerde beleid en de uitkomsten van het beleid. Belangrijke vragen in dit onderzoek zijn, hoe gemeenten hun jeugdbeleid inhoud en 
vorm geven, en hoe deze aspecten samenhangen met resultaten die geboekt worden. Om inzicht in deze materie te krijgen zijn verschillende vragenlijsten uitgezet onder verschillende groeperingen.

Doelpopulatie

Soort onderzoek

Steekproefeenheid

Entiteiten

Steekproefkader

Steekproefmethode

Opdrachtgever
NL-gemeenten

enquêtte

gemeente

gemeenten

gemeenten uit het ILj-onderzoek ('Interviews lokaal jeugdbeleid') uit 1998

volledige steekproefkader: alle gemeenten die in $1 \mathrm{Ljg} 8$ zijn benaderd minus 2 door herindeling

Sociaal en Cultureel Planbureau ( $\mathrm{SCP}$ )

LJB-ambtenaren 2002

Aan ambtenaren uit de onderzoeksgemeenten zijn vragen gesteld over de inhoud van het lokale jeugdbeleid en de participatie van jongeren. De vragen richtten zich op de beleidsinhoud, het beleidsproces en met name op de sturende rol van de gemeente.

Berichtgever

Verzamelmethode

Uitvoerder veldwerk

Veldwerkperiode

Steekproefomvang

Respons gemeenteambtenaren

schriftelijke vragenlijst

Instituut voor Toegepaste Sociale Wetenschappen (ITS)

april - juli 2002

72 gemeenten

60 gemeenten $(83 \%)$

Zie Bijlage $C_{2}$ voor de vragenlijst

\section{LJB-instellingen 2002}

In elke onderzoeksgemeente zijn maximaal tien instellingen benaderd waarvan verondersteld kon worden dat ze bij het jeugdbeleid betrokken waren. Aan de instellingen werden vragen voorgelegd over het beleidsproces (de wijze waarop de instelling bij het lokaal jeugdbeleid betrokken is) en over de beoordeling van verschillende aspecten van het jeugdbeleid.

Berichtgever

Verzamelmethode

Uitvoerder veldwerk

Veldwerkperiode

Steekproefomvang

Respons vertegenwoordigers van uityoerende instellingen schriftelijke vragenlijst Instituut voor Toegepaste Sociale Wetenschappen (ITS) april - augustus 2002 682 instellingen

$37 \mathrm{r}$ instellingen $(55 \%)$

Zie Bijlage $\mathrm{C}_{3}$ voor de vragenlijst 


\section{LJ $\mathrm{B}$-Jongereninspectieteams 2002}

In negen onderzoeksgemeenten die betrokken zijn bij het kwalitatieve onderzoek zijn jongereninspectieteams (J $\mathrm{r}^{\prime}$ 's) ingezet om de jongeren zelf een oordeel te laten vellen over het lokale jeugdbeleid. De JIT-leden hebben in iedere gemeente circa zestig interviews met andere jongeren gehouden.

Respons

504 jongeren uit 9 gemeenten

Zie Bijlage $C_{4}$ voor de vragenlijst en Bijlage D voor een verslag van het veldwerk

\section{LjB-kengetallen 2002}

Het Instituut woor Sociologisch-Economisch Onderzoek (ISEO) van de Erasmus Universiteit in Rotterdam heeft in opdracht van het Sociaal en Cultureel Planbureau ( $\mathrm{SCp}$ ) uit verschillende bronnen kengetallen over het lokaal jeugdbeleid verzameld. Veldwerkperiode maart - november 2002

Nota's jeugdbeleid 2002

Documentanalyse op enkele concrete punten van de voor het jeugdbeleid relevante en beschikbare beleidsdocumenten. In 2002 is deze analyse alleen uitgevoerd voor de 36 gemeenten die sinds 1998 nieuwe, voor het jeugdbeleid relevante kader- of strategische nota"s hebben uitgebracht. Voor de andere gemeenten zijn de resultaten van rgg8 gebruikt.

De nota's zijn op dezelfde punten geanalyseerd als in 1998 en daarnaast op de aandacht voor jeugdparticipatie, regie, beleidsevaluatie en de vier inhoudelijke thema's die in hoofdstuk 4 van dit onderzoek aan de orde komen.

Woonnilieudatabase (WMD)

De woonmilieudatabase is opgezet om op een uniforme en integrale wijze de beschikking te hebben over gegevens op wijk- en buurtniveau. Er wordt naar gestreefd per gebiedseenheid informatie bijeen te brengen over de thema's bevolking, wonen, werk, gebouwen, mobiliteit, voorzieningen, bodemgebruik en bereikbaarheid. De woonmilieudatabase bevat sinds r998 ook gegevens over verhuizingen naar nationaliteit, geboorteland en postcode, en over de vestigingsplaats van winkels.

Doelpopulatie

Entiteiten

Opdrachtgever

Uitvoerder

Frequentie

Verzanelmethode wijken en buurten in Nederland viercijferige postcodegebieden Ministerie van Volkshuisvesting, Ruimtelijke Ordening en Milieu (VROM); Rijks Planologische Dienst (RPD) in samenwerking met het Sociaal en Cultureel Planbureau (SCD) AB Onderzoek (I995) vierjaarlijks compilatie van gegevens van derden, onder meer van PTT, CBS, RPD, Geo-Marktprofiel bv, ministeries, provincies en gemeenten.

Aantal 


\section{Bijlage B Gemeenten in de steekproef}

In 1998 maakten 74 gemeenten deel uit van de steekproef. Door gemeentelijke herindelingen is dit aantal afgenomen tot 72 . Om toch een voldoende grote omvang van de steekproef te behouden, is besloten alleen de gemeenten te verwijderen die door de herindeling zijn opgegaan in een duidelijk groter geheel, waarin zij zelf niet meer als belangrijkste kern kunnen worden aangemerkt. Gemeenten die wel als belangrijkste kern van de nieuw gevormde gemeente zijn aan te merken of gemeenten die samen met een andere, gelijkwaardige gemeente zijn gefuseerd, zijn in de steekproef gehouden. Dit betekent dat ten opzichte van 1998 de gemeenten Egmond en Gendt uit de steekproef zijn verwijderd.

Tabel B.I geeft een overzicht van de steekproefgemeenten inclusief de kenmerken die in de steekproeftrekking zijn betrokken: het inwoneraantal per $\mathrm{x} / \mathrm{I} / \mathrm{1997}$, de sES-score op basis van gegevens uit 1994 en 1995 (zie hoofdstuk 2), en de stedelijkheidsklasse in 1997 . In de laatste kolom is aangegeven of de gemeente in de periode van 1999 tot en met $200 \mathrm{r}$ betrokken is geweest bij een proces van gemeentelijke herindeling.

\section{Tabel B.I}

\section{Steekproefgemeenten en hun kenmerken}

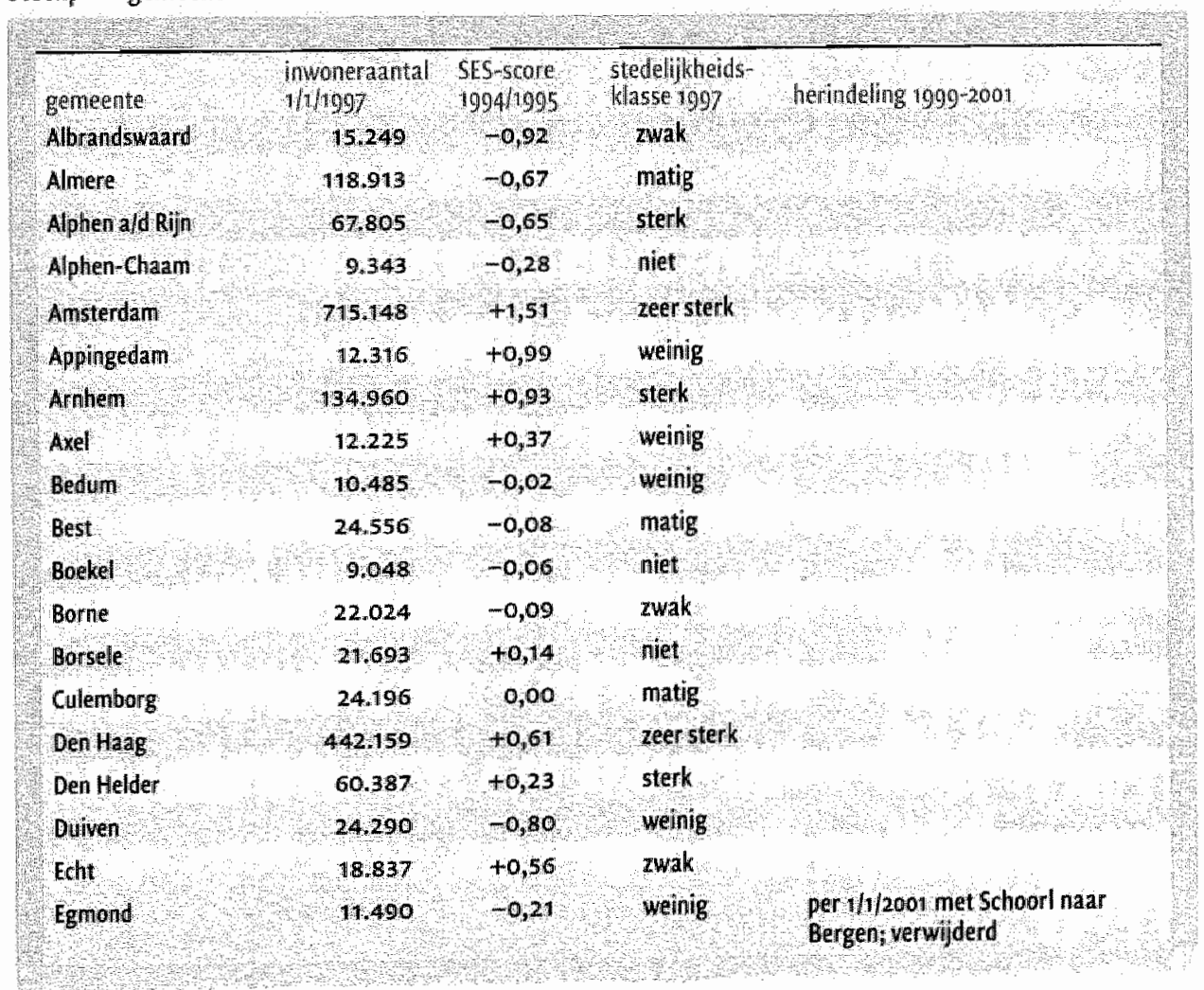


Tabel B.I (vervolg)

Steekproefgemeenten en hun kenmerken

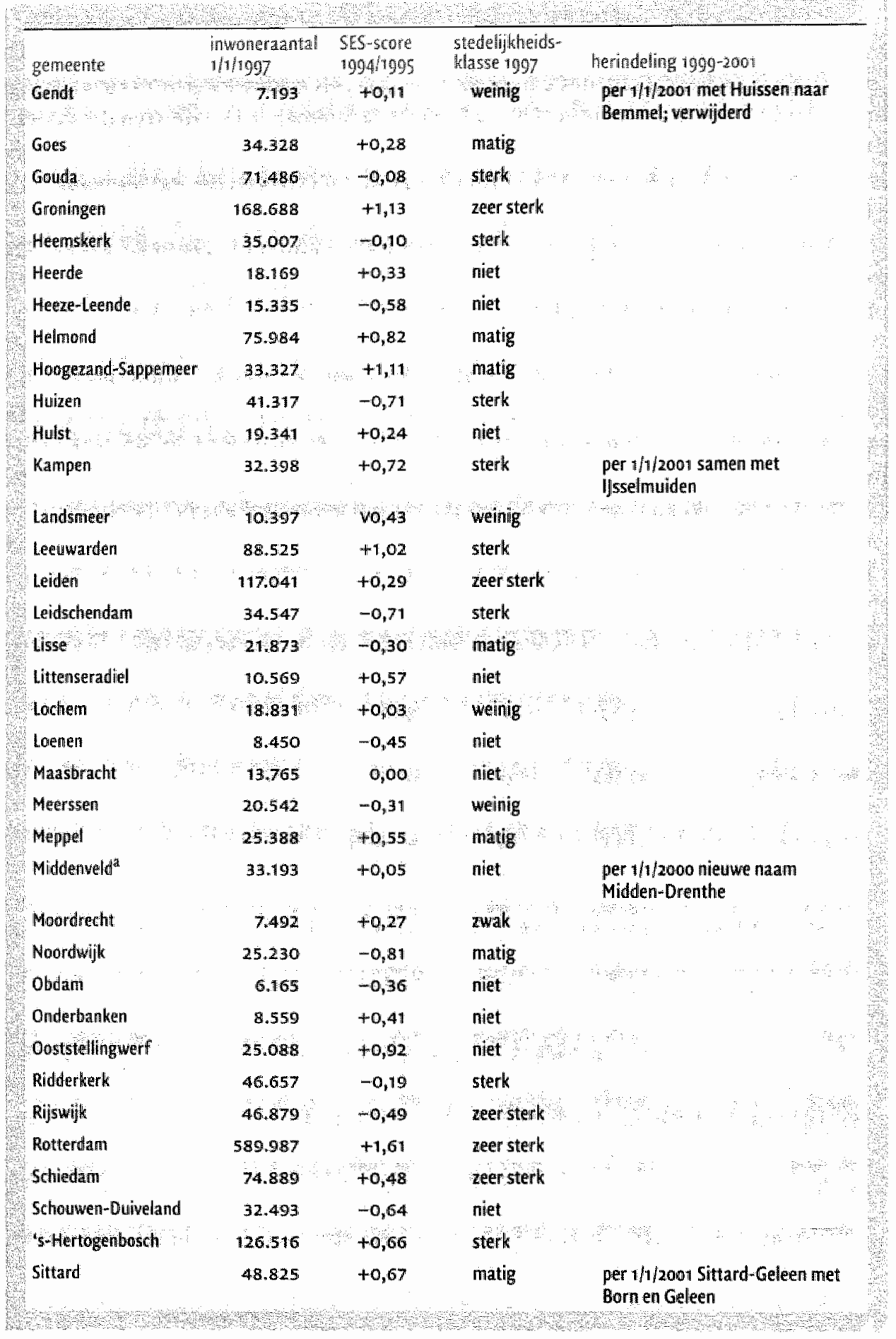


Tabel B.I (verwolg)

Steekproefgemeenten en thun kenmerken

\begin{tabular}{|c|c|c|c|c|}
\hline gemeente & $\begin{array}{l}\text { inwoneraantal } \\
1 / 1 / 1997\end{array}$ & $\begin{array}{l}\text { SES-Score } \\
19941995\end{array}$ & $\begin{array}{l}\text { stedeligheids- } \\
\text { klasse } 1997\end{array}$ & herindeling 19992001 \\
\hline Spijkenisse: & 71.372 & $-0,42$ & sterk & \\
\hline Steenwijk & 22.106 & $+0,72$ & weinig & $\begin{array}{l}\text { per } 1 / 1 / 2001 \text { samen met } \\
\text { Brederwiede en llsselham }\end{array}$ \\
\hline Tiel & 3.5 .690 & $+0,41$ & matig & \\
\hline Uden & 38.144 & $+0,17$ & matig & \\
\hline Utrecht & 233.951 & $+0,72$ & zeer sterk & $\begin{array}{l}\text { per 1/2001 samen met Vleuten- } \\
\text { De Meern }\end{array}$ \\
\hline Valkenburg a/d Geul & 18.170 & $-0,02$ & weining & \\
\hline Veenendaal & 56.688 & $-0,31$ & sterk & \\
\hline Venlo & 64.417 & $+0,55$ & sterk & $\begin{array}{l}\text { per } 1 / 1 / 2001 \text { samen met Belfeld } \\
\text { en Tegelen }\end{array}$ \\
\hline Vlaardingen & 74.352 & $+0,17$ & zeer sterk & ? \\
\hline Vlissingen & 44.568 & $+0,42$ & sterk & \\
\hline Voorburg & 39.357 & $-0,69$ & zeer sterk & \\
\hline Voorschoten & 22.906 & $-0,99$ & sterk & \\
\hline Waddinxveen & 26.129 & $-0,54$ & matig & \\
\hline Wester-Koggenland & 13.203 & $-0,20$ & niet & \\
\hline Zaltbommel & 11.032 & $+0,15$ & weinig & $\begin{array}{l}\text { per } 1 / 1 / 1999 \text { samen met Brakel en } \\
\text { Kenkwijk }\end{array}$ \\
\hline Zandvoort & 15.465 & $-0,38$ & matig & \\
\hline Zeist & 59.460 & $-0,20$ & matig & \\
\hline Zundert & 19.946 & $-1,00$ & niet & \\
\hline Zwolle & 101.902 & $+0,17$ & sterk & \\
\hline
\end{tabular}

a Optelling van de inwanera antaller wan de per $/ / 1,998$ tot Middenweld samengevoeg de gemeenten Beilen Sinilde en Westerbork. 



\section{Bijlage C Vragenlijsten}

C1 Lokaal jeugdbeleid 19g8: interviews ambtelijke sleutelinformanten 


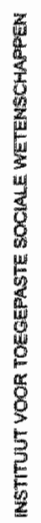

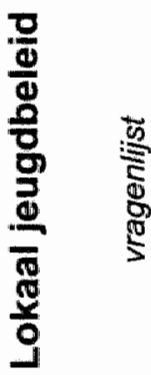

量

4

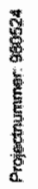

372 Bijlage C Vragenlijsten 


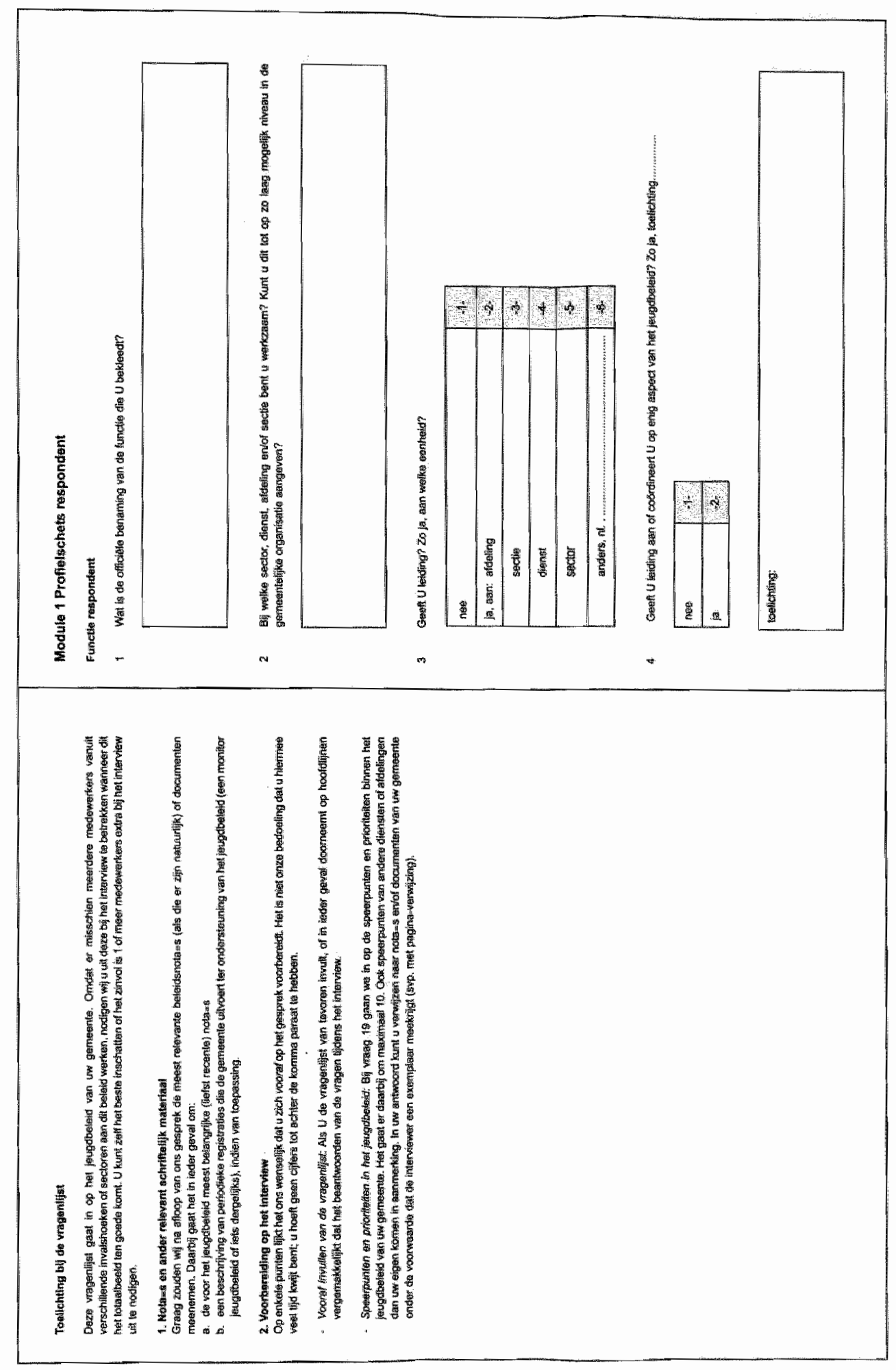




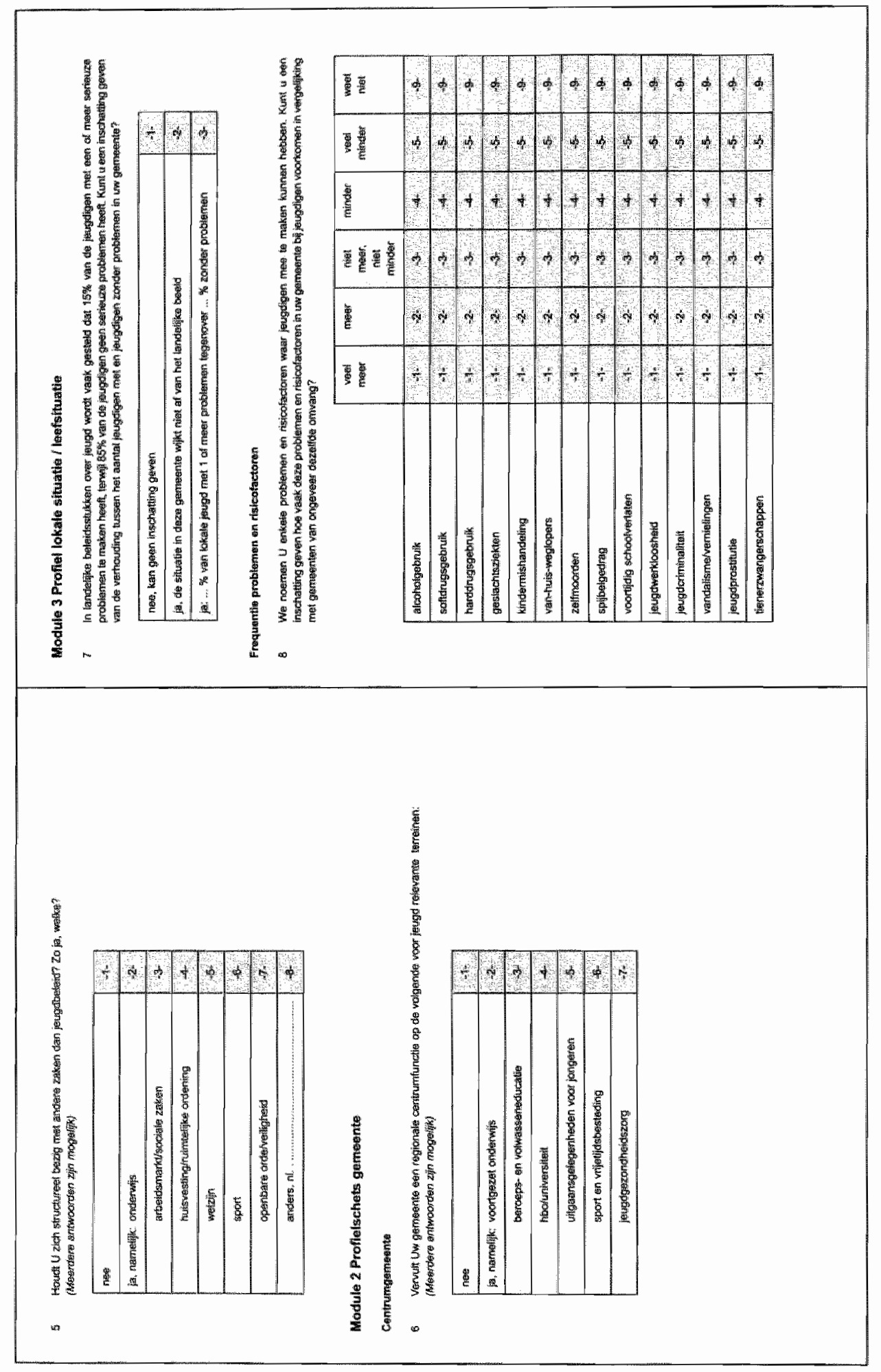




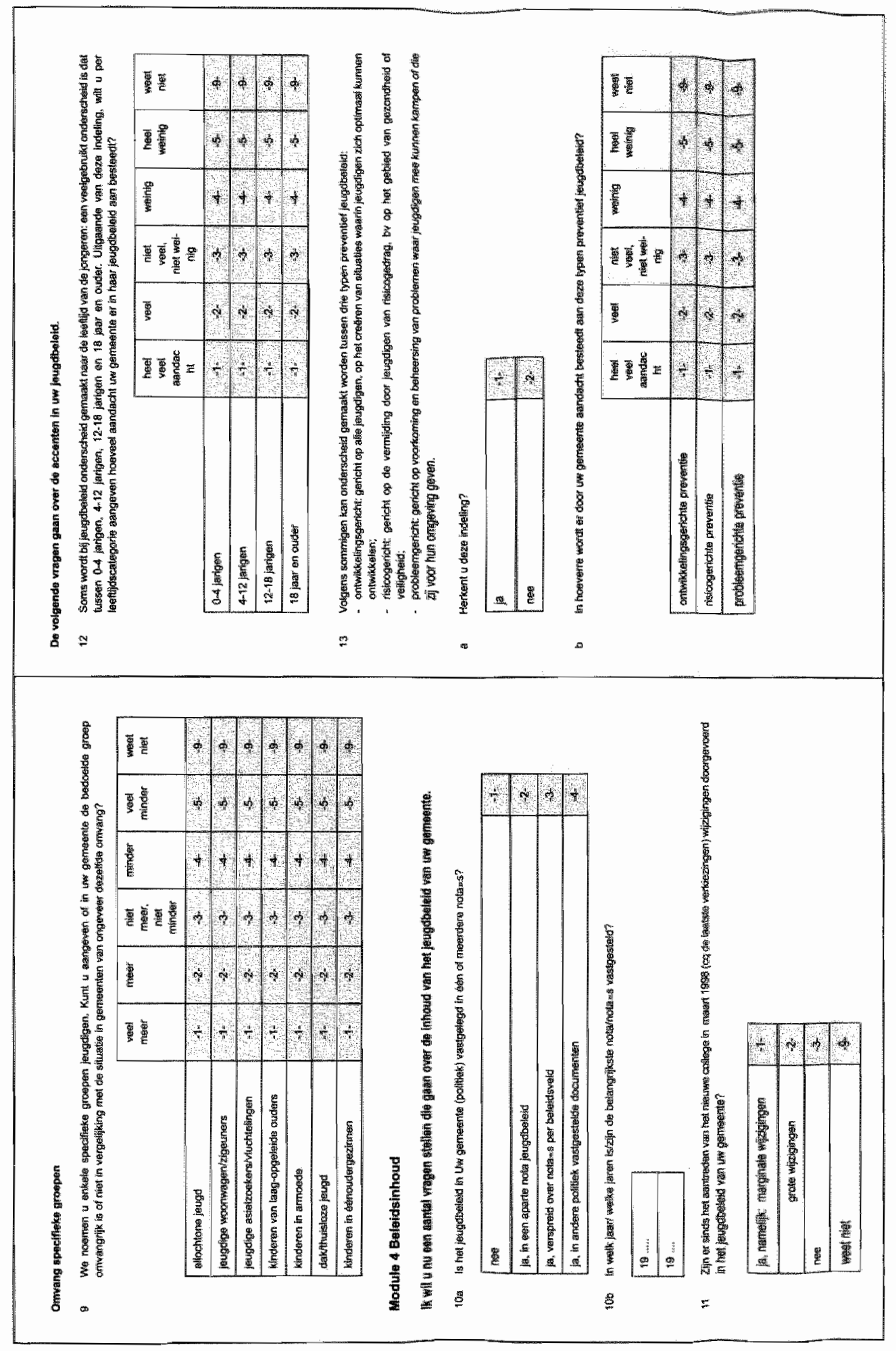



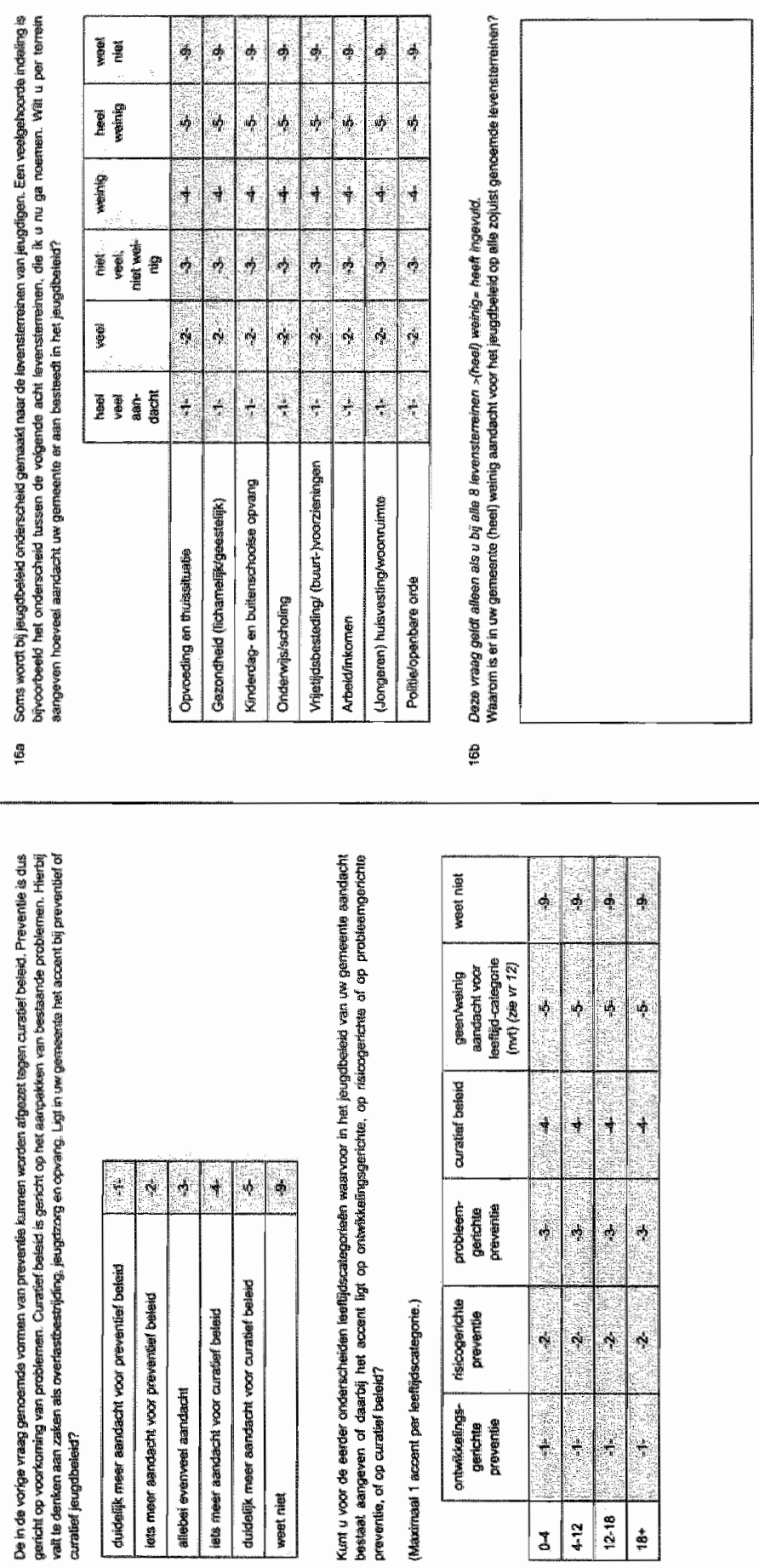

$\pm$

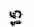




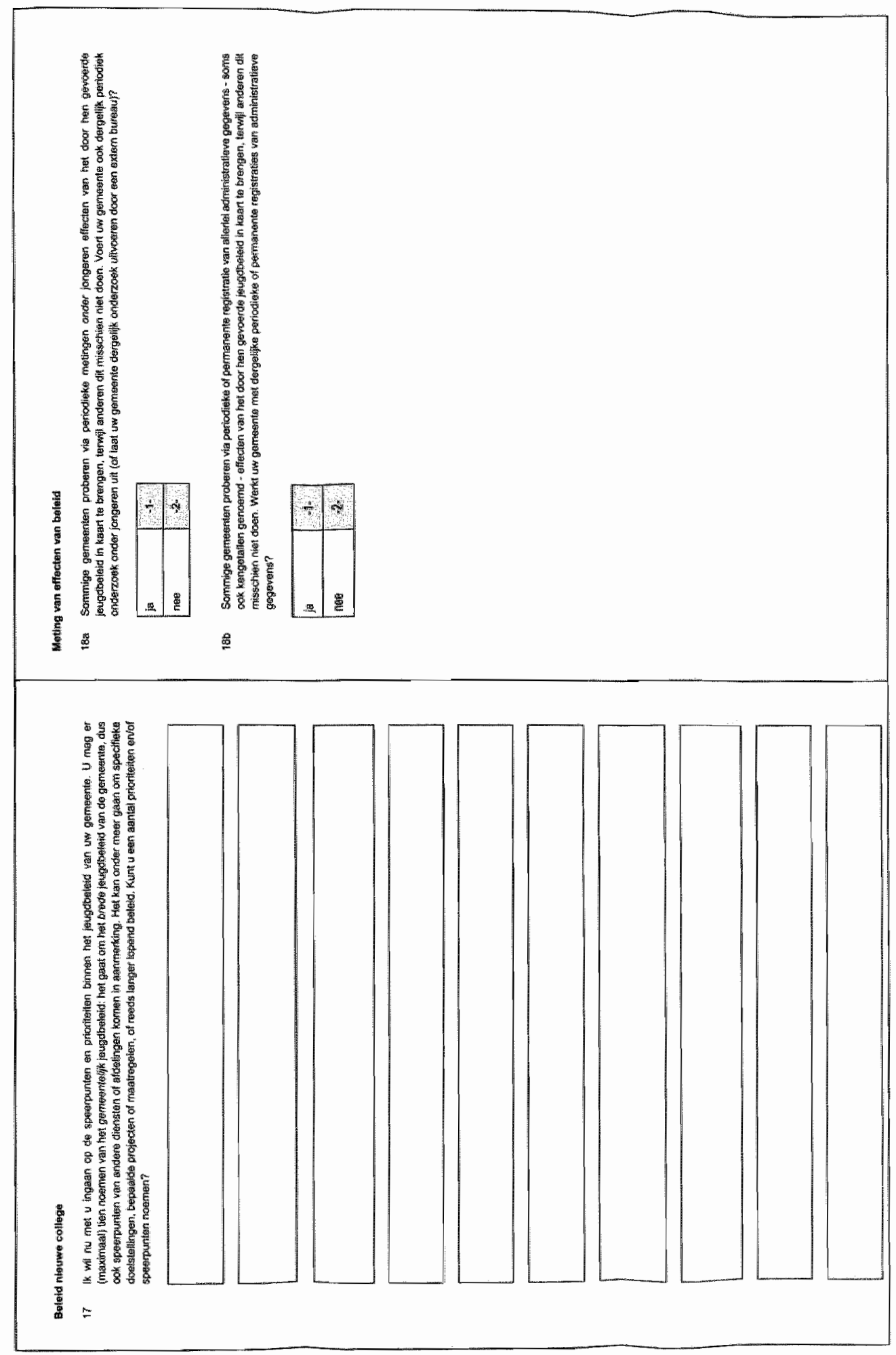



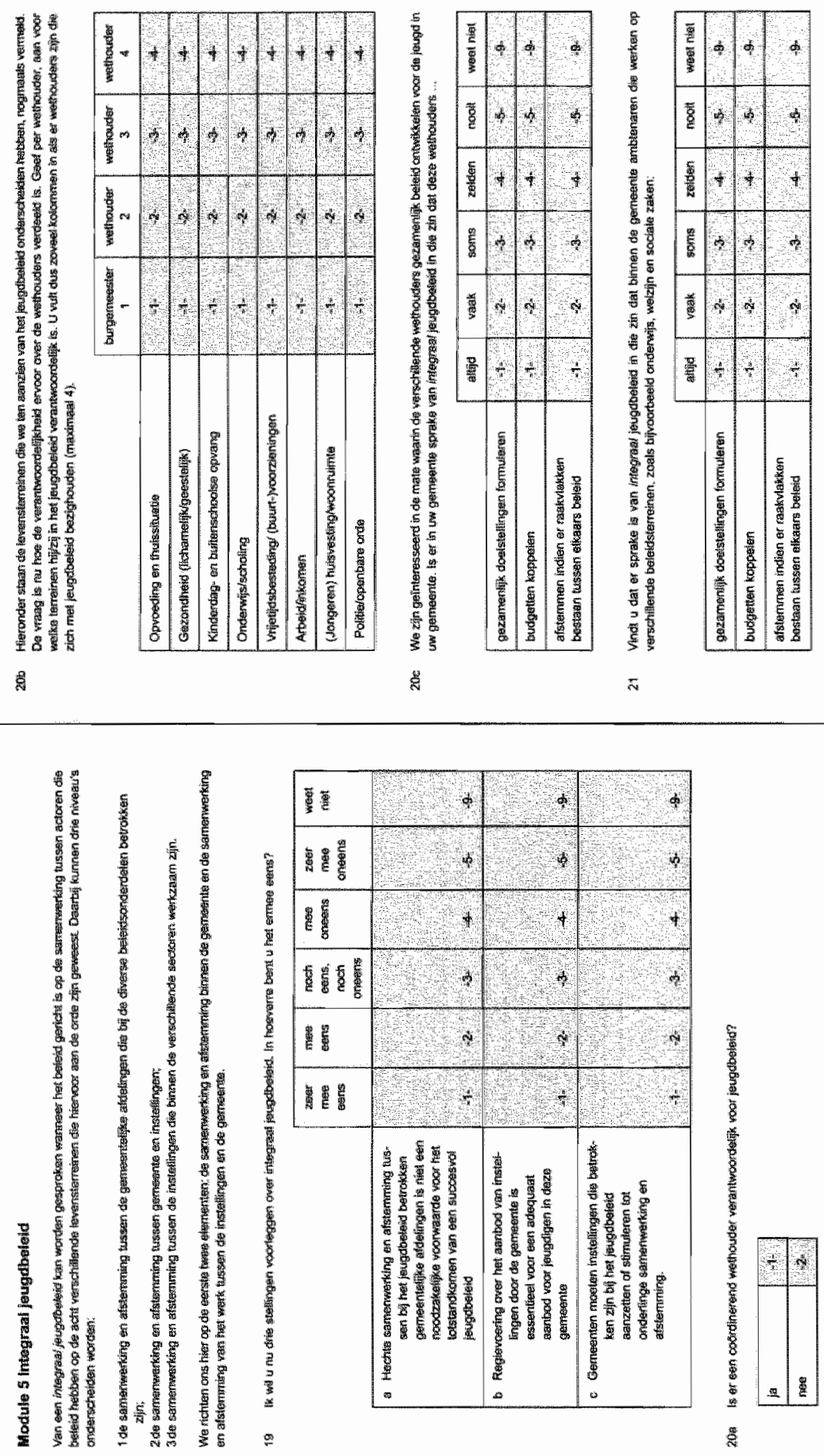


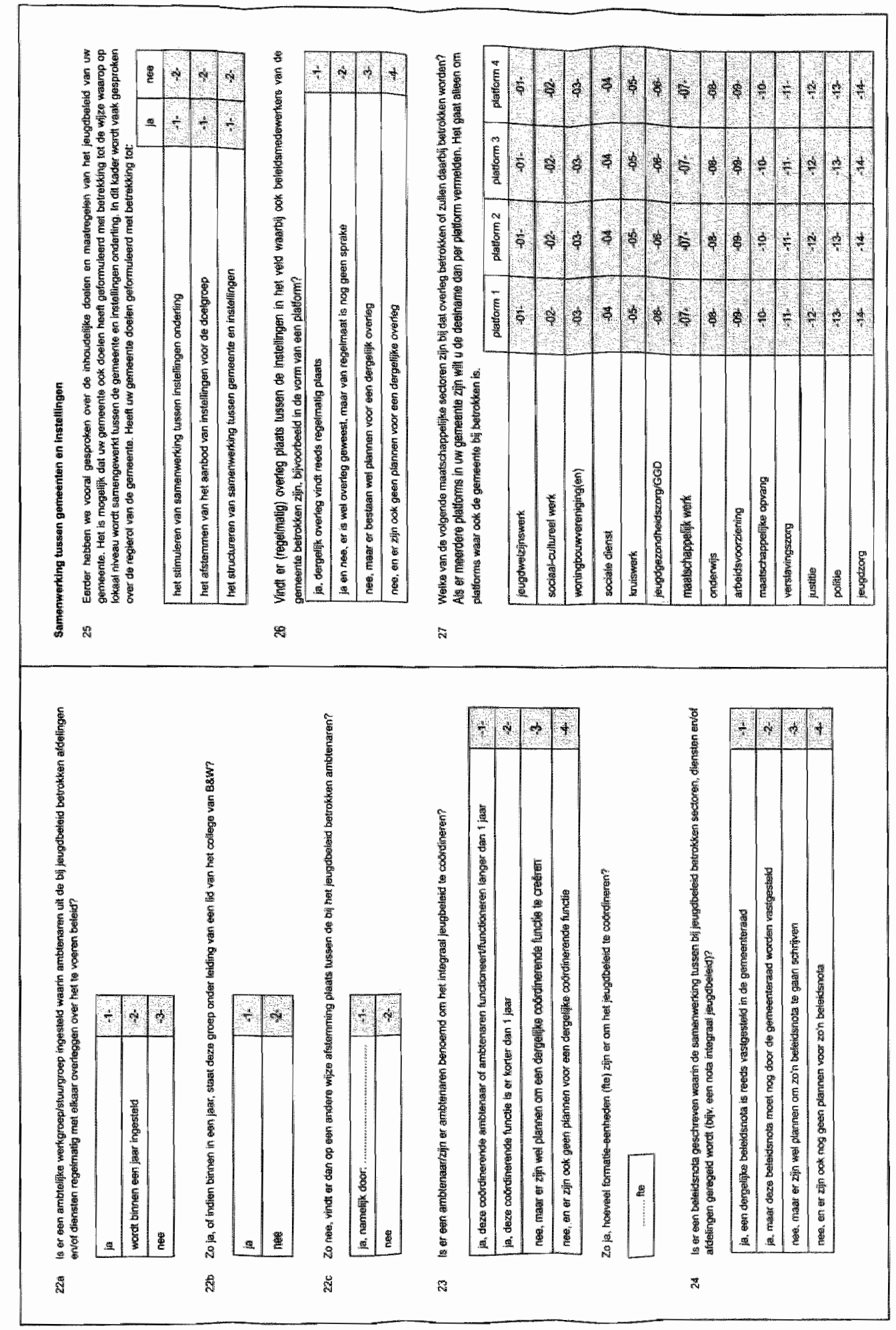




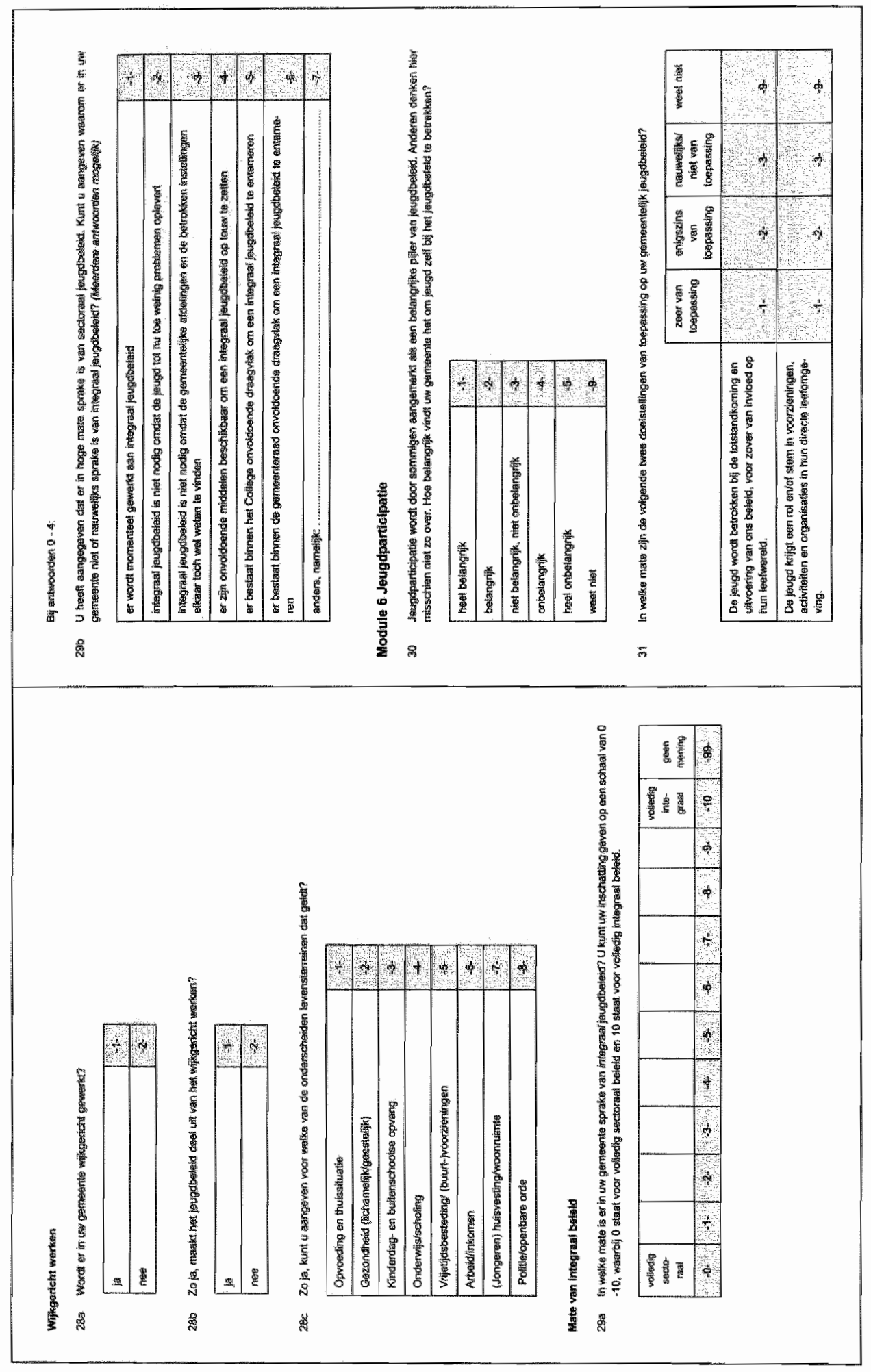



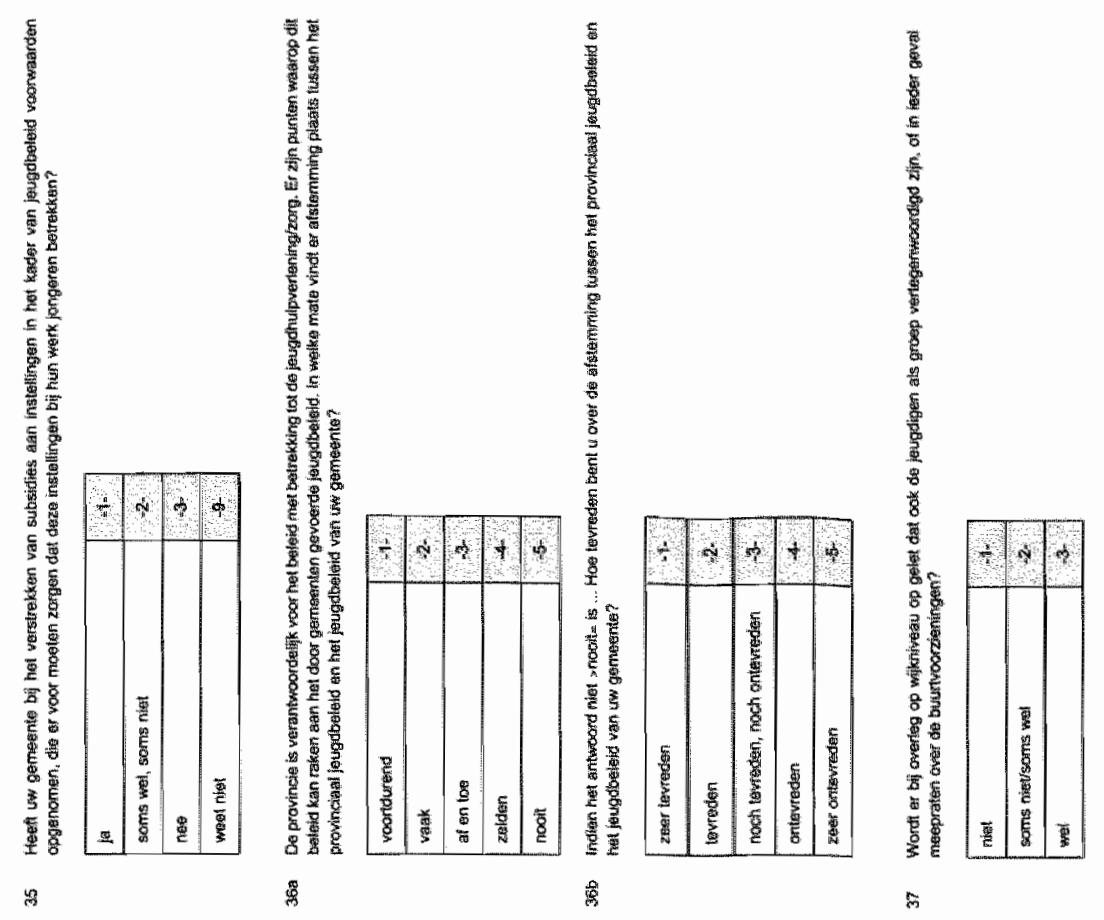

क
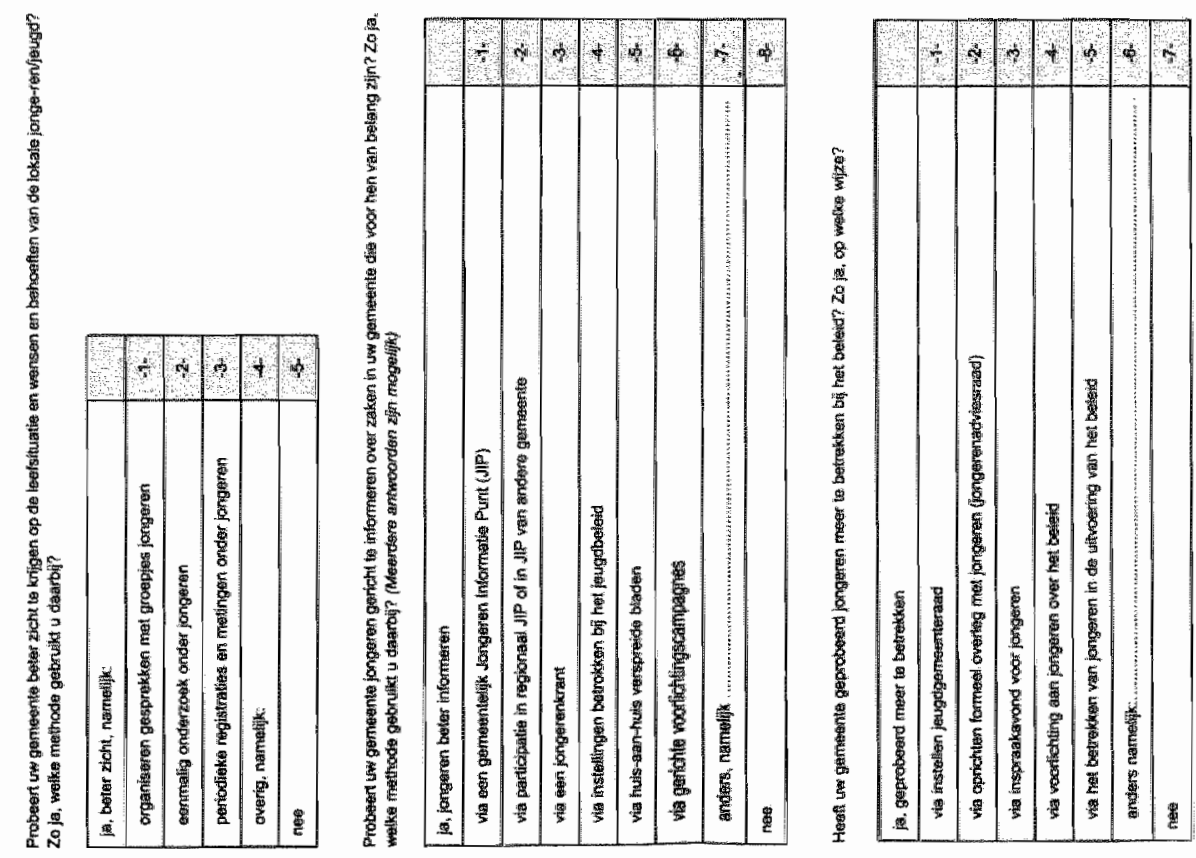

a

品

恶 


$$
\forall
$$


C2 Beleidseffect rapportage Lokaal jeugdbeleid zooz: enquête ambtelijke sleutelinformanter 


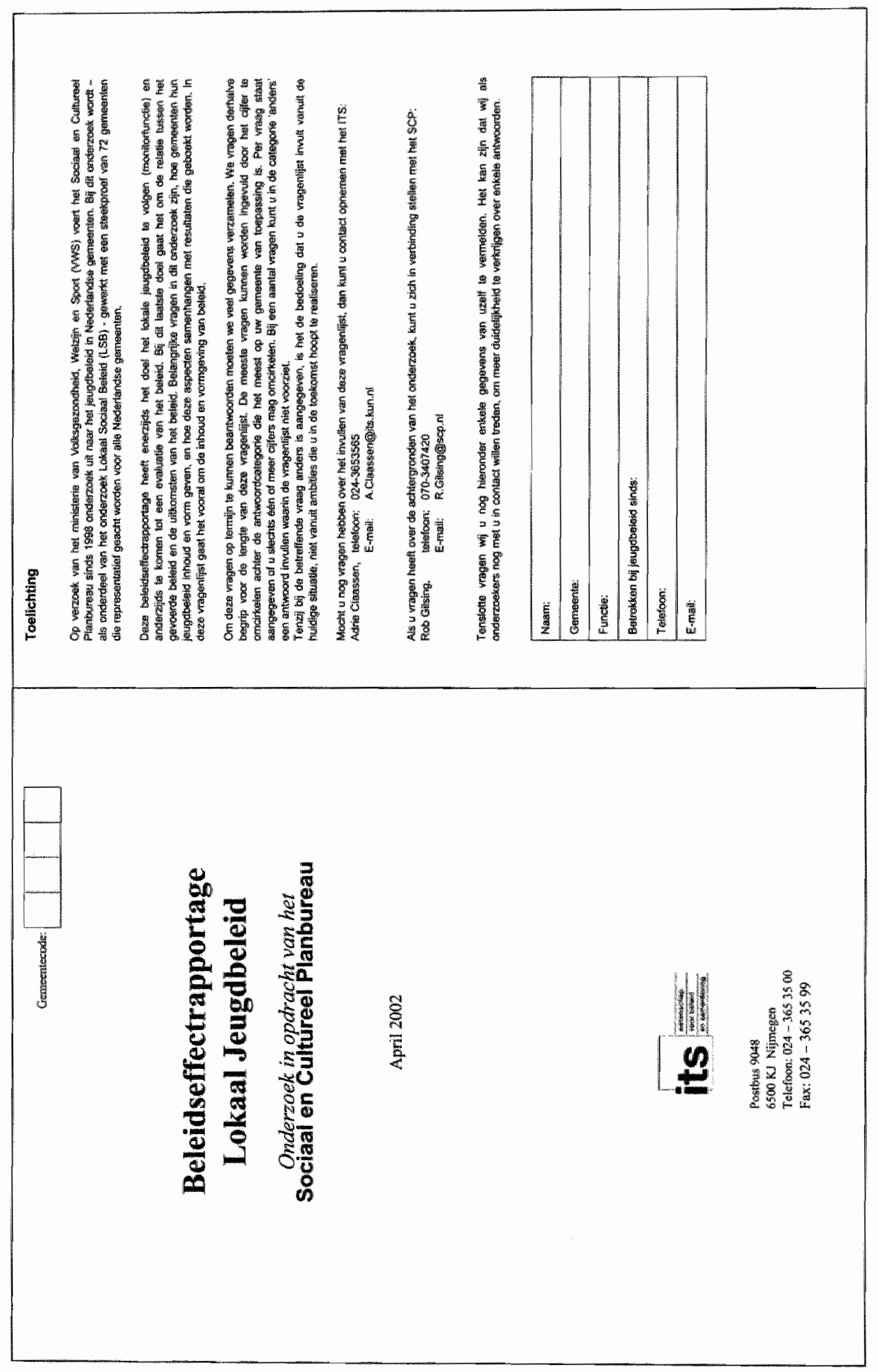




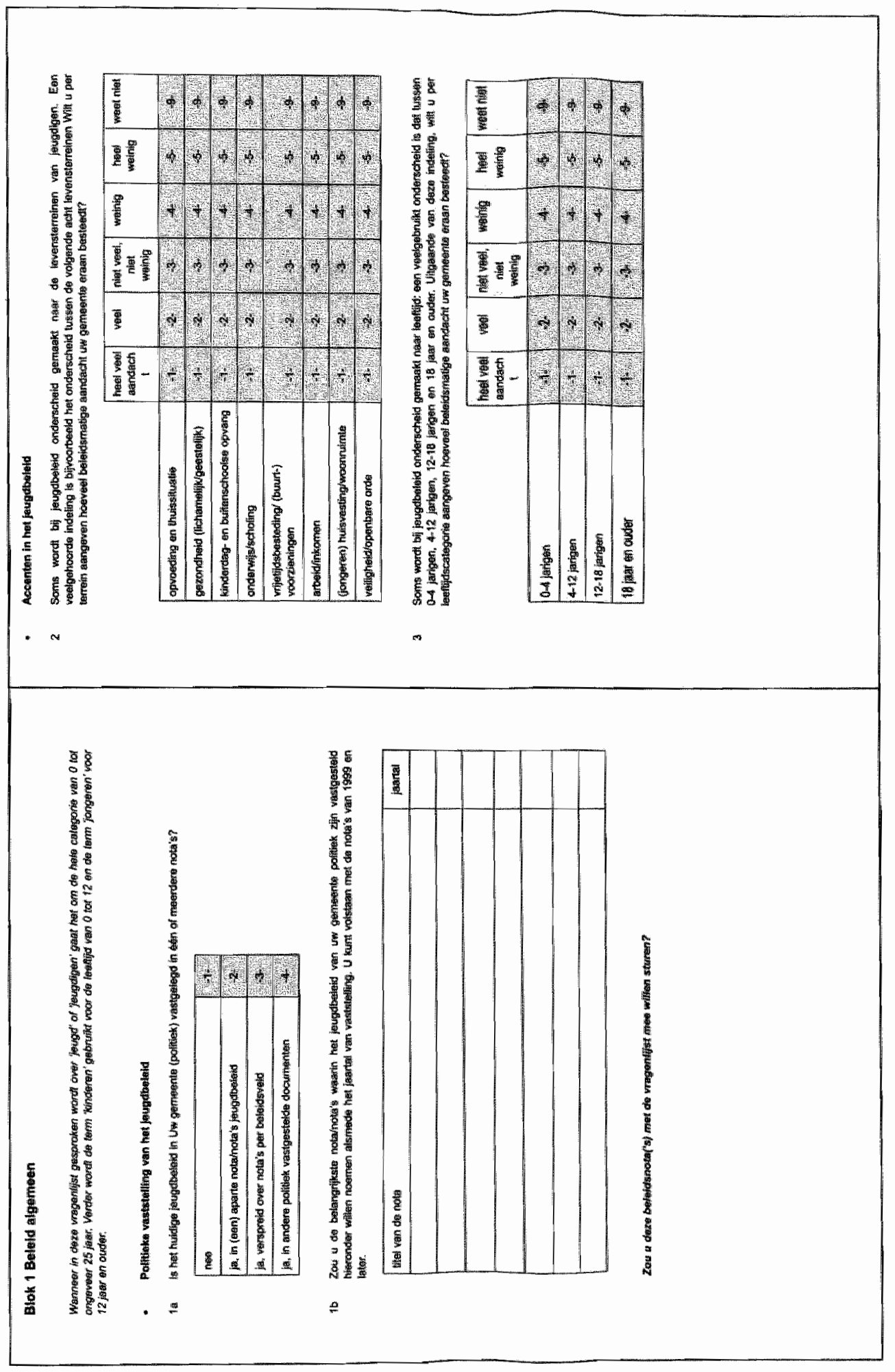




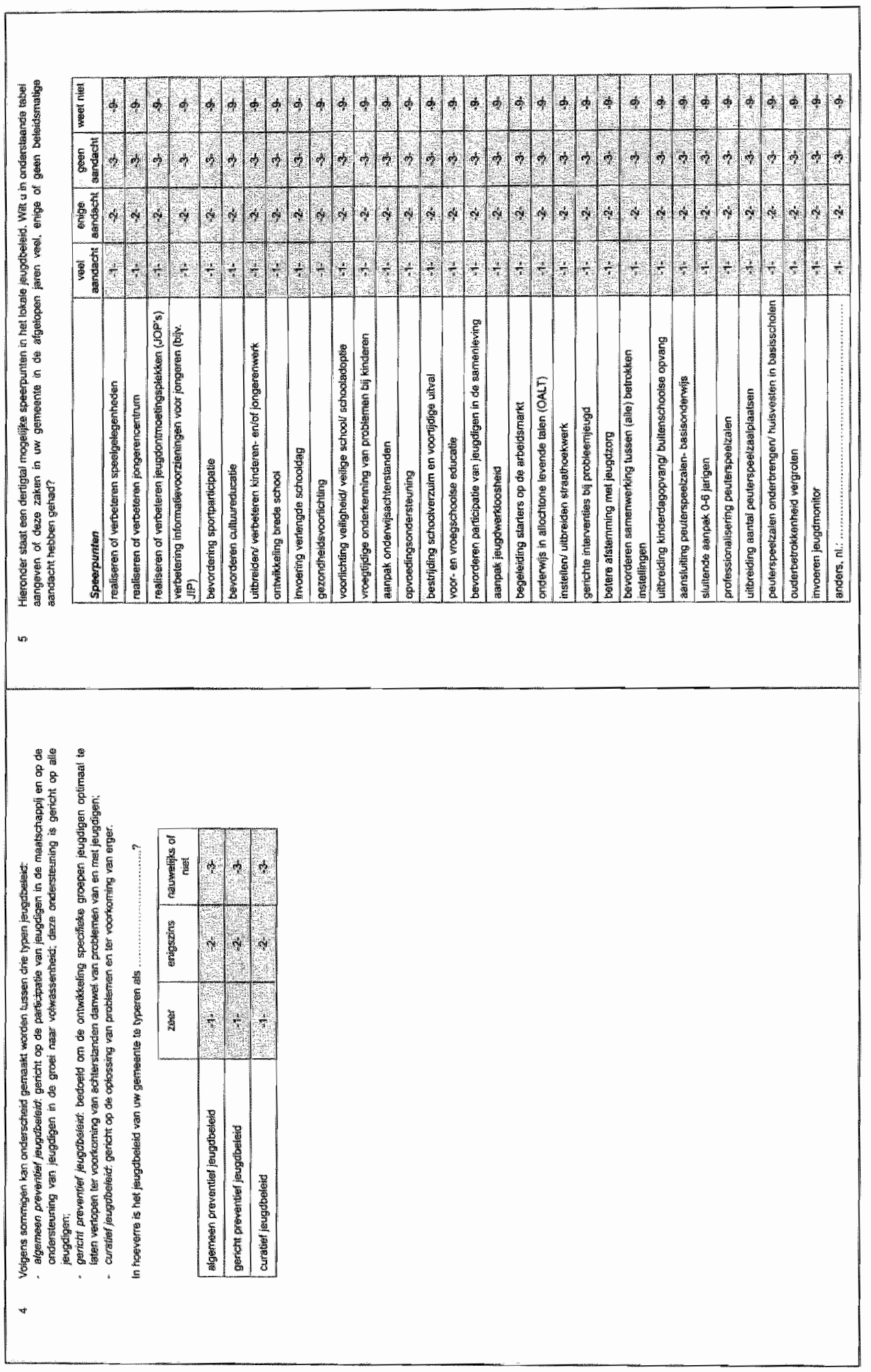




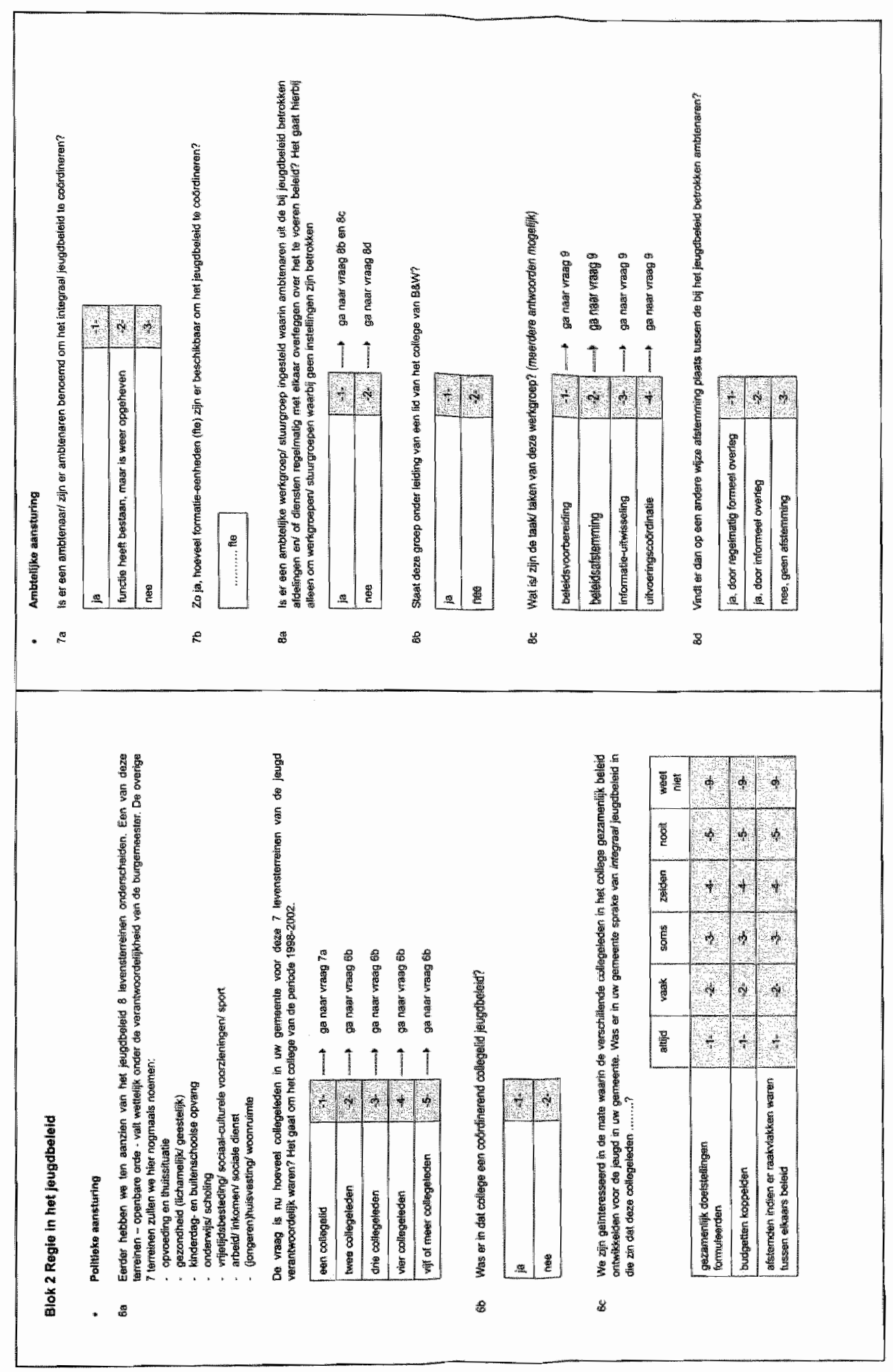



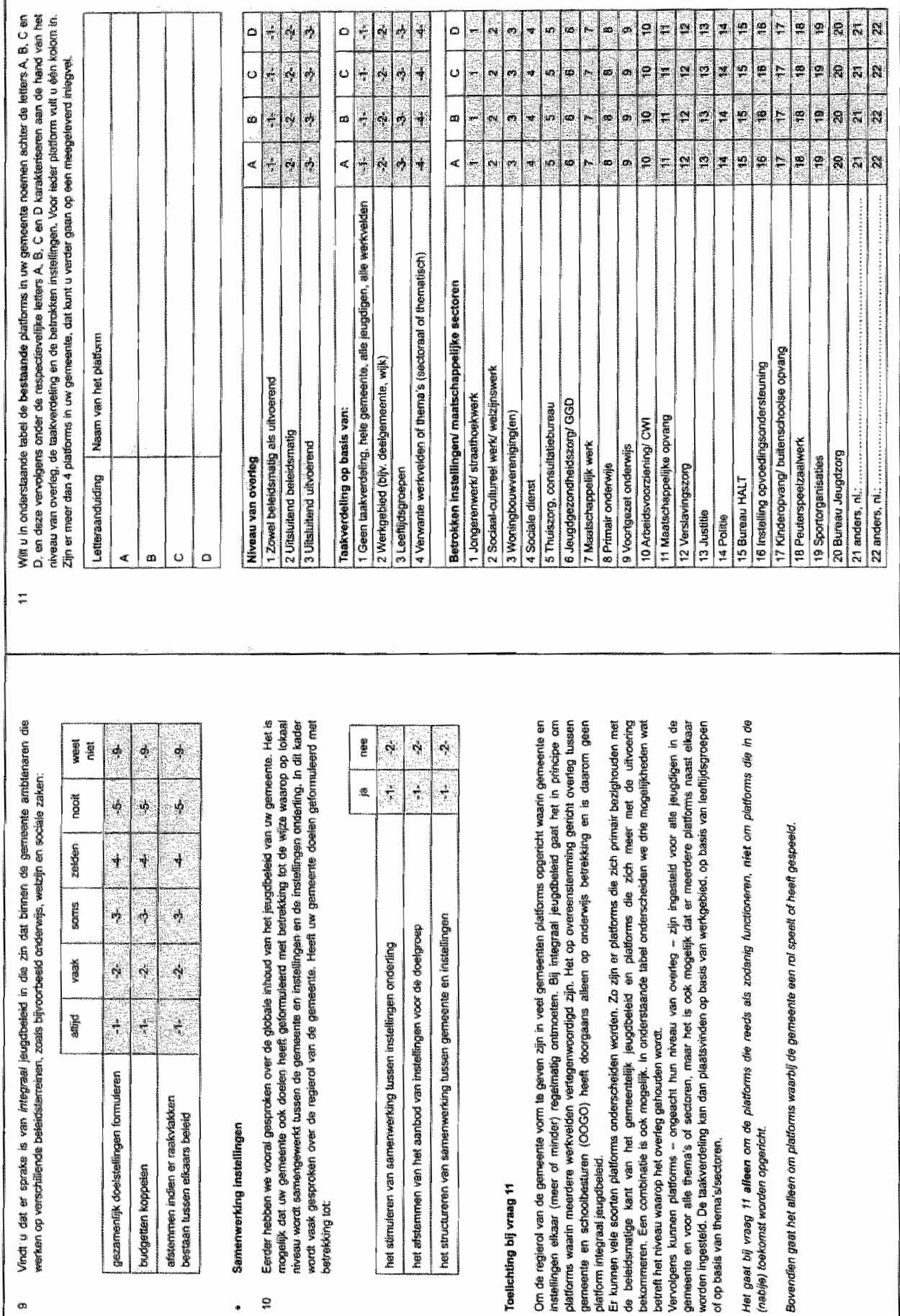


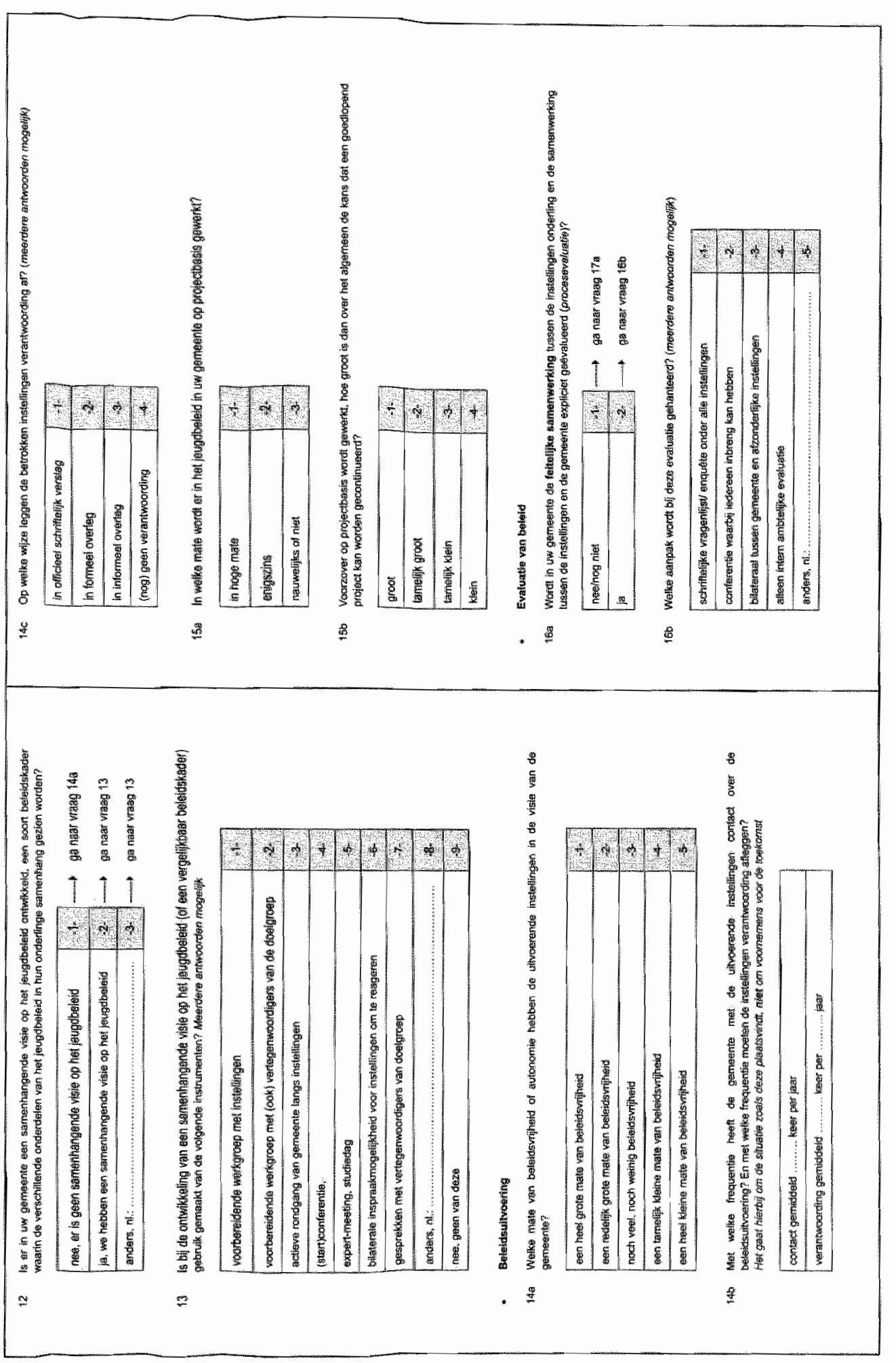




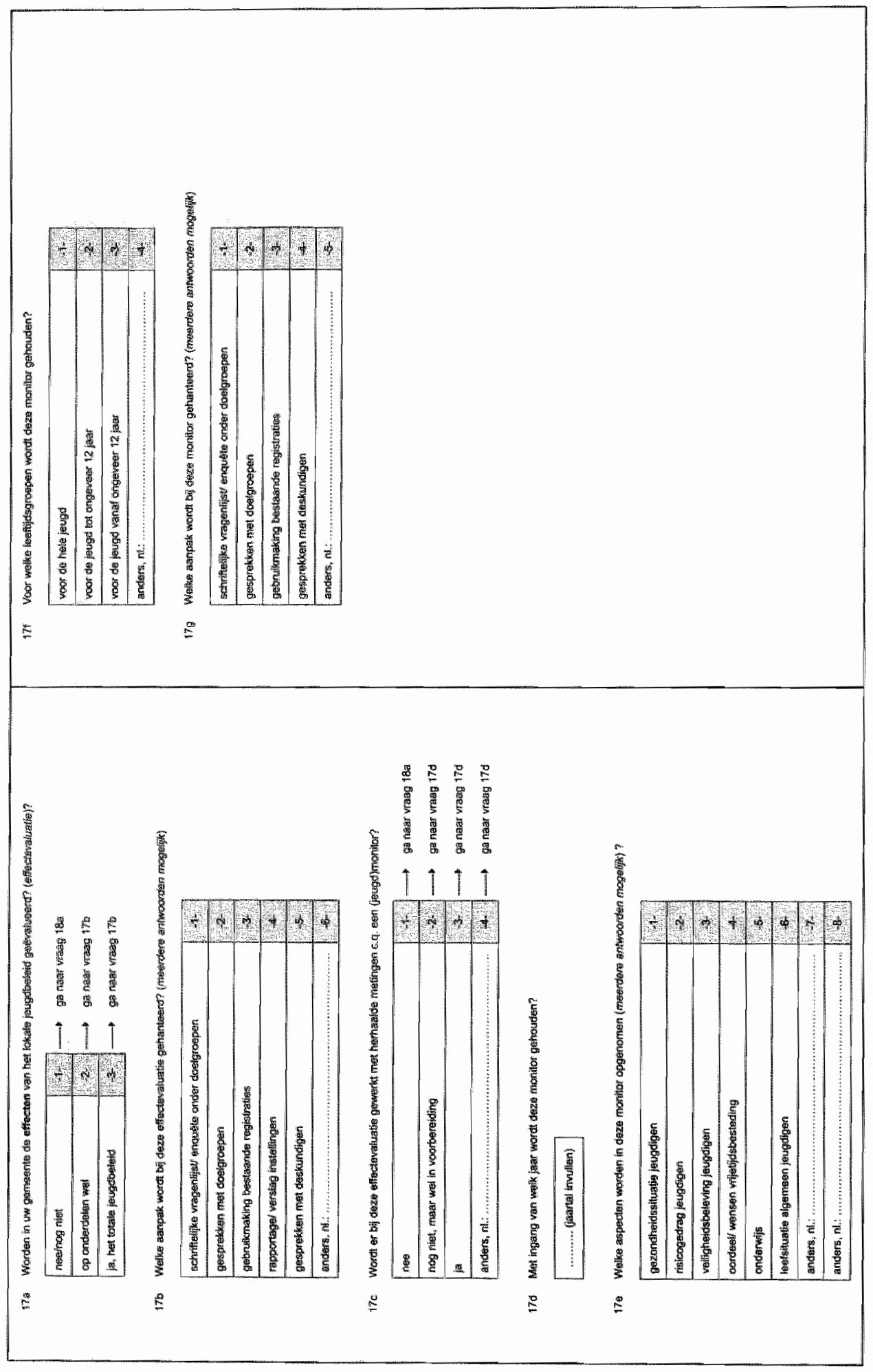




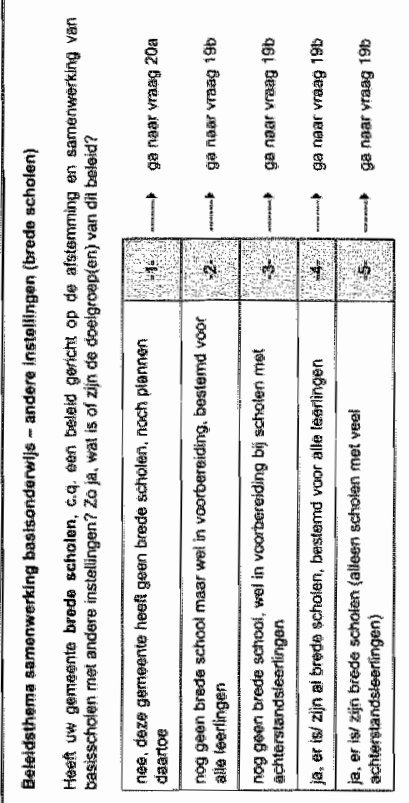

.
要要

형
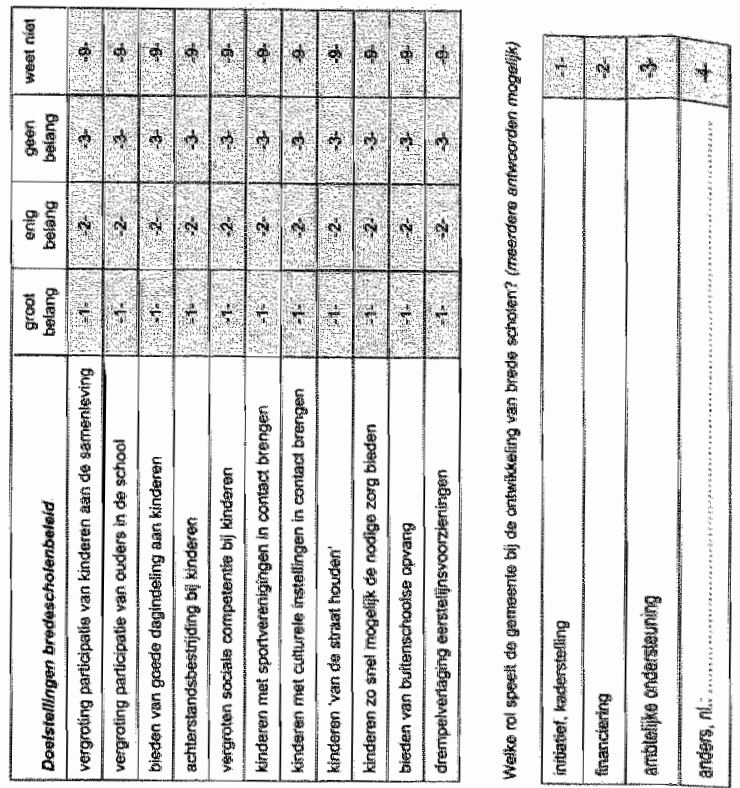

䠰

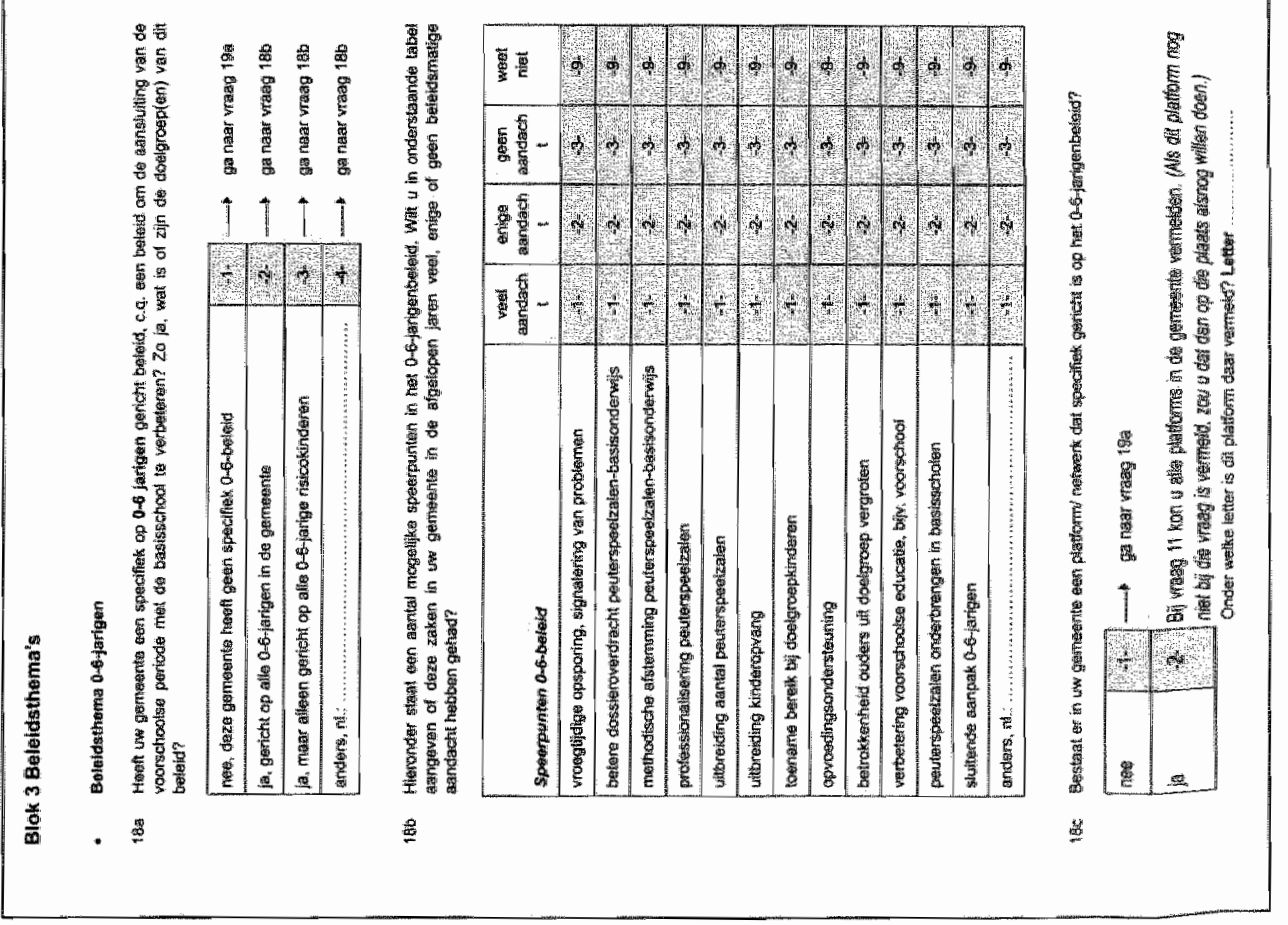



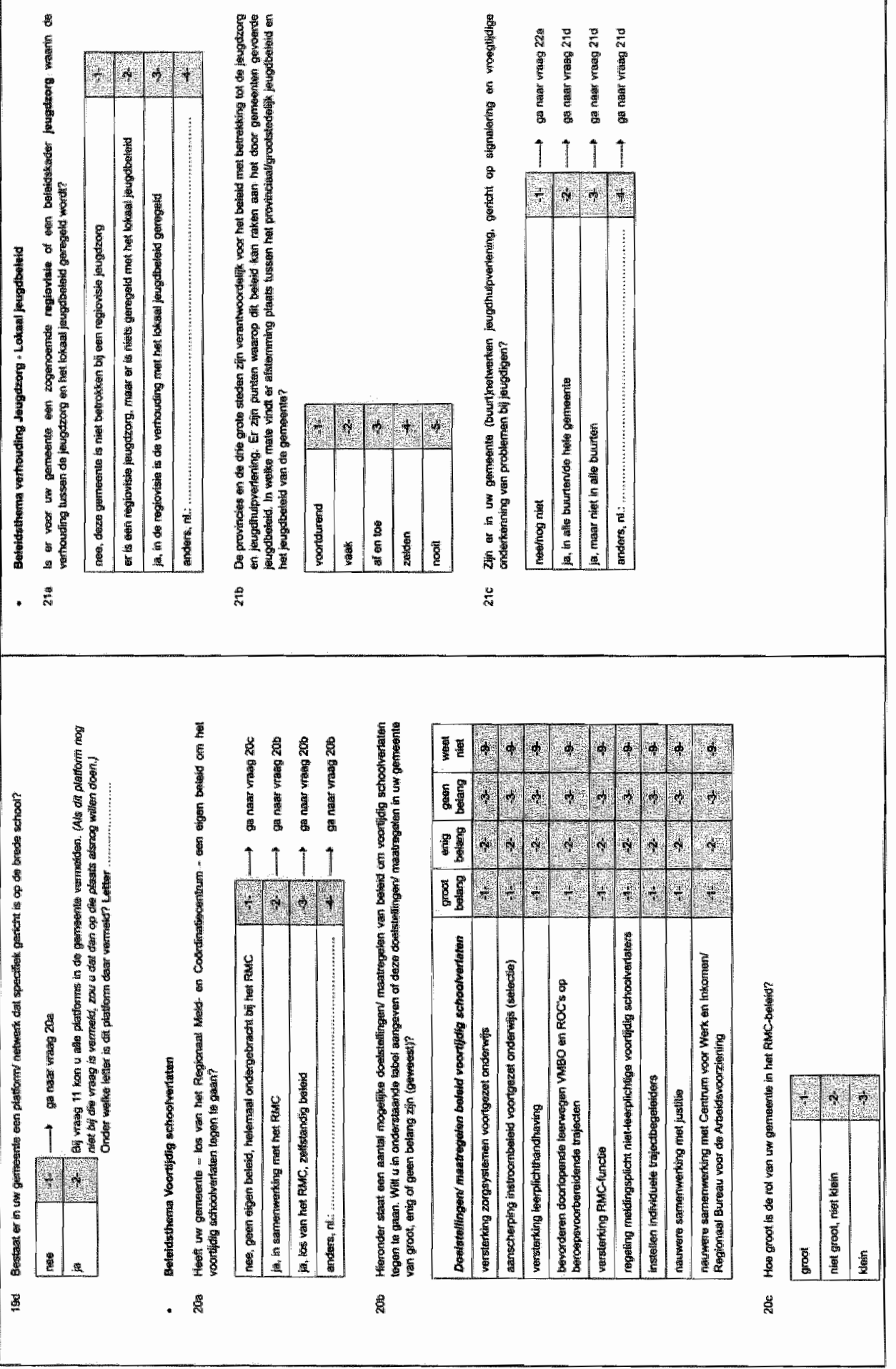

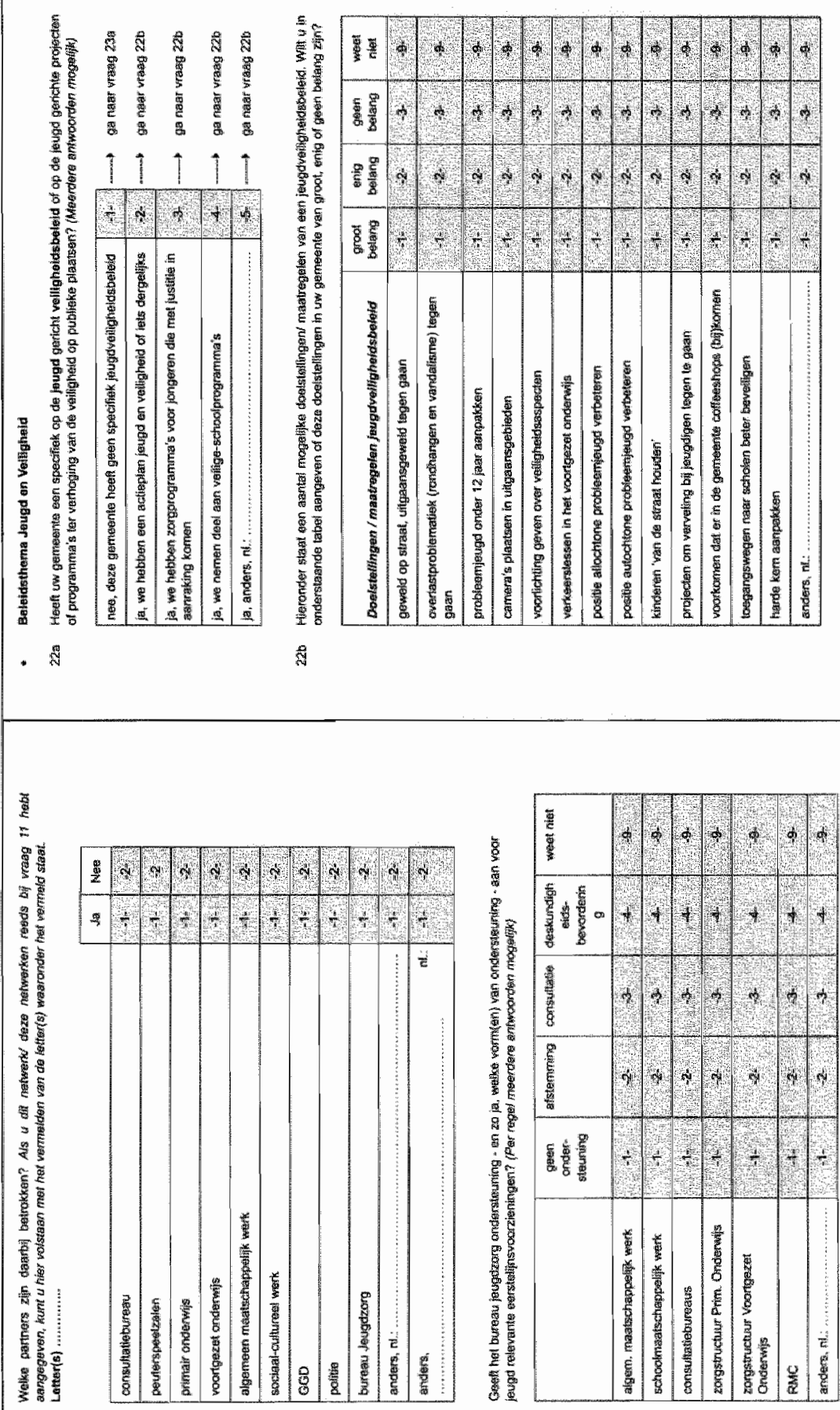

$\stackrel{0}{\circ}$

$\stackrel{2}{*}$ 


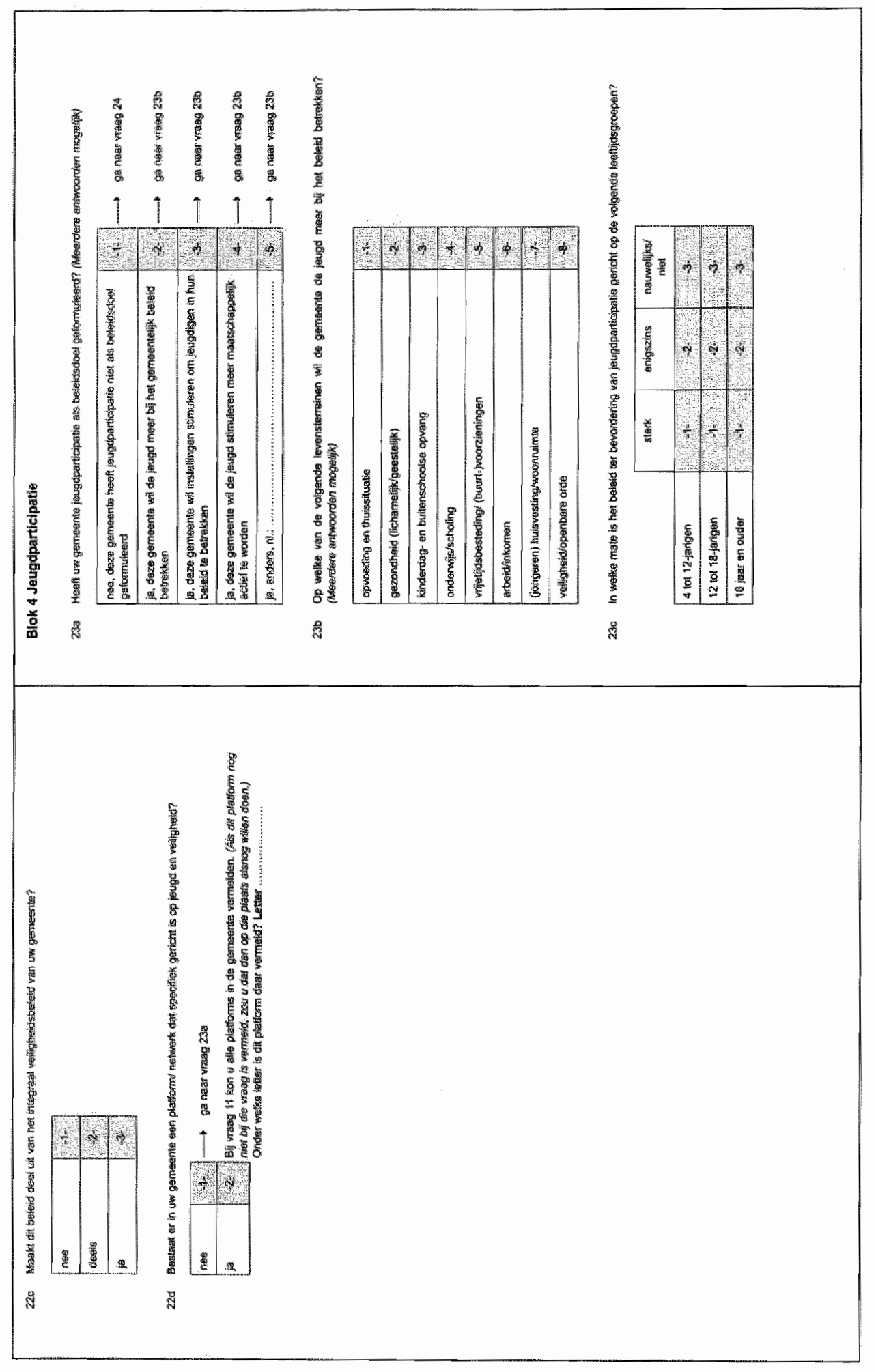




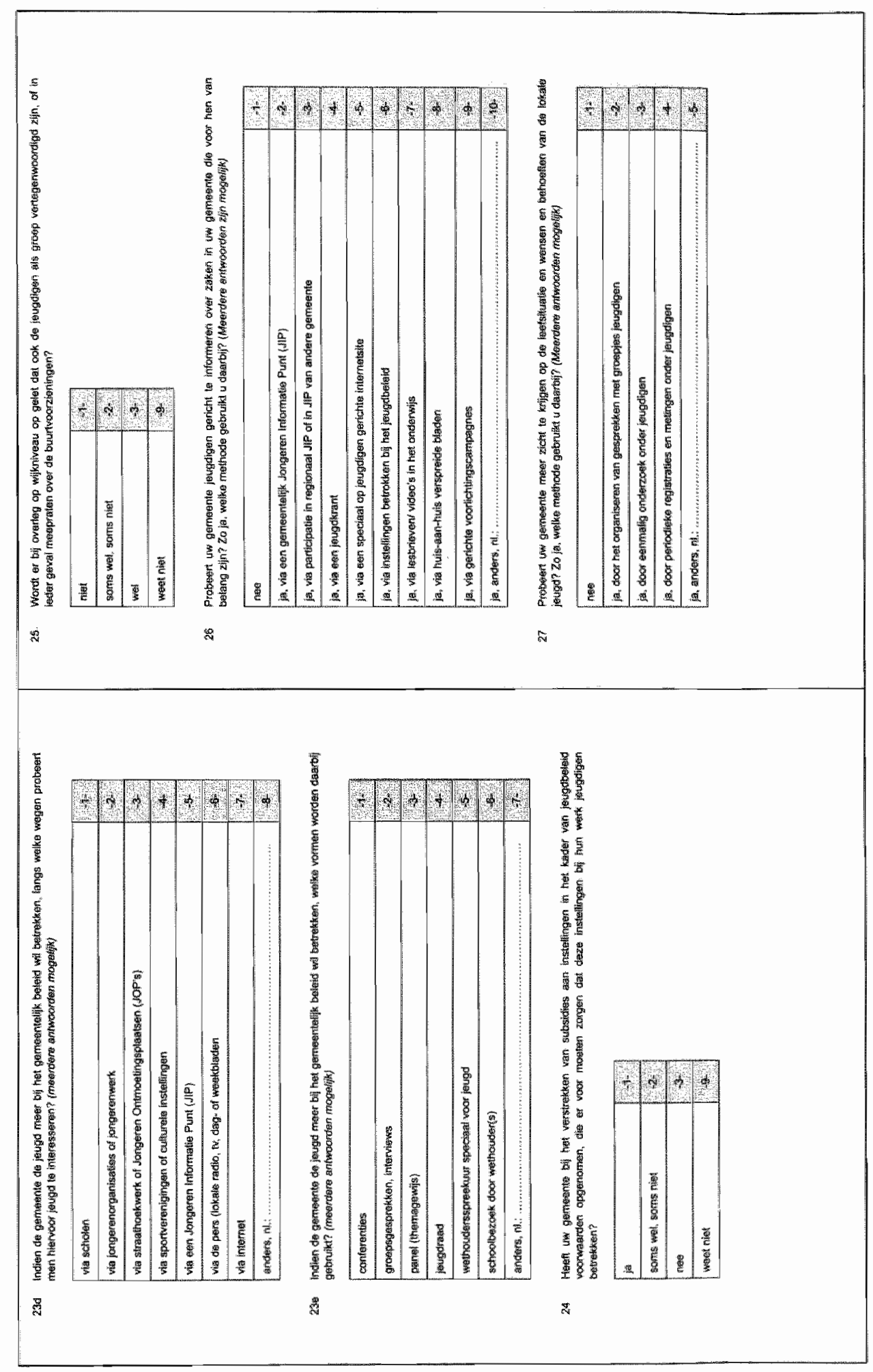




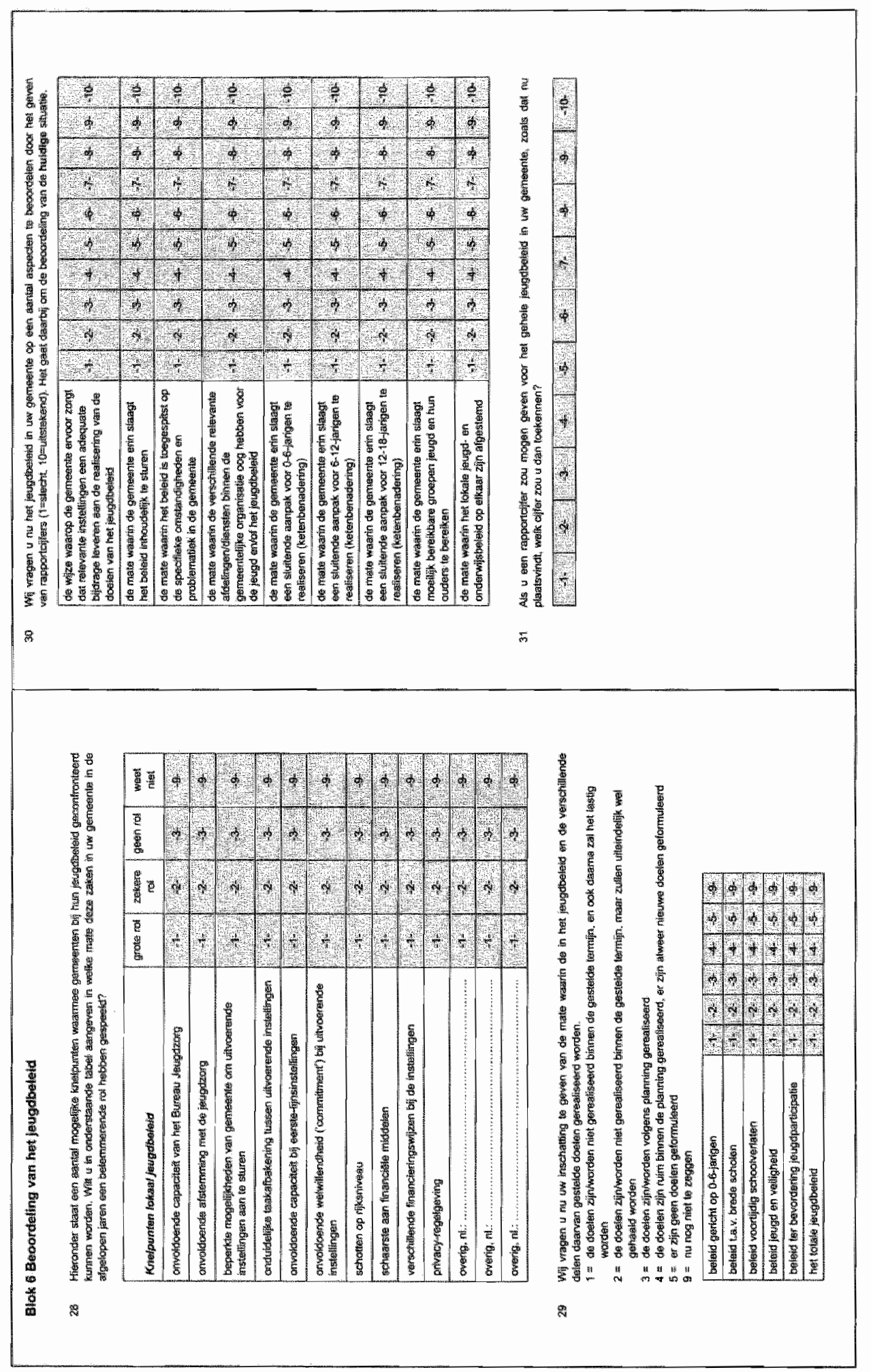




$$
\text { I }
$$


C3 Beleidseffectrapportage Lokaal jeugdbeleid 2002: enquête instellingen 

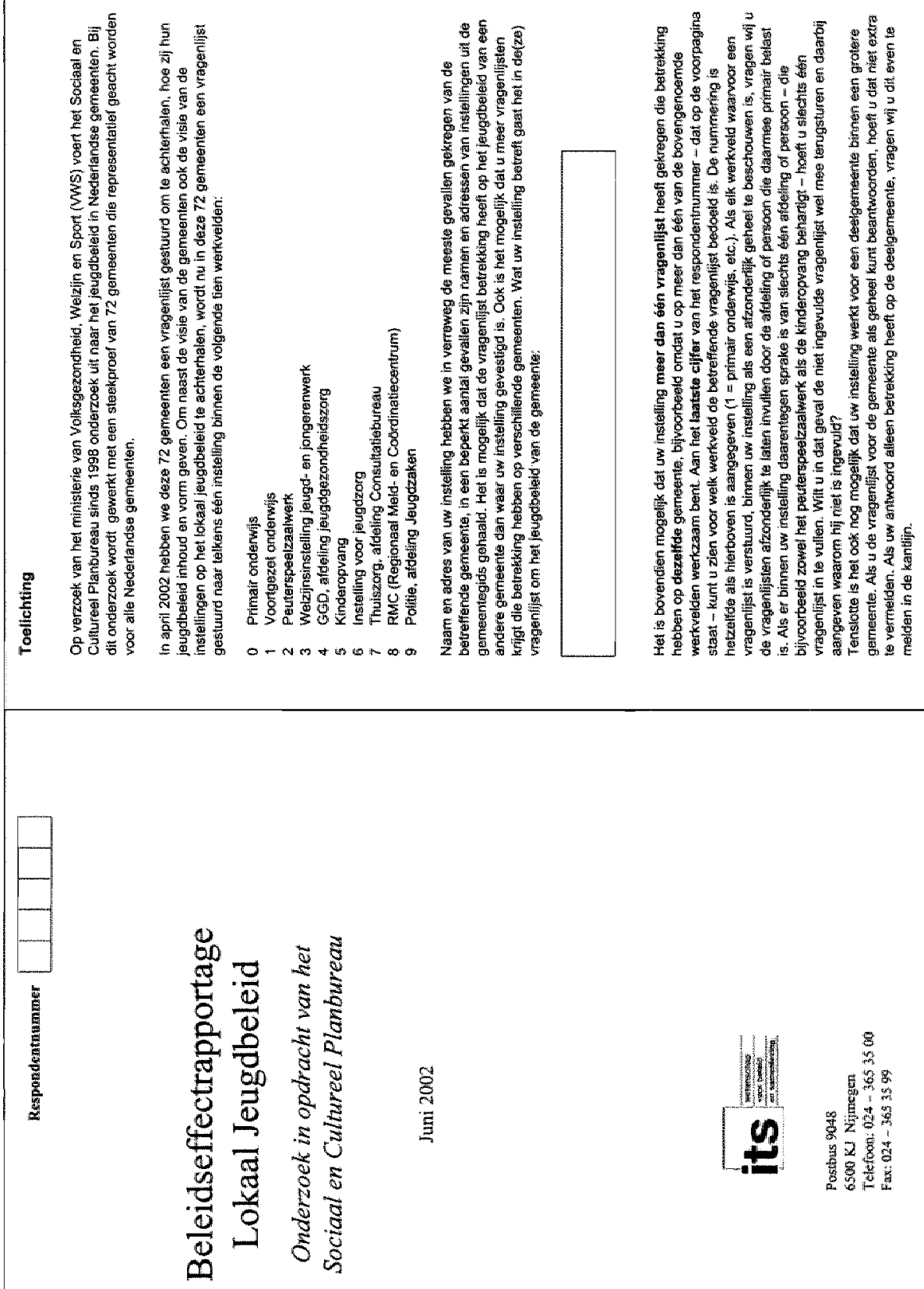


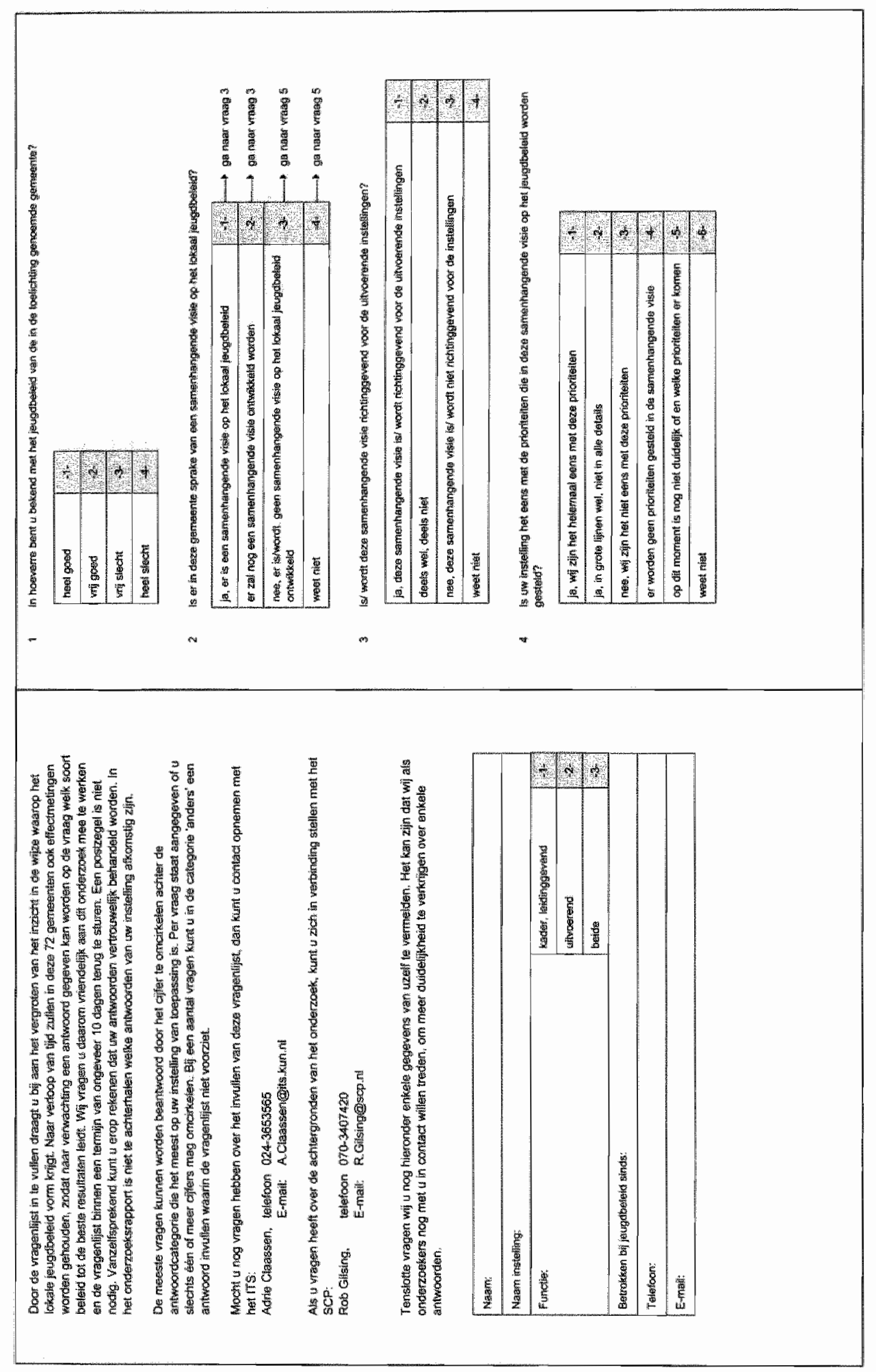




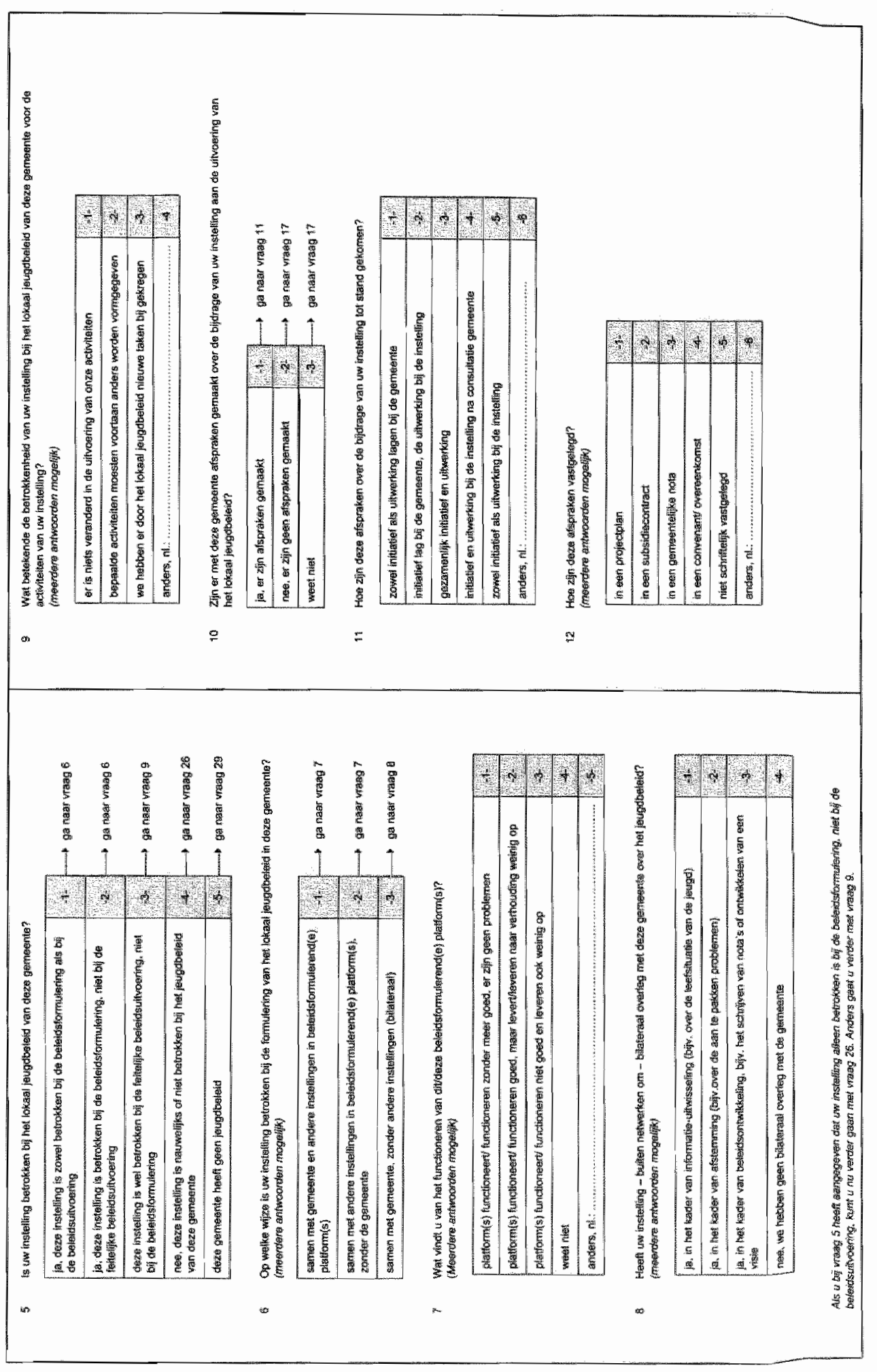




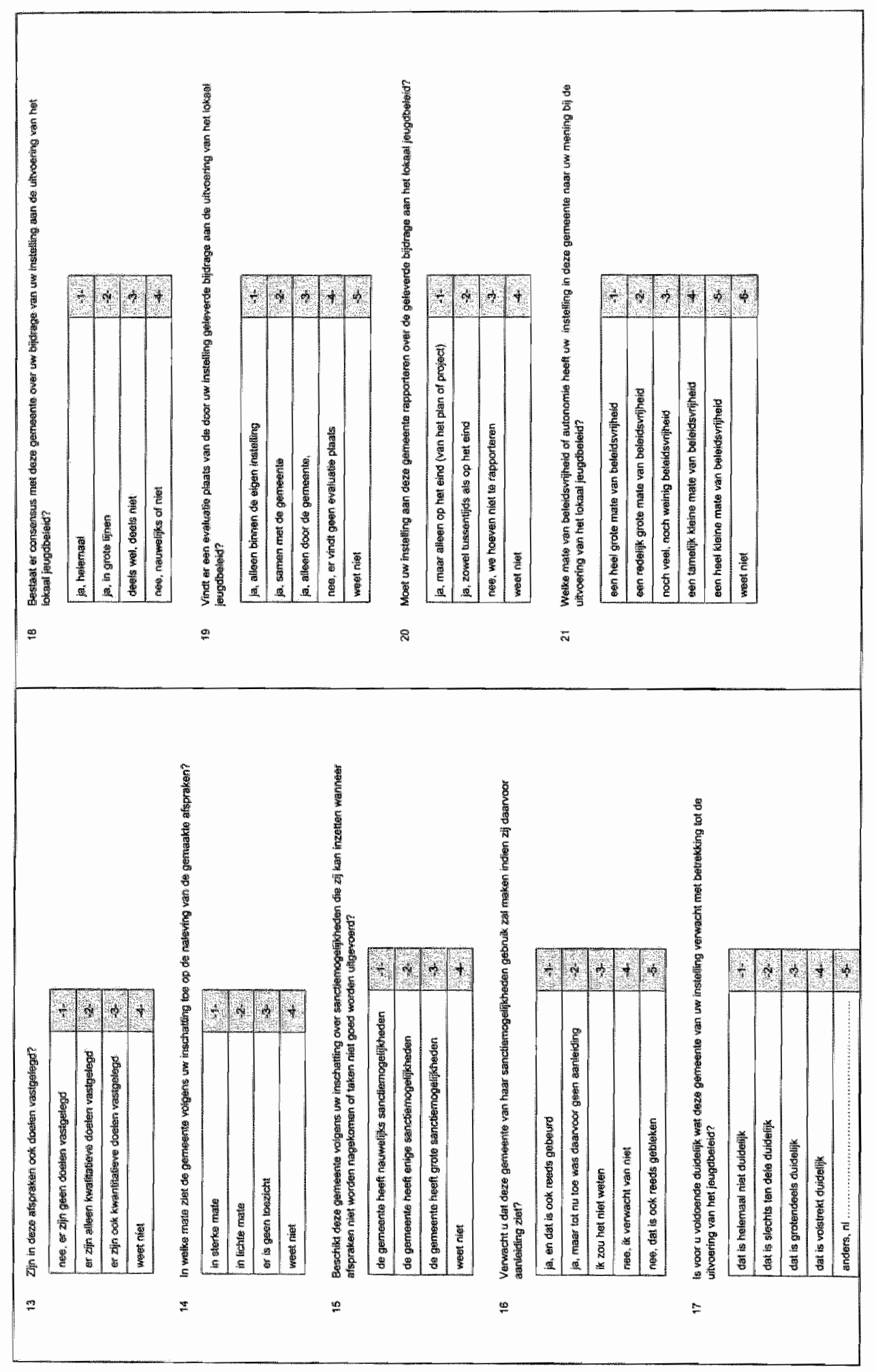




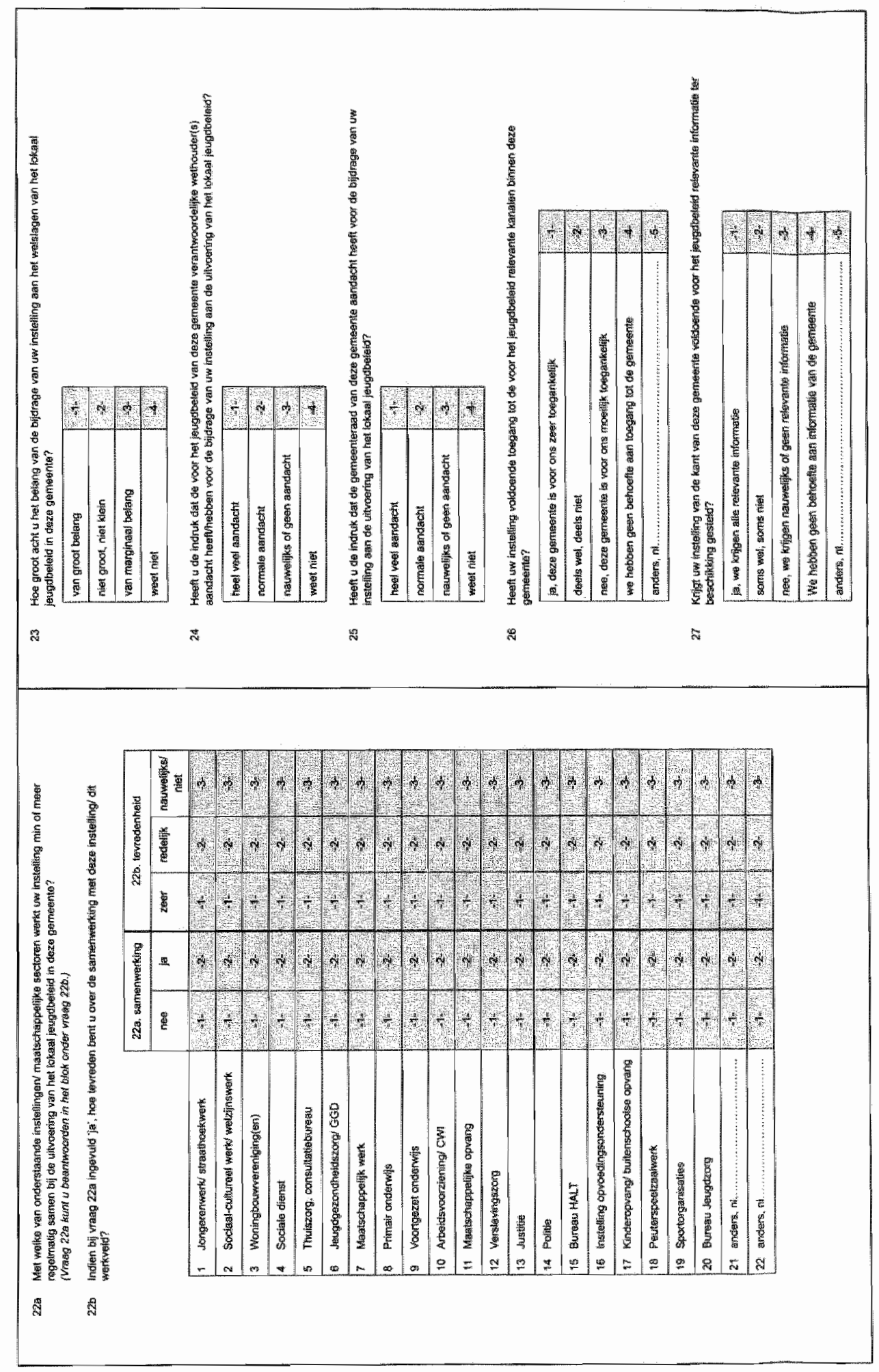




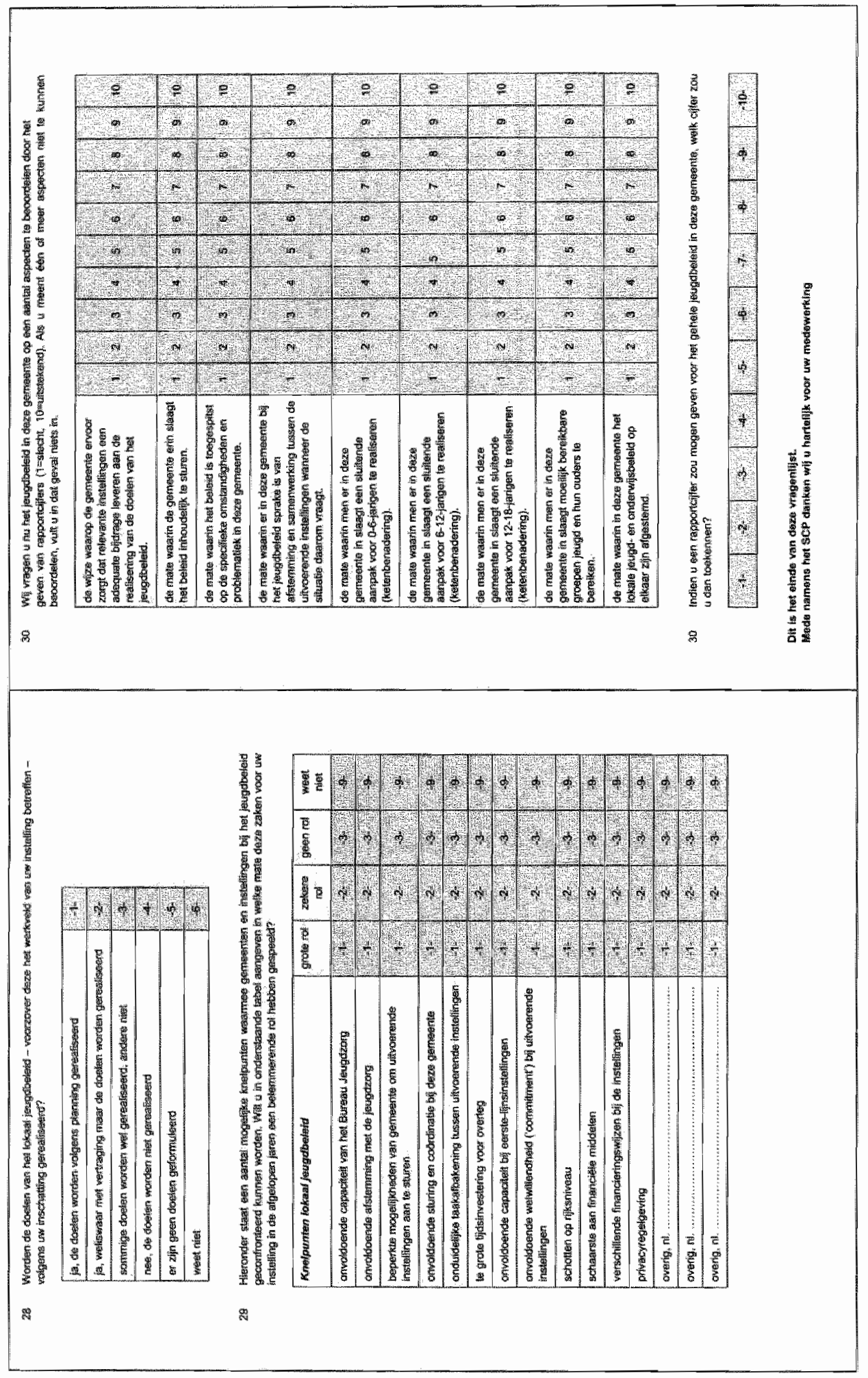


$C_{4}$ Jongereninspectieteams: enquête voor jongeren (basisuragenlijst) 


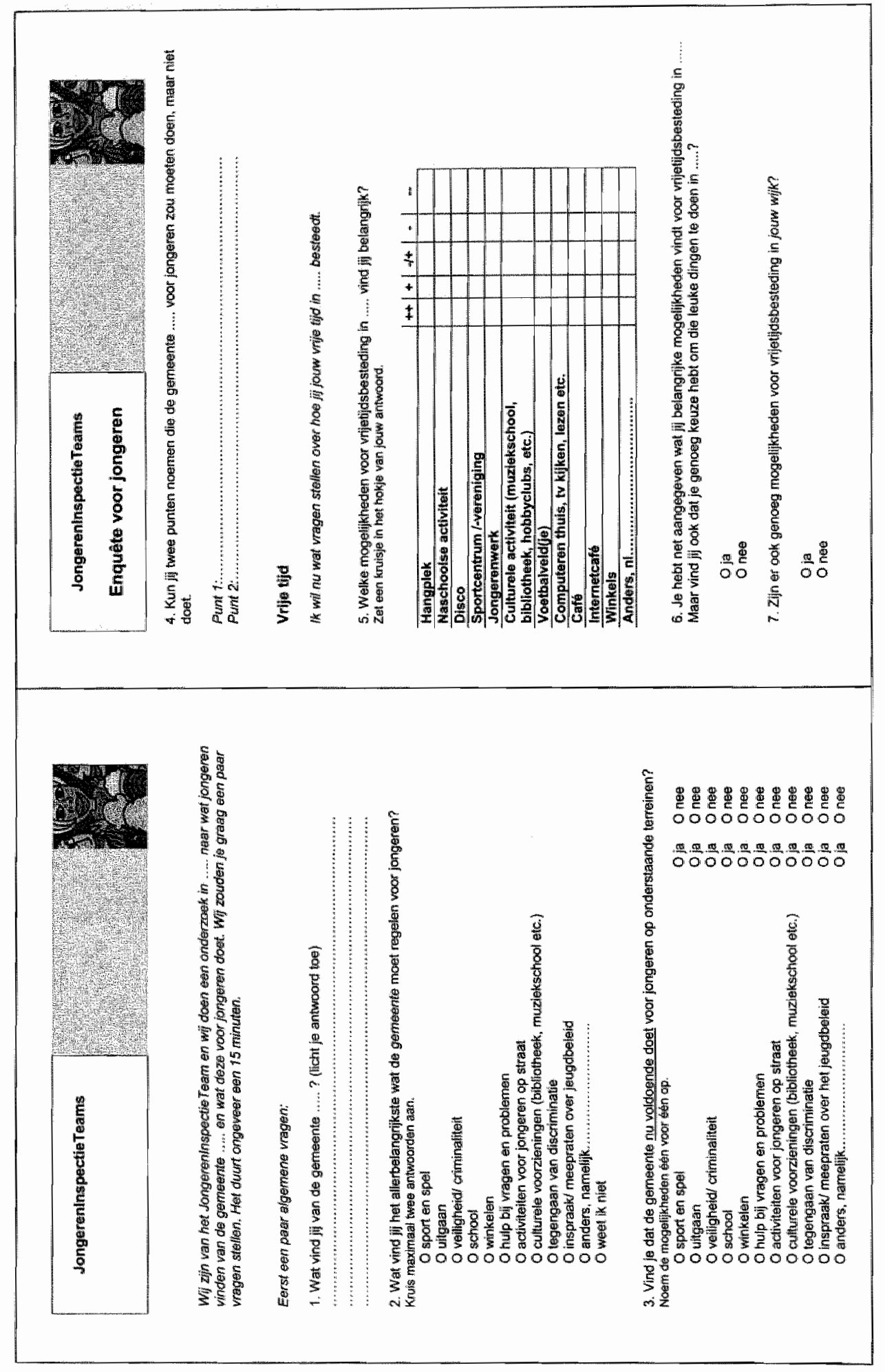




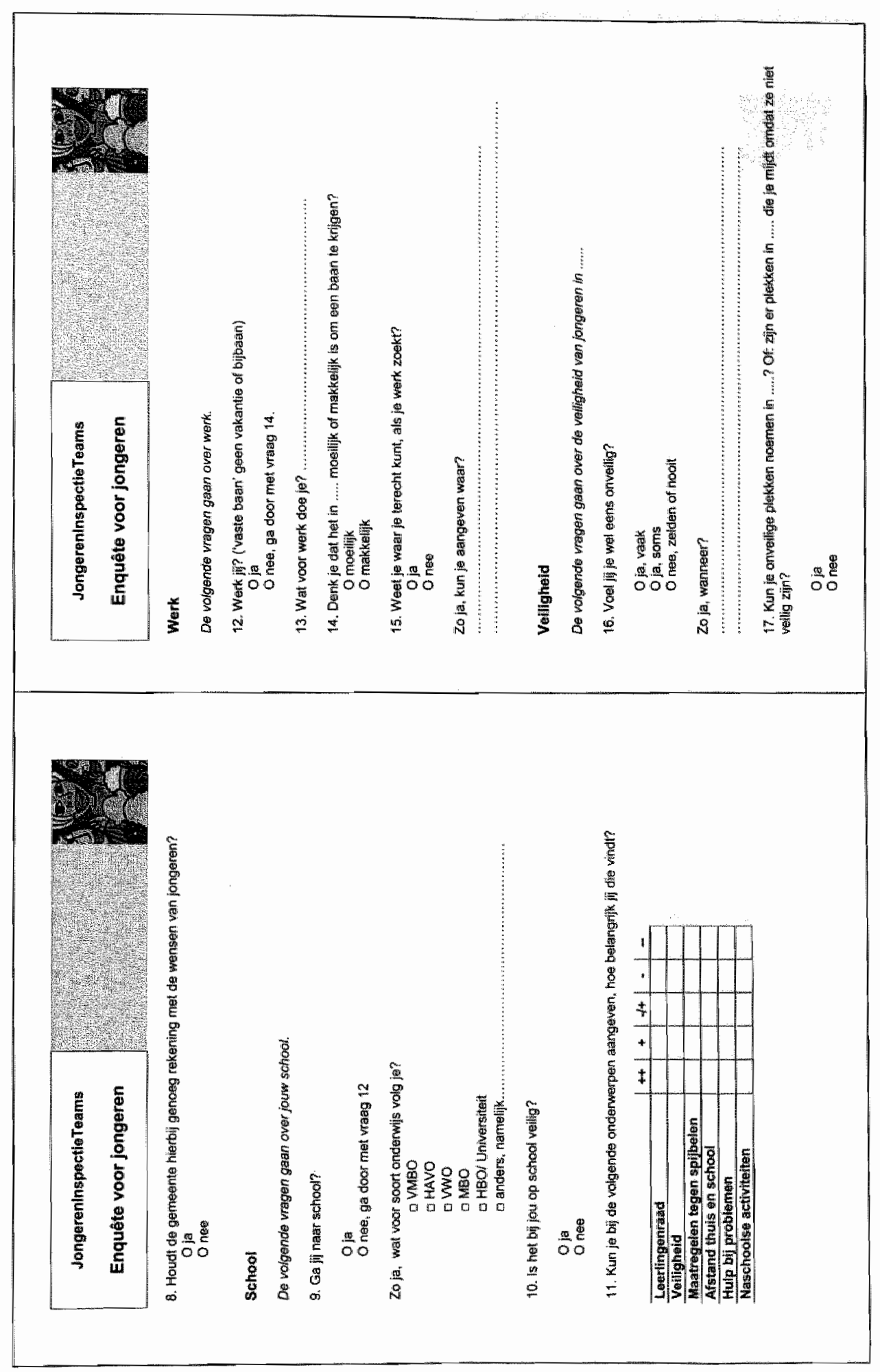




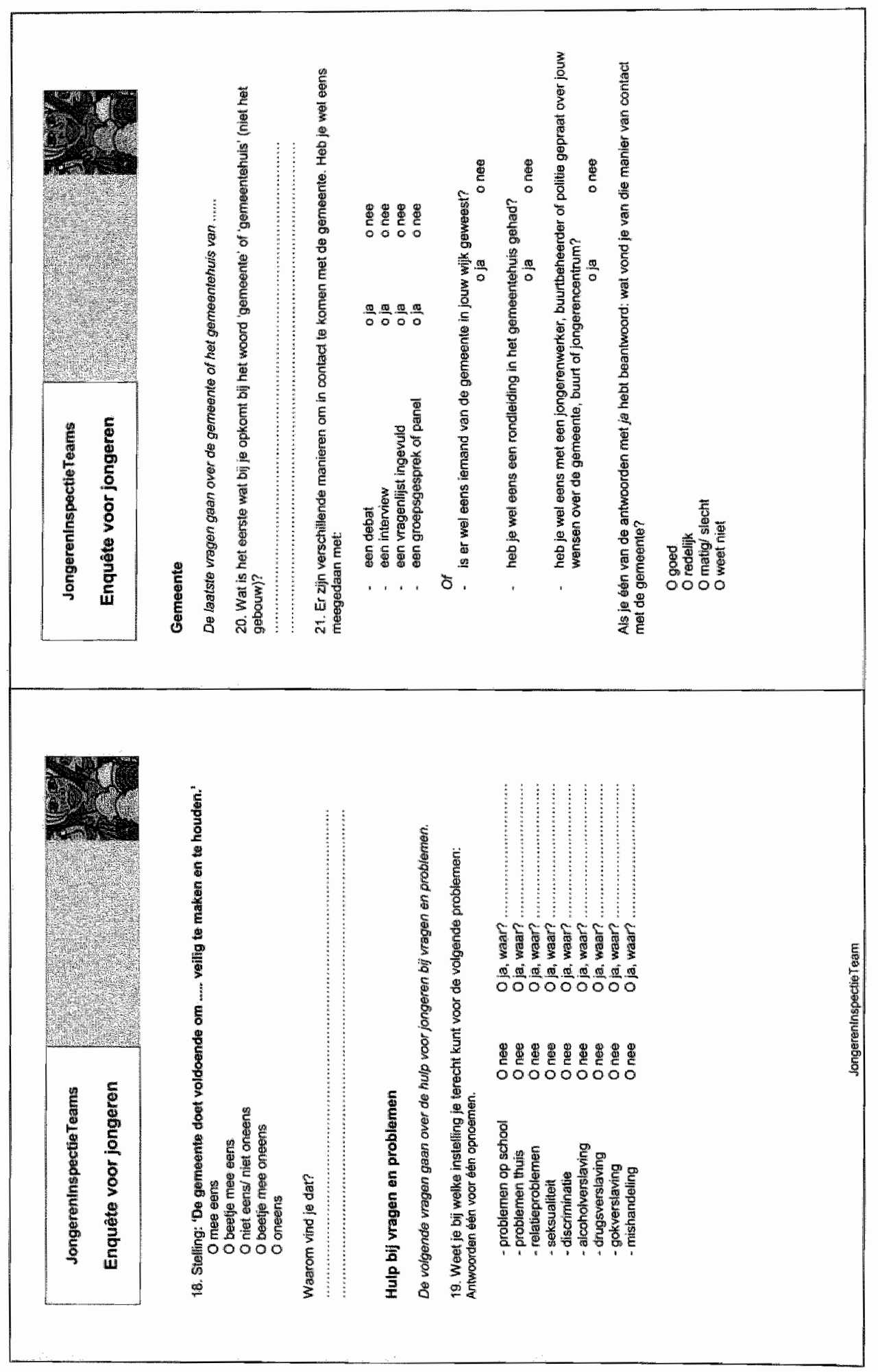




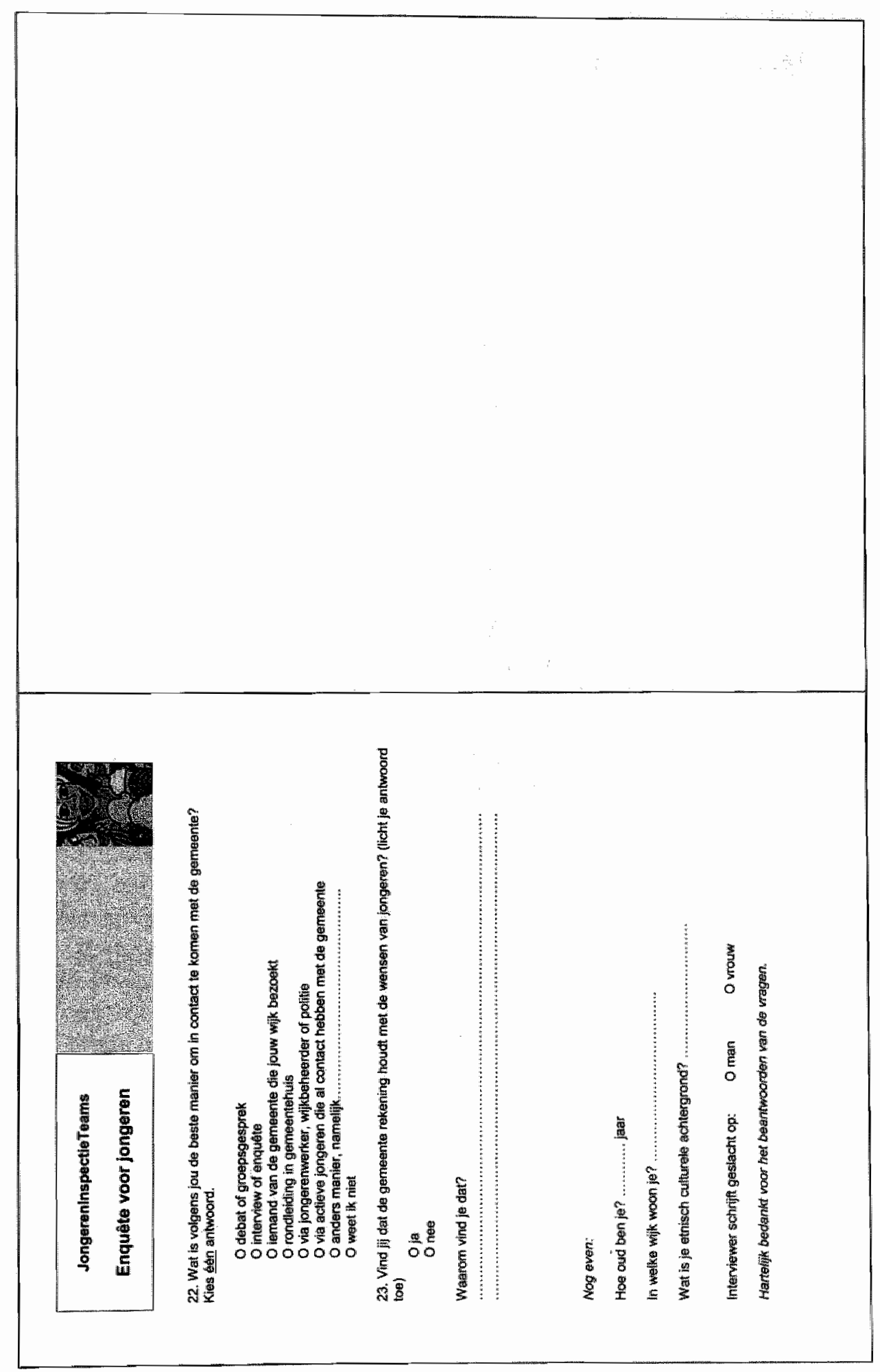




\section{Bijlage D Veldwerkverslag jongeren inspectie teams}

\section{Opzet}

In juni 2002 is gestart met de voorgesprekken met de verantwoordelijke beleidsambtenaren in de negen gemeenten en de werving van de leden wan de Jongeren Inspectie Teams (JT). Eind oktober, begin november 2002 wordt het project afgerond met de eindbesprekingen van alle JT's waarin de teamleden met behulp van de resullaten van hun onderzoek het jeugdbeleid beoordeelden.

Naar aanleiding van het vooroverleg in de gemeenten zijn beslissingen genomen over een gunstige startdatum van de jit's. In de gefuseerde gemeente VoorburgLeidschendam is besloten om het onderzoek te beperken tot Voorburg ${ }^{\circ}$ Groningen fungeerde als de "pilot-gemeente" van het project omdat daar de werving van de JIT-leden al voor de zomervakantie kon plaatsvinden. Op basis van de ervaringen in Groningen is de vragenlijst voor de enquête aangepast om als standaard te dienen in de overige gemeenten waar de JIT's na de zomervakantie aan de slag zouden gaan.

Het JrT Groningen nam naast de enquête ook een aantal diepte-interviews af. Deze werkwijze is in de overige gemeenten losgelaten omdat de gestandaardiseerde vragenlijst soortgelijke resultaten opleverde als de diepte-interviews en omdat jongeren aangaven dat zij liever in een groepsdiscussie met elkaar in gesprek gaan dan in een een-op-eensituatie.

Op basis van de ervaringen in Groningen heeft Stichting Alexander in overleg met het SCP de vormgeving van de bijeenkomsten van de „IT's in de overige gemeenten vastgesteld. In de gewijzigde startbijeenkomst zijn per gemeente ongeveer twaalf jongeren uitgenodigd voor deelname aan het panelgesprek over de gemeente. Uit de deelnemers koos Stichting Alexander vervolgens vier tot zes jongeren die het Jongeren Inspectie Team zouden vormen. Tijdens de tweede bijeenkomst zijn met deze jongeren op basis van de resultaten wan het panelgesprek kwaliteitscriteria opgesteld. De jongeren gaven hierbij aan wanneer het volgens hen in de gemeente goed geregeld zou zijn op het gebied van de gemeente in het algemeen, vrije tijd, wijk, school, werken, wonen, veiligheid, hulp bij vragen en problemen, en inspraak. Tijdens de derde bijeenkomst kregen de jongeren een interviewtraining. Ook werd het enquêteformulier grondig doorgenomen en zo nodig aangepast. Vervolgens hebben de teamleden gemiddeld drie weken de tijd gehad voor het enquêteren van 60 leeftijdsgenoten uit de gemeente. In de vierde bijeenkomst vergeleken de JIT'ers de uitkomsten van de enquête met de opgestelde kwaliteitscriteria van de tweede bijeenkomst. Dat mondde uit in een eindconclusie over het jeugdbeleid. 


\section{Verloop veldwetk}

Na het panelgesprek bleek het geen enkel probleem om jongeren enthousiast te maken voor deelname aan de onderzoeksactiviteiten. Het probleem was eerder dat enthousiaste kandidaten 'nee' moest worden verkocht omdat het Jir al vol zat. De samenstelling van de JIT's varieerde per gemeente. Dit had in eerste instantie te maken met verschillen tussen de gemeenten in de opbouw van de jeugdige bevolking. Zo namen bijvoorbeeld in het vrij multiculturele Spijkenisse jongeren met verschillende culturele achtergronden deel aan het Jongeren Inspectie Team, terwijl de JIT's in Heeze-Leende en Voorburg een afspiegeling vormen van de merendeels autochtone bevolking in deze gemeenten.

De werving van de JIT-leden was deels het resultaat van de medewerking van enthousiaste contactpersonen in de gemeenten, zoals docenten en jongerenwerkers. In het éne geval leverde dit voor een JIT veel vmbo-leerlingen op, zoals bijwoorbeeld in Utrecht, in het andere geval juist veel vwo'ers zoals in Culemborg. Ook de gemiddelde leeftijd verschilde per team. De JIT'ers in Voorburg waren bijvoorbeeld aanzienlijk ouder dan in Culemborg of Heeze-Leende.

\section{Tabel D.:}

Achtergrondkenmerken door JIT's geênqueteerde jongeren (in procenten)

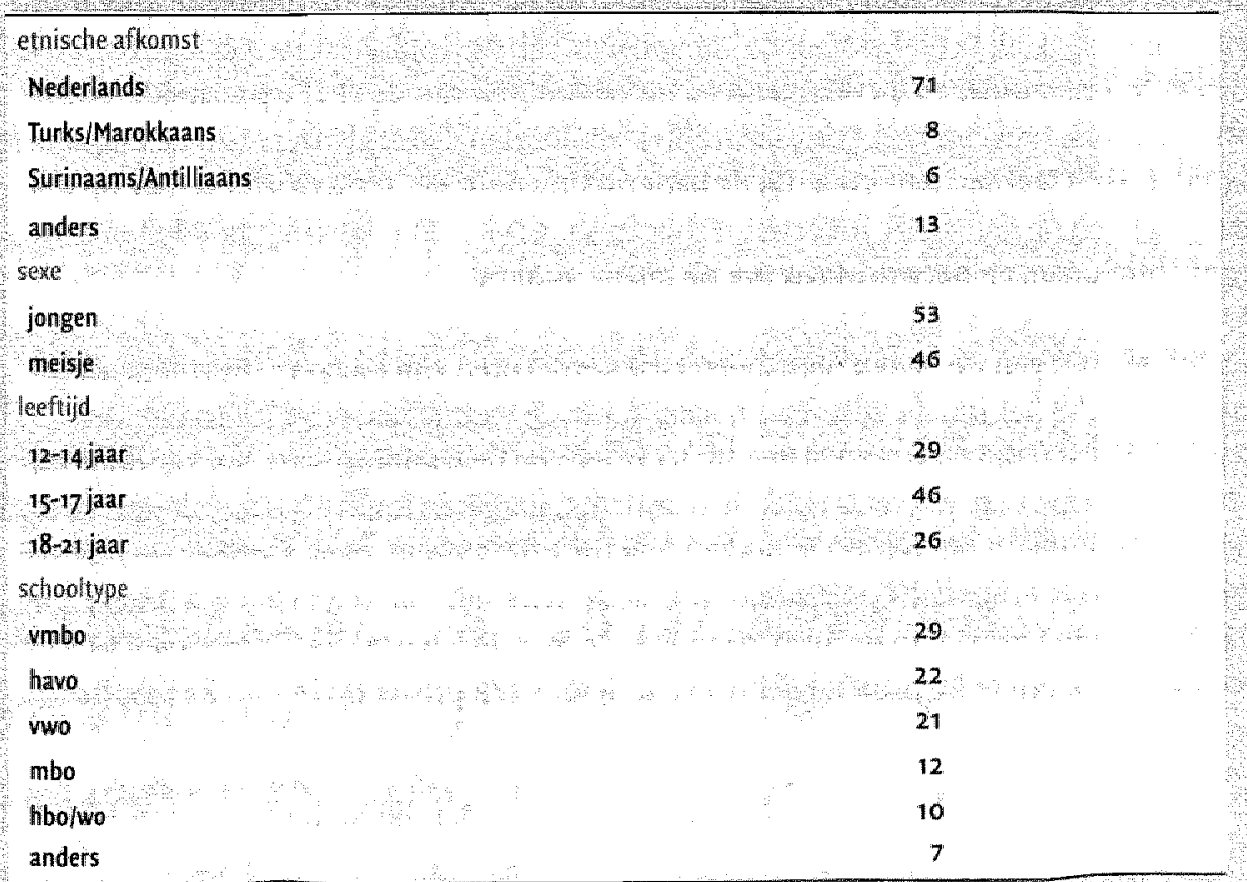

Bron, SCP (LB Jongerenins pectieteans 2002) 
De soms wat uniforme samenstelling van de JIT's betekent niet dat er per gemeente maar een bepaalde groep jongeren is bereikt. Integendeel, de JIT's zijn erin geslaagd ondanks de eigen achtergrond een gemengde groep jongeren te interviewen, meestal ongeveer evenveel meisjes als jongens, jongeren uit werschillende wijken, met verschillende opleidingsniveaus, culturele achtergronden en van alle leeftijden binnen de doelgroep. Dit was voor de JIT'ers overigens niet altijd een makkelijke taak. Zo wonden jonge JIT'ers van 15 jaar het soms moeilijk om oudere jongeren vanaf 18 jaar aan te spreken. In tabel D.r zijn de achtergrondkenmerken van de gehele groep van 504 jongeren beschreven.

Voor alle negen IIT's geldt dat de teamleden hun taak als onderzoeker zeer serieus hebben genomen. Ondanks de instructies tijdens de interviewtraining om de respondenten zo min mogelijk te beïnvloeden in hun antwoorden en om de antwoorden op een neutrale manier en zo volledig mogelijk op te schrijven, blijkt dit voor sommige (enthousiaste) interviewers moeilijk te zijn geweest en hebben zij bij sommige vragen nadere toelichting gegeven. Ook noteerden zij vaak de ongevraagde toelichting bij het antwoord op gesloten vragen. Mede hierdoor hebben veel interviews duidelijk langer geduurd dan de vijftien minuten die daarvoor waren ingepland.

Tijdens de eindbeoordeling zijn de JIT'ers actief op zoek gegaan naar overeenkomsten en verschillen tussen hun eigen mening en die van de ondervraagde jongeren. Hierbij kregen zij te maken met de beperktheid van de resultaten van een gestandaardiseerde vragenlijst en de diepgang en individualiteit van de zelf opgestelde kwaliteitscriteria: veel van hun criteria strekten verder dan de resultaten van de enquête en konden niet worden gemeten. Bij de beoordeling door de 'JrT'ers viel verder op dat de jongeren de gemeente niet snel veroordelen, maar veel rekening houden met de mogelijkheden en beperkingen van de lokale situatie.

In een aantal van de negen geïnspecteerde gemeenten zijn jongerenwerkers actief betrokken bij het JrT. Ze wierven een aantal van de teamleden, regelden vergaderruimte of catering en leverden een bijdrage aan de begeleiding van het JIT door bijvoorbeeld tips te geven over waar de teamleden jongeren konden interviewen of door hen te stimuleren om tempo te maken met het interviewen. Ook hebben de meeste gemeenten belangstelling getoond voor de activiteiten van de JIT's en wilden zij na afloop van het project in gesprek gaan met de teamleden over verbeteringen van het jeugdbeleid, om te beginnen bijvoorbeeld tijdens een presentatie van de resultaten. 




\section{Curriculum vitae}

Rob Gilsing (Best, 5 oktober 1963 ) behaalde in 1982 zijn wwo-diploma aan het Jacob Roelantslyceum in Boxtel. In 1983 begon hij de studie Politicologie aan de Katholieke Universiteit Nijmegen (KUN). In Ig89 behaalde hij zijn doctoraaldiploma, met als afstudeerrichting Internationale betrekkingen. Hij deed een onderzoeksstage op het Secretaría Permanente del Tratado General de la Integración Económica Centroamericana (SIECA) in Guatemala-stad, Guatemala en schreef vervolgens zijn scriptie over het proces van economische integratie in Midden-Amerika. In rggo en rggr deed hij voor de Wetenschapswinkel Nijmegen onderzoek naar de politieke participatie van migranten. Van r $99 \mathrm{I}$ tot 1996 was hij assistent-in-opleiding bij de vakgroep Politicologie van de KUN. Hij deed daar onder meer onderzoek naar bestuurlijke vernieuwing in Nederlandse gemeenten en gaf onderwijs op het gebied van lokaal bestuur. Vanaf 1996 is hij als onderzoeker in dienst bij het Sociaal en Cultureel Planbureau, waar hij onderzoek verricht naar lokaal beleid, in het bijzonder op het gebied van jeugd. 